\title{
Turystyka w okresie pandemii
}

115.

Redakcja naukowa Krzysztof Borodako

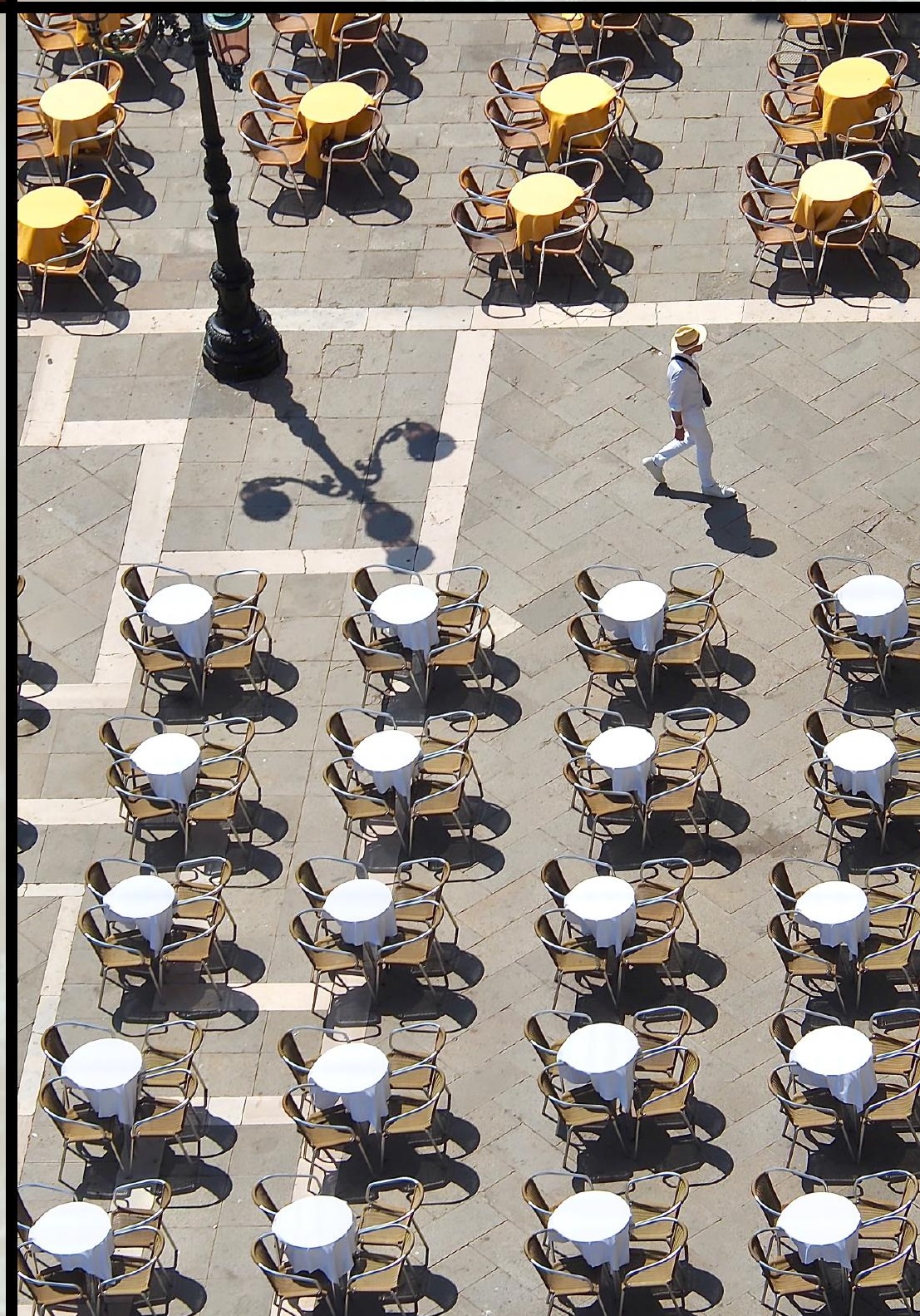


Turystyka w okresie pandemii 



\title{
Turystyka w okresie pandemii
}

\author{
Redakcja naukowa \\ Krzysztof Borodako
}

Bogucki Wydawnictwo Naukowe

Poznań-Kraków 2021 
Wydanie publikacji zostało dofinansowane przez Uniwersytet Ekonomiczny w Krakowie

Recenzenci:

prof. UEW dr hab. Piotr Gryszel

prof. UEP dr hab. Piotr Zmyślony

prof. UEKat dr hab. Katarzyna Czernek-Marszałek

dr hab. Adam Pawlicz

dr Marta Sidorkiewicz

dr Natalia Latuszek

dr Marcin Olszewski

dr Paweł Piotrowski

dr Piotr Zawadzki

Publikowane w poszczególnych rozdziałach teksty mają charakter autorski, a za ich treść odpowiadają poszczególni autorzy.

(C) Copyright by Uniwersytet Ekonomiczny w Krakowie, 2021

ISBN 978-83-7986-350-1

DOI: $10.12657 / 9788379863501$

Bogucki Wydawnictwo Naukowe

ul. Górna Wilda 90, 61-576 Poznań

www.bogucki.com.pl

e-mail: biuro@bogucki.com.pl

Druk i oprawa: PerfektDruk 


\section{Spis treści}

Krzysztof Borodako

Turystyka w czasach pandemii - wprowadzenie do zagadnienia . . . . . . 7

Część 1. Organizacja wydarzeń oraz rynek podróży służbowych . . . . 13

Klaudia Skoczeń

Koncepcja idei Slow Movement na przykładzie organizacji targów

Weronika Stabosz

Konwenty fanów w Polsce jako przykład eventów $\ldots \ldots \ldots \ldots \ldots \ldots$

Aleksandra Mależyna

Eventy sportowe jako czynnik rozwoju turystyki na obszarach

goszczących (na przykładzie siatkarskich imprez organizowanych

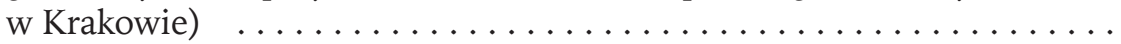

Adrian Urbańczyk

Zmiany w organizacji podróży służbowych wywołane pandemią

COVID-19 wśród pracowników krakowskich korporacji . . . . . . . . . . .

Część 2. Nowe technologie i innowacje w turystyce . . . . . . . . 59

Małgorzata Franczyk

Konsekwencje społeczne i ekonomiczne wydarzeń hybrydowych na

przykładzie piątej edycji kongresu Open Eyes Economy Summit . . . . . .

Aleksandra Dulewska

Wykorzystanie nowoczesnych technologii dla celów promocyjnych przez touroperatorów prowadzących działalność na rynku polskim . . . . . . . . .

Ewa Kamińska

Crowdfunding jako forma finansowania innowacyjnych produktów

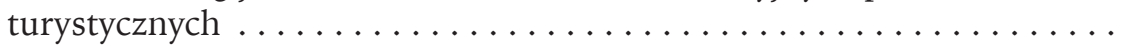

Maciej Kędziera

Analiza technologii informacyjno-komunikacyjnych w aspekcie ekonomii współdzielenia na przykładzie sektora turystycznego $\ldots \ldots \ldots \ldots \ldots$

Dominika Hapek

Wykorzystanie nowych technologii jako element współczesnego

marketingu hotelu niezależnego

Patrycja Żychoń, Michat Piwowarczyk

Aktywność wybranych obiektów szlaku zabytków techniki w mediach społecznościowych w czasie pandemii COVID-19 . . . . . . . . . . 
Część 3. Funkcjonowanie wybranych aspektów podaży turystycznej • 123 Natalia Siwik

Zarządzanie ryzykiem i zarządzanie kryzysowe w kontekście upadku legendarnego biura podróży Thomas Cook . . . . . . . . . . . . 125

Kamil Pawtowski

Uwarunkowania wykorzystania transportu kolejowego w rozwoju turystyki międzynarodowej . ....................... 133

Ewa Iwaniuk

Rola pracowników w zarządzaniu modelem otwartych innowacji . . . . . 145 Joanna Paprzycka

Opinie przedstawicieli łódzkiej branży turystycznej na temat głównych turystycznych aktów prawnych $\ldots \ldots \ldots \ldots \ldots \ldots \ldots \ldots \ldots \ldots$ Artur Żyto

Znaczenie dziedzictwa kulturowego dla rozwoju turystyki w rejonie Parku Narodowego Gór Stołowych . . . . . . . . . . . . . . . . . 165

Barttomiej Łuć

Wpływ rozwoju infrastruktury sportowo-rekreacyjnej na turystykę

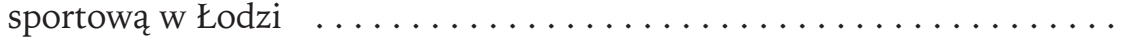

Część 4. Marketing w turystyce - badania rynkowe i zachowania

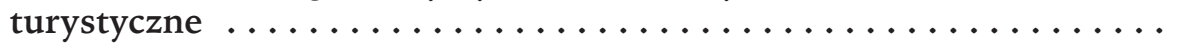

Katarzyna Madras

Zakaz lotów do Polski w czasie pandemii COVID-19 a decyzje

podróżnych

Magdalena Wawoczny

Wpływ pandemii COVID-19 na zmiany w wielkości ruchu pasażerskiego transportu lotniczego w Polsce i na świecie . . . . . . . . . . . . . . . . 199

Franciszek Bolechowski

Socjodemograficzne determinanty aktywności turystycznej

beneficjentów programu socjalnego Rodzina 500+ w Polsce

Magdalena Kosiada-Sylburska

Dlaczego konsumenci angażują się w przygotowanie usług w muzeach?

Wstęp do badań .............................. 219

Agata Smyka

Determinanty rozwoju turystyki w gminie miejsko-wiejskiej Wleń . . . 229

Alicja Chrabańska-Czerwińska

Wpływ „odmrożenia” gospodarki po blokadzie z powodu COVID-19 na natężenie ruchu turystycznego w Tatrzańskim Parku Narodowym . . . 241

Żaneta Zatorska

Dziedzictwo kulinarne województwa małopolskiego

w opinii podróżujących

Łukasz Szat, Weronika Terlecka

Zmiany zachowań wolnoczasowych dotyczących rekreacji fizycznej osób młodych w obliczu pandemii COVID-19 .............. 261 


\section{Krzysztof Borodako}

Uniwersytet Ekonomiczny w Krakowie

borodako@uek.krakow.pl

(D) https://orcid.org/0000-0002-7348-8372

\section{Turystyka w czasach pandemii - wprowadzenie do zagadnienia}

Turystyka przechodzi na początku lat 20. XXI w. wielki kryzys. Jest to związane z globalną pandemią spowodowaną koronawirusem SARS-CoV-2 wywołującym chorobę COVID-19 znaną głównie jako choroba układu oddechowego. Po blisko roku prowadzonych badań medycznych wskazuje się, że choroba ta atakuje także inne układy organizmu (Zaim i in., 2020), tworząc jeszcze większe zagrożenie dla ludzi.

Zgodnie z definicją Światowej Organizacji Turystyki (UNWTO) trzonem turystki jest atrybut podróży, przemieszczania się, a tym samym przebywania poza miejscem zamieszkania. Do tego dochodzą pozostałe kluczowe z punktu widzenia tej definicji cechy tej aktywności, tj. ogół czynności osób podróżujących, ich motywy wyjazdów odwołujące się do potrzeby wypoczynku, względów zawodowych, zdrowotnych i innych (jednak z wykluczeniem celów zarobkowych), przy jednoczesnym czasie trwania nie dłuższym niż rok (UNWTO, 2008). Na tej podstawie widać, że pandemia w pierwszej fazie zablokowała funkcjonowanie turystyki i bardzo mocno ograniczyła w dalszych miesiącach trwania choroby dynamiczny rozwój tej branży.

Aby zobrazować poziom „zniszczeń” spowodowanych pojawieniem się pandemii, warto pokazać dostępne dane z ostatnich lat przed pandemią oraz najnowsze dane dotyczące turystyki w czasie trwania pandemii. Według raportów UNWTO w 2018 r. przyrost podróży międzynarodowych o charakterze turystycznym wynosił 5\%, generując ruch turystyki międzynarodowej na poziomie 1,4 mld wyjazdów. Co warte szczególnego podkreślenia, połowa tego ruchu międzynarodowego była powiązana z rynkiem europejskim poprzez wyjazdy lub przyjazdy do krajów europejskich (lub między nimi). Prezentowane wtedy stanowisko przewidywało średnioroczny wzrost na poziomie około 3,3\%, generując w perspektywie 2030 r. nawet liczbę 1,8 mld wyjazdów turystycznych (UNWTO, 2019). Nadzieję

Cytowanie: Borodako K. (2021). Turystyka w czasach pandemii - wprowadzenie do zagadnienia. W: K. Borodako (red.), Turystyka w okresie pandemii. Bogucki Wydawnictwo Naukowe, Poznań-Kraków, s. 7-12. https://doi. org/10.12657/9788379863501-1 
na dalszy rozwój turystyki wzbudził także rok 2019, pomimo widocznych objawów zwolnienia gospodarczego w części gospodarek świata. W 2019 r. - zgodnie $z$ informacjami pochodzącymi z UNWTO - zanotowano jeszcze większy wzrost ruchu turystyki międzynarodowej na poziomie $4 \%$ (co w liczbach bezwzględnych wynosiło 1,46 mld wyjazdów). Również całkowite wpływy z turystyki międzynarodowej $\mathrm{w}$ omawianym roku przed pandemią ponownie wzrosły globalnie na poziomie $3 \%$. Mimo widocznych oznak zmiany koniunktury na rynkach międzynarodowych i towarzyszącym tym powolnym spadkom dynamiki międzynarodowych przyjazdów, sektor turystyczny wciąż dostrzegał perspektywy rozwoju długofalowego. W niektórych krajach notowano jednocześnie bardzo wysokie wzrosty wydatków związanych z turystyką międzynarodową - za przykład podaje się Francję z aż 11-procentowym wzrostem (UNWTO, 2020). Nikt w tamtym czasie nie mógł przewidzieć globalnej pandemii, która tak mocno uderzy w ten sektor.

Sytuacja $\mathrm{w}$ turystyce europejskiej jest $\mathrm{w}$ dużej mierze odzwierciedleniem turystyki globalnej $\mathrm{w}$ okresie pandemii, chociaż pewne zjawiska mogą przebiegać inaczej i cechować się nieco inną dynamiką. Z tego względu warto zobrazować stan turystyki w tym regionie świata na podstawie najnowszych ( $\mathrm{w}$ chwili pisania tego tekstu) danych statystycznych. Europejska Komisja Podróży (ang. European Travel Commission) w swoim raporcie z czwartego kwartału 2020 r. przedstawiła obraz turystyki w pierwszym roku pandemii. Poziom spadku podróży międzynarodowych w Europie w 2020 r. szacowany był na 69\%, podczas gdy dla podróży krajowych na tym kontynencie na poziomie 35\%. Przy spadku podróży międzynarodowych na świecie na poziomie $73 \%$ i spadku podróży krajowych na świecie na poziomie $34 \%$, rok ten należy uznać za najgorszy od ponad trzydziestu lat (ETC, 2021). Wśród krajów europejskich, które zanotowały najmniejszy spadek podróży, należy wymienić Austrię. Kraj ten cechował spadek podróży jedynie o $53 \%$, co wynikało $z$ otwarcia granic w okresie wakacyjnym oraz dużego udziału podróży krótkodystansowych i krótkoterminowych. Na drugim biegunie krajów, które najbardziej odczuły skutki pandemii, wymienia się Czarnogórę (ze spadkiem podróży na poziomie $85 \%$ ) oraz w dalszej kolejności Rumunię i Cypr (na poziomie 80\%) (ETC, 2021).

Intensywne działania wielu państw świata zmierzające do szybkiego zaszczepienia jak największej liczby ludności oraz coraz łatwiej dostępne i wykonywane w coraz krótszym czasie testy na obecność wirusa w ciele człowieka rodzą nadzieję na stosunkowo szybkie odbicie się turystyki. Dodatkowym wsparciem mogą być zarówno nowe technologie pozwalające na „śledzenie” osób chorych powodujących zarażanie innych (poprzez dedykowane aplikacje), jak i podejmowane w ostatnich miesiącach na poziomie państw inicjatywy wprowadzenia tzw. paszportów szczepionkowych („cyfrowych zielonych paszportów”), potwierdzających nie tylko przyjęcie szczepionki, ale także zawierających informacje o samej chorobie oraz historię negatywnych wyników testów. Pomimo sceptycznego stanowiska $\mathrm{w}$ tym względzie UNWTO (DW, 2021), temat poszukiwania narzędzi szybkiej odbudowy turystyki w Polsce, Europie i na świecie wydaje się wciąż otwarty. 
Badania naukowe nad turystyką prowadzone w kraju w świetle pandemii można uznać wciąż za bardzo ubogie. Omówienie dotychczasowego polskiego dorobku naukowego w tym zakresie należałoby rozpocząć od przeglądowej i inicjującej dalsze badania pracy pod tytułem „Przyczynek do badań nad wpływem pandemii na stan gospodarki turystycznej” (Panasiuk, 2020). Na szczególne podkreślenie zasługują zawarte $\mathrm{w}$ tej pracy zidentyfikowane przez autora grupy zagadnień wymagających pogłębionych badań w świetle panującej pandemii. Wśród innych publikacji można wymienić pracę Widomskiego (2020), która została poświęcona rozpoznaniu opinii i preferencji turystów krajowych w warunkach ogólnoświatowej pandemii COVID-19. Inną pracą w polskim środowisku naukowym jest próba odpowiedzi na pytanie, w jaki sposób współczesna epidemia zmienia turystykę kulturową (von Rohrscheidt, Plichta, 2020). Autorzy przedstawili dyskusję interdyscyplinarną o charakterze eksperckim na ten temat. Problematyka turystyki W dobie pandemii jest także przedmiotem licznych badań za granicą (Benjamin i in., 2020; Correa-Martínez i in., 2020; Zenker, Kock, 2020), które z uwagi na zakres przedmiotowej monografii nie zostaną tu szerzej omówione.

Monografia proponowana czytelnikowi stanowi aktualnie prawdopodobnie najbogatszy zbiór prac badawczych (w formie rozdziałów) poświęconych branży turystycznej w dobie pandemii. Opracowanie podzielono na cztery części, kierując się głównie zawartością merytoryczną rozdziałów. Publikację otwiera część poświęcona funkcjonowaniu branży organizacji wydarzeń oraz związanych z nimi podróży służbowych. Część druga to szeroko rozumiane nowe technologie oraz innowacje wykorzystywane $\mathrm{W}$ turystyce. W części trzeciej przedstawiono funkcjonowanie wybranych podmiotów podaży turystycznej ze zwróceniem uwagi na kwestie transportowe, dziedzictwa kulturalnego oraz infrastruktury sportowo-rekreacyjnej. Ostatnia, ale nie mniej ważna część, dotyczy marketingu w turystyce.

W pierwszym rozdziale książki Klaudia Skoczeń połączyła dwie kwestie funkcjonowanie w dobie pandemii organizatorów targów konsumenckich oraz koncepcję Slow Movement. Omówienie tych dwóch zagadnień pozwoliło na dokładniejsze przedstawienie koncepcji Slow Fashion na przykładzie wydarzeń organizowanych w ostatnich miesiącach w jednym z polskich miast. Drugi rozdział to nadal rozważania nad organizacją wydarzeń, ale skupione na konwentach fanów. Badania przeprowadzone w czasie pandemii pozwoliły Weronice Słabosz na bliższe poznanie motywów uczestnictwa w tego typu wydarzeniach oraz ich porównanie z klasycznymi motywami występującymi w literaturze - ze wskazaniem odmienności dominujących motywów w tym segmencie rynku. W kolejnym rozdziale uwaga badawcza została skupiona na wydarzeniach sportowych jako czynniku rozwoju turystyki. Aleksandra Mależyna w swoim tekście wykazała, w jakim stopniu kibice wydarzeń sportowych podejmują dodatkową aktywność turystyczną w mieście goszczącym dane wydarzenie. Nie mniej interesującym rozdziałem w tej części monografii jest praca Adriana Urbańczyka poświęcona zmianom w organizacji podróży służbowych pracowników badanych korporacji wywołanym pandemią Covid-19. Przedstawione analizy pozwoliły autorowi na wyciągnięcie wniosków, że spotkania w formie online nie są traktowane jako alternatywa dla wyjazdów służbowych w badanych firmach. 
Część drugą otwiera rozdział poświęcony konsekwencjom społecznym i ekonomicznym organizacji wydarzeń opartych na technologiach w formule hybrydowej. Ograniczenia w gromadzeniu się ludzi oraz nowe technologie spowodowały wzrost popularności wydarzeń hybrydowych - wykorzystujących w duży stopniu zaawansowane technologie oraz profesjonalne studia nagrań. Małgorzata Franczyk w swoim rozdziale podjęła ten interesujący temat, stosując metodę badawczą studium przypadku. Aleksandra Dulewska omówiła wykorzystanie nowoczesnych technologii $\mathrm{w}$ obszarze działań promocyjnych touroperatorów. Autorka w efekcie swoich badań wyodrębniła podstawowy zbiór nowoczesnych technologii stanowiących niezbędny element funkcjonowania przedsiębiorstwa turystycznego $\mathrm{w}$ środowisku internetowym. Także kolejny rozdział tej monografii poświęcony jest interesującemu tematowi wykorzystania platform crowdfundingowych na potrzeby finansowania innowacyjnych produktów turystycznych. Ewa Kamińska w swoich badaniach dokonała przeglądu i porównania najważniejszych na polskim rynku platform crowdfundingowych w celu wskazania ich wad i zalet dla przedsiębiorcy. Uzyskane wyniki wydają się niezwykle ważne szczególnie w zbliżającym się okresie odbudowy turystyki po kryzysie pandemii. Kolejny rozdział autorstwa Macieja Kędziery poświęcony został analizie technologii informacyjno-komunikacyjnych wykorzystywanych $\mathrm{w}$ turystyce $\mathrm{w}$ dobie rozwoju ekonomii współdzielenia. Tego typu rozwiązania wydają się warte uwagi szczególnie w czasach unikania zatłoczonych hoteli i środków komunikacji. Nowe technologie informacyjno-komunikacyjne były także przedmiotem badań w tekście autorstwa Dominiki Hapek, w którym autorka skupiła uwagę na zastosowaniu tych technologii $\mathrm{w}$ marketingu hotelu niezależnego. W dobie unikania kontaktów osobistych i zgromadzeń na znaczeniu zyskują media społecznościowe. Wykorzystanie tych mediów przez wybrane obiekty szlaku zabytków techniki było obszarem zainteresowań Patrycji Żychoń i Michała Piwowarczyka. Na podstawie swoich badań autorzy podkreślili, że największą aktywność badane obiekty przejawiały $\mathrm{w}$ mediach społecznościowych (Facebook) w pierwszym okresie zamknięcia społeczeństwa (lockdownu), natomiast z upływem czasu ta aktywność malała. Interesujące może być także spostrzeżenie, że największą aktywnością w mediach społecznościowych cechowały się obiekty publiczne - w przeciwieństwie do obiektów komercyjnych.

Część trzecia rozpoczyna się rozdziałem poświęconym upadkowi legendarnego biura podróży Thomas Cook, co niektórzy traktowali jako zapowiedź poważnych problemów dla turystyki w nadchodzących latach (nie wiedząc jeszcze, że ten kryzys będzie tak wielki, w skali globalnej i wywołany pandemia). Natalia Siwik podejmuje analizę działań związanych z zarządzaniem ryzykiem i zarządzaniem kryzysowym w oparciu o studium przypadku powyższego biura podróży. Rozdział drugi tej części monografii, autorstwa Kamila Pawłowskiego, skupia się na transporcie kolejowym - ze szczególnym uwzględnieniem dostępnych w Polsce transgranicznych połączeń kolejowych. Praca Ewy Iwaniuk ma charakter przeglądowy i dotyczy roli pracowników w modelu otwartych innowacji, które to zagadnienie, miejmy nadzieję, w czasach odbudowy turystyki po pandemii coraz częściej będzie identyfikowane i rozwijane. Joanna Paprzycka skupiła się w swoim 
tekście na analizie opinii przedstawicieli branży turystycznej na temat głównych aktów prawnych związanych $z$ tą branżą. Znaczenie dziedzictwa kulturowego dla rozwoju turystyki w regionie Gór Stołowych było przedmiotem badań podjętych przez Artura Żyto. W świetle ograniczeń w transporcie lotniczym oraz rosnącego zainteresowania turystyką krajową badania przedstawione w tym rozdziale wydają się zarówno bardzo aktualne, jak i ważne dla podmiotów mających wpływ na dziedzictwo tego obszaru. Część trzecią zamyka rozdział autorstwa Bartłomieja Łucia poświęcony znaczeniu infrastruktury sportowo-rekreacyjnej dla turystyki sportowej na przykładzie jednego z polskich miast.

Odbicie się turystyki po współcześnie obserwowanym kryzysie spowodowanym pandemią będzie na pewno mocno powiązane $z$ działalnością marketingową przedsiębiorstw oraz miejsc recepcji turystycznej. $\mathrm{Z}$ tego względu badania marketingowe wydają się ważnym obszarem tej monografii, co ma swoje odzwierciedlenie także $\mathrm{w}$ dużo większej różnorodności tematycznej i liczebności rozdziałów. Decyzje podróżnych związane z zakazem lotów w Polsce w okresie pandemii COVID-19 były przedmiotem rozważań Katarzyny Madras. Kontynuacją tej problematyki jest kolejny rozdział autorstwa Magdaleny Wawoczny poświęcony zmianom wielkości ruchu pasażerskiego transportu lotniczego pod wpływem pandemii. Dwa następne rozdziały skupiają się na badaniach aktywności turystycznej z perspektywy zachowań konsumentów. W rozdziale trzecim tej części książki Franciszek Bolechowski przedstawia socjodemograficzne determinanty aktywności turystycznej beneficjentów programu socjalnego Rodzina 500+. Aktywność turystyczna jest także punktem wyjścia badań przedstawionych przez Magdalenę Kosiada-Sylburską, która stawia pytanie, dlaczego odwiedzający muzea angażują się w przygotowywanie usług muzealnych. Przegląd determinant rozwoju turystyki i ich ocenę omówiła Agata Smyka, wskazując na najważniejsze z nich dla badanej gminy miejsko-wiejskiej. Zachowania turystów analizowała Alicja Chrabańska-Czerwińska, opierając się na danych dotyczących jednego z najbardziej znanych w naszym kraju górskich parków narodowych. Pozostając w tym samym obszarze geograficznym, Żaneta Zatorska przedstawiła opinie podróżujących na temat dziedzictwa kulinarnego Małopolski, wskazując jednoznacznie na najwyższą popularność wśród badanych respondentów oscypka i obwarzanka. Monografię kończy ważna z punktu widzenia radzenia sobie z pandemią problematyka zachowań wolnoczasowych obejmująca kwestie aktywności fizycznej ludzi młodych w czasach pandemii. Zagadnienie to omawiają Lukasz Szał i Weronika Terlecka.

Podsumowując przedstawioną powyżej tematykę, należy bardzo mocno podkreślić, że branża turystyczna jest oceniana jako najbardziej dotknięta wybuchem pandemii w całej gospodarce świata. Notowane na świecie spadki liczby turystów i tym samym generowanych przychodów $z$ turystyki na pewno mocno przełożą się na jakość życia wielu mieszkańców naszego globu. Nadchodzące zmiany w turystyce wymagają pilnego rozwoju aktualnych badań naukowych poświęconych funkcjonowaniu turystyki w tym szczególnym okresie pandemii, ale także w dłuższej perspektywie powrotu turystki do normalności jednocześnie bardziej innowacyjnej, zrównoważonej i dochodowej. 


\section{Literatura}

Benjamin S., Dillette A., Alderman D.H. (2020). "We can't return to normal": committing to tourism equity in the post-pandemic age. Tourism Geographies, 22 (3): 476-483.

Correa-Martínez C.L., Kampmeier S., Kümpers P., Schwierzeck V., Hennies M., Hafezi W., ... Mellmann A. (2020). A pandemic in times of global tourism: Superspreading and exportation of COVID-19 cases from a ski area in Austria. Journal of Clinical Microbiology.

DW (2021, March 6). WHO odrzuca planowane unijne paszporty szczepień. DeutscheWelle - Społeczeństwo (https://p.dw.com/p/3qIdE).

ETC (2021). European Tourism: Trends \& Prospects (Q4/2020). Brussels (www.etc-corporate.org).

Panasiuk A. (2020). Przyczynek do badań nad wpływem pandemii na stan gospodarki turystycznej. W: K. Nessel (red.), Turystyka w naukach społecznych. Instytut Przedsiębiorczości Uniwersytetu Jagiellońskiego, Kraków (www.ruj.uj.edu.pl).

UNWTO (2008). International Recommendations for Tourism Statistics 2008 (IRTS 2008). UN, UNWTO, New York-Madrid.

UNWTO (2019). International Tourism Highlights 2018 Edition. Madrid (https://doi. org/10.18111/9789284421152).

von Rohrscheidt A.M., Plichta P. (2020). Turystyka w czasach zarazy. Jak współczesne epidemie zmieniają turystykę kulturową? Turystyka Kulturowa, 2: 161-184.

Widomski M. (2020). Turystyka krajowa a pandemia.

Zaim S., Chong J.H., Sankaranarayanan V., Harky A. (2020). COVID-19 and Multiorgan Response. Current Problems in Cardiology, 45(8): 100618 (https://doi.org/10.1016/j. cpcardiol.2020.100618).

Zenker S., Kock F. (2020). The coronavirus pandemic. A critical discussion of a tourism research agenda. Tourism Management, 81: 104164. 


\section{Część 1. \\ Organizacja wydarzeń oraz rynek podróży służbowych}



Klaudia Skoczeń

Uniwersytet Ekonomiczny w Krakowie

klaudia.skoczen@interia.pl

\section{Koncepcja idei Slow Movement na przykładzie organizacji targów konsumenckich}

\section{Streszczenie}

Obecnie targi są jedną z popularniejszych form promocji oraz dotarcia do klienta. Jednak, tak jak i w przypadku innych dziedzin życia, nie omijają ich wpływy nowych ruchów czy trendy. Jednym z takich aspektów jest idea Slow Movement, której główną myślą przewodnią jest zmniejszenie tempa życia i skupienie się nie na ilości, a jakości - jej wpływy można odnaleźć m.in. na krakowskich targach. Celem pracy była analiza rozwoju poszczególnych aspektów idei Slow Movement oraz wpływu, jaki wywierają one na obecne wydarzenia. Metodą, którą wykorzystano w badaniach, były wywiady. Badania dotyczyły okresu pandemii, która także wpłynęła na organizację targów. Ich wyniki potwierdziły znaczenie idei Slow Movement w branży spotkań dla organizatorów i uczestników.

\section{Wprowadzenie}

Światowy konsumpcjonizm, który wpływa destrukcyjnie na planetę, objął już wszystkie dziedziny życia. Odpowiedzią na to jest koncepcja idei Slow Movement, która pokazuje, że żyjąc $\mathrm{w}$ inny sposób i w zgodzie z planetą, nadal można żyć na odpowiednim poziomie. Idea ta jest ciekawym i stosunkowo nowym nurtem, więc celem badania było sprawdzenie, czy nie do końca znany nurt potrafi przyciągnąć ludzi na targi konsumenckie, które są jedną z najlepszych metod dotarcia do klienta. Za pomocą wywiadów z twórcami wydarzeń sprawdzono rozmiar wpływu idei. W pierwszej części rozdziału znajduje się analiza genezy rozwoju poszczególnych aspektów idei Slow, które są istotne w kontekście wyników badań zaprezentowanych $\mathrm{w}$ drugiej części rozdziału. Znaczenie ma także okres 
pandemii, podczas którego przeprowadzono badania, gdyż wpłynął on na formę i organizację badanych targów.

\section{Przegląd literatury - geneza rozwoju Slow Life i Slow Food}

Rzeczy i usługi łatwo dostępne, odpowiednio tanie i, co najważniejsze, szybko dostarczane to cechy, jakich obecnie wymaga przeciętny konsument. W opozycji do tego sytuuje się Slow Movement, którego jednym z elementów jest Slow Life. Tak więc co kryje się za pojęciem Slow Life? Wbrew stereotypowemu myśleniu życie zgodne $z$ tą ideą nie oznacza ucieczki z miasta na wieś, by tam delektować się życiem - idea Slow charakteryzuje się brakiem narzucania presji. Zakłada życie $\mathrm{w}$ harmonii $z$ naturą oraz bycie bliżej tradycji, lokalnych rzeczy, autentyczności czy rzeczy zgodnych z zasadą fair. Slow Life związane jest $z$ wybieraniem zrównoważonej produkcji i konsumpcji, która respektuje lokalną różnorodność, szanując środowisko naturalne (Chung i in., 2018).

Ruch Slow Life wyrósł na kanwie ruchu Slow Food, którego początki to rok 1986. Wówczas to za sprawą Petriniego rozpoczął się bunt włoskich restauratorów, którzy gotując wolno, przeciwstawiali się dominacji McDonalds'a w gastronomii, oferującego nie tylko szybkie, ale i niezdrowe jedzenie. Jednocześnie przygotowywane slow food było tożsame z wykorzystaniem świeżych i naturalnych produktów z pominięciem półproduktów czy mrożonek, łącząc więc w sobie i przyjemność z jedzenia, i odpowiedzialność (Slow Food, 2020).

Trzy lata później podpisano dokument „Slow Food Manifesto”, który wskazywał, że szybkość prowadzi do degradacji świata. Lekarstwem na to miała być powolna i długa przyjemność smakowania jedzenia. Slow Food ma być alternatywą, zapewniającą lepszą jakość życia (Slow Food Manifesto, 1989).

Kolejne lata przyniosły ekspansję włoskiej idei na resztę świata. Organizacja Slow Food nie pozostawała jednak biernym obserwatorem świata - powstawały różne projekty, takie jak np. The Slow Food Presidia, który skupia się m.in. na podtrzymywaniu wysokiej jakości produkcji zagrożonej zanikiem. Idee Slow Food przybliżały ludziom także licznie organizowane targi czy światowe spotkania Terra Madre dla społeczności zaangażowanej w tę ideę.

Obecnie, po ponad dwóch dekadach działalności, ruch Slow Food reprezentuje całościowe podejście do żywności i żywienia, oddziałując jednocześnie na politykę, ludzi, kulturę i planetę - obejmując wiele projektów i miliony ludzi w 160 krajach (Slow Food, 2020).

Ruch Slow Food stał się więc podstawą całej idei Slow Movement, którą dzisiaj, oprócz wspomnianego na początku Slow Life, tworzy wiele odrębnych ruchów, wśród których najbardziej rozpoznawalne są m.in.:

- Slow Art \& Slow Art Day - jest to globalny ruch artystyczny, który zapoczątkował Terry, pragnący, by ludzie odwiedzający muzea nie działali w myśl zasady „zobaczyć, ile się da, aż do totalnego zmęczenia” (Morse, 2011), ale by poprzez spowolnienie mogli kontemplować sztukę, która doda energii, a nie zniszczy umysł (Bailey, 2019); 
- Cittaslow (Slow City) - jest to podejście dotyczące rozwoju gospodarczego miasta, oparte na budowaniu jego konkurencyjności z wykorzystaniem lokalnej tożsamości i dziedzictwa kulturowego - szczególnie istotne dla małych miast (Farelnik, 2018);

- Slow Business - polega na położeniu większego nacisku na rozwój z poszanowaniem pracowników, tak by nie doszło do ich wypalenia, co powoduje dużą rotację i ciągłą potrzebę budowania nowego zespołu (Stillman, 2012);

- Slow Tourism - składa się na to proste zakwaterowanie, zdrowa dieta, spokojniejsze tempo życia, lokalna kultura i duże poszanowanie natury (Matos, 2004).

W dalszych rozważaniach zostanie przybliżony szerzej jeszcze jeden odłam związany z ideą Slow Movement. Poznanie jego genezy i założeń będzie niezwykle istotne w kontekście późniejszego studium przypadku.

\section{Geneza rozwoju Slow Fashion}

Dziedziną, w której również rozwinął się ruch Slow, stając się jej ważnym aspektem, jest Slow Fashion. Jednak chociaż ten temat „przewijał” się na przestrzeni lat, stworzenie tego zwrotu przypisuje się Fletcher, która opublikowała na łamach „The Ecologist” artykuł, pokazujący, co Slow Fashion zapożycza ze wspomnianego ruchu Slow Food. Szybkość we współczesnej modzie stała się standardem, a trendy prezentowane na pokazach modowych następnego dnia można znaleźć w sklepach. Jednak w Fast Fashion chodzi nie tylko o szybkość dostarczania rzeczy, ale głównie o maksymalizację zysków, czego ofiarami stają się wykorzystywani pracownicy i zasoby naturalne (Fletcher, 2007).

Slow Fashion to zmiana ukierunkowania na jakość. To model produkcji wykorzystujący lokalne zasoby i tradycyjne metody, oferujący rzeczy wytwarzane na mniejszą skalę, jednak trwałe i klasyczne, więc niepodatne na sezonowe trendy. Często produkty te są droższe, determinuje to jednak świadomy wybór konsumentów, którzy kupując mniej, zużywają mniej zasobów (Fletch, 2010).

W 2014 r. Jung i Jin podjęli się próby zdefiniowania koncepcji Slow Fashion, definiując pięć czynników pokazujących paradygmaty rozwoju skali tego ruchu. Wyodrębnili oni:

- słuszność,

- autentyczność,

- funkcjonalność,

- regionalizm,

- wyłączność (ekskluzywność).

Wymiar słuszności dotyczy świadomości konsumentów na temat uczciwych praktyk w pracy, sprawiedliwego handlu, godziwego wynagrodzenia czy dobrego środowiska pracy. Wymiar autentyczności obejmuje uznanie konsumentów dla rękodzieła i odzieży wykonanej tradycyjnymi metodami. Z kolei wymiar funkcjonalności dotyczy trwałości rzeczy na przestrzeni czasu oraz ich wszechstronności. Regionalizm to wymiar odnoszący się do wspierania marek krajowych 
i doceniania wykorzystania lokalnych materiałów w produkcji. Nie dotyczy to tylko ludności wspierającej rodzime manufaktury, ale też sytuacji, gdy wybierana jest marka rodzima, nie światowa. Ostatni wymiar - wyłączność - ma związek z cenieniem przez konsumentów zakupów ekskluzywnej odzieży, edycji limitowanych lub rzadkich przedmiotów (Jung, Jin, 2014).

Aby idea Slow Fashion mogła w pełni trafić do konsumentów, konieczna jest zmiana ich postrzegania, poprzez pokazanie, że Fast Fashion niesie ze sobą tak samo dużo szkód dla organizmu i świata jak Fast Food.

\section{Targi - istota i charakterystyka}

W kontekście analizy przeprowadzonych badań ważne jest też poznanie terminologii związanej z zagadnieniem targów. Targi są jednym $z$ rodzajów turystyki biznesowej i według definicji Poland Convention Bureau to duże wydarzenia, mające dowolny temat przewodni, które odbywają się najczęściej w obiektach wystawienniczych (Raport..., 2020). Polska Izba Przemysłu Targowego, opierając się na definicji UFI, określa targi jako wydarzenie gospodarcze, kulturowe i społeczne, które służy rozwojowi przedsiębiorstw, promocji dóbr i usług oraz bezpośrednim relacjom międzyludzkim w biznesie, wpływają także na rozwój regionu i kraju. Targi są miejscem bezpośrednich spotkań, które odbywają się regularnie, $\mathrm{w}$ ramach zorganizowanego rynku, w odgórnie ustalonym terminie oraz trwają określony czas; uczestnikami są wystawcy oraz zwiedzający. Zadaniem targów jest umożliwienie wszystkim uczestnikom zaprezentowania wzorów produktów, towarów czy usług $\mathrm{w}$ celach ich promocji oraz dokonania transakcji handlowych w przyszłości (Słownik pojęć..., 2021).

Kalinowska-Żeleźnik i Sidorkiewicz (2010) definiują targi jako określoną i zorganizowaną formę rynku, gdzie dokonywane są zakupy na dużą skalę produktów $\mathrm{z}$ jednej lub wielu branż, $\mathrm{w}$ regularnych odstępach czasu, często $\mathrm{w}$ tym samym miejscu. Jednocześnie wskazane jest, że targi to pokazy, w trakcie których możliwe jest dokonanie transakcji, co tym samym pokazuje, że nie można zastępczo stosować określenia wystawy, gdyż dotyczą one tylko prezentacji dóbr i usług (Sidorkiewicz, 2006).

Szromnik (2014) podkreśla natomiast najważniejsze kwestie związane z targami, do których należy miejsce, spotkanie handlowe, zorganizowanie, regularność, okresowość oraz czasowa ograniczoność trwania. Miejsce, gdyż targi to ściśle określone miejsce o danych cechach urbanistycznych. Spotkanie handlowe dotyczy głównej funkcji targów, czyli handlu. Zorganizowanie - spotkanie jest zorganizowane poprzez m.in. ustalenie miejsca jego odbywania się czy harmonogramu wydarzenia. Regularność targów dotyczy powtarzalności w miejscu odbywania albo terminu. Okresowość z kolei oznacza określony czas trwania targów, który znają uczestnicy - trwają one z reguły od 2 do 7 dni. 
Przytoczone fragmenty literatury pokazują wielowymiarowość targów, które są obecnie jednymi z najchętniej organizowanych wydarzeń i należą do najbardziej popularnych i efektywnych form promocji dóbr i usług oraz dotarcia do klienta.

\section{Metodyka badań}

Celem badań była analiza wpływu idei Slow Movement na organizację targów konsumenckich w Krakowie. Postawiono następujące pytania badawcze: czy wpływ idei jest odczuwalny, jak się przejawia i jakie elementy oraz aspekty są najbardziej popularne, a które się nie przyjęły i jaki był tego powód. Aby jak najlepiej poznać wpływ badanej idei, przeprowadzono wywiady z twórcami dwóch targów konsumenckich.

Wykorzystaną metodą badawczą był wspominany kwestionariusz wywiadu, czyli według najogólniejszej definicji rozmowa kierowana, w której udział biorą minimum dwie osoby: badacz oraz respondent. Cały proces wywiadu opiera się na oddziaływaniu na osobę badanego poprzez stawianie pytań, które mają go tym samym skłonić do rozwiązania postawionego problemu badawczego (Sztumski, 1995).

W realizacji wymienionych uprzednio celów wykorzystuje się kwestionariusz - jest to spis pytań, celowo opracowany i ułożony. Pytania muszą być trafne i rzetelne. Trafność to zdolność do mierzenia danej cechy, aby wartość, która została uzyskana, była jak najbardziej rzeczywista. Z kolei rzetelność oznacza dokładność i stałość czy powtarzalność pytań w kwestionariuszu. Prawidłowo przygotowany kwestionariusz powinien składać się z dobrze dobranych pytań, zarówno pod względem ich liczby, treści, formy, jak i kolejności. Niezwykle istotne jest, aby pytania odnosiły się bezpośrednio do celu badania. Liczba pytań nie może być ani zbyt duża, gdyż może to przytłoczyć badanego, ani zbyt mała, bo nie pozwoliłoby to rozwinąć badanego zagadnienia w pełni (Żelazo, 2013).

Do zalet wywiadu jako metody badawczej można zaliczyć m.in.: zdolność do pełniejszego zrozumienia respondenta; możliwość wspomagania środkami wizualnymi; możliwość zadawania bardziej skomplikowanych pytań; nawiązanie dobrych relacji między badaczem i badanym (wpływa korzystnie na jakość i ilość zebranych informacji). Z kolei wady kwestionariusza wywiadu to m.in.: wysokie koszty; wymagane przeszkolenie ankieterów; trudność w zadawaniu pytań osobistych; jeśli wywiady są przeprowadzane w losowych miejscach, muszą być dobrze zaplanowane, aby próba badawcza była reprezentatywna (Hill, Alexander, 2003).

Kwestionariusz wywiadu to jedna z najpopularniejszych metod badawczych. Cechą szczególną jest bezpośredni kontakt badacza z respondentem, co pozwala lepiej zagłębić się w temat. 


\section{Wyniki badań}

Wywiady miały na celu przybliżenie, jak idea Slow działa na branże spotkań. Aby poznać, jak to wygląda od podstaw, przeprowadzono wywiady z:

- Karoliną Kiepas, która odpowiada za Ekotyki, czyli Targi Kosmetyków Naturalnych, które odbywają cyklicznie zarówno w Krakowie, jak i Katowicach;

- Mateuszem Kaczanem, który wraz z Izabelą Chyłek jest twórcą Kiermashu, czyli Krakowskich Targów Mody Niezależnej i Dizajnu, które od 2014 r. odbywają się w Krakowie.

Z powodu czynników zewnętrznych (pandemia) wywiady przeprowadzono na początku stycznia 2021 r. w sposób zdalny. Zadano 13 pytań otwartych, do których odpowiedzi omówiono poniżej.

Pierwsze pytanie dotyczyło pomysłu na powstanie targów tego typu. W przypadku Kiermashu pomysł narodził się niejako z potrzeby i braku wydarzenia targowego, które byłoby nakierowane głównie na modę. Mateusz Kaczan przed poznaniem Izabeli Chyłek (wspólniczki i drugiego organizatora Kiermashu) współtworzył niewielką krakowską markę odzieżową, stąd posiadał doświadczenie związane z polskimi i światowymi imprezami targowymi. U podłoża decyzji o zrobieniu jednego wydarzenia dotyczącego mody leżała również chęć zobaczenia, czy Kraków „ma ochotę” kupować od polskich i niezależnych projektantów. W przypadku Ekotyków organizowane targi są wynikiem obserwacji Karoliny Kiepas odnoszących się do trendów konsumenckich i reakcji na nie. Twórczyni była też uczestnikiem różnych wydarzeń kulturowych i targowych i zauważyła duży wzrost zainteresowania kosmetykami naturalnymi i akcesoriami zero waste. Mając wieloletnie doświadczenie w organizowaniu targów niszowych, w 2016 r. postanowiła zrealizować wydarzenie, które będzie stricte dedykowane wyłącznie tej branży.

Kolejne pytania dotyczyły zmiany w koncepcji Slow na przestrzeni realizacji kolejnych edycji oraz cech wydarzeń, które są z nią związane. W przypadku obu wydarzeń koncepcja od początku była taka sama - w ramach Kiermashu wszystkie imprezy polegały prawie wyłącznie na wystawianiu się polskich projektantów i rzemieślników tworzących modę i dizajn użytkowy, więc idea Slow była widoczna zawsze. Widać to także w doborze i selekcji wystawców, gdyż zapraszane są jedynie małe niezależne marki, wytwarzające lub projektujące w Polsce w duchu lokalności. Tak samo jest podczas Ekotyków, na których prezentowane są najlepsze polskie marki kosmetyków naturalnych oraz te dystrybuowane w Polsce dla szerokiej publiczności, na targach stacjonarnych, gdzie wejście jest zawsze za darmo.

Następnie poruszono kwestie obszarów i aspektów najbardziej popularnych i przyciągających najwięcej ludzi. Czynnikiem, który według twórców najbardziej przyciąga odwiedzających, są wystawcy i ich odpowiednia selekcja, także termin targów ma duże znaczenie - edycje świąteczne zawsze są najliczniej odwiedzane (w przypadku Kiermashu). Karolina Kiepas potwierdza to, dodając, że magnesem są też promocje, które oferują wystawcy, nowości, właśnie podczas targów mające premiery, czy wreszcie możliwość poznania twórców. By jeszcze uatrakcyjnić Ekotyki, we współpracy z partnerami tworzone są panele dyskusyjne, dotyczące 
m.in. trendów, zero waste czy świadomego dbania o siebie, oraz warsztaty dla uczestników.

Jeśli chodzi o aspekty i obszary, które się nie przyjęły, to zarówno Mateusz Kaczan, jak i Karolina Kiepas nie potrafili nic konkretnego wskazać, gdyż obie koncepcje wydarzeń od początków zostały dobrze przyjęte.

Poruszono także kwestie działalności konkurencyjnej targów w tym zakresie w Polsce. Twórca Kiermashu tak przedstawił sytuację - na terenie kraju jest co najmniej kilka ekip, które tworzą podobne wydarzenia. Jeszcze parę lat temu różne ekipy robiły imprezy targowe w różnych miastach, ale na ten moment wszyscy skupiają się na organizacji wydarzeń w „swoich miastach”. Oczywiście Warszawa ma kilka tego typu wydarzeń, ale pozostałe miasta, takie jak Kraków, Gdańsk, Katowice czy Wrocław, skupiają się raczej na swoim terenie. W przypadku Ekotyków w południowej Polsce, tam gdzie one się odbywają (Kraków, Katowice), nie ma żadnej dużej imprezy dla tej branży. W reszcie kraju obecnych jest kilka innych eventów, ale wydarzenia się nie pokrywają i „nie wchodzą sobie w drogę" - miejsca w Polsce jest wystarczająco dla wszystkich. Jednak, jak pokazują głosy uczestników, odczuwalny jest brak tego typu wydarzeń w mniejszych miastach.

Poruszono także kwestie promocji wydarzenia w kontekście idei Slow. Organizatorzy Kiermashu starają się jak najlepiej promować świadome podejście do konsumpcji na poziomie mody i dizajnu. Jeśli chodzi o promocję targów w kontekście idei Slow Movement, to promocja wygląda podobnie jak promocja jakiegokolwiek innego wydarzenia - jest to skupienie wokół narzędzi social mediów, a także miejskich nośników reklamowych. Z kolei Ekotyki nie promują się stricte pod hasłem Slow Movement, nie chcąc się ograniczać tylko do niszowej grupy - celem jest, aby wiedza o naturalnej pielęgnacji była łatwo dostępna dla całych rzesz osób, zaineresowanych kosmetykami naturalnymi i alternatywnymi produktami.

Kolejne pytania dotyczyły ścieżek rozwoju targów po pandemii oraz jakie znaczenie może zyskać idea Slow w branży targowej. Mateusz Kaczan wierzy, że zarówno klienci, jak i wystawcy będą stęsknieni za takimi wydarzeniami i jeszcze chętniej będą odwiedzać imprezy targowe w nurcie Slow, wspierając tym samym lokalnych przedsiębiorców. Jednak nie przewiduje on dużego wzrostu znaczenia imprez targowych Slow. Niejako w opozycji staje Karolina Kiepas, według której idea Slow w branży targowej może stać się popularnym, powszechnym sposobem życia. Świadomość ekologiczna w Polsce rośnie, podobnie szybko jak grono osób poszukujących naturalnych, zdrowych kosmetyków i środków czystości - pandemia tego nie zatrzymała. Dodaje, że Ekotyki czekają na powrót targów w formie stacjonarnej, gdyż wersja online tego nie zastąpi. Jednocześnie formuła wirtualna nie zostanie całkiem porzucona, gdyż pomaga szerzyć idee Ekotyków na całą Polskę i promować lokalne marki w szerszy sposób.

Głównym aspektem hamującym ludzi przed życiem/zakupami w duchu Slow Movement jest według twórcy Kiermashu fakt, że globalny konsumpcjonizm kieruje się przede wszystkim niską ceną, więc „CCC - cena czyni cuda”. Twórczyni Ekotyków dodaje, że wpływa na to również stereotyp, iż kosmetyk naturalny to ten droższy i mniej wydajny niż drogeryjny. Uchodzi też nadal za trudniej dostępny. 
Analizując oba wydarzenia $\mathrm{w}$ liczbach, można stwierdzić, że $\mathrm{w}$ przypadku Kiermashu (w zależności od edycji) liczba wystawców waha się w przedziale 50200, sprzedana powierzchnia targowa jest ściśle uzależniona od budynku, gdzie odbywa się wydarzenie, więc przedział wynosi $500-2500 \mathrm{~m}^{2}$, a jeśli wziąć pod uwagę liczbę uczestników, jest to 2000-8000 uczestników w trakcie całego weekendu. Natomiast Ekotyki w liczbach to w czasie 2-dniowych targów w Krakowie około 120 wystawców, a podczas 1-dniowych targów w Katowicach - około 100. Wynajmowana przestrzeń eventowa ma minimum $1200 \mathrm{~m}^{2}$ i jest całkowicie wypełniona wystawcami. Szacunkowe obliczenia pozwalają stwierdzić, że 1 dzień targowy przyciąga zazwyczaj od 8000 do 10000 odwiedzających.

Analiza obu wywiadów pokazała, że idea Slow zarówno w przypadku Kiermashu, jak i Ekotyków stała u podstaw ich powstania. Właśnie to, że oba wydarzenia skupiają wystawców działających $\mathrm{w}$ duchu tej idei, jest ich głównym atutem. Nieznaczne różnice widać tylko w podejściu twórców do promocji w kontekście idei Slow Movement oraz znaczeniu idei w branży targowej. Niemniej jednak liczby odwiedzających Kiermash i Ekotyki wskazują, że takie wydarzenia bez wątpienia mają sens i są ważne dla wielu konsumentów.

\section{Zakończenie}

Badania wykazały, że idea Slow Movement leży u podstaw organizacji pokazanych targów konsumenckich i jest silnym magnesem przyciągającym odwiedzających. Organizatorzy widzą, że to właśnie oferowana przez wystawców lokalność stanowi o sile wydarzenia. Oczywiście badania nie dają pełnego obrazu, więc kolejnym krokiem powinno być przeprowadzenie ich wśród uczestników wydarzeń. Niemniej jednak targi konsumenckie organizowane w koncepcji Slow Movement to eventy, których rozwój należy bacznie obserwować, ponieważ są alternatywą dla globalnego konsumpcjonizmu.

\section{Literatura}

Bailey A. (2019). Slow art? It will 'blow your mind' (https://www.bbc.com/news/entertainment-arts-4769900; dostęp: 29.12.2020).

Chung J.Y., Kim J.S., Leeb C.-K., Kim M.J. (2018). Slow-food-seeking behaviour, authentic experience, and perceived slow value of a slow-life festival. Current Issues in Tourism, 21(2): 123-127.

Farelnik D.E. (2018). Idea slow jako wyznacznik działań rewitalizacyjnych podejmowanych na obszarach miejskich. Metropolitan, 1(9): 19-27.

Fletch K. (2010). Slow Fashion: An Invitation for Systems Change. Fashion Practice, 2(2): 259-266.

Fletcher K. (2007). Slow fashion. The Ecologist (https://theecologist.org/2007/jun/01/ slow-fashion; dostęp: 2.12.2020).

Hill N., Alexander J. (2003). Pomiar satysfakcji i lojalności klientów. Oficyna Ekonomiczna Grupa Wolters Kluwer, Kraków. 
Jung S., Jin B. (2014). A theoretical investigation of slow fashion: sustainable future of the apparel industry. International Journal of Consumer Studies, 38(5): 510-519.

Kalinowska-Żeleźnik A., Sidorkiewicz M. (2010). Meeting planning jako narzędzie wspomagające realizację produktów turystyki konferencyjnej. Zeszyty Naukowe Uniwersytetu Szczecińskiego, Ekonomiczne Problemy Turystyki, 568(13): 9-20.

Matos R. (2004). Slow Tourism: An Anidote to Speed and a Promising Niche. W: K. Weiermair, C. Mathies (red.), The tourism and leisure industry: Shaping the future. Haworth Hospitality Press, New York, s. 95-96.

Morse T. (2011). Slow Down, You Look Too Fast (https://www.artnews.com/art-news/ news/slow-down-you-look-too-fast-391/; dostęp: 29.12.2020).

Raport 2020. Przemysł spotkań i wydarzeń w Polsce (2020). Poland Convention Bureau, Polska Organizacja Turystyczna, Warszawa.

Sidorkiewicz M. (2006). Turystyczny przemysł wystawienniczy jako nowoczesny instrument przekazu informacji turystycznej. Zeszyty Naukowe Uniwersytetu Szczecińskiego, Ekonomiczne Problemy Turystyki, 429(7): 246-247.

Slow Food (2020). Our history (https://www.slowfood.com/about-us/our-history; dostęp: 21.11.2020).

Slow Food Manifesto (1989)(https://slowfood.com/filemanager/Convivium\%20Leader\%20Area/Manifesto__ENG.pdf; dostęp: 21.11.2020).

Słownik pojęć branży targowej (2019). Polska Izba Przemysłu Targowego, Poznań.

Stillman J. (2012). Slow Business: The Case Against Fast Growth (https://www.inc. $\mathrm{com} /$ jessica-stillman/slow-business-fast-growth-is-not-good-for-the-company.html; dostęp: 29.12.2020).

Szromnik A. (red.) (2014). Targi w gospodarce rynkowej. edu-Libri, Kraków-Legionowo.

Sztumski J. (1995). Wstęp do metod i technik badań społecznych. Wydawnictwo „Śląsk”, Katowice.

Żelazo M. (2013). Kwestionariusz wywiadu jako narzędzie badawcze. Obronność, Zeszyty Naukowe Wydziału Zarządzania i Dowodzenia Akademii Obrony Narodowej, 2(6): 222-238.

\section{Slow Movement concept on the example of organization consumer trade fair}

Currently fairs are one of the most popular forms of promotion and reach out to clients. However, as other areas of life, they are influenced by new trends, for example Slow Movement, which means - people choose quality not quantity. The aim of the article was to analyse the development of the various aspects of slow movement ideas and the impact they have on current events. The method used in the research was interviews. The research focused on pandemic period, which also affected the organization of the trade fair. The results of the slow movement ideas are important for organizers and participants. 



\section{Weronika Stabosz}

Uniwersytet Jagielloński

w.a.slabosz@gmail.com

\section{Konwenty fanów w Polsce jako przykład eventów}

\section{Streszczenie}

Konwenty fanów w Polsce odbywają się już od przeszło 50 lat. Przez cały ten czas rozwijały się, zachowując jednak formę kilkudniowego eventu, od małych rozmiarów do ogromnych wydarzeń, odbywających się w kompleksach targowo-wystawienniczych. Praca przedstawia konwenty organizowane w Polsce, klasyfikuje je jako przykład turystyki eventowej oraz porównuje założenia i cele tych spotkań z założeniami eventów według Getza $(1998,2008)$. Badania wśród uczestników przeprowadzono w formie ankiet i dotyczyły one uczestnictwa w konwentach. Uzyskano wynik wskazujący na występowanie korzyści innych niż te, które opisywał Getz: głównym celem konwentów nie jest korzyść majątkowa czy biznesowa, a społeczna (przynależność do grupy fanów, kontakty z innymi) i kulturalna.

\section{Wprowadzenie}

Analiza konwentów jako przykładu turystyki eventowej jest nowością w badaniach geograficznych. Do tej pory spotkania te oraz ich wpływ na społeczeństwo były analizowane głównie w socjologii (przynależność do grupy fanów, zjawisko cosplayu i jego odbiór) oraz kulturoznawstwie i literaturoznawstwie (badania czytelnictwa wśród konwentowiczów, opisy poszczególnych środowisk, np. graczy).

$\mathrm{Z}$ uwagi na powyższe oraz wieloletnie badania $\mathrm{w}$ formie obserwacji uczestniczącej, prowadzone przez autorkę, celem rozdziału jest opisanie tego zjawiska jako przykładu turystyki eventowej. Aby go osiągnąć, przeprowadzono badania $\mathrm{w}$ formie ankietowej, a przez trwającą pandemię wykonano je za pośrednictwem formularza Google. Formularz zawierał pytania odnoszące się zarówno do treści 
związanych stricte $z$ konwentami, jak i tych ewidentnie wskazujących na elementy turystyczne. Wyniki przeanalizowano, porównano w formie tabel przestawnych oraz dokonano analizy poszczególnych odpowiedzi.

Praca składa się ze streszczenia, wprowadzenia, opisu konwentów, porównania ich z pracą Getza oraz opisu badań i wniosków z analiz.

\section{Przegląd literatury}

Jak wspomniano, zakres badań nad konwentami w Polsce ogranicza się głównie do prac socjologicznych (Kaszkowiak, 2015), literaturoznawczych (Guttfeld i in., 2013) czy kulturoznawczych (Czerniuk, 2012). Analizy spotkań fandomowych oparto jednak na pracy Getza $(1998,2008)$. Same informacje na temat konwentów, ich funkcjonowania oraz historii podano w oparciu o publikację Pindla (2019). Opracowanie to jest zbiorem wspomnień i wywiadów z osobami organizującymi te spotkania. Uzupelniające dane pochodzą z wieloletnich obserwacji i rozmów autorki z uczestnikami konwentów w różnych miastach.

\section{Podstawowe pojęcia związane $z$ tematyką badań}

Społeczność fandomowa komunikuje się pomiędzy sobą za pomocą charakterystycznego slangu. Aby zrozumieć tę grupę, poniżej wyjaśniam słownictwo najczęściej przez nią używane:

1. Konwent, $z$ ang. convention, spotkanie fanów szeroko pojętej fantastyki. Zaliczają się do niego imprezy typu stricte konwentowego, ale także targi książek, niektóre konferencje czy mistrzostwa e-sportowe.

2. Fandom, czyli społeczność fanów fantastyki. Można uważać za fandom zarówno wszystkich fanów, jak i poszczególne, małe ugrupowania, tworzące własny fandom (np. Fani Harry'ego Pottera, potocznie zwani Potterheads).

3. Fantasta, potoczne określenie na fana fantastyki, szczególnie zachodniej.

4. Otaku, japońskie negatywne określenie na maniakalnego fana, w społeczności europejskiej i amerykańskiej przyjęło się jako określenie fana popkultury azjatyckiej, szczególnie japońskiej ( $\mathrm{z}$ uwagi na rozpowszechnienie anime, czyli animacji na podstawie japońskich komiksów: mang).

5. RPG, $z$ ang. role-play game, gra papierowa, w której gracze odgrywają postacie, a mistrz gry (GM, Game Master) „opowiada" ich historię i prowadzi ją w oparciu o dany system gry (np. Dungeons \& Dragons).

6. LARP, $z$ ang. live action role play, czyli zabawa polegająca głównie na odgrywaniu postaci w czasie rzeczywistym z rekwizytami, strojami i makietami. Gry te często funkcjonują na podstawie określonego uniwersum $z$ własnymi zasadami, historią itp.

7. Cosplay, $z$ ang. costume playing, forma zabawy w przebieranie się oraz odgrywanie postaci z popkultury. Na konwentach często organizowane są konkursy cosplay różnej rangi, także eliminacje do konkursów międzynarodowych. 


\section{Turystyka eventowa}

Pojęcie turystyki eventowej zostało wprowadzone przez Getza (1998) jako rodzaj turystyki skupiający się na uczestnictwie w wydarzeniach. Wskazuje on, że jest to typ turystyki łączący tradycyjne podejście nauk o turystyce i zarządzania branżą turystyczną z zarządzaniem i organizacją imprez masowych (Getz, 2008). Oczywiście istnieje wiele rodzajów eventów, każdy skupiający się na nieco innych korzyściach; do najważniejszych należą imprezy kulturalne (festiwale, imprezy religijne), polityczne (np. związane z rodzinami królewskimi czy wizytami urzędników państwowych), artystyczne (koncerty i występy), biznesowe (targi, spotkania biznesowe), naukowe (seminaria, kongresy), sportowe i związane z rekreacją (mistrzostwa sportowe profesjonalistów i amatorów) oraz wszelkie imprezy prywatne (Getz, 2008).

Jak sam Getz (2008) zaznacza, jednym z pierwszych czynników, który został dogłębnie zbadany w kontekście turystyki eventowej i studiów związanych z eventami, były korzyści ekonomiczne z takich wydarzeń. Szczególnie odnosiło się to do mega eventów, takich jak np. olimpiady, które faktycznie wywierały ogromny wpływ na miejsce, w którym się odbywały. Mając to na uwadze, wskazuje on, że często zdarza się, iż władze i inwestorzy skupiają się tylko na eventach przynoszących namacalne korzyści, ignorując mniejsze festiwale, szczególnie te lokalne lub o tematyce nieskoncentrowanej na zagadnieniach z możliwym potencjalnym zyskiem (Getz, 2008). Inne badania także mniej lub bardziej skupiają się na korzyściach finansowych, szukając modelu turysty eventowego, jego motywacji oraz sposobów na przyciągnięcie go na takie wydarzenie, a co za tym idzie - zwiększenie zysku z organizacji eventu (Getz, 2008). Z powodu skupienia na zagadnieniach ekonomicznych w badaniach nad eventami często pomija się korzyści niematerialne, które też mogą być ważną, a niekiedy główną przyczyną przyjazdu turysty na wydarzenie.

\section{Konwenty w Polsce: historia i charakterystyka}

Konwenty, czyli spotkania fandomu, pojawiły się w Polsce w latach 70. XX w. $\mathrm{Z}$ racji panującego wówczas systemu komunistycznego, który walczył z napływem zachodniej literatury, spotkania te miały kameralną, zamkniętą formę i odbywały się w gronie znajomych należących zazwyczaj do jednego klubu fantastyki w małych salkach lub mieszkaniach prywatnych. Obawiano się wówczas głównie konfliktu z władzą, wywołanego nielegalnym rozprowadzaniem i kopiowaniem literatury fantastycznej, często spoza kraju (Pindel, 2019). Z czasem konwenty wykształciły formę podobną do amerykańskich spotkań: otwartą i ogólnodostępną o często sporych rozmiarach. Odbywały się w domach kultury i szkołach, a najpopularniejsze, których liczba uczestników szybko rosła, zaczęły szukać nowych lokalizacji, mogących pomieścić wszystkich fanów. Największe imprezy tego typu w kraju, takie jak Pyrkon, Magnificon czy Falkon, odbywają się na terenie obiektów targowych (kolejno Międzynarodowe Targi Poznańskie, Kraków EXPO oraz 
Targi Lublin), a inne, np. Niucon, na terenie kampusu uniwersyteckiego (Uniwersytet Przyrodniczy we Wrocławiu, obecnie zrezygnowano z tej lokalizacji). Są również spotkania w lokalizacjach nietypowych, często motywowanych tematem przewodnim konwentu. Przykładowo niektóre spotkania LARP-owe odbywają się na zamkach, w ruinach czy na terenach zielonych.

Obecnie w Polsce organizuje się średnio od 30 do ponad 50 imprez tego typu, każda o tematyce bliżej lub dalej związanej z fantastyką. W ogólnym pojęciu fanów konwenty dzielą się głównie na fantastyczne (związane $z$ fantastyką zachodnią) oraz azjatyckie, potocznie zwane mangowymi (od mangi, japońskiego komiksu), które także reprezentują fantastykę, lecz często nawiązują również do kultury i sztuki krajów azjatyckich (Japonii, Korei, Chin, czasami innych). Poza nimi występują też konwenty mieszane, w których coś dla siebie znajdzie zarówno typowy fantasta, jak i otaku (tab. 1).

Tabela 1. Podział konwentów

\begin{tabular}{lll}
\hline $\begin{array}{c}\text { Typ konwentu } \\
\text { (temat nadrzędny) }\end{array}$ & \multicolumn{2}{c}{ Podział niższego rzędu (przykład) } \\
\hline Mangowy & Anime (Magnificon EXPO) & Kulturowy (Hinamatsuri) \\
Fantastyczny & Literacki (targi książki); & RPG-owy i gier planszowych \\
& komiksowy (Poznański Festiwal & (Lajconik); LARP (OldTown) \\
Mieszany & Sztuki Komiksowej) & Tematyczny, np. świąteczny \\
& All-in-one (Pyrkon) & (Xmas Time) \\
\hline
\end{tabular}

Źródło: opracowanie własne.

Spotkania te organizowane są cyklicznie w podobnym okresie roku przez grupę, którą najczęściej są kluby fantastyki czy organizacje non profit, działające aktywnie w danym mieście lub rejonie. Kierują się one zasadą „od fanów dla fanów”, co można w prosty sposób przenieść na formę tych spotkań: w znaczącej większości konwenty są imprezami nieprzynoszącymi żadnego zysku w sensie ekonomicznym, a wpływy z biletów i atrakcji przeznaczane są na organizację obecnej lub następnej edycji imprezy. Działa to także w drugą stronę: jeżeli uczestnik chce, może pomóc $\mathrm{w}$ organizacji takiej imprezy jako prelegent, helper (określenie na pomocnika organizacji, zajmującego się głównie pracami porządkowymi) czy osoba $z$ tzw. patrolu konwentowego lub patrolu pokojowego (określenie przeniesione z Pokojowego Patrolu Wielkiej Orkiestry Świątecznej Pomocy: zespołu przeszkolonych ochroniarzy, pilnujących porządku na imprezie w ramach wolontariatu), za co najczęściej w formie zapłaty otrzymuje darmową wejściówkę lub zniżkę. Widać jednak, że granica dzieląca organizatora i uczestnika jest bardzo cienka lub właściwie nie występuje; wielu organizatorów bierze udział w atrakcjach własnego konwentu jako uczestnicy, a uczestnik, jak wspomniano, może sam współtworzyć konwent. Obaj więc nie otrzymują wynagrodzenia lub korzyści ekonomicznych, gdyż robią to na zasadzie wolontariatu.

Wiadomo jednak, że imprezy jakiegokolwiek rodzaju przynoszą zyski, podobnie jest więc $z$ konwentami. Uczestnicy poza przejazdami i noclegiem zawsze 
wydają pieniądze w sklepach w danej miejscowości, często nie tylko w tych zapewniających żywność i artykuły pierwszej potrzeby, ale także w sklepach z pamiątkami czy muzeach; część uczestników łączy bowiem wyjazd na konwent ze zwiedzaniem miasta, zwłaszcza gdy jest to miasto ciekawe historycznie i kulturowo. Miejscowości czerpią więc pośrednie zyski z przyjazdu konwentowiczów, czasami „odwdzięczając się” im w postaci dodatkowych atrakcji czy udogodnień (tu przykładowo miasto Poznań umożliwiło darmowy przejazd komunikacją miejską w trakcie trwania festiwalu Pyrkon). Mamy więc do czynienia z zyskiem, nie jest to jednak główny cel przyjazdu na imprezy fandomowe.

Spotkania fandomowe najliczniej występują na południu i w centrum kraju w największych ośrodkach miejskich (Warszawa, Wrocław, Kraków, Poznań) oraz w małych gminach, często o statusie wsi lub małych miast, w których jest to próba zaistnienia małych społeczności fanów i aktywizacji młodszych mieszkańców (np. Głuchów w województwie łódzkim, Chojnice w województwie pomorskim).

Imprezy te często mają wieloletnią tradycję. Za najstarszy polski konwent uznaje się Polcon, który funkcjonuje od 1985 r. Czerpie on pomysły od zagranicznych konwentów, zarówno jeżeli chodzi o tematykę (szeroko pojęta fantastyka), jak i formę (impreza „wędrująca”, rokrocznie zmieniająca miasto i organizatora). Jest to model znany z Worldconów i Euroconów. Jednak to nie Polcon uznaje się w społeczności fanów za najważniejszy konwent w kraju. Tytuł ten przypada Pyrkonowi, a właściwie Festiwalowi Fantastyki Pyrkon, który od roku 2000 odbywa się w Poznaniu z inicjatywy Klubu Fantastyki Druga Era. Impreza ta odniosła niesamowity sukces, już na pierwszej edycji przyciągając około 500 uczestników (dla porównania inne konwenty podczas pierwszej edycji mogą obecnie zebrać minimalnie zaledwie kilkudziesięciu uczestników). Dziś, gdy impreza odbywa się na terenie Międzynarodowych Targów Poznańskich, uczestników zależnie od źródła danych może być nawet ponad 50 tys. Pyrkon urósł więc nie tylko rangą, ale i rozmiarami, otwierając się na uczestników i gości z zagranicy, przez co jest obowiązkowym przystankiem na konwentowej mapie Polski. Jest też niepowtarzalny ze względu na różnorodność programu, co uwydatnia zróżnicowanie zainteresowań fanów fantastyki oraz ich otwartość na nowości. Program, poza tradycyjnymi prelekcjami i konkursami związanymi z fantastyką, obfituje co roku w wydarzenia kulturowe (pokazy teatralne, muzyczne, modowe) czy naukowe (wystawy naukowe, prelekcje; w przypadku Pyrkonu mówimy tu głównie o współpracy z Uniwersytetem im. Adama Mickiewicza, w przypadku innych konwentów są odpowiednio inne, lokalne uczelnie). Również tematyka prelekcji na różnych konwentach może z fantastyki płynnie przechodzić od nauk ścisłych (technika, inżynieria, rozwój człowieka), przez kulturę (teatr, sztuka, literatura), do zagadnień humanistycznych, socjologicznych i światopoglądowych (socjologia, historia świata, kultura regionów, zagadnienia seksualności człowieka i LGBT). Widać więc, że spotkania te nie skupiają się tylko na czytaniu komiksów i kłótniach grup fanów Marvela i DC, a na integracji i poznawaniu nowych rzeczy. 


\section{Metodyka badań}

Aby zrealizować cele badawcze pracy, przeprowadzono anonimową ankietę, początkowo planowaną $\mathrm{w}$ formie tradycyjnej, jednak $\mathrm{w}$ związku $\mathrm{z}$ pandemią COVID-19 ostatecznie wykorzystano formularz Google. Ankieta miała formę mieszaną, z pytaniami otwartymi i zamkniętymi, pojedynczego i wielokrotnego wyboru. Wraz z metryczką zawierała ona 22 pytania i odbyła się na przełomie października i listopada 2020 r. Dzięki rozpowszechnieniu jej na grupach fanów na Facebooku, ostatecznie uzyskano 848 odpowiedzi z całego kraju.

Pytania w większości miały charakter jakościowy (opisy, wybór odpowiedzi przygotowanych przez autorkę), uniemożliwiło to więc niektóre typy analiz. $Z$ tej racji zdecydowano się na zestawienie danych w postaci tabel przestawnych oraz wizualizację wyników w formie tradycyjnych wykresów, ukazujących zróżnicowanie odpowiedzi w zależności od różnych czynników (wiek, płeć, pochodzenie, wykształcenie i inne). Do analizy wyników wykorzystano także obserwację i obserwację uczestniczącą autorki oraz rozmowy (wywiady) przeprowadzone w ciągu wielu lat podczas różnych konwentów w Polsce.

\section{Wyniki badań}

Wśród 848 respondentów ankiet większość stanowily kobiety (68,28\% przy $31,72 \%$ mężczyzn). Najliczniejszą grupą były osoby w wieku $17-21$ lat (46,34\%) i 22-30 lat (34,55\%). Z grup społecznych najwięcej było studentów lub absolwentów uczelni wyższych (ryc. 1). Można więc zauważyć, że głównymi odbiorcami tych imprez są osoby młode, w trakcie lub zaraz po studiach.

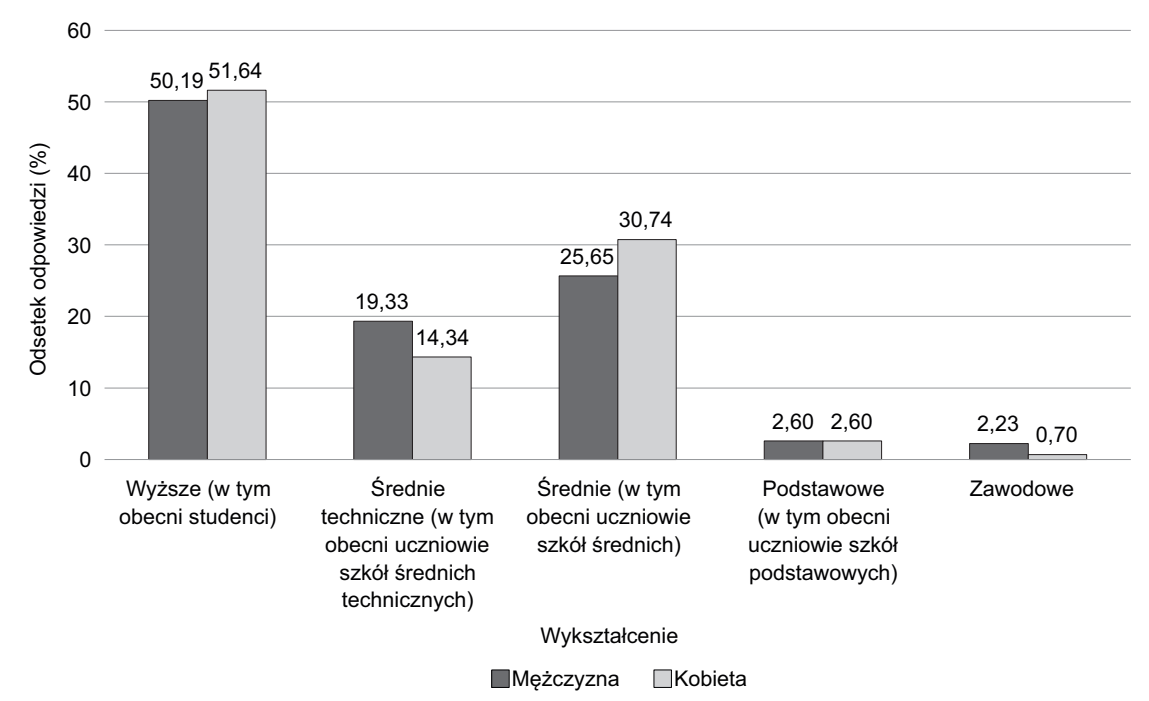

Ryc. 1. Wykształcenie respondentów z podziałem na płeć

Źródło: opracowanie własne. 
Wśród respondentów zdecydowanie przeważyły osoby mieszkające w miastach powyżej 500000 mieszkańców, takich jak Poznań (tutaj wynik jasny z powodu umieszczenia ankiety na grupie fanów Pyrkonu), Wrocław, Szczecin, Trójmiasto, Łódź, Kraków i Warszawa.

$\mathrm{W}$ ankiecie zawarto również pytania o zagadnienia związane z korzystaniem $z$ bazy noclegowej oraz infrastruktury transportowej (ryc. 2). Uczestnicy najczęściej korzystali z transportu kolejowego oraz z samochodów prywatnych. Sporo osób, bo prawie $10 \%$ respondentów, nie wyjeżdża na konwenty poza miejscowość swojego zamieszkania. Znacząca większość jednak jest gotowa opuścić miejsce zamieszkania, żeby móc uczestniczyć w konwencie.

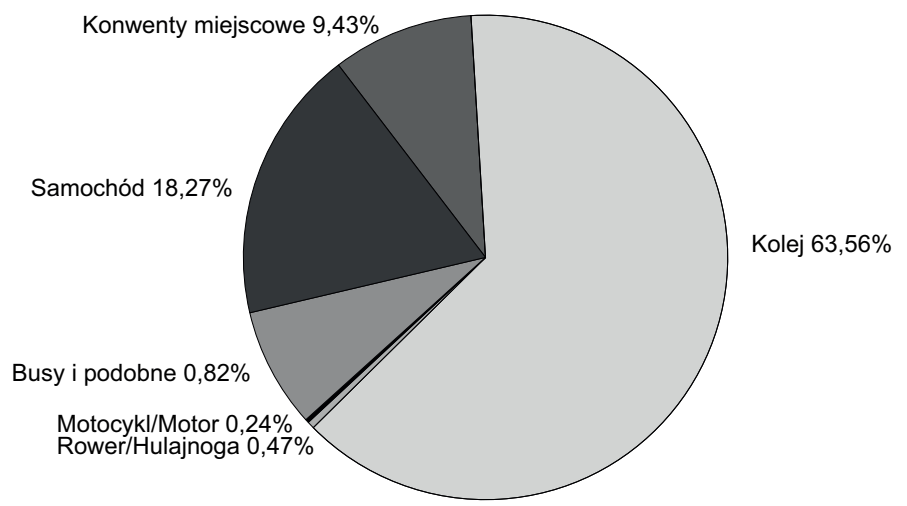

Ryc. 2. Środek transportu wybierany przez uczestników konwentów Źródło: opracowanie własne.

Na każdym konwencie jest wyodrębnione miejsce do spania dla uczestników, nazywane noclegownią konwentową. Jak widać na rycinie 3, jest to nadal najpopularniejsza opcja (44,33\%), najpewniej z racji darmowego lub bardzo taniego

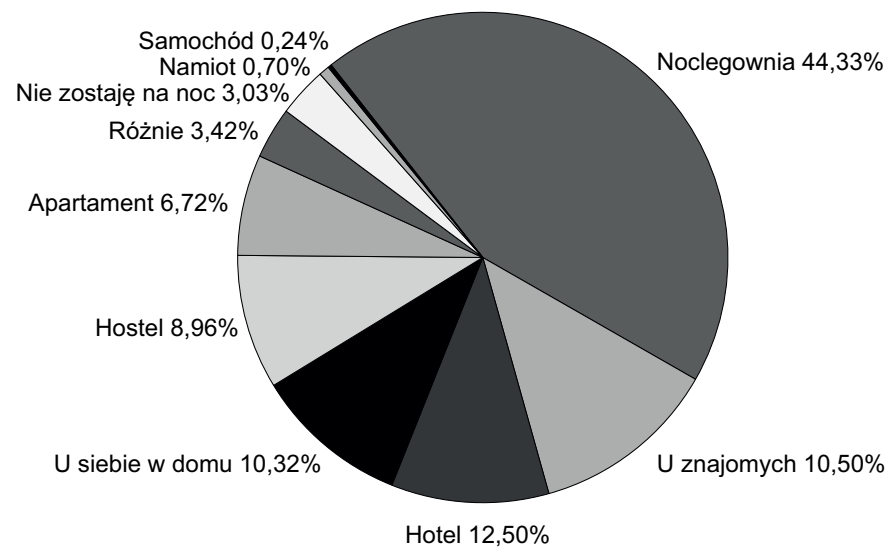

Ryc. 3. Rodzaje noclegów

Źródło: opracowanie własne. 
użytkowania (zazwyczaj w cenie biletu lub za symboliczną dopłata). Następne jednak są hotele $(12,50 \%)$, które szczególnie w wypadku dużych, trzydniowych konwentów są wybierane przez uczestników (często z uwagi na spokój i łatwy dostęp do łazienki, które na noclegowni praktycznie nie istnieja). Poza noclegami u rodziny czy znajomych popularnością cieszą się także hostele $(8,96 \%)$ oraz apartamenty wynajmowane $(6,72 \%)$. Poniżej $1 \%$ respondentów wskazuje odpowiedzi o noclegu w namiocie i w samochodzie.

Można jednak zauważyć, że częstotliwość występowania konwentów oraz spore rozmiary niektórych $z$ nich (np. tych, które gromadzą minimum 100 osób) mogą generować korzyści dla miejscowości w postaci dochodów z noclegów, przejazdów czy zakupów dokonywanych przez uczestników na miejscu. Jako że mamy do czynienia $z$ wyjazdem poza miejsce zamieszkania z noclegiem i głównie w celu uczestnictwa w wydarzeniu czasowym, konwenty fanów można $z$ całą pewnością uznać za rodzaj turystyki eventowej.

Aby dowiedzieć się dokładnie, jakie kwoty uczestnicy mogą wydać podczas trwania konwentu, zadano pytanie o wydatki z wykluczeniem kosztów przejazdu i noclegu. Przy użyciu zestawienia tabelą przestawną porównano je ze statusem danej osoby (uczeń, uczeń pracujący, student, student pracujący, osoba pracująca, osoba szukająca pracy). Dzięki temu łatwo zauważyć, że najwięcej pieniędzy wydają osoby pracujące (w przedziale $251-500$ oraz 501-1000 zł było to $11,08 \%$ odpowiedzi) oraz osoby, co ciekawe, nadal uczące się (w tym samym przedziale było to $11,44 \%$ respondentów). Ta druga grupa często obejmowała jednak osoby nieco starsze, które zdecydowały się na dokształcanie. Niezależnie od statusu najczęstszymi odpowiedziami na pytanie o kwoty pozostawiane w trakcie konwentu były przedziały od 101 do $250 \mathrm{zł} \mathrm{(46,23 \%} \mathrm{odpowiedzi)} \mathrm{oraz} \mathrm{między} 251$ a $500 \mathrm{zł}$ (27,24\% odpowiedzi).

Inną ważną kwestią była główna korzyść wynikająca z uczestnictwa w konwentach. Jak już wspomniano, konwenty działają na zasadzie wolontariatu (z pojedynczymi wyjątkami), lecz na ich terenie zawsze funkcjonują strefy targowe, gdzie można zakupić gadżety, książki, przedmioty rękodzielnicze i inne, oraz strefy gastronomiczne. Zakupy $w$ obrębie konwentu są więc jednym $z$ determinantów wyjazdu, jak zresztą widać na rycinie 4.

Warto jednak zwrócić uwagę, że zakupy są dopiero trzecim celem (z wynikiem $54,42 \%$ wskazań); najważniejsze dla znacznej większości uczestników są dobra zabawa $(84,20 \%)$ oraz spotkania ze znajomymi $(69,10 \%)$. Podobnie sprawa ma się z motywacjami pokazanymi na rycinie 5 .

Duży wpływ na decyzję o wzięciu udziału w konwencie ma tematyka wydarzenia $(68,75 \%)$ oraz plan atrakcji $(57,67 \%)$. Warto jednak zaznaczyć, że w analizie danych wielokrotnie napotykano dopisane odpowiedzi, które uzależniały wyjazd od obecności znajomych, szczególnie w przypadku, gdy dana osoba jeździła na konwenty rzadko (maksymalnie do pięciu razy w roku; najczęściej w przypadku Pyrkonu jako jedynego konwentu $\mathrm{w}$ roku). W rozmowach z uczestnikami także najczęściej przy pytaniu o powód wyjazdów czy determinantę uzyskiwano odpowiedzi typu „klimat spotkania”, „ludzie”, „oderwanie od nudnej rzeczywistości”, „organizacja fajnego spotkania” (tutaj zapewne organizator) czy „spotkania 


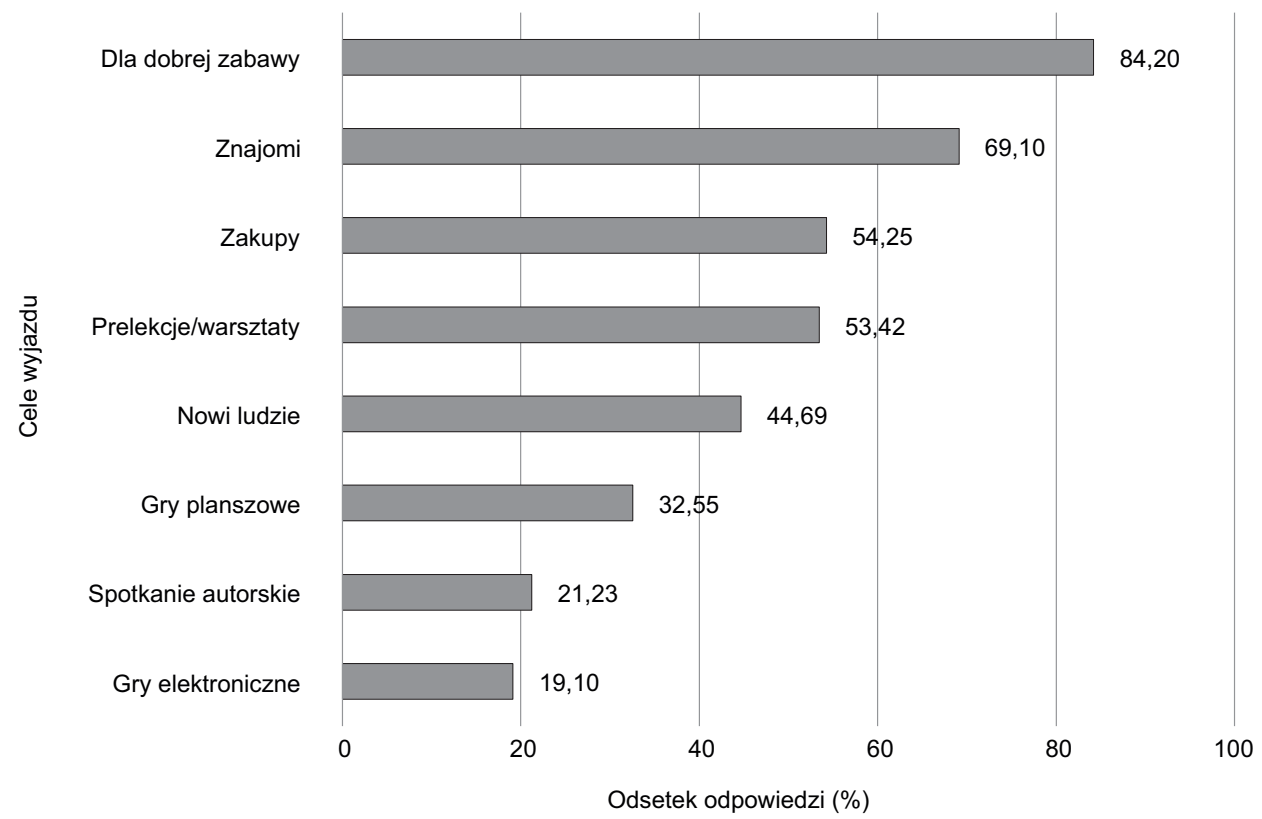

Ryc. 4. Cel wyjazdu na konwent

Źródło: opracowanie własne.

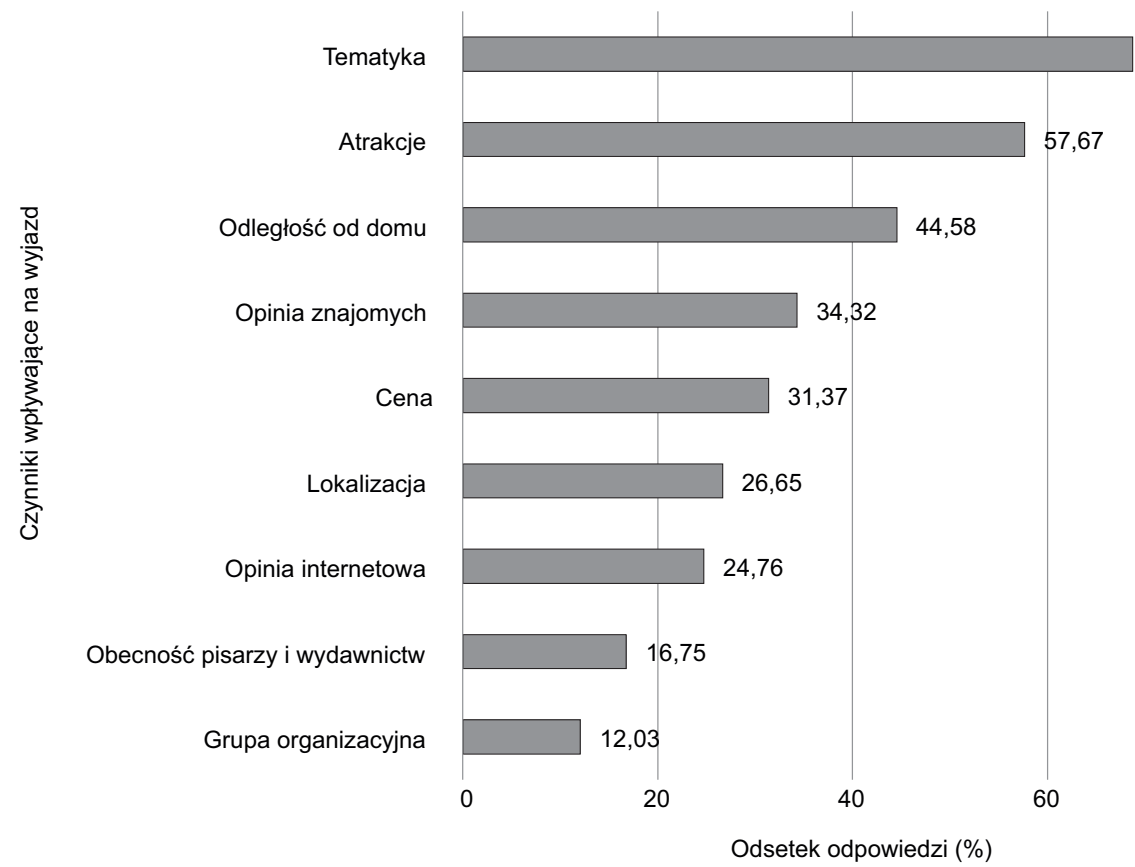

Ryc. 5. Elementy wpływające na decyzję o wyjeździe na konwent Źródło: opracowanie własne. 
z ludźmi o podobnych zainteresowaniach". Jasno wynika więc, że znacząca większość uczestników konwentów nie szuka w nich korzyści materialnych (są one raczej drugorzędne), lecz kontaktu z ludźmi z tej samej społeczności fanów (fandomu) oraz spędzenia czasu na rozrywkach konwentowych.

\section{Zakończenie}

Konwenty fanów w Polsce są tematem ciekawym zarówno pod względem socjologiczno-kulturowym, jak i w badaniach geograficznych ze szczególnym uwzględnieniem turystyki. Jako przykład turystyki eventowej wyróżniają się one przede wszystkim celem i motywacją, która w przeciwieństwie do innych festiwali nie niesie ze sobą korzyści finansowych dla organizatorów. Nadrzędną korzyścią konwentów były i nadal pozostają kontakty w grupie fanów oraz promocja kultury i popkultury zawartej w mediach fandomowych. Uczestnicy tych spotkań, członkowie fandomu, są grupą, która może wskazać nam trendy w rozwoju konwentów, mają oni również znaczenie dla miejscowości, w których odbywają się spotkania, zostawiając tam pieniądze oraz rozpowszechniając wiedzę o danym miejscu. Warto więc pochylić się nad tym tematem, który cały czas się rozwija wraz z wachlarzem różnorodnych imprez w Polsce i na całym świecie.

\section{Literatura}

Czerniuk J. (2012). + 50 do współczynnika kultura. Reportaż o środowisku graczy w Poznaniu. Czas Kultury: Podskórny Poznań, 167(2): 60-67.

Getz D. (1998). Event tourism and the authenticity dilemma. W: W.F. Theobald (red.), Global tourism: the next decade. Butterworth-Heinemann, Oxford, s. 409-427.

Getz D. (2008). Event tourism: Definition, evolution and research. Tourism Management, 29: 403-428.

Guttfeld D., Jankowiak D., Krawczyk S. (2013). Fantastyczni 2012. Badanie czytelnictwa fantastyki. Anatomia Fantastyki. Dział Wydawniczy Gdańskiego Klubu Fantastyki, Gdańsk.

Kaszkowiak Ł. (2015). Społeczny świat polskich fanów fantastyki. Opuscula Sociologica, 14(4): $31-42$.

Pindel T. (2019). Historie fandomowe. Wydawnictwo Czarne, Wołowiec.

\section{Fan conventions in Poland as example of events}

Fan conventions in Poland have been taking place for over 50 years. During all this time, they have developed, maintaining the form of a few days' event, from small sizes to huge events taking place in trade fair and exhibition complexes. The article presents conventions based on examples from Poland, classifies them as an example of event tourism and compares the assumptions and goals of these meetings with those of the events according to Getz $(1998,2008)$. Research among participants was conducted in the form of ques- 
tionnaires and concerned participation in conventions. The obtained result indicates the existence of benefits other than those described by Getz: the main purpose of conventions is not property or business benefit, but social (belonging to a group of fans, contacts with others) and cultural benefit.

Translated by Weronika Słabosz 

Aleksandra Mależyna

olamalezyna@interia.pl

\section{Eventy sportowe jako czynnik rozwoju turystyki na obszarach goszczących (na przykładzie siatkarskich imprez organizowanych w Krakowie)}

\section{Streszczenie}

Kraków dzięki doskonałemu położeniu komunikacyjnemu, infrastrukturze sportowej - TAURON Arena Kraków - może być areną wielkich wydarzeń sportowych. Rozdział poza zagadnieniami teoretyczno-terminologicznymi zawiera analizę wpływu Memoriału Huberta Jerzego Wagnera i Mistrzostw Europy Siatkarzy 2017 na gospodarkę Krakowa w świetle własnych badań empirycznych. Celem badań była próba wykazania, w jakim stopniu kibice podejmują dodatkową aktywność turystyczną w mieście przy okazji udziału w tych eventach. Imprezy siatkarskie typu mistrzowskiego generują większy ruch turystyczny, przyciągają większą liczbę osób spoza obszaru, w którym się odbywają. Osoby te łączą kibicowanie ze zwiedzaniem miejsca, w którym przebywają, dłużej zostają w Krakowie i chcą skorzystać m.in. z bogatej oferty kulturalnej.

\section{Wprowadzenie}

Obserwowany w ostatnich latach wzrost liczby eventów sportowych przyczynia się do zwiększonego zainteresowania ze strony kibiców, dla których uczestnictwo w tego typu wydarzeniach stało się popularną formą spędzania czasu wolnego. Podróże kibiców zainteresowanych sportem, zaangażowanie w tworzenie ważnych eventów oraz zainteresowanie sławnymi sportowcami powoduje, że fani stają się także turystami przebywającymi na miejscu istotnych wydarzeń. Organizacja imprez sportowych przynosi nie tylko wymierne korzyści materialne, ale także przyczynia się do promocji danego miejsca bądź regionu. Kraków

Cytowanie: Mależyna A. (2021). Eventy sportowe jako czynnik rozwoju turystyki na obszarach goszczących (na przykładzie siatkarskich imprez organizowanych w Krakowie). W: K. Borodako (red.), Turystyka w okresie pandemii. Bogucki Wydawnictwo Naukowe, Poznań-Kraków, s. 36-47. https://doi.org/10.12657/9788379863501-4 
W widoczny sposób zaznacza swoją pozycję na mapie wydarzeń organizowanych w Polsce i na świecie. Dotyczy to zwłaszcza okresu po roku 2014, kiedy oddano do użytku główny obiekt - TAURON Arena Kraków. Przyczyniło się to do organizacji w mieście różnych eventów sportowych na skalę krajową i międzynarodową. Kibicowanie ulubionym zespołom sprzyja wspólnemu przeżywaniu emocji oraz integracji społecznej. Siatkarskie eventy cieszą się ogromną popularnością. Jak podał Polski Związek Piłki Siatkowej, Mistrzostwa Europy Siatkarzy 2017 (LOTTO EUROVOLLEY POLAND 2017) obejrzało na żywo 213089 kibiców (z czego ponad $40 \%$ zasiadło na trybunach PGE Stadionu Narodowego, ERGO Arena Gdańsk/Sopot i TAURON Arena Kraków) oraz miliony telewidzów z całej Europy dzięki przekazom medialnym. Według raportu „Wpływ i działanie promocyjne polskich miast i regionów. Edycja 2018" Kraków, w porównaniu do miast takich, jak: Warszawa, Toruń czy Katowice, przeznaczył zaledwie $10 \mathrm{mln}$ zł na wydatki promocyjne. Włodarze miasta zdają sobie sprawę, że organizacja eventów niesie ze sobą także dodatkową wartość medialną. Kraków dzięki doskonałemu położeniu, sprawnie działającej komunikacji, bardzo dobrej bazie noclegowej, nowo powstałej infrastrukturze sportowej może być areną wielkich wydarzeń siatkarskich zarówno niższej rangi, jak i mistrzowskiej. Celem badań, przeprowadzonych w 2017 r. na potrzeby pracy magisterskiej, była próba wykazania, w jakim stopniu kibice podejmują dodatkową aktywność turystyczną w mieście przy okazji udziału w eventach, oraz dowiedzenia, że siatkarskie imprezy sportowe są czynnikiem, mającym wpływ na rozwój turystyki w mieście. Analizy miały na celu pozyskanie informacji, która $z$ dwóch prestiżowych imprez: towarzyska - Memoriał Huberta Jerzego Wagnera, rozgrywany w stolicy województwa małopolskiego cyklicznie od roku 2016 - bądź mistrzowska - Mistrzostwa Europy Siatkarzy 2017 - ma większy wpływ na gospodarkę Krakowa. Należy podkreślić, że badaniami objęto niewielką grupę kibiców biorących udział w Memoriale Jerzego Huberta Wagnera oraz Mistrzostwach Europy Siatkarzy w 2017 r. w Krakowie. Liczba otrzymanych ankiet nie pozwala na uogólnienia, umożliwia natomiast formułowanie pewnych wniosków dotyczących przebadanej próby.

\section{Przegląd literatury}

Termin „event” wywodzi się z języka angielskiego i w dosłownym tłumaczeniu na język polski oznacza „wydarzenie”. Określenie to jest jednak zbyt ogólne i mylące, gdyż nie każde wydarzenie można nazwać eventem. Trudno w języku polskim znaleźć precyzyjny termin, który oddawałby znaczenie owego słowa. W literaturze przedmiotu odszukano kilka definicji.

Event - to niecodzienne i wyjątkowe, aczkolwiek zaplanowane, wydarzenie dla ludzi, które ma za pomocą określonego budżetu i nakładów pracy ludzkiej dostarczyć przeżyć i emocji, będących celem organizatora, przy czym cel ten może mieć znaczenie $\mathrm{w}$ aspekcie marketingowym, PR-owym, politycznym, społecznym, rekreacyjnym, kulturalnym, dobroczynnym lub psychologicznym (Bączek, 2011, s. 13). 
Same wydarzenia marketingowe, nazywane również imprezami specjalnymi, definiowane są jako jednorazowe lub rzadko powtarzane wydarzenia poza normalnym programem działania sponsorów lub organizatorów, będące dla konsumenta okazją do przeżycia o charakterze rekreacyjnym, społecznym lub kulturalnym, wykraczające poza powszechnie dostępne oferty lub codzienne doświadczenia (Richards, 2004, s. 17)

„Ich znaczenie jako narzędzia komunikacji marketingowej, której celem jest m.in. budowanie wizerunku, wynika z ich interaktywności oraz zdolności do wzbudzania zainteresowania mediów" (Proszowska-Sala, Florek, 2010, s. 204). Niemieccy badacze Gebhard i Hitzer (2000) dość szczegółowo definiują owe zjawisko. Według nich eventy to wydarzenia niecodzienne, masowe spektakle łączące różnorodne elementy. $\mathrm{Z}$ reguły zorganizowane $\mathrm{w}$ celach komercyjnych, których nadrzędnym zadaniem jest dostarczenie silnych emocji. Przykładowo Bączek (2011) dzieli eventy na kilka rodzajów, m.in. ze względu na dostępność (zamknięte - wstęp biletowany, otwarte - powszechne), czas trwania (jedno-, wielodniowe, etapowe), formę (filmowe, sportowe, muzyczne, multimedialne, rekreacyjne). W anglojęzycznych źródłach znaleziono podział według Getz (2005) ze względu na rodzaj m.in. na: wydarzenia polityczne i państwowe (wizyty VIP-ów, szczyty), biznesowe i handlowe (targi, wystawy, spotkania itd.), rozgrywki sportowe (profesjonalne, amatorskie) oraz zasięg oddziaływania: megaeventy (transmitowane na całym świecie, przygotowywane z wyprzedzeniem, np. Mistrzostwa Europy w Piłce Siatkowej), hallmark event (kojarzone z danym miastem bądź państwem, unikatowy produkt turystyczny, np. Memoriał Huberta Jerzego Wagnera), regionalne eventy (mniejszej rangi, wypromowane na arenie krajowej, typu mistrzostwa krajowe w danej dyscyplinie), lokalne eventy (nieduże imprezy o niskim budżecie i frekwencji widzów - rozgrywki lokalnych drużyn). W polskiej i obcojęzycznej literaturze przedmiotu nie ma jednoznacznie sformułowanej i powszechnie obowiązującej typologii eventów. Jest to na tyle młode i dynamicznie rozwijające się zjawisko, że można je klasyfikować według różnych kryteriów.

\section{Eventy sportowe}

Specyficznymi wydarzeniami z uwagi na znaczący wpływ na rozwój turystyki są eventy sportowe. „Udział w wydarzeniu sportowym często stymuluje poczucie jedności wśród jego uczestników, wspólne przeżywanie emocji i doznań z innymi osobami dzielącymi podobne zainteresowania, niepowtarzalność przeżyć, rywalizację zawodników i znaczący wydźwięk w przekazie medialnym” (Poczta, Malchrowicz-Mośko, 2016, s. 154). Wyżej wspomniane autorki zwracają także uwagę na aktywność turystyczną biernych uczestników eventów sportowych przy okazji badań przeprowadzonych w Poznaniu. Literatura przedmiotu mianem eventu o charakterze sportowym określa wydarzenie, które podlega pewnym zasadom i rytuałom panującym w konkretnej dyscyplinie sportu. Jak zauważa Freyer (1998), kibice interesują się tego typu imprezami ze względu na: 
- widowiskowość i efektywność,

- ogarniające podekscytowanie i niepewność co do ostatecznego rezultatu sportowego pojedynku,

- oczekiwane show oraz rozrywkę,

- duże zainteresowanie medialne możliwe dzięki środkom masowego przekazu,

- zainteresowanie ze strony sponsorów,

- utożsamianie się „fanów” ze swoimi ulubionymi drużynami sportowymi bądź sławnymi sportowcami.

\section{Metodyka badań}

Na potrzeby pracy magisterskiej przeprowadzono badania, w których wzięli udział kibice sportowi uczestniczący w imprezie o charakterze towarzyskim Memoriale Huberta Jerzego Wagnera oraz mistrzowskim - Mistrzostwach Europy Siatkarzy 2017 (LOTTO EUROVOLLEY POLAND 2017). Populację badawczą stanowili kobiety i mężczyźni. Wykorzystano do tego metodę kwestionariusza ankietowego. Opracowano dwa podobne kwestionariusze ankietowe, które składały się z 19 pytań głównych oraz 6 pytań metryczkowych, dotyczących ogólnych cech społeczno-demograficznych respondentów. Wśród pytań głównych dominowały półotwarte jednokrotnego wyboru (obok pytania można było wpisać dodatkową odpowiedź, uznaną za istotną $\mathrm{w}$ danej kwestii) oraz dwa pytania otwarte odnoszące się do najważniejszych atrakcji turystycznych Krakowa i procentowego udziału środków pieniężnych na poszczególne kategorie wydatków. Pojawiły się pytania ogólne, na które odpowiedzi były udzielane przez wszystkich respondentów, oraz pytania szczegółowe dedykowane wyłącznie kibicom, którzy na stałe nie mieszkają w Krakowie i poza zamiarem kibicowania przybyli także w celach turystycznych. Ankiety skierowano do osób posługujących się językiem polskim. Dane do analizy zebrano na terenie obiektu TAURON Arena Kraków 11 sierpnia 2017 r. w trakcie Memoriału Huberta Jerzego Wagnera przed meczami: RosjaKanada oraz Polska-Francja, a także 26 sierpnia 2017 r. w trakcie Mistrzostw Europy Siatkarzy 2017 przed meczami fazy grupowej: Słowenia-Rosja oraz Bulgaria-Hiszpania. Łącznie uzyskano 168 poprawnie wypełnionych kwestionariuszy ankiety (odpowiednio po 84 kwestionariusze w trakcie każdego wydarzenia sportowego). Zebrane informacje umożliwiły oszacowanie, jaki procent badanych nocuje w Krakowie, a jaki w pobliskich miejscowościach, $z$ jakiego rodzaju obiektów korzystano, ile dni spędzono w Krakowie oraz jaki procent środków pieniężnych przeznaczono na poszczególne kategorie wydatków. Pytanie dotyczące najważniejszych atrakcji turystycznych, które respondenci planowali zobaczyć w trakcie pobytu w Krakowie, pozwoliło stworzyć ranking obiektów, które cieszą się największą popularnością. Analizę statystyczną wyników badania ankietowego wykonano za pomocą specjalnie przygotowanego w arkuszu kalkulacyjnym Excel narzędzia do gromadzenia, porządkowania, klasyfikowania oraz podsumowywania wyników. Pozwoliło to na opracowanie zebranego materiału statystycznego i prezentację danych $\mathrm{w}$ formie tabeli, w której symbolem $N$ oznaczono 
liczbę odpowiedzi, oraz kołowych i słupkowych wykresów statystycznych. Liczba otrzymanych ankiet nie pozwala na uogólnienia, umożliwia za to formułowanie pewnych wniosków odnośnie do przebadanej próby.

\section{Wyniki badań}

Badania poruszają kilka ważnych kwestii z punktu widzenia włodarzy miast. Czy warto organizować jednorazowe mega eventy na wielką skalę czy lepiej cykliczne hallmark event takie jak Memoriał Huberta Jerzego Wagnera. Należy podkreślić, że badaniami objęto niewielką grupę kibiców biorących udział w obu wydarzeniach sportowych w Krakowie.

Po zakończeniu meczów znaczna większość respondentów w ramach Memoriału Huberta Jerzego Wagnera (73,8\%) i Mistrzostw Europy Siatkarzy 2017 $(88,1 \%)$ nocowała w Krakowie. Należy dodać, że w grupie tej znalazły się także osoby, które na stałe mieszkają w Krakowie - w przypadku Memoriału Jerzego Huberta było to 26 ankietowanych, a Mistrzostw Europy - 20.

Podczas Memoriału Huberta Jerzego Wagnera 22 z 84 badanych respondentów $(26,2 \%)$ nocowało poza Krakowem. Wszystkie te osoby przebywały w miejscowościach na terenie województwa małopolskiego. Prawdopodobnie ma na to wpływ odpowiednia infrastruktura drogowa oraz stosunkowo niewielka odległość dzieląca te miejscowości od Krakowa (maksymalnie 70 km).

Dla porównania w przypadku Mistrzostw Europy Siatkarzy 2017 zaledwie 10 z 84 przebadanych respondentów (czyli 11,9\%) nocowało poza Krakowem. 4 osoby w Bielsku-Białej w województwie śląskim oraz w województwie małopolskim po 2 osoby w Łękawicy (powiat wadowicki), Mszanie Dolnej (powiat limanowski) i Zakopanem (powiat tatrzański). Dla wszystkich ankietowanych były to miejscowości ich stałego pobytu.

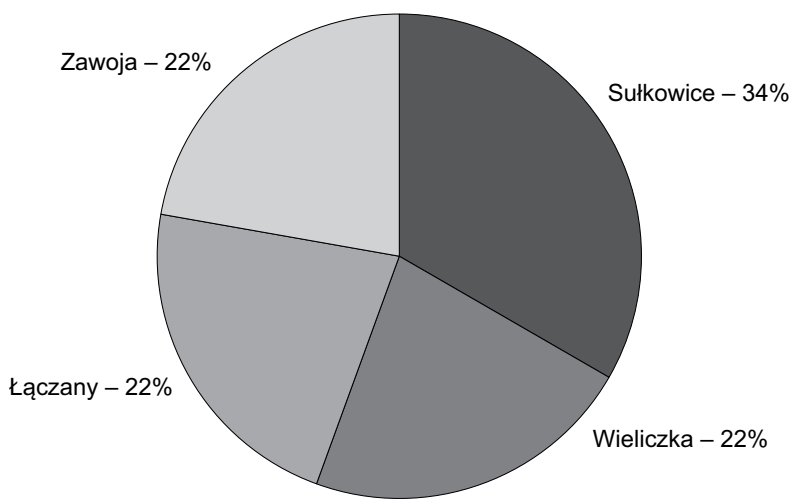

Ryc. 1. Miejsce pobytu respondentów po meczach Memoriału Huberta Jerzego Wagnera poza Krakowem

Źródło: opracowanie własne. 


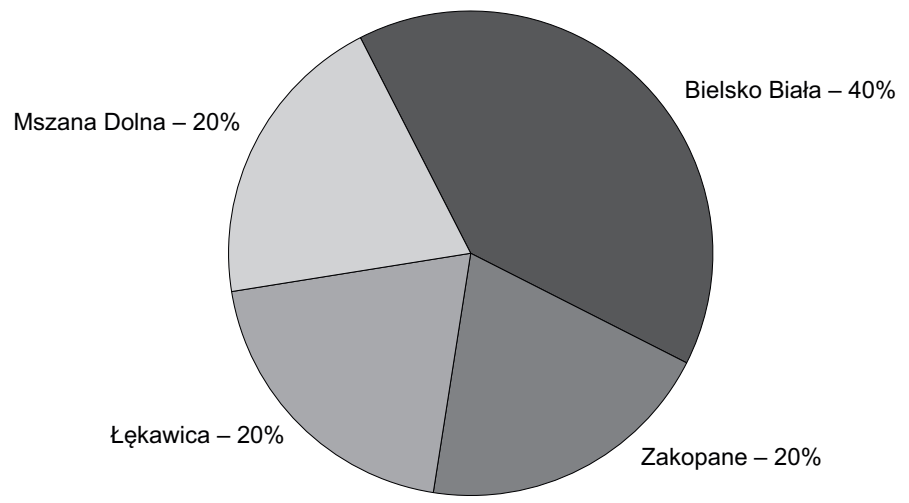

Ryc. 2. Miejsce pobytu respondentów po meczach Mistrzostw Europy Siatkarzy 2017 poza Krakowem

Źródło: opracowanie własne.

Zróżnicowanie bazy noclegowej jest ważnym czynnikiem wpływającym na atrakcyjność danego miasta. Wyniki badań jednoznacznie pokazują, że preferencje respondentów Memoriału Huberta Jerzego Wagnera oraz Mistrzostw Europy Siatkarzy 2017 są odmienne. Z krakowskiej bazy noclegowej nie korzystało łącznie 88,1\% uczestników Memoriału Huberta Jerzego Wagnera oraz 47,6\% uczestników Mistrzostw Europy Siatkarzy 2017. Podczas eventu niższej rangi 31\% osób nocowało u krewnych lub przyjaciól, dla porównania zaledwie 11,9\% w trakcie Mistrzostw Europy Siatkarzy 2017. Kategorię „,inne” w przypadku Memoriału Huberta Jerzego Wagnera stanowiły osoby, które na co dzień mieszkają w Krakowie $(30,9 \%)$ oraz $26,2 \%$ mieszkających na stałe w sąsiednich miejscowościach, takich jak: Sułkowice (7\%), Wieliczka (6,4\%), Zawoja (6,4\%) i Łączany $(6,4 \%)$. Wśród uczestników Memoriału korzystających z krakowskiej bazy noclegowej największą popularnością cieszyły się hotele (szczególnie 3-gwiazdkowe)/motele, wybrało je 7,1\% respondentów. Zauważono, że osoby uczestniczące w meczach Mistrzostw Europy Siatkarzy 2017 częściej korzystały z krakowskich obiektów noclegowych $(52,4 \%)$. Największą popularnością cieszyły się hostele $(28,6 \%)$, a średnio co czwarty fan piłki siatkowej zatrzymał się w hotelu/motelu. Najczęściej wybierano hotele 3-gwiazdkowe bądź 4-gwiazdkowe. Kategorię „inne” stanowiło: 23,8\%

Tabela 1. Rodzaj obiektu noclegowego wybrany przez respondentów

\begin{tabular}{lcccc}
\hline \multirow{2}{*}{ Rodzaj obiektu } & \multicolumn{2}{c}{$\begin{array}{c}\text { Memoriał Huberta } \\
\text { Jerzego Wagnera }\end{array}$} & \multicolumn{2}{c}{ Mistrzostwa Europy } \\
& Siatkarzy & 2017 \\
\cline { 2 - 5 } & $\mathrm{N}$ & $\%$ & $\mathrm{~N}$ & $\%$ \\
\hline Hotel/motel & 6 & 7,1 & 20 & 23,8 \\
Hostel & 4 & 4,8 & 24 & 28,6 \\
Pensjonat & 0 & 0 & 0 & 0 \\
Mieszkanie u krewnych/znajomych & 26 & 31,0 & 10 & 11,9 \\
Inna & 48 & 57,1 & 30 & 35,7 \\
Razem & 84 & 100,0 & 84 & 100,0 \\
\hline
\end{tabular}

Źródło: opracowanie własne. 
osób z Krakowa oraz 11,9\% mieszkających na stałe w Bielsku-Białej (4,7\%), Łękawicy (2,4\%), Mszanie Dolnej (2,4\%) i Zakopanem (2,4\%). Pensjonaty nie były obiektami wybieranymi przez respondentów obu imprez sportowych.

Analiza rozkładu uzyskanych odpowiedzi pozwala wysunąć wnioski, że osoby uczestniczące w towarzyskiej imprezie sportowej decydowały się spędzić w Krakowie 1 dzień bez noclegu (37,9\%) bądź 2 dni (46,6\%). Wynik ten jest następstwem faktu, że pobytom jednodniowym służy niewielka odległość pomiędzy miejscowością zamieszkaną a odwiedzaną. Na pobyt 3-4-dniowy i dłuższy decydowały się osoby spoza województwa małopolskiego. Ankietowani uczestniczący w meczach Mistrzostw Europy Siatkarzy 2017 częściej deklarowali chęć dłuższego pobytu. Co drugi z nich planował spędzić w Krakowie 3 dni, natomiast średnio co czwarty 4 dni i więcej.

Tabela 2. Długość pobytu w Krakowie

\begin{tabular}{lcccc}
\hline \multirow{2}{*}{ Długość pobytu } & \multicolumn{2}{c}{$\begin{array}{c}\text { Memoriał Huberta } \\
\text { Jerzego Wagnera }\end{array}$} & \multicolumn{2}{c}{$\begin{array}{c}\text { Mistrzostwa Europy } \\
\text { Siatkarzy } 2017\end{array}$} \\
\cline { 2 - 5 } & $\mathrm{N}$ & $\%$ & $\mathrm{~N}$ & $\%$ \\
\hline 1 dzień (bez noclegu) & 22 & 37,9 & 10 & 15,6 \\
$2 \mathrm{dni}$ & 27 & 46,6 & 7 & 10,9 \\
$3 \mathrm{dni}$ & 6 & 10,3 & 32 & 50,0 \\
4 dni i więcej & 3 & 5,2 & 15 & 23,5 \\
Razem* & 58 & 100,0 & 64 & 100,0 \\
\hline
\end{tabular}

Źródło: opracowanie własne.

* W analizie wyników nie uwzględniono ankietowanych, którzy na co dzień mieszkają w Krakowie 26 osób w przypadku Memoriału Huberta Jerzego Wagnera oraz 20 osób podczas Mistrzostw Europy Siatkarzy 2017.

Poznanie, jaki procent środków pieniężnych respondenci mieszkający poza Krakowem przeznaczą na nocleg, wyżywienie, komunikację, program turystyczny, pamiątki i „inne”, pozwoli określić, na którą kategorię wydatków przeznaczą najwięcej pieniędzy. W poniższej analizie podzielono ankietowanych na tych, którzy przybyli do Krakowa na 1 dzień bez noclegu oraz 2-4 dni i dłużej. Największą kategorią wydatków dla uczestników obu wydarzeń, którzy spędzili w Krakowie 1 dzień bez noclegu, były koszty wyżywienia. W przypadku osób zasiadających na trybunach Memoriału Huberta Jerzego Wagnera drugą kategorię wydatków pod względem wielkości stanowiły tzw. koszty „inne” 25,8\%, w ramach których wymieniano głównie zakupy. Dla porównania osoby uczestniczące w Mistrzostwach Europy Siatkarzy 2017 na drugim miejscu wskazywały koszty związane z programem turystycznym $(24,7 \%)$.

Natomiast w przypadku 2-4-dniowych i dłuższych pobytów w Krakowie procentowy rozkład środków pieniężnych prezentował się nieco inaczej. Podobnie jak przy 1-dniowych pobytach bez noclegu, największą kategorię wydatków dla ankietowanych zarówno na Memoriale Huberta Jerzego Wagnera (33,5\%), jak i Mistrzostwach Europy Siatkarzy 2017 (30,5\%) stanowiły koszty wyżywienia. Na drugim miejscu uplasowały się wydatki związane z programem turystycznym,. 


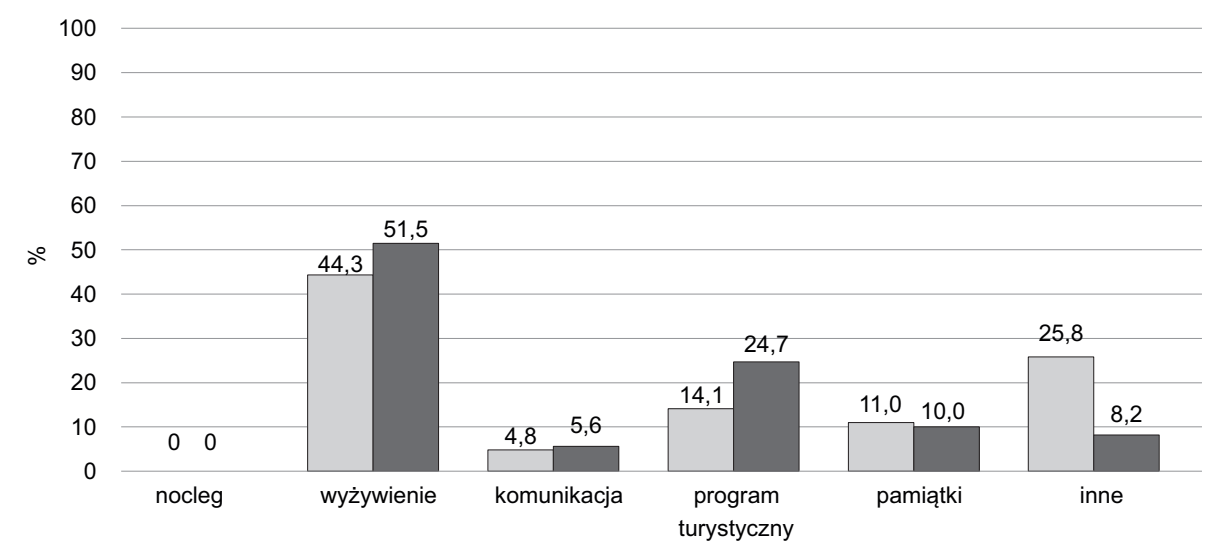

$\square$ Memoriał Huberta Jerzego Wagnera $\quad \square$ Mistrzostwa Europy Siatkarzy 2017

Ryc. 3. Planowane wydatki respondentów w trakcie 1-dniowego pobytu bez noclegu w Krakowie

Źródło: opracowanie własne.

Osoby uczestniczące w Mistrzostwach Europy przeznaczyły więcej pieniędzy na nocleg. Ankietowani deklarujący dłuższy pobyt w Krakowie wydali także więcej na komunikację, która umożliwiła im sprawne poruszanie się po mieście. Najmniejszą część środków pieniężnych przeznaczano na zakup pamiątek.

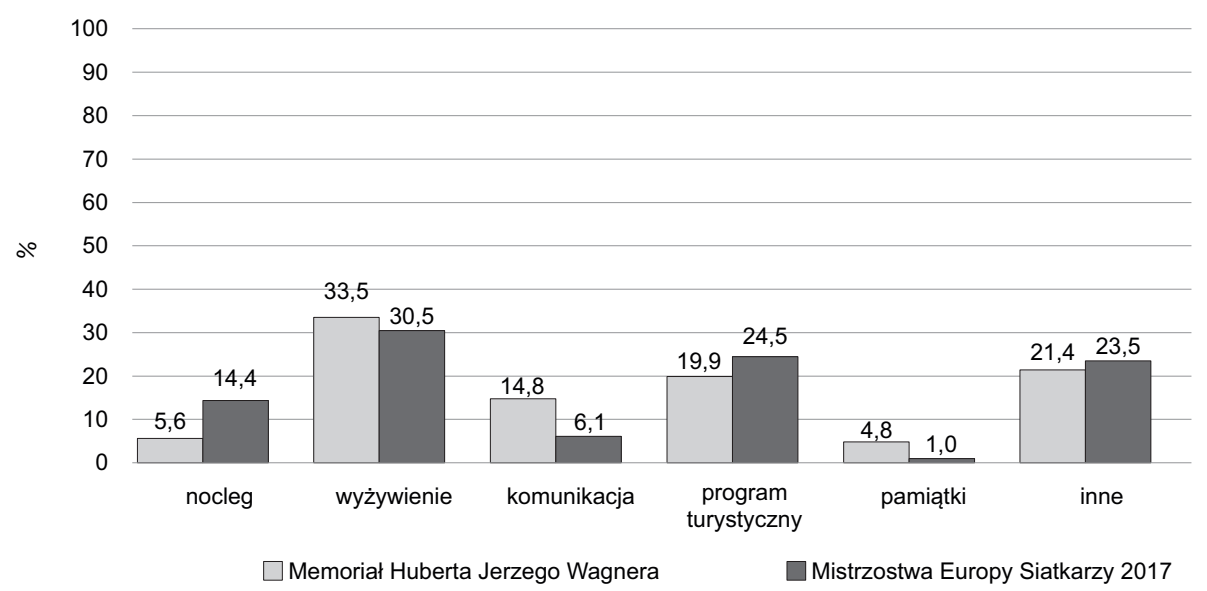

Ryc. 4. Planowane wydatki respondentów w trakcie 2-4-dniowego i dłuższego pobytu w Krakowie

Źródło: opracowanie własne.

Badani respondenci mieszkający poza Krakowem zostali poproszeni o wskazanie 3 głównych atrakcji zlokalizowanych na terenie miasta, które chcieliby zobaczyć w trakcie swojego pobytu. Pytanie to miało charakter otwarty, gdyż w żaden sposób nie chciano nic sugerować respondentom i ograniczać ich wyboru. Odpowiedzi pozwoliły określić stopień popularności danej atrakcji turystycznej 
oraz stan wiedzy ankietowanych na temat krakowskich atrakcji. Za najważniejsze obiekty turystyczne Krakowa uznano Wawel, Sukiennice i Fabrykę Oskara Schindlera. W obu przypadkach $100 \%$ respondentów wymieniło Wawel jako sztandarową atrakcję Krakowa. Świadczy to o stabilnej pozycji tego obiektu jako „perły miasta Krakowa".

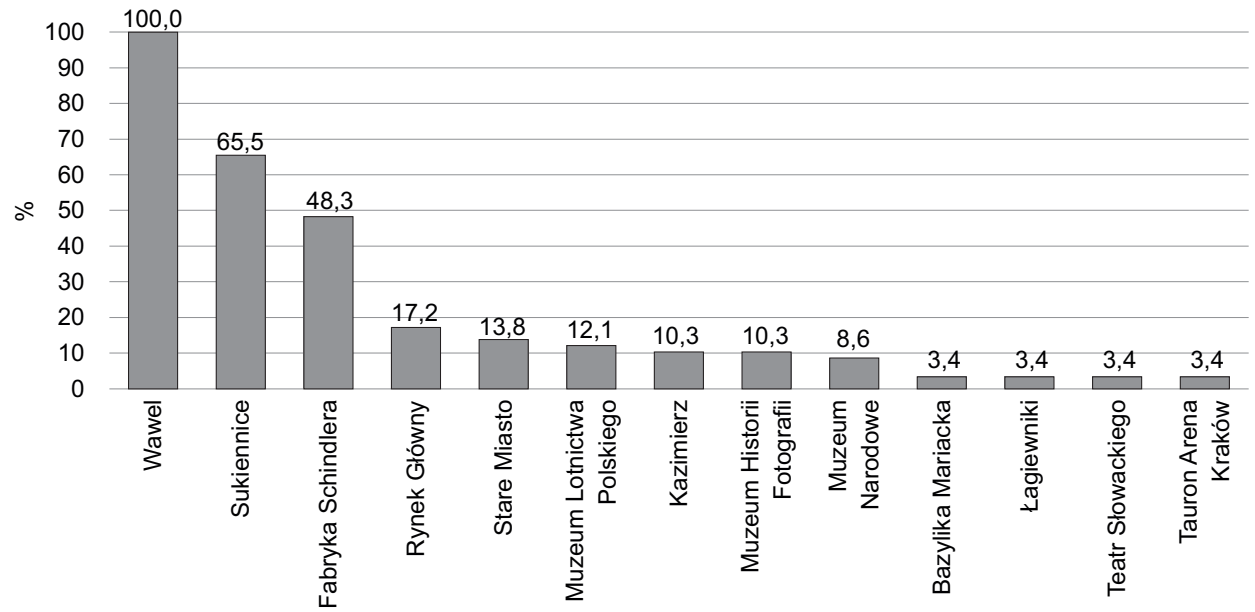

Ryc. 5. Ranking atrakcji Krakowa według respondentów biorących udział w Memoriale Huberta Jerzego Wagnera

Źródło: opracowanie własne.

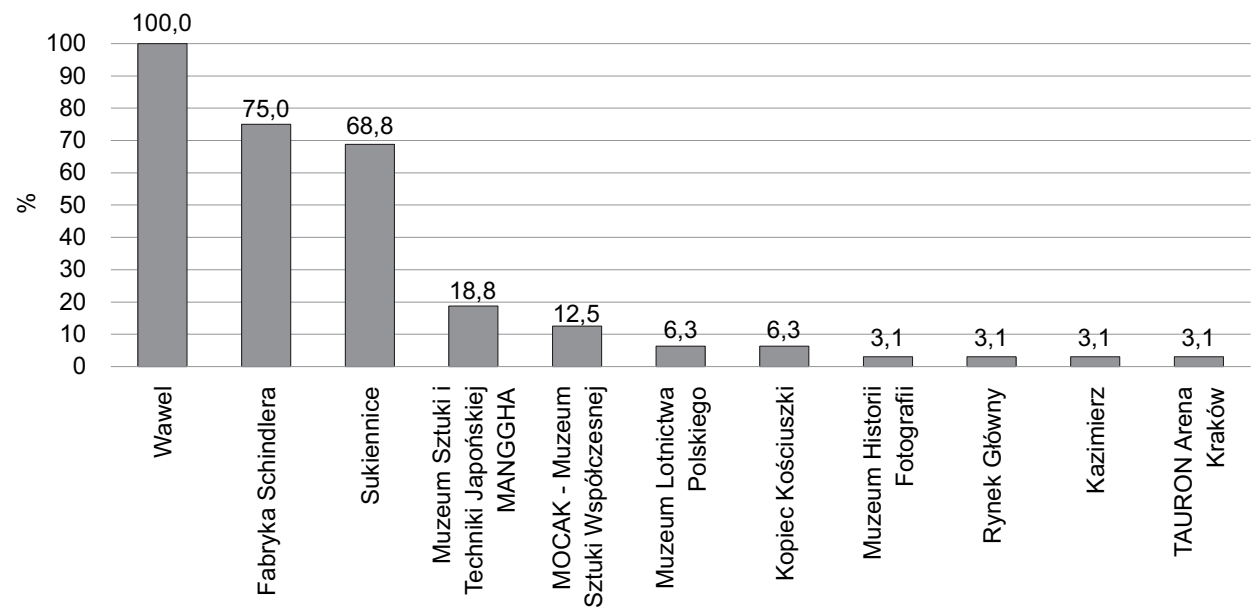

Ryc. 6. Ranking atrakcji Krakowa według respondentów biorących udział w Mistrzostwach Europy Siatkarzy 2017

Źródło: opracowanie własne.

Natomiast trzy czwarte respondentów Mistrzostw Europy Siatkarzy 2017 planowało zobaczyć Fabrykę Schindlera oraz Sukiennice $(68,8 \%)$. Pozostałe atrakcje Krakowa wymieniane przez uczestników obu imprez nie przekraczają $20 \%$. 


\section{Zakończenie}

Imprezy sportowe cieszą się ogromnym zainteresowaniem, gromadząc przy tym rzeszę wiernych kibiców. Niosą korzyści nie tylko jej uczestnikom, władzom lokalnym, ale przede wszystkim są bodźcem zmian gospodarczych oraz istotnym czynnikiem wpływającym na rozwój turystyki. Współcześnie sport jest formą promocji miasta i kreowania pozytywnego wizerunku jakieś destynacji. Władze miast konkurują między sobą o organizowanie prestiżowych, międzynarodowych pojedynków sportowych. Znaczna część turystów odwiedza dane miejsce tylko i wyłącznie ze względu na uczestnictwo w wydarzeniu, które właśnie tam się odbywa. W świetle przeprowadzonych badań wśród respondentów biorących udział w Memoriale Huberta Jerzego Wagnera oraz Mistrzostwach Europy Siatkarzy 2017 wyciągnięto pewne wnioski na temat przebadanej próby. Eventy sportowe różnej rangi są jednym z czynników wpływających na rozwój turystyki na obszarach goszczących. Imprezy typu mistrzowskiego przyciągają większą liczbę osób spoza obszaru, w którym się odbywają. Osoby te łączą kibicowanie ze zwiedzaniem miejsca, w którym przebywają. Planowały spędzić w Krakowie więcej dni (3-4 dni i dłużej) niż uczestnicy Memoriału Huberta Jerzego Wagnera (1 dzień bez noclegu bądź 2 dni) oraz częściej korzystały z krakowskiej bazy noclegowej. Największą kategorię wydatków stanowiły koszty związane z wyżywieniem. Badani uczestniczący w wydarzeniach siatkarskich, poza udziałem w meczach, planowali także skorzystać z bogatej oferty kulturalnej Krakowa. Jako najważniejsze atrakcje turystyczne wskazywano Wawel, Sukiennice oraz Fabrykę Oskara Schindlera. Stwierdzono, że kibice podejmują dodatkową aktywność przy okazji udziału w wydarzeniach sportowych, co wpływa na rozwój turystyki na obszarze goszczącym. Jednak ze względu na niewielką grupę badawczą niemożliwe jest wyciągnięcie jednoznacznych wniosków. Rekomenduje się ponowne przeprowadzenie badań na większej grupie respondentów.

\section{Literatura}

Bączek J.B. (2011). Psychologia eventów. Wydawnictwo Stageman Polska.

Freyer W. (1998). Event-Management im Tourismus. Kulturveranstaltungen \& Festivals als touristische Leistungsangebote. W: W. Freyer, D. Meyer, K. Scherhag (red.), Events - Wachstumsmarkt im Tourismus? Tagungsband zum 3. Dresdner Tourismussymposium, Dresden, s. 17-50.

Getz D. (2005). Event management \& Event tourism. Cognizant Communication Corporation.

Piotrowski P. (2012). Determinanty skuteczności wydarzeń marketingowych w tworzeniu turystycznego wizerunku miasta. W: T. Żabińska (red.), Turystyka na obszarach miejskich - uwarunkowania rozwoju. Narzędzia promocji. Studia Ekonomiczne, Zeszyty Naukowe Wydziałowe Uniwersytetu Ekonomicznego w Katowicach.

Poczta J., Malchrowicz-Mośko E. (2016). Wpływ eventów sportowych na rozwój turystyki w mieście na przykładzie poznańskich imprez sportowych. Journal of Education, Health and Sport, 6(4): 151-166. 
Proszowska-Sala A., Florek M. (2004). Promocja miasta. Nowa perspektywa. Stroer.

Richards B. (2004). Marketing atrakcji turystycznych - jak zwiększyć frekwencję i dochody. Polska Organizacja Turystyczna, Warszawa.

Stępowski R. (2018). Wpływ i działanie promocyjne polskich miast i regionów. Edycja 2018 (http://marketingmiejsca.com.pl/media/uploaded/raport4-0y34mwy5/Raport_2018.pdf; dostęp: 10.01.2021).

Willems H. (2000). Events: Kultur - Identität - Marketing. W: W. Gebhardt, R. Hitzler, F. Liebl Events (red.), Soziologie des Außergewöhnlichen. Opladen.

\section{Sporting events as a factor in the development of tourism in host areas (on the example of volleyball events organized in Krakow)}

Krakow can be a place for great sports events thanks to its perfect communication location and sports infrastructure like TAURON Arena Krakow. Apart from theoretical and terminological issues, the article contains an analysis of the impact of the Hubert Jerzy Wagner Memorial and the 2017 European Volleyball Championships on the economy of Krakow in the light of own empirical research. The research aimed to show the extent to which fans undertake additional tourist activity in the city while participating in these events. Championship volleyball events generate more tourist traffic and attract more people from outside the area where they are held. These people combine cheering with visiting the place where they are staying, they stay longer in Krakow and want to take advantage of a wide range of cultural offers. 

Adrian Urbańczyk

Uniwersytet Ekonomiczny w Krakowie

urbanczykadrian@gmail.com

\section{Zmiany w organizacji podróży służbowych wywołane pandemią COVID-19 wśród pracowników krakowskich korporacji}

\section{Streszczenie}

W niniejszym rozdziale przedstawiono wyniki autorskich badań dotyczących zmian w organizacji podróży służbowych spowodowanych pandemią koronawirusa. Sondaż diagnostyczny przeprowadzony został za pomocą techniki CAWI na przełomie 2020 i $2021 \mathrm{r}$. Podmiotem badań byli pracownicy korporacji w Krakowie. Próba badawcza obejmowała 183 osoby. Wyniki pozwoliły stwierdzić, że istnieją zależności między strukturą zawodową respondentów a uczestnictwem $\mathrm{w}$ podróżach służbowych. Wykazano również, że obecne spotkania w formie online nie stanowią alternatywy dla wyjazdów biznesowych.

\section{Wprowadzenie}

Znaczącą rolę w funkcjonowaniu wszelkiego rodzaju podmiotów gospodarczych, w tym m.in. korporacji czy określonych grup społecznych, odgrywają podróże służbowe (Borodako i in., 2015). Wskazuje się, że ideą wyjazdów w celach biznesowych jest przede wszystkim wymiana informacji, odbycie lub przeprowadzenie szkolenia bądź spotkania przy zwieraniu umów handlowych. Nie bez powodu podróże służbowe stanowią współcześnie jeden z najważniejszych celów wyjazdów. Jednak w wyniku rozwoju pandemii COVID-19 w 2020 r. krajowe i zagraniczne podróże służbowe zostały znacznie ograniczone, m.in. w krakowskich korporacjach, które mają największy udział w działalności typu BPO/SSC w Polsce.

Głównym celem pracy jest zobrazowanie wpływu pandemii koronawirusa na zmiany w sposobie organizacji podróży służbowych wśród pracowników korporacji w Krakowie. Przeprowadzono autorskie badania empiryczne, których 
szczegółowa analiza pozwoliła nie tylko zrealizować cel główny pracy i odpowiedzieć na postawione pytania badawcze, ale również wskazać możliwości wyjazdów o charakterze służbowym w 2019 i 2020 r., uwzględniając m.in. stopień zawodowy, staż pracy, główny cel wyjazdu biznesowego czy podejmowane dodatkowe aktywności turystyczne w miejscu recepcji.

\section{Przegląd literatury}

\section{Podróże służbowe w literaturze przedmiotu}

Podróże służbowe są jednym z najbardziej dochodowych oraz najszybciej rozwijających się sektorów turystyki (Borodako i in., 2014). Najogólniej podróże służbowe (definiowane również jako turystyka biznesowa) można określić jako ogół czynności osób, które podróżują i przebywają w celach służbowych nie dłużej niż rok bez przerwy poza swoim zwykłym otoczeniem (Gaworecki, 2010). W literaturze przedmiotu pojęcie turystyki biznesowej jest określane na wiele sposobów, jednak dwa nurty definicyjne są dominujące. Pierwszy z nich, behawioralny, definiuje turystykę biznesową na podstawie charakteru aktywności podmiotów interakcji. Takie podejście prezentuje Davidson (2003), który utożsamia ten rodzaj turystyki $\mathrm{z}$ osobami podróżującymi $\mathrm{w}$ celach bezpośrednio związanych $\mathrm{z}$ pracą zawodową. Podobne stanowisko zajmują Medlik (1995) i Bhatia (2006), traktując turystykę biznesową jako podróże odbywane przez pracowników i inne osoby w ramach ich pracy. Ponadto Davidson i Cope (2003) oraz Rogers (2008) zwracają uwagę na aspekt dobrowolności oraz fakt, że aktywność niejednokrotnie może być podejmowana w grupach; autorzy nie zaliczają jednak wyjazdów indywidualnych do turystyki biznesowej, które mimo charakteru służbowego pozbawione są dowolności (Nawrocka, 2013). Podejście to uzupełnia Mika (2008), który wskazuje, że indywidualny wyjazd służbowy można zaliczyć do turystyki biznesowej, jeśli zawiera element turystyczny. Oznacza to, że podróżujący powinien korzystać nie tylko $z$ bazy hotelowej i szerzej rozumianych usług turystycznych $w$ ramach podróży biznesowej, ale również zaspokajać swoje potrzeby rekreacyjne, poznawcze oraz te związane z rozrywką i kulturą poza obowiązkami służbowymi (Kurek, 2007).

Drugi nurt, opisowo-wyliczający, polega na identyfikacji elementów wchodzących w skład turystyki biznesowej. W takim ujęciu turystyka biznesowa obejmuje wszelkie podróże odbywane przez pracowników i inne osoby w ramach ich pracy zawodowej, czyli udział w spotkaniach, takich jak: konferencje, zjazdy, kongresy, szkolenia, seminaria, targi, wystawy, imprezy motywacyjne, zawieranie kontraktów czy szkolenia (Różycki, 2009; Celuch, 2012; Berbeka i in., 2013). W literaturze anglojęzycznej termin ten określa się mianem „turystyki MICE” (ang. Meeting, Incentives, Conferences and Events), w której podkreśla się planowanie podróży służbowych dużych grup, spotykających się $\mathrm{w}$ jednym określonym miejscu we wspólnym celu (Świątecki, 2005; Klimek, 2012). Współcześnie jednak określenie 
„MICE” jest zastępowane terminem „przemysł spotkań” (Wróblewski, 2014), który z podmiotowej strony wskazuje na szerszy zakres interesariuszy, m.in. lokalną społeczność (Borodako i in., 2015).

Niektórzy autorzy prezentują ponadto w swoich badaniach podejście atrybutowe (Cooper i in., 1993; Swarbrooke, Horner, 2001; Davidson, Cope, 2003; Gołembski, 2008; Gaworecki, 2010), które odznacza się wskazaniem istotnych cech podróży służbowych, w tym m.in. małą wrażliwością na zmiany kosztów podróży, dużym uzależnieniem od ogólnej koniunktury gospodarczej, nietypowym sposobem pozyskiwania klientów, podwyższonym standardem, brakiem widocznej sezonowości czy wykorzystywaną infrastrukturą i usługami.

Szeroki zakres definicyjny i różne podejścia do tematyki podróży służbowych nie pozwalają na jej jednolitą klasyfikację. Przykładowo podział zastosowany przez Davidsona i Cope’a (2003) wskazuje, że podróże służbowe można podzielić na indywidualne podróże służbowe (np. prezentacje, konsultacje, badania) oraz turystykę biznesową (np. seminaria i konferencje, podróże motywacyjne, wystawy, targi, turystykę korporacyjna). Inny podział klasyfikacyjny przyjmuje Światowa Organizacja Turystyki UNWTO, która dzieli podróże służbowe na indywidualne oraz grupowe (Davidson, Cope, 2003). Pierwsze z nich podejmowane są przez jedną lub kilka osób w interesach. Należą do nich podróże: handlowe do innych przedsiębiorstw, odbywane w celu zawarcia kontraktów, i wizytacje, odbywane w celu wygłaszania wykładów lub dawania koncertów, związane z instalowaniem urządzeń, odbywane w związku z zawodowym uprawianiem sportu oraz misje rządowe i dyplomatyczne. Z kolei wśród grupowych wyjazdów biznesowych wyróżnia się: szkolenia, seminaria, sympozja, podróże związane ze studiami oraz podróże edukacyjne, konferencje, kongresy i konwencje, podróże motywacyjne, targi i wystawy. Jak wskazuje Instytut Rynku Hotelarskiego (2008), inny podział można również spotkać w społecznej definicji turystyki biznesowej w Wikipedii. Wśród elementów składowych turystyki biznesowej wyróżnia się: podróże służbowe (związane z umowami obsługi, napraw i montażu, zawieraniem kontraktów, uczestnictwem w posiedzeniach lub penetracją nowych rynków), turystykę konferencyjno-kongresową (uczestnictwo w konferencjach, kongresach, seminariach, sympozjach i konwencjach), turystykę targową, turystykę motywacyjną, turystykę korporacyjną, udział w kursach i szkoleniach.

$\mathrm{Z}$ powyższej analizy wynika, że istnieje rozbieżność poglądów na istotę podróży służbowych i ich elementów składowych. Niemniej szczegółowa kwerenda literatury przedmiotu pozwala wskazać na liczne podobieństwa. W niniejszym opracowaniu za podróże służbowe przyjmuje się wszelkie wyjazdy indywidualne i grupowe w celach biznesowych, w trakcie których uczestnik korzysta z infrastruktury turystycznej danego miejsca recepcji oraz zaspokaja potrzeby turystyczne (np. rekreacyjne, kulturowo-rozrywkowe) po realizacji zadań wynikających z obowiązków zawodowych. 


\section{Podróże służbowe w dobie pandemii COVID-19}

Turystyka jest jednym z sektorów bezpośrednio dotkniętych obecnym kryzysem wynikającym z pandemii koronawirusa. W związku z ogłoszeniem w Polsce od 14 marca 2020 r. stanu zagrożenia epidemiologicznego ograniczona została m.in. działalność związana z prowadzeniem obiektów noclegowych czy gastronomicznych. Ponadto ograniczenie przemieszczania się osób spowodowało spadek liczby podróżujących w celach turystycznych i służbowych (GUS, 2020). W związku z tym Ministerstwo Rozwoju, Pracy i Technologii, w oparciu o raport CDC, wskazało tymczasowe zalecenia dla pracodawców (MRPiT, 2020). Wśród nich wymienia się te, które bezpośrednio wpływają na podróże w celach biznesowych:

- oddelegowanie pracowników do wykonywania pracy w domu,

- ograniczenie liczby pracowników przebywających w zakładzie pracy w tym samym czasie,

- rezygnacja z konferencji i szkoleń (zalecana forma online na platformach inter/intranetowych),

- ograniczenie podróży służbowych i delegacji zagranicznych.

Z kolei Poland Convention Bureau oraz Polska Organizacja Turystyczna przygotowały raport zatytułowany „Raport 2020. Przemysł spotkań i wydarzeń w Polsce" (Raport..., 2020), który wskazuje możliwe scenariusze wpływu pandemii koronawirusa na europejską branżę spotkań. Scenariusz podstawowy zakłada obniżenie się liczby uczestników (w stosunku do 2019 r.) o 25\% w 2021 r. i 5\% w 2022 r. Natomiast w 2023 r. przewidywana jest znaczna poprawa. Scenariusze optymistyczne i pesymistyczne uwzględniają dwie alternatywne prognozy, które przewidują spadek liczby uczestników w przemyśle spotkań kolejno o 36\% i 77\% w 2021 r. Scenariusz optymistyczny zakłada powrót do regularnej organizacji spotkań w 2023 r., a scenariusz pesymistyczny w 2024 r.

Pandemia COVID-19 znacznie wpłynęła na zmiany w sposobie organizacji pracy w wielu firmach i instytucjach. Wpływ ten zauważalny jest również w krakowskich korporacjach, szczególnie w sektorach BPO/SSC (BPO - Business Process Outsourcing; SSC - Shared Services Centers). Obecnie Kraków charakteryzuje się najwyższym średnim zatrudnieniem $\mathrm{w}$ centrach usług (prawie $1 / 4 \mathrm{w}$ perspektywie krajowej). W Krakowie znajduje się prawie 200 firm, a swoje biura posiadają największe światowe marki, m.in.: ABB, Accenture, BBH, Capgemini, Comarch, Heineken, HSBC, IBM, Lufthansa, Nokia, Philip Morris, Shell czy State Street (www. korporacje.weebly.com). Mimo że krakowskie korporacje zatrudniają ponad 64 tys. osób, to jednak w dalszym ciągu rośnie zapotrzebowanie na pracowników biurowych (Kariera w finansach, 2018). Stąd też należy przyjąć, że wprowadzenie całkowitej lub częściowej pracy zdalnej spowodowało, iż większość planowanych podróży służbowych krajowych i zagranicznych, niezależnie od motywu wyjazdu, przeniosła się do sfery wirtualnej. Zjawisko to postanowiono zbadać bardziej szczegółowo w oparciu o wyniki badań własnych. 


\section{Metodyka badań}

Celem głównym badań była analiza wpływu pandemii COVID-19 na zmiany w organizacji podróży służbowych wśród pracowników korporacji w Krakowie. W pracy postanowiono odpowiedzieć na następujące pytania badawcze:

1. Jaka jest różnica w specyfice podróży biznesowych w latach 2019 i 2020 ?

2. W jakim stopniu zostały ograniczone wyjazdy służbowe w 2020 r.?

3. Jakie alternatywne formy dla podróży służbowych zostały zastosowane w krakowskich korporacjach?

Materiałami badawczymi były publikacje oraz raporty z zakresu omawianej tematyki. Podmiotem badań byli pracownicy krakowskich korporacji. Badanie zostało przeprowadzone na przełomie grudnia 2020 r. i stycznia 2021 r. na grupie 183 osób. Podstawową metodą badawczą w pracy był sondaż diagnostyczny, a narzędziem autorski kwestionariusz ankiety w wersji elektronicznej, który respondenci wypełniali samodzielnie (technika CAWI). Wielkość próby nie jest reprezentatywna (przy założeniu, że wskaźnik poziomu ufności wynosi , wielkość frakcji: 0,5, błąd maksymalny: 7\%, a wielkość populacji: 64 tys. osób), jednak wyniki badań i wnioski dają pogląd co do stanu poruszanej tematyki.

\section{Wyniki badań własnych}

W badaniach wzięło udział 183 pracowników, w tym 74,3\% $\left(n_{1}\right)$ i 5,5\% $\left(n_{2}\right)$ osób, które podróżowały za granicę w celach służbowych w latach $2019\left(n_{1}\right)$ i 2020 $\left(n_{2}\right)$. Wyniki badań odnośnie do struktury zawodowej ankietowanych prezentuje tabela 1.

Tabela 1. Struktura zawodowa $\left(X_{u}\right)$ badanych a uczestnictwo w podróżach służbowych w latach 2019-2020

\begin{tabular}{|c|c|c|c|c|c|c|}
\hline \multirow{2}{*}{\multicolumn{2}{|c|}{ Struktura zawodowa $\left(X_{u}\right)$}} & \multirow{3}{*}{$\begin{array}{c}N=183 \\
56\end{array}$} & \multicolumn{2}{|c|}{2019 r. } & \multicolumn{2}{|c|}{2020 r. } \\
\hline & & & \multirow{2}{*}{$\frac{n_{1}=136}{18}$} & \multirow{2}{*}{$\begin{array}{c}n_{1} / N \times \\
100 \% \\
32,1\end{array}$} & \multirow{2}{*}{$\begin{array}{c}n_{2}=10 \\
0\end{array}$} & \multirow{2}{*}{$\begin{array}{c}n_{1} / n_{2} \times \\
100 \% \\
0,0\end{array}$} \\
\hline \multirow{4}{*}{$\begin{array}{l}\text { Stoplen } \\
\text { zawodowy }\end{array}$} & Junior Specialist $\left(X_{1}\right)$ & & & & & \\
\hline & Specialist $\left(X_{2}\right)$ & 85 & 76 & 89,4 & 0 & 0,0 \\
\hline & Senior Specialist $\left(X_{3}\right)$ & 27 & 27 & 100,0 & 5 & 18,5 \\
\hline & Management $\left(X_{4}\right)$ & 15 & 15 & 100,0 & 5 & 33,3 \\
\hline \multirow[t]{4}{*}{ Dział firmy } & Finanse $\left(X_{5}\right)$ & 65 & 42 & 64,6 & 2 & 3,1 \\
\hline & Human Resources $\left(X_{6}\right)$ & 48 & 35 & 72,9 & 1 & 2,1 \\
\hline & $\operatorname{IT}\left(X_{7}\right)$ & 43 & 39 & 90,7 & 4 & 9,3 \\
\hline & Handel, sprzedaż $\left(X_{8}\right)$ & 27 & 20 & 74,1 & 3 & 11,1 \\
\hline \multirow{4}{*}{$\begin{array}{l}\text { Staż pracy } \\
\text { (w latach) }\end{array}$} & $<1\left(X_{9}\right)$ & 34 & 3 & 8,8 & 0 & 0,0 \\
\hline & $1-2\left(X_{10}\right)$ & 22 & 15 & 68,2 & 0 & 0,0 \\
\hline & $3-5\left(X_{11}\right)$ & 85 & 76 & 89,4 & 0 & 0,0 \\
\hline & $>5\left(X_{12}\right)$ & 42 & 42 & 100,0 & 10 & 23,8 \\
\hline
\end{tabular}

Źródło: badania własne. 
Zasadniczą część badań stanowił zbiór pytań dotyczących podróży służbowych respondentów, w tym:

- głównego kierunku podróży służbowej: Europa $\left(Y_{1}\right)$, Azja $\left(Y_{2}\right)$, Ameryka Północna $\left(Y_{3}\right)$, Ameryka Południowa $\left(Y_{4}\right)$;

- czasu trwania podróży służbowej: 1 dzień $\left(Y_{5}\right), 2-3$ dni $\left(Y_{6}\right), 4-5$ dni $\left(Y_{7}\right)$, powyżej 5 dni $\left(Y_{8}\right)$;

- odległości obiektu noclegowego od siedziby biura: poniżej $5 \mathrm{~km}\left(Y_{9}\right)$, powyżej $5 \mathrm{~km}\left(Y_{10}\right)$;

- głównego celu uczestnictwa w podróży służbowej: kursy i szkolenia $\left(Y_{11}\right)$, udział w konferencji $\left(Y_{12}\right)$, udział w targach i wystawach $\left(Y_{13}\right)$, zawieranie kontraktów $\left(Y_{14}\right)$, związane $z$ umowami $\left(Y_{15}\right)$;

- dodatkowej aktywności turystycznej w miejscu recepcji: brak $\left(Y_{16}\right)$, zwiedzanie miasta $\left(Y_{17}\right)$, zwiedzanie miasta i okolic $\left(Y_{18}\right)$;

- udziału środków własnych (pieniężnych) w podróży służbowej: poniżej 50 euro $\left(Y_{19}\right)$, 50-100 euro $\left(Y_{20}\right)$, powyżej 100 euro $\left(Y_{21}\right)$.

Szczegółowe wyniki badań dotyczące wybranych elementów podróży służbowej w odniesieniu do struktury zawodowej ankietowanych przedstawia tabela 2 .

W 2019 r. niespełna 75\% respondentów brało udział przynajmniej jeden raz w podróży służbowej. Największy odsetek dotyczył pracowników szczebla menedżerskiego i starszego specjalisty - 100\%. Z kolei wśród osób średniego szczebla podróże służbowe stanowiły prawie $90 \%$, wśród osób niższego szczebla - około $32 \%$. Najwięcej podróży służbowych odbyły natomiast osoby ze stażem pracy powyżej 5 lat (100\%) oraz pracujące w branży IT (90,7\%). Dalsza analiza badań własnych pozwala zidentyfikować następujące trendy:

- najwięcej wyjazdów w celach biznesowych odbyło się do krajów Europy, w tym głównie do Niemiec, Szwajcarii i Hiszpanii (58,8\%) oraz Azji, w szczególności na Filipiny i do Japonii $(30,2 \%)$;

- czas całej podróży służbowej wynosił najczęściej 2-3 dni (46,3\%) oraz 4-5 dni $(33,1 \%)$;

- głównym celem wyjazdu było uczestnictwo w kursach i szkoleniach $(67,7 \%)$, udział w konferencjach $(11,8 \%)$ oraz targach i wystawach $(9,6 \%)$;

- pracownicy nocowali najczęściej w obiektach hotelowych oddalonych poniżej $5 \mathrm{~km}$ od lokalnego biura $(74,3 \%)$;

- tylko nieliczna grupa ankietowanych nie podejmowała dodatkowej aktywności turystycznej w miejscach recepcji (12,5\%); za najczęstszy powód wskazywali brak czasu ze względu na obowiązki służbowe $(58,8 \%)$;

- respondenci wydawali średnio poniżej 50 euro podczas całego wyjazdu służbowego $(71,3 \%)$, przede wszystkim na aktywność turystyczną po realizacji obowiązków służbowych.

Inaczej przedstawia się charakter wyjazdów służbowych w 2020 r. Świadczy o tym fakt, że tylko 7,3\% badanych ponownie podróżowało w celach biznesowych. Kraje Europy stanowiły główne miejsce wyjazdów (80\%), które trwały najczęściej 1 dzień (70\%). Cele wyjazdu były na ogół związane z umowami (70\%). Ponadto sytuacja epidemiologiczna spowodowała, że ankietowani nie podejmowali dodatkowej aktywności turystycznej, z obawy przed zachorowaniem bądź 
Tabela 2. Wybrane elementy podróży służbowej $\left(Y_{j}\right)$ w strukturze zawodowej $\left(X_{u}\right)$ respondentów w latach 2019-2020

\begin{tabular}{|c|c|c|c|c|c|c|c|c|c|c|c|c|c|c|c|c|c|c|c|}
\hline \multirow{2}{*}{$\begin{array}{l}\text { Elementy } \\
\text { podróży } \\
\text { służbowej² }^{2}\end{array}$} & \multicolumn{6}{|c|}{ Stopień zawodowy } & \multicolumn{8}{|c|}{ Branża } & \multicolumn{5}{|c|}{ Staż pracy } \\
\hline & $X_{1}$ & $X_{2}$ & $X_{3}$ & & $X_{4}$ & $X_{4}^{*}$ & $X_{5}$ & & $X_{6}$ & & $X_{7}$ & $X_{7}^{*}$ & & $X_{8}^{*}$ & $X_{9}$ & $X_{10}$ & $X_{11}$ & ${ }_{1} X_{1}$ & 12 \\
\hline \multicolumn{20}{|c|}{ Główny kierunek podróży służbowej $\left(Y_{1}-Y_{4}\right)$} \\
\hline$Y_{1}$ & 13 & 44 & 16 & 5 & 7 & 3 & 29 & 2 & 24 & 1 & 17 & 3 & & 2 & 2 & 11 & 41 & & 26 \\
\hline$Y_{2}$ & 4 & 24 & 9 & - & 4 & 1 & 10 & - & 7 & - & 18 & 1 & 6 & - & 1 & 3 & 27 & & 10 \\
\hline$Y_{3}$ & 1 & 8 & - & - & 4 & 1 & 1 & - & 4 & - & 4 & - & 4 & 1 & - & 1 & & 6 & 6 \\
\hline$Y_{4}$ & - & - & 2 & - & - & - & 2 & - & - & - & - & - & - & - & - & - & 2 & 2 & - \\
\hline \multicolumn{20}{|c|}{ Czas trwania podróży służbowej $\left(Y_{5}-Y_{8}\right)$} \\
\hline$Y_{5}$ & 5 & & - & 5 & - & 2 & 4 & 1 & 4 & 1 & 3 & 3 & - & 2 & 2 & 3 & 4 & $t$ & 2 \\
\hline$Y_{6}$ & 3 & 48 & 5 & - & 7 & 1 & 20 & 1 & 15 & - & 12 & 1 & 16 & - & - & 3 & 52 & & 8 \\
\hline$Y_{7}$ & 7 & 19 & 15 & - & 4 & 2 & 14 & - & 12 & - & 15 & - & 4 & 1 & - & 7 & 19 & & 19 \\
\hline$Y_{8}$ & 3 & 3 & 7 & - & 4 & - & 4 & - & & - & 9 & - & - & - & 1 & 2 & 1 & 13 & 3 \\
\hline \multicolumn{20}{|c|}{ Odległość obiektu noclegowego od siedziby biura $\left(Y_{9}-Y_{10}\right)$} \\
\hline$Y_{9}$ & 9 & 58 & 25 & 5 & 9 & 5 & 33 & 2 & 29 & 1 & 36 & 4 & 3 & 3 & - & 9 & 58 & 3 & 34 \\
\hline$Y_{10}$ & 9 & 18 & 2 & - & 6 & - & 9 & - & 6 & - & 3 & - & 17 & - & 3 & 6 & 18 & & 8 \\
\hline \multicolumn{20}{|c|}{ Główny cel uczestnictwa w podróży służbowej $\left(Y_{11}-Y_{15}\right)$} \\
\hline$Y_{11}$ & 17 & 61 & 13 & - & 1 & 1 & 33 & - & 24 & - & 30 & 1 & 5 & - & 3 & 14 & 62 & 13 & 13 \\
\hline$Y_{12}$ & - & & 4 & - & 8 & - & & - & 6 & - & 7 & - & - & - & - & - & 2 & & 14 \\
\hline$Y_{13}$ & 1 & 4 & 4 & - & 4 & - & 2 & - & 1 & - & 2 & - & 8 & - & - & 1 & 5 & & 7 \\
\hline$Y_{14}$ & - & & 2 & 1 & - & - & - & - & 2 & - & - & - & 7 & 1 & - & - & 7 & 7 & 2 \\
\hline$Y_{15}$ & - & - & 4 & 4 & 2 & 4 & 4 & 2 & 2 & 1 & - & 3 & - & 2 & - & - & - & - & 6 \\
\hline \multicolumn{20}{|c|}{ Aktywność turystyczna w miejscu recepcji $\left(Y_{16}-Y_{18}\right)$} \\
\hline$Y_{16}$ & 5 & & - & 4 & 4 & 5 & 4 & 2 & 6 & 1 & 7 & 4 & - & - & 2 & 3 & 6 & 5 & 6 \\
\hline$Y_{17}$ & 3 & 20 & 4 & 1 & 3 & - & 14 & - & 8 & - & 2 & - & 6 & 1 & - & 3 & 22 & & 5 \\
\hline$Y_{18}$ & 10 & 48 & 23 & - & 8 & - & 24 & - & 21 & & 30 & - & 14 & - & 1 & 9 & 48 & & 31 \\
\hline \multicolumn{20}{|c|}{ Udział środków własnych (pieniężnych) $\left(Y_{19}-Y_{21}\right)$} \\
\hline$Y_{19}$ & 6 & 55 & 26 & 5 & 10 & 5 & 28 & 5 & 26 & 1 & 28 & 4 & 15 & 3 & - & 6 & 55 & 53 & 36 \\
\hline$Y_{20}$ & 12 & 20 & 1 & - & 5 & - & 14 & - & 9 & - & 10 & - & 5 & - & 3 & 9 & 20 & & 6 \\
\hline$Y_{21}$ & - & 1 & - & - & - & - & - & - & - & - & 1 & - & - & - & - & - & -1 & 1 & - \\
\hline
\end{tabular}

* Dane za $2020 \mathrm{r}$.

Źródło: badania własne.

w wyniku ograniczeń wprowadzonych przez poszczególne rządy krajów. Z tego powodu pracownicy nocowali w obiektach zbiorowego zakwaterowania w odległości do $5 \mathrm{~km}$ od biura. Na podstawie wyników badań zaprezentowanych w powyższych tabelach można stwierdzić, że podróże służbowe wśród pracowników krakowskich korporacji zostały znacznie ograniczone w 2020 r.

W badaniach postanowiono również zapytać respondentów o formę wykonywania czynności zawodowych w dobie pandemii koronawirusa. W skali wszystkich ankietowanych $(N=183)$ całkowitą pracę zdalną ( $z$ możliwością przyjścia do biura na własną odpowiedzialność) wykonuje 86,3\%, a częściową pracę zdalną 
(w systemie 2-3 dni w biurze) - 9,3\%. Brak możliwości pracy zdalnej deklaruje natomiast 4,4\% osób. Udział w większości kursów i szkoleń, konferencji czy posiedzeń zespołu został przeniesiony do sfery wirtualnej (najczęściej za pośrednictwem aplikacji Microsoft Teams). Ponadto znaczna część osób (80,3\%) wskazuje, że dzięki pracy zdalnej ma możliwość uczestnictwa w spotkaniach online, które zastąpiły wyjazdy służbowe (odsetek wśród osób niepodróżujących w celach służbowych w 2019 r. wynosił 89,4\%). Tym samym osoby wykluczone z wyjazdów biznesowych mają obecnie szansę rozwoju i poznania współpracowników z innych krajów. Należy jednak przy tym dodać, że aż 77,9\% osób biorących udział w wyjazdach biznesowych w 2019 r. jest zdania, że obecne formy spotkań online nie stanowią alternatywy dla podróży służbowej.

\section{Zakończenie}

Współczesny rynek turystyczny dotknięty został kryzysem spowodowanym pandemią koronawirusa. Dotyczy to nie tylko ograniczeń związanych z usługami stricte turystycznymi (np. noclegowymi, gastronomicznymi, przewodnickimi), ale również z szeroko rozumianą turystyką biznesową. Działania wprowadzone przez poszczególne rządy krajów spowodowały znaczne ograniczenia w podróżach służbowych.

W niniejszej publikacji przedstawiono wyniki autorskiego badania dotyczącego zmian organizacji podróży służbowych wywołanych pandemią COVID-19 wśród pracowników krakowskich korporacji. Cel pracy powstał w oparciu o podkreślaną $\mathrm{w}$ literaturze przedmiotu rolę podróży służbowych $\mathrm{w}$ funkcjonowaniu współczesnych podmiotów gospodarczych oraz obostrzenia w wyjazdach spowodowane rozwojem koronawirusa. W badaniach przeprowadzonych na przełomie 2020 i 2021 r. wzięły udział 183 osoby. Badanie zrealizowano za pomocą internetowego kwestionariusza ankiety.

Zebrany materiał empiryczny i jego interpretacja pozwala stwierdzić, że pandemia COVID-19 przyczyniła się do spadku zagranicznych wyjazdów służbowych respondentów. O ile w 2019 r. w podróży służbowej wzięło udział 136 ankietowanych, to w $2020 \mathrm{r}$. w celach biznesowych podróżowało tylko 10 osób. Wprowadzone ograniczenia spowodowały, że pracownicy na niższych i średnich szczeblach zostali całkowicie wykluczeni $z$ wyjazdów, bowiem cel podróży dotyczył przede wszystkim spraw związanych z zawieraniem umów. Ponadto respondenci nie podejmowali dodatkowej aktywności turystycznej, co przekłada się na mniejsze dochody społeczności obszarów recepcji. Należy również dodać, że dla większości badanych obecne formy spotkań online nie stanowią alternatywy dla podróży służbowych. Opinie te potwierdzają podstawowe założenia, że turystyka zajmuje szczególne miejsce w systemie potrzeb człowieka. Daje bowiem możliwość bezpośredniej konfrontacji różnych postaw i światopoglądów, sprzyja procesom globalizacji, a w przypadku wyjazdów w celach biznesowych - podnosi prestiż zawodu, pozwala na samorealizację oraz rozwijanie umiejętności i kompetencji zawodowych. 


\section{Literatura}

Berbeka J., Borodako K., Niemczyk A., Seweryn R. (2013). Przemysł spotkań w Krakowie oraz Małopolsce w 2012 roku. Fundacja Uniwersytetu Ekonomicznego w Krakowie, Kraków.

Bhatia A.K. (2006). The Business of Tourism. Sterling, New Delhi.

Borodako K., Berbeka J., Rudnicki M. (2014). Usługi specjalistyczne w turystyce biznesowej. Fundacja Uniwersytetu Ekonomicznego w Krakowie, Kraków.

Borodako K., Berbeka J., Rudnicki M. (2015). Zarządzanie innowacjami w przemyśle spotkań. Wydawnictwo C.H. Beck, Warszawa.

Celuch K. (2012). Przemysł spotkań i wydarzeń w Polsce - Poland Meetings and Events Industry. Raport. Wydawnictwo Polskiej Organizacji Turystycznej, Warszawa.

Cooper C., Fletcher J., Gilbert D., Wanhill S. (1993). Tourism. Pitman Publishing, London.

Davidson R. (2003). Turystyka biznesowa. Konferencje, podróże motywacyjne, wystawy, turystyka korporacyjna. Polska Organizacja Turystyczna, Warszawa.

Davidson R., Cope B. (2003). Turystyka biznesowa. Polska Organizacja Turystyczna, Warszawa.

Gaworecki W.W. (2010). Turystyka. PWE, Warszawa.

Gołembski G. (red.) (2008). Nowe trendy w turystyce. PWSZ, Sulechów.

GUS (2020). Turystyka w Polsce w obliczu pandemii COVID-19. Informacje sygnalne (www. https://stat.gov.pl/obszary-tematyczne/kultura-turystyka-sport/turystyka/turystyka-w-polsce-w-obliczu-pandemii-covid-19,13,1.html; dostęp: 3.01.2021).

Instytut Rynku Hotelarskiego (2008). Badanie pilotażowe rynku turystyki biznesowej (MICE) (województwo wielkopolskie). Metodologia oraz raport z badania (www.prot. gda.pl/wp-content/uploads/2018/03/Badanie-pilota\%C5\%BCowe-rynku-turystykibiznesowej1-1.pdf; dostęp: 19.12.2020).

Kariera w finansach (2018). BPO/SSC w Polsce: Kraków, czyli miasto przyszłości sektora nowoczesnych usług biznesowych (www.karierawfinansach.pl/artykul/raporty/krakow-bpo-scc-miasto-przyszlosci; dostęp: 3.01.2021).

Klimek K. (2012). Turystyka biznesowa na globalnym rynku usług turystycznych. Wydawnictwo Uniwersytetu Ekonomicznego w Krakowie, Kraków.

Kurek W. (red.) (2007). Turystyka. Wydawnictwo Naukowe PWN, Warszawa.

Medlik S. (1995). Leksykon podróży, turystyki i hotelarstwa. Wydawnictwo Naukowe PWN, Warszawa.

Mika M. (2008). Formy turystyki biznesowej. W: W. Kurek (red.), Turystyka. Wydawnictwo Naukowe PWN, Warszawa, s. 300-313.

MRPiT (2020). Tymczasowe zalecenia dla pracodawców w związku z koronawirusem SARS-CoV-2 (https://www.gov.pl/web/rozwoj-praca-technologia/tymczasowe-zaleceniadla-pracodawcow-w-zwiazku-z-koronawirusem-sars-cov-2; dostęp: 3.01.2021).

Nawrocka E. (2013). Istota turystyki biznesowej, stan i czynniki jej rozwoju na przykładzie Wrocławia. Rozprawy Naukowe Akademii Wychowania Fizycznego we Wrocławiu, 41: 76-85.

Raport 2020. Przemysł spotkań i wydarzeń w Polsce (2020) (https://www.pot.gov.pl/attachments/article/148/RAPORT\%202020_PL_14.09.pdf; dostęp: 3.01.2021).

Rogers T. (2008). Conferences and Conventions. Butterworth-Heinemann, Oxford.

Różycki P. (2009). Zarys wiedzy o turystyce. Proksenia, Kraków.

Swarbrooke J., Horner S. (2001). Business Travel and Tourism. Butterworth-Heinemann, Oxford.

Świątecki A. (red.) (2005). Nowy Incentive w Polsce. ELECT Business Service \& Travel, Warszawa.

www.korporacje.weebly.com (dostęp: 3.01.2021). 


\section{Changes in the organization of business travels caused by the COVID-19 pandemic among employees of corporations in Cracow}

This article presents the results of the author's research on changes in the organization of business travels caused by the coronavirus pandemic. The diagnostic survey was conducted using the CAWI technique at the turn of 2020 and 2021. The study concerned corporate employees in Krakow. The research sample included 183 people. The results of the research allowed to state that there are dependencies between the occupational structure of the respondents and participation in business travels. It has also been shown that the online meetings currently offered are not an alternative to business travel.

Translated by Adrian Urbańczyk 


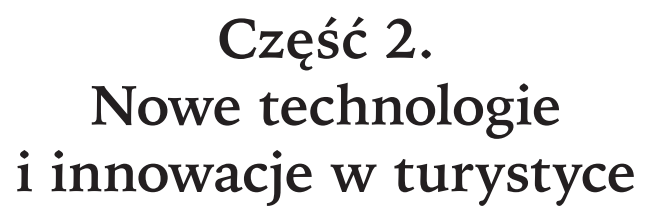





\section{Małgorzata Franczyk}

Uniwersytet Ekonomiczny w Krakowie

malgorzata.franczyk1@gmail.com

\section{Konsekwencje społeczne i ekonomiczne wydarzeń hybrydowych na przykładzie piątej edycji kongresu Open Eyes Economy Summit}

\section{Streszczenie}

Z uwagi na bardzo szybki rozwój branży spotkań oraz pandemię COVID-19 profesjonaliści zajmujący się organizacją spotkań starają się wdrażać technologię, aby wydarzenia mogły dalej się odbywać w celu wzbogacenia doświadczeń uczestników. Odpowiedzią na powyższe są wydarzenia hybrydowe, które łączą w sobie tradycyjne elementy spotkań z innowacyjnymi technologiami. Celem pracy jest zbadanie konsekwencji ekonomicznych i społecznych wspomnianych wydarzeń z perspektywy organizatora. Metodą badawczą zastosowaną w opracowaniu jest studium przypadku: analiza kongresu Open Eyes Economy Summit oraz wywiad $z$ jego organizatorami. Z badań wynika, że ten sposób organizacji przynosi wiele wymiernych korzyści, przyczynia się do powstawania nowego trendu oraz upatruje się w nim przyszłość branży spotkań.

\section{Wprowadzenie}

Wydarzenia hybrydowe w roku 2020, na skutek pandemii COVID-19, stały się nowym standardem i nową rzeczywistością w branży spotkań. Organizatorzy stanęli przed wyzwaniem przeniesienia wydarzeń stacjonarnych do strefy wirtualnej. Powodem podjęcia tego tematu była chęć usystematyzowania definicji wydarzenia hybrydowego i jego konsekwencji, ponieważ obecna literatura naukowa na ten temat jest niewystarczająca. Celem pracy jest wskazanie konsekwencji ekonomicznych i społecznych wydarzeń hybrydowych z punktu widzenia organizatora piątej edycji Open Eyes Economy Summit. W części pierwszej rozdziału dokonano przeglądu dostępnej literatury zarówno krajowej, jak i międzynarodowej 
z zakresu branży spotkań oraz wydarzeń hybrydowych. W kolejnej części pracy opisano i uzasadniono wybór metody badawczej - studium przypadku - oraz przedstawiono wyniki badań własnych. Opisano kongres Open Eyes Economy Summit i proces organizacji, a także korzyści i bariery formy hybrydowej na podstawie wywiadu przeprowadzonego $z$ organizatorami wspomnianego kongresu. W zakończeniu wyszczególniono najważniejsze wnioski oraz omówiono wyzwania, jakie stoją przed organizatorami.

\section{Przegląd literatury}

Termin branża spotkań jest pojęciem trudnym do jednoznacznego zdefiniowania i sklasyfikowania ze względu na jego stosunkowy młody i złożony charakter (Borodako i in., 2018). W literaturze przedmiotu brakuje systematyzacji pojęciowej, która by w sposób precyzyjny i jednoznaczny wymieniała rodzaje spotkań i wydarzeń mieszczących się $\mathrm{w}$ tym terminie.

Punktem wyjścia jest definicja słowa spotkanie (ang. meeting), które według United Nations World Tourism Organization oznacza: „zgromadzenie w jednym miejscu pewnej liczby osób w celu naradzenia się lub wykonania określonej czynności. Kluczowym celem spotkań jest motywowanie uczestników i prowadzenie działalności biznesowej. Częstotliwość może mieć charakter doraźny lub zgodny $z$ ustalonym schematem, jak np. coroczne walne zgromadzenia, posiedzenia komitetów itp." (Global Meetings Initiative, 2008, s. 2).

Z kolei w „Leksykonie przemysłu spotkań” (Celuch, 2015) spotkanie określane jest jako wydarzenie, podczas którego podstawową aktywnością uczestników jest udział w sesjach edukacyjnych i biznesowych, a także w wydarzeniach towarzyszących powiązanych $z$ danym tematem.

Zamiennie używa się terminu przemysł spotkań, który definiowany jest jako „całość zjawisk i procesów związanych z organizacją spotkań na danym terenie w określonym czasie. Zastosowanie terminu przemysł spotkań podkreśla gospodarcze (i w konsekwencji społeczne) znaczenie przeprowadzania spotkań dla danego obszaru - miasta, regionu, kraju" (Borodako i in., 2014, s. 63).

Szeroko rozumiany rynek przemysłu spotkań tworzą dwie strony: podmioty reprezentujące stronę popytową oraz podażową. Osoby zgłaszające popyt na usługi organizacji wydarzeń to najczęściej korporacje, organizacje rządowe i pozarządowe. Stronę podażową natomiast reprezentują pośrednicy oraz dostawcy usług cząstkowych, np. obiekty spotkań, obiekty noclegowe czy firmy transportowe (Cieślikowski, 2015).

Pośrednicy mogą reprezentować stronę popytową, w imieniu nabywców, a także stronę podażową, w imieniu dostawców. Do pierwszej kategorii zaliczyć można profesjonalnego organizatora konferencji i kongresów (Professional Conference Organiser, w skrócie PCO). Davidson i Cope (2003) definiują PCO jako menedżera produktu, w tym wypadku całej imprezy, oraz konsultanta doradzającego często w takich kwestiach, jak: techniki komunikacji, marketing czy public relations. W imieniu nabywców działają również venue finder agencies, czyli agencje 
zajmujące się wyszukiwaniem odpowiednich miejsc do organizacji wydarzenia. Po stronie pośredników pracujących w imieniu dostawców wyróżnia się convention bureau - biura spotkań, które są organizacjami non profit, reprezentującymi dane państwo, miasto lub region oraz firmy zajmujące się określoną destynacją (destination management companies, w skrócie DMC).

Z uwagi na dynamiczny rozwój branży spotkań, coraz częściej w celu zwiększenia konkurencyjności na rynku wprowadza się szereg innowacji do procesu organizacji i realizacji wydarzenia. Przykładem może być wydarzenie hybrydowe, które identyfikowane jest jako najnowszy gatunek planowanych spotkań o kluczowym znaczeniu dla rozwoju branży. Dostępna literatura naukowa dotycząca spotkań wirtualnych jest niewystarczająca, odnotowano bardzo niewiele badań akademickich w tym zakresie. Sam termin wydarzenia hybrydowe w polskiej literaturze naukowej jest nowy, jego definicja tworzy się teraz, w czasie rzeczywistym, którym jest okres światowej pandemii.

W oparciu o przytoczone definicje branżowe wirtualne spotkanie jest „spotkaniem na żywo z wykorzystaniem wirtualnej platformy dostarczanej przez korporację platformy wirtualnej (eventowej) (lub takiej, która została zbudowana na zamówienie klienta), lub prezentowanej w wirtualnym świecie" (Sox i in., 2017). Technologia ta wykorzystywana jest przede wszystkim do sprawniejszej komunikacji z uczestnikami spotkania.

Wydarzenie hybrydowe jest zatem spotkaniem, które „obejmuje połączenie zdarzeń fizycznych i cech spotkania wirtualnego, zazwyczaj odbywającego się jednocześnie, z nakładającymi się na siebie informacjami i komponentami interaktywnymi" (Virtual Edge Community, 2009). W modelu hybrydowym możliwość jednoczesnego zaangażowania mają osoby przebywające fizycznie w obiekcie, a także wirtualni uczestnicy.

Sox i in. (2014) przytaczają definicję, w której wydarzenia hybrydowe to wydarzenia cyfrowe, spotkania i technologie edukacyjne, które obejmują: media strumieniowe, rzeczywistość wirtualną (2D i 3D). Transmisja strumieniowa daje dostęp do zasobów takich, jak pliki audio i wideo: „treści multimedialne są jednocześnie pozyskiwane i transmitowane w czasie bliskim czasu rzeczywistego. Dane multimedialne docierają do wszystkich użytkowników z dowolnego, odległego od nich miejsca na świecie. Ponieważ zdarzenia utrwalone za pomocą danych multimedialnych są przekazywane do użytkownika na bieżąco, użytkownik nie ma możliwości sterowania transmisją" (Sulej, Ziółkowska, 2011). Platforma musi być zabezpieczona, aby tylko zarejestrowani uczestnicy mogli dołączyć do spotkania. Zapewniona musi być również pomoc i obsługa uczestników w przypadku problemów z podłączeniem się do wydarzenia.

Wydarzenia są nagrywane jako pliki multimedialne i ponownie strumieniowane w różnych formatach, co oznacza, że różni odbiorcy mobilni mogą odbierać transmisję strumieniową i brać udział w wydarzeniu zdalnie. Sposób ten ułatwia dotarcie do większej liczby odbiorców na całym świecie. Transmisja jest zazwyczaj nagrywana, dzięki czemu materiały mogą być udostępnione uczestnikom po zakończeniu wydarzenia, co daje możliwość powrotu do prezentacji (Hoods, Pakarinen, 2018). 
Jednakże, aby wydarzenie wirtualne zaklasyfikowane zostało jako wydarzenie w ramach branży spotkań, musi zaistnieć interakcja z uczestnikami. Kluczowe jest zapewnienie strefy networkingu, gdzie spotykają się dwa komponenty - świata realnego i wirtualnego, czyli tradycyjne elementy spotkania $z$ innowacyjną technologią. Wirtualna rzeczywistość jest nieograniczona, wykorzystywane platformy pozwalają na łączenie $\mathrm{w}$ pokoje wirtualne, wykonywanie wspólnych zadań, dyskutowanie, rozmawianie z partnerami i sponsorami wydarzenia. Dzięki temu w trakcie sesji uczestnicy są praktycznie obecni i mogą współdziałać tak, jak w przypadku tradycyjnego wydarzenia. Bycie faktycznie obecnym pozwala na utrzymanie zainteresowania. Wiedza, tematy i prezenterzy są jednym z powodów, dla których uczestnicy biorą udział w wydarzeniach. Drugim jest właśnie kontakt z ludźmi, budowanie kontaktów społecznych i biznesowych (Hoods, Pakarinen, 2018).

\section{Metodyka badań}

W niniejszej pracy wybrano metodę jakościową - studium przypadku (ang. case study), ponieważ cechuje się ona holistycznym podejściem. Nie polega tylko na zbieraniu danych, dokumentowaniu ich i przeszukiwaniu materiałów, ale także na głębokiej analizie i zrozumieniu pojedynczego przypadku. „Charakteryzuje się rygorystycznymi wymogami, ale dopuszcza znaczną elastyczność, zwłaszcza gdy chodzi o nietypowy problem badawczy" (Wójcik, 2013, s. 18). Według Yina (2003) ta metoda badania składa się z trzech głównych etapów: (1) definiowania i projektowania badania, (2) przygotowania do zbierania danych, (3) zbierania danych i ich analizy oraz wnioskowania.

Za pomocą tej metody można znaleźć odpowiedzi na pytania, ,jak” i „dlaczego" omawiane zjawisko występuje. Dodatkowo stwarza ona możliwość wyjaśnienia związków przyczynowo-skutkowych, których nie da się zweryfikować i ocenić za pomocą ankiety. Case study jest szczególnie przydatne do badań ewaluacyjnych, które pozwalają dokonać oceny badanych zjawisk (Lisiecka, Kostka-Bochenek, 2009). „Każda $z$ technik badawczych może być zastosowana przy metodzie indywidualnych przypadków, jeżeli przyniesie pożądane skutki. Wysoce użyteczny pod względem badawczym jest wywiad, badania środowiskowe, a także badania dokumentów" (Apanowicz, 2002, s. 70). Powodem użycia tej metody była wyjątkowość opisywanego zjawiska.

Pierwszym etapem procesu badawczego była analiza wydarzenia Open Eyes Economy Summit na podstawie informacji dostępnych na stronie internetowej wydarzenia oraz publikowanych postów w social mediach. Drugim etapem było przeprowadzenie wywiadu z organizatorami tegoż kongresu. Celem badawczym była analiza wydarzenia hybrydowego oraz wskazanie skutków ekonomicznych i społecznych, jakie niesie ze sobą ten model organizacji z punktu widzenia organizatora OEES. Wywiad składał się z jedenastu pytań otwartych merytorycznych oraz dwóch pytań metryczkowych. 


\section{Wyniki badań}

Wywiad udało się przeprowadzić zdalnie na początku stycznia 2021 r. z dyrektorem zarządzającym Open Eyes Economy Summit - Kingą Taćkiewicz, która koordynuje prace organizacyjne i produkcyjne całego zespołu, zarządza budżetem i harmonogramem oraz prowadzi ewaluację projektu.

Międzynarodowy Kongres Ekonomii Wartości Open Eyes Economy Summit (w skrócie OEES) to doroczny szczyt ekonomiczny odbywający się w Krakowie od 2016 r. Jego celem jest szerzenie i realizacja nowych, otwartych spojrzeń na ekonomię, a także inspirowanie do działania i wymyślania alternatywnych sposobów rozumienia gospodarki opartej na wartościach. Prowadzone są debaty, seminaria i konferencje, łączące ludzi z rozmaitych branż i środowisk, poruszające różnorodne tematy oraz tworzące niestandardowe i nieoczekiwane połączenia. Udział w kongresie biorą politycy, aktywiści, naukowcy, studenci, dziennikarze i artyści. Jak mówią o sobie sami organizatorzy - OEES to „tygiel nowych idei, fuzja rozmaitych horyzontów i prawdziwa współczesna agora" (https://oees.pl; dostęp: 2.01.2021). Piąta edycja Open Eyes Economy Summit odbyła się 17-18 listopada $2020 \mathrm{r}$. i przyjęła formę hybrydową.

Pierwsze cztery edycje OEES (2016-2019) każdego roku gromadziły w Centrum Kongresowym ICE prawie 3 tys. uczestników i 200 prelegentów z całego świata. Organizując poprzednie edycje, nie korzystano z narzędzi zdalnego łączenia się - uczestnicy i prelegenci spotykali się w Krakowie, gdzie w ciągu dwóch dni na żywo dyskutowali o ekonomii przyszłości. Nie oznacza to jednak, że organizatorzy OEES nie mieli doświadczenia w wirtualnych wydarzeniach. Jak mówi Kinga Taćkiewicz: „po ogłoszeniu obostrzeń w związku z pandemią COVID-19 ruszyliśmy z szeregiem projektów i mniejszych wydarzeń online, których w pierwszej połowie roku 2020 zorganizowaliśmy ponad 30. To doświadczenie doskonale przygotowało zespół do organizacji w formule hybrydowej tak dużego przedsięwzięcia jak OEES".

Razem $z$ wprowadzeniem technologii do branży spotkań, tradycyjne zarządzanie wydarzeniami znacznie się zmieniło - obecnie panuje czas wydarzeń wirtualnych. Podczas rozmowy zapytano o korzyści wynikające $z$ hybrydowego modelu organizacji eventu z punktu widzenia właściciela wydarzenia oraz wszystkich pozostałych firm tworzących zespół organizatora. Dyrektor zarządzający jako największą korzyść wskazała zwiększenie dostępności kongresu dla odbiorców - zarówno uczestników, jak i prelegentów. Brak konieczności podróży do Krakowa daje szansę na dotarcie do dotychczas nieosiągalnych prelegentów. Jako potwierdzenie można wskazać wystąpienie w piątej edycji OEES laureata Pokojowej Nagrody Nobla - Muhammada Yunusa. Omawiana edycja OEES „odbyła się pod hasłem \#wszedziegdziechcesz, dzięki temu promowaliśmy możliwość uczestniczenia w Kongresie $z$ każdego miejsca na świecie: $z$ biura, z plaży, z łóżka, w podróży - wszędzie. Technologia, jaką przygotowaliśmy na OEES, dawała takie rozwiązania”. Kolejne wymierne korzyści można wskazać dla firm zajmujących się produkcją i realizacją wydarzeń, które szybko odnalazły się w nowej 
rzeczywistości i zaczęły budować platformy do streamingu, oferować usługi zdalnej organizacji wydarzeń z całą obsługą technologiczną.

Korzyści pojawiają się również w kwestii ekonomicznej. Koszty wzięcia udziału dla uczestników piątej edycji kongresu zostały obniżone o $25 \%$ w porównaniu z poprzednią edycją. Czyni to wydarzenie jeszcze bardziej dostępnym dla większego grona potencjalnych zainteresowanych. Jeśli chodzi o całkowity budżet, można stwierdzić, że koszt organizacji wydarzenia online jest niższy, w przypad$\mathrm{ku}$ OEES o $15 \%$.

Niestety pozostałe gałęzie branży spotkań (hotele, gastronomia, transport) ponoszą duże straty ze względu na brak spotkań na żywo. Brak uczestników czy mniejsza liczba uczestników na miejscu automatycznie oznacza zmniejszenie zapotrzebowania na te usługi. Jak zauważa Kinga Taćkiewicz: „wydarzenie w zdalnej formule niestety znacząco skraca łańcuch dostawców". Zapytano więc, jakie działania i rozwiązania wykorzystano przy organizacji OEES, aby zachować łańcuch podwykonawców i które z tych działań były innowacyjne. W kwestii produkcji i realizacji wizji, obsługi multimediów i systemu rejestracyjnego organizatorzy skorzystali $z$ usług tych samych firm, co przy poprzednich edycjach. Zmieniło się zamówienie na catering, było 10 razy mniejsze, współpraca z hotelami również była symboliczna. „Zdecydowaną innowacją był fakt, że zdecydowaliśmy się wysłać welcome-packi do domów naszych zarejestrowanych uczestników, co zrealizowaliśmy przy nieocenionej pomocy zaprzyjaźnionej firmy kurierskiej oraz wsparciu naszych partnerów, którzy wypełnili przesyłkę gadżetami i publikacjami".

Wirtualna frekwencja to zupełnie nowy sposób uczestniczenia w wydarzeniach, który wpływa na proces uczenia się, zdobywania wiedzy oraz doświadczenia uczestników i prelegentów w sferze networkingu. Rozmówca wskazuje, że „organizując OEES $5 \mathrm{w}$ formule hybrydowej, musieliśmy kompletnie przeprogramować swoje myślenie o Kongresie, a cały know-how zdobyty przy poprzednich edycjach okazał się niewystarczający. Musieliśmy zdynamizować program, zaplanować go tak, aby uczestnik nigdy się nie znudził, aby każdy kolejny punkt, każda aktywność na platformie była bardziej angażująca niż poprzednia”. Zbudowana, na potrzeby piątej edycji OEES, platforma dawała możliwość „networkingu przy 5 stolikach tematycznych, czytania publikacji przygotowanych specjalnie na kongres, odwiedzania wirtualnych stanowisk partnerów, a nawet łączenia się z nimi, zadawania pytań prelegentom $\mathrm{w}$ indywidualnych sesjach Q\&A, a do tego przez dwa dni nadawaliśmy program OEES równolegle $z$ czterech scen, a w przerwach działało studio live, które pokazywało to, co działo się w Centrum Kongresowym ICE". Z ankiet, które organizatorzy przeprowadzili wśród uczestników, wynika, że w kwestii zdobywania wiedzy uczestnicy zyskali więcej w porównaniu z wydarzeniem stacjonarnym. Z łatwością można było przemieszczać się między scenami, wystąpieniami, odtwarzać nagrania, prowadzić dyskusje na czacie i komentować panele.

W realizacji wydarzenia hybrydowego niezbędne jest wykorzystanie innowacji technologicznych. Organizatorzy OEES 5 są zadowoleni z narzędzi, z jakich skorzystali podczas całego procesu organizacji. „Za innowacyjną uważamy przede 
wszystkim zbudowaną przez nas platformę OEES 5 - to przełomowe pod kątem funkcjonalności rozwiązanie w branży, które umożliwiło uczestnikom dostęp do:

1. 4 scen live i studia OEES.

2. 5 networkingowych stolików tematycznych wraz z Q\&A z wybranymi mówcami.

3. 19 stanowisk $\mathrm{w}$ strefie expo, w tym 16 spotkań live z przedstawicielami partnerów.

4. Aktualnej agendy z możliwością dodania poszczególnych punktów do swojego kalendarza.

5. Profili speakerów.

6. Publikacji OEES i materiałów kongresowych do pobrania.

7. Sklepu internetowego z możliwością zakupu publikacji prelegentów (BOOKSHOP).

8. Live chatów wraz z możliwością prywatnych czatów pomiędzy użytkownikami”. Kongres OEES 5 stał się największym wydarzeniem zdalnym w kraju. Wzięło w nim udział 3000 osób, w tym 160 prelegentów, z 27 krajów. W przyszłości planuje się nadal wykorzystywać streaming i możliwość zdalnego łączenia mówców, a także rozszerzenie hybrydy do obecności publiczności w liczbie około 100 osób. To pozwoli zwiększyć frekwencję, a co najważniejsze, dać wybór uczestnikom: „dla osób, dla których najważniejszy jest networking, będzie możliwość udziału stacjonarnie, a ci, którzy bardziej dbają o merytorykę i zwiększenie wiedzy, obejrzą Kongres z dowolnego, wybranego przez siebie miejsca”. Ta wypowiedź wskazuje na tworzenie się trendu dotyczącego różnicowania uczestników ze względu na ich potrzeby i cele - uczestnicy online, którzy jako główny motyw udziału w wydarzeniu wirtualnym widzą aspekt merytoryczny i zdobywanie wiedzy, oraz uczestnicy stacjonarni, dla których ważniejsze są relacje i kontakty z innymi ludźmi.

\section{Podsumowanie}

Badania wskazują wiele korzyści, ale również barier i negatywnych skutków hybrydowego modelu organizacji wydarzenia. Organizatorom rzeczywistość wirtualna pomaga obniżyć koszty i zwiększyć zyski, ponieważ liczba uczestników jest dowolna, a samo wydarzenie nie jest ograniczone żadnymi elementami fizycznymi. Oszczędności wynikają z braku konieczności rezerwacji obiektów noclegowych, biletów lotniczych i kolejowych dla mówców, mniejszej potrzeby korzystania z usług cateringowych oraz firm transportowych. Swoje zyski zdecydowanie zwiększają firmy zajmujące się produkcją i realizacją wydarzeń poprzez stworzone platormy do streamingu oraz oferty zdalnej organizacji wydarzenia.

Brak konieczności podróży do danego miejsca i możliwość wirtualnego łączenia się zwiększa dostępność wydarzenia dla uczestników i przyczynia się do poszerzenia potencjalnych kręgów osób zainteresowanych danym produktem, w tym wypadku kongresem OEES. Stworzona platforma i szereg wprowadzonych innowacji pozwala również budować przewagę konkurencyjną na rynku. 
Konsekwencje społeczne zauważa się też w strukturze zatrudnienia. Wydarzenia wirtualne znacząco skracają łańcuch podwykonawców w porównaniu z wydarzeniem stacjonarnym. Przekłada się to realnie na zmniejszenie wielkości zatrudnienia w pozostałych gałęziach branży spotkań, takich jak gastronomia, transport czy zakwaterowanie.

Dla organizatorów wydarzeń hybrydowych kluczem do sukcesu jest zaangażowanie wszystkich uczestników i sprawienie, by czuli się oni częścią danego wydarzenia, a także umiejętność odpowiedzi na powstający nowy trend wśród uczestników, czyli zapewnienie możliwości uczestnictwa stacjonarnego osobom, dla których ważny jest networking, ale również uczestnictwa zdalnego osobom, dla których priorytetem jest aspekt merytoryczny. Analizowany model organizacji wydarzeń daje ogrom możliwości i wymiernych korzyści. Nie bez powodu zatem w formie hybrydowej upatruje się przyszłość branży spotkań.

\section{Literatura}

Apanowicz J. (2002). Metodologia ogólna. Wydawnictwo Diecezji Pelplińskiej Bernardinum, Gdynia.

Borodako K., Berbeka J., Niemczyk A., Seweryn R. (2014). Wpływ ekonomiczny przemysłu spotkań na gospodarkę Krakowa. Fundacja Uniwersytetu Ekonomicznego w Krakowie, Kraków.

Borodako K., Berbeka J., Niemczyk A., Seweryn R. (2018). Wpływ ekonomiczny branży spotkań na gospodarkę Krakowa. Małopolska Organizacja Turystyczna, Kraków.

Celuch K. (2015). Leksykon przemysłu spotkań. Turystyka biznesowa, event marketing, podróże motywacyjne. Biblioteka Meeting Plannera, Warszawa.

Cieślikowski K. (2015). Zarządzanie turystyką biznesową. Wybrane aspekty globalne i lokalne. Wydawnictwo Akademii Wychowania Fizycznego w Katowicach, Katowice.

Davidson R., Cope B. (2003). Turystyka biznesowa. Konferencje, podróże motywacyjne, wystawy, turystyka korporacyjna. Polska Organizacja Turystyczna, Warszawa.

Global Meetings Initiative (2008). Identifying the link between tourism and the Meeting Industry: case studies. Vol. 1. UNWTO Department of Statistics and Tourism Satellite Account, Madrid.

Hoods J., Pakarinen T. (2018). From hybrid events to the next generation - interactive virtual events. Viewed from three different stakeholders' point of view. Lahti University of Applied Sciences, Lahti.

Lisiecka K., Kostka-Bochenek A. (2009). Case study research jako metoda badań naukowych. Przegląd Organizacji, 10(837).

Open Eyes Economy Summit (https://oees.pl; dostęp: 2.01.2021).

Sox C., Crews T., Kline S. (2014). Virtual and Hybrid Meetings for Generation X: Using the Delphi Method to Determine Best Practices, Opportunities, and Barriers. Journal of Convention \& Event Tourism, 15: 150-169.

Sox C., Kline S., Crews T. (2017). Virtual and Hybrid Meetings: Gaining Generational Insight From Industry Experts. International Journal of Hospitality \& Tourism Administration, 18, 2: 133-170.

Sulej W., Ziółkowska M. (2011). Efektywność mediów strumieniowych. Biuletyn Instytutu Automatyki i Robotyki, 30. 
Wójcik P. (2013). Znaczenie studium przypadku jako metody badawczej w naukach o zarządzaniu. E-mentor, 1(48): 17-22.

Virtual Edge Community (2009). Virtual Event Definitions (www.virtualedge.org/page/ virtual-event-definitions; dostęp: 21.12.2020).

Yin R. (2003). Case study research: design and methods. Thousand Oaks, London-New Delhi.

\section{Social and economic consequences of hybrid events in the 5th Edition of the Open Eyes Economy Summit}

Due to the very rapid development of the meeting industry and the COVID-19 pandemic, meeting professionals are trying to implement technology so that events can continue in order to enrich the experience of participants. The answer to this is hybrid events, which combine traditional meeting elements with innovative technologies. The purpose of this work is to examine the economic and social consequences of these events from the perspective of the event organiser. The research method used in the study is a case study - an analysis of the Open Eyes Economy Summit Congress and an interview with its organizers. Research has shown that this way of organizing brings many tangible benefits, contributes to a new trend and sees the future of the meeting industry. 



\author{
Aleksandra Dulewska \\ Akademia Wychowania Fizycznego im. Bronisława Czecha w Krakowie \\ oladulewska@wp.pl
}

\title{
Wykorzystanie nowoczesnych technologii dla celów promocyjnych przez touroperatorów prowadzących działalność na rynku polskim
}

\section{Streszczenie}

W niniejszym rozdziale dokonano rozpoznania sposobów wykorzystania nowoczesnych technologii dla celów promocji przez największych touroperatorów funkcjonujących na rynku krajowym (polskim). Badania empiryczne zrealizowano w drodze analizy środowiska internetowego, tj. stron internetowych 22 największych touroperatorów działających na rynku krajowym (polskim) oraz ich profili w mediach społecznościowych. Badania pokazały podobieństwa i różnice występujące w promocji większych touroperatorów, stopień wykorzystania poszczególnych narzędzi oraz możliwości ich zastosowania w kampaniach promocyjnych. Wyodrębniono zbiór nowoczesnych technologii, jakie stanowią podstawę funkcjonowania przedsiębiorstwa w środowisku internetowym.

\section{Wprowadzenie}

W ciągu ostatnich lat zaobserwowano coraz większą cyfryzację świata spowodowaną dynamicznym rozwojem nowoczesnych technologii. Korzysta z nich nie tylko znaczna część społeczeństwa dla celów prywatnych, ale także producenci oraz dostawcy wielu dóbr i usług funkcjonujący na rynkach krajowych i międzynarodowych. Wspomniane rozwiązania na ogół są proste w obsłudze, intuicyjne i nie generują wysokich kosztów użytkowania. W zdecydowanej większości nie wymagają nabywania specjalistycznego sprzętu - konieczne jest jedynie posiadanie np. komputera lub smartfona, aby za pomocą wbudowanego oprogramowania oraz Internetu można było z nich korzystać. 
Celem pracy jest rozpoznanie oraz analiza sposobów wykorzystania nowoczesnych technologii przez przedsiębiorstwa funkcjonujące na rynku turystycznym jako touroperatorzy. Dzięki przeprowadzonym badaniom możliwe będzie wskazanie podobieństw i różnic występujących $\mathrm{w}$ kampaniach promocyjnych większych organizatorów turystyki. W rozdziale wyodrębniono podstawowy „zbiór” nowoczesnych technologii, które dla współczesnych touroperatorów stanowią fundament kampanii promocyjnej.

Opracowanie składa się z czterech części poprzedzonych wprowadzeniem. $\mathrm{W}$ pierwszej zaprezentowano wyniki dotychczasowych badań związanych z promocją $\mathrm{w}$ środowisku internetowym. W drugiej przedstawiono zastosowane metody badań. Trzecia zawiera wyniki badań empirycznych, wyodrębniono w niej podrozdziały odpowiadające poszczególnym etapom analizy środowiska internetowego, a także podsumowanie wyników. W ostatniej części pracy zamieszczono wnioski będące rezultatem badań.

\section{Przegląd literatury}

W dzisiejszych czasach znaczna część społeczeństwa codziennie korzysta z Internetu, dlatego funkcjonowanie w środowisku wirtualnym w dobie XXI w. wydaje się czymś naturalnym. Badania stron internetowych oraz wykorzystania mediów społecznościowych mają w Polsce długoletnią tradycję. Już na początku XXI w. można było zaobserwować początek handlu elektronicznego w branży turystycznej. Za pomocą wirtualnych sklepów kupowano imprezy turystyczne czy wynajmowano sprzęt turystyczny. Niektórzy przedsiębiorcy prowadzili działalność wyłącznie $\mathrm{w}$ środowisku internetowym, a inni również stacjonarnie. Niewielka część organizatorów turystyki umożliwiała wówczas dokonanie wszelkich formalności związanych z zakupem usług za pośrednictwem swojej strony, w większości przypadków można było jedynie rezerwować imprezę turystyczną, natomiast płatności dokonywano przelewem na poczcie lub podczas osobistej wizyty w punkcie sprzedaży organizatora. Strony WWW touroperatorów zawierały m.in. takie elementy, jak: oferty imprez turystycznych, informacje prawne, medyczne i ubezpieczeniowe związane $z$ wyjazdami, przewodniki turystyczne, zdjęcia, informacje o działalności firmy, dane kontaktowe, kursy walut, newsletter. W 2002 r. przeprowadzono badania stron internetowych 30 najbardziej popularnych biur podróży funkcjonujących na polskim rynku, analizowano dostępność, wygląd oraz funkcjonalność witryn przedsiębiorców. Badania pokazały, że większość touroperatorów korzystała ze stacjonarnych form promocji i dystrybucji, stosunkowo niewielka część badanych (1/3 próby) nie miała własnych zdjęć na stronach WWW, 60\% organizatorów nie wykorzystywało animowanych form reklamy. Wygląd witryn został oceniony pozytywnie, podobnie jak intuicyjność $\mathrm{w}$ obsłudze oraz kwestie techniczne odpowiadające za funkcjonowanie strony. Podkreślono także zbyt wąski zakres usług w środowisku internetowym, który należałoby uzupełnić, wychodząc naprzeciw oczekiwaniom potencjalnych klientów (Chmielarz, 2002). 
Podobne badania serwisów internetowych pod kątem funkcjonalności witryn oraz elementów wpływających na lepsze postrzeganie firmy i wzrost sprzedaży usług zostały przeprowadzone w 2006 r. wśród 20 największych biur podróży działających na rynku turystycznym w Polsce. Podczas analizy stron WWW zwracano uwagę na elementy, które wpływają na odbiór przez potencjalnych klientów, czyli system nawigacyjny, zawartość i wygląd strony oraz jej interaktywność. Ponad połowa badanych zamieszczała na stronach WWW dane kontaktowe (90\%), informacje o firmie (90\%), adresy swoich agentów (80\%), system wyszukiwania ofert $(75 \%)$ oraz przewodniki turystyczne (70\%). Wśród najmniej popularnych elementów witryn zauważono informacje związane z reklamacjami (5\%), dostępność wirtualnego konsultanta (5\%) czy komentarze klientów (10\%). W toku badań zaobserwowano postęp (w porównaniu do wcześniejszych analiz) - przedsiębiorcy zaczęli zauważać możliwości dystrybucji usług za pośrednictwem Internetu, jednak zaledwie wśród $55 \%$ badanych strony internetowe pozwalały na dokonanie bezpośredniej rezerwacji imprezy turystycznej, nadal bez możliwości dokonania płatności online (Rusiecki, 2006).

Kolejne badania związane $\mathrm{z}$ marketingiem internetowym biur podróży działających w Polsce miały miejsce w latach 2014-2015, obejmowały znacznie większą grupę badawczą niż poprzednie - 290 podmiotów, z czego 49,31\% stanowili touroperatorzy. W głównej mierze analizowano, w jaki sposób przedsiębiorcy uzyskują dane o potencjalnych klientach - większość (co 3 badany) wskazywała stronę internetową jako istotne źródło danych, zarówno jeśli chodzi o częstotliwość odwiedzin witryny, jak i liczbę logowań - na co zwracał uwagę co czwarty podmiot. Aktywność potencjalnych klientów w mediach społecznościowych również pozwalała na pozyskanie pewnych informacji o ich preferencjach czy zainteresowaniach, jednak było to zdecydowanie rzadziej wykorzystywane źródło w porównaniu do witryn touroperatorów. Podobny problem dostrzeżono w przypadku aplikacji mobilnych, zatem przedsiębiorcy wciąż nie wykorzystują możliwości promocji, jakie dają social media oraz rozwiązania dedykowane urządzeniom mobilnym, dopiero zyskują one na popularności (Rapacz, Michalska-Dudek, 2017).

Nowoczesne technologie należą do grupy bardzo dynamicznie rozwijających się narzędzi. Postęp technologiczny wymusza automatyzację pewnych rozwiązań, których celem jest ułatwienie wykonywania wielu czynności, a dodatkowo wprowadzenie funkcji oddziałujących na większą liczbę zmysłów ludzkich. Te innowacyjne rozwiązania coraz bardziej wypierają tradycyjne formy promocji, są przyszłościowym kanałem komunikacji przedsiębiorstwa z rynkiem, który zaczyna odgrywać coraz istotniejszą rolę w wirtualnym świecie.

\section{Metodyka badań}

Celem badań było rozpoznanie, jakie nowoczesne technologie są wykorzystywane w promocji przez największych touroperatorów. Podczas badań została podjęta próba wyjaśnienia następujących kwestii: 
- Jakie nowoczesne technologie są wykorzystywane w promocji wśród wybranych touroperatorów?

- Czy wybrani touroperatorzy stosują takie same czy inne narzędzia promocji spośród nowoczesnych technologii?

W badaniach zastosowano 2 metody: analizę stron WWW oraz profili w mediach społecznościowych grupy 22 touroperatorów: Itaka, TUI Poland, Rainbow, Grecos Holiday, Wezyr Holidays, Exim Tours, Grupa Almatur, Logos Tour, Ecco Holiday, Prima Holiday, Funclub, Best Reisen Group, Wygoda Travel, Interhome, Patron Travel, Almatur Katowice, CT Poland, Student Travel, Trade\&Travel, Logos Travel, Sun\&Fun, BUT. Próba badawcza została wybrana w sposób celowy, na podstawie ratingu liderów turystyki wyjazdowej, którzy w latach 2017-2018 utrzymywali przychody na poziomie powyżej $10 \mathrm{mln}$ zł w skali roku (Frydrykiewicz, 2019). Po analizie stron WWW organizatorów turystyki badano ich działalność w mediach społecznościowych (Facebook, Instagram). Podczas przeglądu profili zwracano uwagę przede wszystkim na to, jakie rozwiązania spośród nowoczesnych technologii można dostrzec.

\section{Wyniki badań}

\section{Analiza środowiska internetowego}

Na podstawie analizy firmowych stron WWW badanych udało się pozyskać dane dotyczące stosowanych narzędzi promocji spośród nowoczesnych technologii, co zaprezentowano na rycinie 1 .

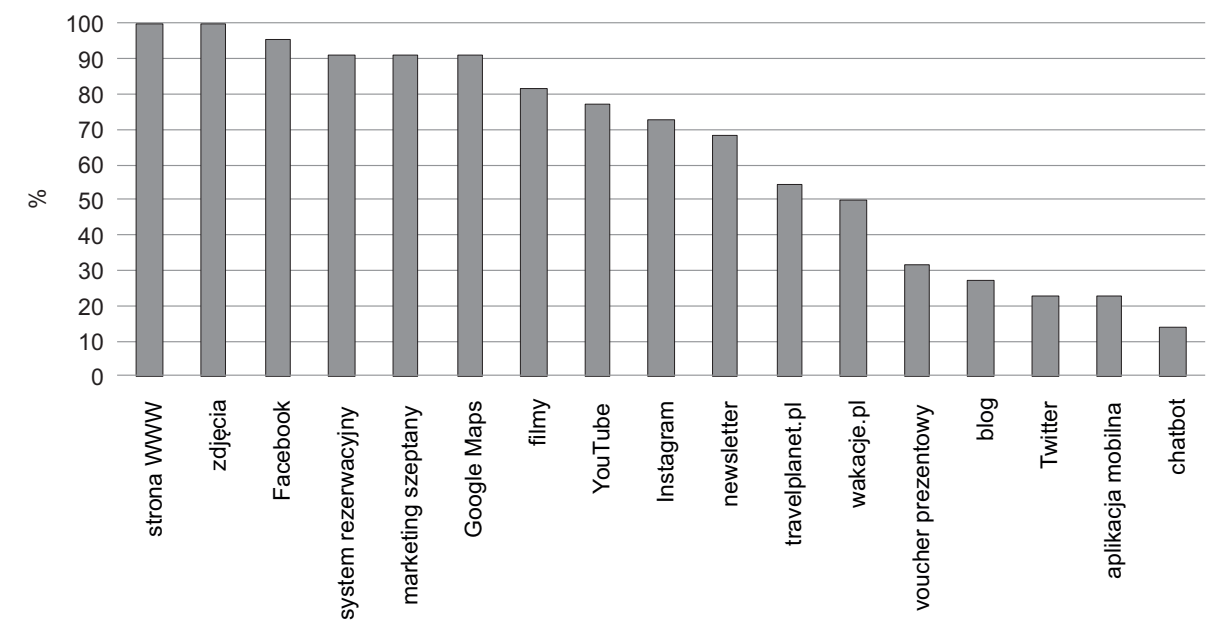

Ryc. 1. Wykorzystywanie nowoczesnych technologii wśród badanych touroperatorów Źródło: opracowanie własne.

Badania pozwoliły stwierdzić, że touroperatorzy prowadzący kampanię promocyjną $\mathrm{w}$ Internecie $\mathrm{w}$ większości stosują następujące narzędzia: stronę WWW 
(100\%), zdjęcia (100\%), profil na Facebooku (95\%), system rezerwacyjny (91\%), marketing szeptany (91\%), Google Maps (91\%) oraz filmy (82\%). Dzięki takim rozwiązaniom touroperatorzy mają możliwość zaistnienia w środowisku online, porozumiewania się z docelowymi segmentami, prezentowania ofert czy też wpływania na decyzje dotyczące wyboru punktu sprzedaży zlokalizowanego najbliżej osoby poszukującej. Stosunkowo niewielka liczba touroperatorów decyduje się na takie rozwiązania, jak: prowadzenie bloga $(28 \%)$, profil na Twitterze $(23 \%)$, aplikacja mobilna (23\%) czy chatbot (14\%). Biorąc pod uwagę aktualne trendy, aplikacje mobilne dopiero zyskują popularność, natomiast stosunkowo niski odsetek wykorzystywania pozostałych trzech narzędzi może oznaczać, że nie są one zbyt skuteczne lub są zastępowane innymi rozwiązaniami. Stosowanie chatbota, który pozwala być $\mathrm{w}$ kontakcie $\mathrm{z}$ klientem głównie poza godzinami pracy biura, okazało się najmniej popularnym rozwiązaniem wśród badanych.

W kolejnej części analizy skupiono uwagę na zależności między poziomem przychodów poszczególnych touroperatorów a liczbą stosowanych rozwiązań $\mathrm{z}$ ryciny 1 , co przedstawiono $\mathrm{w}$ tabeli 1 .

Tabela 1. Wykorzystanie nowoczesnych technologii przez poszczególnych touroperatorów

\begin{tabular}{|c|c|c|}
\hline Touroperator & Liczba stosowanych rozwiązań & $\begin{array}{c}\text { Przychody z imprez } \\
\text { turystycznych w mln zł (2018) }\end{array}$ \\
\hline Itaka & $16(76,19 \%)$ & 2503,06 \\
\hline TUI & $14(66,67 \%)$ & 2184,58 \\
\hline Rainbow & $14(66,67 \%)$ & 1467,74 \\
\hline Grecos Holiday & $14(66,67 \%)$ & 522,78 \\
\hline Exim Tours & $14(66,67 \%)$ & 205,91 \\
\hline Logos Tour & $14(66,67 \%)$ & 70,70 \\
\hline Ecco Holiday & $14(66,67 \%)$ & 52,91 \\
\hline Prima Holiday & $13(61,9 \%)$ & 46,70 \\
\hline Sun\&Fun & $13(61,9 \%)$ & brak danych \\
\hline Funclub & $12(57,14 \%)$ & 40,55 \\
\hline Coral Travel & $12(57,14 \%)$ & 638,989 \\
\hline Best Reisen Group & $11(52,38 \%)$ & 26,53 \\
\hline Wygoda Travel & $10(47,62 \%)$ & brak danych \\
\hline Almatur & $10(47,62 \%)$ & 72,22 \\
\hline Interhome & $9(42,86 \%)$ & 18,09 \\
\hline CT Poland & $9(42,86 \%)$ & 15,93 \\
\hline Student Travel & $9(42,86 \%)$ & 14,42 \\
\hline BUT & $9(42,86 \%)$ & brak danych \\
\hline Logos Travel & $7(33,33 \%)$ & 12,98 \\
\hline Patron Travel & $6(28,57 \%)$ & 18,09 \\
\hline Almatur Katowice & $6(28,57 \%)$ & 17,18 \\
\hline Trade\&Travel & $4(19,05 \%)$ & 14,20 \\
\hline
\end{tabular}

Źródło: opracowanie własne. 
Na tej podstawie można zaobserwować, że w przypadku większości badanych touroperatorów liczba wykorzystywanych narzędzi spośród nowoczesnych technologii zależy od wysokości generowanych przychodów (wg danych z 2018 r.) - im niższy poziom przychodów osiąga dany touroperator, tym mniej rozwiązań stosuje. Jest to bardzo ciekawa zależność, ponieważ znaczna część nowoczesnych technologii to bezpłatne narzędzia, niewielki ich zbiór obejmuje płatne formy promocji.

\section{Analiza profili w mediach społecznościowych}

Badanie profili $\mathrm{w}$ mediach społecznościowych zostało przeprowadzone 11-18 maja 2020 r., a dotyczyło działalności od początku 2020 r. Na podstawie analizy aktywności poszczególnych touroperatorów stworzono kartę ukazującą standardowy profil organizatora na Facebooku, co przedstawiono w tabeli 2.

Tabela 2. Analiza profili w mediach społecznościowych - karta typowego touroperatora na Facebooku

\begin{tabular}{ll}
\hline \multicolumn{2}{c}{ Rodzaj medium społecznościowego: www.facebook.com } \\
\hline Informacje o firmie zamieszczone & - data założenia działalności [80\%] \\
na profilu (zakładka & - dane kontaktowe: telefon [100\%], adres \\
„Informacje”) & strony WWW [95\%], link do czatu w aplikacji \\
& Messenger [85\%], e-mail [75\%] \\
& - krótki opis działalności [95\%] \\
& - informacje o oferowanych produktach [70\%] \\
& - strona główna [100\%] \\
Zakładki widoczne na profilu & zdjęcia [100\%] \\
użytkownika & - filmy [95\%] \\
& - informacje [100\%] \\
& - posty [100\%] \\
& - społeczność [100\%] \\
& - zdjęcia nawiązujące do oferty [95\%] \\
& - krótkie informacje o destynacjach/atrakcjach \\
Treści publikowane na profilu & turystycznych [75\%] \\
(zakładka „Posty”) & informacje i linki do aktualnych ofert wycieczek \\
& - informacje o promocjach [85\%] \\
& - życzenia świąteczne [75\%] \\
& - autorskie zdjęcia [95\%] \\
Nowoczesne technologie & linki do firmowej strony WWW [80\%] \\
widoczne na koncie użytkownika &
\end{tabular}

Źródło: opracowanie własne.

Zgodnie z zaprezentowanymi danymi wśród informacji zamieszczanych o firmie znalazły się takie pozycje, jak: data rozpoczęcia działalności, dane kontaktowe, krótki opis działalności oraz informacje o oferowanych produktach. Są to dokładnie takie same dane, jakie można znaleźć na stronach WWW touroperatorów; można zatem powiedzieć, że konto na Facebooku również jest wizytówką 
firmy, dzięki której potencjalny klient może znaleźć podstawowe informacje o prowadzonej przez przedsiębiorcę działalności.

Kolejnym etapem analizy było rozpoznanie elementów z zakresu nowoczesnych technologii, jakie występują na profilach badanej grupy, co zostało zaprezentowane na rycinie 2 .

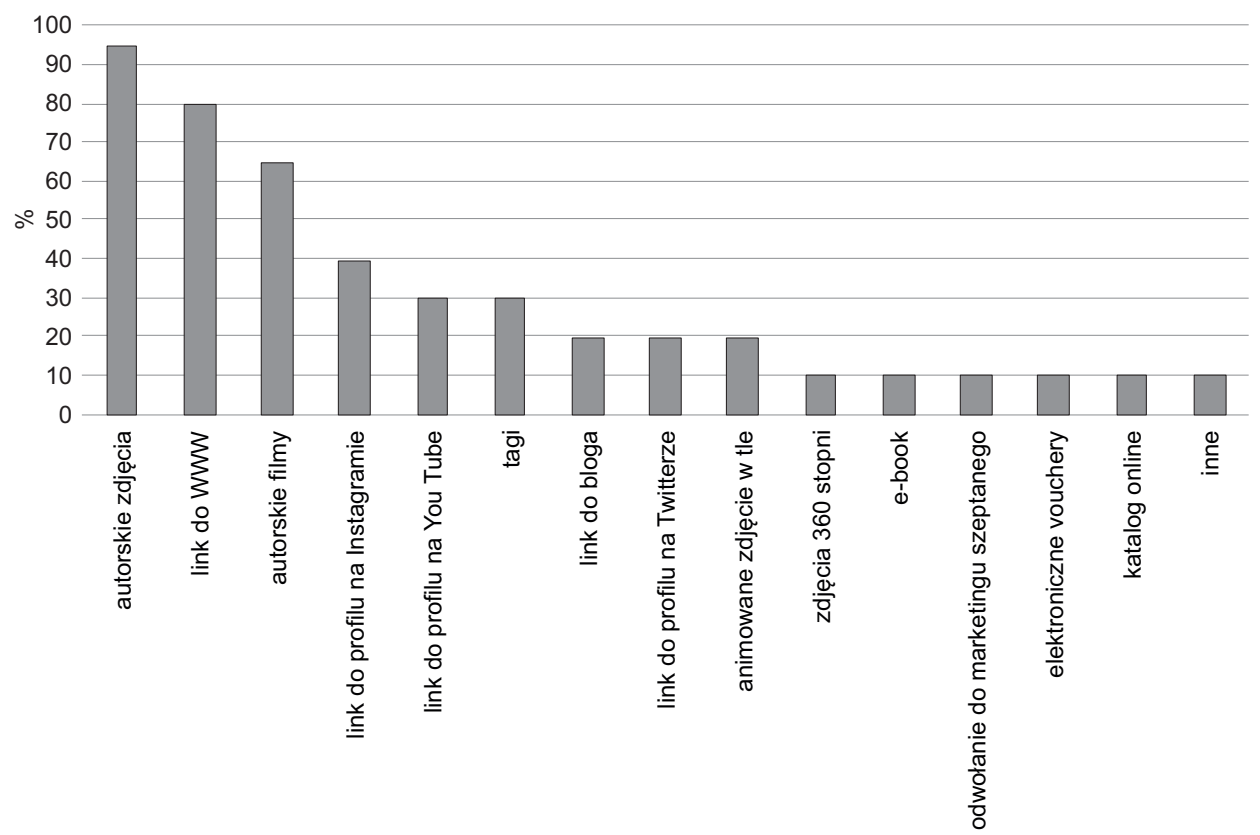

Ryc. 2. Nowoczesne technologie widoczne na profilu użytkownika na Facebooku Źródło: opracowanie własne.

Poza nowoczesnymi technologiami, jakie zostały zamieszczone na karcie typowego profilu touroperatora, większość badanej grupy publikuje również autorskie filmy (65\%). Blisko połowa przedsiębiorców (40\%) udostępnia link do swojego profilu w czasie aktywności na Facebooku. Zaskakujące jest, że zaledwie $30 \%$ touroperatorów, publikując treści, używa tagów związanych z prezentowanymi $\mathrm{w}$ poście informacjami. Powiązanie $\mathrm{z}$ wiadomościami zawartymi w różnych wpisach $z$ odwołaniem do strony WWW za pomocą tagów wpływa na lepsze pozycjonowanie witryny $\mathrm{w}$ momencie wyszukiwania różnych haseł $\mathrm{w}$ przeglądarce internetowej. Ciekawym przypadkiem zyskującym na popularności są zdjęcia $360^{\circ}$, które wykorzystuje jedynie 2 touroperatorów spośród badanej grupy: Itaka oraz Rainbow. W równie niewielkim stopniu przedsiębiorcy publikują posty z informacjami takimi, jak: e-book, odwołanie do marketingu szeptanego (który pełni przecież istotną rolę $\mathrm{w}$ procesie decyzyjnym obecnego konsumenta usług), elektroniczne vouchery oraz katalogi online. Na etapie tej analizy został dostrzeżony jeszcze jeden nietypowy format publikowanych zdjęć, mianowicie 3D. Rozwiązanie to wyróżnia jednego z touroperatorów w badanej grupie - Itakę. 
W drugiej części analizy skupiono uwagę na badaniu profili touroperatorów na Instagramie; na tej podstawie również stworzono kartę ukazującą standardowy profil organizatora (z elementami, które znalazły zastosowanie wśród co najmniej 70\% badanych), co przedstawiono w tabeli 3 .

Tabela 3. Analiza profili w mediach społecznościowych - karta typowego touroperatora na Instagramie

\begin{tabular}{ll}
\hline \multicolumn{2}{c}{ Rodzaj medium społecznościowego: www.instagram.com } \\
\hline $\begin{array}{l}\text { Informacje o firmie } \\
\text { zamieszczone na profilu }\end{array}$ & Brak \\
\hline $\begin{array}{l}\text { Czy profil jest } \\
\text { ogólnodostępny? }\end{array}$ & Tak \\
\hline $\begin{array}{l}\text { Treści publikowane na } \\
\text { profilu }\end{array}$ & $\begin{array}{l}\text { - zdjęcia destynacji i atrakcji turystycznych z oferty [86\%] } \\
\text { - pobudzanie aktywności obserwujących użytkowników - } \\
\end{array}$ \\
$\begin{array}{ll}\text { prośby o dodawanie komentarzy w nawiązaniu do tematu } \\
\text { wpisu [79\%] }\end{array}$ \\
$\begin{array}{ll}\text { Nowoczesne technologie } \\
\text { widoczne na koncie }\end{array}$ & $\begin{array}{l}\text { - autorskie zdjęcia [86\%] } \\
\text { użytkownika }\end{array}$
\end{tabular}

Źródło: opracowanie własne.

$\mathrm{Na}$ podstawie wskazanej karty można stwierdzić, że profil na Instagramie nie jest tak wykorzystywany, jak konto na Facebooku - być może ze względu na mniejsze możliwości tego medium. Znaczna część touroperatorów publikuje zdjęcia destynacji i atrakcji turystycznych $z$ oferty, pobudza aktywność odbiorców poprzez nawiązywanie konwersacji w postaci zadawania pytań odnoszących się do tematów wpisu (zwykle są to pytania o doświadczenie i przeżycia $z$ danego miejsca, którego fotografia jest opublikowana), a także informacje o promocjach. Wśród nowoczesnych technologii, jakie można zauważyć na profilach badanej grupy, są w przeważającej liczbie autorskie zdjęcia oraz tagi nawiązujące do tematu wpisu. Te ostatnie są dość charakterystycznym elementem, dlatego zaskakujące jest to, że jednak nie wszyscy touroperatorzy stosują tę technikę. Odpowiednie wykorzystanie tego narzędzia pozwala na dotarcie do znacznej grupy odbiorców, ponieważ wpis pojawia się wówczas na innych stronach na Instagramie; bardzo często firmy stosują jakieś własne tagi, dzięki którym łatwo jest im stworzyć połączenie między poszczególnymi mediami społecznościowymi a stroną WWW, pod warunkiem że wszędzie używają tego elementu.

Kolejnym $z$ aspektów analizy są nowoczesne technologie widoczne na profilach użytkowników, co zostało przedstawione na rycinie 3 . Na podstawie tej części danych można powiedzieć, że udostępnianie zdjęć oraz stosowanie tagów stanowią pewne minimum poziomu aktywności użytkowników Instagrama. W przypadku tego medium zbiór rozwiązań jest nieco uboższy: większość firm udostępnia linki do firmowej strony WWW (57\% badanych) podczas zamieszczania również innych informacji we wpisie. Niewielka liczba touroperatorów publikuje autorskie filmy (21\%), najrzadziej spotykanym elementem okazało się 
udostępnianie linków do bloga (7\% badanych). Można więc zauważyć, że aktywność użytkowników Instagrama w znacznej części opiera się na publikowaniu zdjęć wraz z odpowiednim opisaniem ich za pomocą tagów, nie przekazuje się tu informacji w postaci dłuższych wpisów, co może mieć miejsce np. na Facebooku. To medium społecznościowe opiera się głównie na elementach graficznych, a nie przekazie merytorycznym.

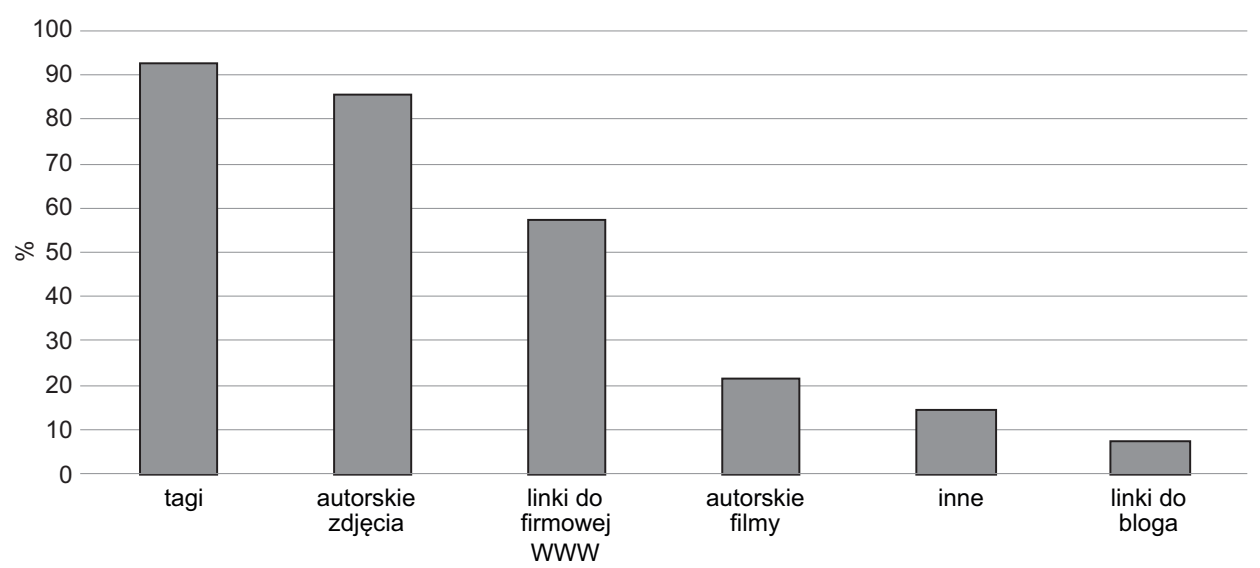

Ryc. 3. Nowoczesne technologie widoczne na profilach użytkowników na Instagramie Źródło: opracowanie własne.

Dotychczasowe rozważania pokazują, że największą ilość różnorodnych rozwiązań obserwuje się na Facebooku, który jest najbardziej dynamicznie rozwijającym się medium. Analizując karty prezentujące typowe profile touroperatorów w mediach społecznościowych, można zauważyć, że jedynie trzech przedstawicieli posiada wszystkie informacje tam zawarte: TUI, Rainbow oraz Sun\&Fun.

\section{Zakończenie}

Na podstawie danych zebranych podczas badań można wysunąć szereg wniosków dotyczących wykorzystywania nowoczesnych technologii w promocji przez największych touroperatorów na rynku polskim.

Zgromadzono szczegółowe informacje o tym, jakie nowoczesne technologie są wykorzystywane w promocji przez badanych. Najważniejszymi elementami z tego zakresu są witryna internetowa przedsiębiorstwa oraz media społecznościowe, bez których firma nie ma szans na zaistnienie w świadomości odbiorców w obecnych czasach. Najwięksi touroperatorzy stosują podobne rozwiązania $\mathrm{w}$ zakresie prowadzonych kampanii promocyjnych w środowisku internetowym.

Mając na uwadze wyniki dotychczasowych badań, warto zaznaczyć, że touroperatorzy coraz częściej sięgają po innowacyjne rozwiązania, wychodząc naprzeciw oczekiwaniom klientów, którzy spędzają więcej czasu w środowisku internetowym. Zauważają oni nowe możliwości nowoczesnych form promocji oraz 
korzyści, jakie dają, co również wpływa na konkurencyjność i przewagę firmy na rynku krajowym.

Nowoczesne technologie znacznie ułatwiają prowadzenie kampanii promocyjnych $z$ uwagi na spersonalizowany charakter, są przystępne i wygodne w użyciu dla przedsiębiorców oraz potencjalnych klientów. Mając na uwadze nieustający postęp technologiczny na świecie, można stwierdzić, że nowoczesne technologie są przyszłościowym rozwiązaniem, które prawdopodobnie wkrótce zastąpi tradycyjne narzędzia promocji dzięki powszechności ich stosowania. Bez wątpienia są skuteczniejszym rozwiązaniem stosowanym $\mathrm{w}$ promocji touroperatorów w porównaniu do tradycyjnych odpowiedników, które dodatkowo generują dużo większe koszty kampanii.

\section{Literatura}

Bonek T., Smaga M. (2012). Biznes w Internecie. Praktyczny poradnik o marketingu, sprzedaży, public relations on-line i promocji w mediach społecznościowych. Wydawnictwo Wolters Kluwer, Warszawa.

Chmielarz W. (2002). Analiza i ocena stron internetowych biur turystycznych działających na terenie Polski. Folia Oeconomica, Łódź.

Frydrykiewicz F. (2019). 29 liderów turystyki wyjazdowej - ratingi i ranking. Rzeczpospolita (http://info.rp.pl/temat/984572.html; dostęp: 16.03.2020).

Furgała A. (2015). Social Media (FB, YouTube) oraz narzędzie Web Analytics (Google Analytics) w budowaniu wizerunku. W: J. Gołuchowski, Z. Spyra (red.), Nowe media i technologie w komunikacji marketingowej - współczesne wyzwania i trendy. Wydawnictwo Proksenia, Kraków.

Kruczek Z., Walas B. (2010). Promocja i informacja w turystyce. Wydawnictwo Proksenia, Kraków.

Lipska A. (2015). Blog firmowy jako skuteczne narzędzie komunikacji marketingowej. W: J. Gołuchowski, Z. Spyra (red.), Nowe media i technologie w komunikacji marketingowej - współczesne wyzwania i trendy. Wydawnictwo Proksenia, Kraków.

Pawlicz A. (2012). E-turystyka. Wydawnictwo Naukowe PWN, Warszawa.

Rapacz A., Michalska-Dudek I. (2017). Wiedza o nabywcach usług turystycznych w świetle badań ankietowych biur podróży w Polsce. Ekonomiczne Problemy Turystyki, 38.

Rusiecki P. (2006). Analiza funkcjonalna serwisów internetowych biur podróży na rynku organizatorów imprez turystycznych w Polsce. W: T. Porębska-Miąc, H. Sroka (red.), Systemy wspomagania organizacji.

Wielki J. (2000). Elektroniczny marketing poprzez Internet. Wydawnictwo Naukowe PWN, Wrocław.

Wiktor J.W. (2001). Promocja. System komunikacji przedsiębiorstwa z rynkiem. Wydawnictwo Naukowe PWN, Warszawa.

\section{Use of modern technologies for promotional purposes by tour operators functioning on the Polish market}

The purpose of this article is recognising the ways of using modern technologies for promotional purposes by biggest touroperators functioning on domestic market (Polish). Em- 
pirical research was completed by analysis of internet environment - the internet websites of 22 biggest touroperators functioning on domestic market (Polish) and their profiles in social media. Research has shown similarities and differences occurring in promotion of bigger touroperators, the degree of use of individual tools and possibilities of their uses in promotional campaigns. A basic set of modern technologies which constitute the basis of functioning of enterprises in internet environment was determined.

Translated by Aleksandra Dulewska 



\section{Ewa Kamińska}

Uniwersytet Ekonomiczny w Krakowie

kaminska96@gmail.com

(D) https://orcid.org/0000-0002-7762-6189

\section{Crowdfunding jako forma finansowania innowacyjnych produktów turystycznych}

\section{Streszczenie}

Crowdfunding to stosunkowo nowa i dynamicznie rozwijająca się forma finansowania różnego rodzaju innowacyjnych projektów. Dane pokazują, że crowdfunding to przykład źródła finansowania o sporym znaczeniu dla wielu przedsiębiorstw, szczególnie w początkowej fazie ich rozwoju.

Celem pracy jest ocena crowdfundingu w Polsce jako alternatywnego źródła finansowania poprzez zaprezentowanie najefektywniejszej platformy crowdfundingowej dla innowacyjnego produktu turystycznego. Wybrana metoda badawcza polegała na analizie porównawczej platform crowdfundingowych w Polsce.

Analiza ta nie pozwoliła wyodrębnić jednego typu platformy, najchętniej stosowanego do finansowania społecznościowego w specyficznym produkcie turystycznym na terenie miasta Krakowa. Jednak udowodniono, że crowdfunding to forma odpowiednia do finansowania projektów innowacyjnych, zwłaszcza start-upów o podwyższonym poziomie ryzyka.

\section{Wprowadzenie}

Współzawodnictwo między przedsiębiorstwami turystycznymi przyczyniło się do sytuacji, w której firmy, aby osiągnąć skuteczną przewagę konkurencyjną, usiłują rywalizować w celu poszukiwania oryginalnych, a zarazem kłopotliwych do skopiowania produktów turystycznych. W literaturze przedmiotu oraz praktyce zarządzania rozpowszechniło się zgodne stwierdzenie, że jednym z fundamentalnych czynników konkurencyjności współczesnych przedsiębiorstw usługowych, do których należy turystyka, są innowacje w oferowanym produkcie turystycznym. 
Niezbędnym zasobem do podjęcia działań innowacyjnych są odpowiednie mechanizmy ich finansowania. Utrata zaufania do tradycyjnych instytucji oraz zwiększone wymagania stawiane przed przedsiębiorcami chcącymi pozyskać kapitał na działalność i inwestycje doprowadziły do poszukiwania alternatywnych rozwiązań, takich jak crowdfunding.

Celem tego rozdziału jest ocena crowdfundingu w Polsce jako alternatywnego źródła finansowania poprzez zaprezentowanie najefektywniejszej platformy crowdfundingowej dla innowacyjnego produktu turystycznego. Opracowanie ma charakter teoretyczno-empiryczny. Analiza porównawcza platform crowdfundingowych w Polsce opiera się na danych wtórnych ze stron wyspecjalizowanych platform internetowych i stanowi bazę źródłową do dalszych, pogłębionych badań nad perspektywami rozwoju crowdfundingu w polskiej rzeczywistości gospodarczej.

Praca składa się z czterech części, w których kolejno omówiono: produkt turystyczny i innowacje, formy finansowania produktu turystycznego, metodykę badań oraz przedstawiono analizę platform crowdfundingowych w Polsce.

\section{Produkt turystyczny i innowacje}

W literaturze przedmiotu można spotkać wiele definicji produktu turystycznego (Altkorn, 1994). Jedną $z$ takich prostych, strukturalnych definicji podaje Gołembski (1998, s. 24), uznając, że „produktem turystycznym są wszystkie dobra i usługi tworzone i kupowane $\mathrm{w}$ związku $\mathrm{z}$ wyjazdem poza miejsce stałego zamieszkania, i to zarówno przed rozpoczęciem podróży, w trakcie podróży, jak i w czasie pobytu poza swoją rodzinną miejscowością". Dobro turystyczne to element środowiska przyrodniczego lub kulturowego, na które występuje popyt turystyczny. Z kolei usługi turystyczne to produkty kreowane w celu zaspokojenia potrzeb osób podróżujących oraz osiągnięcia zysku przez wytwórców tych usług (Kaczmarek i in., 2010).

Jak sugerują Janasz i Kozioł (2007), w literaturze przedmiotu oraz praktyce zarządzania rozpowszechniło się zgodne stwierdzenie, że jednym $z$ fundamentalnych czynników konkurencyjności współczesnych przedsiębiorstw usługowych, do których należy turystyka, są innowacje. Kompetencja do implikowania innowacji uważana jest za jedną z najważniejszych determinant sukcesu ekonomicznego w branży turystycznej.

Innowacyjność polega na poszukiwaniu nowych rozwiązań, wzbudzających zainteresowanie turystów, a jednocześnie umożliwiających podtrzymanie trwałości funkcji turystycznej (Zaitseva i in., 2019). Jedną z nowych idei, wokół których buduje się współcześnie produkt turystyczny, jest idea turystyki kreatywnej, która ściśle współgra $z$ innowacyjnością.

Wzrastająca potrzeba indywidualizacji przeżyć turystycznych, odwrócenie od standaryzacji produktów turystycznych, w tym produktów miast opartych na klasycznym poznawaniu dziedzictwa kulturowego, może być przyczyną powstania innowacyjnej usługi przewodnictwa $\mathrm{w}$ formie gry planszowej. $\mathrm{Z}$ kolei, jak 
stwierdza Żyto (2018), zastosowanie elementów charakterystycznych dla gier podczas zwiedzania jest odpowiedzią na potrzeby generacji turystów obcujących na co dzień ze światem technologii cyfrowych.

Innowacje $\mathrm{w}$ przedsiębiorstwach turystycznych, bez względu na zakres, adresatów, poziom zaangażowanych zasobów, wymagają wysiłku w celu ich realizacji. Podejmowanie działań innowacyjnych jest warunkiem koniecznym do uzyskania w przyszłości satysfakcjonującej pozycji w gospodarce światowej. Dlatego gwarancją powodzenia ryzykownych przedsięwzięć jest zapewnienie trwałego finansowania, które w tym kontekście przeznaczane jest na działalność innowacyjną.

\section{Formy finansowania produktu turystycznego}

\section{Źródła finansowania}

Pierwszym krokiem do realizacji innowacyjnego produktu turystycznego jest pozyskanie odpowiedniego wkładu finansowego. Źródło finansowania dotyczy „miejsca” pochodzenia środków pieniężnych wykorzystywanych w przedsiębiorstwie.

Biorąc pod uwagę fakt, że działalność przedsiębiorstw turystycznych realizowana jest na różnych etapach ich rozwoju, wymagania w zakresie źródeł pozyskania kapitału zdeterminowane są określonym poziomem tego rozwoju. W początkowej fazie wzrostu finansowanie opiera się głównie na wykorzystaniu własnych zasobów finansowych, często pochodzących z tzw. boostrappingu, czyli oszczędności własnych lub z pożyczki czy darowizny (Wieczorek, 2017). Publiczne dofinansowanie biznesu ze środków unijnych, dotacje z urzędu pracy czy środki z funduszy venture capital lub aniołów biznesu odnoszą się do późniejszych etapów rozwoju. Dzięki tym inwestycjom przedsiębiorstwa turystyczne stają się wystarczająco dużymi podmiotami, aby zainteresować potencjalnych inwestorów gotowych zaangażować swoje środki finansowe (Wojtowicz, 2013).

Źródłem finansowania udzielanego przez banki dla przedsiębiorstw legitymujących się stażem dłuższym niż rok są kredyty czy pożyczki bankowe. Wraz ze zwiększeniem poziomu ryzyka utraty płynności spada również zdolność kredytowa przedsiębiorstwa. Dlatego ciekawym rozwiązaniem może być finansowanie społecznościowe zwane crowdfundingiem.

\section{Crowdfunding}

Na skutek zmian technologicznych na przełomie XX i XXI w. pojawiła się metoda pozyskiwania środków finansowych, która jest określana mianem crowdfundingu (Mazurek-Łopacińska, Sobocińska, 2016). Nastąpiła zmiana metody dotarcia do potencjalnych inwestorów jako cyfrowego tłumu poprzez wykorzystanie Internetu oraz portali społecznościowych.

Crowdfunding, ze względu na potencjał zmian, jakie wnosi do systemu finansowego, uznano za innowację finansową (Husain, Root, 2015). Innowacja odnosi 
się do stopnia, w jakim jest nowatorska i odbiega od istniejących produktów i procesów. Istotną cechą radykalnych innowacji jest ich zdolność do kreowania popytu, którego dotychczas nie dostrzegano. W turystyce zauważa się ogromną konkurencyjność, szczególnie jeśli chodzi o produkty lokalne. Jak sugerują Waszkiewicz i Kukurba (2020), kreowanie dodatkowego popytu, który stwarza crowdfunding, jest bardzo istotną cechą i determinuje wybór tego finansowania.

Crowdfunding, zwany inaczej w Polsce finansowaniem społecznościowym, pojawił się jako alternatywne źródło finansowania dla młodych przedsiębiorców w początkowej fazie, tzw. start-upu (Xu, 2015). Związany jest z opublikowaniem na jednej $z$ platform crowdfundingowych opisu projektu, dla którego poszukiwane jest wsparcie finansowe. Znalezienie wsparcia wymaga dotarcia do jak największego grona potencjalnych inwestorów, którzy najczęściej wpłacają niewielkie kwoty w ustalonym z góry czasie. Projekt określa zazwyczaj kilka kwot wsparcia, przy czym do każdej kwoty przypisany jest zestaw nagród, zwykle $\mathrm{w}$ formie przedsprzedaży produktu końcowego.

$\mathrm{W}$ praktyce gospodarczej może być realizowany w różnych formach. W literaturze przedmiotu wyodrębnia się najczęściej crowdfunding udziałowy lub nieudziałowy w zależności od korzyści, jaką otrzyma dostawca kapitału. Crowdfunding nieudziałowy możemy zaś podzielić na donacyjny z nagradzaniem oraz donacyjny bez nagradzania, który jest klasycznym finansowaniem społecznościowym. Poza powyższymi modelami rozwijają się coraz węższe kategorie związane $z$ obiektem finansowania, takim jak np. gry planszowe (Waszkiewicz, 2016). Można spodziewać się, że z upływem czasu będą powstawać coraz nowsze kierunki i modele crowdfundingu.

W efekcie analizy cech projektodawców, wspierających, a także właścicieli platform wymieniono zalety i wady crowdfundingu jako innowacyjnej formy pozyskania kapitału za pośrednictwem platformy finansowania społecznościowego (tab. 1).

Tabela 1. Zalety i wady finansowania społecznościowego

\begin{tabular}{ll}
\hline \multicolumn{1}{c}{ Zalety } & \multicolumn{1}{c}{ Wady } \\
\hline efektywne medium komunikacji & niebezpieczeństwo kopiowania pomysłów \\
forma analizy rynku pod względem & osiągnięcie odpowiedniej liczby \\
zapotrzebowania na produkt & wspierających \\
budowanie bazy potencjalnych klientów & czasochłonność prowadzenia kampanii \\
możliwość uzyskania wyższego & możliwość bankructwa i utraty pieniędzy \\
finansowania & przez finansujących \\
budowanie i kształtowanie relacji & fałszywa jakość produktu \\
z inwestorami & niejasne przepisy podatkowe \\
promocja marki & niepewność pozyskania zakładanych \\
brak wymogu posiadania kapitału & środków pieniężnych \\
własnego &
\end{tabular}

Źródło: opracowanie własne na podstawie Czajkowska (2017). 
Crowdfunding ma swoje wady i zagrożenia jak każde inne formy finansowania. Jednak posiadając innowacyjny pomysł na działalność gospodarczą i dokładnie planując wszystkie kroki, można zminimalizować ryzyko nieosiągnięcia ustalonych progów finansowych. Biorąc pod uwagę powyższe zalety oraz wady, a także dotychczasowe doświadczenia w finansowaniu projektów gospodarczych, można stwierdzić, że crowdfunding stanowi interesujące rozwiązanie, o wielkim potencjale rozwoju, niosącym wiele możliwości i szans dla przedsiębiorstw i ich innowacyjnych przedsięwzięć gospodarczych (Czajkowska, 2017).

Uzależnienie pokoleń od Internetu daje podstawy do stwierdzenia, że właśnie ten sposób finansowania działalności może być podstawowym źródłem kapitału małych przedsiębiorstw. Z kolei różnorodność platform crowdfundingowych na rynku powoduje, że jest to elastyczne źródło dopasowania się zarówno dla przedsiębiorstw, jak i odbiorców (Motylska-Kuźma, 2018).

\section{Metodyka badań}

Tematem badań jest analiza i ocena crowdfundingu w Polsce na przykładzie wybranych platform crowdfundingowych, w których projekt innowacyjny produkt turystyczny jest możliwy do realizacji. Wybór platform opierał się na rankingach dostępnych w literaturze oraz Internecie, a także własnej opinii.

Celem badań jest wybór najefektywniejszej platformy crowdfundingowej dla innowacyjnego produktu turystycznego na terenie Krakowa. Wyjaśnieniem zawężenia analizy platform na terenie Polski jest miejscowe wykorzystanie innowacyjnego produktu turystycznego.

Można postawić hipotezę, że w Polsce inicjatywy crowdfundingowe realizowane są przede wszystkim na platformach dedykowanych nieudziałowym formom finansowania społecznościowego. Dlatego wybór platform jest uzależniony od modelu, jaki dana platforma prowadzi, z wykluczeniem modelu udziałowego również ze względu na ograniczenie generowania dodatkowych kosztów w fazie rozwoju start-upu oraz mały zasięg.

Przygotowując badanie, wykorzystano metodę porównawczą. Bazę źródłową do analiz rozwoju crowdfundingu w Polsce stanowiły dane wtórne ze stron wyspecjalizowanych platform internetowych. Parametry badawcze zostały skonstruowane na podstawie danych dostępnych na platformach oraz uzyskanych od przedstawicieli platform drogą mailową. Porównano siedem elementów, które odróżniają poszczególne platformy. Elementy analizy subiektywnie opisują potrzeby realizacji konkretnej inwestycji. Analiza dotyczyła składników ilościowych oraz jakościowych. Platformy zostały uporządkowane według wielkości rynku oraz udanych kampanii. 
Tabela 2. Analiza porównawcza platform crowdfundingowych w Polsce

\begin{tabular}{|c|c|c|c|c|c|c|}
\hline \multirow{2}{*}{$\begin{array}{l}\text { Anali- } \\
\text { zowany } \\
\text { element }\end{array}$} & \multicolumn{6}{|c|}{ Nazwa platformy } \\
\hline & $\begin{array}{l}\text { Polak } \\
\text { Potrafi }\end{array}$ & Wspieram.to & OdpalProjekt & $\begin{array}{l}\text { Wspólny } \\
\text { projekt }\end{array}$ & Zrzutka & $\begin{array}{c}\text { Zagramw. } \\
\text { to }\end{array}$ \\
\hline $\begin{array}{l}\text { Zakres/ } \\
\text { kategoria } \\
\text { projektów }\end{array}$ & ogólny & ogólny & ogólny & ogólny & ogólny & $\begin{array}{l}\text { gry plan- } \\
\text { szowe } \\
\text { i karciane }\end{array}$ \\
\hline $\begin{array}{l}\text { Motyw } \\
\text { zbiórki/ } \\
\text { model }\end{array}$ & $\begin{array}{l}\text { bonuso- } \\
\text { wy }\end{array}$ & bonusowy & bonusowy & $\begin{array}{l}\text { bonuso- } \\
\text { wy }\end{array}$ & $\begin{array}{l}\text { dona- } \\
\text { cyjny, } \\
\text { bonu- } \\
\text { sowy }\end{array}$ & $\begin{array}{l}\text { bonuso- } \\
\text { wy }\end{array}$ \\
\hline Prowizja & $\begin{array}{l}7,4 \% \\
\text { platforma } \\
+2,5 \% \\
\text { system } \\
\text { płatności }\end{array}$ & $\begin{array}{l}\text { wszystko } \\
\text { albo nic: } \\
8,5 \% \\
\text { platforma }+ \\
2,5 \% \text { system } \\
\text { płatności, } \\
\text { bierzesz, ile } \\
\text { zbierzesz: } \\
9,5 \% \\
\text { platforma }+ \\
2,5 \% \text { system } \\
\text { płatności }\end{array}$ & $\begin{array}{l}\text { wszystko albo nic: } \\
4,9 \% \text { platforma } \\
+2,5 \% \text { system } \\
\text { płatności, bierzesz, } \\
\text { ile zbierzesz: } \\
6,9 \% \text { platforma } \\
\text { + 2,5\% system } \\
\text { płatności lub *4,9\% } \\
\text { platforma }+2,5 \% \\
\text { system płatności, } \\
\text { jeśli uda się zebrać } \\
\text { zakładaną kwotę }\end{array}$ & $\begin{array}{l}7 \% \text { plat- } \\
\text { forma }\end{array}$ & $\begin{array}{l}0 \% \\
\text { plat- } \\
\text { forma } \\
+0 \% \\
\text { system } \\
\text { płatno- } \\
\text { ści }\end{array}$ & $\begin{array}{l}\text { brak in- } \\
\text { formacji }\end{array}$ \\
\hline $\begin{array}{l}\text { Klasyfika- } \\
\text { cja wypłat }\end{array}$ & $\begin{array}{l}\text { wszystko } \\
\text { albo nic, } \\
\text { bierzesz, } \\
\text { ile zbie- } \\
\text { rzesz }\end{array}$ & $\begin{array}{l}\text { wszystko } \\
\text { albo nic, } \\
\text { bierzesz, ile } \\
\text { zbierzesz }\end{array}$ & $\begin{array}{l}\text { wszystko albo } \\
\text { nic, bierzesz, ile } \\
\text { zbierzesz }\end{array}$ & $\begin{array}{l}\text { mini- } \\
\text { malna } \\
\text { kwota } \\
\text { pozwa- } \\
\text { lająca na } \\
\text { za- } \\
\text { mknięcie } \\
\text { projektu } \\
\text { to } 80 \%\end{array}$ & $\begin{array}{l}\text { bie- } \\
\text { rzesz, } \\
\text { ile } \\
\text { zbie- } \\
\text { rzesz } \\
\\
\end{array}$ & $\begin{array}{l}\text { wszystko } \\
\text { albo nic }\end{array}$ \\
\hline $\begin{array}{l}\text { Dodatko- } \\
\text { we usługi } \\
\text { (płatne) }\end{array}$ & $\begin{array}{l}\text { Brand24, } \\
\text { FastTony, } \\
\text { Envelo, } \\
\text { sklep } \\
\text { Polak- } \\
\text { Promuje, } \\
\text { w którym } \\
\text { m.in. lan- } \\
\text { dingpage, } \\
\text { new- } \\
\text { sletter, } \\
\text { promocja } \\
\text { w social } \\
\text { mediach }\end{array}$ & $\begin{array}{l}\text { Brand24, } \\
\text { freshmail, } \\
\text { szkole- } \\
\text { nia, sklep } \\
\text { Crowdmade } \\
\text { z produk- } \\
\text { tami swojej } \\
\text { kampanii, } \\
\text { landing page }\end{array}$ & $\begin{array}{l}\text { obsługa prawna, } \\
\text { usługi marketin- } \\
\text { gowe i PR, copyw- } \\
\text { riting i projek- } \\
\text { towanie nagród, } \\
\text { szkolenia }\end{array}$ & FastTony & 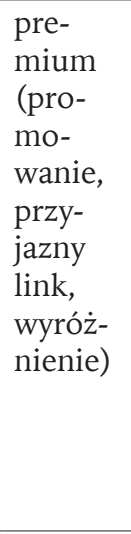 & $\begin{array}{l}\text { brak in- } \\
\text { formacji }\end{array}$ \\
\hline
\end{tabular}


Tabela 2. cd.

\begin{tabular}{|c|c|c|c|c|c|c|}
\hline \multirow{2}{*}{$\begin{array}{l}\text { Anali- } \\
\text { zowany } \\
\text { element }\end{array}$} & \multicolumn{6}{|c|}{ Nazwa platformy } \\
\hline & $\begin{array}{c}\text { Polak } \\
\text { Potrafi }\end{array}$ & Wspieram.to & OdpalProjekt & $\begin{array}{l}\text { Wspólny } \\
\text { projekt }\end{array}$ & Zrzutka & $\begin{array}{l}\text { Zagramw. } \\
\text { to }\end{array}$ \\
\hline $\begin{array}{l}\text { Łatwość } \\
\text { W zało- } \\
\text { żeniu } \\
\text { kampanii }\end{array}$ & $\begin{array}{l}\text { bardzo } \\
\text { latwa }\end{array}$ & bardzo łatwa & łatwa & łatwa & $\begin{array}{l}\text { wzor- } \\
\text { cowa }\end{array}$ & trudna \\
\hline $\begin{array}{l}\text { Rozpo- } \\
\text { znawal- } \\
\text { ność }\end{array}$ & wysoka & wysoka & średnia & średnia & wysoka & niska \\
\hline
\end{tabular}

Źródło: opracowanie własne na podstawie danych zamieszczonych na stronach wyszczególnionych platform crowdfundingowych (wg stanu na 1.09.2020).

\section{Wyniki badań}

Zgodnie z celem badań dotyczącym analizy polskich platform crowdfundingowych wyróżniono sześć platform, w których szansa na sfinansowanie start-upu jest największa.

Wszystkie podane platformy oferują możliwość założenia kampanii w szerokim zakresie $z$ wyjątkiem portalu zagramw.to, który jest przeznaczony dla twórców gier „bez prądu”, czyli gier planszowych i karcianych.

Dominacja modelu bonusowego jest wyraźna, co przejawia się przede wszystkim w zaproponowaniu nagród przez twórców kampanii w zamian za jej dofinansowanie. Portal zrzutka.pl jako jedyny nie oferuje nagród. Jest to spowodowane zbiórkami charytatywnymi, które w głównej mierze się tam odbywają.

Źródłem przychodu platform crowdfundingowych najczęściej są prowizje. Brakiem prowizji charakteryzuje się portal zrzutka. Najwyższą prowizję pobiera platforma wspieram.to dla projektów autorskich gier planszowych i karcianych w kategorii „gry bez prądu”.

Klasyfikacja wypłat jest istotna, ponieważ wpływa na pozyskanie środków od wspierających. W zależności od tego, jaki model dana platforma oferuje. W modelu „Wszystko albo nic” środki można otrzymać po osiągnięciu celu finansowego i wtedy też prowizja platform jest $\mathrm{z}$ reguły niższa; w modelu „bierzesz, ile zbierzesz" środki można otrzymać w każdym momencie, niezależnie od tego czy realizacja celu finansowego doszła do skutku. Większość czołowych platform umożliwia wybór pomiędzy dwoma modelami uzyskania wypłaty.

Im bardziej rozwinięta platforma, tym więcej proponuje usług dodatkowych, które mogą wypromować projekt, a także zdobyć rzeszę darczyńców. Najwięcej usług dodatkowych oferuje platforma polakpotrafi: Brand24; FastTony; Envelo; sklep PolakPromuje $z$ ofertą promocji kampanii. Równie dobrą ofertę usług dodatkowych posiada portal wspieram.to: Brand24, freshmail, szkolenia, sklep Crowdmade $z$ produktami swojej kampanii, landing page. Informacje o usługach dodatkowych na profilu zagramw.to będą dostępne po akceptacji projektu. 
W związku z hermetyzacją platformy zagramw.to dostrzega się dbałość o każdego twórcę kampanii oraz szczególną pomoc w rozwoju projektu.

Im bardziej funkcjonalne platformy, tym prościej jest założyć kampanie. Wzorcową platformą, która stawia na uproszczenie formalności, jest zrzutka. Użyteczność jest główną jej ideą. Bardzo łatwo jest założyć kampanię na portalach polakpotrafi oraz wspieram.to. Mimo że platformy skupiają się na rozwoju usług dodatkowych oraz poszerzaniu rynku wspierających, założenie kampanii nie powinno sprawić problemu.

Najbardziej rozpoznawalne platformy to polakpotrafi oraz wspieram.to. Cieszą się one liczną i bardzo aktywną rzeszą zwolenników.

\section{Model działalności crowdfundingu dla gry miejskiej}

Analiza porównawcza nie pozwoliła wyodrębnić jednego typu platformy, który najlepiej nadaje się do finansowania społecznościowego w specyficznym produkcie turystycznym. Jedynie próba stworzenia kampanii na jednym z portali mogłaby pomóc $\mathrm{w}$ wyborze najadekwatniejszej platformy. Z kolei prawidłowością, na którą można tu wskazać, jest próba wyodrębnienia platformy przede wszystkim ze względu na prowizje, dodatkowe usługi wzmacniające wizerunek kampanii, a także wielkość rynku, która sugeruje rozpoznawalność platformy.

Najskuteczniej prezentuje się platforma wspieram.to. Ma ona najniższą prowizję $(3,5 \%) \mathrm{w}$ obu modelach dla projektów autorskich gier planszowych i karcianych w kategorii „gry bez prądu”. Szeroki wachlarz usług dodatkowych oraz pomoc $\mathrm{w}$ zakresie przygotowania kampanii stawia platformę wysoko na tle konkurencji. Dodatkowo spory zasięg rynku i duża rozpoznawalność może świadczyć o wysokim współczynniku udanych kampanii.

Kolejnym ciekawym wyborem jest hermetyczna platforma zagramw.to. Ogromna pomoc, którą oferuje, nie tylko w samej kampanii, ale także w przedsprzedaży produktu, stawia ją wśród najbardziej prorozwojowych platform. Bliska współpraca z zagramw.to gwarantuje sporą dawkę wiedzy. Niestety brak informacji o prowizjach i innych szczegółach obniża jej status wyboru.

Niskokosztowa, ale też elastyczna i wygodna jest platforma zrzutka. Jej wadami są niewielki zasięg oraz brak wsparcia. To najprostsza w użyciu platforma, przez którą uzyskanie odpowiedniego rynku zbytu może jednak okazać się trudne.

Szanse powodzenia projektu nie muszą wszak wiązać się z wymienionymi wartościami, ale mogą zależeć od odpowiednio przygotowanej strategii marketingowej. Istotne przy wyborze odpowiedniej platformy są potrzeby odbiorców projektów, którzy mają decydujący wpływ na ostateczny gest wsparcia danego przedsięwzięcia. Dlatego wybór właściwej platformy jest tylko elementem uzyskania sukcesu przez finansowanie crowdfundingowe. Dalsze etapy analizy potrzeb odbiorców mogą pomóc dokonać jednoznacznego wyboru. Takie wnioski można wysnuć z analizy większej grupy projektów zakończonych sukcesem. 


\section{Zakończenie}

Postęp techniczny i rozwój gospodarczy z tego wynikający wymuszają wprowadzenie innowacji w branży turystycznej, które przyczyniają się do zwiększenia konkurencyjności oraz płynności finansowej. Innowacje w przedsiębiorstwach turystycznych, bez względu na zakres, adresatów, poziom zaangażowanych zasobów, wymagają wysiłku w celu ich realizacji. Dlatego gwarancją powodzenia ryzykownych przedsięwzięć jest zapewnienie trwałego finansowania, które w tym kontekście przeznaczane jest na działalność innowacyjną. Wątpliwości banków oraz innych instytucji finansowych wobec projektów i firm działających w branży turystycznej przyczyniają się do stałego poszukiwania nowych metod pozyskiwania niezbędnego kapitału.

Analiza porównawcza udowodniła, że crowdfunding to forma odpowiednia do finansowania projektów innowacyjnych, zwłaszcza start-upów o podwyższonym poziomie ryzyka, a także rozwiązań, które ze względu na ryzyko transakcyjne, historię kredytowania innowatora czy brak niezbędnych zabezpieczeń majątkowych po stronie przedsiębiorcy nie mogą uzyskać finansowania z tradycyjnych źródeł. Portal crowdfundingowy postrzegany jest również jako narzędzie marketingowe, służące do promocji nowych rozwiązań, co w przypadku gry miejskiej jest skutecznym rozwiązaniem z powodu braku bazy klientów.

Polskie portale crowdfundingowe odznaczają się ogromną dywersyfikacją przedsięwzięć. Powstają portale tematyczne dopasowane do kryteriów projektowych, co znacznie upraszcza działalność oraz selekcję portali pod kątem innowacyjnego produktu turystycznego.

Analiza porównawcza nie pozwoliła wyodrębnić jednego typu platformy, który najlepiej nadaje się do finansowania społecznościowego w specyficznym produkcie turystycznym na terenie miasta Krakowa. Tylko próba stworzenia kampanii na jednym z portali mogłaby pomóc w wyborze najadekwatniejszej platformy.

\section{Literatura}

Altkorn J. (1994). Marketing w turystyce. Wydawnictwo PWN, Warszawa.

Czajkowska A. (2017). Crowdfunding jako instrument finansowania przedsiębiorstw. [W:] Ł. Prysiński (red.), Wybrane problemy zarządzania i finansów w sektorze publicznym i prywatnym. T. 18. Wydawnictwo Społecznej Akademii Nauk, Warszawa, s. 15-18.

Gołembski G. (1998). Przedsiębiorstwo turystyczne w gospodarce wolnorynkowej. Wydawnictwo AE, Poznań.

Husain S., Root A. (2015). Crowdfunding for Entrepreneurship - Special Report. Allied Crowds.

Janasz W., Kozioł K. (2007). Determinanty działalności innowacyjnej przedsiębiorstw. Wydawnictwo PWE, Warszawa.

Kaczmarek J., Stasiak A., Włodarczyk B. (2010). Produkt turystyczny. Wydawnictwo PWE, Warszawa.

Mazurek-Łopacińska K., Sobocińska M. (2016). Crowdsourcing i crowdfunding w kreowaniu innowacji w konsumpcji. Prace Naukowe WNEIZ, 43(2). 
Motylska-Kuźma A. (2018). Alternative finance and sustainable development. The Central European Review of Economics and Management, 2.

Waszkiewicz A. (2016). Finanse alternatywne - elektroniczne innowacje finansowe (http://dx.doi.org/10.18778/0208-6018.319.09; dostęp: 12.09.2020).

Waszkiewicz A., Kukurba M. (2020). Crowdfunding and financial system models. Prace Naukowe UEK, 64(2).

Wieczorek M. (2017). Prawo dla startupu. Wydawnictwo Helion, Gliwice.

Wojtowicz K. (2013). Pozyskanie kapitału przez spółki innowacyjne w oparciu o pierwszą emisję akcji. [W:] A. Buszko (red.), Finansowanie innowacji. Wydawnictwo Uniwersytetu Warmińsko-Mazurskiego, Olsztyn.

$\mathrm{Xu}$ B. (2015). Configurational paths to sponsor satisfaction in crowdfunding. Journal of Business Research.

Zaitseva V., Tsviliy S., Bublei H. (2019). Innovation Facilities of the Tourist Business of Small and Medium Enterprises of the Region. Czasopismo Ekonomiczne Kujawsko-Pomorskiej Szkoły Wyższej, 12.

Żyto A. (2018). Gry turystyczne jako narzędzie promocji dziedzictwa militarnego Poznania. Czasopismo Turystyka Kulturowa, 1.

\section{Crowdfunding as a form of financing innovative tourism products}

Crowdfunding is a relatively new and dynamically developing form of financing various types of innovative projects. The data show that crowdfunding is an example of a source of financing of considerable importance for many enterprises, especially in the initial stage of their development.

The aim of the article is to evaluate crowdfunding in Poland as an alternative source of financing by presenting the most effective crowdfunding platform for an innovative tourist product. The chosen research method was based on a comparative analysis of crowdfunding platforms in Poland.

The comparative analysis did not allow to identify one type of platform that is best used for crowdfunding in a specific tourist product in the city of Krakow. However, it has been proven that crowdfunding is a suitable form of financing innovative projects, especially start-ups with an increased level of risk.

Translated by Ewa Kamińska 
Maciej Kędziera

Uniwersytet Ekonomiczny w Krakowie

maciej.kedziera@phd.uek.krakow.pl

(D) https://orcid.org/0000-0003-3931-419X

\section{Analiza technologii informacyjno- -komunikacyjnych $\mathrm{w}$ aspekcie ekonomii współdzielenia na przykładzie sektora turystycznego}

\section{Streszczenie}

Technologia informacyjno-komunikacyjna stanowi siłę napędową współczesnego rynku i usprawnia procesy biznesowe. Nowoczesne platformy internetowe rozpowszechniające ekonomię współdzielenia cieszą się coraz większą popularnością w branży turystycznej. Celem pracy jest ukazanie znaczenia budowania wirtualnej społeczności platformy internetowej Couchsurfing w aspekcie ekonomii współdzielenia w turystyce. W części teoretycznej zaprezentowano przegląd literatury. Część badawcza przedstawia studium przypadku międzynarodowej platformy internetowej Couchsurfing. Badanie pokazuje wpływ technologii informacyjno-komunikacyjnej, umożliwiającej budowanie wirtualnej społeczności w kontekście ekonomii współdzielenia, na branżę turystyczną. Dzięki wykorzystaniu nowych technologii wzrasta popularność i dostępność ekonomii współdzielenia, która przynosi korzyści społeczne, materialne i ekologiczne.

\section{Wprowadzenie}

Rozwój technologii informacyjno-komunikacyjnych przekształca świat i usprawnia procesy biznesowe. Pod wpływem technologii zmianie ulega tradycyjne świadczenie usług, które coraz częściej przybierają postać wirtualną. Nowoczesne platformy internetowe przyczyniają się do tworzenia wiedzy i dzielenia się nią. Szybkość i łatwość w dostępie do Internetu stwarza doskonałe warunki do

Cytowanie: Kędziera M. (2021). Analiza technologii informacyjno-komunikacyjnych w aspekcie ekonomii współdzielenia na przykładzie sektora turystycznego. W: K. Borodako (red.), Turystyka w okresie pandemii. Bogucki Wydawnictwo Naukowe, Poznań-Kraków, s. 93-101. https://doi.org/10.12657/9788379863501-9 
tworzenia globalnej społeczności użytkowników portali internetowych. Specjalnie zaprojektowane do łączenia użytkowników i wymiany wiedzy portale internetowe stwarzają dobre warunki dla ekonomii współdzielenia (ang. sharing economy). Dzięki technologii informacyjno-komunikacyjnej sektor turystyczny może charakteryzować się zupełnie nowym wymiarem i formą podróżowania. Głównym celem pracy jest pokazanie znaczenia budowania wirtualnej społeczności platformy internetowej Couchsurfing w aspekcie ekonomii współdzielenia w sektorze turystycznym. Część teoretyczna rozdziału stanowi przegląd literatury, w którym zawarto zagadnienia związane $z$ technologią informacyjno-komunikacyjną i ekonomią współdzielenia. W części badawczej zaprezentowane zostało studium przypadku ( $z$ ang. case study) międzynarodowej platformy internetowej Couchsurfing. Analiza pokazuje wpływ technologii informacyjno-komunikacyjnej, umożliwiającej budowanie wirtualnej społeczności w aspekcie ekonomii współdzielenia, na sektor turystyczny.

\section{Przegląd literatury}

\section{Istota i znaczenie technologii informacyjnej}

Nowe technologie dają współczesnym organizacjom odpowiednie narzędzia, dzięki którym mogą udoskonalać procesy w nich zachodzące i oferować coraz lepsze usługi. Technologie przyczyniają się także do wygody i łatwiejszego funkcjonowania ludzi w życiu codziennym, dając lepszy dostęp do wiedzy. Postęp technologiczny sprawił, że przedsiębiorstwa są bardziej przejrzyste i transparentne, co przełożyło się na większy wpływ ludzi na otoczenie. Przełomowym momentem było powstanie Internetu, któremu zawdzięczamy radykalną zmianę sposobu komunikowania się, jak również szybkości oraz dokładności uzyskiwanych informacji (Ratnicyn, 2016). Różnice spowodowane postępem technologicznym można dostrzec w niemalże każdej sferze życia, również w turystyce. Najczęściej wykorzystywane są technologie z zakresu informatyki i telekomunikacji.

Termin ,technologie informacyjno-komunikacyjne” został użyty po raz pierwszy przez badaczy w latach 80. i zinterpretowany jako „wszystkie możliwe typy systemów elektronicznych, które służą nadawaniu komunikacji, a także te pośredniczące w komunikowaniu się" (Melody, 1986).

Technologie informacyjno-komunikacyjne są ściśle powiązane ze zbieraniem, przetwarzaniem, przesyłaniem i prezentacją informacji. Oprócz technologii komunikacyjnych zawierają one również technologie komputerowe. Technologie informacyjne należą do dziedziny wiedzy z pogranicza informatyki oraz telekomunikacji (Matusiak, 2008).

Technologia informacyjna zmienia świat i podejście do biznesu. Otwiera też nowe możliwości w ekonomii współdzielenia w branży turystycznej. Dzięki niej wspierane są procesy zachodzące $\mathrm{w}$ organizacji. Dotyczy ściśle procedur oraz zadań występujących w organizacji, zaś sposób, w jaki wspiera biznes, w głównej mierze zależy od tego, jak jest on prowadzony (Romanowska, Trocki, 2004). 


\section{Technologia informacyjno-komunikacyjna w turystyce}

Technologia informacyjno-komunikacyjna dotyczy niemalże każdego sektora gospodarki światowej. Badanie problematyki związanej z technologią informacyjną i turystyką wynika z potencjału, jaki technologia ta wnosi w rozwój turystyki. Internet staje się dla ludzi, a szczególnie dla pokolenia cyfrowego, podstawowym źródłem wiedzy turystycznej. Coraz bardziej w niepamięć odchodzą drukowane mapy. Rozwój technologiczny spowodował, że w Internecie turyści mogą zdobyć znacznie więcej informacji, co w konsekwencji przyczyniło się do powstawania licznych stron internetowych o tematyce turystycznej (Brown i in., 2001).

Dzięki technologii większość turystów planuje podróż za pomocą aplikacji mobilnych i platform internetowych, korzystając m.in. z mobilnych map w swoich smartfonach, wspólnych przejazdów oferowanych przez platformę internetową Blablacar, noclegów proponowanych przez platformę internetową Couchsurfing. Aplikacje mapowe dostarczają turystom szeroki wachlarz dodatkowych funkcji, których mapa analogowa nie jest w stanie zaoferować (Pauschert i in., 2011). Przykładem dodatkowych funkcji może być mapa z nawigacją, która informuje użytkownika o zagrożeniach na planowanej drodze przejazdu lub korkach, jednocześnie inteligentnie sugerując zmianę trasy na szybszą. Innym przykładem dodatkowych funkcji mapy jest aplikacja Yanosik, która oprócz funkcji mapy z nawigacją posiada system ostrzegania przed policyjną kontrolą prędkości, lokalizacją fotoradarów oraz zagrożeniami na drodze. Mobilna aplikacja Yanosik zrzesza ponad 1,5 mln kierowców miesięcznie, tworząc wirtualną społeczność (Yanosik, 2020).

Należy zauważyć, że najważniejszą innowacją w marketingu turystycznym jest jego wirtualizacja, rozumiana jako wyparcie materialnych zasobów, realnych procesów oraz relacji marketingowych przez ich odpowiedniki w wirtualnej rzeczywistości (Rapacz, Jaremen, 2015).

Technologia informacyjna nie jest niezawodna, zdarzają się błędy informacyjne i natury technicznej, jednak można zaobserwować coraz doskonalsze systemy, które na przestrzeni lat zostały na tyle ulepszone, że można mówić o ich wysokiej jakości i niezawodności (Stankov i in., 2018). Wciąż zatem postępuje rozwój technologii informacyjnej również w branży turystycznej i zaufanie turystów do tej technologii stopniowo wzrasta.

Wraz z rozwojem technologii informacyjnej pojawił się nowy trend w sektorze turystycznym - inteligentna turystyka. Pod tym pojęciem kryje się np. szereg zależności pomiędzy miejscami turystycznymi, branżami turystycznymi a różnymi formami technologii informacyjno-komunikacyjnych (Gretzel i in., 2015). Obecnie funkcjonują inteligentne wyszukiwarki internetowe, dzięki którym oprócz skonkretyzowanych obiektów turysta może napotkać inne, sugerowane do odwiedzenia miejsca, znajdujące się w pobliżu szukanego obiektu. 


\section{Charakterystyka platform internetowych w aspekcie ekonomii współdzielenia}

Ekonomia współdzielenia w radykalny sposób zmienia rzeczywistość. Wszechobecny postęp technologiczny, w tym era cyfryzacji oraz coraz bardziej zaawansowane technologie informacyjno-komunikacyjne, wpływają na rozwój ekonomii współdzielenia.

W literaturze istnieje wiele definicji ekonomii współdzielenia, jednak na potrzeby niniejszego rozdziału przyjęto jej interpretację jako system gospodarczy, który jest tworzony przy wykorzystaniu platform internetowych dzięki optymalizacji oraz dzielonej alokacji przestrzeni, czasu, dóbr i usług (Mikołajewska-Zając, Rodak, 2016). Wspomniana interpretacja podkreśla rolę technologii informacyjno-komunikacyjnych w ekonomii współdzielenia. Ekonomię współdzielenia można również interpretować wprost jako platformę internetową, za pomocą której jednostki mogą brać udział we wzajemnej wymianie dóbr. Podkreślana jest też ogromna i niespotykana wcześniej skala tego zjawiska (Martin i in., 2015).

Rynek platform internetowych cechuje się dość niskimi kosztami wejścia, a także tym, że nie są potrzebne specjalne zezwolenia. Koszty zbudowania i utrzymania platformy internetowej nie należą do wysokich. Na globalnym rynku dostępnych jest wiele platform internetowych działających w oparciu o ekonomię współdzielenia, lecz ze względu na dość szeroką tematykę, często nie stanowią one dla siebie konkurencji. Większość funkcjonuje w niszach rynkowych (nocleg w połączeniu z nauką języków, opieka nad zwierzętami czy parkowanie przyczep kempingowych). Platformy te dzielą się na płatne i darmowe (Pawlicz, 2019).

Można zauważyć silny rozwój, a także powstawanie nowych platform internetowych (również mobilnych aplikacji) umożliwiających np. współdzielenie przejazdów, które wpływają na sposób poruszania się ludzi. Powstają nowe platformy internetowe pozwalające na zakwaterowanie typu „peer-to-peer”, które szczególnie zachęca pokolenie młodych ludzi do częstego podróżowania do różnych miejsc na świecie (Bae i in., 2017).

Platformy internetowe działające $\mathrm{w}$ aspekcie ekonomii współdzielenia przyciągają nowych użytkowników, ułatwiają wymianę informacji pomiędzy nimi oraz zachęcają do wspólnego budowania zaufania i aktywnego uczestnictwa (Moser i in., 2017). Dzięki nim rośnie znaczenie kapitału społecznego (Yuan i in., 2018), a wymiana dóbr jest łatwo dostępna i prosta. Informacja na temat oferowanych dóbr jest rozpowszechniana na coraz większą skalę dzięki technologiom informacyjno-komunikacyjnym, takim jak np. platformy internetowe, mobilne aplikacje czy media społecznościowe.

\section{Metodyka badań}

Do analizy problematyki związanej $z$ technologiami informacyjno-komunikacyjnymi w aspekcie ekonomii współdzielenia zastosowano badania jakościowe. 
Praca została podzielona na dwie części - teoretyczną i badawczą. W części teoretycznej wykorzystano przegląd literatury, ze szczególnym uwzględnieniem jej aktualności. Część badawcza została poświęcona analizie budowania wirtualnej społeczności platformy internetowej Couchsurfing w aspekcie ekonomii współdzielenia w turystyce. Metodą badawczą zastosowaną w niniejszym rozdziale jest studium przypadku tej platformy. Uzasadnieniem wyboru była duża jej rozpoznawalność, korzystanie z technologii informacyjno-komunikacyjnych oraz działalność oparta na ekonomii współdzielenia. Couchsurfing jest jedną z czterech firm mających największy udział w rynku turystycznych platform internetowych (Pawlicz, 2019), co świadczy o jej globalnym zasięgu.

Cel pracy został zrealizowany metodą studium przypadku. Ma ona charakter empiryczny, ponieważ ocenia oraz analizuje zjawiska występujące w rzeczywistości. W odniesieniu do nauk o zarządzaniu metoda ta jest rozumiana jako dokładny opis zazwyczaj szczegółowego zjawiska gospodarczego. Zgromadzone informacje na potrzeby studium przypadku umożliwiają wykonanie dokładnej analizy badanego problemu, a także przedstawienie jego charakterystyki oraz relacji z innymi elementami organizacji lub jej otoczenia (Grzegorczyk, 2015).

Studium przypadku pozwala na wszechstronną analizę wykorzystania technologii informacyjno-komunikacyjnych w aspekcie ekonomii współdzielenia. Należy dodać, że zaprezentowane w publikacji wyniki analizy mogą być uogólniane na inne sytuacje, charakteryzujące się zbliżonymi uwarunkowaniami i cechami.

\section{Wyniki badań}

\section{Historia powstania Couchsurfingu}

Historia powstania Couchsurfingu sięga 1999 r. Wszystko zaczęło się, gdy ówczesny student, a zarazem programista - Casey Fenton - znalazł tani, okazyjny lot z Bostonu na Islandię, ale niestety nie miał zakwaterowania. Fenton, włamując się do bazy danych Uniwersytetu Islandzkiego, wysłał 1500 maili do losowo wybranych studentów z zapytaniem o nocleg. W odpowiedzi otrzymał od 50 do 100 propozycji zakwaterowania. Podczas powrotu do Bostonu wpadł na pomysł zbudowania strony internetowej, zaś domenę couchsurfing.com zarejestrował 12 czerwca 1999 r. (Moran, 2011).

Oficjalnie platforma internetowa została uruchomiona 12 czerwca 2004 r. przy współpracy Dana Hoffera, Sebastiana Le Tuana i Leonarda Silvery (Couchsurfing, 2020). Od 2006 r. do momentu uzyskania przez firmę finansowania w 2011 r. działania mające na celu rozwój i rozbudowę platformy internetowej odbywały się w przeważającej części w ramach wydarzenia o nazwie Couchsurfing Collectives, kiedy to członkowie zespołu spotykali się dobrowolnie w celu ulepszenia platformy (Camillo, 2015).

Przełomowym momentem w historii Couchsurfingu był 2012 r., w którym to firma uruchomiła aplikacje mobilne na systemy operacyjne Android oraz iOS (Roudman, 2013). Wtedy dostęp do informacji stał się jeszcze wygodniejszy i szybszy. 


\section{Technologia informacyjno-komunikacyjna wykorzystywana w Couchsurfing}

Couchsurfing jest platformą internetową łącząca użytkowników oferujących zakwaterowanie w swoim mieszkaniu lub domu z użytkownikami szukającymi zakwaterowania. Użytkownicy poszukujący zakwaterowania mają dostęp do wyszukiwarki $z$ informacjami o ofertach zakwaterowania w wielu miejscach na świecie. Couchsurfing to globalna społeczność 14 mln ludzi w ponad 200 tys. miast, którzy dzielą swoje życie, świat i podróże (Couchsurfing, 2020).

Idea funkcjonowania platformy jest przykładem zastosowania technologii informacyjno-komunikacyjnej w celu rozwinięcia ekonomii współdzielenia. Przyglądając się działaniom platformy internetowej Couchsurfing, można zauważyć jej silny udział w ekonomii współdzielenia poprzez wykorzystanie technologii informacyjno-komunikacyjnych. Kamieniem milowym Couchsurfingu było wprowadzanie aplikacji mobilnych na smartfony, dzięki czemu dostęp do platformy był jeszcze wygodniejszy i szybszy. Z pewnością przyczyniło się to również do szybszego przepływu informacji pomiędzy użytkownikami, a także do mobilnych aktualizacji udostępnianych informacji.

Platforma internetowa Couchsurfing spowodowała upowszechnienie się nowych mediów i technologii informacyjno-komunikacyjnych. Spopularyzowanie nowych technologii informacyjno-komunikacyjnych zwiększa zaufanie do komunikacji za pośrednictwem komputera, na co zwrócił uwagę Tan (2010) w swojej pracy. Badania wskazują, że dla ponad $80 \%$ respondentów korzystających z portalu internetowego Couchsurfing ważny jest aspekt oszczędności. Głównym bodźcem motywującym do korzystania z Couchsurfingu jest m.in. „chęć poznawania nowych ludzi” czy też „chęć bycia częścią międzynarodowej wspólnoty podróżników” (Juda, 2013). Zatem można zwrócić uwagę na wymiar zarówno społeczny, jak i finansowy zachęcający do korzystania z portalu Couchsurfing.

Technologia mediów społecznościowych wspiera system wzajemnej wymiany. Dzięki niej poprzez prezentację uczestników zwiększa się transparentność Couchsurfingu i możliwość ustalenia wzajemnych relacji między gospodarzami a gośćmi przed spotkaniem twarzą w twarz. Gospodarz przedstawia swoje zasady w ogłoszeniu i może także zadawać dodatkowe pytania zainteresowanym gościom, np.: „Dlaczego chcesz mnie poznać?”. Zastosowany mechanizm pozwala na odpowiedni dobór gości i gospodarzy.

Technologia informacyjno-komunikacyjna wykorzystywana przez Couchsurfing pomaga zatem spełniać niezwykle ważną funkcję budowania wirtualnej społeczności i poczucia przynależności do niej. Użytkownicy tym samym tworzą przywiązanie do platformy internetowej i chętnie uczestniczą w jej życiu. Couchsurfing służy także jako ważne miejsca interakcji i zwiększania udziału w ruchach społecznych. Znaczenie funkcji budowania wirtualnej społeczności przez platformy internetowe podkreślają również Sutherland i Jarrahi (2017). Couchsurfing łączy podróżników z globalną siecią ludzi, którzy chcą się dzielić tym, co mają, dzięki czemu podróż staje się prawdziwym społecznym przeżyciem. Poprzez 
zastosowanie nowych technologii Couchsurfing stał się platformą modną, łatwo dostępną, łączącą ludzi, którzy czerpią korzyści w aspekcie społecznym i ekonomii współdzielenia.

\section{Zakończenie}

Technologie informacyjno-komunikacyjne zmieniają dostęp do informacji i sposoby komunikowania się. Coraz bardziej widoczna staje się wirtualizacja usług na globalnym rynku. Nowoczesne platformy internetowe i towarzyszące im aplikacje mobilne stwarzają nowe możliwości rozwoju ekonomii współdzielenia. Działające w sektorze turystycznym platformy internetowe oparte na ekonomii współdzielenia, takie jak Couchsurfing, są doskonałym przykładem obrazującym znaczenie technologii informacyjno-komunikacyjnych umożliwiających budowanie wirtualnej społeczności. Wykorzystanie nowych technologii przyczynia się do wzrostu popularności i dostępności ekonomii współdzielenia, która przynosi pozytywne korzyści społeczne oraz finansowe.

\section{Literatura}

Anuar F.I., Gretzel U. (2011). Privacy Concerns in the Context of Location Based Services for Tourism. ENTER 2011 Conference, Innsbruck, Austria, January 26-28, 2011 (http://ertr.tamu.edu/enter-2011-short-papers/; dostęp: 1.03.2015)

Bae S.J., Lee H., Suh E.K., Suh K.S. (2017). Shared experience in pretrip and experience sharing in posttrip: a survey of Airbnb users. Inf. Manag. 54(6): 714-727.

Barua Z., Aimin W., Hongyi X. (2018). A perceived reliability-based customer satisfaction model in self-service technology. The Service Industries Journal, 38(7-8): 446-466.

Brown A., Emmer N., van den Worm J. (2001). Cartographic design and production in the internet era: the example of tourist web maps. The Cartographic Journal, 38(1): 61-72.

Camillo A. (2015). Handbook of Research on Global Hospitality and Tourism Management. IGI Global.

Gretzel U., Sigala M., Xiang Z., Koo C. (2015). Smart tourism: Foundations and developments. Electronic Markets, 25(3): 179-188.

Grzegorczyk W. (2015). Wybrane problemy zarządzania i finansów: studia przypadków. Wydawnictwo Uniwersytetu Łódzkiego, Łódź.

Juda A. (2013). Dlaczego konsumpcjonizm już nie wystarcza - kolaboratywna konsumpcja w Polsce na przykładzie Couchsurfingu (http://krytyka.org/wp-content/uploads/2014/03/Aleksandra-JudaAlternatywna-konsumpcja.pdf; dostęp: 4.01.2021).

Martin C.J., Upham P., Budd L. (2015). Commercial orientation in grassroots social innovation: Insights from the sharing economy. Ecological Economics, 118: 240-251.

Matusiak K.B. (2008). Innowacje i transfer technologii. Słownik pojęć. Wydawnictwo PARP, Warszawa.

Mazurek G. (2012). Znaczenie wirtualizacji marketingu w sieciowym kreowaniu wartości. Wydawnictwo Poltext, Warszawa. 
Melody W.H. (1986). Information and communication technologies: social. Social science research and training. A Report by the ESRC Programme on Information and Communication Technologies. United Kingdom.

Mikołajewska-Zając K., Rodak O. (2016). Platformy spółdzielcze jako próba rewizji korporacyjnego modelu gospodarki współdzielonej. E-Mentor, 4(66): 67-73.

Moran G. (2011). How CouchSurfing Got its Start, and Landed VC Millions. Entrepreneur (https://www.entrepreneur.com/article/220724; dostęp: 2.01.2020).

Moser C., Resnick P., Schoenebeck S. (2017). Community commerce: Facilitating trust in mom-to-mom sale groups on facebook. Proceedings of the $2017 \mathrm{CHI}$ Conference on Human Factors in Computing Systems, 4344-4357 CHI' 17.

Pauschert C., Riplinger E., Tiede C., Coors V. (2011). Benefits through linking of analogue and digital maps. Advances in Cartography and GIScience, 1: 205-217.

Pawlicz A. (2019). Ekonomia współdzielenia na rynku usług hotelarskich. Niedoskonałości - Pośrednicy - Regulacje. Wydawnictwo Uniwersytetu Szczecińskiego, Szczecin.

Rapacz A., Jaremen D.E. (2015). ICT a innowacje marketingowe w przedsiębiorstwach turystycznych. Logistyka, 2: 1346-1354.

Ratnicyn K. (2016). Jak nowe technologie zmieniają biznes. Wydawnictwo Słowa i Myśli, Lublin.

Romanowska M., Trocki M. (2004). Podejście procesowe w zarządzaniu. Wydawnictwo SGH, Warszawa.

Roudman S. (2013). How to Lose Funds and Infuriate Users: Couchsurfing, a Cautionary Tale From the Sharing Economy (http://techpresident.com/news/24498/couchsurfing2; dostęp: 3.01.2020).

Stankov U., Filimonau V., Slivar I. (2018). Calm ICT design in hotels: A critical review of applications and implications. International Journal of Hospitality Management.

Sutherland W., Jarrahi M.H. (2017). The gig economy and information infrastructure: The case of the digital nomad Community. Proceedings of the ACM on Human Computer Interaction, 1(1).

Tan J.E. (2010). The Leap of Faith from Online to Offline: An Exploratory Study of Couchsurfing.org. W: A. Acquisti, S.W. Smith, A.R. Sadeghi (red.), Trust and Trustworthy Computing. Trust 2010. Lecture Notes in Computer Science, 6101.

Wozniak T., Liebrich A., Senn Y., Zemp M. (2016). Alpine tourists' willingness to engage in virtual Co-creation of experiences. W: A. Inversini, R. Schegg (red.), Information and communication technologies in tourism 2016, s. 281-294.

Yanosik (2020) (www.yanosik.pl; dostęp: 27.12.2020).

Yuan T., Wen C., Hanrahan B.V., Carroll J.M. (2018). Is there social capital in service exchange tools? Investigating timebanking use and social capital development. Computers in Human Behavior, 81: 274-281.

\section{Analysis of information and communication technologies in the aspect of the economics of sharing on the example of the tourism sector}

Information and communication technology is the driving force of the modern market and improves business processes. Modern online platforms that spread the sharing economy are becoming more popular in the tourism industry. The aim of the article is to show the importance of building a virtual community in online platform - Couchsurfing, in regards to sharing economy in tourism. The theoretical part of the article presents a literature review. The research part presents a case study of Couchsurfing - an international online 
platform. The study shows the effect of informational-communicative technology, which allows for building a virtual community, in the context of the sharing economy influencing the tourism industry. The use of new technologies increases the popularity and accessibility of the sharing economy, which has social, material and environmental benefits.

Translated by Maciej Kędziera 



\author{
Dominika Hapek \\ Uniwersytet Ekonomiczny w Krakowie \\ dominika.hapek@phd.uek.krakow.pl \\ (D) https://orcid.org/0000-0001-6826-254X
}

\title{
Wykorzystanie nowych technologii jako element współczesnego marketingu hotelu niezależnego
}

\section{Streszczenie}

Wykorzystanie nowych technologii stało się integralną częścią otaczającego nas świata w każdej dziedzinie życia. Trend ten przeniósł się na płaszczyznę funkcjonowania obiektów hotelowych, w których współczesny marketing jako podstawowe narzędzie pozyskiwania klientów nierozerwalnie połączony jest z zastosowaniem nowych rozwiązań w budowaniu przewagi konkurencyjnej. Dotychczasowe badania opierały się na ocenie i analizie popytowej strony użycia nowych technologii w branży turystycznej z wyszczególnieniem obiektów hotelowych. Celem rozdziału jest określenie wykorzystania nowych technologii jako elementu współczesnego marketingu hoteli niezależnych na przykładzie wybranych hoteli województwa małopolskiego. Badania pilotażowe zostały przeprowadzone na podstawie wywiadów z menedżerami hoteli metodą analizy studium przypadków. Wyniki potwierdziły, że urządzenia mobilne i media społecznościowe stały się głównymi kanałami marketingu badanych hoteli.

\section{Wprowadzenie}

Transformacyjne skutki technologii cyfrowych są widoczne w prawie wszystkich branżach i środowiskach biznesowych (Chanias i in., 2019). W szczególności technologia informacyjna przekształciła rynek turystyczny i hotelarski (Sigala, 2018). W przemyśle turystycznym, zwłaszcza w sektorze hotelowym, efektywne wykorzystywanie nowych technologii jest podstawą w planowaniu strategii zarządzania. Zmieniający się system dystrybucji spowodowany rosnącą dominacją 
kanałów dystrybucji online, rozwój modeli biznesowych opartych na platformie ekonomicznej oraz stale rosnący wpływ treści generowanych przez użytkowników zmusiły hotele do ponownego rozważenia nowych technik zarządzania dochodami (z ang. Revenue Management RM) i strategii cenowej (Cross, 2016).

Możliwości technologii cyfrowych nie ograniczają się jednak do funkcji informowania i pośredniczenia w procesie rezerwacji. Technologie te umożliwiają szybkie i tanie pozyskiwanie danych dotyczących preferencji konsumentów oraz ich cech społeczno-demograficznych. Dostępność tego rodzaju danych pozwala na dopasowanie oferty do potrzeb zróżnicowanych grup odbiorców. Jest ona również warunkiem koniecznym do prowadzenia efektywnych, skalowalnych i spersonalizowanych działań marketingowych.

Ze strony klientów szybkie i łatwe rozwiązania mobilne są opracowane i opublikowane w literaturze przedmiotu. Kompleksowy przegląd pokazuje, że większość badań koncentruje się na kontekście doświadczeń turystycznych i branży hotelarskiej. Nieproporcjonalnie więcej badaczy skupiło się na konsumentach niż na dostawcach (Law, 2018).

W literaturze polskiej i zagranicznej wiele miejsca poświęcono na badania marketingowe hoteli z punktu widzenia konsumenta, analizy hoteli wykorzystujących technologię. „Najczęściej technologia informatyczna używana jest we wszelkiego typu systemach rezerwacji oraz informacji, i w tym zakresie jest też najczęściej omawiana jako przykład innowacyjny" (Bednarczyk, Handzel, 2007). Autorka skupiła się przede wszystkim na hotelach niezależnych, które niejednokrotnie nie dysponują takim kapitałem, zespołem pracowników - specjalistów, brandem jak międzynarodowe sieci hotelowe, co na starcie utrudnia im walkę o zainteresowanie klienta, w dodatku wymusza na nich większą kreatywność działania przy wykorzystaniu dostępnych form przekazu. Autorka przeprowadziła pilotażowe badania na wybranej grupie hoteli, inspirując się badaniami przeprowadzonymi w 23 luksusowych hotelach w Jordanii (Alrawadieh i in., 2020).

Dokładna kwerenda literatury pozwoliła stwierdzić, że brakuje publikacji związanych $z$ omawianym tematem poświęconych polskiemu rynkowi, co stanowiło jedną z głównych przesłanek podjęcia badań. Wybór tematyki nie jest przypadkowy. Poprzedzono go analizą literatury przedmiotu, wnikliwą obserwacją podmiotów funkcjonujących na rynku usług hotelowych oraz przedstawiono wnioski dotyczące wpływu zastosowania nowych technologii jako elementu marketingu hoteli niezależnych. Celem pracy jest określenie stopnia wykorzystania nowych technologii jako elementu współczesnego marketingu hoteli niezależnych.

\section{Przegląd literatury}

Rosnące uzależnienie od technologii cyfrowej jest dostrzegane $\mathrm{w}$ wielu branżach, turystyka nie jest wyjątkiem (Buhalis i in., 2019). Wykorzystanie nowych technologii stało się niezbędne, aby firmy mogły osiągnąć kluczowe cele biznesowe obejmujące poprawę jakości usług, redukcję kosztów, uzyskanie przewagi konkurencyjnej, tworzenie wiedzy i maksymalizację przychodów (Camilleri, 2018). Van 
der Wagen i Goonetilleke (2008) podkreślają, że „W dokonywaniu transformacji technologii informatycznych branża turystyczna wyprzedziła wszystkie inne gałęzie przemysłu". Rozwój technologii informacyjno-komunikacyjnych umożliwił digitalizację informacji (Kachniewska, 2017).

Poziom wykorzystania danych i technologii cyfrowych do celów analitycznych i marketingowych przez polskie przedsiębiorstwa turystyczne należy do najniższych w Europie. Wyniki takie daleko odbiegają od średniej państw europejskich. Również poniżej średniej europejskiej Polska wypada pod względem odsetka przedsiębiorstw wykorzystujących w swojej działalności media społecznościowe - rozwiązanie takie stosuje $67 \%$ polskich firm w porównaniu ze średnim wynikiem państw Unii Europejskiej wynoszącym 74\% (Czernecki i in., 2020).

Znaczący wpływ na rozwój operacyjny sektora usług hotelarskich wywierają innowacyjne narzędzia i kanały dystrybucji. Współcześnie $\mathrm{w}$ dystrybucji online dominują: internetowe biura podróży (OTA), platformy rezerwacyjne oraz urządzenia mobilne (smartfony $\mathrm{i}$ aplikacje) (Alrawadieh $\mathrm{i}$ in., 2020).

Mnogość ofert, które dziennie klient widzi na ekranie telefonu, sprawia, że robi to automatycznie, nie skupiając specjalnie uwagi na treściach. W świecie zdominowanym przez smartfon, w którym kupujący ma automatyczny dostęp do wyszukiwarki ofert, porównywarki cen, portali opiniotwórczych, z punktu widzenia marketingu hotelu ważne jest zaistnienie w świadomości odbiorcy i wyróżnienie swojej oferty. Dlatego też w XXI w. tradycyjny marketing już nie wystarczy. Nowoczesne ujęcie marketingu wychodzi poza typową działalność handlową, skupia się bardziej na formie kontaktu między ludźmi, umożliwiając dotarcie do klienta różnymi kanałami dystrybucji, ważne, żeby były one twórcze, innowacyjne $\mathrm{i}$ oryginalne.

Kurletko (2013) podjęła próbę „zaprezentowania oddziaływania nowych technologii komunikacyjno-informacyjnych i innych na zarządzanie przedsiębiorstw turystycznych., wskazując na możliwość przetwarzania danych i redukcję kosztów".

\section{Metodyka badań}

Celem pracy jest określenie wykorzystania nowych technologii jako elementu współczesnego marketingu hoteli niezależnych na przykładzie wybranych hoteli województwa małopolskiego. Badania pilotażowe zostały przeprowadzone na podstawie wywiadów z menedżerami hoteli metodą analizy studium przypadków.

Rozmówcy zostali poproszeni o wskazanie elementów nowoczesnego marketingu wykorzystywanego $\mathrm{w}$ działaniach promocyjnych, tworząc spersonalizowane kampanie w mediach społecznościowych (social mediach), docierając do poszczególnych grup docelowych. W badaniu skupiono się na formach wykorzystania informacji o kliencie, pozyskanych za pomocą CRM oraz przez pracowników recepcji. Drugim ważnym zagadnieniem w wywiadzie było wykorzystanie aplikacji mobilnych synchronizujących Booking.com i Facebook, które ułatwiają gościom dokonywanie rezerwacji usług bezpośrednio z Facebooka. Istotną kwestią było, 
w jaki sposób hotele używają bazy mailingowej, jakie działania podejmują, budując relacje $z$ gościem jeszcze przed przyjazdem, w trakcie pobytu oraz po wyjeździe. Autorka pogrupowała pytania w wywiadzie w 5 kluczowych jej zdaniem zakresów tematycznych:

- kampanie w mediach społecznościowych,

- wykorzystanie aplikacji mobilnych,

- kampanie reklamowe z udziałem fanów i celebrytów,

- tworzenie bazy mailingowej,

- dodatkowe funkcjonalności na stronie internetowej hotelu.

\section{Wyniki badań}

Badania pilotażowe w zakresie wykorzystania nowoczesnych technologii jako elementu współczesnego marketingu wykonano na grupie 15 menedżerów niezależnych hoteli 3-, 4- i 5-gwiazdkowych na terenie województwa małopolskiego. Badany okres obejmował miesiące od lipca do grudnia 2019 r. Autorka przeprowadziła badanie w listopadzie-grudniu 2020 r., wybrała technikę wywiadu na podstawie kwestionariusza wywiadu $z$ kafeterią półotwartą. Do badania zostało zaproszonych 20 menedżerów hoteli, z czego 15 przyjęło zaproszenie, 5 odmówiło.

Wszyscy respondenci odpowiedzieli na każde z zadanych pytań. Wśród rozmówców było 10 kobiet i 5 mężczyzn. Zdecydowana większość była w przedziale wiekowym 31-35 lat, 3 osoby powyżej 40. roku życia i $2 \mathrm{w}$ wieku 26-30 lat. W zakresie wykształcenia 9 badanych wskazało wykształcenie wyższe magisterskie, a 6 osób licencjat/inżynier. Większość rozmówców wskazała miejsce zamieszkania jako miasto powyżej 500 tys. mieszkańców, 3 osoby zadeklarowały zamieszkanie na terenach wiejskich. Hotele 3-gwiazdkowe jako miejsce pracy wskazało 9 menedżerów, w hotelu 4-gwiazdkowym pracowały 4 osoby i 2 wskazały na pracę w hotelu 5-gwiazdkowym.

Menedżerowie kilku obiektów prosili o anonimowość, dlatego na potrzeby publikacji hotele oznaczono w kolejności od A do O.

Respondenci zostali poproszeni o udzielenie informacji dotyczących wykorzystania nowych technologii w działaniach marketingowych. Najczęściej pojawiającą się odpowiedzią było posiadanie strony internetowej hotelu. W 7 hotelach można dokonać rezerwacji usługi bezpośrednio na stronie www hotelu, pozostałe 8 obiektów dysponowało formularzem z zapytaniem o dostępność wolnych pokoi w wybranym terminie.

„Najczęściej pytania przesyłane przez nasz formularz dotyczą terminów na przyjęcia okolicznościowe, wesela, wynajem sali konferencyjnej na szkolenia lub eventy. Goście zdecydowanie częściej kontaktują się z hotelem telefonicznie. Są to najczęściej zapytania o rezerwację noclegu na ten sam dzień" - mówi menedżer hotelu N.

Wśród wszystkich badanych hoteli tylko 2 mają stronę internetową dostosowaną do urządzeń mobilnych, pomimo że większość rezerwacji dokonywanych 
przez klientów w XXI w. odbywa się przy użyciu smartfona. Umożliwiając gościom rezerwację pokoju lub usługi bezpośrednio na stronie internetowej hotelu, obiekty ograniczają udział OTA i GDS w procesie rezerwacji. „Przez brak możliwości dokonania rezerwacji noclegów bezpośrednio na stronie hotelu płacimy wyższe faktury prowizyjne pośrednikom, np. OTA" - stwierdził menedżer hotelu H. System rezerwacji w formie aplikacji mobilnej, np. IdoBooking, umożliwiającej dokonywanie szybko i prosto rezerwacji bezpośrednio na Facebooku, nie jest używany w badanych obiektach.

Aplikacje mobilne są kosztownym wydatkiem, który często wykracza poza możliwości hotelu niezależnego finansowanego przez prywatnego właściciela. „Właściciel hotelu niechętnie inwestuje pieniądze w dodatkowe aplikacje na urządzenia mobilne, które ułatwiają i mogłyby wspierać codzienną pracę i zarządzanie obiektem" - skomentował menedżer hotelu J.

Wszystkie hotele miały swój fanpage na Facebooku, zróżnicowanie pojawiło się w codziennych aktywnościach i prezentowanych treściach. Hotele miały zaplanowaną spójną strategię promocji dedykowaną mediom społecznościowym. W jednym z obiektów wszystkie kampanie prowadzi agencja reklamowa, w pozostałych 14 zajmują się tym pracownicy recepcji lub menedżer.

Zapytano menedżerów, jak wykorzystują siłę Facebooka jako element marketingu i reklamy o dalekich zasięgach. W tym miejscu najczęściej pojawiały się odpowiedzi dotyczące planowania kampanii. „Prowadzimy długoterminowa przemyślaną strategię z ułożonym kalendarzem publikacji postów, dopracowaną grafiką i treściami spójnymi z aktualnymi działaniami obiektu" - przyznał menedżer hotelu C. „Skupiamy się na dodawaniu wyłącznie postów z informacją o ofercie specjalnej, rabatach, obniżkach cen. Robimy dość regularnie promocje, o których informujemy za pośrednictwem social mediów" - tłumaczył menedżer hotelu P. W odpowiedziach menedżerów najczęściej występowały płatne reklamy na Facebooku jako kampanie marketingowe tworzone w okresie lipiec-grudzień 2019 r. Pojawiły się też hotele, które nie korzystały z tej formy przekazu. „Nie tworzyliśmy płatnych kampanii na social mediach, ponieważ ze względu na lokalizację mamy wysoki wskaźnik obłożenia przez cały rok" - mówił menedżer hotelu B.

Najczęściej hotele robią krótkie posty na portalu Facebook. Dzięki skomplikowanym algorytmom Facebook skutecznie wspiera działania promocyjne hoteli, które mają dużą ilość polubień i komentarzy pod swoimi postami, dzięki czemu zwiększa się zasięg publikowanych wiadomości na fanpage'u hotelu. Turyści chętnie obserwują hotele, w których regularnie aktualizowana jest lista wydarzeń. Dodatkowo udostępnianie w mediach społecznościowych na żywo relacji z wydarzeń w hotelu stało się bardzo popularne i często wykorzystywane. Wystarczy nakręcić smartfonem lub tabletem krótki film i dodać na Facebook lub Instagram, oznaczając osoby biorące udział w tym wydarzeniu. „Z chęcią pokazujemy klientom wydarzenia w hotelu. Zwykle to ja nagrywam krótki film - relację z każdego eventu. Często robię zdjęcia nowości w karcie menu restauracji i dodaję na social media. Wiem, jak ważne jest bycie obecnym w sieci. Klienci podczas meldowania proszeni są o polubienie naszego fanpage'u na Facebooku, tak zdobywamy like. 
Goście w zamian otrzymują voucher zniżkowy do naszej restauracji do wykorzystania w trakcie pobytu" - tłumaczy menedżerka hotelu K.

Żaden z hoteli nie ma kanału na Youtube i konta na kanale TicTok. Znikoma część menedżerów dostrzega potrzebę komunikowania się z klientami za pośrednictwem Instagrama.

Wyniki badań wskazują, że obiekty położone ściśle w centrum miasta Krakowa nie inwestują w kampanie reklamowe, ponieważ idealna lokalizacja zapewnia im gości. Żaden $z$ hoteli nie korzysta z usług celebrytów, fanów mających dużą liczbę odbiorców na kanałach You Tube, Instagram czy Facebook czy w celu promocji. Live i nagrania na żywo zdarzały się dość często w 4 obiektach, głównie z celebrytami i popularnymi aktorami nocującymi w hotelu.

W grupie menedżerów hoteli 3-gwiazdkowych nie są prowadzone analizy pozyskanych danych o klientach. Karty meldunkowe zawierają pole e-mail, niemniej recepcjoniści rzadko proszą o ich uzupełnianie. Wśród menedżerów hoteli położonych poza Krakowem w miejscowościach ościennych często pojawiało się stwierdzenie, że pozyskiwanie e-maili klientów nie jest potrzebne, ponieważ nie prowadzili i nie planują prowadzenia kampanii wysyłki newslettera lub spersonalizowanych ofert. W hotelach 4- i 5-gwiazdkowych trend jest zupełnie odmienny. Położony jest bardzo duży nacisk na marketing lojalnościowy, stali klienci otrzymują bonifikaty oraz $\mathrm{z}$ wyprzedzeniem informowani są o najnowszych ofertach hotelu wysyłanych za pośrednictwem e-maila. „Wysyłka e-maili w naszym hotelu prowadzona jest przez pracowników recepcji lub dział marketingu" - wyjaśnił menedżer hotelu A.

\section{Zakończenie}

Reasumując, wykorzystanie nowych technologii jako elementu współczesnego marketingu $\mathrm{w}$ badanych przez autorkę hotelach może pomóc stworzyć skuteczny i efektywny plan działania i zautomatyzować pracę personelu. Menedżerowie rozumieją potrzebę inwestowania w strony internetowe dostosowane do urządzeń mobilnych oraz aplikacje mobilne, jednak niechętnie korzystają z tego rodzaju aplikacji głównie przez wysokie koszty inwestycji i niepewny zwrot. Zauważyć można zróżnicowanie w podejściu do działań marketingowych pomiędzy hotelami 3- i 5-gwiazdkowymi. Najczęściej stosowaną praktyką jest umieszczanie postów lub filmów w mediach społecznościowych ze zdjęciami popularnych aktorów czy celebrytów, którzy nocują w hotelu. Żaden z badanych hoteli nie współpracuje na stałe ze znanymi i popularnymi w mediach społecznościowych celebrytami czy fanami, związane jest to przede wszystkim z ograniczonym budżetem. Menedżerowie hoteli prywatnych wykazują się pomysłowością, kreatywnością i mają większą możliwość kontaktu z gościem i spersonalizowania oferty. Cechą wspólną wszystkich obiektów jest sprzedawanie usług i ofert pakietowych (nocleg plus gastronomia lub SPA) za pomocą swojej strony internetowej. Każdy $z$ badanych hoteli ma własną stronę internetową, ale tylko hotele 5-gwiazdkowe 
z badanej grupy mają stronę www dostosowaną do urządzeń mobilnych, pomimo że klienci coraz częściej korzystają ze smartfona, dokonując rezerwacji.

Kluczem do zwiększenia zainteresowania menedżerów hoteli, inwestowania w nowe technologie jest używanie mediów społecznościowych oraz angażowanie fanów w celu promowania hotelu jako jeden $z$ elementów współczesnego marketingu. Zakup aplikacji mobilnych wykorzystywanych do działań promujących sprzedaż usług hotelowych i rezerwacje dokonywane bezpośrednio przez stronę hotelu będą zmniejszały koszty prowizji płaconych dotychczas pośrednikom.

Popularyzacja i szeroko pojęta dostępność w mediach społecznościowych, przy współpracy z fanami, popularnymi aktorami, celebrytami, właścicielami popularnych kanałów na YouTube czy Instagramie, będą warunkowały według autorki dalszy wzrost znaczenia elementów nowoczesnego marketingu wśród hoteli niezależnych. W świetle zaprezentowanych wyników należy uznać, że zagadnienie nowych technologii w działaniach marketingowych hoteli jest wciąż mało zbadaną i interesującą dziedziną. Przedstawione badania mają kilka ograniczeń. Jakościowe podejście badawcze, wybranie grupy hoteli niezależnych czy lokalizacja (obiekty z województwa małopolskiego) eliminuje możliwość uogólniania wyników na całą branżę hotelarską. Temat jest złożony i ważny z punktu widzenia menedżerów na etapie określania strategii działań marketingowych hoteli, wymaga pogłębienia z perspektywy pozostałych pracowników hotelu z działu sprzedaży, marketingu i IT. W przyszłości badania należy rozszerzyć m.in. o aspekty barier zastosowania współczesnego marketingu z wykorzystaniem urządzeń mobilnych w hotelach.

\section{Literatura}

Alrawadieh Z., Alrawadieh Z., Cetin G. (2020). Digital transformation and revenue management: Evidence from the hotel industry. Tourism Economics, 1-8, doi: 10.1177/1354816620901928.

Barsoux J.L., Wade M., Bouquet C. (2019). Jak wcielać w życie przełomowe koncepcje. Harvard Business Review, lipiec-sierpień: 84-97.

Buhalis D., Harwood T., Bogicevic V. i in. (2019). Technological disruptions in services: lessons from tourism and hospitality. Journal of Service Management, 30(4): 484-506.

Buhalis D., Law R. (2008). Progress in Tourism Management. Progress in Information Technology and Tourism Management - The State of e-Tourism Research. Tourism Management, 29(4): 609-623.

Camilleri M.A. (2018). The promotion of responsible tourism management through digital media. Tourism Planning \& Development, 15(6): 653-671.

Chabrzyk, Drapała, Raszkowska, Suhov, Wodzyńska (2020). Branża turystyczna w Polsce. Obraz sprzed pandemii. Polski Instytut Ekonomiczny, Warszawa.

Chanias S., Myers M.D., Hess T. (2019). Digital transformation strategy making in pre-digital organizations: the case of a financial services provider. The Journal of Strategic Information Systems, 28(1): 17-33.

Clero C., Gloton R. (1976). Twórcza aktywność dziecka. Wydawnictwa Szkolne i Pedagogiczne, Warszawa, s. 36. 
Czernicki Ł., Kukołowicz P., Miniszewski M. (2020). Branża turystyczna w Polsce. Obraz sprzed pandemii. Polski Instytut Ekonomiczny, Warszawa.

Femenia-Serra F., Gretzel U. (2020). Technologie informacyjne i komunikacyjne w turystyce 2020. Materiały z międzynarodowej konferencji w Surrey, Wielka Brytania, 8-10 stycznia 2020 r. Information and Communication Technologies in Tourism, s. 65-78.

Florida R. (2010). Narodziny klasy kreatywnej oraz jej wpływ na przeobrażenia w charakterze pracy, wypoczynku, społeczeństwa i życia codziennego. Tłum. T. Krzyżanowski, M. Penkala. Narodowe Centrum Kultury, Warszawa, s. 51.

Hjalager A.M. (2010). A Review of Innovation Research in Tourism. Tourism Management, 31: 1-12.

Jedlińska M. (2006). Wejście międzynarodowych systemów hotelowych na rynek polski a modyfikacja oczekiwań gości hotelowych. [W:] A. Rapacz (red.), Gospodarka turystyczna w regionie. Przedsiębiorstwo, samorząd, współpraca. Wyd. Wyższej Szkoły Zarządzania, Jelenia Góra.

Kachniewska M. Innowacyjne modele biznesu jako strategia przetrwania niezależnych obiektów hotelowych w warunkach polaryzacji rynku turystycznego.

Kim E., Nam D.I., Stimpert J.L. (2004). The Applicability of Porter's Generic Strategies in the Digital Age, Assumptions, Conjectures and Suggestions. Journal of Management, $30,5$.

Kisielnicki J. (2002). Systemy informatyczne jako narzędzie dla zarządzania wiedzą - efekty i bariery. Inżynieria Maszyn, R. 7, 2: 29-33.

Kuczamer-Kłopatowska S., Piekarska K. (2018). Realizacja funkcji influencer marketing w opinii influencerów i ich followersów. Zarządzanie i Finanse, Journal of Management and Finance, 16, $3 / 3$.

Kurleto M. (2013). Wpływ nowych technologii na zarządzanie przedsiębiorstwem turystycznym. Zarządzanie Publiczne, 1(21): 91-102.

Niezgoda A., Markiewicz E. (2015). Uniwersytet Ekonomiczny w Poznaniu. Zmiany w zachowaniu konsumentów na rynku turystycznym w erze społeczeństwa twórczego. Zeszyty Uniwersytetu Szczecińskiego, 865, Problemy Zarządzania, Finansów i Marketingu, 38.

Nowacki R. (2009). Rozwój usług marketingowych w Polsce a ich jakość. Handel Wewnętrzny, 2: 18.

Paraskevas A., Buhalis D. (2002). Information Communication Technologies Decisionmaking: The ASP Outsourcing Model from the Small Hotel Owner/Manager Perspective. The Cornell Hotel Restaurant Administration Quarterly, 43, 2: 27-39.

Paraskevas A., Buhalis D. (2002). Information Communication Technologies Decisionmaking: The ASP Outsourcing Mediarun, Smartfon coraz ważniejszy dla handlu. Co z pozostałymi kanałami? (www.mediarun.com/pl/digital/smartfon-coraz-wazniejszy-dla-handlu-pozostalymi-kanalami.html; dostęp: 15.01.2021).

Sigala M. (2018). New technologies in tourism: from multi-disciplinary to anti-disciplinary advances and trajectories. Tourism Management Perspectives, 25: 151-155.

Szewczuk W. (1985). Słownik psychologiczny. Wiedza Powszechna, Warszawa, s. 327.

Wagen L. van der, Goonetilleke A. (2008). Hospitality Management: Strategy and Operations. Wyd. 2. Pearson Education, Australia

Wyrwisz J. (2019). Influencer marketing w komunikacji marketingowej marki. W: M. Cisek (red.), Innowacje i cyfryzacja gospodarki. Wydawnictwo Naukowe Uniwersytetu Przyrodniczo-Humanistycznego, Siedlce, s. 79-88. 


\section{The use of new technologies as an element of contemporary marketing of an independent hotel}

The use of new technologies has become an integral part of the world around us in every area of life. This trend has reached the level of hotel facilities, where modern marketing as a basic tool for attracting customers is permanently linked with the use of new solutions in building competitive advantage. Research to date has been based on the assessment and analysis of the demand side of the use of new technologies in the tourism industry, with a special focus on hotel facilities. The aim of the paper is to determine the use of new technologies as an element of modern marketing of independent hotels on the example of selected hotels in the Małopolska province. The initial research was based on interviews with hotel managers, using the case study analysis method. The results of the research confirmed that mobile devices and social media have become the main marketing channels of the studied hotels. 

Patrycja Żychoń, Michat Piwowarczyk

Uniwersytet Ekonomiczny w Katowicach

patrycja.zychon@edu.uekat.pl,michal.piwowarczyk@edu.uekat.pl

\section{Aktywność wybranych obiektów szlaku zabytków techniki w mediach społecznościowych w czasie pandemii COVID-19}

\section{Streszczenie}

Celem pracy jest zidentyfikowanie różnic w aktywności obiektów Szlaku Zabytków Techniki w mediach społecznościowych w czasie pandemii. Analizie poddano media społecznościowe wybranych obiektów ze szlaku, zgrupowane według 3 kategorii: browar, kopalnia oraz muzeum. Analiza wykazała, że obiekty ze sobą współpracowały, przeprowadzały dużo akcji promujących swoje ekspozycje oraz wychodziły $z$ aktywizującymi inicjatywami. Podstawę badań stanowiła krytyczna analiza literatury przedmiotu oraz studium przypadku - Szlaku Zabytków Techniki.

\section{Wprowadzenie}

Pandemia COVID-19, która zaczęła się na przełomie lat 2019 i 2020, wywołuje negatywne konsekwencje dla wielu branż. W wyniku wprowadzanych obostrzeń m.in. placówki kulturalne i turystyczne zostają zamknięte, co skutkuje ograniczeniem ich działalności, w niektórych okresach w zasadzie tylko do sfery wirtualnej. Narzędzia online, w tym media społecznościowe, stają się głównym miejscem, w którym odbiorca ma możliwość poznania walorów kulturowych, a wzbudzone w ten sposób zainteresowanie może przełożyć się na odwiedzenie danej atrakcji, gdy będzie to już możliwe.

Celem pracy jest zidentyfikowanie różnic w aktywności zarządcy Szlaku Zabytków Techniki i wybranych obiektów znajdujących się na nim w mediach 
społecznościowych $\mathrm{w}$ okresie przymusowego zamknięcia obiektów, spowodowanego pandemią COVID-19 w roku 2020. Autorzy założyli, że taka aktywność może w przyszłości przełożyć się na zwiększony ruch turystyczny, po zniesieniu obostrzeń. Przynależność do sieciowego produktu turystycznego, jakim jest szlak, daje w tych okolicznościach pewne szanse wynikające z możliwości współpracy i realizacji wspólnych przedsięwzięć promocyjnych. Jednocześnie region, w którym znajduje się szlak - województwo śląskie - szczególnie w pierwszej połowie 2020 r. zmagał się z negatywnym wizerunkiem wynikającym z dużej liczby zakażeń w kopalniach, które mogły wpływać negatywnie na postrzeganie kopalń udostępnionych do zwiedzania turystom. A takie są częścią Szlaku Zabytków Techniki.

Autorzy scharakteryzowali działania promocyjne podjęte przez zarządcę szlaku w obliczu pandemii, jak również przeanalizowali działania wybranych obiektów według trzech kategorii: browar, kopalnia, muzeum. Badania przeprowadzono w oparciu o aktywność tych obiektów na Facebooku oraz kwerendę literatury i stron internetowych.

\section{Istota Szlaku Zabytków Techniki w dobie pandemii COVID-19}

Produkt turystyczny - szlak kulturowy - obejmuje zestawienie różnorodnych atrakcji kulturowych oraz powiązanych z nimi usług i innych produktów turystycznych $w$ celu korzystania $z$ nich podczas pobytu turysty na szlaku. Do jego cech należą: określona przestrzeń z wyznaczonymi obiektami, złożoność produktów, multiwytwarzalność, która oznacza wiele podmiotów biorących udział w procesie świadczenia usług, oraz synergiczność (Stasiak, 2006).

$\mathrm{Z}$ przedstawionych cech wynika, że produkt turystyczny - szlak - może być także produktem sieciowym. Produkt sieciowy skupia w sobie zarówno elementy materialne, jak i niematerialne, należące do sieci podmiotów, których głównym celem jest odpowiedź na wiele zróżnicowanych potrzeb turystów, charakteryzuje się pewną nadrzędną ideą (marka) oraz danym przedstawicielem tej sieci (Maciąg, 2015).

Sieciowość produktu turystycznego daje wiele wymiernych korzyści. Należą do nich m.in.: elastyczniejsze dopasowanie się do zmieniających się warunków, promocja całego produktu sieciowego oraz poszczególnych obiektów, wzajemna pomoc i współpraca (Balińska, 2017).

Przykładem takiego produktu jest znajdujący się w województwie śląskim Szlak Zabytków Techniki (SZT). Jest to szlak samochodowy, obejmujący 41 obiektów. To industrialna trasa pozwalająca na poznanie przemysłu obejmującego m.in.: górnictwo, kolejnictwo czy hutnictwo. Szlak zawiera m.in.: różnego rodzaju muzea, kopalnie, osiedla, wieże, co świadczy o jego dużej różnorodności. Obiekty można zwiedzać wewnątrz lub tylko z zewnątrz, jak np. osiedla. Gospodarzem szlaku jest Muzeum Górnictwa Węglowego w Zabrzu. SZT posiada 
unikatowe zabytki industrialne, które należą do Gwiazd Techniki. Zostały one wyróżnione ze względu na prezentowane walory kulturowe oraz kompleksową ofertę turystyczną (www.zabytkitechniki.pl).

W Polsce od 12 marca zaczął obowiązywać stan zagrożenia epidemiologicznego. W krótkim czasie nastąpiło zamrożenie gospodarki (tzw. lockdown), w tym również placówek oświatowych i turystycznych. Edukacja i inne sfery życia zaczęły funkcjonować przy wykorzystaniu narzędzi online (www.wiadomosci.onet.pl).

W tym momencie można wyrazić opinię, że o ile przy pierwszym zamknięciu zarządcy obiektów mogli być zaskoczeni nagłą sytuacją, to za drugim razem powinni się lepiej przygotować i można było oczekiwać większej aktywności w mediach społecznościowych.

Epidemia COVID-19 przyniosła negatywne konsekwencje także dla województwa śląskiego, w którym znajduje się analizowany SZT. W województwie tym od maja do sierpnia odnotowywano jedne $z$ najwyższych wartości zachorowań na tle kraju. Głównymi ogniskami wirusa stały się śląskie kopalnie. Ze względu na występowanie ognisk wirusa w kopalniach, obiekty SZT znalazły się w niekorzystnej sytuacji. Na SZT znajdują się nieczynne kopanie, które obecnie pełnią rolę muzeów. Ze względu na wysoki przyrost zachorowań i występowanie ognisk właśnie w kopalniach wizerunek tych obiektów uległ pogorszeniu, co przełożyło się na zmniejszenie frekwencji pomiędzy dwoma okresami zamknięcia (www.portal.abczdrowie.pl).

W związku z tym odpowiednia komunikacja marketingowa była szczególnie ważna. Komunikacja marketingowa, w tym promocja obiektów kulturalnych, polega przede wszystkim na dialogu z otoczeniem. Do jej celów należą: informowanie turystów o atrakcjach kulturowych i ich walorach, zachęcanie do skorzystania $z$ tych atrakcji oraz budowanie więzi z miejscem (Kasperska, 2013).

Promocja obiektów kulturalnych i turystycznych w mediach społecznościowych $\mathrm{w}$ dobie pandemii nie została jeszcze wyczerpująco przeanalizowana $\mathrm{w}$ literaturze. Jedna z pierwszych publikacji wykazała, że: obiekty kulturalne mogą organizować wystawy wirtualne, które poprzedzają promujące posty, publikować filmiki przedstawiające zgromadzone zbiory, organizować konferencje i różnego rodzaju spotkania online (rodzaj public relations), podejmować działania aktywizujące i budujące wizerunek obiektu w mediach, np. urządzać konkursy online. Łącznikiem tych wymienionych wyżej przykładów jest zmobilizowanie odbiorcy do odwiedzenia obiektu po zniesieniu restrykcji. Ponadto obiekty w celu podtrzymania komunikacji marketingowej częściej powinny zamieszczać posty (Kłusek, 2020).

\section{Działania podjęte przez zarządcę szlaku}

Zarządca przeprowadzał różnego rodzaju działania, które były odpowiedzią na zaistniałą sytuację pandemiczną oraz spadek frekwencji w obiektach kopalnianych $\mathrm{w}$ roku 2020. W okresie zamknięcia, czyli wtedy kiedy turysta nie mógł fizycznie zwiedzać obiektu, zarządca organizował różnego rodzaju wydarzenia 
online, natomiast $\mathrm{w}$ okresie otwarcia starał się zachęcić do fizycznego odwiedzenia szlaku poprzez różnego rodzaju wydarzenia organizowane na szlaku. Do głównych działań podjętych przez zarządcę można zaliczyć następujące przedsięwzięcia: „Wybieram Śląskie”, konkurs fotograficzny „Rozumiem Sląskie”, kampanię „Technika. To Was zaskoczy” oraz „Industriadę”.

Kampania „Wybieram Śląskie”, przeprowadzona w lipcu, polegała na zachęcaniu przez znane osoby do odpoczynku w województwie śląskim, pełnym różnych możliwości turystycznych, bogatej kultury i przyrody. Zarządca SZT był partnerem kampanii (www.zabytkitechniki.pl).

Konkurs fotograficzny „Rozumiem Śląskie”, który trwał do końca 2020 r., polegał na umieszczaniu zdjęć na Instagramie związanych z własną interpretacją obiektów szlaku. Miały one wykazać autorskie podejście do walorów regionu poprzez prezentacje fotografii poszczególnych obiektów (www.zabytkitechniki.pl).

Kolejna kampania „Technika. To Was zaskoczy” zaprasza do eksplorowania mniej znanych miejsc SZT. Polega ona na publikowaniu na profilu szlaku na Facebooku oraz na YouTube filmów przedstawiających ciekawostki na temat obiektów. Ambasadorem kampanii jest Tomasz Rożek z kanału na YouTube „Nauka. To Lubię" (www.zabytkitechniki.pl).

„Industriada” to święto szlaku. Corocznej imprezie towarzyszy wiele wydarzeń organizowanych w obiektach. Pierwotnie impreza miała się odbyć w czerwcu, jednakże ze względu na sytuację epidemiologiczną święto zostało przeniesione na 26 września. Turyści z całego kraju w określonym reżimie sanitarnym mogli uczestniczyć $\mathrm{w}$ wielu pokazach związanych $\mathrm{z}$ pracą maszyn górniczych, poznać dawne życie w zakładach przemysłowych i kulturę industrialną (www.industriada.pl).

Z przytoczonych działań na poziomie całego SZT można wywnioskować, że zarządca poprzez różnorodność promocyjnych, aktywizujących wydarzeń starał się zachęcić turystów do pogłębiania wiedzy o zgromadzonych obiektach na szlaku oraz odkrywać nowe, mniej poznane miejsca, do których w rzeczywistości turyści rzadko zaglądają. Ponadto ważnym aspektem jest utrwalanie w świadomości turystów przy użyciu narzędzi online walorów kulturowych szlaku oraz korzyści wynikających z odwiedzin, by po zniesieniu restrykcji fizycznie odwiedzili Szlak Zabytków Techniki.

\section{Metodyka badań}

Kwerenda piśmiennictwa związana ze zdefiniowaniem produktu turystycznego - szlaku - i produktu sieciowego pomogła $\mathrm{w}$ zrozumieniu istoty funkcjonowania Szlaku Zabytków Techniki i zarządzania nim. Przedstawienie wpływu pandemii na województwo śląskie pokazuje, $z$ jak trudnym zadaniem, polegającym na zwalczaniu niekorzystnego wizerunku oraz zachęcaniu do odwiedzin szlaku, przyszło zmagać się zarządcom poszczególnych obiektów.

Zakres podmiotowy stanowią celowo wybrane obiekty, których ekspozycję turysta zwiedza wewnątrz, reprezentujące 3 kategorie: browary, kopalnia, muzea. Przedstawione grupy oddają charakter grup obiektów ze szlaku. Autorzy dokonali 
takiej kategoryzacji ze względu na różnorodność obiektów SZT oraz na ich sytuację $\mathrm{w}$ czasie pandemii. $\mathrm{Z}$ powodu wprowadzonych obostrzeń obiekty z ekspozycją urządzoną wewnątrz, zostały nimi najbardziej dotknięte. Funkcjonowanie tych obiektów było uzależnione od rozwoju pandemii.

Browary analizowane w pracy to Tyskie Browary Książęce, Browar Obywatelski w Tychach oraz Browar Zamkowy w Cieszynie. Są to podmioty prywatne. Tyskie Browary Książęce to Gwiazda Techniki. Z uwagi na specyfikę miejsca aktywność w mediach społecznościowych mogła być ograniczona, ponieważ osoby poniżej 18 roku życia nie mogą spożywać piwa, co przekłada się na mniejszą grupę odbiorców.

Kopalnie poddane analizie to Kopalnia Guido w Zabrzu, Kopalnia Srebra w Tarnowskich Górach i Sztygarka w Dąbrowie Górniczej. Ekspozycje zwiedzane w tych kopalniach znajdują się pod ziemią oraz prezentują, jak kiedyś wyglądała praca górnika. Kopalnia Guido w Zabrzu oraz Kopalnia Srebra w Tarnowskich Górach znajdują się na liście Gwiazd Techniki. Te 3 kopalnie należą do sektora publicznego.

Muzea wybrane przez autorów to Muzeum Śląskie, Stara Fabryka w Bielsku, Muzeum Hutnictwa Cynku w Katowicach „Walcownia” oraz Muzeum Chleba, Szkoły i Ciekawostek w Radzionkowie. Muzeum Śląskie i Stara Fabryka w Bielsku to podmioty publiczne, natomiast pozostałe należą do sektora prywatnego. W obiektach tych pokazano na ekspozycjach dawne życie na śląsku, sztukę i kulturę industrialną oraz pracę w fabryce.

Zakres przedmiotowy badań dotyczy profili (publikowanych postów) tych obiektów w mediach społecznościowych, konkretnie na Facebooku. Facebook umożliwia wzajemną komunikację, dzielenie się treścią z innymi użytkownikami, obserwowanie aktywności innych użytkowników oraz interakcje. Do grupy postów zaklasyfikowano wszystko to, co można zobaczyć na oficjalnym profilu na Facebooku obiektu. Posty analizowano pod kątem zawartości, przyjęto następujący klucz kategoryzacyjny:

1. Informacje na temat ekspozycji - informacje o posiadanej ekspozycji, prezentowanie jej walorów kulturowych, zdjęć itp.

2. Informacje organizacyjne - dotyczące zamknięcia obiektu, wymogów sanitarnych itp.

3. Informacje odnoszące się do promocji wytwarzanych produktów - prezentacje produktu na sprzedaż, opis produktu i jego oferty oraz ceny.

4. Organizowanie różnego rodzaju działalności online, np. webinariów.

5. Udostępnianie aktywności online innych podmiotów o tematyce zbliżonej do tej, którą zajmuje się obiekt.

6. Udostępnianie aktywności ze strony/profilu Szlaku Zabytków Techniki.

7. Społeczna odpowiedzialność przedsiębiorstw - promocja akcji na rzecz pomocy innym, np. szycie maseczek.

8. Inne.

Zakres czasowy badań obejmuje daty: 11 marca-4 maja 2020 r. oraz 7 listopada-15 grudnia 2020 r. Są to daty związane z pełnym zamknięciem obiektów, które obsługują m.in. ruch turystyczny. Daty kończące największe obostrzenia 
umożliwiały ponowne funkcjonowanie placówek turystycznych, jednak to, czy dana placówka wznowi tradycyjne funkcjonowanie i kiedy to nastąpi, było zależne od samych zarządców.

\section{Wyniki badań}

Autorzy przeprowadzili analizy postów publikowanych na Facebooku w dwóch okresach zamknięcia. Poniżej zamieszczono trzy tabele przedstawiające dokonaną analizę. Numery kolumn odpowiadają opisowi klucza kategoryzacyjnego w metodyce badań.

Pierwszą analizowaną grupę stanowiły browary. Wyniki analiz zestawiono w tabeli 1.

Tabela 1. Analiza aktywności na Facebooku obiektów browarnianych

\begin{tabular}{lccccccccc}
\hline \multicolumn{1}{c}{ Obiekt } & Okres & 1. & 2. & 3. & 4. & 5. & 6. & 7. & 8. \\
\hline Browar Obywatelski Tychy & $11.03-4.05$ & 0 & 5 & 9 & 1 & 0 & 0 & 1 & 0 \\
& $7.11-15.12$ & 0 & 0 & 1 & 0 & 1 & 0 & 0 & 0 \\
Browar Zamkowy Cieszyn & $11.03-4.05$ & 0 & 3 & 8 & 2 & 0 & 0 & 3 & 2 \\
& $7.11-15.12$ & 0 & 2 & 7 & 1 & 2 & 0 & 0 & 0 \\
Muzeum Tyskie Browary & $11.03-4.05$ & 2 & 1 & 1 & 0 & 0 & 0 & 0 & 0 \\
Książęce & $7.11-15.12$ & 1 & 0 & 0 & 0 & 0 & 0 & 0 & 0 \\
\hline
\end{tabular}

Źródło: opracowanie własne na podstawie stron internetowych obiektów na Facebooku.

W kategorii browary można wywnioskować, że aktywność opiera się głównie na promocji produktów i usług oferowanych przez nie oraz informacji dotyczącej działalności obiektu. Wyraźnie można zauważyć, że aktywność w pierwszym okresie zamknięcia jest większa niż w drugim. W Browarze Obywatelskim Tychy aktywność w pierwszym okresie zamknięcia na profilu przejawia się głównie poprzez promocję oferty (usługi i produkty oferowane na miejscu lub na wynos, przez stronę internetowa) oraz informacje odnoszące się do działalności obiektu. W drugim okresie aktywność prawie zanikła. Browar Zamkowy Cieszyn w obu okresach aktywnie promował swoje wyroby. W pierwszym udostępniał posty z przekazania szpitalom zgrzewek napoi, w drugim uprawiał aktywność online. Umożliwiał też wirtualne zwiedzanie browaru oraz urządzał we współpracy webinaria i promocje swoich produktów. Jakość postów jest wysoka i odznacza się dużą estetyką, w szczególności materiały w postach promujących sprzedawane napoje. W Muzeum Tyskie Browary Książęce analiza wykazywała w obu okresach minimalną aktywność, głównie informacyjną, dotyczącą ekspozycji, oraz promocyjną.

Drugą analizowaną grupę stanowiły kopalnie. Wyniki analiz przedstawiono w tabeli 2.

Obiekty wykazywały się różnorodną aktywnością, jednak w okresie od 7 listopada aktywność spadła. Charakterystyczne jest, że obiekty przejawiały aktywność 
Tabela 2. Analiza aktywności na Facebooku obiektów kopalnianych

\begin{tabular}{lcrrrrrrrr}
\hline \multicolumn{1}{c}{ Obiekt } & Okres & 1. & 2. & 3. & 4. & 5. & 6. & 7. & 8. \\
\hline Kopalnia Guido & $11.03-4.05$ & 0 & 5 & 1 & 14 & 0 & 0 & 10 & 2 \\
& $7.11-15.12$ & 3 & 0 & 6 & 16 & 7 & 1 & 0 & 2 \\
Zabytkowa Kopalnia Srebra & $11.03-4.05$ & 4 & 3 & 7 & 13 & 1 & 0 & 1 & 4 \\
Tarnowskie Góry & $7.11-15.12$ & 2 & 1 & 3 & 1 & 1 & 0 & 0 & 0 \\
Muzeum Sztygarka & $11.03-4.05$ & 6 & 3 & 2 & 13 & 41 & 0 & 0 & 52 \\
& $7.11-15.12$ & 46 & 6 & 11 & 20 & 28 & 0 & 1 & 23 \\
\hline
\end{tabular}

Źródło: opracowanie własne na podstawie stron internetowych obiektów na Facebooku.

online, poprzez webinaria, reprodukcję filmów, zabaw interaktywnych, quizów i zadań mających na celu zaangażowanie obserwujących. Kopalnia Guido cechowała się podobną aktywnością zarówno w pierwszym, jak i drugim okresie zamknięcia. Zorganizowała serię filmów tematycznych. W pierwszym okresie ponadto upowszechniała posty dotyczące szycia maseczek przez pracowników muzeum. Jako jedyny obiekt udostępniała aktywności profilu Szlaku Zabytków Techniki. Kopalnia Srebra Tarnowskie Góry wykazywała głównie aktywność online, taką jak webinaria, konkursy itp. W drugim okresie widoczna była zmniejszona aktywność online. Profil Muzeum Sztygarka był prowadzony bardzo aktywnie, lecz niespójnie - treść stanowią posty o różnorodnej tematyce, często niezwiązanej z działalnością muzeum, stąd duża liczba postów w kategorii inne. W obu badanych okresach występuje różnica w jakości treści. Na uwagę zasługuje duża liczba postów dotycząca ekspozycji muzealnej dobrana do okoliczności czasowych oraz produkcja filmów edukacyjnych.

Trzecią analizowaną grupą były muzea. Wyniki analiz przedstawiono w tabeli 3.

Tabela 3. Analiza aktywności na Facebooku obiektów muzealnych

\begin{tabular}{lcrrrrrrrr}
\hline \multicolumn{1}{c}{ Obiekt } & Okres & 1. & 2. & 3. & 4. & 5. & 6. & 7. & 8. \\
\hline Muzeum Śląskie & $11.03-4.05$ & 31 & 1 & 3 & 8 & 1 & 0 & 1 & 1 \\
& $7.11-15.12$ & 29 & 1 & 9 & 34 & 6 & 0 & 0 & 3 \\
Stara Fabryka Bielsko-Biała & $11.03-4.05$ & 1 & 0 & 0 & 0 & 0 & 0 & 0 & 0 \\
& $7.11-15.12$ & 2 & 0 & 1 & 0 & 0 & 0 & 0 & 0 \\
Walcownia & $11.03-4.05$ & 34 & 1 & 2 & 9 & 4 & 0 & 2 & 8 \\
Muzeum Chleba & $7.11-15.12$ & 14 & 2 & 3 & 6 & 3 & 1 & 0 & 3 \\
W Radzionkowie & $11.03-4.05$ & 7 & 2 & 0 & 1 & 1 & 0 & 1 & 3 \\
& $7.11-15.12$ & 0 & 0 & 0 & 0 & 1 & 0 & 0 & 1 \\
\hline
\end{tabular}

Źródło: opracowanie własne na podstawie stron internetowych obiektów na Facebooku.

Obiekty muzealne w badanych okresach największą aktywność skupiły na prezentowaniu ekspozycji, np. zdjęć, obrazów, ciekawostek o maszynach przemysłowych, oraz na przeprowadzaniu różnego rodzaju działań online. Pierwszy okres zamknięcia badanych obiektów został wykorzystany głównie na prezentację 
zbiorów muzealnych, natomiast $\mathrm{w}$ drugim okresie można zaobserwować ich spadek. Obiekty te chętnie udostępniają wydarzenia online innych podmiotów oraz promują własne wyroby i gadżety ze swoich sklepów. Największą aktywność zaobserwowano w Muzeum Śląskim. Potwierdza to rangę obiektu, który świadczy kompleksową ofertę dostosowaną do każdej grupy odbiorców. Najmniejszą aktywność odnotowano w Starej Fabryce Bielsko-Biała. Muzeum Walcownia publikowało najwięcej postów związanych z ekspozycją w pierwszym okresie zamknięcia. Natomiast Muzeum Chleba w Radzionkowie tylko w pierwszym badanym okresie wykazywało aktywność.

\section{Zakończenie}

Z aktywności podmiotów na portalu społecznościowym Facebook można wyciągnąć kilka wniosków.

Po pierwsze, aktywność obiektów była wyraźnie większa w pierwszym okresie lockdownu i była ona próbą ratowania działalności zagrożonej nową, dynamicznie rozwijającą się sytuacją. W drugim, jesiennym okresię, widoczny jest spadek lub prawie całkowity zanik aktywności. Może on wynikać z przyzwyczajenia się do sytuacji, większych ograniczeń państwowych bądź większego doświadczenia w zarządzaniu obiektami w niesprzyjających warunkach. Obiekty w czasie pierwszego lockdownu zdobyły pewne doświadczenie, które pomogło im podjąć decyzję co do dalszej aktywności na Facebooku, przez co jedne ograniczyły, nawet znacząco, udostępnianie treści, a inne je rozwinęły. Największą aktywność można zauważyć w obiektach z sektora publicznego.

Kolejny wniosek nasuwający się na podstawie analizy obiektów ze szlaku jest taki, że jakość postów w miarę rozwoju kryzysu nie zmieniła się znacząco. Wiele obiektów, jak w przypadku Muzeum Sztygarka w Dąbrowie Górniczej, nie prowadzi polityki promocyjnej w social mediach, przez co treści udostępniane na portalach są słabej jakości, nie wyróżniają się w szumie medialnym i nie wywołują przez to pożądanych efektów. Analizowane obiekty udostępniały posty o różnorodnej tematyce, często posiłkując się aktywnością innych podmiotów, co świadczy o pewnym rozeznaniu co do możliwości social mediów oraz chęci współpracy poprzez zgrupowanie w sieci podmiotów na SZT.

Trudno jest wskazać, która $z$ trzech badanych kategorii obiektów poradziła sobie najlepiej. $Z$ tego wynika, że rodzaj obiektu nie miał większego znaczenia w przypadku aktywności na Facebooku. Przedstawione wnioski w pracy warto byłoby skonfrontować $z$ wypowiedziami przedstawicieli obiektów, co może stanowić dalszy kierunek badań.

Powyższa analiza pokazuje jedynie efekt wprowadzenia obostrzeń spowodowanych pandemią COVID-19 na aktywność wybranych obiektów ze Szlaku Zabytków Techniki w mediach społecznościowych. W czasie opracowania tego rozdziału epidemia koronawirusa i związane $z$ tym obostrzenia społeczno-gospodarcze nadal trwały, przez co analiza jest ograniczona i prowadzona „na gorąco”. Efekty aktywności badanych obiektów na Facebooku będą widoczne prawdopodobnie za 
kilka miesięcy, kiedy w okresie letnim przewidywane jest powolne odchodzenie od ograniczeń i przywracanie porządku gospodarczego po okresie pandemicznym. Wtedy będzie można ocenić wpływ aktywności na Facebooku na popularność obiektu i, co za tym idzie, liczbę odwiedzających oraz wpływy z biletów. Może to stanowić przedmiot dalszych badań. Jednakże, aby dobrze wykorzystać swoje możliwości, zarządcy obiektów powinni cały czas być aktywni w mediach społecznościowych oraz organizować różnego rodzaju inicjatywy online.

\section{Literatura}

Balińska A. (2017). Sieciowe produkty turystyczne jako przykład przedsiębiorczości na obszarach wiejskich. Turystyka i Rozwój Regionalny, 8: 5-14.

Browar Obywatelski Tychy (https://pl-pl.facebook.com/BrowarObywatelskiTychy/; dostęp: 12.12.2020).

Browar Zamkowy Cieszyn (https://www.facebook.com/BrowarCieszyn/; dostęp: 12.12.2020).

Industriada (http://industriada.pl/; dostęp: 10.12.2020).

Kasperska E. (2013). Promocja instytucji kultury na przykładzie muzeów etnograficznych na wolnym powietrzu. Zeszyty Naukowe Uniwersytetu Szczecińskiego, 30: 59-74.

Kłusek B. (2020). Funkcjonowanie Muzeum Niepodległości online w okresie lockdownu instytucji kultury. Niepodległość i Pamięć, 3(71): 131-150.

Kopalnia Guido (https://pl-pl.facebook.com/kopalniaguido; dostęp: 11.12.2020).

Kopalnia Srebra Tarnowskie Góry (https://pl-pl.facebook.com/ZabytkowaKopalniaSrebra; dostęp: 12.12.2020).

Maciąg J. (2015). Jakość sieciowego produktu turystycznego - definiowanie, wymiary i cechy jakości. Studia Ekonomiczne, Zeszyty Naukowe Uniwersytetu Ekonomicznego w Katowicach, 215: 40-56.

Muzeum Chleba w Radzionkowie (https://www.facebook.com/MuzeumChleba; dostęp: 10.12.2020).

Muzeum Sztygarka (https://pl-pl.facebook.com/pages/category/History-Museum/Muzeum-Miejskie-Sztygarka-Mms-298462153698416; dostęp: 14.12.2020).

Muzeum Śląskie (https://www.facebook.com/muzeumslaskie; dostęp: 12.12.2020).

Muzeum Tyskie Browary Książęce (https://www.facebook.com/browarytyskie; dostęp: 11.12.2020).

Polska Organizacja Turystyczna (www.pot.gov.pl; dostęp: 5.12.2020).

Portal ABCZdrowie (www.portal.abczdrowie.pl; dostęp: 10.12.2020).

Stara Fabryka Bielsko-Biała (https://www.facebook.com/pages/Stara\%20Fabryka\%20 Bielsko-Biala/1642975679338452; dostęp: 15.12.2020).

Stasiak A. (2006). Produkt turystyczny - szlak. Turystyka i Hotelarstwo, 10: 9-40.

Walcownia (https://www.facebook.com/walcownia; dostęp: 14.12.2020).

Wiadomości Onet (https://wiadomosci.onet.pl/kraj/koronawirus-jak-rozwijala-sieepidemia-w-polsce-i-na-swiecie-kalendarium/xgt8wcd; dostęp: 10.12.2020).

Zabytki Techniki (https://www.zabytkitechniki.pl/news/1019153/rusza-kampania-wybieram-slaskie-slaskie-smaki; dostęp: 5.12.2020).

Zabytki Techniki (https://www.zabytkitechniki.pl/news/1019743/uwaga-mamy-dla-was-konkurs; dostęp: 5.12.2020). 
Zabytki Techniki (https://www.zabytkitechniki.pl/news/1020020/technika-to-was-zaskoczy; dostęp: 10.12.2020).

Zabytki Techniki (www.zabytkitechniki.pl; dostęp: 15.12.2020).

\section{Activity of selected objects of the industrial monuments trail in the social media during COVID-19 pandemic}

The main aim is to compare the activity of the Industrial Monuments Trail in the social media during the COVID-19 pandemic. The social media of selected objects from the Trail were analyzed, grouped according to 3 categories: brewery, mine and museum. The analysis showed that the objects cooperated with each other, carried out a lot of campaigns to promote their exhibitions. The research was based on a critical analysis of the literature on the subject and the case study - Industrial Monuments Route.

Translated by Patrycja Żychoń 
Część 3.

Funkcjonowanie wybranych aspektów podaży turystycznej 

Natalia Siwik

Uniwersytet Ekonomiczny w Krakowie

natka.siwik@gmail.com

\section{Zarządzanie ryzykiem i zarządzanie kryzysowe w kontekście upadku legendarnego biura podróży Thomas Cook}

\section{Streszczenie}

Upadek najstarszego biura podróży Thomas Cook rozszedł się szerokim echem na całym świecie. Chociaż od tego wydarzenia minął rok, kwestia ta wciąż wydaje się aktualna, a przyczyny upadku firmy dalej są dyskutowane. Obok czynników finansowych, pogodowych i społecznych wymienia się brak przygotowania biura i niewłaściwe zarządzanie. Celem rozdziału jest przybliżenie błędów firmy Thomas Cook oraz podkreślenie ważności relacji, więzi, zarządzania kryzysowego i zarządzania ryzykiem. W pracy wykorzystano kwerendę literatury oraz analizę netograficzną, a wyniki badań wskazały na bezpośredni powód upadku biura, czyli jego stagnację i powierzchowne więzi bez zabezpieczenia w zarządzaniu. W ramach wniosków podkreślono ważne składowe postępowania w zarządzaniu i relacjach biura podróży, co może się okazać podstawą przyszłych badań.

\section{Wprowadzenie}

Zarządzanie kryzysowe oraz zarządzanie ryzykiem to bardzo szerokie pojęcia, wiążące się z wieloma dziedzinami. Od 2000 r. wciąż pojawiają się kolejne prace opisujące powyższe zagadnienia. Ich liczba zależna jest głównie od obecnej sytuacji (chociażby gospodarczej), czego dowodem jest mnogość wyników dla frazy „zarządzanie ryzykiem” w Google Scholar. Chociaż oba zagadnienia są zauważane i ciągle badane, wiele przedsiębiorstw wciąż bagatelizuje znaczenie wcześniejszego przygotowania na sytuacje kryzysowe oraz odczytywania sygnałów alarmowych płynących z otoczenia, czego przykładem jest upadłe biuro podróży Thomas Cook. Nadal brakuje oficjalnych opisów powyższego procesu oraz publikacji 
badaczy, jednakże można zauważyć pewne luki i poważne zaniedbania w zarządzaniu kryzysowym i zarządzaniu ryzykiem (przyczyny upadku firmy Thomas Cook wynikają bezpośrednio $z$ wadliwego zarządzania). Żeby jednak dobrze to zrozumieć, $\mathrm{w}$ pierwszej części zdefiniowano powyższe pojęcia w oparciu o każde przedsiębiorstwo, a dopiero $\mathrm{w}$ drugiej postawiono pytanie, czy błędne zarządzanie tym biurem podróży faktycznie miało wpływ na jego upadek.

\section{Przegląd literatury}

\section{Ogólne pojęcie zarządzania kryzysowego i zarządzania ryzykiem}

Zarządzanie kryzysowe i zarządzanie ryzykiem, chociaż mają ze sobą wiele wspólnego, są odrębnymi zagadnieniami. Pierwsze powiązane jest ze słowem „kryzys”, a ten według „Encyklopedii zarządzania” jest jedną z czterech faz cyklu koniunkturalnego, który obrazuje krzywą wahań w gospodarce. Jego przyczyn można szukać zarówno poza systemem gospodarczym (w wojnach lub odkryciach geograficznych), jak i zakładając, że każdy rozkwit owocuje załamaniem i odwrotnie (Urbanik i Dudkiewicz). W znaczeniu ogólnym kryzys jest okresem przesilenia, przełomu. Zarządzanie kryzysem z kolei jest radzeniem sobie z nim w ramach przepisów prawnych. Oprócz zasad, źródeł i zakresów wyróżnione zostały cztery fazy cyklu zarządzania kryzysowego (Wróblewski, 2014). Pierwszą jest zapobieganie jeszcze przed wystąpieniem wydarzenia, co wiąże się z redukcją ryzyka. Jako drugą fazę wyróżniono przygotowanie się, którego owocem są plany reagowania kryzysowego. Kolejno wymieniono reagowanie po wystąieniu zagrożenia, do którego potrzebne jest jednak jego wcześniejsze wykrycie, oraz odbudowę, czyli przywrócenie stanu sprzed kryzysu, co wiąże się ściśle z pojęciem organizacji uczącej się. Cały cykl powinny poprzedzać systemy wczesnego ostrzegania (SWO), bowiem służą one do identyfikacji wszelkich zakłóceń jeszcze przed wystąpieniem realnego zagrożenia. Jak podaje Stabryła (2018), SWO obserwowane są każdego dnia, chociażby w przyrodzie lub w wojsku. Powyższe fakty to jedynie podstawy bardzo złożonego zagadnienia, które wymaga doprecyzowania i bardziej szczegółowego określenia, czego regres dotyczy. Podobnie jest z definiowaniem ryzyka - na różne aspekty zwracają uwagę badacze kolejnych dziedzin, od ekonomii i prawa po przyrodę, hazard oraz gry. Najkrócej można je opisać jako prawdopodobieństwo wystąpienia strat będących efektami decyzji ekonomicznych (Czerwonka i in.), co wiąże się z upływem dłuższego czasu. W zarządzaniu nim powstała formuła, a dokładnie zbiór działań opisujących właściwe zachowanie $\mathrm{w}$ przypadku pojawienia się ryzyka, jednocześnie będące jego czterema podstawowymi funkcjami. Są to kolejno: identyfikacja (źródeł ryzyka, zdarzeń oraz sygnałów), pięcioetapowa analiza, projektowanie reakcji na ryzyko oraz monitorowanie go (Stabryła, 2018).

Z powyższego zestawienia obu zagadnień można zatem wysunąć tezę, że istnieją pewne podobieństwa między fazami cyklu zarządzania kryzysowego oraz zbiorem działań w zarządzaniu ryzykiem. Oba procesy są bardzo złożone 
i wieloaspektowe, jednocześnie wymagające od strony podażowej oraz biur podróży wysiłku, wcześniejszego przygotowania, prognozowania, czujności oraz wrażliwości na obecną sytuację. Obok zarządzania kryzysowego i zarządzania ryzykiem powinno się omówić jeszcze inne elementy, takie jak zarządzanie strategiczne, drzewo celów, hierarchia, wiedza, zaufanie, głębsze SWO, więzi i zależności oraz błędy w komunikacji. Jednakże są to kwestie bardzo szerokie, a wymienione definicje i narzędzia są wystarczające do omówienia błędów, jakie popełniło biuro podróży Thomas Cook w ostatnich latach swojej działalności.

\section{Metodyka badań}

Na firmie Thomas Cook, tak jak na każdym biurze podróży, spoczywa albo spoczywała zawsze duża odpowiedzialność i wiele zobowiązań. Kwestie te wymagają od przedsiębiorstw bardzo dobrej organizacji. Podobnie jest z zarządzaniem w kryzysie i zarządzaniem ryzykiem - oba zagadnienia powinny być w biurach wysoko rozwinięte, zwłaszcza że turystyka jest bardzo wrażliwa i narażona na wszelkie zmiany (chociażby pogody oraz chęci kupujących). Żeby jednak dobrze zobrazować znaczenie powyższych kwestii, autorka przeprowadziła przegląd artykułów, reportaży, wykresów oraz danych, którego wyniki mogą posłużyć do dalszych badań.

\section{Wyniki badań}

\section{Pierwszy kryzys biura podróży w okresie 2007-2012}

W kryzysie, jaki spotkał 178-letnie biuro podróży, potrzebne było dobre zarządzanie kryzysowe, a także wcześnie wszczęte zarządzanie ryzykiem i SWO. Na zagadnienia te w firmie Thomas Cook zwrócono uwagę, jednakże było już za późno na wdrażanie planu ratunkowego. Analizę powyższych procesów w tym biurze podróży należy zacząć od roku 2007, bowiem już wtedy powinny zostać dostrzeżone sygnały alarmowe otoczenia i podjęte konkretne działania (szczególnie że ryzyko rozpatrywane jest w długim okresie). Trudno powiedzieć, czy Thomas Cook brał pod uwagę fazy cyklu zarządzania kryzysowego oraz zarządzanie ryzykiem - prawdopodobnie już na zawsze pozostanie to sekretem przedsiębiorstwa. Przed 2007 r. biuro rozwijało się jednak prawidłowo - kontynuowało wspaniałą spuściznę, miało wielu lojalnych klientów i stale się przekształcało, chociażby z Thomas Cook \& Son na Thomas Cook AG w 2001 r. (Thomas Cook Group plc, 2007). Co więcej, firma sprzedawała swoje spółki oraz kupowała kolejne - do 2007 r. Thomas Cook AG posiadał biura o tej samej nazwie w wielu krajach Europy i w Chinach, Neckermanna w Polsce, w Czechach i na Węgrzech, Neckermanna Reisen w Austrii oraz Szwajcarii, a także linię lotniczą Condor (Thomas Cook Group plc, 2007). W tym też roku Thomas Cook AG połączył się z kolejnym globalnym zespołem, grupą MyTravel, zmieniając nazwę na Thomas 
Cook Group plc. Decyzja ta miała w przyszłości przynieść fatalne skutki, bowiem w skład grupy MyTravel wchodziły kolejne dwie linie lotnicze, skandynawskie biura podróży Ving, Tjæreborg i Spies oraz kanadyjskie ALBA Tours i Sunquest Vacations (Thomas Cook Group plc, 2007). Cała inicjatywa była bardzo kosztowna - żeby ją sfinalizować, firma Thomas Cook wzięła kredyt o wysokości 1,7 mld funtów. Obliczono, że dla spłaty samych odsetek biuro musiałoby sprzedawać 3 mln wycieczek rocznie (CNBC, 2019). Celem transakcji był plan zaoszczędzenia 75 mln funtów rocznie, jednakże Thomas Cook naraził się tym samym na zbyt duże ryzyko, bowiem połączenie grup zbiegło się $\mathrm{w}$ czasie $\mathrm{z}$ początkami kryzysu finansowego na świecie z lat 2007-2009 (Holzer, 2009) oraz z późniejszym regresem gospodarczym 2011-2012 (Forbes, 2012). Mimo trudniejszego okresu i dużego ryzyka (nie wiadomo, czy biuro korzystało wtedy z funkcji zarządzania ryzykiem) przedsiębiorstwo przeprowadzało kolejne transakcje, przyłączając do grupy niemiecką spółkę Öger Tours (2010), rosyjskie Intourist (2011) oraz bułgarskie Astral Holidays (2013). W 2011 r. oraz 2012 r. pojawiło się realne zagrożenie, które powinno było zostać wykryte już wcześniej przez SWO (jeśli Thomas Cook takowych systemów używał). Lata te były okresem, kiedy analitycy zaczęli podważać przyszłość biura, głównie przez kolejne kredyty zaciągane $\mathrm{w}$ bardzo krótkich odstępach czasu. Można uznać, że były to pierwsze sygnały alarmowe z otoczenia. Co więcej, ze swojego stanowiska zrezygnował ówczesny prezes biura, spadła również wartość akcji o 75\% (Scuffham, 2011). Wobec kryzysu firmy wypowiedział się chociażby analityk Espirito Santo Geetanjani Sharma (który przewidywał brak płaszcza dla biura od banków) oraz były prezes Manny Fontenla-Novoa (potwierdził spadek notowań), o czym również wspomina Scuffham (2011). Przywołuje on także optymistyczną wypowiedź dyrektora naczelnego firmy Thomas Cook Sama Weihagena, który nie widział zagrożenia, uważał biuro podróży za silne przedsiębiorstwo, a odpowiedzialnością obarczył problemy globalne. Analizując powyższe decyzje firmy oraz ówczesną sytuację na świecie, można wysunąć kilka wniosków. Po pierwsze, Thomas Cook nie powinien szukać przyczyny regresu jedynie $\mathrm{w}$ otoczeniu zewnętrznym, ale także $\mathrm{w}$ wewnętrznym (czyli w zarządzaniu). Co więcej, zaciąganie kolejnych kredytów jest posunięciem bardzo gwałtownym, podjętym prawdopodobnie bez wcześniejszej analizy zarządzania ryzykiem. Należy także zauważyć, że gdyby nie pożyczkodawcy, Thomas Cook zbankrutowałby już w 2012 r., z czego biuro podróży również powinno wyciągnąć wnioski, chociażby w ramach ostatniej fazy zarządzania kryzysowego, jaką jest odbudowa i uczenie się przedsiębiorstwa. Oprócz tego touroperator pokładał złudne nadzieje w swoich spółkach spoza Wielkiej Brytanii, zapominając, że sytuacja w spółce matce jest kluczowa dla przetrwania spółek córek. Z powyższej refleksji można więc wywnioskować, że w latach 2007-2012 w biurze podróży Thomas Cook brakowało prawidłowego i skutecznego zarządzania w kryzysie oraz zarządzania ryzykiem. Wspomniane procedury powinny być przeprowadzone nawet po czasie, bowiem uchroniłoby to przedsiębiorstwo przed kolejnym kryzysem w 2019 r. Oprócz korzyści dla firmy, powyższe działania są po prostu uczciwe wobec interesariuszy, akcjonariuszy i otoczenia, bowiem każde z wymienionych może dotknąć regres $\mathrm{w}$ następstwie kryzysu w biurze, z którym łączą 
je więzi i relacje. Kryzys wywołuje fatalne skutki, chociażby w trzech sferach: finansowej, bezpieczeństwa publicznego, a nawet może skutkować utratą życia (Coombs, 2007). Żeby temu zapobiec, powstał kolejny podział w procesie zarządzania kryzysem, składający się z trzech faz: pre-crisis (przed), crisis response (odpowiedź na kryzys) oraz post-crisis (po), o czym również wspomina Coombs (2007). Powyższy cykl jest bardzo podobny do czterech faz zarządzania kryzysowego, jednakże w ramach trzyczęściowego procesu dokładnie wyszczególniono: stworzenie złożonego planu zarządzania kryzysowego (CMP), utrzymanie relacji $z$ otoczeniem, szybką, dokładną oraz logiczną reakcję, a także odbudowę wizerunku, relacji i samej firmy (Coombs, 2007). Ważne jest również współczucie dla poszkodowanych. Odnosząc podaną procedurę do działań biura podróży Thomas Cook, można wyciągnąć wnioski, że zarządzanie kryzysowe i zarządzanie ryzykiem w tej firmie nie istniały albo były nieskuteczne. Należy jednak pamiętać, że do wiadomości publicznej nie trafiły dokładne dane na ten temat, co mogło być rodzajem strategii, jednakże wciąż powinno zapewniać bezpieczeństwo publiczne. O nieskuteczności zarządzania kryzysowego i zarządzania ryzykiem w Thomas Cook świadczą też decyzje podjęte w latach 2013-2019.

\section{Działalność biura podróży Thomas Cook w latach 2013-2019, drugi kryzys i upadek firmy}

Kryzys przedsiębiorstwa Thomas Cook z 2012 r. wydawał się względnie zażegnany. W 2014 r. ze swojego stanowiska zrezygnowała jednak nowa dyrektor generalna biura, Harriet Green, co wiązało się ze spadkiem wartości akcji o $350 \mathrm{mln}$ funtów (Thomas, 2014). Co więcej, wciąż żywa była ekspozycja firmy na ryzyko kredytowe. W latach 2013-2019 zmniejszyła się również objętość raportów wydanych przez biuro podróży w I kwartale roku za październik, listopad i grudzień roku poprzedniego w porównaniu do jego konkurentów. Co więcej, firma całkowicie zrezygnowała z prezentacji w 2018 r. i 2019 r. (Zespół Instytutu Badań Rynku Turystycznego TravelDATA i www.wczasopedia.pl, 2019). Fakt ten mógł świadczyć o słabnącej komunikacji między firmą Thomas Cook a otoczeniem, czym firma naraziła się na ryzyko utraty zaufania w przyszłości. Należy jednak pamiętać, że jest to tylko subiektywny wniosek, bowiem przyczyny mniejszej liczby stron $\mathrm{w}$ raportach i relacje $z$ udziałowcami w tym okresie pozostaną sekretem firmy. We wspomnianym czasie, a dokładnie po incydencie z 2015 r., spadła także lojalność klientów, kiedy ponownie wszczęto postępowanie sądowe po śmierci dwójki dzieci Shepard na wakacjach $\mathrm{z}$ biurem Thomas Cook (spowodowanej zatruciem tlenkiem węgla). Biuro podróży otrzymało wtedy $3 \mathrm{mln}$ funtów (od hotelu, w którym wydarzyła się tragedia), które bez porozumienia z rodzicami dzieci przekazało na rzecz UNICEF (Brinded, 2015). Posunięcie to skutkowało utratą klientów i spadkiem wartości akcji o 4\%. Firmie wytknięto także brak bezpośrednich przeprosin i brak ludzkiego współczucia, a jej działania nazwane zostały „chwyceniem pokrzywy" (Media First, 2015), co wiąże się również z błędnym zarządzaniem sławą. W kolejnych latach sytuacja się nie poprawiła - od października 2018 r. 
stopniowo zaczęła spadać wartość obligacji, co przedstawił Rosik (2019). W tym samym czasie notowano drastyczny spadek cen akcji - porównano zyski dla 2010 i 2018 r. oraz potwierdzono stratę w wysokości 1,5 mld funtów w maju 2019 r. (Mallinson, 2019). Powyższe kwestie skłoniły Thomas Cook do wdrożenia planu ratunkowego i zaawansowanych rozmów z udziałowcami i pożyczkodawcami, a w szczególności z chińską spółką Fosun. Planowano też restrukturyzację firmy. Rozmowy z instytucjami finansowymi nie doszły jednak do skutku, bowiem zażądano od biura $250 \mathrm{mln}$ dolarów na początek (Rosik, 2019). Powyższa kwestia oraz wiele innych czynników finansowych, społecznych, pogodowych, politycznych (Florencka, 2019), a także złudne skupienie na lojalności klientów, spadek wartości akcji, fala upałów, spadek wartości funta oraz skłonność Brytyjczyków do oszczędzania spowodowały, że w nocy z 22 na 23 września 2019 r. Thomas Cook ogłosił niewypłacalność. Upadek firmy skomentował prezes grupy TUI Friedrich Joussen, który podkreślił, że przez stagnację i niczym niewyróżniającą się ofertę Thomas Cook zmuszony był konkurować z biurami podróży w Internecie oraz z tanimi liniami lotniczymi (German, 2019). Podobne przemyślenia można wyczytać w komentarzu Tima Jeansa, szefa lotniska, który ocenił, że upadła firma realizowała „analogowy model biznesowy w cyfrowym świecie” (Florencka, 2019), a więc przysłowiowe „spoczywanie na laurach”. W decyzjach Thomas Cook w latach 2013-2019, tak jak w latach 2007-2012 można zauważyć, że biuro wciąż błędnie zarządzało kryzysem, a podejmowane przez nie ryzyko było zbyt duże i wiązało się z brakiem głębszej refleksji. Mimo wszystko Thomas Cook nawet po swoim upadku dalej obarczał winą pożyczkodawców, którzy ponoć nie wsparli planu ratunkowego. Inaczej upadek biura postrzegają pracownicy, którzy stawiają zarządzanie Thomas Cook w niekorzystnym świetle - zarzucali oni touroperatorowi złe kierowanie, a także brak strategii i celów (Glassdoor). Nie był to jedyny sygnał ostrzegawczy z otoczenia, biorąc pod uwagę również wcześniej wymienione opinie analityków, prezesa TUI, szefa lotniska oraz treść wielu stron internetowych - przykładem może być „Infinite Global”, na której opisano Petera Frankhausera (prezesa biura podróży w momencie jego upadku) obarczającego winą otoczenie (Barrett, Taylor, 2019). Podobne błędy w komunikacji cechowały decyzje firmy Thomas Cook już kilka lat wcześniej. Powyższe dane wskazują tym samym na zaniedbania biura podróży zarówno w komunikacji z otoczeniem, jak i w zarządzaniu ryzykiem i zarządzaniu w kryzysie.

\section{Zakończenie}

Upadek biura podróży Thomas Cook miał miejsce ponad rok temu, jednakże wciąż brakuje głębszych wniosków, badań oraz analiz tego tematu, które odpowiedziałyby na wiele pytań $i$ były przestrogą dla innych przedsiębiorstw $z$ tego sektora gospodarczego. Każdy z opisanych $w$ rozdziale elementów (zarządzanie kryzysowe, zarządzanie ryzykiem, otoczenie oraz więzi) jest ważną kwestią w zarządzaniu każdym przedsiębiorstwem. Brak prawidłowych nawyków w firmie Thomas Cook bezpośrednio przyczynił się do jej upadku, z kolei wadliwe zarządzanie było 
prawdopodobnie głównym powodem, dla którego touroperator musiał ogłosić niewypłacalność. Na upadek 178-letniego biura podróży składa się znacznie więcej przyczyn, jednakże wszystkie błędy, które popełnił Thomas Cook (zaciągnięcie wielu kredytów, obarczanie winą otoczenia, błędne wybory oraz zbyt późne wszczęcie procedury ratowania firmy), wiążą się z początkowymi decyzjami biura w zarządzaniu ryzykiem i zarządzaniu kryzysowym jeszcze w 2007 r. Być może gdyby Thomas Cook nie połączył się z grupą MyTravel, wciąż by istniał.

\section{Literatura}

Barrett P., Taylor M. (2019). Crisis and reputation management in the fallout from the Thomas Cook collapse (www.infiniteglobal.com; dostęp: 28.12.2020).

Brinded L. (2015). Thomas Cook's Facebook page is filling up with outraged comments over a $£ 3$ million payment the company received for the death of two children at one of its hotels (www.businessinsider.com; dostęp: 28.12.2020).

Coombs W.T. (2007). Crisis Management and Communications (www instituteforpr.org; dostęp: 28.12.2020).

CNBC (2019). British travel firm Thomas Cook collapses, stranding 600,000 people abroad (www.cmbc.com; dostęp: 27.12.2020).

Czerwonka K., Cież M., Kowal M. Ryzyko (www.mfiles.pl; dostęp: 26.12.2020).

Florencka K. (2019). Eksperci o powodach upadku Thomas Cook. „Analogowy biznes w cyfrowym świecie" (www.innpoland.pl; dostęp: 28.12.2020).

Forbes (2012). Spowolnienie w 2012 gorsze od kryzysu finansowego (www.forbes.pl; dostęp: 26.12.2020).

German M. (2019). Szef TUI: Thomas Cook upadł, bo się nie wyróżniał (www.turystyka. rp.pl; dostęp: 28.12.2020).

Glassdoor. Thomas Cook Reviews (www.glassdoor.com; dostęp: 28.12.2020).

Holzer R. (2009). Jak rozwijał się kryzys 2007-2009 - infografika, kalendarium (www. obserwatorfinansowy.pl; dostęp: 26.12.2020).

Mallinson H. (2019). Thomas Cook collapse: Now TUI cancels flights for customers after holiday firm collapse (www.express.co.uk; dostęp: 28.12.2020).

Media First (2015). Thomas Cook - a textbook case of how not to handle a crisis (www. mediafirst.co.uk; dostęp: 28.12.2020).

Rosik P. (2019). Upadło najstarsze biuro podróży na świecie Thomas Cook. To ważne ostrzeżenie dla inwestorów (www.strefainwestorow.pl; dostęp: 28.12.2020)

Scuffham M. (2011). Thomas Cook shares crash after default warning (www.reuters.com; dostęp: 27.12.2020).

Stabryła A. (red.) (2018). Podstawy organizacji i zarządzania. Podejścia i koncepcje badawcze. Wydawnictwo Uniwersytetu Ekonomicznego w Krakowie, Kraków, s. 33-35, 128, 142.

Thomas Cook Group plc. (2007). Annual Report \& Accounts (www.annualreports.com; dostęp: 27.12.2020).

Thomas N. (2014). More than £350m wiped off Thomas Cook after chief Harriet Green steps down (www.telegraph.co.uk; dostęp: 27.12.2020).

Urbanik G., Dudkiewicz A. Kryzys (www.mfiles.pl; dostęp: 26.12.2020). 
Wróblewski D. (red.) (2014). Zagadnienia ogólne z zakresu zarządzania ryzykiem i zarządzania kryzysowego. Analiza wybranych przepisów. Wydawnictwo CNBOP-PIB, Józefów, s. 13-14, 20.

Zespół Instytutu Badań Rynku Turystycznego TravelDATA i www.wczasopedia.pl. (2019). Analiza informacji mających wpływ na branżę turystyczną. Nastroje konsumenckie mocno psują biznes organizatorom i agentom... (www.wczasopedia.pl; dostęp: 28.12.2020).

\section{Risk management and crisis management in the context of the fall of the legendary travel agency Thomas Cook}

The fall of the oldest tourist agency 'Thomas Cook' spread loudly all over the world. Although a year has passed since this event, the issue still seems to be up-to-date, and the reasons for the company's collapse are still under discussion. Apart from financial, weather and social factors, the lack of company preparation and improper management are also mentioned. The aim of this article is to introduce the mistakes of 'Thomas Cook' agency and to emphasize the importance of relationships, ties, crisis management and risk management. The literature query and the netographic analysis were used in this case study, and the results indicated the direct reason for the collapse of the travel agency, which means its stagnation and superficial ties without security in management. The conclusions highlight important components of travel agency management and relations, which may prove to be the basis for future research.

Translated by Natalia Siwik 
Kamil Pawtowski

Uniwersytet Ekonomiczny w Krakowie

camil1999@gmail.com

\section{Uwarunkowania wykorzystania transportu kolejowego w rozwoju turystyki międzynarodowej}

\section{Streszczenie}

Transgraniczne połączenia kolejowe są ważnym elementem turystyki międzynarodowej. Jej rosnące znaczenie znajduje odwzorowanie w stale poszerzanej ofercie przewoźników kolejowych. W rozdziale dokonano analizy dostępnej oferty połączeń transgranicznych w Polsce. Porównano takie parametry, jak: liczba miejsc, czas przejazdu czy cena w oparciu o dostępną siatkę połączeń. Celem opracowania jest zbadanie obecnego stanu połączeń transgranicznych pod kątem wykorzystania ich jako turystycznego środka transportu. W pracy została przedstawiona syntetyczna analiza dostępnych połączeń kolejowych oraz ich porównanie ze sobą. Prezentowane rozważania stanowią próbę odpowiedzi na pytanie, czy transport kolejowy przyczynia się do rozwoju turystyki międzynarodowej. Mogą być traktowane jako inspiracja do badań związanych z tematyką kolei transgranicznej w Polsce.

\section{Wprowadzenie}

Transgraniczne połączenia kolejowe dają możliwość przekraczania granic. Kolej od zawsze sprzyjała rozwojowi różnych form turystyki. Szersze możliwości podróżowania pojawiły się po transformacji w roku 1991. Kamieniami milowymi do rozwoju turystyki międzynarodowej były jednak: wstąpienie Polski do UE w roku 2004 oraz przystąpienie do strefy Schengen (Beim, Soczówka, 2016), co ułatwiło przekraczanie granic koleją. Z roku na rok liczba połączeń rośnie (ryc. 1).

Aby dobrze zrozumieć transgraniczne połączenia kolejowe, warto pochylić się w tym miejscu nad definicją turysty. Jest to bowiem fundamentalne zagadnienie, które umożliwia zrozumienie istoty turystyki (Candela, Figini, 2012). 


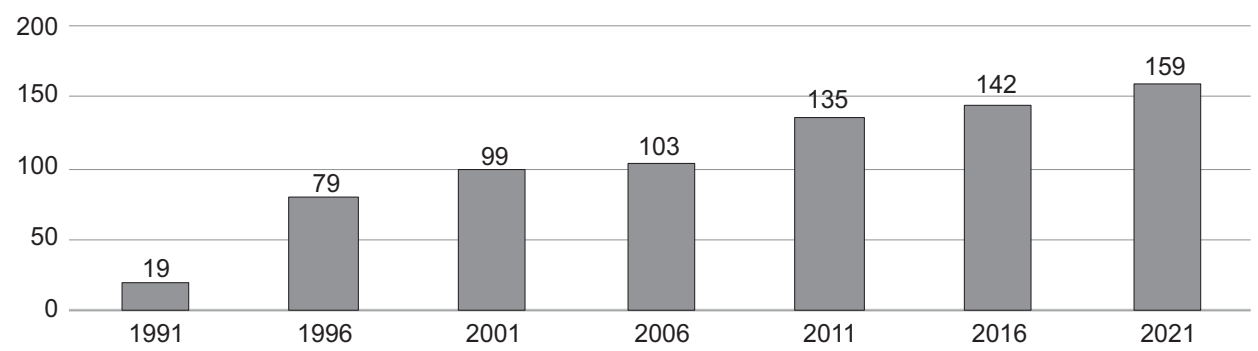

Ryc. 1. Liczba połączeń transgranicznych w latach 1991-2021

Źródło: opracowanie własne na podstawie Beim i Soczówka (2016) i rozkładu jazdy.

Według UNWTO, turysta to: „,osoba, która w kraju czasowego pobytu spędziła przynajmniej jedną noc w jego bazie hotelowej w celach: wypoczynkowych, leczniczych, krajoznawczych, religijnych, sportowych, służbowych, rodzinnych, społecznych, politycznych itp.” (Brożek, Błądek, 2020). Część osób, które podróżują połączeniami transgranicznymi, nie będzie turystami. Przekroczą oni wprawdzie granicę kraju, ale nie nocują w dostępnych tam obiektach noclegowych. Będą to wycieczkowicze, którzy spędzą w innym kraju mniej niż 24 godziny, a także nie korzystają z bazy noclegowej. Osoby, które spędzą noc w pociągu, również nazywane są wycieczkowiczami (Gaworecki, 2003). Połączenia transgraniczne wydają się wykazywać znaczący potencjał w obszarze turystyki kolejowej, dlatego można zaklasyfikować je jako jej istotny element (Anisiewicz, 2020).

\section{Przegląd literatury i wyniki badań}

Funkcje turystyki możemy zdefiniować jako: ,zbiór relacji jednoznacznych, zachodzących między dwoma lub więcej zbiorami elementów" (Meyer, 2006). Można je dostrzec $\mathrm{w}$ turystyce kolejowej. Oddziałują na „sferę społeczno-kulturalną życia ludzkiego" (Bebenow, 2015). Z kolei region transgraniczny to „terytorialny układ społeczno-gospodarczy, który jest wyrazem eliminacji lub niskiej formalizacji granicy państwowej” (Przybła, 1995). Turystykę transgraniczną można postrzegać jako „migrację w obrębie jednego regionu, który wchodzi w skład dwóch lub więcej państw, i której motywację stanowi markowy produkt turystyczny tego regionu" (Duda, 2018). Jednym z trzech podstawowych elementów turystyki jest transport, bez którego nie mogłaby się rozwijać (Michniak, 2016), a szczególnie ważnym środkiem transportu kolej, dla której rozwoju kamieniem milowym było wykorzystanie silnika parowego (Mammadov, 2012). W efekcie zyskała ona również znaczenie w obsłudze ruchu międzynarodowego. Obecnie stanowi płaszczyznę integracji europejskiej oraz jest uzupełnieniem oferty przewozowej obszarów nadgranicznych (Beim, Soczówka, 2016). Istotnym aspektem rozwoju było otwarcie granic oraz wsparcie kolei środkami unijnymi (Gosik, Zimon, 2014). Turystyka jest jednych z kluczowych elementów rozwoju gospodarczego (Kovačić, Milošević, 2016). Skuteczny rozwój wymaga pewnego rodzaju współdziałania we wszystkich dziedzinach życia (Niemczyk, 2010). To zadanie spełnia 
turystyka kolejowa, przyczyniając się do rozwoju obszarów transgranicznych. Powyższa argumentacja wskazuje na znaczenie transportu kolejowego w turystyce międzynarodowej.

W tabeli 1 zaprezentowano zbiorcze zestawienie wszystkich przejść granicznych, z liczbą pociągów przekraczających granicę w latach 2019 i 2021.

Tabela 1. Zbiorcze zestawienie kolejowych przejść transgranicznych w Polsce

\begin{tabular}{|c|c|c|c|}
\hline $\begin{array}{c}\text { Państwo } \\
\text { (liczba przejść) }\end{array}$ & Odcinek graniczny & $\begin{array}{c}\text { Oferta } \\
\text { 2019/lato }\end{array}$ & $\begin{array}{c}\text { Oferta } \\
\text { kwiecień } \\
\text { 2021/lato }\end{array}$ \\
\hline \multirow[t]{7}{*}{ Niemcy (7) } & Świnoujście Centrum (DB)-Ahlbeck Grenze & 28 & $19 / 28$ \\
\hline & Szczecin Gumieńce-Grambow & $9 / 8$ & $9 / 8$ \\
\hline & Szczecin Gumieńce-Tantow & $8 / 7$ & $9 / 8$ \\
\hline & Kostrzyn-Küstrin-Kietz & $19 / 17$ & $13^{\mathrm{b}}$ \\
\hline & Rzepin-Frankfurt (Oder) & $10 / 9$ & $11 / 10$ \\
\hline & Żagań/Zasieki-Forst (Lausitz) & $3 / 3$ & 2 \\
\hline & Zgorzelec-Görlitz & $14 / 15$ & $23 / 22$ \\
\hline Suma Niemcy & & $91 / 87$ & $92 / 97$ \\
\hline \multirow[t]{9}{*}{ Czechy (9) } & Szklarska Poręba Jakuszyce-Harrachov & $4 / 11$ & $4 / 11$ \\
\hline & Lubawka-Královec & $7 / 4$ & 6 \\
\hline & Mieroszów-Meziměstí & $0 / 4$ & $0 / 2$ \\
\hline & Międzylesie-Lichkov & 4 & $4 / 5$ \\
\hline & Głuchołazy-Mikulovice & 4 & 4 \\
\hline & Głuchołazy-Jindřichov ve Slezsku & 4 & 4 \\
\hline & Chałupki-Bohumín & $11 / 12$ & $16 / 20$ \\
\hline & Zebrzydowice- Bohumín & 5 & 1 \\
\hline & Cieszyn-Český Těšín & 9 & 9 \\
\hline Suma Czechy & & $48 / 57$ & $48 / 62$ \\
\hline \multirow[t]{3}{*}{ Słowacja (3) } & Zwardoń-Skalité-Serafinov & $5 / 4$ & $5 / 3$ \\
\hline & Muszyna-Plaveč & $0 / 2$ & $0 / 2$ \\
\hline & Łupków-Medzilaborce Mesto & $0 / 2$ & $0 / 2$ \\
\hline Suma Słowacja & & $5 / 8$ & $5 / 7$ \\
\hline \multirow[t]{2}{*}{ Ukraina (2) } & Przemyśl Gł.-L’viv & $4 / 5$ & $4 / 5$ \\
\hline & Chełm-Kovel/Kiev Pass. & $2 / 1$ & 1 \\
\hline Suma Ukraina & & $6 / 7$ & $5 / 6$ \\
\hline \multirow[t]{2}{*}{ Białoruś/Rosja (2) } & Terespol-Brest Centralnyj & 4 & 7 \\
\hline & Kuźnica Białostocka-Hrodna & 1 & 1 \\
\hline \multicolumn{2}{|c|}{ Suma Białoruś/Rosja } & 5 & 8 \\
\hline Litwa (1) & Trakiszki-Šeštokai & $1 / 2$ & 1 \\
\hline Razem & & $156 / 166$ & $159 / 181$ \\
\hline
\end{tabular}

a Planowany stan na dzień 4 lipca 2021 r.

${ }^{\mathrm{b}}$ Brak danych, założono do zestawienia zbiorczego taką samą liczbę połączeń jak w wariancie rozkładu ważnego do 13 marca 2021 r. - 13 połączeń

Źródło: opracowanie własne na podstawie Dębicki (2019) i rozkładu jazdy. 
Liczba połączeń pomiędzy rokiem 2019 a 2021 wzrosła. Zmianę tę widać szczególnie w okresie wakacyjnym. Połączenia obsługiwane są przez następujących przewoźników kolejowych: PKP Intercity, Pol Regio, Koleje Dolnośląskie, Koleje Śląskie, Deutsche Bahn oraz Leo Ekspress. Większość przejść granicznych wykorzystywana jest do migracji krótkookresowych, w formie jednodniowych wycieczek. Takie kierunki to głównie: Niemcy (bez przejścia Rzepin-Frankfurt/ Oder), Czechy (bez przejścia w Bohuminie) i Słowacja. Pozostałe przejścia graniczne służą turystyce krótkookresowej. Największe znaczenie ma oferta połączeń z Niemcami: w 2019 - 58,33\%, w 2021 - 57,86\% wszystkich połączeń międzynarodowych. Zjawisko spowodowanie jest tym, że w północnej części pograniczna - Świnoujście, Szczecin czy Kostrzyn - ruch transgraniczny jest dość intensywny (Dębicki, 2019). Część miast jest podzielona granica, co zdradza potrzebę ich integracji ze względu na podobne funkcje, takie jak: ,,obsługa ruchu granicznego, tranzytu i turystyki" (Więckowski, 2020). Podobna sytuacja występuje w miejscowościach takich, jak: Cieszyn, Terespol, Zgorzelec czy Słubice (Więckowski, 2020).

\section{Metodyka badań}

Rozdział prezentuje przegląd transgranicznych połączeń kolejowych w Polsce. Zostały one porównane ze sobą na podstawie takich parametrów, jak: liczba miejsc, czas przejazdu czy cena, w oparciu o dostępną siatkę połączeń. Aby zrealizować poczynione założenia, wykorzystano metodę analizy rozkładów jazdy. Jest ona stosowana jako narzędzie badawcze w literaturze naukowej (zob. Beim, Soczówka, 2016; Dębicki, 2019; Małysz, 2020). W większości przypadków do analizy przyjęto rozkład z 13 kwietnia 2021 r. Przedstawione dane są opracowane na podstawie wchodzącego w życie nowego rozkładu jazdy 2020/2021. Należy jednak podkreślić, że połączenia mogą ulec częściowej zmianie ze względu na trwającą pandemię COVID-19.

W toku badań podstawowym źródłem informacji był Sieciowy Rozkład Jazdy Pociągów (SRJP). Uzupełniającym źródłem badań była strona z zestawieniem składów pociągów (VagonWeb). Rozkład jazdy jest obciążony pewnymi niedogodnościami metodologicznymi, ponieważ w Polsce zmienia się on 5 razy do roku. Ponadto często w każdym rozkładzie występują różne warianty - choćby dodatkowe połączenia $\mathrm{w}$ weekendy. Na potrzeby pracy dane tego typu zostały uśrednione. Ponadto część prezentowanych treści została opracowana na podstawie własnych obserwacji.

\section{Analiza rozkładu jazdy}

Głównym przewoźnikiem, mającym największe znaczenie w tworzeniu turystyki międzynarodowej, jest PKP Intercity, który obsługuje połączenia dalekobieżne. Pociągi tego operatora łączą największe polskie miasta $z$ różnymi destynacjami turystycznymi, takimi jak: Berlin, Praga, Budapeszt czy Lwów. 
W tabeli 2 zaprezentowano wszystkie połączenia przewoźnika PKP Intercity na podstawie dostępnych źródeł, policzono maksymalną pojemność przewozową pociąu $^{1}$. Zostały też przedstawione dodatkowe usługi, które podnoszą jakość przewozów, takie jak: wagon restauracyjny, przewóz rowerów, przystosowanie do wózków inwalidzkich.

Tabela 2. Zestawienie międzynarodowych pociągów dalekobieżnych uruchamianych przez PKP IC ${ }^{\text {a }}$ w rozkładzie jazdy $2020 / 21^{\text {b }}$

\begin{tabular}{|c|c|c|c|c|c|c|c|c|}
\hline Pociąg & Relacja & $\begin{array}{l}\text { Pora } \\
\text { dnia }\end{array}$ & 1 & 2 & $\sum$ & WR & $\mathrm{N}$ & $\mathrm{R}$ \\
\hline 304 Hańcza & Kraków Gł.-Grodno & $\mathrm{D}$ & - & 3 & 212 & - & - & 18 \\
\hline 128 Skaryna & Warszawa Zach.-Brest Cent. & $\mathrm{D}$ & 1 & 5 & 406 & - & - & 12 \\
\hline 126 Mickiewicz & Warszawa Zach.-Brest Cent. & $\mathrm{D}$ & 1 & 5 & 406 & - & - & 12 \\
\hline 116 Silesia & Warszawa Wsch.-Praha Hl. n & $\mathrm{D}$ & $1,5^{\mathrm{c}}$ & 3 & 255 & $\mathrm{X}$ & $\mathrm{X}$ & 12 \\
\hline 103 Polonia & Warszawa Wsch.-Wien Hbf. & $\mathrm{D}$ & 1 & 3 & 236 & $\mathrm{X}$ & $\mathrm{X}$ & 8 \\
\hline 131 Batory & $\begin{array}{l}\text { Brest Cent - Budapest } \\
\text { Nyugati/ (Praha Hl. N) }\end{array}$ & $\mathrm{D}$ & 1 & $\begin{array}{c}2 \\
(4)\end{array}$ & $\begin{array}{c}188 \\
(278)\end{array}$ & - & - & $\begin{array}{c}0 \\
(4)\end{array}$ \\
\hline 112 Silesia & Warszawa Wsch.-Praha Hl. n & $\mathrm{D}$ & 1 & 6 & 460 & - & - & 8 \\
\hline 110 Silesia & $\begin{array}{l}\text { Warszawa Wsch.-Ostrava } \\
\text { Svinov }\end{array}$ & $\mathrm{D}$ & 1 & 6 & 466 & - & - & 8 \\
\hline 407 Chopin & Warszawa Wsch.-Bohumin ${ }^{\mathrm{e}}$ & $\mathrm{N}$ & \multicolumn{3}{|c|}{$\begin{array}{l}272 \text { miejsca } \\
\text { do leżenia, } \\
444 \text { miejsca do } \\
\text { siedzenia }^{\mathrm{f}}\end{array}$} & - & - & - \\
\hline $17 / 409$ & Moskva Bel.-Nice Ville & $\mathrm{D} / \mathrm{N}$ & \multicolumn{3}{|c|}{$\begin{array}{l}248 \text { miejsc do } \\
\text { leżenia }\end{array}$} & $\mathrm{X}$ & - & - \\
\hline 310 Roztocze & Lublin Gł.-Bohumin & $\mathrm{D}$ & - & 4 & 300 & - & - & - \\
\hline 248 Berolinum & Warszawa Wsch.-Berlin Hbf. & $\mathrm{D}$ & 1 & 4 & 302 & $\mathrm{X}$ & $\mathrm{X}$ & 8 \\
\hline 246 Wisła & Warszawa Wsch.-Berlin Hbf. & $\mathrm{D}$ & 1 & 4 & 302 & $\mathrm{X}$ & $\mathrm{X}$ & 8 \\
\hline 48 Odra & Warszawa Wsch.-Berlin Hbf. & $\mathrm{D}$ & 1 & 4 & 308 & $\mathrm{X}$ & $\mathrm{X}$ & 8 \\
\hline 44 Spree & Warszawa Wsch.-Berlin Hbf. & $\mathrm{D}$ & 1 & 4 & 302 & $\mathrm{X}$ & $\mathrm{X}$ & 8 \\
\hline 40 Varsovia & Warszawa Wsch.-Berlin Hbf. & $\mathrm{D}$ & 1 & 4 & 302 & $\mathrm{X}$ & $\mathrm{X}$ & 8 \\
\hline $13 / 440$ & Moskva Bel.-Berlin Ostbf. & $\mathrm{D} / \mathrm{N}$ & \multicolumn{3}{|c|}{$\begin{array}{l}174 \text { miejsca } \\
\text { do leżenia, } 40 \\
\text { miejsc z fotela- } \\
\text { mi wypoczyn- } \\
\text { kowymi }\end{array}$} & $\mathrm{X}$ & $\mathrm{X}$ & - \\
\hline $23 / 452$ & Moskva Bel.-Paris Est. & $\mathrm{D} / \mathrm{N}$ & \multicolumn{3}{|c|}{$\begin{array}{c}224 \text { miejsca do } \\
\text { leżenia }\end{array}$} & $\mathrm{X}$ & - & - \\
\hline $68 \mathrm{Kiev}$ Express & Warszawa Zach.-Kiev Pass. & $\mathrm{D} / \mathrm{N}$ & 1 & 5 & 396 & - & - & 6 \\
\hline 90 & Przemyśl Gł.-L’viv & $\mathrm{D}$ & - & 6 & 216 & - & - & - \\
\hline 705 & Przemyśl Gł.-Kiev Pass. & $\mathrm{D}$ & 3 & 6 & 576 & $X^{g}$ & - & - \\
\hline 715 & Przemyśl Gł.-Kiev Pass. & $\mathrm{D}$ & 3 & 6 & 576 & $X^{c}$ & - & - \\
\hline
\end{tabular}

1 Założono maksymalne możliwości przewozowe. Obecnie w PKP IC możliwe jest jednak zajęcie 50\% wszystkich miejsc siedzących (stan na 2 stycznia 2021 r.). 


\begin{tabular}{|c|c|c|c|c|c|c|c|c|}
\hline Pociąg & Relacja & $\begin{array}{l}\text { Pora } \\
\text { dnia }\end{array}$ & 1 & 2 & $\Sigma$ & WR & $\mathrm{N}$ & $\mathrm{R}$ \\
\hline 36 & Przemyśl Gł.-Odessa Hl. & $\mathrm{N}$ & \multicolumn{3}{|c|}{$\begin{array}{l}216 \text { miejsc do } \\
\text { leżenia }\end{array}$} & - & - & - \\
\hline 114 Cracovia & $\begin{array}{l}\text { Przemyśl Gł.-Praha Hl. N/ } \\
\text { (Budapest Nyugati) }^{\mathrm{h}}\end{array}$ & $\mathrm{D}$ & $0,5^{\mathrm{i}}$ & $\begin{array}{c}2 \\
(2)\end{array}$ & $\begin{array}{c}168 \\
(160)\end{array}$ & $\mathrm{X}$ & $\mathrm{X}^{\mathrm{j}}$ & $\begin{array}{c}4 \\
(8)\end{array}$ \\
\hline $\begin{array}{l}105 \text { Porta } \\
\text { Moravica }\end{array}$ & Przemyśl Gł.-Graz Hbf. & $\mathrm{D}$ & 1 & 3 & 254 & $\mathrm{X}^{\mathrm{k}}$ & - & 4 \\
\hline 300 Galicja & Przemyśl Gł.-Ostrava Svinov & $\mathrm{D}$ & 1 & 4 & 356 & - & - & 0 \\
\hline $\begin{array}{l}52 \text { Lwów } \\
\text { Ekspress }\end{array}$ & Wrocław Gł.-L’viv ${ }^{1}$ & $\mathrm{~N}$ & \multicolumn{3}{|c|}{$\begin{array}{l}120 \text { miejsc do } \\
\text { leżenia }\end{array}$} & - & $\mathrm{X}$ & - \\
\hline 56 Wawel & Kraków Gł.-Berlin Hbf. & $\mathrm{D}$ & 1 & 4 & 308 & $\mathrm{X}$ & $\mathrm{X}$ & 8 \\
\hline 101 Moravia & Katowice -Wien Hbf. & $\mathrm{D}$ & 1 & 3 & 236 & $\mathrm{X}$ & $\mathrm{X}$ & 8 \\
\hline 107 Sobieski & Gdynia Gł.-Wien Hbf. & $\mathrm{D}$ & 1 & 3 & 236 & $\mathrm{X}$ & $\mathrm{X}^{\mathrm{m}}$ & 8 \\
\hline 402 Wydmy $^{\mathrm{n}}$ & Hel/Łeba ${ }^{\circ}-$ Bohumin & $\mathrm{N}$ & - & 10 & 683 & - & - & 25 \\
\hline 456 Nighjet $^{\mathrm{p}}$ & $\begin{array}{l}\text { Wien Hbf.-Berlin } \\
\text { Charlottenburg }\end{array}$ & $\mathrm{N}$ & \multicolumn{3}{|c|}{$\begin{array}{l}310 \text { miejsc } \\
\text { do leżenia, } \\
198 \text { miejsc do } \\
\text { siedzenia }^{q}\end{array}$} & - & - & - \\
\hline 400 Wolin $^{\mathrm{i}}$ & Świnoujście-Bohumin & $\mathrm{N}$ & - & 5 & 291 & - & - & 25 \\
\hline 404 Pirat $^{\mathrm{i}}$ & Kołobrzeg-Bohumin & $\mathrm{N}$ & - & 4 & 260 & - & - & 25 \\
\hline 58 Gedania & Gdynia Gł.-Berlin Hbf. & $\mathrm{D}$ & 1 & 4 & 302 & $\mathrm{X}$ & $\mathrm{X}$ & 8 \\
\hline
\end{tabular}

Legenda: D - pociąg dzienny; $\mathrm{N}$ - pociąg nocny; X - tak; 1 - liczba wagonów 1 kl.; 2 - liczba wagonów $2 \mathrm{kl}$.; $\Sigma$ - suma miejsc siedzących w pociągu; WR - wagon restauracyjny; $\mathrm{N}$ - wagony przystosowane do przewozu osób niepełnosprawnych na wózkach inwalidzkich; R - wagon przystosowany do przewozu rowerów.

${ }^{a}$ Ze współpracą z innymi przewoźnikami.

${ }^{\mathrm{b}}$ Rozkład jazdy może być modyfikowany ze względu na sytuację epidemiologiczną.

c Jeden z wagonów 1 klasy: połowa to 1 klasa, połowa to wagon gastronomiczny.

d Na stacji Bohumin cztery wagony do Pragi przepina się do pociąu 114 Cracovia.

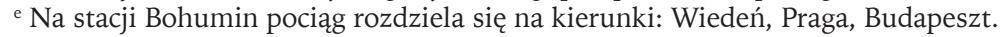

${ }^{\mathrm{f}}$ Liczba miejsc na odcinku Warszawa Wsch.-Bohumin.

g Usługi gastronomiczne od Lwowa do Kijowa.

${ }^{\text {h }} \mathrm{Na}$ stacji Bohumin dwa wagony do Budapesztu przepinane są do pociągu 131 Batory.

i Połowa wagonu to 1 klasa, połowa to wagon restauracyjny.

j Kursuje w relacji Przemyśl Gł.-Budapest Nyugati.

${ }^{k}$ Wars Minibar kursuje od Przemyśla Gł. do Bohumina.

${ }^{1}$ Jeden wagon do stacji Kiev Pass.

m Od 24 czerwca $2021 \mathrm{r}$.

${ }^{\mathrm{n}}$ Pociąg kursujący w sezonie wakacyjnym.

- Wagony rozdzielane na stacji Gdynia Główna.

P Do pociągu dołączane są wagony z pociągów: 476 Metropol, 36170 Pogórze.

q Obowiązuje od Wrocławia Gł. do Berlina.

Źródło: opracowanie własne na podstawie rozkładu jazdy.

Z zestawienia w tabeli 2 możemy wywnioskować, że większość kursów transgranicznych to połączenia dzienne. Rola wagonów sypialnych zmniejszyła się z powodu rozwoju lotnictwa (Beim, Soczówka, 2016). Część pociągów ma możliwość przewozu roweru, a także dostosowania do przewozu osób niepełnosprawnych. 
Na rycinie 2 przedstawiono średnie dzienne możliwości przewozowe pociągów, aby łatwiej porównać dostępne połączenia międzynarodowe. Dane zostały uśrednione, ponieważ pociągi nr 409, 440, 452 nie kursują codziennie.

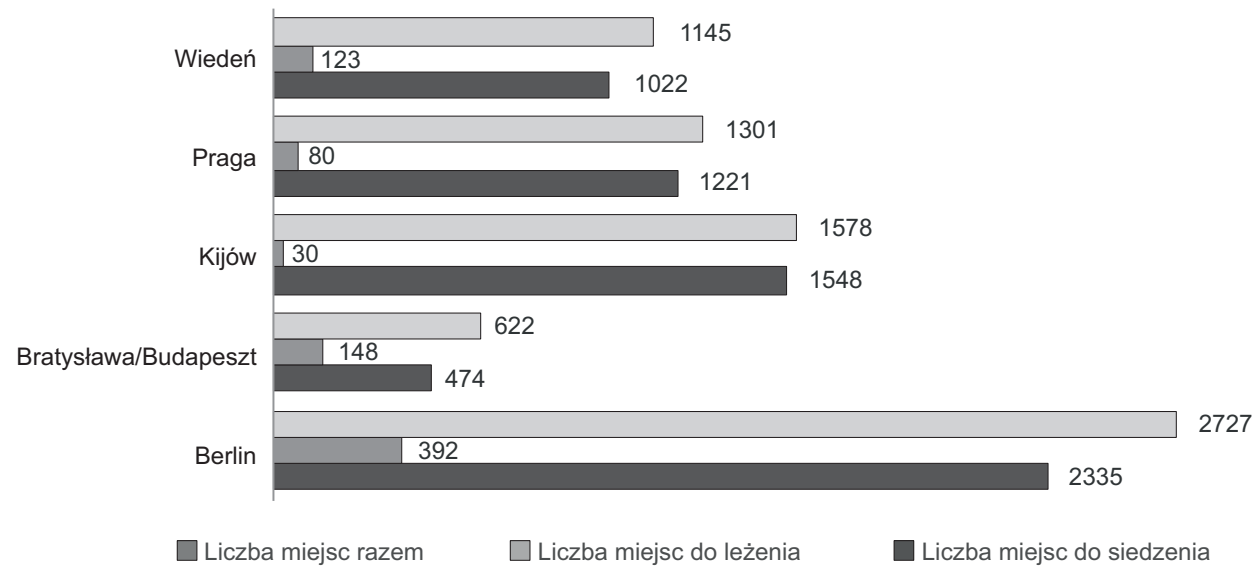

Ryc. 2. Średnie dzienne możliwości przewozowe do wybranych stolic europejskich pod względem liczby miejsc

Źródło: opracowanie własne.

Największe możliwości przewozowe mają połączenia transgraniczne do Niemiec. Pociągi mogą przewieźć w ciągu doby ponad 2,7 tys. podróżnych. Ruch kolejowy odbywa się przez najważniejsze przejście graniczne pomiędzy Słubicami a Frankfurtem nad Odrą. W tym miejscu granicę przekraczają pociągi z: Warszawy, Gdyni, Przemyśla oraz połączenia transkontynentalne (Dębski, 2019). Zaletą tych kursów jest dobra dostępność przewozowa.

Drugie miejsce $\mathrm{w}$ zestawieniu zajmuje Ukraina. Połączenia do tego kraju wyróżniają się niską ceną. Aby dotrzeć koleją na Ukrainę, zwykle jednak trzeba skorzystać z przesiadki w Przemyślu (73\% dostępnych miejsc). Ruch pasażerski odbywa się na przejściach granicznych w Medyce i Dorohusku. Pomiędzy Polską a Ukrainą istnieje różnica w rozstawie szyn. Jest to pewna bariera, która wymusza konieczność stosowania nowoczesnych rozwiązań technicznych, a także z zakresu planowania przestrzennego (Gamon, Gómez, 2019). Zaletą przejścia granicznego w Medyce jest to, że jest to linia zelektryfikowana i ruch odbywa się po obu rozstawach szyn - 1435 i $1520 \mathrm{~mm}$ (Graff, 2017).

Niskie znaczenie przewozowe mają pociągi do Budapesztu/Bratysławy. Wynika to z okrężnej trasy do tych miast. W kierunku tych stolic europejskich ruch odbywał się głównie przez przejście graniczne w Muszynie (Beim, Soczówka, 2016). Obecnie kursują tam tylko 2 połączenia weekendowe pomiędzy Muszyną a Popradem. Realizowane są one przez Koleje Małopolskie we współpracy z Kolejami Słowackimi. Ruch do Budapesztu i Bratysławy odbywa się przez Chałupki lub Zebrzydowice, co wydłuża odległość, a tym samym - czas jazdy. Aktualny stan infrastruktury kolejowej nie pozwala na prowadzenie konkurencyjnej oferty 
pomiędzy Krakowem a Muszyną. Średnia prędkość pociągu IC z Krakowa do Muszyny wynosi 59 km/godz., zaś z Krakowa do Chałupek 77 km/godz. ${ }^{2}$

W tabeli 3 przeanalizowano najpopularniejsze połączenia. Porównano: odległość, średnią prędkość, a także cenę. Pozwala to wyróżnić mocne i słabe strony transgranicznych połączeń międzynarodowych.

Tabela 3. Zestawienie wybranych relacji pociągów międzynarodowych IC ${ }^{a}$

\begin{tabular}{|c|c|c|c|c|c|c|}
\hline Trasa & $\mathrm{n}$ & $\mathrm{s}(\mathrm{km})$ & $\mathrm{t} \min$. & $\begin{array}{c}\text { V śr. } \\
(\mathrm{km} / \mathrm{h})\end{array}$ & $\begin{array}{c}\text { Cena biletu } \\
\text { promocyjne- } \\
\text { go }^{\text {b }} \text { (euro) }\end{array}$ & $\begin{array}{c}\text { Cena } \\
\text { bazowa } \\
\text { (euro) }\end{array}$ \\
\hline Kraków-Grodno & 1 & 562 & $8 \mathrm{~h} 16 \mathrm{~min}$ & 68,03 & - & 21,50 \\
\hline Warszawa-Grodno & 1 & 269 & $5 \mathrm{~h} 06 \mathrm{~min}$ & 52,75 & - & 15,70 \\
\hline Warszawa-Berlin & 5 & 570 & $5 \mathrm{~h} 27 \mathrm{~min}$ & 104,59 & $24,90-42,90$ & 52,60 \\
\hline Poznań-Berlin & 6 & 258 & $2 \mathrm{~h} 47 \mathrm{~min}$ & 92,81 & $14,90-24,90$ & 39,80 \\
\hline Gdynia-Berlin & 1 & 591 & $6 \mathrm{~h} 05 \mathrm{~min}$ & 97,20 & $24,90-42,90$ & 52,00 \\
\hline $\begin{array}{l}\text { Kraków-Berlin } \\
\text { dzienny/nocny }\end{array}$ & $1 / 1$ & $609 / 649$ & $\begin{array}{l}6 \mathrm{~h} 58 \mathrm{~min} / \\
9 \mathrm{~h} 08 \mathrm{~min}\end{array}$ & $\begin{array}{c}87,37 / \\
71,08\end{array}$ & $19,90-39,90$ & 45,00 \\
\hline Warszawa-Praga & 2 & 748 & $7 \mathrm{~h} 58 \mathrm{~min}$ & 93,85 & $19,90-54,90$ & 88,20 \\
\hline $\begin{array}{l}\text { Warszawa-Wiedeń } \\
\text { dzienny/nocny }\end{array}$ & $2 / 1$ & $660 / 760$ & $\begin{array}{l}7 \mathrm{~h} 10 \mathrm{~min} / \\
11 \mathrm{~h} 16 \mathrm{~min}\end{array}$ & $\begin{array}{r}92,05 / \\
67,44\end{array}$ & $19,90-54,90$ & 69,00 \\
\hline $\begin{array}{l}\text { Warszawa-Buda- } \\
\text { peszt }\end{array}$ & 1 & 873 & $10 \mathrm{~h} 31 \mathrm{~min}$ & 82,98 & $19,90-54,90$ & 106,60 \\
\hline Przemyśl-Lwów & 3 & 98 & $1 \mathrm{~h} 52 \mathrm{~min}$ & 52,40 & - & 7,40 \\
\hline Przemyśl-Kijów & 2 & b.d. & $7 \mathrm{~h} 12 \mathrm{~min}$ & b.d. & - & 22,40 \\
\hline Przemyśl-Odessa & 1 & b.d. & $15 \mathrm{~h} 26 \mathrm{~min}$ & b.d. & - & 32,60 \\
\hline
\end{tabular}

Legenda: $\mathrm{n}$ - liczba par połączeń; s - odległość; $\mathrm{t}$ min. - minimalny czas przejazdu; V śr. - średnia prędkość; b.d. - brak danych.

${ }^{\text {a }}$ Planowany stan na dzień 13 kwietnia $2021 \mathrm{r}$.

${ }^{\mathrm{b}}$ Bilet Oferty Super Promo International, który nie podlega ani wymianie, ani zwrotowi.

Źródło: opracowanie własne na podstawie rozkładu jazdy i Taryfy Międzynarodowej pociągów PKP IC.

W tabeli możemy też znaleźć kilka zależności. Największą prędkość osiągają kursy w kierunku Niemiec, co skutkuje najkorzystniejszym czasem przejazdu. Połączenia te obsługiwane są pociągami wyższej kategorii - EIC, które mają priorytet przejazdu w Polsce. Służą one rozwojowi turystyki międzynarodowej, a także tzw. city breaków. Składy te są nowoczesne, mają w większości wagon restauracyjny, który jest udogodnieniem dla podróżnych. Dostosowane są również do przewozów osób niepełnosprawnych, zapobiegając ich wykluczeniu. Ważną zmianą w rozkładzie jazdy 2020/21 jest powrót pociągu IC Wawel z Krakowa do Berlina. Połączenie pierwotnie kursowało do Hamburga. W 2012 r. zostało zawieszone m.in. ze względu na zły stan infrastruktury kolejowej na odcinkach: Kraków-Katowice oraz Opole-Kędzierzyn Koźle (Budzowski, 2015). Obecnie poprawiła się szybkość jazdy pomiędzy Krakowem a Katowicami, co wpłynęło na krótszy czas przejazdu kilku połączeń międzynarodowych.

\footnotetext{
Według rozkładu jazdy funkcjonującego do 13 marca $2021 \mathrm{r}$.
} 
Na granicy z Białorusią odnotowano wzrost liczby pasażerów, co ma związek z rozwojem turystyki zakupowej (Beim, Soczówka, 2016). Najwięcej pasażerów przekracza granicę w Terespolu. Przez drugie przejście (Kuźnica Białostocka) kursuje pociąg IC Hańcza (relacji Kraków Gł.-Grodno). Porusza się on z dużą prędkością z Krakowa do Warszawy (97,02 km/godz.). Prędkość ta jest rezultatem małej liczby postojów ${ }^{3}$, a także przejazdu Centralną Magistralą Kolejową ${ }^{4}$ Z Warszawy do Białegostoku pociąg jedzie wolniej niż z Krakowa do Warszawy (modernizacja linii kolejowej, więcej postojów handlowych). Dodatkowo czas przejazdu wydłuża postój w Białymstoku, w którym rozdzielane są wagony: część jedzie do Suwałk, pozostała do Grodna. Zaletą tego pociągu jest duża liczba miejsc dla rowerów, co ułatwia uprawianie turystyki rowerowej.

Warto zauważyć, że pociągi nocne jadą dłużej niż dzienne. W przypadku kursu z Krakowa (IC Podgórze ${ }^{5}$ i Warszawy (IC Chopin ${ }^{6}$ ) wynika to z wydłużenia trasy. Dodatkowo pierwszy z nich ma dłuższy postój we Wrocławiu spowodowany przepinaniem wagonów IC Podgórze do pociągu NightJet, zaś drugi jedzie objazdem na trasie Miechów-Kraków ${ }^{7}$ (dodatkowe 46 min podróży) ${ }^{8}$.

\section{Zakończenie}

Obszary transgraniczne są bardzo ważnymi miejscami destynacji turystów krajowych i zagranicznych (Więckowski, 2011). Należy zatem zwiększać rolę turystyki transgranicznej. Odcinki graniczne różnią się od siebie w aspektach technicznych i operacyjnych (Gamon, Gómez, 2019), co utrudnia szybki transfer. Sytuacja połączeń poprawia się systematycznie. Jednakże nie udało się zlikwidować wszystkich barier związanych z brakiem połączeń lub znikomą ich liczbą (Budzowski, 2015). Stopniową poprawę połączeń zaobserwowano w kierunku Niemiec i Czech (Beim, Soczówka, 2016). Na znaczną poprawę w kierunku Czech, Austrii i Węgier można liczyć dopiero po roku 2030 (Sitarz i in., 2019). Należy kontynuować procesy integracji europejskiej w celu ułatwienia przekraczania granic transportem kolejowym.

Spadek podróży kolejowych ma przyczynę we wzroście motoryzacji, a także nietrwałości regionalnych połączeń (Beim, Soczówka, 2016). Aby turystyka międzynarodowa miała rację bytu z udziałem transportu kolejowego, należy utrzymać dość stabilną siatkę pomiędzy sąsiadami Polski, wprowadzić atrakcyjne ceny biletów oraz zadbać o odpowiednią promocję i informację. Zintegrowane działania pomiędzy państwami pomogą realizować transgraniczne połączenia kolejowe. W tym kontekście na uwagę zasługuje spojrzenie na taryfę międzynarodową. Jest

3 Do Warszawy tylko 3 postoje.

4 Obecnie najszybsza linia kolejowa w kierunku Warszawy, pociąg IC Hańcza porusza się nią na trasie od Psar do Grodziska Mazowieckiego.

5 Pociąg relacji Przemyśl Gł.-Wrocław Gł. z grupą wagonów docelowych do Berlina.

6 Pociąg relacji Warszawa Wsch.-Wien Hbf., z wagonami bezpośrednimi do Budapesztu i Pragi.

7 Średni czas przejazdu pociągu IC na tym 42-kilometrowym odcinku to $30 \mathrm{~min}$. IC Chopin jedzie trasą o długości $71 \mathrm{~km}$, w czasie 1 godz.16 min.

8 Według rozkładu jazdy funkcjonującego do 13 marca 2021 r. 
ona nieatrakcyjna pod względem cen. Bilet w bezpośredniej relacji jest dużo droższy od sumy biletów krajowych. Wprowadzenie limitowanych biletów Spar Day/ Night nie poprawiło tej sytuacji (Beim, Soczówka, 2016). Często podróżni kupują bilet krajowy do stacji granicznej, następnie „przejściówkę"9 u drużyny konduktorskiej i bilet na odcinek za granicą w tańszej ofercie przewoźnika. Jednakże wiąże się to ze skomplikowanym procesem kupna biletów. Ważnym elementem rozwoju połączeń międzynarodowych będzie szersza dystrybucja biletów międzynarodowych na stronie operatora PKP IC. Obecnie można przez tę stronę kupić jedynie bilety do Berlina i na pojedyncze połączenia do Wiednia. Pozostałe oferty dostępne są wyłącznie w kasie biletowej przewoźnika.

$\mathrm{Na}$ Ukrainie często wybieranym środkiem lokomocji jest pociąg ze względu na stosunkowo niską cenę biletu. Utrudnieniami w transporcie kolejowym w tym kraju są: obowiązkowa kontrolna celna, inny rozstaw szyn i konieczność przesiadki w zdecydowanej ilości połączeń. Te czynniki wydłużają czas przejazdu do miejsca destynacji turystycznych. Zarówno połączenia z Ukrainą, jak i z Białorusią są bardzo ważnym elementem próby integracji tych państw z Unią Europejską.

Głównymi celami transportu kolejowego na najbliższe lata, w płaszczyźnie połączeń międzynarodowych, powinny być: próba integracji systemów taryfowych pomiędzy członkami Unii Europejskiej, skrócenie czasu przejazdu oraz rewitalizacja zamkniętych odcinków transgranicznych, które mogą być atrakcyjne ze względu na swoje walory.

\section{Literatura}

Anisiewicz R. (2020). Tourist assets of the cross - border railway line Brest-WłodawaChełm. Transport Geography Papers of Polish Geographical Society, 23(4): 19-31.

Bebenow F. (2015). Turystyka kolejowa w Polsce. Bogucki Wydawnictwo Naukowe, Poznań. Beim M., Soczówka A. (2016). Rozwój kolejowych, regionalnych połączeń transgenicznych w Polsce. Transport Miejski i Regionalny, 10: 19-24.

Brożek P., Błądek M. (2020). Turystyka (https://mfiles.pl/pl/index.php/Turystyka; dostęp: 27.12.2020).

Budzowski A. (2015). Problem międzynarodowych połączeń kolejowych Krakowa w kontekście aktualnego Planu zrównoważonego rozwoju publicznego transportu zbiorowego. Transport Miejski i Regionalny, 1: 15-23.

Candela G., Figini P. (2012). The economics of Tourism destinations. Springer, Heidelberg.

Dębicki M. (2019). Wyczytane z rozkładu jazdy. Transgraniczne połączenia kolejowe Polski - portret ilościowy i wstępne tropy interpretacyjne. UR Journal of Humanities and Social Sciences, 4(13): 112-130.

Duda T. (2018). Kierunki i perspektywy rozwoju turystyki kulturowej w transgranicznej przestrzeni współdzielonego dziedzictwa (przykład Pomorza Zachodniego). Folia Turistica, AWF w Krakowie, 48: 41-60.

Gamon W., Gómez J. (2019). Main Problems of Railway Cross-Border Transport Between Poland, Germany and Czech Republic. Sustainability, 11(18): 4900.

Gaworecki W. (2003). Turystyka. Polskie Wydawnictwo Ekonomiczne, Warszawa.

\footnotetext{
9 Bilet pomiędzy stacjami granicznymi.
} 
Gosik B., Zimon G. (2014). Usługi transportowe w obsłudze ruchu turystycznego. Zeszyty Naukowe Uniwersytetu Szczecińskiego, 843, Problemy Transportu i Logistyki, 28.

Graff M. (2017). Komunikacja kolejowa pomiędzy Polską i Ukrainą. TTS Technika Transportu Szynowego, R. 24, 7-8: 55-71.

Kovačić M., Milošević T. (2016). Interdependence of Transport and Tourism. Pomorski zbornik, 52: 99-111.

Małysz M. (2020). Nocne pociągi dalekobieżne w przestrzeni Polski - zarys historyczny i perspektywy rozwoju. Prace Geograficzne, 160: 53-73.

Mammadov R. (2012). The Importance of Transportation in Tourism Sector. Silk Road International Conference „Challenges and Opportunities of Sustainable Economic Development in Eurasian Countries”, s. 381-386.

Meyer B. (2006). Funkcje turystyki. W: A. Panasiuk (red.), Ekonomika turystyki. Wydawnictwo Naukowe PWN, Warszawa, s. 31-43.

Michniak D. (2016). Role of railway transport in tourism: selected problems and examples in Slovakia. Quaestiones Geographicae, 35(4): 107-120.

Niemczyk A. (2010). Turystyka transgraniczna w powiecie nowosądeckim - szanse i zagrożenia. Sądeckie Zeszyty Naukowe, s. 77-88.

Przybła Z. (1995). Problemy współpracy ekonomicznej regionów przygranicznych (na przykładzie euroregionu Nysa). Prace Naukowe Akademii Ekonomicznej we Wrocławiu, 708: 201.

Sitarz M., Bużałek T., Pomykała A., Raczyński J. (2019). Katowicki Węzeł Kolejowy - uwarunkowania historyczne i perspektywy rozwoju TEN-T. TTS Technika Transportu Szynowego, R. 26, 11-12: 35-46.

Więckowski M. (2010). Turystyka na obszarach przygranicznych Polski. Instytut Geografii i Przestrzennego Zagospodarowania PAN, Warszawa.

Więckowski M. (2011). Kształtowanie się transgranicznych regionów turystycznych na granicach Polski. Prace Kom. Geogr. Komunik. PTG, 18: 171-190.

Więckowski M. (2020). Symboliczne łączenie transgranicznych miast nadmorskich. Przykład Świnoujście-Heiringsdorf. Studia Polityczne, 48, 2: 241-259.

\section{Determinants of the use of rail transport in the development of international tourism}

Cross-border rail links are an important part of international tourism. Its importance is growing, which is reflected in the constantly expanding range of rail operators. The article analyses the available offer of cross-border connections in Poland. It compares parameters such as the number of seats, journey time and price based on the available network of connections. The fundamental objective of the article is to examine the current state of cross-border connections with a view to their use as a tourist means of transport. In the paper a synthetic analysis of the available railway connections was made, as well as their comparison with each other. The considerations presented are an attempt to answer the question whether rail transport contributes to the development of international tourism. They can be treated as an inspiration for research related to the subject of cross-border railways in Poland. 



\section{Ewa Iwaniuk}

Politechnika Białostocka

iwaniukewaa@gmail.com

\section{Rola pracowników w zarządzaniu modelem otwartych innowacji}

\section{Streszczenie}

Zarówno w teorii, jak i w praktyce wprowadzanie innowacji uznaje się za jeden z najważniejszych czynników we współczesnej działalności przedsiębiorstw decydującej o ich przetrwaniu i konkurencyjności. Niezbędne do wprowadzenia innowacji jest odpowiednie dobranie metod zarządzania, jakimi są modele zarządzania innowacjami. Odchodzi się od tradycyjnych modeli i uwagę poświęca nowym, jednym z nich jest otwarty model innowacji powstały na początku XXI w., wraz z którym zmieniło się podejście organizacyjne przedsiębiorstwa. Spowodował on zmiany w sposobie zarządzania zasobami ludzkimi poprzez odrzucenie tradycyjnego podejścia zarządzania pracownikami i wybranie nowoczesnych metod menedżerskich angażujących pracowników w tworzenie wartości dodanej dla przedsiębiorstwa. Celem niniejszego rozdziału jest przedstawienie roli pracowników na różnym szczeblach w przedsiębiorstwie stosującym model otwartych innowacji.

\section{Wprowadzenie}

Pojęcie innowacji jest bardzo szerokim zagadnieniem, które obejmuje zarówno zjawiska finansowe, ekonomiczne, techniczne, jak i organizacyjne. Samo słowo „innowacja” łączy się z szeregiem terminów synonimicznych, takich jak „usprawnienie”, „unowocześnienie”, „modernizacja”, „modyfikacja” lub „poprawa”. W dzisiejszych czasach innowacja bardzo często wiąże się ze zmianą, ale może odnosić się do każdego obszaru, którego ta zmiana dotyczy. Innowację można zdefiniować jako każdą zmianę dla organizacji, niezależnie od tego, czy jest ona nowa na rynku, czy jest to zmiana imitacyjna zaczerpnięta z otoczenia, pod warunkiem że jej wprowadzenie przynosi korzystne zmiany w przedsiębiorstwie. Innowacja to zmiana, która powinna być wprowadzana świadomie i celowo oraz 
mieć charakter trwały, modyfikować stare lub tworzyć zupełnie nowe elementy w sposobie funkcjonowania danego podmiotu gospodarczego (Białoń, 2018). Przedmiotem innowacji może być doskonalenie usług lub produktów poprzez wdrażanie nowych rozwiązań lub zastępowanie istniejących metod nowymi, zmiana systemu zarządzania, marketingu, procesów produkcyjnych, organizacji, a także wykorzystanie nowych technik (Szymańska, 2013).

Możliwość tworzenia innowacji przez przedsiębiorstwo nie oznacza, że są one rzeczywiście wprowadzane. W praktyce, aby wdrażanie innowacji było skuteczne, konieczne jest dostosowanie zarówno czynników wewnętrznych, jak i zewnętrznych wpływających na funkcjonowanie organizacji, pozwala na to odpowiednie dobranie modelu zarządzania innowacjami przez przedsiębiorstwo. Implementacja innowacji wiąże się z procesem działania zespołu - od koncepcji do jej zastosowania. W literaturze przedmiotu proces innowacyjny przedstawiany jest często w ujęciu modelowym, według Druckera można go zdefiniować jako: skoordynowane, systematyczne, zorganizowane i celowe działanie, oparte na stosunkowo prostych zasadach postępowania, umożliwiające racjonalne i powtarzalne przekształcenie idei w innowację (Drucker, 1994). Model innowacji to zatem schemat działań, podejmowanych w przedsiębiorstwie w celu wdrożenia innowacji.

\section{Istota modelu otwartych innowacji}

W literaturze proces innowacyjny przedstawiany jest $\mathrm{w}$ formie systemowej lub modelowej. W latach 90. XX w. wyodrębniono 5 generacji modeli innowacji, które wystąpiły do tego czasu. Dokonał tego Rothwell (1992). Model otwartych innowacji można uznać za kolejną, 6 generację modeli innowacji. Inne podejście do zarządzania innowacjami przedstawił Chesbrough (1994), który sklasyfikował modele od tradycyjnych poprzez sprzężone i równoległe do nowoczesnych (Rojek, 2014).

Pierwszym tradycyjnym modelem procesu innowacyjnego był model liniowy podażowy opierający się na teorii Schumpeterowskiej, jego koncepcja dominowała od lat 50. do lat 80. XX w. Model ten opiera się na ośrodku badań i rozwoju (B+R) zlokalizowanym $\mathrm{w}$ przedsiębiorstwie lub jego otoczeniu, który korzysta $\mathrm{z}$ różnych odkryć naukowych. Składa się on z 4 uporządkowanych chronologicznie faz (badania podstawowe, badania stosowane, wdrożenie oraz marketing) (Reformat, 2018). Model popytowy podobnie jak podażowy składa się z 4 uporządkowanych faz, jednak jego najważniejszym czynnikiem jest potrzeba rynkowa, która odgrywa rolę bodźca powstania innowacji. Po tej fazie przeprowadzane są prace rozwojowe, a następnie wdrożenie oraz sprzedaż. W odróżnieniu od modelu podażowego w modelu popytowym badania i rozwój nie są konieczne, istotny jest rynek, który jest źródłem pomysłów, oraz potrzeby klientów (Kozioł, 2008). W przejściowym etapie ewolucji, między tradycyjnym i nowoczesnym modelem, wyodrębniono model sprzężony niemający liniowego charakteru, a będący modelem interakcyjnym. Dotyczy on wzajemnych powiązań pomiędzy firmą i jej otoczeniem, uwzględnia powiązania między poszczególnymi elementami wynikającymi ze sprzężenia 
między rynkiem, potrzebami potencjalnych nabywców, przedsiębiorstwem a nauką (Stabryła, 2012). Następny w ewolucji, model równoległy, który w literaturze zwany jest samouczącym się, charakteryzuje się współpracą oraz powiązaniami pomiędzy firmą, dostawcami oraz klientami. Dąży do wprowadzania zmian w koncepcji przedsiębiorstwa oraz podnoszenia jego sprawności. Koncentruje się na uczeniu się i zarządzaniu wiedzą (Szymańska, 2009). Uznany za nowoczesny, model sieciowy uwzględnia zewnętrzne i wewnętrzne powiązania oraz sprzężenia zwrotne zachodzące między strefą $B+R$, produkcja, marketingiem, firmami i instytucjami, a także współpracę z klientami oraz dostawcami w zakresie marketingu i badań (Turek i in., 2011). Model otwartych innowacji to nowoczesne podejście do zarządzania innowacjami zaprezentowane przez Chesbrougha (1994). Model otwartej innowacji polega na współpracy przedsiębiorstwa $z$ otoczeniem. Zakłada się w nim, że istotne pomysły innowacyjne można znaleźć wszędzie, a najskuteczniejsze rezultaty przynosi łączenie pomysłów innowacyjnych z wewnętrznych i zewnętrznych źródeł organizacji. Przedsiębiorstwo czerpie wiedzę ze swojego makro- i mikrootoczenia, równocześnie dzieląc się własną wiedzą. Proces ten pozwala pozyskiwać firmie wiedzę techniczną z takich zewnętrznych źródeł, jak: klienci, dostawcy, eksperci, uniwersytety, jednostki badawczo-rozwojowe, konkurenci od innych podmiotów otoczenia rynkowego (Pichlak, 2012).

Tradycyjne modele procesu innowacyjnego zwane „zamkniętymi innowacjami" opierają się wyłącznie na zasobach własnych organizacji, wszelkie badania $\mathrm{B}+\mathrm{R}$, własność intelektualna, wynalazki lub patenty są silnie chronione przed konkurencją. Tradycyjne modele wymagają dużych nakładów finansowych, przez co wykorzystywane i wdrażane są jedynie przez silne finansowo przedsiębiorstwa. Nowoczesne modele procesu innowacyjnego zwane „otwartymi innowacjami” są przeciwieństwem wcześniejszych modeli (Kozioł-Nadolna, 2012). Różnicę między zamkniętymi oraz otwartymi innowacjami przedstawiono w tabeli 1.

Tabela 1. Porównanie koncepcji zamkniętej i otwartej innowacji

\begin{tabular}{ll}
\hline Wyszczególnienie & Koncepcja zamkniętej innowacji \\
\hline Sposób tworzenia & Sukces wynika z uzyskania \\
wartości dodanej & przewagi nad konkurenta- \\
& mi w zakresie pierwszeństwa \\
& wprowadzonych na rynek inno- \\
& wacji.
\end{tabular}

Koncepcja otwartej innowacji Synergia wynika $z$ dopasowania zewnętrznych i wewnętrznych zasobów wiedzy w celu dostarczania wartości akceptowanej przez rynek. Zewnętrzne zasoby stanowią istotną wartość, podczas gdy wewnętrzne zasoby $B+R$ odpowiedzialne są za właściwe wykorzystanie tej wartości.

Forma
organizacyjna
systemu
innowacji

Działalność innowacyjna realizowana jest w oparciu o zaplanowany proces innowacyjny z ustaloną konfiguracją łańcucha wartości kształtowaną przez inicjujące przedsiębiorstwo.

Działalność innowacyjna koordynowana jest przez przedsiębiorstwo, natomiast zakres i sposób działania zależą od wzajemnych interakcji z podmiotami otoczenia. 


\begin{tabular}{|c|c|c|}
\hline Wyszczególnienie & Koncepcja zamkniętej innowacji & Koncepcja otwartej innowacji \\
\hline $\begin{array}{l}\text { Kluczowy czynnik } \\
\text { sukcesu }\end{array}$ & $\begin{array}{l}\text { Koncentracja na planowanym } \\
\text { rozwoju własnych zasobów na } \\
\text { potrzeby działalności B+R oraz } \\
\text { zabezpieczeniu korzyści wyni- } \\
\text { kających z wyłączności dyspo- } \\
\text { nowania innowacją na rynku. }\end{array}$ & $\begin{array}{l}\text { Zapewnienie koordynacji dzia- } \\
\text { łań poszczególnych podmiotów } \\
\text { w procesie innowacji. Koncentra- } \\
\text { cja na podnoszeniu efektywności } \\
\text { procesu innowacji i generowaniu } \\
\text { strumieni przychodów. }\end{array}$ \\
\hline $\begin{array}{l}\text { Regulacja } \\
\text { współpracy }\end{array}$ & $\begin{array}{l}\text { Dominuje podejście oparte na } \\
\text { teorii zasobowej. Przedsiębior- } \\
\text { stwo dąży do akumulacji z oto- } \\
\text { czenia zasobów w oparciu o re- } \\
\text { lacje podwykonawstwa. }\end{array}$ & $\begin{array}{l}\text { Dominuje podejście oparte na } \\
\text { teorii kosztów transakcyjnych. Za- } \\
\text { kres współpracy zależy od celów } \\
\text { przedsiębiorstwa kształtujących } \\
\text { relacje z otoczeniem. Relacje bila- } \\
\text { teralne oparte są na transakcjach } \\
\text { i częściowo współdzieleniu zaso- } \\
\text { bów. }\end{array}$ \\
\hline Efekty prac $B+R$ & $\begin{array}{l}\text { Własność intelektualna jest } \\
\text { traktowana jako źródło przewa- } \\
\text { gi konkurencyjnej i tym samym } \\
\text { ma być chroniona przed rozpo- } \\
\text { wszechnianiem. }\end{array}$ & $\begin{array}{l}\text { Powstające innowacje są wynikiem } \\
\text { wspólnych prac kooperujących } \\
\text { podmiotów. Innowacje wytworzo- } \\
\text { ne przez przedsiębiorstwo, które } \\
\text { nie mogą być dyskontowane w ra- } \\
\text { mach obecnego modelu bizneso- } \\
\text { wego, należy komercjalizować. }\end{array}$ \\
\hline $\begin{array}{l}\text { Dystrybucja } \\
\text { korzyści z prac } \\
\mathrm{B}+\mathrm{R}\end{array}$ & $\begin{array}{l}\text { Dążenie do przechwycenia } \\
\text { wartości. Działalność B+R jest } \\
\text { jednym z głównych procesów } \\
\text { kreujących przewagę konkuren- } \\
\text { cyjną. }\end{array}$ & $\begin{array}{l}\text { Zależna jest od decyzji zaangażo- } \\
\text { wanych przedsiębiorstw. Organi- } \\
\text { zacje są zainteresowane współpra- } \\
\text { cą i dzieleniem korzyści. }\end{array}$ \\
\hline
\end{tabular}

Źródło: Mielcarek (2018).

W literaturze przedmiotu występuje wiele definicji otwartych innowacji, najczęściej autorzy powołują się na definicję Chesbrougha (1994), w tabeli 2 przedstawiono wybrane definicje otwartych innowacji.

Tabela 2. Wybrane definicje otwartych innowacji

\begin{tabular}{ll}
\hline \multicolumn{1}{c}{ Autor } & \multicolumn{1}{c}{ Definicja } \\
\hline $\begin{array}{l}\text { Chesbrough } \\
(2003)\end{array}$ & $\begin{array}{l}\text { Koncepcja otwartych innowacji jest paradygmatem, w którym fir- } \\
\text { my mogą i powinny wykorzystywać zarówno zewnętrzne, jak i we- } \\
\text { wnętrzne pomysły w swoich procesach innowacyjnych oraz we- } \\
\text { wnętrzne i zewnętrzne ścieżki wprowadzania innowacji na rynek. }\end{array}$ \\
\hline Chesbrough & Otwarte innowacje to celowy przypływ i wypływ wiedzy, który \\
przyspiesza wewnętrzne innowacje w firmie. Otwarte podejście \\
Oznacza, że firmy powinny w większym stopniu korzystać z ze- \\
wnętrznych pomysłów i technologii oraz pozwalać korzystać in- \\
nym firmom z nieużywanych obecnie pomysłów.
\end{tabular}




\begin{tabular}{ll}
\hline \multicolumn{1}{c}{ Autor } & \multicolumn{1}{c}{ Definicja } \\
\hline West, Gallagher & $\begin{array}{l}\text { Podejście open innovation oznacza systematyczne dopingowanie } \\
\text { i badanie wewnętrznych i zewnętrznych źródeł dla innowacji, co } \\
\text { integruje badania z możliwościami i zasobami firmy. }\end{array}$ \\
\hline Laursen, Salter & $\begin{array}{l}\text { Otwartość rozumiana jest jako liczba różnych zewnętrznych źró- } \\
\text { deł aktywności innowacyjnej firmy. Zgodnie z tą logika, im więk- } \\
\text { sza liczba zewnętrznych źródeł, tym większa otwartość firmy. }\end{array}$ \\
\hline
\end{tabular}

Źródło: Kozioł-Nadolna (2012).

Chesbrough (1994) w swym modelu zakłada, że firma nie ma możliwości zatrudnienia wszystkich najlepszych specjalistów, dlatego istotne jest nawiązanie współpracy $z$ partnerami $z$ różnych środowisk. Przedsiębiorstwo nie musi prowadzić własnych prac badawczo-rozwojowych, może korzystać z zewnętrznych dokonań w zakresie B+R. Korzystanie z zewnętrznej wiedzy oraz własności intelektualnej jest zalecane, jeżeli ulepszy to działanie organizacji (Jasiński, 2019). Zgodnie z założeniem modelu, firmy powinny nabywać patenty, własność intelektualną i inne innowacyjne rozwiązania, jednocześnie udostępniając swoje wynalazki i prace badawczo-rozwojowe, które nie zostały przez nie wykorzystane (Zajkowska, 2017).

\section{Rola pracowników w zarządzaniu innowacjami}

Tradycyjna rola pracownika w organizacji opiera się na dopasowaniu do powstałych procedur, zadaniem pracownika jest wykonywanie ściśle określonych działań, które podlegają kontroli. Powinien on wykonywać swoją pracę jak najszybciej i jak najsprawniej, nie wymaga się od niego odpowiedzialności i wykazywania inicjatywy, jak również nie stwarza się możliwości samodzielnego decydowania o przebiegu jego pracy (Grzeganek-Więcek, 2014). W modelu otwartych innowacji rolą pracownika jest ciągłe zdobywanie wiedzy, podnoszenie kwalifikacji oraz zdobywanie doświadczenia, którym następnie powinien się dzielić z kadrą kierowniczą i współpracownikami. Pracownik powinien dążyć do samorealizacji poprzez własny rozwój oraz do optymalizacji własnego potencjału, który następnie zostanie wykorzystany jako wartość dodana dla przedsiębiorstwa. Zgłaszanie pomysłów, inicjowanie działań oraz poszukiwanie informacji i wiedzy z zewnątrz jest propagowane przez przełożonych. Model otwartych innowacji zakłada pracę w grupie, w której znajdują się samodzielne jednostki posiadające odpowiednie cechy, wiedzę oraz doświadczenie, natomiast wymiana informacji między pracownikami pracującymi w grupie zwiększa jej efektywność (Wiśniewska, 2013).

Praca $\mathrm{w}$ zespole wyklucza podejście indywidualne, dlatego grupa pracowników wymaga kierownictwa osoby decyzyjnej, odpowiedzialnej za zarządzanie $\mathrm{w}$ trakcie procesu innowacyjnego. Taką funkcję pełni menedżer. Menedżerowie zarządzający innowacjami są elementem systemu zarządzania innowacjami przyjętego w przedsiębiorstwie. 
Rola kierownictwa w zarządzaniu innowacjami jest niezmiernie ważna, menedżerowie mają za zadanie ustalanie celów, organizowanie struktury pracy i działań pracownika poprzez dzielenie zadań oraz dobieranie odpowiednich ludzi do ich realizacji, motywowanie i informowanie, aby stworzyć zintegrowany zespół, ustalanie miernika oceny wyników dla określenia wydajności całego zespołu i pojedynczych jego członków oraz wpływanie na rozwój pracowników. Dodatkowym zadaniem menedżera jest upowszechnianie wizji rozwoju przedsiębiorstwa, tworzenie kultury zarządzania innowacją, kształtowanie otoczenia oraz propagowanie nowych idei wśród podwładnych (Wyroba, 2015).

Menedżer reprezentuje też organizację podczas spotkań lub kontaktów z innymi przedsiębiorcami oraz jest łącznikiem, utrzymując kontakty z partnerami, organizacjami, uczelniami itp. Zawiera umowy oraz prowadzi działania zewnętrzne. Szczegółowe zadania menedżera przedstawiono w tabeli 3.

We współczesnym zarządzaniu kierownik zespołu powinien wyzwalać i utrzymywać zaangażowanie pracowników, które przekłada się na tworzenie wartości dodanej dla przedsiębiorstwa, zaangażowanie buduje się w 4 formach (Marek, 2015):

1. zaangażowanie $\mathrm{w}$ organizację, dotyczy identyfikowania się pracownika $z$ celami, misją oraz wspólną wartością firmy,

2. zaangażowanie $w$ pracę, wiążące się $z$ jak najlepszym i profesjonalnym wykonywaniem pracy,

3. zaangażowanie w zawód, stałe podnoszenie kwalifikacji niezbędnych do realizacji ścieżki kariery zawodowej pracownika

4. zaangażowanie w środowisko społeczne, czyli relacje ze współpracownikami oraz przełożonymi.

Często menedżer wykorzystuje w zarządzaniu podwładnymi instrumenty mające na celu ułatwienie rozwiązywania problemów oraz podnoszenie wydajności

Tabela 3. Zadania menedżera

\begin{tabular}{ll}
\hline Sterowanie & - formułowanie celów \\
zasobami ludzkimi & - planowanie zatrudnienia \\
& - planowanie kosztów \\
& - podejmowanie decyzji dotyczących realizacji zadań \\
& - sterowanie działalnością szkoleniową \\
\hline Organizowanie & - dobór kandydatów do pracy \\
zasobów ludzkich & - wartościowanie pracy \\
& - gospodarowanie czasem pracy \\
& - organizowanie zespołów zadaniowych \\
\hline Motywowanie & - kształtowanie stosunków międzyludzkich w środowisku pracy \\
pracowników & - kształtowanie rozwoju potencjału pracy \\
& - polityka płacowa i stosowanie innych bodźców \\
\hline Kontrolowanie & - ocenianie pracowników \\
procesów pracy & - nadzór nad funkcjonowaniem systemu zadaniowego \\
& - nadzór nad ilościowym i jakościowym wykonaniem pracy \\
\hline
\end{tabular}

Źródło: Walicka-Chowaniec (2012, s. 5, 200-209). 
organizacyjnej. W modelu otwartych innowacji wykorzystuje się metody, takie jak: podróże edukacyjne, umacnianie więzi osobowych, krótkoterminowa wymiana pracowników, szkolenia, monitoring relacji poświęconych rozwojowi projektów innowacyjnych, kontrola komunikacji z dostawcami i między nimi, a w dużych przedsiębiorstwach powołuje się mistrza innowacji.

Mistrz innowacji zwany również pośrednikiem ds. innowacji, pośrednikiem innowacji lub mistrzem sieci to „człowiek, którego rolą jest skłaniać dostawców do pracy w modelu otwartych innowacji” (Stawiarska, 2019). Jego zadaniem jest wspieranie projektów B+R w ich wczesnej fazie, opieka nad grupami współpracujących organizacji, ma on również za zadanie wyszukiwanie i dokonanie selekcji dostawców, wyszukiwanie inżynierów, którzy mają wesprzeć projekt B+R, promowanie projektu, negocjowanie warunków, a także wspieranie projektów realizowanych w przedsiębiorstwach, z którymi współpracuje jego firma (Stawiarska, 2019).

\section{Zakończenie}

Model otwartych innowacji zmienił sposób organizacji pracy od przedmiotowego podejścia, w którym powtarzano rutynowe działania, do działania opartego na wiedzy, w którym kwalifikacje, umiejętności oraz doświadczenie pracownika przynosi wartość dodaną dla przedsiębiorstwa. Sprawność realizacji procesu innowacyjnego zależy od właściwego zarządzania innowacjami, które obejmuje podejmowanie decyzji, organizowanie, przewodzenie oraz kontrolowanie. Dlatego niezbędne jest wyznaczenie w organizacji kierownika procesu innowacji, który zadba o odpowiedni przepływ informacji oraz koordynację pracy. Motywowanie pracownika do podnoszenia swoich kwalifikacji, zdobywania wiedzy i dzielenia się nią spoczywa na barkach przywódcy. Menedżerowie zarządzający innowacjami powinni wykorzystywać dostępne narzędzia oraz szukać nowych pomocnych w rozwoju pracowników, efektem będzie pojawienie się nowych innowacji w organizacji.

\section{Literatura}

Białoń L. (2010). Zręby teorii innowacji. W: L. Białoń (red.), Zarządzanie działalnością innowacyjną. PLACET, Warszawa.

Drucker P.F. (1994). Innovation and Entrepreneurship. Practice and Principles. Heinemann, London.

Grzeganek-Więcek B., Szopa R., Więcek D. (2014). Tradycyjne i innowacyjne modele pracy we współczesnych organizacjach. Race Naukowe Akademii im. Jana Długosza w Częstochowie, VIII.

Jasiński A.H., Głodek P., Jurczylk-Bunkowska M. (2019). Organizacja i zarządzanie procesami. Polskie Wydawnictwo Ekonomiczne, Warszawa.

Kozioł K. (2008). Modele procesu innowacyjnego w przedsiębiorstwie w Wielkopolsce w latach 1994-2006. Studia i Prace Wydziału Nauk Ekonomicznych i Zarządzania, 6. 
Kozioł-Nadolna K. (2012). Modele zarządzania innowacjami w XXI wieku. W: B. Mikuła (red.), Historia i powstanie nauk o zarządzaniu. Wydawnictwo Uniwersytetu Ekonomicznego w Krakowie, Kraków.

Marek J. (2015). Zaangażowanie pracowników w rozwój przedsiębiorstw innowacyjnych. Zarządzanie. Teoria i Praktyka, 1(11): 5-17

Mielcarek P. (2018). Od zamkniętej innowacji do otwartej innowacji 2.0. Ewolucja czy rewolucja? Przedsiębiorczość i Zarządzanie, Entrepreneurship and Management, 19: 209-222.

Pichlak M. (2012). Otwarte innowacje jako nowy paradygmat w zarządzaniu innowacjami. Zeszyty Naukowe Politechniki Śląskiej, Organizacja i Zarządzanie, 60.

Reformat B. (2018). Modele procesów innowacyjnych a stadia rozwoju współczesnej gospodarki. Zeszyty Naukowe Politechniki Śląskiej, Organizacja i Zarządzanie, 130.

Rojek D. (2014). Otwarte innowacje jako model interaktywnego zarządzania innowacjami. Zeszyty Naukowe Uniwersytetu Przyrodniczo-Humanistycznego w Siedlcach, 101.

Rothwell R. (1992). Successful Industrial Innovation: Critical Factors for the 1990's. R and D Management, 22.

Starbryła A., Małkus T. (red.) (2012). Strategie rozwoju organizacji. Encyklopedia Zarządzania, Kraków.

Stawiarska E. (2019). Modele zarządzania innowacjami w łańcuchach i sieciach dostaw międzynarodowych koncernów motoryzacyjnych. CeDeWu, Warszawa.

Szymańska E. (2009). Innowacyjność przedsiębiorstw turystycznych w Polsce. Oficyna Wydawnicza Politechniki Białostockiej, Białystok.

Szymańska E. (2013). Proces innowacyjności przedsiębiorstw świadczących usługi w zakresie organizacji imprez turystycznych. Oficyna Wydawnicza Politechniki Białostockiej, Białystok.

Turek M., Jonek-Kowalska I., Ganszczyk Z. (2011). Determinanty innowacyjności w przedsiębiorstwach górniczych. Zeszyty Naukowe, Organizacja i Zarządzanie, 55.

Walicka-Chowaniec K. (2012). Rola współczesnego menedżera i jego nowe koncepcje w zarządzaniu zasobami ludzkimi. Czasopismo Logistyka, 5: 200-209.

Wyroba A., Tkaczyk J. (2015). Zarządzanie innowacjami. ABC Jakości. Badania. Certyfikacja. Notyfikacja. Quality Review, 2(82).

Zajkowska M. (2017). Otwarte innowacje w małych i średnich przedsiębiorstwach. W kierunku zintegrowanego modelu współpracy. Zeszyty Naukowe SGGW, Polityki Europejskie, Finanse i Marketing, 17.

\section{Employee roles in managing the open innovation model}

Both in theory and in practice, the introduction of innovation is considered to be one of the most important factors in the contemporary activity of companies that determines its survival and competitiveness. It is necessary for the introduction of innovations to choose appropriate management methods, such as innovation management models. The traditional models are being abandoned and attention is being paid to new management models, one of them is an open model of innovation created at the beginning of the 21 st century, with which the organizational approach of the enterprise has changed. It caused changes in the way of human resources management by rejecting the traditional approach to employee management and choosing modern management methods involving employees in creating added value for the company. The aim of the present one is to present the role of employees at different levels, in the company applying the model of open innovation.

Translated by Ewa Iwaniuk 
Joanna Paprzycka

Uniwersytet Łódzki

joanna.paprzycka@edu.uni.lodz.pl

\section{Opinie przedstawicieli lódzkiej branży turystycznej na temat głównych turystycznych aktów prawnych}

\section{Streszczenie}

Celem pracy jest przedstawienie analizy opinii pracowników łódzkiej branży turystycznej na temat głównych turystycznych aktów prawnych, ze szczególnym odniesieniem do zmian dokonanych w ostatnich kilku latach w prawie branżowym. Metody badawcze zastosowane w opracowaniu to wywiad standaryzowany pogłębiony oraz obserwacja uczestnicząca. W badaniu zwrócono uwagę m.in. na ocenę dokonanych zmian oraz potrzebę dalszych uregulowań prawnych, nieprecyzyjność terminologiczną najważniejszych aktów prawnych, wciąż nierozwiązany w branży turystycznej problem „szarej strefy” czy ocenę respondentów funkcjonowania Turystycznego Funduszu Gwarancyjnego. W wyniku przedstawionej analizy autorka dostrzega duże rozbieżności w postrzeganiu głównych turystycznych aktów prawnych, modyfikowanych w ciągu ostatnich kilku lat.

\section{Wprowadzenie}

Prawo turystyczne w ostatnich kilku latach poddane zostało gruntownej zmianie. Uznano, że treści przedstawiane przez turystyczne akty prawne obowiązujące od 1997 r. z upływem czasu uległy dezaktualizacji względem rozwijającego się rynku usług turystycznych. Ewolucja tych treści miała na celu m.in. usprawnienie pracy branży turystycznej, zwłaszcza touroperatorów, zwiększenie klarowności, usprawnienie obsługi klienta i zwiększenie jego bezpieczeństwa. Dokonane zmiany prawne mają duży wpływ na działalność przedsiębiorstw, jednak wzbudzają też wiele kontrowersji. Celem opracowania jest identyfikacja i przedstawienie analizy opinii pracowników łódzkiej branży turystycznej na temat głównych

Cytowanie: Paprzycka J. (2021). Opinie przedstawicieli łódzkiej branży turystycznej na temat głównych turystycznych aktów prawnych. W: K. Borodako (red.), Turystyka w okresie pandemii. Bogucki Wydawnictwo Naukowe, Poznań-Kraków, s. 153-163. https://doi.org/10.12657/9788379863501-15 
turystycznych aktów prawnych, ze szczególnym odniesieniem do zmian dokonanych w ostatnich kilku latach w prawie branżowym. Badani stanowią grupę głównych użytkowników wymienionego prawa, których opinie wydają się niekiedy pomijane, wraz z ewolucją aktów prawnych. Dla potrzeb niniejszego opracowania wykorzystano formy badań pierwotnych. Badania opinii autorka pracy wykonała przy zastosowaniu wywiadu standaryzowanego pogłębionego oraz obserwacji uczestniczącej.

W poniższym rozdziale autorka zwróciła uwagę na główne akty prawne regulujące funkcjonowanie branży turystycznej, charakterystykę badań oraz najważniejsze wnioski płynące $z$ zebranych opinii. Kluczową rolę odgrywają ustawy i rozporządzenia dotyczące branży turystycznej oraz relacji przedsiębiorstwoklient, m.in. ustawa o imprezach turystycznych i powiązanych usługach turystycznych (Dz.U. 2017 poz. 2361) wraz z aktami wykonawczymi do ustawy, a także ustawa o usługach hotelarskich oraz usługach pilotów wycieczek i przewodników turystycznych (Dz.U. 1997 nr 133 poz. 884). Przytoczone akty prawne były dla autorki podstawą przygotowania głównego narzędzia badawczego oraz przeprowadzenia badań, stanowiły również fundament całego opracowania. Autorka wzbogaciła swoją wiedzę o treści zawarte $\mathrm{w}$ informatorze wydanym przez Ministerstwo Sportu i Turystyki na temat ustawy o imprezach turystycznych i powiązanych usługach turystycznych, prezentującą treści ustawy budzące wątpliwości z perspektywy autorów ustawy, główne cele i założenia dokonanych zmian prawnych oraz uzasadnienie zmian. Jako że nie minęło wiele czasu od opublikowania zmodyfikowanych aktów prawnych, autorce opracowania nie udało się dotrzeć do podobnych badań prowadzonych $\mathrm{w}$ odniesieniu do wyżej wymienionych aktów prawnych.

\section{Przegląd literatury}

Jak wskazują Cybula i Raciborski (2008), prawo związane z branżą turystyczną przez wiele lat było marginalizowane w przestrzeni legislacyjnej. Fakt ten można wiązać z ograniczeniem dostępu do usług turystycznych i brakiem ich komercjalizacji. Wraz z przemianami gospodarczymi i wzmożeniem zainteresowania turystyką pojawiły się zagrożenia dla interesów uczestników turystyki. Za okres przełomowy dla branżowych kwestii prawnych uznać można ostatnią dekadę XX w. Wtedy właśnie, w oparciu o prawo Unii Europejskiej, w celu eliminacji wspomnianych zagrożeń stworzona została ustawa o usługach turystycznych z dnia 29 sierpnia $1997 \mathrm{r}$. Był to pierwszy branżowy akt prawny, kompleksowo omawiający funkcjonowanie przedsiębiorstw turystycznych. Zagadnienie owej ustawy $\mathrm{i}$ jej powiązań z innymi krajowymi oraz międzynarodowymi aktami prawnymi omawia Gospodarek (2006). Kwestie te z punktu widzenia prawniczego w kolejnych publikacjach przybliżają także m.in. Cybula oraz Raciborski (2008).

Wraz ze zmianami prawnymi dokonanymi w drugiej dekadzie XXI w. pojawiły się kolejne kontrowersje dotyczące prawa turystycznego. Część z nich odnaleźć można w publikacji Ministerstwa Sportu i Turystyki (2018). Opracowanie zawiera 
rozważania nad kwestiami spornymi w branży turystycznej, a także proponowane rozumienie tych treści przez przedstawicieli MSiT. Kwestie sporne dotyczą treści m.in. terminologii użytej w ustawie, funkcjonowania przedsiębiorstw turystycznych, odpowiedzialności prawnej podmiotów oraz obszaru dla funkcjonowania tzw. szarej strefy, zawartych w ustawie o imprezach turystycznych i powiązanych usługach turystycznych.

\section{Charakterystyka podziału regulacji prawnych}

Dla uporządkowania zagadnień związanych z prawem turystycznym, a w szczególności z jego rodzajami, autorka opracowała schemat obrazujący opisywane zagadnienie. Jako pierwszy etap podziału autorka wyodrębniła dwa rodzaje prawa wykorzystywanego w branży turystycznej, po uwzględnieniu jego pierwotnego przeznaczenia wobec turystyki (ryc. 1).

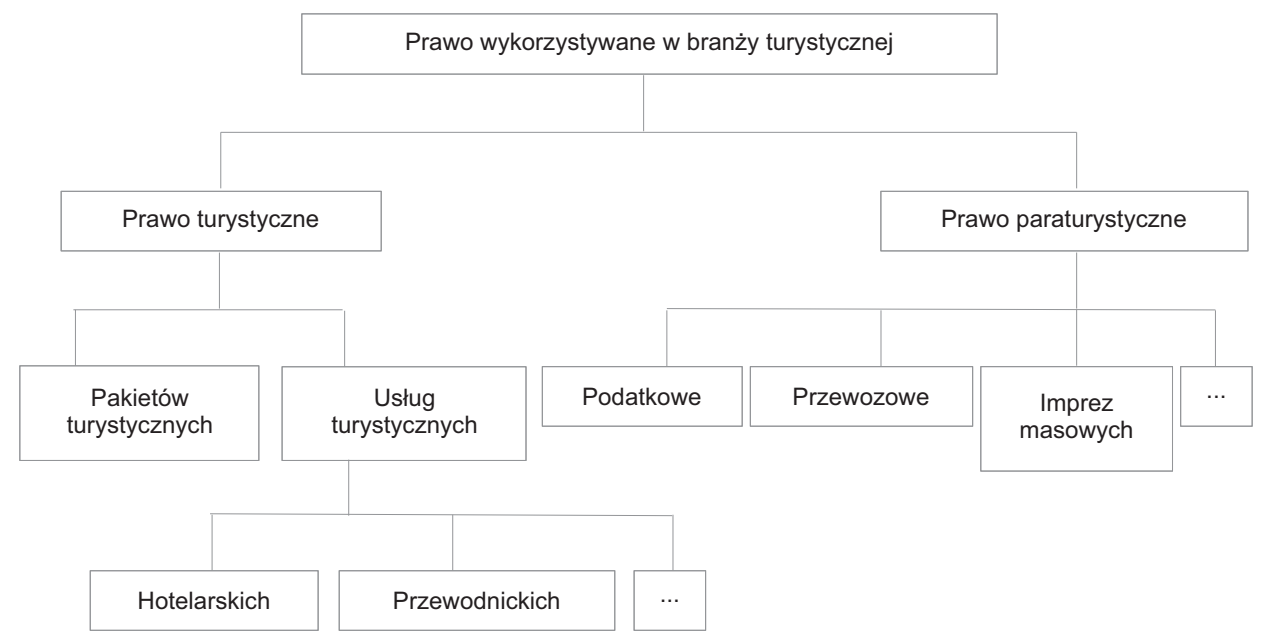

Ryc. 1. Schemat obrazujący prawo wykorzystywane w branży turystycznej

Źródło: opracowanie własne.

Pierwszy rodzaj prawa stanowi stricte prawo turystyczne, które należy rozumieć jako wszelkie akty prawne powstałe w celu regulacji aktywności związanych z działalnością turystyczną. Autorka zaproponowała dalszy podział prawa turystycznego na regulacje dotyczące pakietów turystycznych oraz poszczególnych usług turystycznych. Miano pakietów turystycznych obejmuje m.in. imprezy turystyczne, tj. połączenie minimum dwóch usług, objętych wspólną ceną i programem. Regulacje odnoszące się do usług turystycznych to m.in. wytyczne w dziedzinie świadczenia usług w obiektach hotelarskich, świadczenia usług przewodnickich i inne. Drugim rodzajem prawa wyodrębnionego przez autorkę opracowania jest tzw. „prawo paraturystyczne”. Termin ten określa rodzaj prawa, które przygotowane zostało na potrzeby innych branż, dziedzin życia oraz społeczności 
niezwiązanych z turystyką, jednak pośrednio lub bezpośrednio dotyczy turystów, przedsiębiorców oraz usługodawców turystycznych. Przykładami takich regulacji mogą być akty prawne w zakresie prawa podatkowego, przewozowego, imprez masowych i inne. Określenie to nie obowiązuje obecnie w literaturze przedmiotu i stanowi propozycję autorki dla podjęcia dalszych rozważań terminologicznych.

\section{Metodyka badań}

Spośród ogólnie dostępnych metod badawczych autorka wybrała następujące metody do zbadania zjawiska opinii publicznej na temat prawa turystycznego w gronie przedstawicieli branży: wywiad standaryzowany pogłębiony oraz obserwację. Według autorki metody te są najbardziej miarodajne dla zagadnienia dotyczącego opinii na temat prawa turystycznego, ponieważ pozwalają na największą swobodę wypowiedzi. Co za tym idzie, opinia respondenta jest wyrazem subiektywnego poglądu, wyrobionego na podstawie aktów prawnych oraz doświadczenia zawodowego ankietowanego. Jak opisuje Apanowicz (2002), wywiad polega na pozyskiwaniu danych $w$ bezpośredniej rozmowie. Obserwacja natomiast stanowi według Apanowicza postrzeganie jednostkowych faktów, zjawisk i osób w wyznaczonym miejscu i czasie. Przedmiot obserwacji w badaniach naukowych stanowić może wszystko, co jest możliwe i dostępne zmysłom obserwatora.

Narzędziem przeprowadzenia wywiadów był kwestionariusz wywiadu. Jest to główne narzędzie badawcze opracowane przez autorkę, składające się z wprowadzenia oraz z pytań podzielonych na trzy części, w zależności od tematyki i stopnia szczegółowości: pierwszej - ogólnej, drugiej - dotyczącej treści ustawy o imprezach turystycznych i powiązanych usługach turystycznych oraz trzeciej przeznaczonej do zebrania opinii od przedstawicieli biur podróży.

Metoda obserwacyjna wdrożona została w formie obserwacji uczestniczącej, narzędziem badawczym był arkusz na własne uwagi, stworzony i zastosowany przez autorkę. Obserwacji podlegali respondenci badań ankietowych podczas bezpośredniej rozmowy $\mathrm{z}$ autorka, $\mathrm{w}$ trakcie oraz po przeprowadzeniu wywiadu. Dotyczyła ona zależności w przekazie werbalnym oraz niewerbalnym uczestników badania. Przekaz ten prowadził do różnych wniosków. Obserwacja miała charakter jawny. Oznacza to, że jej uczestnicy wiedzieli o udziale w badaniu.

Analiza materiałów źródłowych dokonana została poprzez porównanie treści nowelizowanych ustaw oraz komentarzy pracowników branży, w tym specjalistów w dziedzinie prawa turystycznego. W celu przeprowadzenia analizy wywiadów autorka wykonała zestawienie odpowiedzi respondentów w programie Microsoft Excel, które kolejno zostały porównane do całości opinii uzyskanych $\mathrm{w}$ wyniku badań. Obserwacja była uzupełnieniem informacji uzyskanych $\mathrm{w}$ trakcie wywiadu. Karta obserwacji dołączona została do właściwego kwestionariusza wywiadu i stanowiła obszar analizy w odniesieniu do odpowiedzi konkretnego respondenta.

Przy dobraniu, skonstruowaniu i zastosowaniu właściwych narzędzi badawczych autorka korzystała z publikacji Apanowicz (2002). Słownik językowy 
Drabik i in. (2006) posłużył do wyjaśnienia kluczowych definicji, zarówno dla przeprowadzenia badań, jak i poddania ich wyników dalszej analizie.

O udział w badaniu poproszono łącznie około 280 osób. Autorka odwiedziła w sumie 36 instytucji zlokalizowanych na terenie Łodzi. Do odwiedzonych placówek należały m.in. biura podróży, stowarzyszenia i organizacje zajmujące się turystyką na terenie miasta, województwa oraz o zasięgu ogólnokrajowym. W efekcie autorce udało się przeprowadzić wywiad z 50 reprezentantami branży turystycznej. Byli to przedstawiciele obu płci, zajmujący się zawodowo turystyką (pracownicy biur podróży, piloci, przewodnicy), prawem turystycznym oraz pokrewnymi profesjami (specjaliści ds. turystyki w organizacjach lokalnych). Wśród 50 respondentów było 26 mężczyzn oraz 24 kobiety, zajmowali oni różne stanowiska pracy (zwykłe lub kierownicze), mieli różne wykształcenie czy staż pracy. Profil respondentów był zróżnicowany, co dało szansę poznania opinii możliwie najbardziej miarodajnej i bezstronnej. Na możliwość udziału w badaniu decydujący wpływ miała kompleksowa znajomość aktów prawnych regulujących działalność branży turystycznej.

\section{Wyniki badań}

Na początku badania ankietowani zostali zapytani o ocenę regulacji prawnych dokonanych $\mathrm{w}$ ciągu ostatnich lat w głównych turystycznych aktach prawnych, tj. m.in. ustawie o usługach hotelarskich oraz usługach pilotów wycieczek i przewodników turystycznych (1997), ustawie o imprezach turystycznych i powiązanych usługach turystycznych (2017) oraz w powiązanych aktach prawnych (ryc. 2).

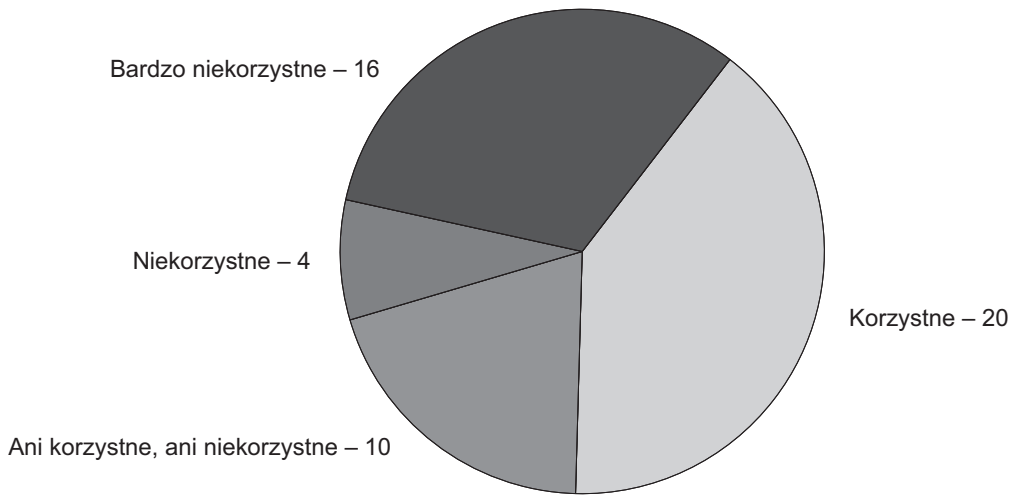

Ryc. 2. Ocena uregulowań prawnych z ostatnich lat Źródło: opracowanie własne.

Jak pokazuje analiza opinii, nikt z ankietowanych nie wskazał wysokich korzyści ze zmian prawnych. Po 20 osób wskazało, że zmiany były korzystne oraz niekorzystne w różnym stopniu. Wydaje się to o tyle niepokojące, że negatywny wpływ uregulowań podkreślały głównie osoby o najdłuższym stażu zawodowym. 
Doświadczenie tych osób świadczyć może o bardziej zaawansowanym stanie wiedzy i skali porównawczej na przestrzeni lat.

Kolejną kluczową kwestią poruszoną podczas wywiadu były niedogodności wynikające ze zmian prawnych względem przedsiębiorców. Ankietowani zostali zapytani, czy takowe zauważają. 33 z 50 osób przyznało, że widzi niedogodności będące rezultatem zmian $w$ prawie turystycznym. W efekcie poproszono o doprecyzowanie, o jakie niedogodności głównie chodzi. Respondenci mogli wskazać więcej niż jedną propozycję oraz rozwinąc ją o własne uwagi (ryc. 3).

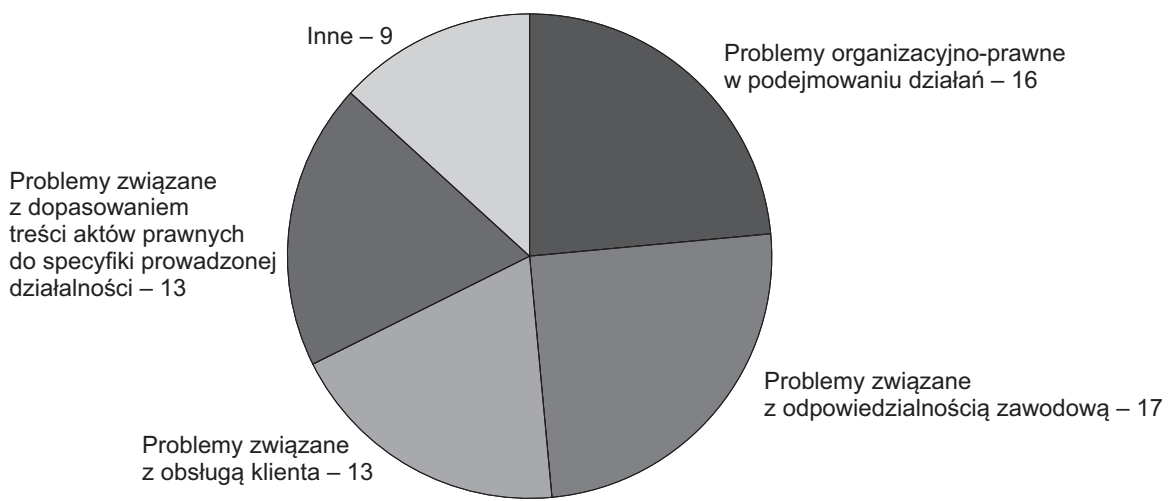

Ryc. 3. Opinie na temat niedogodności wynikających ze zmian prawnych Źródło: opracowanie własne.

Zdania przedstawicieli łódzkiej branży turystycznej były bardzo podzielone. Najwięcej osób wskazało, że w związku ze zmianami powiększyły się problemy $z$ odpowiedzialnością zawodową. W ramach pogłębienia tematyki badani wiązali niedogodności $\mathrm{w}$ tym zakresie szczególnie z „uwolnieniem” zawodu pilota i przewodnika turystycznego. Drugą najczęściej wskazywaną odpowiedzią okazały się problemy organizacyjno-prawne, zwłaszcza nadmierna ilość dokumentów biurowych, które muszą zostać wypełnione. W ramach pogłębienia problematyki respondenci wyrażali opinię o tzw. „nadmiarze biurokracji”. Ich zdaniem wypełnianie dokumentów często ma miejsce kosztem czasu, który można byłoby poświęcić interesariuszowi. Wskazywali oni potrzebę ograniczenia liczby wymaganych dokumentów wraz z kolejnymi zmianami prawa turystycznego, co miałoby wpłynąć na jakość obsługi klienta. Najrzadziej wybieraną odpowiedzią była „inne”, jednak osoby wybierające tę opcję i proszone o doprecyzowanie zwracały uwagę na działalność tzw. „szarej strefy”. Jak sugerują Drabik i in. (2006), „szara strefa" oznacza niezarejestrowaną lub niezgodną z obowiązującymi przepisami działalność gospodarczą, a także osoby i firmy prowadzące taką działalność. W treści rozdziału pojęcie „szarej strefy” powinno być również rozumiane jako działalność funkcjonująca na podstawie niedoprecyzowania przepisów prawnych.

Ankieterka zapytała respondentów, czy zauważają potrzebę dalszych zmian w prawie turystycznym. Większość osób (36 z 50) uznała, że istnieje taka potrzeba. Osoby te zostały poproszone o wskazanie głównych potrzeb względem 
dalszych zmian w prawie turystycznym, z możliwością wyboru więcej niż jednej odpowiedzi (ryc. 4).

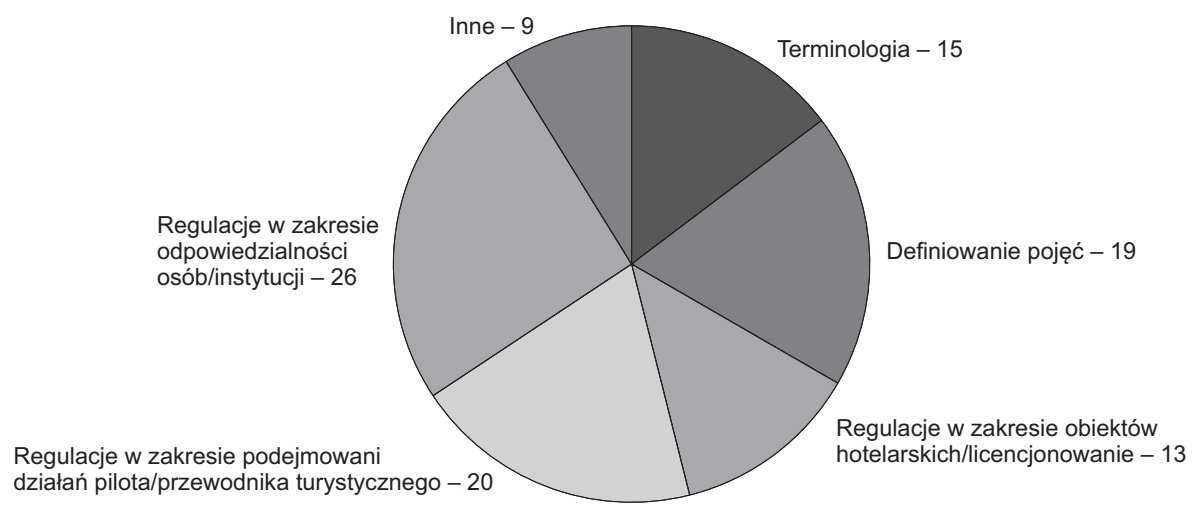

Ryc. 4. Charakterystyka potrzeb dalszych zmian prawnych

Źródło: opracowanie własne.

W opinii respondentów zdecydowanie niezbędne są zmiany dotyczące odpowiedzialności osób i instytucji, co wskazała ponad połowa ankietowanych, a także regulacje związane $z$ podejmowaniem aktywności i licencjonowaniem pilotów oraz przewodników turystycznych. Wiele osób zauważyło potrzebę udoskonalenia $\mathrm{w}$ zakresie terminologii i definiowania pojęć. Zapytano też o to, w których aktach prawnych najbardziej potrzebne są takie zmiany. Największą konieczność zmian wskazano w ustawie o imprezach turystycznych i powiązanych usługach turystycznych (2017). Ten akt prawny, jako obszar konieczny do zmiany, wskazało 35 spośród 50 osób. 2/5 badanej grupy podkreśliło potrzebę zmian w ustawie o usługach hotelarskich oraz usługach pilotów wycieczek i przewodników turystycznych (1997).

Druga i trzecia część pytań skupiała się na uszczegółowieniu opinii dotyczących treści objętych ustawą o imprezach turystycznych i powiązanych usługach turystycznych (2017). Ponad połowa ankietowanych wskazała, że ustawa jest nieprzydatna lub mało przydatna ze względu na niedoprecyzowanie przepisów. Jak wykazało pogłębienie problematyki wywiadu $\mathrm{w}$ tych częściach, najbardziej kłopotliwe jest niedoprecyzowanie treści ustawy i zawartych w niej definicji. Stwarza to niekiedy możliwość swobodnej interpretacji przepisów, co prowadzi do podejmowania działań poza prawem. Mniej więcej połowa ankietowanych wskazała potrzebę dokładniejszej regulacji odpowiedzialności podmiotów organizujących imprezy i powiązane usługi turystyczne oraz jednostek zajmujących się ich sprzedażą. Średnio co drugi respondent akcentował potrzebę doprecyzowania wymagań stawianych organizatorom imprez turystycznych. Jak wykazały badania pogłębione, wymagania te mają w opinii respondentów znaczący wpływ na ewentualną możliwość rozwoju tzw. „szarej strefy”.

W kolejnym pytaniu autorka chciała się dowiedzieć, czy wraz z dokonaniem zmian prawnych możliwość dla działania szarej strefy została zlikwidowana lub ograniczona (ryc. 5). 


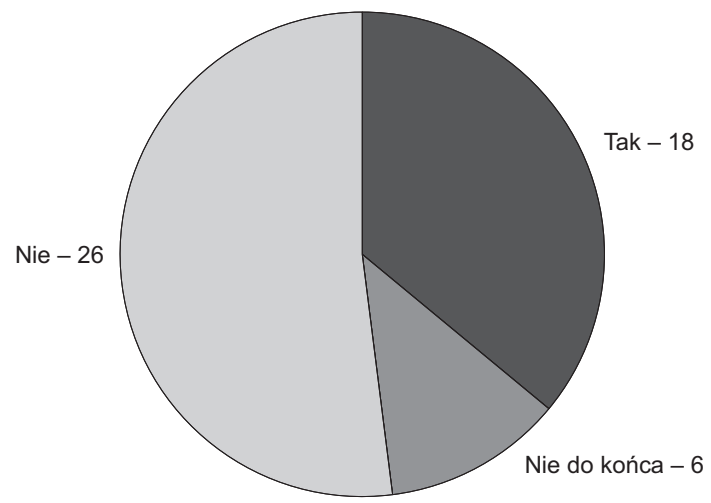

Ryc. 5. Ocena likwidacji możliwości funkcjonowania „szarej strefy” Źródło: opracowanie własne.

Jak wskazuje analiza opinii, ponad połowa osób uważa, że wątpliwości związane $z$ działaniem "szarej strefy” nie do końca zostały zlikwidowane lub kategorycznie nie zostały zlikwidowane. Dalszą możliwość dla działania „szarej strefy” wskazały głównie osoby o najdłuższym stażu pracy. 9 z 50 badanych osób w ramach pogłębienia tematyki „szarej strefy” uzupełniło swoją opinię o ocenę, że możliwość jej funkcjonowania została poszerzona wraz ze zmianami prawnymi.

Ostatnim pytaniem w trakcie wywiadu było pytanie o działalność Turystycznego Funduszu Gwarancyjnego. Adresowane było ono głównie do osób stanowiących przedstawicielstwo biur podróży, jednak zdecydowali się odpowiedzieć na nie również niektórzy przewodnicy, regularnie współpracujący z touroperatorami. Ankietowani zostali poproszeni o ocenę przejrzystości zasad funkcjonowania rachunku. Aż 32 osoby wskazały, że zasady funkcjonowania funduszu są jasne i obecnie nie wymagają dalszych modyfikacji (ryc. 6).

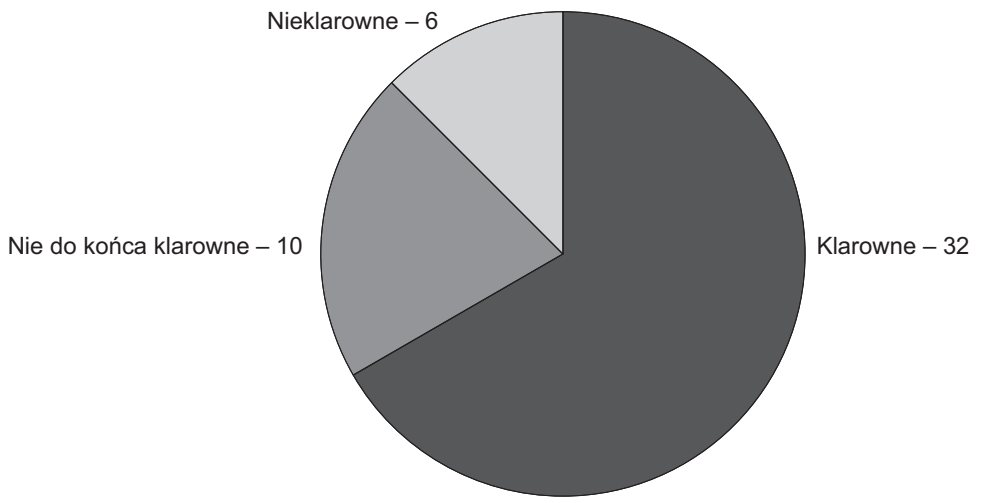

Ryc. 6. Ocena klarowności funkcjonowania TFG

Źródło: opracowanie własne.

W ramach uzupełnienia zagadnienia Turystycznego Funduszu Gwarancyjnego ankieterka zapytała, czy respondenci uważają wysokość gwarancji za adekwatną do zakresu działalności. Ponad połowa ankietowanych uznała, że stawki są 
adekwatne, jednak 20 osób wskazało na rozbieżności w ich wysokości. W pogłębionym wywiadzie osoby te wyraziły opinie, że stawki są zawyżane dla małych przedsiębiorstw, a zaniżane dla dużych touroperatorów.

Obserwacje własne autorki pozwoliły zauważyć wybiórczą znajomość prawa turystycznego poszczególnych grup zawodowych, niekiedy ukrywaną, zwłaszcza przez osoby zajmujące stanowiska wyższego szczebla, głównie kierownicze. Badania pokazały, że większość przedsiębiorstw zatrudnia pracownika zewnętrznego, wyspecjalizowanego w zakresie prawa turystycznego. Metoda obserwacji umożliwiła autorce wyciągnięcie wniosków, że najbardziej kompleksową wiedzę teoretyczną z zakresu prawa turystycznego posiadali pracownicy przedsiębiorstw turystycznych, będący jednocześnie przedstawicielami placówek oświatowych, natomiast największą wiedzą praktyczną z zakresu funkcjonowania przedsiębiorstw turystycznych dysponowali piloci i przewodnicy turystyczni. Większość przedstawicieli ostatniej wspomnianej grupy zawodowej przed rozpoczęciem badania wyraziła obawę o swoją niską lub wybiórczą znajomość prawa branżowego. W rzeczywistości stanowili oni najbardziej rzetelne źródło opinii na temat prawa turystycznego. W trakcie badania najbardziej okrojone opinie oraz brak znajomości niektórych treści wykazali przedstawiciele organizacji i stowarzyszeń turystycznych (instytucji społecznych).

Największą trudnością w czasie badań okazał się fakt, że z grona 280 osób $z$ łódzkiej branży turystycznej, udało się przeprowadzić jedynie 50 wywiadów. Jak wskazała znaczna część podmiotów poproszonych o udział w badaniu, taki stan rzeczy wiąże się z wybiórczą znajomością prawa turystycznego lub niekiedy jej brakiem wśród potencjalnych respondentów. Wielu pracowników turystycznych zna jedynie fragmenty ustawy lub innych branżowych aktów prawnych. Dla przykładu znaczna część łódzkich pilotów i przewodników turystycznych przyznaje, że koncentruje się głównie na znajomości ustawy o usługach hotelarskich oraz usługach pilotów wycieczek i przewodników turystycznych (1997). Głównymi, choć oczywiście nie jedynymi użytkownikami i zarazem „znawcami” ustawy o imprezach turystycznych i powiązanych usługach turystycznych (2017) są pracownicy biur podróży oraz osoby o wykształceniu turystycznym, pracujące w edukacji i nauczające treści ustaw.

\section{Zakończenie}

Zgodnie $\mathrm{z}$ celem opracowania w rozdziale zidentyfikowano i przedstawiono analizę opinii pracowników branży turystycznej na temat głównych turystycznych aktów prawnych. $Z$ badań wynika, że podmioty objęte ankietą mają bardzo rozbieżne opinie na temat nowelizacji prawa turystycznego dokonanego w Polsce w ostatnich latach, jednak opinie te są coraz bardziej krytyczne względem kolejnych aktów prawnych. Niezmiennie wskazywane są potrzeby dalszego udoskonalania głównych krajowych aktów prawnych na rzecz turystyki. Do obszarów stwarzających największe problemy branżowe zaliczane jest przyzwolenie na działalność tzw. „szarej strefy”, co może skutkować zwiększeniem jej zasięgu na rynku turystycznym. 
Podsumowując wyniki badań ankietowych, należy stwierdzić, że ponad połowa respondentów z branży turystycznej uważa, iż konieczne są dalsze zmiany $\mathrm{w}$ prawie turystycznym. Główne problemy wynikają z niedoprecyzowania w zakresie odpowiedzialności osób i instytucji, a także podejmowania aktywności i licencjonowania pilotów oraz przewodników turystycznych. W opinii podmiotów objętych badaniem wraz z kolejnymi zmianami prawnymi ograniczona powinna zostać liczba dokumentów wymaganych w ramach działalności biur podróży, co miałoby znaczący wpływ na obsługę klientów. Wielu badanych zauważyło potrzebę udoskonalenia treści i sformułowań użytych w ustawach. Najczęściej wskazywanym dokumentem, w którym dalsze zmiany są niezbędne, jest ustawa o imprezach turystycznych i powiązanych usługach turystycznych (2017). Ustawa ta wymaga doprecyzowania w zakresie terminologicznym i definiowania pojęć w niej zawartych. Turystyczny Fundusz Gwarancyjny i zasady jego działania wydają się dość jasne w funkcjonowaniu, wątpliwości budzą stawki ustalane dla biur podróży. Według części opinii są one zaniżane dla dużych touroperatorów, natomiast zawyżane dla małych.

Wiedza podmiotów objętych badaniem na temat turystycznych aktów prawnych okazała się bardzo zróżnicowana. Wbrew powszechnie panującej opinii najbardziej kompleksową wiedzą praktyczną o prawie turystycznym wykazali się przewodnicy turystyczni i piloci wycieczek z lódzkiego środowiska branżowego. Najwyższym stopniem wiedzy teoretycznej dysponowali pracownicy jednostek oświatowych, będący jednocześnie przedstawicielami przedsiębiorstw turystycznych.

Autorka powyższego opracowania rekomenduje dalsze badania nad prawem turystycznym $w$ świetle satysfakcji z jego zmian i funkcjonowania jednostek regulowanych przez poszczególne akty prawne. Badanie może opierać się zarówno na opiniach przedsiębiorców, jak i próbie określenia satysfakcji turystów z obsługi oraz ochrony w zakresie m.in. ich bezpieczeństwa ekonomicznego, zdrowia lub powierzonego mienia w imię działalności regulowanej treścią prawa.

\section{Literatura}

Apanowicz J. (2002). Metodologia ogólna. Wydawnictwo WSAiB, Gdynia.

Cybula P., Raciborski J. (2008). Turystyka a prawo. Wyższa Szkoła Turystyki i Ekologii, Kraków.

Drabik L., Kubiak-Sokół A., Sobol E. (2006). Słownik języka polskiego PWN. Wydawnictwo Naukowe PWN, Warszawa.

Gospodarek J. (2006). Prawo turystyczne. Centrum Doradztwa i Informacji Difin, Warszawa.

Ministerstwo Sportu i Turystyki (2018). Ustawa o imprezach turystycznych i powiązanych usługach turystycznych.

Ustawa z dnia 24 listopada 2017 r. o imprezach turystycznych i powiązanych usługach turystycznych (Dz.U. 2017 poz. 2361).

Ustawa z dnia 29 sierpnia 1997 r. o usługach hotelarskich oraz usługach pilotów wycieczek i przewodników turystycznych (Dz.U. 1997 nr 133 poz. 884). 


\section{Łódź tourist industry employees' opinions concerning the main tourist legal acts}

The purpose of this study is to present an analysis of the opinions of employees of the tourism industry in Łódź on the main tourist legal acts, with particular reference to the changes made in the last few years in the tourism law. The research methods used in the study are standardized deepened interview and participant observation. The study is focused on, among others, evaluation of the changes made and the need for further legal changes, imprecision in terminology of the most important legal acts, the still unsolved problem of the gray area in the tourism industry, or the evaluation by the respondents in reference to the functioning of the Tourist Guarantee Fund. As a result of the presented analysis, the author notices large discrepancies in the perception of the main tourist legal acts that have been modified in the last few years.

Translated by Joanna Paprzycka 

Artur Żyto

Uniwersytet im. Adama Mickiewicza w Poznaniu

artur.zyto@amu.edu.pl

\section{Znaczenie dziedzictwa kulturowego dla rozwoju turystyki w rejonie Parku Narodowego Gór Stołowych}

\section{Streszczenie}

Wzrastający ruch turystyczny w Górach Stołowych generuje potrzebę jego deglomeracji, co możliwe jest m.in. poprzez wykorzystanie obiektów dziedzictwa kulturowego. Celem rozdziału jest określenie ich znaczenia dla rozwoju turystyki na badanym obszarze. W tekście przedstawiono preferencje turystów dotyczące wyboru odwiedzanych atrakcji kulturowych, ich przegląd, a także ogólną charakterystykę zasobów kulturowych na terenie Parku Narodowego Gór Stołowych. Metodyka badań obejmowała pozyskanie danych od turystów przy użyciu kwestionariusza wywiadu oraz inwentaryzację terenową. Dziedzictwo kulturowe Gór Stołowych jest komplementarnym celem wyjazdów turystycznych. Turystyka kulturowa rozwija się głównie w większych miejscowościach, a obiekty kulturowe na obszarze parku wymagają promocji i udostępnienia, np. w postaci szlaków tematycznych.

\section{Wprowadzenie}

Obszary o nagromadzeniu wysokich walorów przyrodniczych sprawiają, że ruch turystyczny w ich otoczeniu systematycznie wzrasta (Łysoń, 2019). Przykładem tego typu regionu w południowej części Polski są Sudety, gdzie rozwój turystyki stymulowany jest przede wszystkim na terenie dwóch parków narodowych - Karkonoskiego oraz Gór Stołowych (dalej: PNGS). Funkcja turystyczna obszarów prawnie chronionych może być postrzegana jako konfliktogenna (Stasiak, 1997), ze względu na konieczność równoczesnego pełnienia zadań ochronnych, edukacyjnych, jak i udostępniania cennego obszaru (ustawa z dnia 16 kwietnia 2004 r. o ochronie przyrody). Jednym z możliwych do zastosowania środków,

Cytowanie: Żyto A. (2021). Znaczenie dziedzictwa kulturowego dla rozwoju turystyki w rejonie Parku Narodowego Gór Stołowych. W: K. Borodako (red.), Turystyka w okresie pandemii. Bogucki Wydawnictwo Naukowe, Poznań-Kraków, s. 165-174. https://doi.org/10.12657/9788379863501-16 
łagodzącym konflikty związane $z$ ochroną przyrody i ich turystyczną penetracją, jest odpowiednie kierowanie ruchem turystycznym oraz limitowanie jego wielkości (Stasiak, 1997). Z tego powodu w destynacjach narażonych na zwiększony ruch turystyczny należy opracować rozwiązania służące kontrolowanej dyspersji turystycznej. Proces ten przebiegać może w oparciu o wypromowane i udostępnione obiekty dziedzictwa kulturowego, rozumianego jako całość materialnego i niematerialnego dorobku społeczeństwa (Kozioł i in., 2013), które często pełnią rolę komplementarnych walorów turystycznych regionu.

Głównym celem rozdziału jest określenie roli dziedzictwa kulturowego w rozwoju turystyki w rejonie Gór Stołowych. W ramach jego realizacji określono cele cząstkowe, do których zaliczono przedstawienie przeglądu najważniejszych atrakcji kulturowych obszaru oraz rozpoznanie obiektów będących zasobami kulturowymi, zlokalizowanych w granicach PNGS.

Metodyka obejmowała badania sondażowe techniką PAPI w rejonie Błędnych Skał i Szczelińca Wielkiego w latach 2015-2019, na podstawie których uzyskano dane dotyczące najchętniej odwiedzanych atrakcji kulturowych. We wrześniu 2019 r. przeprowadzono ich inwentaryzację, w trakcie której dokonano przeglądu oferty i towarzyszącej im infrastruktury turystycznej. Kontynuacją badań terenowych była inwentaryzacja zasobów kulturowych na obszarze PNGS, która miała miejsce w lipcu $2020 \mathrm{r}$.

\section{Przegląd literatury}

Problematyka dotycząca dziedzictwa kulturowego w rejonie Gór Stołowych została opisana przez Latochę (2011, 2012, 2017), Latochę i Roszczewską (2011) oraz Latochę i Migonia (2018), a w szczególności w pierwszym monograficznym opracowaniu poświęconym temu tematowi (Latocha 2020). W innym ujęciu Rogowski i Żyto (2018) przedstawili profile turystów kulturowych, koncentrując się na podobieństwach i różnicach w zakresie motywów, preferencji i zachowań w stosunku do ogółu przyjezdnych i określili ich ogólny udział w strukturze ruchu turystycznego. Szereg zapisów odnoszących się do uwarunkowania i rozwoju turystyki kulturowej znalazł się w „Strategii rozwoju turystyki w Parku Narodowym Gór Stołowych" (Czerniak, 2020).

Czynnikiem motywującym do podróży kulturowych w rejonie Gór Stołowych jest bogate dziedzictwo kulturowe tego transgranicznego obszaru. Obejmuje ono wielonarodową i wielokulturową spuściznę wyrażaną poprzez obiekty materialne, wytworzone przez przedstawicieli różnych narodowości (polskiej, niemieckiej i czeskiej) i wyznań oraz przekazywane z pokolenia na pokolenie wartości, tradycje i praktyki. Jego współczesnym wyrazem jest przede wszystkim willowa zabudowa miejscowości uzdrowiskowych wraz z parkami zdrojowymi, obiekty militarne, sakralne (kościoły, kapliczki, krzyże przydrożne, krzyże pokutne), ruiny zamków, skanseny, muzea, zabudowa wiejska śląsko-czeskiego pogranicza, a także cykliczne wydarzenia kulturalne, m.in. Międzynarodowy Festiwal Chopinowski, Festiwal Moniuszkowski i Święto Papieru. Zgodnie z periodyzacją 
dziejów turystyki sudeckiej (Potocki, 2012), większość zachowanych do dzisiaj obiektów materialnych ma swoje początki w okresie niemieckim, datowanym od zakończenia wojny siedmioletniej w 1763 r. (Staffa i in., 1992).

Jeżeli zwiedzanie obiektów dziedzictwa kulturowego nie jest dla turystów głównym motywem podejmowanych podróży, a przyrodnicze cele wyjazdu związane są ze środowiskiem gospodarowanym przez człowieka (np. parki narodowe), to osoby te można postrzegać jako tzw. turystów przyrodniczo-kulturowych (Mikos von Rohrscheidt, 2016). Zgodnie z szerszym ujęciem definicji turysty kulturowego, grupę tę będą tworzyć osoby korzystające podczas wyjazdu z oferty kulturowej lub zawierającej elementy kulturowe (obok innych propozycji turystycznych), dla których występowanie tego typu walorów/atrakcji nie jest decydującym motywem podjęcia podróży (Mikos von Rohrscheidt, 2008a). Atrakcje kulturowe stają się komplementarne względem głównej, rozpoznawalnej na rynku „marki turystycznej” regionu, którą w przypadku badanego obszaru jest PNGS (Kruczek, 2017). W literaturze anglojęzycznej pojęcie turystyki przyrodniczo-kulturowej można porównywać do ekoturystyki, w ramach której kreuje się ofertę turystyczną opartą na walorach przyrodniczych i kulturowych, co staje się narzędziem zrównoważonego rozwoju obszarów cennych przyrodniczo (Aciksoz $\mathrm{i}$ in., 2010; Cajee, 2014; Carvache-Franco i in., 2019; Sgroi, 2020; Wei i in., 2020).

\section{Wyniki badań}

\section{Struktura ruchu turystycznego}

Charakterystykę struktury ruchu turystycznego na obszarze PNGS przeprowadzono w oparciu o wyniki uzyskane z 3305 prawidłowo wypełnionych kwestionariuszy ankiet. Badania sondażowe zrealizowane zostały przez grupę studentów działających w Studenckim Kole Naukowym Geografów im. S. Pawłowskiego w latach 2015-2019. W niniejszym opracowaniu przytoczono jedynie część wyników powiązaną z podjętą problematyką badawczą.

Turyści, dla których głównym celem przyjazdu na badany obszar był motyw kulturowy, rozumiany jako "poznanie i podziwianie obiektów zabytkowych", stanowią co roku najmniejszy odsetek spośród innych możliwych do wyboru motywów (1-2\%). Analiza drugorzędnych celów podejmowania podróży pozwala zidentyfikować $\mathrm{w}$ strukturze ruchu turystycznego turystów o profilu przyrodniczo-kulturowym. Dla tej grupy osób (14-27\%) kontakt z dziedzictwem kulturowym lub uczestnictwo w wydarzeniach kulturalnych jest istotnym komplementarnym czynnikiem motywujący do wypoczynku w Górach Stołowych.

Badani, oprócz Szczelińca Wielkiego i Błędnych Skał, odwiedzali najczęściej: Kudowę-Zdrój (11-14\%), Duszniki-Zdrój (3-6\%), Wambierzyce (5-11\%) oraz Kaplicę Czaszek w Czermnej (3-12\%). Wszystkie miejscowości zlokalizowane

Kafeteria odpowiedzi zawarta w kwestionariuszu wywiadu zawierała również opcję „Uczestnictwo w ofercie wydarzeń kulturalnych", co nie zostało jednak nigdy wskazane przez ankietowanych. 
są wokół PNGS, który jest zarówno centralnie położoną atrakcją turystyczną, jak i obszarem tranzytowym. Na tej podstawie wyróżnić można potencjalne miejscowości uprawiania turystyki kulturowej, które mogłyby być chętniej odwiedzane przez turystów pod warunkiem odpowiedniego wypromowania znajdujących się tam walorów antropogenicznych. Część z nich znajduje się poza regionem Gór Stołowych, jednak pozostają one w przestrzeni penetracji turystycznych turystów wypoczywających na badanym obszarze (ryc. 1).

\section{Lokalizacja atrakcji kulturowych w rejonie Gór Stołowych}

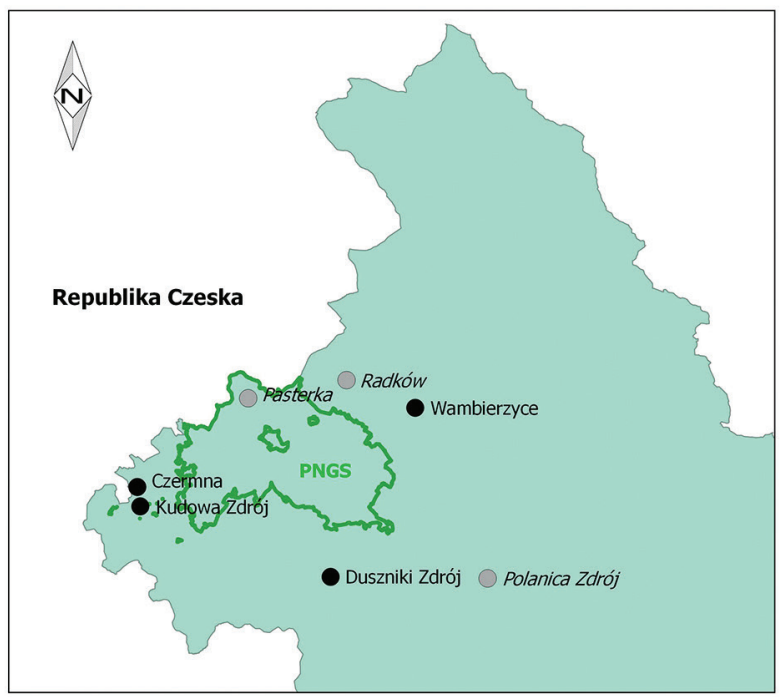

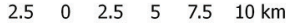

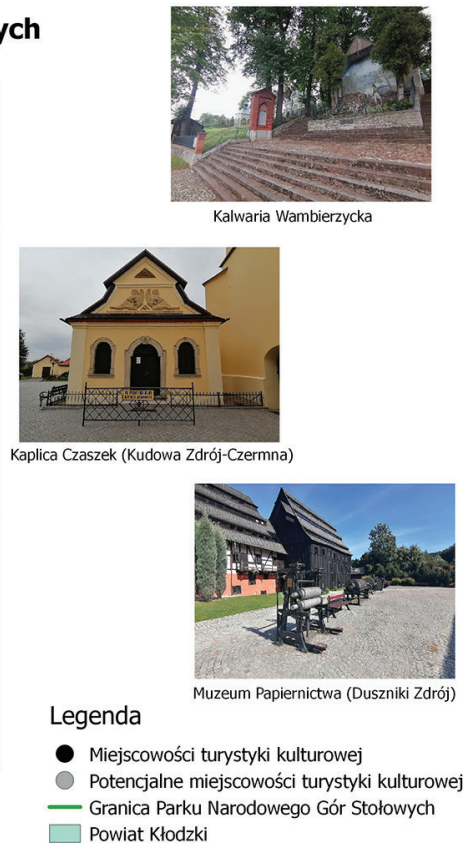

Ryc. 1. Lokalizacja głównych atrakcji kulturowych w rejonie Gór Stołowych Źródło: opracowanie własne.

\section{Kulturowe atrakcje turystyczne}

Najchętniej odwiedzaną destynacją kulturową w Górach Stołowych jest Kudowa-Zdrój, w której granicach mieszczą się również obecnie dawne wioski: Czermna i Pstrążna. Szczególny rozwój miasta przypadł na okres zaboru pruskiego, kiedy to wzniesiono wiele zabudowań związanych $z$ rozwojem i funkcjonowaniem uzdrowiska, w tym charakterystyczną zabudowę willową i park zdrojowy.

Drugim pod względem popularności miastem turystyczno-uzdrowiskowym są Duszniki-Zdrój, których rozwój wynika również ze znajdującego się w jego granicach kurortu narciarskiego - Zieleniec Ski Arena.

Ważnym ośrodkiem kulturowo-religijnym są Wambierzyce, nazywane Dolnośląską Jerozolimą. Określenie to zawdzięczają kalwarii rozbudowywanej od XVIII do XX w. Ten rozległy zespół krajobrazowo-architektoniczny jest jednym z największych tego typu w Polsce i w Europie. Najważniejsze obiekty dziedzictwa 
kulturowego regionu Gór Stołowych, w powiązaniu z możliwymi rozwiniętymi w oparciu o nie rodzajami turystyki kulturowej, zestawiono w tabeli 1.

Tabela 1. Kulturowe atrakcje turystyczne rejonu Gór Stołowych

\begin{tabular}{|c|c|c|}
\hline & Przykładowe atrakcje turystyczne & $\begin{array}{c}\text { Rodzaje } \\
\text { turystyki } \\
\text { kulturowej }\end{array}$ \\
\hline Kudowa-Zdrój & $\begin{array}{l}\text { Park Zdrojowy, neobarokowa pijalnia wód leczniczych, } \\
\text { Sanatorium Polonia z Teatrem Zdrojowym (1905 r.), } \\
\text { Hala Spacerowa „Teatr pod Blachą”, ewangelicko-au- } \\
\text { gsburska kaplica pw. Chrystusa Króla (1798 r.), Altana } \\
\text { Miłości (punkt widokowy na miasto), Muzeum Kultu- } \\
\text { ry Ludowej Przedgórza Sudeckiego, Skansen w Pstrąż- } \\
\text { nej, Muzeum Minerałów, Muzeum Zabawek, Kaplica } \\
\text { Czaszek i kościół pw. św. Bartłomieja z cmentarzem } \\
\text { parafialnym (XVIII w.), ruchoma szopka w Czermnej } \\
\text { (XIX w.), Gospodarstwo „Szlak Ginących Zawodów” }\end{array}$ & \multirow{3}{*}{$\begin{array}{l} \\
\text { dziedzictwa } \\
\text { kulturowego, } \\
\text { prawnie } \\
\text { chronionego } \\
\text { dziedzictwa } \\
\text { kulturowego, } \\
\text { muzealna, } \\
\text { religijna, } \\
\text { hobbystyczna, } \\
\text { obiektów za- } \\
\text { bytkowych, } \\
\text { stylów archi- } \\
\text { tektonicznych, } \\
\text { etniczna (sen- } \\
\text { tymentalna), } \\
\text { kultury ludo- } \\
\text { wej, eventowa }\end{array}$} \\
\hline Duszniki-Zdrój & $\begin{array}{l}\text { Muzeum Papiernictwa - obiekt wpisany na listę Po- } \\
\text { mników Historii, XIX-wieczna pijalnia wód mineral- } \\
\text { nych z Pawilonem Muzycznym, Szpital Uzdrowiskowy } \\
\text { Jan Kazimierz, Teatr Zdrojowy, Pawilon Źródła Pie- } \\
\text { niawa Chopina, Kolorowa Fontanna, kościół pw. NSPJ } \\
\text { (1899-1902), kamienice wraz z ratuszem (XVI, XVIII, } \\
\text { XIX w.), pomnik Sybiraków, pręgierz, kolumna wotyw- } \\
\text { na Matki Boskiej z Dzieciątkiem (1725 r. jako wotum } \\
\text { za uratowanie miasta od zarazy), kościół pw. Matki } \\
\text { Bożej Różańcowej z lapidarium (1845-1846, świątynia } \\
\text { ewangelicka, obecnie polskokatolicka), kościół św. św. } \\
\text { Apostołów Piotra i Pawła (1708-1730), barokowa bu- } \\
\text { dowla, w której wnętrzu uwagę zwraca ambona - tzw. } \\
\text { „dusznicki wieloryb” - nawiązująca do motywu biblij- } \\
\text { nego Jonasza, będącego symbolem zmartwychwstania } \\
\text { w czeskim, bawarskim i austriackim baroku }\end{array}$ & \\
\hline Wambierzyce & $\begin{array}{l}\text { Sanktuarium Wambierzyckiej Królowej Rodzin (XVIII w.), } \\
\text { Kalwaria Wambierzycka, ruchoma szopka (XIX w.) }\end{array}$ & \\
\hline
\end{tabular}

Źródło: opracowanie własne na podstawie Ryś (2000), Papaj (2015), Staffa i in. (1992), http://parafiaduszniki.pl/, http://visitduszniki.pl/.

\section{Kulturowe zasoby turystyczne Parku Narodowego Gór Stołowych}

Na podstawie inwentaryzacji terenowej zidentyfikowano na obszarze PNGS 94 punktowe obiekty kulturowe. W grupie tej znalazły się m.in. pozostałości fortu Karola oraz schronisko PTTK „Na Szczelińcu”, które stanowią przykład miejsc chętnie odwiedzanych przez turystów. Z tego względu wyróżniają się W grupie zasobów kulturowych i należy je postrzegać jako atrakcje turystyczne. Rozmieszczenie potencjalnych walorów kulturowych jest nierównomierne, a w dodatku nie wszystkie obiekty znajdują się obecnie bezpośrednio przy szlakach turystycznych (ryc. 2). 


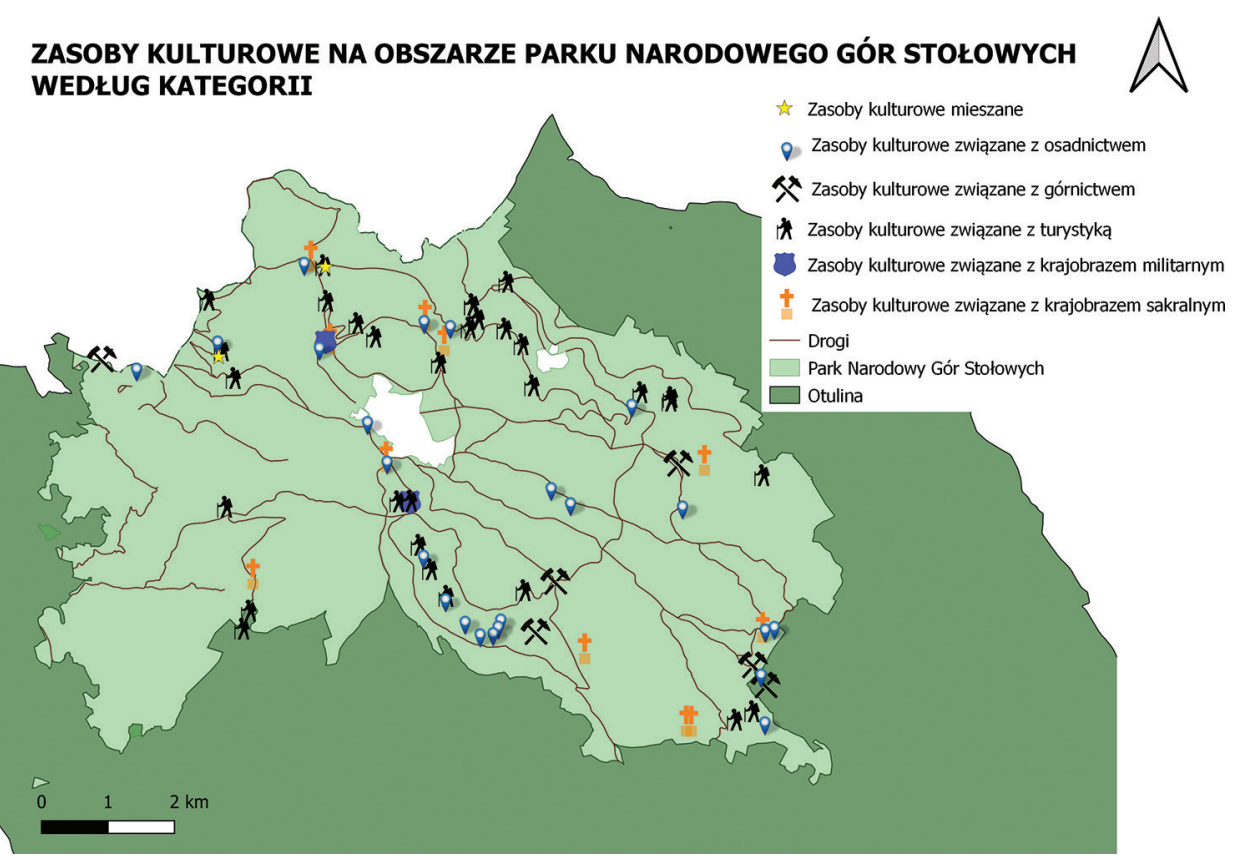

Ryc. 2. Zasoby turystyczne na obszarze Parku Narodowego Gór Stołowych Źródło: opracowanie własne.

Badania terenowe umożliwiły dokonanie wstępnej klasyfikacji tematycznej zasobów kulturowych, w której odniesiono się przede wszystkim do pierwotnych funkcji poszczególnych obiektów. Najbardziej liczną kategorię stanowi grupa obiektów związanych z osadnictwem (35). Umieszczono w niej artefakty będące wynikiem przekształcania przez człowieka terenu, których nie sklasyfikowano $\mathrm{w}$ ramach pozostałych, węższych pojęciowo grup tematycznych. W drugiej pod względem liczebności grupie znalazły się obiekty, które pojawiły się w krajobrazie Gór Stołowych w związku z rozwojem turystyki na tym obszarze, m.in. kamienne szlakowskazy, punkty widokowe, zabytkowa infrastruktura turystyczna (31). Do grupy obiektów skategoryzowanych pod nazwą „krajobraz sakralny" zaliczono kapliczki, krzyże oraz pozostałe elementy wpisujące się w definicję krajobrazu sakralnego, zaproponowaną przez Lehmanna (2007; za: Holly, 2014), dla którego obejmuje on „dziedzictwo duchowe i kulturowe wyrażone za pomocą obiektów sakralnych w krajobrazie" (16). Wśród zasobów kulturowych odnoszących się do górnictwa uwzględniono przede wszystkim pozostałości infrastruktury związanej z dawnym funkcjonowaniem kamieniołomów (8). Najmniej liczne grupy (po 2 obiekty) dotyczą krajobrazu militarnego (pozostałości bastionów) oraz tzw. zasobów kulturowych mieszanych, które składają się z obiektów o różnej funkcji, zlokalizowanych bezpośrednio w sąsiedztwie - przy schronisku „Na Szczelińcu” oraz w Ostrej Górze. Przykłady zinwentaryzowanych zasobów turystycznych zamieszczono w tabeli 2. 
Tabela 2. Wybrane obiekty kulturowe na obszarze PNGS według kategorii

$$
\text { Przykładowe obiekty dziedzictwa kulturowego }
$$

Osadnictwo Kamienie graniczne włości, drogowskazy, odrestaurowany system kaskadowych suchych zbiorników retencyjnych, elementy infrastruktury drogowej, pomnik pamięci, pozostałości zabudowań w dawnych wsiach (np. Karłówek), pozostałości huty szkła w Batorowie, drewniana dzwonnica sygnałowa.

Turystyka Szlakowskazy, wyrzeźbione w skałach „kanapy i fotele” wypoczynkowe na szlaku, tablice edukacyjne, punkty widokowe, infrastruktura turystyczna przy wodospadzie Pośny, pomnik „Serce pozostawione w Pasterce”.

Krajobraz Kapliczki, krzyże, XVIII-wieczny kościół pw. św. Jana Chrzciciela w Pastersakralny ce wraz z cmentarzem, XVIII-wieczna kaplica pw. św. Anny na Wzgórzu św. Anny w Batorowie wraz z kalwarią, fragment ścieżki pątniczej do Wambierzyc.

Górnictwo Odsłonięcia skalne, pochylnie, kamienie młyńskie, drogi, schody, kamień górniczy pola górniczego w masywie Skalniaka.

Krajobraz Pozostałości XVIII-wiecznego fortu Karola na górze Ptak, obszar militarny XVIII-wiecznego fortu w Pasterce.

Źródło: opracowanie własne na podstawie inwentaryzacji terenowej (lipiec 2020).

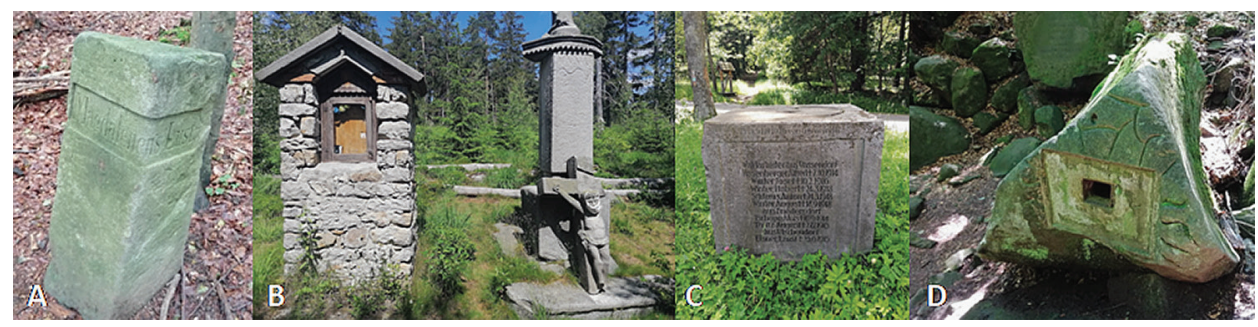

Ryc. 3. Zasoby kulturowe: A. szlakowskaz, B. kapliczka i krzyż na dawnym szlaku pątni-

czym, C. pomnik w Karłowie poświęcony pamięci ofiar I wojny światowej, D. dawna skarbonka dla turystów przy wodospadzie Pośny

Źródło: fot. wykonana przez autora (lipiec 2020).

Zinwentaryzowane obiekty charakteryzują się różnym stopniem zachowania i dostępności. Wiele z nich mogłoby już obecnie wzbogacać ofertę turystyczną PNGS, jednak ze względu na brak odpowiedniej infrastruktury turystycznej wciąż pozostają one zasobami turystycznymi.

\section{Zakończenie}

Zróżnicowane walory i zasoby kulturowe rejonu Gór Stołowych są istotnym czynnikiem, wokół którego można budować szlaki kulturowe oraz produkty turystyczne. Konieczność ich tworzenia znajduje uzasadnienie w narastającym ruchu turystycznym, a także w coraz częściej odczuwanej potrzebie zachowania bezpiecznego dystansu społecznego z powodu epidemii wywołanej wirusem 
SARS-CoV-2. Wzbogacona oferta turystyczna umożliwiłaby dyspersję kierunków zwiedzania, co uchroniłoby cenny przyrodniczo obszar przed przesyceniem turystycznym, a także zwiększyło atrakcyjność turystyczną rejonu. Z drugiej strony istnieje zagrożenie niepożądanego zachowania turystów na szlakach odwiedzanych jak dotąd rzadziej. Dlatego należy wypracować odpowiedni sposób monitoringu ruchu turystycznego oraz uwzględnić działania o charakterze edukacyjnym, zwiększające świadomość ekologiczną odwiedzających. Zarządzający ruchem turystycznym powinni jednakowo troszczyć się o opracowanie i promocję tras przyrodniczych, kulturowych oraz łączących elementy naturalne i antropogeniczne, co może zawierać się $\mathrm{w}$ trasach krajoznawczych. Ich zróżnicowanie może zainteresować różne grupy konsumentów, którzy odpowiednio wypromowany region uznają za atrakcyjny turystycznie. Postrzeganie środowiska geograficznego jako spójnego i funkcjonalnego systemu umożliwia zachowanie jego walorów. Autentyczność ta jest istotna zarówno z punktu widzenia gestorów turystyki, jak i samych turystów. Kreowanie oferty przyrodniczo-kulturowej powinno odbywać się ze szczególnym uwzględnieniem wychowawczej funkcji turystyki, na którą składają się funkcja kształcenia świadomości ekologicznej i funkcja edukacji kulturowej. Za właściwą formę harmonijnego rozwoju turystyki na tym obszarze można uznać ekoturystykę, którą Kurek (2004) wskazuje jako najbardziej optymalną w parkach narodowych. W przestrzeni wytworzonej pomiędzy walorami (atrakcjami) przyrodniczymi a kulturowymi należy stymulować rozwój innych form turystyki, np. geoturystykę, turystykę edukacyjną, turystykę aktywną, które mogą stanowić dodatkowe źródło dochodu dla miejscowej ludności. Równolegle do rozwoju turystyki kulturowej na obszarze parku istnieje potrzeba lepszej promocji obiektów dziedzictwa kulturowego znajdującego się w miejscowościach położonych wzdłuż tras dojazdowych do rozpoznanych już atrakcji kulturowych. Wzbogaciłyby one ofertę $\mathrm{w}$ większości dobrze przygotowanych do obsługi turystów wypromowanych już kulturowych atrakcji turystycznych. Kompleksowemu rozpoznaniu kulturowej atrakcyjności turystycznej tego obszaru może służyć kontynuacja badań, obejmująca m.in. wielowymiarową analizę porównawczą gmin znajdujących się w otulinie PNGS, a także badania związane z oczekiwaniami turystów i oceną atrakcji turystycznych, na których wartość aplikacyjną zwraca uwagę Kruczek (2005). Cały czas aktualne pozostają sugestie wskazane przez Mikosa von Rohrscheidta (2008b), który postulował rozwój na Ziemi Kłodzkiej turystyki militarnej, religijnej, obiektów i zabytków techniki, kulturowo-przyrodniczej, muzealnej i wypraw tematycznych związanych ze sztuką i architekturą. Nie należy pomijać również ważnej w tym regionie turystyki etnicznej Niemców i Czechów (zwłaszcza na obszarze tzw. Czeskiego Kątka²), związanej zarówno z miejscami i obiektami przodków, jak i różnymi wydarzeniami historycznymi i przejawami wytworów kultury.

Wzrost świadomości odwiedzających na temat bogactwa i zróżnicowania dziedzictwa kulturowego rejonu Gór Stołowych może przyczynić się do wzrostu

2 Obszar rozciągający się na południowy zachód od Błędnych Skał - pomiędzy Lewinem a czeskim Náchodem. 
liczby turystów motywowanych walorami antropogenicznymi. Umożliwiłoby to rozwój turystyki kulturowej już nie tylko w oparciu o cykliczne wydarzenia kulturalne, lecz także unikalne obiekty dziedzictwa, które są formą kapitału kulturowego łączącego ludzi ze sobą i środowiskiem (Harrison, 2010, za: Nowacki, 2012). Podstawowym działaniem powinno być opracowanie koncepcji systemu informacji turystycznej objaśniającego znaczenie poszczególnych elementów dziedzictwa kulturowego, a następnie wytyczenie szlaków tematycznych. Proponowane w tym rozdziale działania są zgodne z obowiązującą Strategią Rozwoju Turystyki w PNGS (Czerniak i in., 2020), co nadaje podjętej problematyce badawczej charakter aplikacyjny.

\section{Literatura}

Aciksoz S., Gormus S., Karadeniz N. (2010). Determination of ecotourism potential in national parks: Kure mountains national park, Kastamonu-Bartin, Turkey. African Journal of Agricultural Research, 5(8): 589-599.

Cajee L. (2014). Eco-Cultural Tourism: A Tool for Environmental, Cultural and Economic Sustainability (A Case Study of Darap Village, West Sikkim). SHS Web of Conferences, 12.

Carvache-Franco M., Segarra-Ona M., Carrascosa-Lopez C. (2019). Segmentation and motivations in eco-tourism: The case of a coastal national park. Ocean \& Coastal Management, 178.

Czerniak A. (red.) 2020. Strategia rozwoju turystyki w Parku Narodowym Gór Stołowych. Biuro Urządzania Lasu i Geodezji Leśnej Oddział w Brzegu.

Holly G. (2014). Przekształcenia krajobrazu sakralnego na pograniczu polsko-słowacko-ukraińskim (XIX-XXI wiek). Monografie Bieszczadzkie, 15. Bieszczadzki Park Narodowy, Ustrzyki Dolne.

http://parafiaduszniki.pl/ (dostęp: 20.12.2020).

http://visitduszniki.pl/ (dostęp: 20.12.2020).

Kozioł A., Trelka M., Florjanowicz P. (2013). Społeczno-gospodarcze oddziaływanie dziedzictwa kulturowego. Raport z badań społecznych. Narodowy Instytut Dziedzictwa, Warszawa.

Kruczek Z. (2005). Metody badań atrakcji turystycznych. W: R. Winiarski, W. Alejziak (red.), Turystyka w badaniach naukowych. AWF, Kraków, WZiZ, Rzeszów, s. 35-46.

Kruczek Z. (2017). Frekwencja w polskich atrakcjach turystycznych 2011-2015. Wydawnictwo Proksenia, Kraków.

Kurek W. (2004). Turystyka na obszarach górskich Europy. Instytut Geografii i Gospodarki Przestrzennej Uniwersytetu Jagiellońskiego, Kraków.

Latocha A. (2011). Contemporary landscape of depopulated areas as a mosaic of relict and active landscape features (Stołowe Mts. case study). The Problems of Landscape Ecology, 30: 309-316.

Latocha A. (2012). Śladami dawnego osadnictwa w Sudetach (1) - Karłówek. Sudety, 4(133): $28-31$.

Latocha A. (2017). Odradzanie wsi? Przemiany ludnościowo-osadnicze na ziemi kłodzkiej w okresie powojennym. Studia Obszarów Wiejskich, 48: 29-50.

Latocha A. (2020). Krajobraz kulturowy Gór Stołowych. Wędrówki w czasie i w terenie. Wydawnictwo cyfrowe, Park Narodowy Gór Stołowych. 
Latocha A., Migoń P. (2018). Geneza i przemiany krajobrazu kulturowego Gór Stołowych. W: C. Kabała (red.), Góry Stołowe. Przyroda i ludzie. Park Narodowy Gór Stołowych, Kudowa-Zdrój, s. 47-61.

Latocha A., Roszczewska M. (2011). Zmiany krajobrazu na terenie Parku Narodowego Gór Stołowych w ostatnich stu latach. Przyroda Sudetów, 14: 125-140.

Łysoń P. (2019). Turystyka w Polsce w 2018 roku. GUS, Warszawa.

Mikos von Rohrscheidt A. (2008a). Turystyka kulturowa: fenomen, potencjał, perspektywy. GWSHM Milenium, Gniezno.

Mikos von Rohrshcheidt A. (2008b). Waloryzacja turystyczno-kulturowa miasta i powiatu Kłodzko. Turystyka Kulturowa, 2: 36-47.

Nowacki M. (2012). Dziedzictwo i turystyka: relacje i ewolucja koncepcji. W: B. Włodarczyk, B. Krakowiak (red.), Kultura i turystyka - wspólne korzenie. Regionalna Organizacja Turystyczna Województwa Łódzkiego, Łódź, s. 35-49.

Papaj M. (2015). Kudowa-Zdrój w Górach Stołowych. Wydawnictwo Turystyczne Plan, Jelenia Góra.

Potocki J. (2016). Góry Stołowe i Adsrpassko-Teplicke Skaly. Wydawnictwo Turystyczne Plan, Jelenia Góra.

Rogowski M., Żyto A. (2018). Co turysta kulturowy robi w parku narodowym? Motywy i preferencje turystów kultu-rowych w Parku Narodowym Gór Stołowych. Turystyka Kulturowa, 4: 63-77.

Ryś S. (2000). Kudowa-Zdrój. Przewodnik turystyczny. Wydawnictwo Kartograficzne Karta, Katowice.

Sgroi F. (2020). Forest resources and sustainable tourism, a combination for the resilience of the landscape and development of mountain areas. Science of The Total Environment, 736.

Staffa M., Janczak J., Mazurski K., Zając C., Czerwiński J. (1992). Słownik geografii turystycznej Sudetów. T. 13. Góry Stołowe. Wydawnictwo PTTK „Kraj”, Warszawa-Kraków.

Stasiak A. (1997). Turystyka w parkach narodowych - obszary konfliktów. Turyzm, 7(2): 5-23.

Wei C., Dai S., Xu H., Wang H. (2020). Cultural worldview and cultural experience in natural tourism sites. Journal of Hospitality and Tourism Management, 43: 241-249.

Ustawa z dnia 16 kwietnia 2004 o ochronie przyrody.

Badania zostały sfinansowane w ramach projektu GEO-INTER-APLIKACJE - wysokiej jakości interdyscyplinarny program studiów doktoranckich POWR.03.02.00-00-I027/17.

\section{The importance of cultural heritage for tourism development in the National Park of the Stable Mountains}

The growing tourist traffic in the Stołowe Mountains generates the need for its deglomeration, which is possible, among others, by through the use of cultural heritage objects. The aim of the article is to determine its significance for the development of tourism in the studied area. The text presents the cultural attractions visited as well as the genera overviev of cultural attractions and resources in the PNGS area. The methodology of the conducted research included obtaining data from tourists using an interview questionnaire and field inventory. The cultural heritage of the Stolowe Mts. is a complementary motivation for tourist trips. Cultural tourism develops mainly in towns, and cultural resources, located in the park area, require promotion and sharing, e.g. in the form of thematic routes.

Translated by Artur Żyto 


\author{
Bartłomiej Łuć \\ Uniwersytet Łódzki \\ bartlomiej.luc@op.pl \\ (D) https://orcid.org/0000-0003-0798-675X
}

\title{
Wpływ rozwoju infrastruktury sportowo- rekreacyjnej na turystykę sportową w Łodzi
}

\section{Streszczenie}

Niniejszy rozdział podsumowuje rozważania dotyczące łódzkiej infrastruktury sportowo-rekreacyjnej i szeroko rozumianej turystyki sportowej. Zebrane materiały źródłowe i literatura umożliwiły autorowi opisanie wpływu rozwoju bazy sportowo-rekreacyjnej w Łodzi na turystykę sportową. Główną metodę badawczą stanowiła kwerenda literatury związanej z turystyką sportową i inwentaryzacja łódzkich obiektów sportowo-rekreacyjnych. Ponadto autor zaprezentował część wyników swoich badań przeprowadzonych w trakcie Młodzieżowych Mistrzostw Świata U-20 w Piłce Nożnej Mężczyzn 2019. Nadrzędnym celem było pokazanie, w jaki sposób rozwój wspomnianej infrastruktury wpłynął na turystykę sportową w Łodzi. Analiza pozwoliła stwierdzić, że dynamiczny rozwój łódzkiej infrastruktury sportowo-rekreacyjnej wywarł istotny wpływ na wzrost znaczenia turystyki sportowej, głównie w postaci rosnącej liczby wydarzeń sportowych.

\section{Wprowadzenie}

Ostatnie kilkadziesiąt lat to okres gwałtownych zmian w Polsce, zarówno gospodarczych, społecznych, jak i związanych z rozwojem infrastruktury. Zmiany te w znacznym stopniu widoczne są także w przypadku infrastruktury sportowo-rekreacyjnej. Najczęściej przejawia się to poprzez budowę nowoczesnych stadionów piłkarskich i hal widowiskowo-sportowych. Wspomniana infrastruktura sportowo-rekreacyjna rozwinęła się także w Łodzi. Rosnąca liczba obiektów sportowo-rekreacyjnych oraz coraz lepszy stan infrastruktury umożliwia organizowanie dużej liczby wydarzeń sportowych o zasięgu ogólnopolskim i międzynarodowym. Wszystkie te czynniki wpływają na rozwój turystyki sportowej. 
W niniejszym rozdziale podjęto próbę przeanalizowania tego, jak rozwój łódzkiej infrastruktury sportowo-rekreacyjnej oddziaływał na turystykę sportową w mieście. Aspektem sprzyjającym rozwojowi tej formy aktywności turystycznej jest z pewnością korzystne położenie Łodzi i poprawiający się stan bazy noclegowej (Włodarczyk, 2016). Pod uwagę wzięto przede wszystkim wydarzenia sportowe organizowane $\mathrm{w}$ największych obiektach sportowo-rekreacyjnych, takich jak Stadion Miejski Widzewa czy hala Atlas Arena. Dokonano również inwentaryzacji i klasyfikacji wspomnianych obiektów ze względu na ich funkcjonalność i czas powstania.

Za miarę wpływu rozwoju infrastruktury sportowo-rekreacyjnej na turystykę sportową w Łodzi uznano wzrastającą systematycznie liczbę obiektów oraz rosnącą proporcjonalnie liczbę wydarzeń sportowych.

\section{Przegląd literatury}

Zależnościami pomiędzy infrastrukturą sportowo-rekreacyjną a turystyką sportową zajmowało się wielu naukowców, zarówno polskich, jak i zagranicznych, m.in. Kowalczyk (2005), Coleman i in. (2005), Hadzik (2010), Fourie i Santana-Galla (2011), Bosiacki i Śniadek (2012), Berbeka (2013) czy też Cieślikowski (2017). Kowalczyk (2005) podkreślił, że wydarzenia organizowane w obiektach sportowo-rekreacyjnych powodują rozwój wielu form turystyki miejskiej, w tym w dużym stopniu turystyki sportowej. Coleman i in. (2005) stwierdzili z kolei, że inwestycje $\mathrm{w}$ infrastrukturę sportową są czynione m.in. w celu przyciągnięcia do miast turystów. Hadzik (2010) uważał, że wydarzenia sportowe i budowane ze względu na ich organizację obiekty sportowe w znacznym stopniu zwiększają potencjał turystyczny miast. Fourie wraz z Santana-Gallego (2011) sądzili zaś, że wydarzenia organizowane $\mathrm{w}$ obiektach sportowo-rekreacyjnych przyczyniają się do przyjazdu turystów krajowych i zagranicznych. Bosiacki i Śniadek (2012) przytoczyli argument, że wydarzenia organizowane na tych obiektach mogą być kluczowym elementem strategii promocji miast. Według Berbeki (2013) obiekty sportowo-rekreacyjne są najprostszym elementem sportowym zlokalizowanym w przestrzeni miasta. Mogą one być fundamentalną częścią rekreacyjnych i sportowych obszarów miasta. Funkcjonalność oraz wpływ obiektów sportowych na turystykę sportową pokazał również Cieślikowski (2017). Podkreślił on, że obiekty takie mogą w późniejszej perspektywie czasowej stanowić produkty turystyczne.

Ponadto kilku naukowców ukazało, w jaki sposób obiekty sportowe mogą wpływać na rozwój turystyki sportowej w polskich miastach. Przykładem tego jest chociażby praca Borzyszkowskiego (2012), który zajął się analizą tego zjawiska w polskich miastach, w których odbywały się mecze podczas Mistrzostw Europy w Piłce Nożnej Mężczyzn Euro 2012. Cieślikowski i Kantyka (2015) przedstawili natomiast sytuację Katowic. Na łódzkiej infrastrukturze sportowo-rekreacyjnej i jej wpływie na turystykę w mieście skupił się Włodarczyk (2016). 
Kluczowym pojęciem stosowanym w pracy jest turystyka sportowa. Po przeanalizowaniu powstałych dotychczas definicji uznano, że najlepsza będzie ta opracowana przez Gibsona (1998). Jego zdaniem jest to podróż poza miejsce stałego zamieszkania $\mathrm{w}$ celu uczestnictwa $\mathrm{w}$ wydarzeniu sportowym $\mathrm{w}$ roli kibica lub widza oraz podróż do miejsc ściśle związanych ze sportem. W definicji tej zawarto najistotniejsze elementy kształtujące zjawisko turystyki sportowej.

Wpływ infrastruktury sportowo-rekreacyjnej na turystykę sportową zauważalny jest również w Łodzi. Większość badań naukowych związanych z tym aspektem prowadzona była $\mathrm{w}$ trakcie konkretnych wydarzeń sportowych lub też w odniesieniu do konkretnych obiektów sportowych. Niniejsze praca jest pierwszą próbą zaprezentowania ogólnego wpływu rozwijającej się infrastruktury sportowo-rekreacyjnej na turystykę sportową w Łodzi.

\section{Metodyka badań}

Podstawową metodą badawczą była kwerenda literatury dotycząca turystyki sportowej i materiałów źródłowych opracowanych przez władze miejskie, MOSiR i instytucje zarządzające danymi obiektami. Zaprezentowano również część wyników badań ankietowych przeprowadzonych w 2019 r. w trakcie Młodzieżowych Mistrzostw Świata U-20 w Piłce Nożnej Mężczyzn. Wzięło w nich udział 200 przypadkowo spotkanych obok Stadionu Widzewa kibiców bezpośrednio przed rozpoczęciem meczów. Respondentów zapytano m.in. o długość pobytu w Łodzi, obiekt noclegowy, z którego usług korzystali w czasie pobytu, czy też o ogólną ocenę organizacji turnieju. Wyniki tych badań pozwoliły w znacznym stopniu scharakteryzować ruch turystyczny związany ze sportem w trakcie trwania większego wydarzenia sportowego w Łodzi.

\section{Wyniki badań}

Kwerenda literatury i innych źródeł informacji oraz badania ankietowe okazały się kluczowe dla opracowania niniejszego rozdziału. Po przeanalizowaniu historii rozwoju łódzkiej infrastruktury sportowo-rekreacyjnej pokazano, w jakim stopniu wpłynęło to na wzrost liczby wydarzeń sportowych od kilkunastu lat organizowanych w nowo powstałych obiektach.

\section{Historia łódzkiej infrastruktury sportowo-rekreacyjnej}

Narodziny łódzkiej infrastruktury sportowej datowane są na początek XX w. Były one związane $z$ powstaniem kilku towarzystw piłkarskich wspieranych przez władze miejskie poprzez przeznaczenie terenów na inwestycje (Włodarczyk, 2016). Jednym z najbardziej charakterystycznych obiektów zbudowanych w tamtym 
czasie był Stadion Miejski ŁKS-u. Ponadto przed II wojną światową powstało kilka kompleksów kortów tenisowych oraz do uprawiania jeździectwa (ryc. 1).

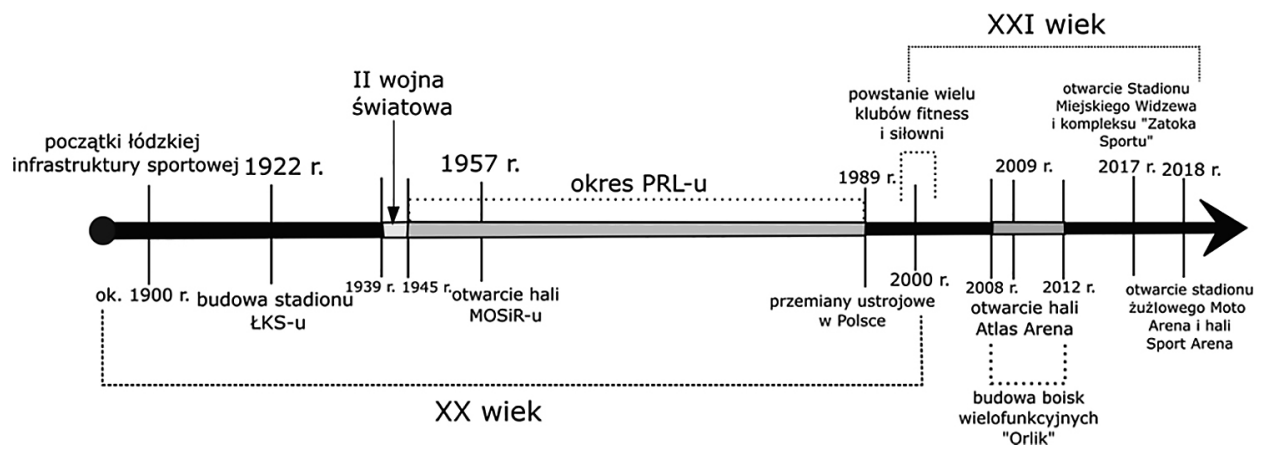

Ryc. 1. Etapy rozwoju łódzkiej infrastruktury sportowo-rekreacyjnej

Źródło: opracowanie własne.

Po wojnie do czasu przemian ustrojowych w 1989 r. w Łodzi powstawały przede wszystkim kryte pływalnie budowane przy szkołach i innych placówkach edukacyjnych. W 1957 r. zbudowano również halę widowiskowo-sportową łódzkiego MOSiR-u, która przez ponad 50 lat była jednym z najważniejszych łódzkich obiektów sportowych. W roku 1989 w Łodzi znajdowało się około 35 obiektów sportowo-rekreacyjnych (ryc. 2). Ich lokalizacja skupiona była przede wszystkim w pobliżu centrum miasta w dzielnicy Śródmieście. Duża liczba obiektów usytuowana była też w dzielnicy Widzew (ryc. 3). Niewiele obiektów wzniesiono na przedmieściach.

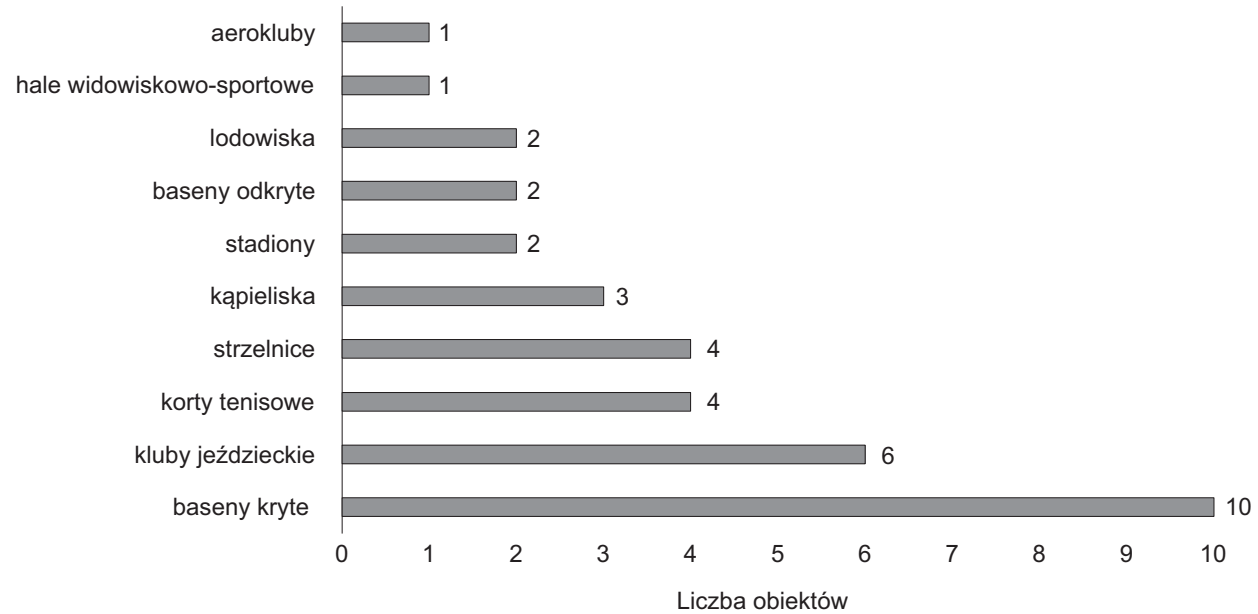

Ryc. 2. Liczba poszczególnych łódzkich obiektów sportowo-rekreacyjnych w roku 1989 Źródło: opracowanie własne na postawie http://www.mosir.lodz.pl/. 


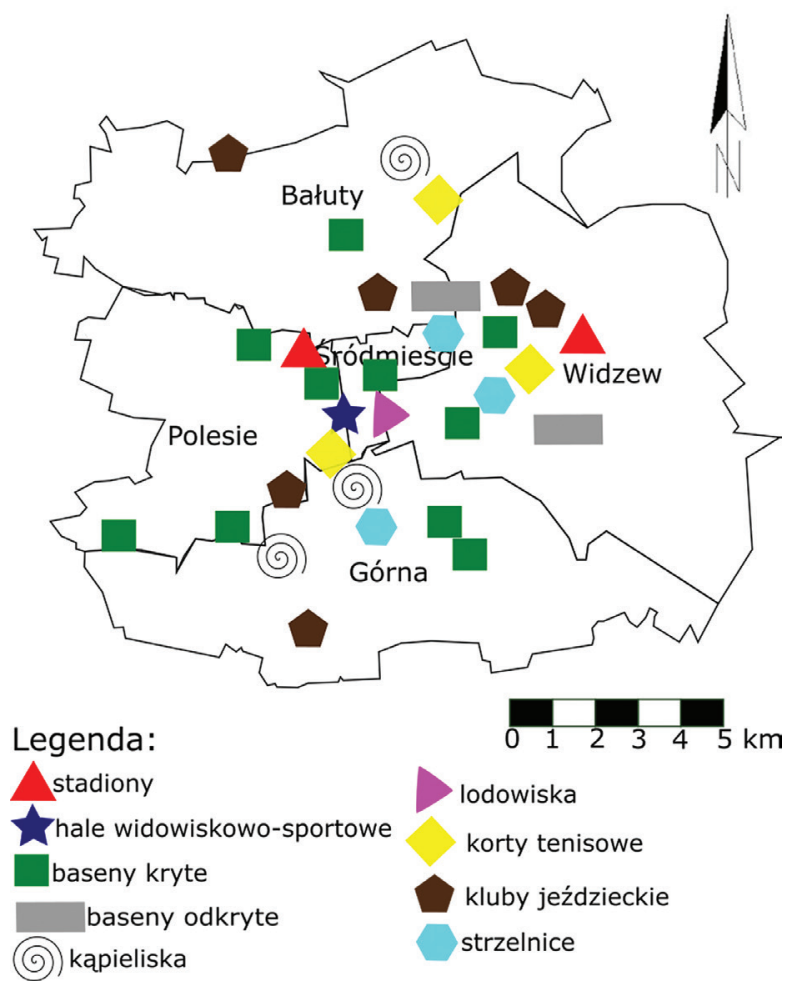

Ryc. 3. Infrastruktura sportowo-rekreacyjna w Łodzi w roku 1989 Źródło: opracowanie własne na postawie http://www.mosir.lodz.pl/.

Od momentu przemian ustrojowych nastąpił dynamiczny rozwój łódzkiej infrastruktury sportowo-rekreacyjnej. W szczególności dynamika ta widoczna jest na przestrzeni ostatnich kilkunastu lat. Na przełomie XX i XXI w. masowo powstawały siłownie i kluby fitness. Od 2008 do 2012 r. zbudowano także kilkadziesiąt boisk wielofunkcyjnych, tzw. „Orlików”. Był to rezultat rządowego programu związanego z organizacją przez Polskę i Ukrainę Mistrzostw Europy w Piłce Nożnej Mężczyzn Euro 2012 (ryc. 4). Boiska te powstawały przede wszystkim przy szkołach i placówkach edukacyjnych oraz na osiedlach mieszkaniowych.

Ostatnie lata to okres, w którym zbudowano największe łódzkie obiekty sportowo-rekreacyjne. Dużym echem odbiło się otwarcie hali widowiskowo-sportowej Atlas Arena w 2009 r. Innym okazałym obiektem jest Stadion Widzewa wzniesiony na miejscu poprzedniego przestarzałego już obiektu. Ponadto zbudowano takie obiekty, jak: stadion żużlowy Moto Arena, hala widowiskowo-sportowa Sport Arena czy Akademickie Centrum Sportowo-Dydaktyczne Politechniki Łódzkiej „Zatoka Sportu”. Na zaawansowanym etapie budowy jest stadion ŁKS-u. Nowo powstałe obiekty mogą się także pochwalić największą pojemnością spośród wszystkich łódzkich aren sportowych (tab. 1). 


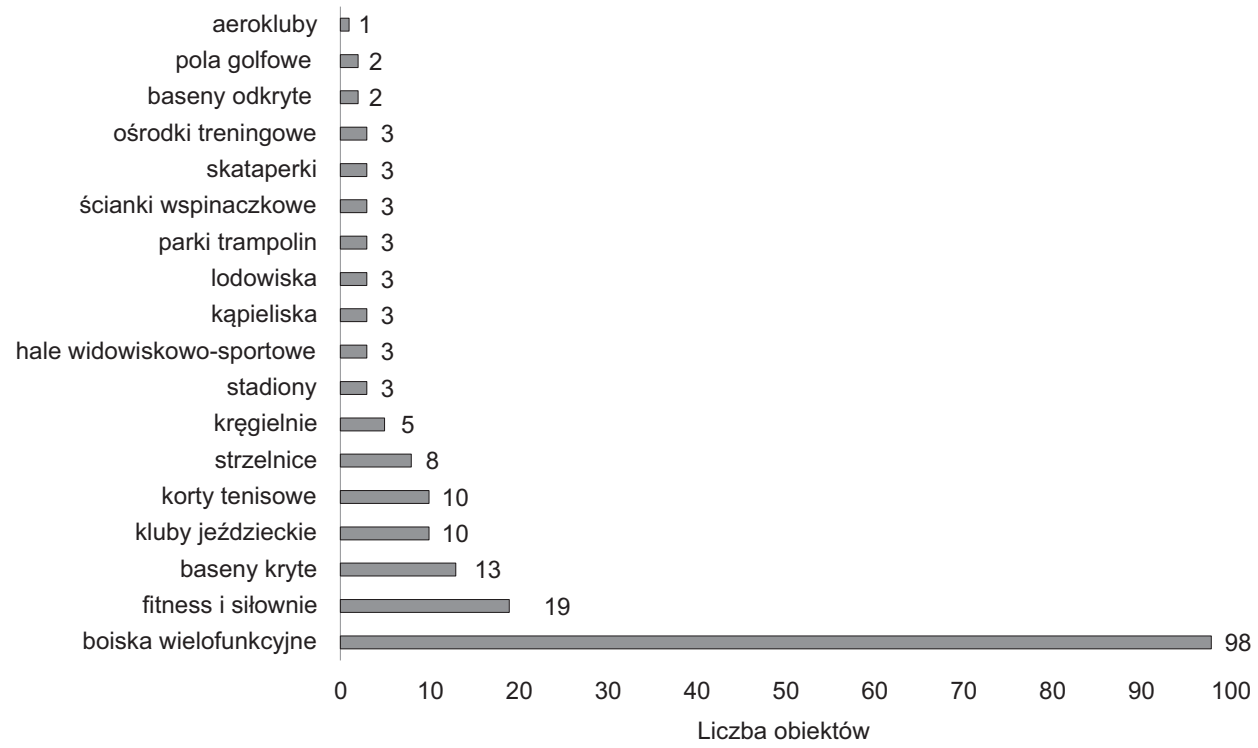

Ryc. 4. Liczba poszczególnych łódzkich obiektów sportowo-rekreacyjnych w roku 2020 Źródło: opracowanie własne na postawie http://www.mosir.lodz.pl/.

Tabela 1. Największe łódzkie obiekty sportowo-rekreacyjne - stan na 2020 r.

\begin{tabular}{lllcr}
\hline Lp. & Nazwa obiektu & $\begin{array}{c}\text { Lokalizacja } \\
\text { (dzielnica Łodzi) }\end{array}$ & Rok powstania & $\begin{array}{c}\text { Pojemność } \\
\text { (liczba miejsc } \\
\text { siedzących) }\end{array}$ \\
\hline \multicolumn{5}{c}{ Stadiony } \\
\hline 1. & Stadion Widzewa & Widzew & 2017 & 18018 \\
2. & Moto Arena & Polesie & 2018 & 10350 \\
3. & Stadion Miejski & Polesie & 2015 (w trakcie dal- & 5700 \\
\multicolumn{5}{c}{ szej rozbudowy) } \\
\hline 1. & Atlas Arena & Hale widowiskowo-sportowe & 13806 \\
2. & Hala MOSiR & Polesie & 2009 & 9010 \\
3. & Sport Arena & Polesie & 1957 & 3017 \\
\hline
\end{tabular}

Źródło: opracowanie własne na podstawie http://stadiony.net/ oraz https://makis.pl/.

Obecnie obiekty sportowo-rekreacyjne zlokalizowane są na terenie całego miasta. Ich największa koncentracja występuje w centralnych obszarach miasta. W porównaniu ze stanem infrastruktury sportowo-rekreacyjnej sprzed czasów transformacji ustrojowej widoczny jest jej rozwój na terenach zlokalizowanych w dalszej odległości od centrum i na peryferiach (ryc. 5). 


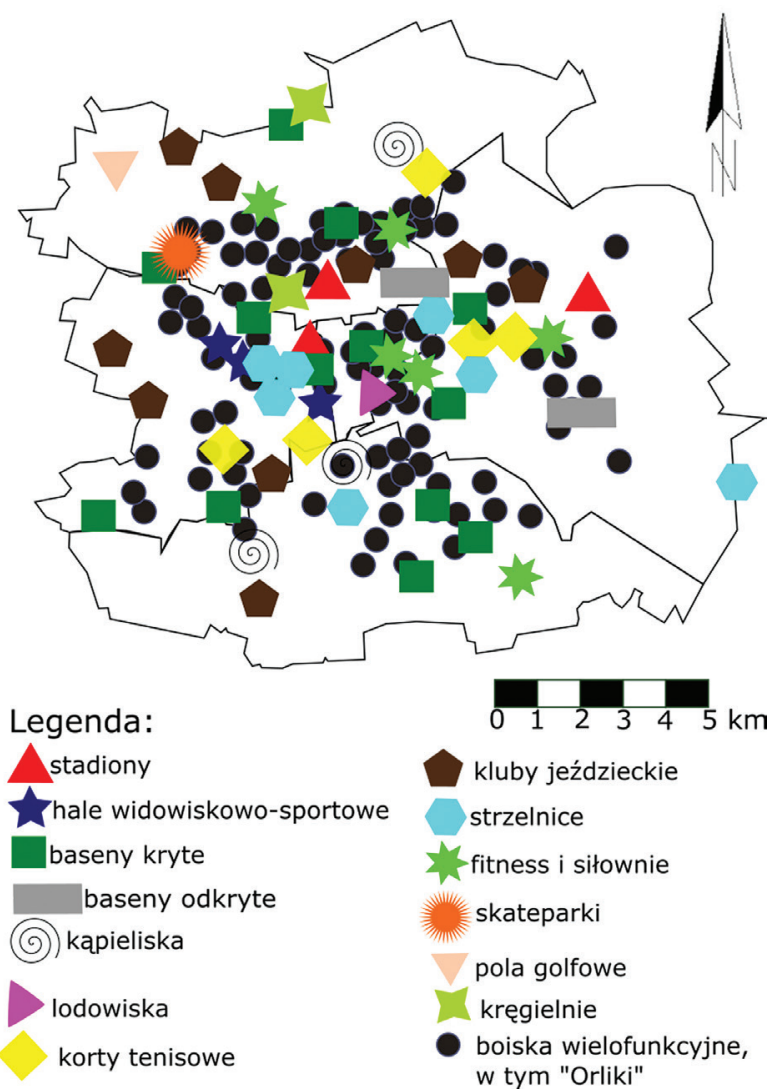

Ryc. 5. Infrastruktura sportowo-rekreacyjna w Łodzi - stan na 2020 r. Źródło: opracowanie własne na postawie http://www.mosir.lodz.pl/.

\section{Wydarzenia sportowe w Łodzi}

Rozwój łódzkiej infrastruktury sportowej w znacznym stopniu przyczynił się do wzrostu znaczenia turystyki sportowej. Ta forma turystyki rozwinęła się głównie poprzez organizowanie coraz większej liczby wydarzeń sportowych, na które przyjeżdżają przede wszystkim kibice z Polski i z zagranicy. Ważnym momentem było otwarcie hali widowiskowo-sportowej Atlas Arena oraz powstanie w kolejnych latach takich obiektów, jak np. Stadion Widzewa czy stadion Moto Arena. Wcześniej liczba wydarzeń sportowych organizowanych w Łodzi nie była zbyt okazała. Sporadycznie odbywały się jedynie mecze siatkarskiej reprezentacji Polski mężczyzn w starej hali łódzkiego MOSiR-u lub mecze piłkarskiej reprezentacji Polski na starym Stadionie Miejskim Widzewa. Od momentu otwarcia Atlas Areny odbyło się tam kilka znaczących wydarzeń sportowych o zasięgu międzynarodowym. Obiekt ten najczęściej miał okazję być „gospodarzem” imprez siatkarskich $z$ udziałem obydwu polskich reprezentacji oraz siatkarzy Skry Bełchatów. 
Dużą popularnością cieszą się również mitingi lekkoatletyczne Pedro’s Cup czy różnego rodzaju gale sztuk walki.

Na początku 2017 r. otwarto również nowy Stadion Miejski Widzewa. Jest on w głównej mierze obiektem, na którym swoje mecze rozgrywa piłkarska drużyna Widzewa Łódź, jednak miał on także okazję gościć kilka wydarzeń o zasięgu międzynarodowym. Do tej pory największym z nich były Młodzieżowe Mistrzostwa Świata U-20 w Piłce Nożnej Mężczyzn 2019.

Pierwszym większym wydarzeniem sportowym zorganizowanym w Łodzi były Mistrzostwa Europy w Koszykówce Mężczyzn 2009. W hali Atlas Arena rozegrano 9 meczów, w tym 3 mecze reprezentacji Polski. Przy okazji tego wydarzenia utworzono m.in. tzw. „strefę kibica” w centrum handlowym Manufaktura. Na czas wydarzenia uruchomiono też darmową komunikację miejską (Włodarczyk, 2016).

Kilka dni później rozpoczęły się Mistrzostwa Europy w Piłce Siatkowej Kobiet. W Łodzi wszystkie swoje mecze rozegrała reprezentacja Polski. Odbyły się tu również mecze finałowej fazy turnieju. Przy okazji organizacji turnieju na placu Dąbrowskiego stworzono „strefę kibica” wraz z Piknikiem Siatkarskim (Włodarczyk, 2016).

Obydwa wspomniane wydarzenia przyczyniły się do poprawy ogólnego wizerunku miasta wśród turystów. Atlas Arena otrzymała również status Sportowego Obiektu Roku 2009. W tym roku ponad 36\% turystów zagranicznych przyjechało do Łodzi w celu uczestnictwa w tych wydarzeniach (Tanaś, 2010).

Kolejnym istotnym wydarzeniem były zorganizowane w $2011 \mathrm{r}$. Mistrzostwa Europy w Koszykówce Kobiet. Atlas Arena gościła najważniejsze mecze turnieju, w tym mecz finałowy. Podobnie jak w przypadku poprzednich imprez utworzona została „strefa kibica” (Włodarczyk, 2016).

Bardzo ważnym wydarzeniem były też Mistrzostwa Świata w Piłce Siatkowej Mężczyzn w 2014 r. Była to jedna z największych imprez sportowych, które do tej pory odbyły się w Łodzi, reklamowana na długo przed jej rozpoczęciem. Przeprowadzono wiele działań promocyjnych polegających m.in. na intensywnym informowaniu o wydarzeniu poprzez montaż wielkoformatowych banerów, graficznej szaty pojazdów komunikacji miejskiej czy organizację mniejszych imprez poprzedzających. W trakcie turnieju w centrum handlowym Manufaktura zorganizowano „strefę kibica” (Włodarczyk, 2016). Hala Atlas Arena gościła mecze drugiej i trzeciej fazy turnieju. Swoje spotkania rozegrała tu także reprezentacja Polski. Łącznie odbyło się tutaj 13 meczów. Szacuje się, że średnia frekwencja wyniosła ponad 95\%. W trakcie turnieju Łódź odwiedziło ponad 100 tys. turystów.

Badania przeprowadzone podczas turnieju pokazały, że największa liczba przyjezdnych pochodziła z województw: łódzkiego (35\%), mazowieckiego (25\%) i wielkopolskiego (10\%). Respondenci w pięciostopniowej skali najwyżej ocenili atmosferę wydarzenia $(4,83)$ i nagłośnienie obiektu $(4,64)$. Najgorzej oceniono dostępność miejsc parkingowych $(3,68)$. Największa liczba kibiców przybyła do Łodzi samochodami osobowymi. Ankietowanym w trakcie pobytu najczęściej towarzyszyli znajomi i rodzina. Ponad $70 \%$ badanych uczestniczyło w jednym meczu, byli to więc tzw. odwiedzający jednodniowi (Sobierajska, 2015). Mimo tego lódzkie hotele odnotowały w tym czasie stosunkowo duże obłożenie pokoi 
(ryc. 6). Dla przyjezdnych miasto przygotowało również ofertę uzupełniającą w postaci zniżek za bilety wejściowe do muzeów i kilku obiektów sportowych. Niestety atrakcje te odwiedził tylko niecały $1 \%$ kibiców (ryc. 7). Turniej okazał się dla Łodzi sukcesem zarówno pod względem organizacji, jak i budowania wizerunku miasta wśród turystów (Włodarczyk, 2016).

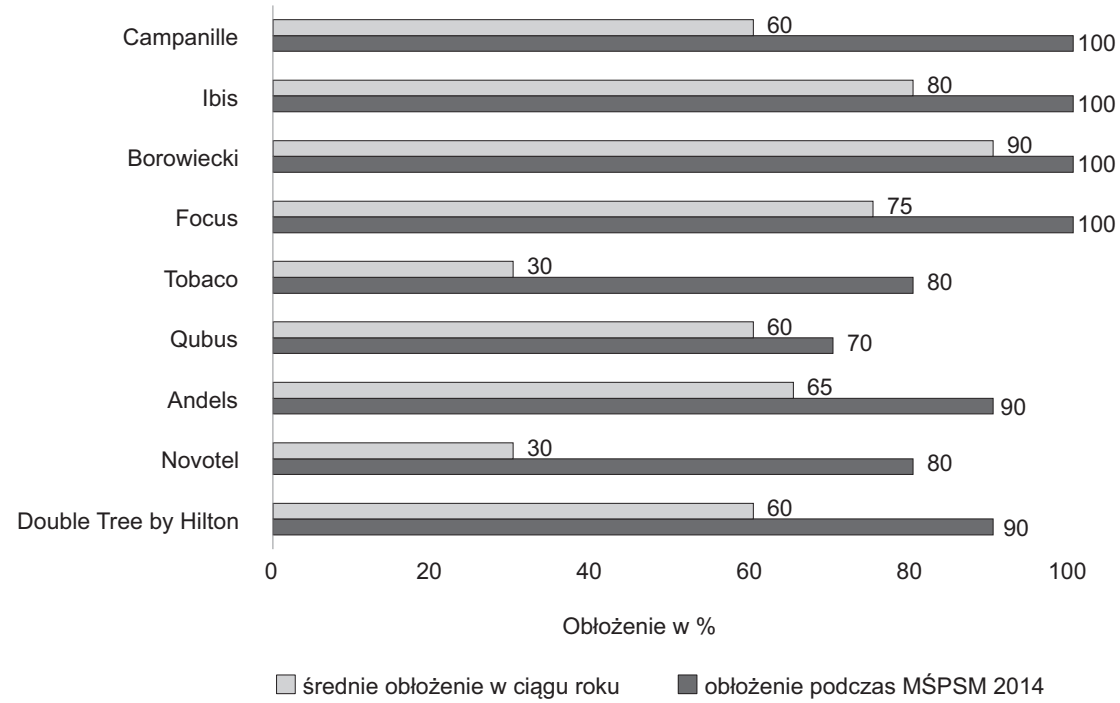

Ryc. 6. Obłożenie wybranych łódzkich hoteli w ciągu roku i w trakcie trwania MŚPSM 2014

Źródło: opracowanie własne na podstawie Włodarczyk (2016, za: www.lodz.gazeta.pl).

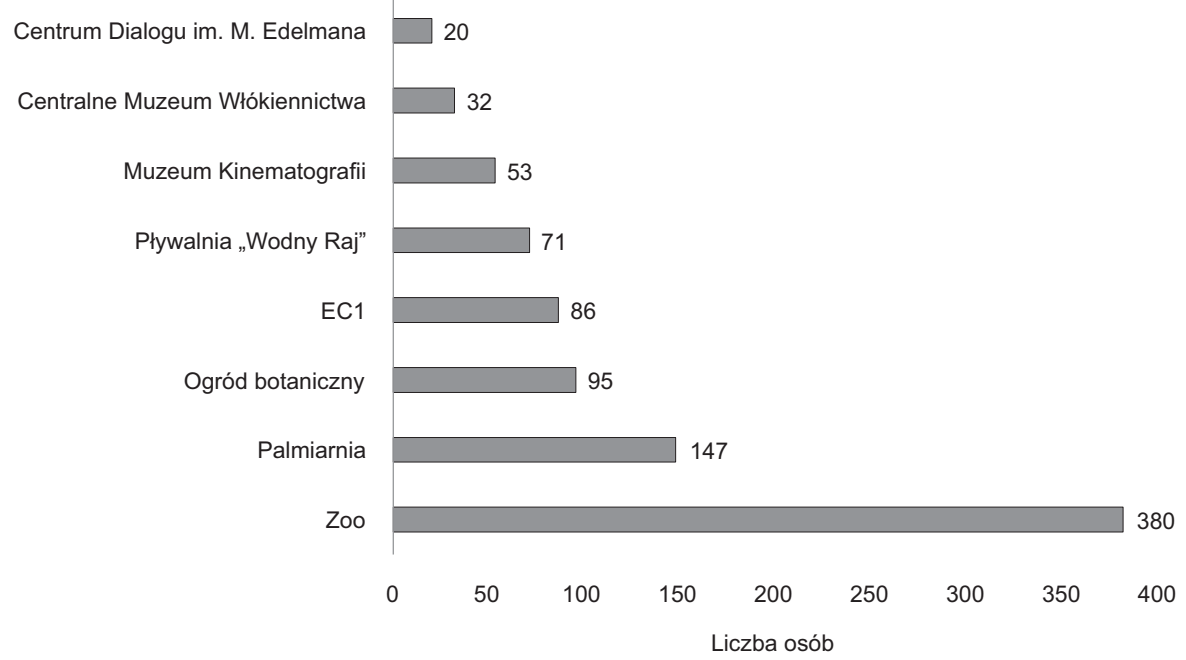

Ryc. 7. Liczba odwiedzających Łódź w wybranych obiektach w trakcie trwania MŚPSM 2014 za okazaniem biletu na mecz

Źródło: opracowanie własne na podstawie Włodarczyk (2016, za: www.lodz.gazeta.pl). 
Innym ważnym wydarzeniem sportowym zorganizowanym w Łodzi były Młodzieżowe Mistrzostwa Świata w Piłce Nożnej Mężczyzn w 2019 r. Odbyły się one na nowo powstałym Stadionie Miejskim Widzewa. W trakcie turnieju rozegrano tu 10 meczów, w tym mecze grupowe reprezentacji polski i mecz finałowy. Średnia frekwencja wyniosła ponad 10 tys. widzów, co stanowiło około $56 \%$ łącznego obłożenia. W porównaniu z opisywanymi wcześniej siatkarskimi mistrzostwami świata impreza ta cieszyła się o wiele mniejszą popularnością. Działania promocyjne również były mniej intensywne i oparte jedynie na pojedynczych banerach i folderach. W trakcie turnieju przeprowadzono badania z osobami, które przyjechały na mecz. Byli to przede wszystkim kibice z województwa łódzkiego (29\%), zaś w drugiej kolejności z województwa mazowieckiego (7\%) i kujawsko-pomorskiego (7\%).

Wśród ankietowanych około $36 \%$ to byli obywatele z innych krajów, głównie Korei Południowej i Nowej Zelandii (Łuć, 2020). Ich obecność była spowodowana jednak tym, że ich drużyny rozgrywały swoje mecze właśnie w Łodzi. W zdecydowanej większości respondenci w trakcie turnieju nocowali w łódzkich hotelach (ryc. 8). Najczęściej ich pobyt w Łodzi trwał jedynie kilka godzin. Poza oglądaniem meczu bardzo rzadko decydowali się na zwiedzanie miasta. Ponad $80 \%$ badanych docierało na mecze samochodami osobowymi.

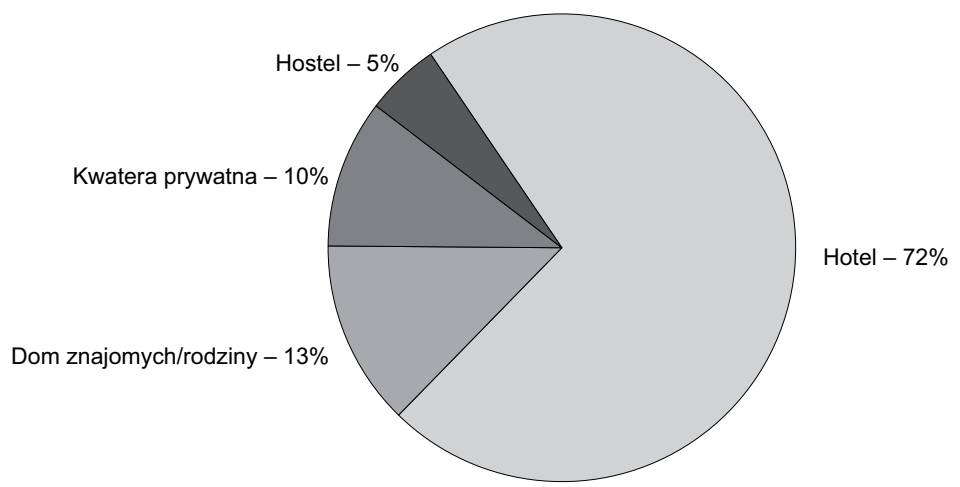

Ryc. 8. Obiekty noclegowe, w których nocowali ankietowani Źródło: opracowanie własne.

Organizację turnieju w największym odsetku ocenili dobrze (ryc. 9). Podkreślano duże zaangażowanie wolontariuszy oraz wysoki poziom infrastruktury stadionu i najbliższej okolicy. Wśród negatywnych aspektów wymieniano problemy z zaparkowaniem samochodu przed meczem oraz duże natężenie ruchu na łódzkich ulicach. W pięciostopniowej skali ocena organizacji turnieju przez Łódź oceniona została na 4,05 . Nieco lepsze oceny wskazali polscy respondenci $(4,07 \mathrm{przy}$ średniej ocenie zagranicznych badanych 3,25) (Łuć, 2020). W przeciwieństwie do innych wspomnianych wydarzeń sportowych w Łodzi Młodzieżowe Mistrzostwa Świata U-20 w Piłce Nożnej nie do końca okazały się sukcesem organizacyjnym. Władze miejskie stosunkowo słabo promowały ten turniej, nie prowadziły tak dynamicznych działań jak chociażby w przypadku siatkarskich mistrzostw świata. 
W trakcie turnieju jedynym miejscem poza stadionem, w którym znajdowały się jakiekolwiek motywy związane z imprezą, była ulica Piotrkowska. Ponadto niewielu kibiców zwiedzało atrakcje turystyczne Łodzi i korzystało z jakichkolwiek usług turystycznych. Wszystko to sprawiło, że organizacja turnieju nie mogła poprawić wizerunku miasta w świadomości turystów i pomóc w skutecznej promocji turystycznej.

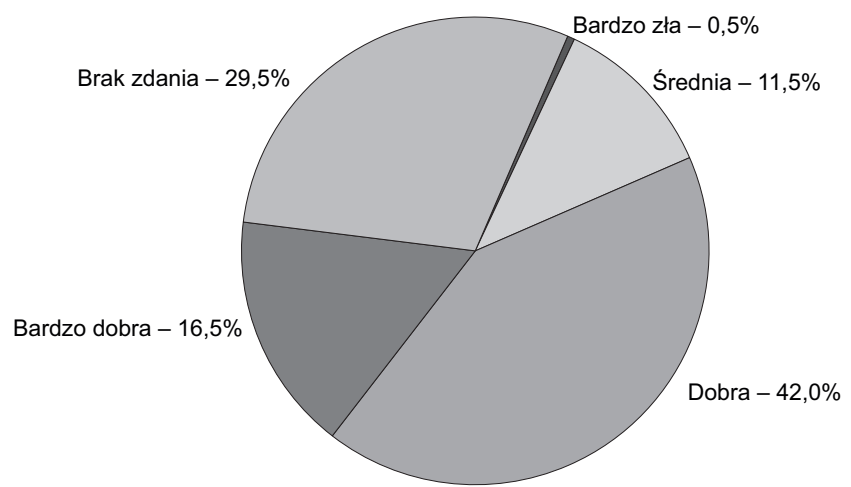

Ryc. 9. Organizacja Młodzieżowych Mistrzostw Świata U-20 w Łodzi w opinii ankietowanych Źródło: opracowanie własne.

\section{Zakończenie}

Kwerenda literatury i badania ankietowe wykazały, że rozwijająca się infrastruktura sportowo-rekreacyjna może stanowić dużą szansę dla rozwoju turystyki sportowej. Powstające obiekty sportowo-rekreacyjne są miejscami, w których mogą odbywać się wydarzenia sportowe przyciągające turystów z innych miast i krajów. W przypadku Łodzi rosnąca liczba wydarzeń sportowych w nowo powstałych obiektach sportowych nie zawsze jednak przekłada się na rozwój turystyki sportowej. Pod tym względem sukcesem zakończyła się większość wydarzeń zorganizowanych w hali Atlas Arena, zwłaszcza Mistrzostwa Świata w Piłce Siatkowej Mężczyzn 2014. Były jednak i takie wydarzenia, jak Młodzieżowe Mistrzostwa Świata U-20 w Piłce Nożnej Mężczyzn 2019, które w niewielkim stopniu wpłynęły na turystykę sportową i nie przyczyniły się do poprawy wizerunku miasta wśród turystów. Mimo wszystko budowa nowoczesnych obiektów sportowych to duża szansa dla każdego miasta na poprawę wizerunku i przyciągnięcia turystów uprawiających nie tylko turystykę sportową, ale też inne formy turystyki miejskiej.

\section{Literatura}

Berbeka J. (2013). Ewolucja form i roli obiektów sportowych w turystyce miejskiej. Studia Ekonomiczne, Uniwersytet Ekonomiczny w Katowicach, 147: 9-20.

Borzyszkowski J. (2012). Mistrzostwa Europy w Piłce Nożnej UEFA EURO 2012 a turystyka w Polsce - wstępna ocena. Turystyka Kulturowa, 9: 55-68. 
Bosiacki S., Śniadek J. (2012). Sport jako element strategii promocji miasta. Przedsiębiorczość i Zarządzanie, 13, 10: 13-23.

Cieślikowski K. (2017). Nowoczesne obiekty sportowe jako atrakcyjne produkty turystyczne regionu. Przedsiębiorczość i Zarządzanie, 18, 8, 3: 347-361.

Cieślikowski K., Kantyka J. (2015). Wykorzystanie wielkich wydarzeń w promocji miasta - na przykładzie Katowic. Zeszyty Naukowe Uczelni Vistula, 40: 29-41.

Coleman R., Gratton C., Shibli S. (2005). The economics of sport tourism at major sport events. W: J. Higham (red.), Sport tourism destinations: issues, opportunities and analysis. Elsevier Butterworth Heinemann, Oxford, s. 233-247.

Fourie J., Santana-Gallego M. (2011). The impact of mega-sport events on tourist arrivals. Tourism Management, 32(6): 1364-1370.

Gazeta.pl (https://www.gazeta.pl/0,0.html; dostęp: 6.12.2020).

Gibson H. (1998). Active Sport Tourism, Who Participe? Leusier Studies, 17(2): 155-179.

Hadzik A. (2010). Infrastruktura wielkich wydarzeń sportowych jako element współczesnego potencjału turystycznego w Polsce. Zeszyty Naukowe Uniwersytetu Szczecińskiego, Ekonomiczne Problemy Usług, 52: 465-474.

Kowalczyk A. (2005). Nowe formy turystyki miejskiej. Prace i Studia Geograficzne, 35: 155-197.

Łuć B. (2020). Fanoturyści podczas Młodzieżowych Mistrzostw Świata U-20 w Piłce Nożnej Mężczyzn FIFA 2019 w Łodzi. Turystyka Kulturowa, 2: 24-40.

MAKiS Miejska Arena Kultury i Sportu (https://makis.pl; dostęp: 4.12.2020).

MOSiR Miejski Ośrodek Sportu i Rekreacji (http://www.mosir.lodz.pl; dostęp: 5.12.2020).

Sobierajska K. (2015). Wpływ wielkich wydarzeń sportowych na turystykę w Łodzi - przykład Mistrzostw Świata w Piłce Siatkowej Mężczyzn 2014. Praca magisterska napisana pod kier. prof. B. Włodarczyka w Instytucie Geografii Miast i Turyzmu UŁ.

Stadiony Net (https://stadiony.net.pl; dostęp: 6.12.2020).

Tanaś S. (2010). Charakterystyka uczestników ruchu turystycznego. W: S. Liszewski (red.), Ruch turystyczny w Łodzi i województwie łódzkim w 2009 roku. Oficyna Wydawniczo-Reklamowa SAGALARA, Łódź, s. 79-87.

Włodarczyk B. (2016). Łódź jako arena wielkich wydarzeń sportowych - wybrane przykłady. Turyzm, 26(1): 51-62.

\section{Impact of the development of sports and recreational infrastructure on sports tourism in Łódź}

This article is a summary of the considerations concerning the sports and recreation infrastructure in Łódź and widely understood sports tourism. The collected source materials and literature allowed the author to describe the impact of the development of sports and recreation facilities in Łódź on sports tourism. The main research method was a query of literature related to sports tourism and an inventory of sports and recreation facilities in Łódź. In addition, the author presented some of the results of his research carried out during the U-20 Men's Football World Cup 2019. The overriding goal was to show how the development of the aforementioned infrastructure had an impact on sports tourism in Łódź. The conducted analysis made it possible to conclude that the dynamic development of the sports and recreational infrastructure in Łódź had a significant impact on the increase in the importance of sports tourism, mainly in the form of an increasing number of sports events. 


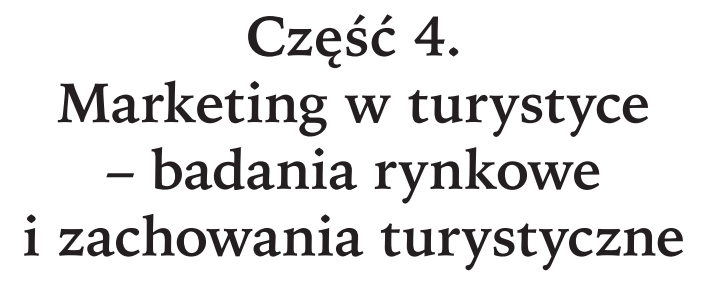



Katarzyna Madras

Uniwersytet Ekonomiczny w Poznaniu

katarzyna.madras@gmail.com

\section{Zakaz lotów do Polski w czasie pandemii COVID-19 a decyzje podróżnych}

\section{Streszczenie}

W niniejszej pracy skupiono się na wprowadzonym zakazie lądowania na terytorium Polski samolotów cywilnych wykonujących loty międzynarodowe w czasie pandemii COVID-19. Celem rozdziału jest zaprezentowanie postaw podróżnych w stosunku do wprowadzonego ograniczenia. W pracy przedstawiono próbę odpowiedzi na pytania: Czy polscy turyści zmieniali swoje plany wyjazdowe czy z nich zrezygnowali? Czy polscy turyści wierzą w istnienie pandemii COVID-19 i jak oceniają zagrożenie z nią związane? Jaki mają stosunek do zakazu lotów do Polski, wprowadzony przez polski rząd? Badanie opiera się na analizie dokumentów urzędowych i przekazów medialnych oraz na ankiecie przeprowadzonej na portalu społecznościowym.

\section{Wprowadzenie}

Rok 2020 w Polsce i na świecie będzie zapamiętany jako rok COVID-19. Pierwsze udokumentowane przypadki tej choroby wirusowej, prowadzącej do niewydolności oddechowej, pochodziły z chińskiego Wuhan z początku grudnia 2019 r. (WHO, 2020). 31 grudnia WHO wydało oświadczenie o nowej chorobie. W styczniu 2020 r. rozpoznano przypadki w innych krajach azjatyckich i Ameryce. 14 lutego COVID-19 dotarł do Europy - do Francji. Tydzień później Włochy rozpoczęły walkę o życie pacjentów. Pierwsza chora osoba w Polsce została zdiagnozowana 4 marca (Krzysztofik i in., 2020). To pokazuje, jak szybko rozprzestrzeniał się wirus, a tym samym, jak krótki czas na reakcje miały rządy poszczególnych państw. W marcu WHO ogłosiło pandemię COVID-19, co potwierdziło globalność opisywanego zjawiska. Głowy państw zaczynały zatwierdzać coraz nowsze 
i daleko idące restrykcje, które często prowadziły do praktycznie całkowitego zamrożenia gospodarek (z wyjątkiem punktów z produktami podstawowymi), zamknięcia zewnętrznych granic, zakazów gromadzenia się, a nawet wychodzenia z domów (ogólnokrajowa kwarantanna). Lato przyniosło względną stabilizację liczby zachorowań i zgonów w związku z wirusem. Większość obostrzeń została złagodzona lub całkowicie zniesiona. Nastąpiła chwila „normalności”. Jednak nie trwała ona długo, ponieważ praktycznie z nadejściem jesieni pojawiła się tzw. „druga fala" pandemii, a restrykcje wróciły.

Najbardziej dotkniętym pandemią sektorem gospodarki jest turystyka, co wynika $z$ wrażliwości popytu turystycznego na wszelkie zdarzenia tego typu (Niezgoda, 2012). Międzynarodowy zakaz lotów miał wpływ na 90\% populacji świata (Gössling i in., 2020, za: Roman i in., 2020). Światowa Organizacja Turystyki podaje, że w ciągu pierwszych dziesięciu miesięcy 2020 r. przejazdy międzynarodowe turystów spadły o $72 \%$. Pomimo to w Europie w lipcu (71\%), sierpniu (67\%) i wrześniu (72\%) można było zauważyć ożywienie turystki, w Amerykach natomiast od lipca rozpoczął się nieznacznie rosnący trend (88-81\%). Jednak pozostałe regiony świata od kwietnia stale notowały spadek w granicach $99-87 \%$, z czego najbardziej ucierpiały Azja i Pacyfik. Podsumowując, w skali globalnej spadki i nieliczne ożywienia na rynku turystycznych przejazdów międzynarodowych wpłynęly negatywnie na turystykę - przemieściło się o $900 \mathrm{mln}$ mniej turystów niż w 2019 r., a straty wynosiły 935 mld dolarów i były 10-krotnie większe w porównaniu do skutków kryzysu gospodarczego w 2009 r. Rok 2020 uznano za najgorszy w historii turystyki.

W Polsce restrykcje zostały różnie ocenione. Jedne cieszyły się dużym poparciem, np. noszenie maseczek, inne zdecydowanie mniejszym - zakaz wchodzenia do lasów (Wróblewski i in., 2020). Jak dotąd nie zbadano jednak postaw polskich podróżników względem zakazu lotów na terytorium Polski w 2020 r. oraz tego, jak wpłynął on na ich decyzje o wyjazdach. Dlatego w tej pracy przedstawiono wyniki badania dotyczącego oceny zakazu lądowania na terytorium Polski samolotów cywilnych wykonujących loty międzynarodowe (popularnie zwanego: „zakazem lotów”), wprowadzonego przez krajowy rząd i modyfikowanego na przestrzeni miesięcy. Przeprowadzono ankietę internetową, w której wzięło udział 91 osób, z czego 23 odpowiedziały na pytania odnoszące się bezpośrednio do zakazu.

\section{Przegląd literatury}

Epidemie (liczba zakażeń lub zachorowań na chorobę zakaźną na danym obszarze wyraźnie większa niż we wcześniejszym okresie albo wystąpienie zakażeń lub chorób zakaźnych dotychczas niewystępujących) ${ }^{1}$ i pandemie (nazwa epidemii

\footnotetext{
${ }_{1}$ Obwieszczenie Marszałka Sejmu Rzeczypospolitej Polskiej z dnia 8 października 2020 r. w sprawie ogłoszenia jednolitego tekstu ustawy o zapobieganiu oraz zwalczaniu zakażeń i chorób zakaźnych u ludzi.
} 
o szczególnie dużych rozmiarach, obejmującej kraje, a nawet kontynenty) ${ }^{2}$ są znanymi zjawiskami w dziejach ludzkości. Dżuma, zwana „czarną śmiercią”, grypa „hiszpanka”, „świńska grypa” czy SARS we wschodniej Azji - wszystkie one zebrały śmiertelne żniwo, zabijając nawet, w przypadku „hiszpanki”, od 50 do 100 mln istnień (Brydak, 2012). Należy wspomnieć, że najczęściej próbowano ograniczyć rozprzestrzenianie się zarazy poprzez izolację chorych, noszenie maseczek, ograniczenie przemieszczania się ludności oraz zwiększoną dbałość o higienę (Wnęk, 2014; Lisiecki, 2016), co jest kontynuowane w dobie pandemii COVID-19.

Wyjątkiem od obecnie stosowanych reguł była epidemia „świńskiej grypy” z 2009 r., w ramach której WHO zdecydowało się nie rejestrować wszystkich przypadków zakażeń, a jedynie te ciężkie i śmiertelne, jak również nie rekomendowało ograniczenia lotów międzynarodowych: „Obecnie podróże międzynarodowe szybko się rozwijają, a wiele osób odwiedza różne części świata. Nałożenie ograniczeń w podróżowaniu miałoby bardzo niewielki wpływ na powstrzymanie rozprzestrzeniania się wirusa, ale byłoby wysoce uciążliwe dla społeczności globalnej" (WHO, 2009). Warto wspomnieć, że w wypadku SARS (odmiana koronawirusa będącego również przyczyną COVID-19) WHO stwierdziło: „Ryzyko transmisji w samolocie jest bardzo niskie" (WHO, 2003) i nakazywało unikania podróży przez pasażerów mających objawy, tym samym zachęcając do mierzenia temperatury i obserwowania turystów na lotniskach (WHO, 2003).

\section{Działania polskiego rządu w czasie pandemii - zakaz lotów}

Pierwszy komunikat na stronie Ministerstwa Spraw Zagranicznych odnoszący się do podróży w czasie pandemii został opublikowany 13 marca 2020 r. Rekomendował on „unikanie wszelkich podróży zagranicznych, które nie są konieczne"3. Z dniem 15 marca 2020 r. do odwołania ograniczono ruch na lotniczych przejściach granicznych. Ustanowiono, że z Polski mogą startować wyłącznie samoloty bez pasażerów w celu umożliwienia Polakom powrotu do kraju, z czego wynika, że na terytorium państwa mogły lądować jedynie maszyny z polskimi obywatelami na pokładzie ${ }^{4}$. Rozpoczęła się operacja \#LOTdoDomu realizowana przez rząd i Polskie Linie Lotnicze LOT przy współpracy z Lotniskiem Chopina w Warszawie, PKP Intercity i firmą Polonus. Misją inicjatywy było sprowadzenie do kraju, drogą powietrzną przez narodowego przewoźnika - PPL LOT, Polaków niemogących przekroczyć granicy transportem kołowym. Do końca operacji (ostatnie połączenia zostały zrealizowane 5 kwietnia 2020 r.) wykonano 388

\footnotetext{
2 Internetowa encyklopedia PWN.

3 Wszystkie przywołane komunikaty MSZ pochodziły ze strony www.gov.pl (dostęp: 13.01.2021).

4 Wyjątki od rozporządzenia zostały zawarte w rozporządzeniu Ministra Spraw Wewnętrznych i Administracji z dnia 13 marca 2020 r. w sprawie czasowego zawieszenia lub ograniczenia ruchu granicznego na określonych przejściach granicznych.
} 
rejsów z ponad 71 miejsc recepcji na sześciu kontynentach. Z rozwiązania tego skorzystało 55 tys. ludzi. Kolejne obostrzenia zostały przedstawione w tabeli 1 .

Tabela 1. Zakaz lotów w komunikatach MSZ

\begin{tabular}{ccccccccc}
\hline Lp. & $\begin{array}{c}\text { Rozpo- } \\
\text { rządzenie } \\
\text { (Dz.U. }\end{array}$ & $\begin{array}{c}\text { Data } \\
\text { wydania } \\
\text { rozporzą- } \\
\text { dzenia }\end{array}$ & $\begin{array}{c}\text { Data } \\
\text { publikacji } \\
\text { na stronie } \\
\text { MSZ }\end{array}$ & $\begin{array}{c}\text { Data } \\
\text { wejścia } \\
\text { w życie }\end{array}$ & $\begin{array}{c}\text { Data } \\
\text { wyga- } \\
\text { śnięcia }\end{array}$ & $\begin{array}{c}\text { Współ- } \\
\text { czynnik }\end{array}$ & $\begin{array}{c}\text { Czerwo- } \\
\text { na strefa }\end{array}$ & $\begin{array}{c}\text { Poma- } \\
\text { rań- } \\
\text { czowa } \\
\text { strefa }\end{array}$ \\
\hline 1 & poz. 1498 & 31.08 & 07.09 & 2.09 & 15.09 & 60 & 44 & 21 \\
2 & poz. 1587 & 15.09 & 15.09 & 16.09 & 29.09 & 90 & 30 & 14 \\
3 & poz. 1587 & 15.09 & $18.09 *$ & 16.09 & 29.09 & 90 & 29 & 12 \\
4 & poz. 1665 & 28.09 & 29.09 & 30.09 & 13.10 & 90 & 28 & 14 \\
5 & poz. 1786 & 13.10 & - & 14.10 & 27.10 & 90 & 29 & - \\
6 & poz. 1887 & 23.10 & 27.10 & 28.10 & 10.11 & 90 & 32 & 16 \\
7 & poz. 1982 & 6.11 & 10.11 & 11.11 & 24.11 & 270 & 10 & 9 \\
8 & poz. 2069 & 20.11 & 24.11 & 25.11 & 8.12 & 440 & 9 & 4 \\
9 & poz. 2189 & 7.12 & 8.12 & 9.12 & 31.12 & 440 & 9 & 11 \\
\hline
\end{tabular}

Legenda: Od pozycji 3 możliwe zwolnienie kraju z zakazu, gdy zagwarantuje on wejście na pokład tylko osobom z negatywnym wynikiem testu na COVID (*Francja skorzystała $z$ takiej możliwości. W następnych rozporządzeniach ZEA i Katar). Od pozycji 4 wyłączenie z zakazu krajów UE, EOG, strefy Schengen oraz Ukrainy.

Źródło: opracowanie własne.

W tabeli 1 przedstawiono spis i charakterystykę zakazów w ruchu lotniczym. $\mathrm{Z}$ państw i terytoriów objętych czerwoną strefą zabronione było wykonywanie lotów międzynarodowych na terytorium Polski. Pomarańczową strefą były obejmowane kraje i terytoria, które $\mathrm{w}$ dniu wprowadzania rozporządzenia charakteryzowały się wyższym współczynnikiem niż ustalony jako graniczny i przy zachowaniu tendencji wzrostowej zachorowań możliwe było rozszerzenie zakazu o te państwa. Współczynnik był ustalany na bazie 14-dniowej skumulowanej liczby zachorowań na COVID-19 na 100000 osób w oparciu o dane publikowane przez Europejskie Centrum ds. Zapobiegania i Kontroli Chorób. Z państw i terytoriów objętych zakazem lotów możliwy był powrót w ramach zorganizowanych grup turystycznych samolotami wyczarterowanymi przed dniem wejścia $\mathrm{w}$ życie rozporządzania. Innymi sposobami były zmiana środka transportu bądź rejs przez państwo nieobjęte czerwoną strefą. Po powrocie $z$ kraju bądź terytorium wpisanego na zakazaną listę obowiązywała 14-dniowa kwarantanna.

Analizując tabelę 1, warto zwrócić uwagę na datę wydania rozporządzenia oraz jego publikacji na stronie Ministerstwa Spraw Zagranicznych. Zauważono, że w większości przypadków miało miejsce kilkudniowe opóźnienie. Przy pierwszym rozporządzeniu umieszczenie na stronie internetowej nastąpiło już po rozpoczęciu obowiązywania przepisu. W pozostałych przypadkach (prócz jednego, w którym wpis nie miał miejsca) publikacja następowała dzień przed wchodzeniem zakazu w życie. Strona MSZ nie była jedynym źródłem informacji dla podróżnych, należy tutaj wspomnieć również o portalach informacyjnych, 
podróżniczych i innych, które donosiły o planowanych obostrzeniach niedługo po zatwierdzeniu rozporządzeń, a często przed stroną $\mathrm{MSZ}^{5}$.

\section{Polacy wobec pandemii i działań rządu}

Z badań przeprowadzonych od 29 marca do 17 kwietnia przez Malesza i Kaczmarek (2020) wynika, że 79,8\% Polaków źle ocenia precyzyjność działań polskiego rządu (28\% - głównie niepoprawne, 47,3\% - niepoprawne) oraz 62,6\% zarządzanie w czasie pandemii (29\% - bardzo nieskuteczne, 50,8\% - nieskuteczne). Nie spodziewają się również efektywnej kontroli w przyszłości (37,5\% - bardzo nieprawdopodobne, $25,1 \%$ - nieprawdopodobne). Badania przeprowadzone w Instytucie Badań Socjologii UMK w Toruniu w dniach 3-20 listopada 2020 r. (Wróblewski i in., 2020) również potwierdzają i podtrzymują niskie zaufanie do sprawujących władzę tylko $21 \%$ osób dobrze lub bardzo dobrze ocenia walkę rządu z pandemią, co plasuje go na przedostatnim miejscu ze wszystkich badanych instytucji.

Niezmiennie, zarówno na początku pandemii, jak i w późniejszych badaniach opinii Polaków, jednym z najbardziej popieranych obostrzeń/zaleceń było ograniczanie podróży zagranicznych. Początek pandemii - $70,6 \%{ }^{6}$ respondentów wybiera „unikanie podróży” jako rekomendowane ochronne zachowanie i działanie zapobiegające COVID-19. Dla porównania 80,1\% wybrało częstsze mycie rąk, $68,4 \%$ noszenie maseczek (Malesza i Kulesza, 2020). W listopadzie w innym badaniu 59\% respondentów oceniło ograniczenie podróży międzynarodowych jako najbardziej uzasadnioną lub uzasadnioną restrykcję. Był to najwyższy wynik. Na drugim miejscu uplasował się nakaz noszenia maseczek na ulicach (57\%) i dalej zamknięcie szkół podstawowych i średnich (51\%) (Wróblewski i in., 2020).

Autorka nie znalazła prac naukowych badających zagadnienie „zakazu lotów” w Polsce, a tym bardziej postaw wobec niego. Dotychczasowe badania miały na celu przedstawienie ogólnego wpływu pandemii COVID-19 na turystykę w Polsce bądź na konkretne jej sektory (Roman i in., 2020; Walas, 2020; Widomski, 2020). Należy również wspomnieć, że w momencie pisania pracy większość analiz bazowała na danych pozyskanych głównie w okresie marzec-kwiecień 2020 r., czyli na początku pandemii.

\section{Metodyka badań}

Celem badania było rozpoznanie postaw polskich podróżników względem zakazu lotów międzynarodowych na terytorium Polski w 2020 r., a także zapoznanie się ze zmianami, jakie wprowadzony przepis wymusił w planach turystów. Dane do analizy zostały pozyskane dzięki przeprowadzeniu ankiety na portalu społecznościowym Facebook: na grupach podróżniczych Tanie podróżowanie

\footnotetext{
Analiza stron internetowych dokonana przez autorkę.

6 Pytanie umożliwiało udzielenie więcej niż jednej odpowiedzi.
} 
(388,9 tys. członków) oraz Tanie loty (41,8 tys.), poprzez profil autorki, grupę wewnętrzną jej kierunku studiów oraz uczelni. Warto zauważyć, że członkowie grup turystycznych często należą do kilku jednocześnie. W okresie 7-25 grudnia 2020 r. zostało zebranych 91 wypełnionych kwestionariuszy.

Uczestnikami badania mogły zostać tylko osoby, które planowały wyjazd zagraniczny w 2020 r. Ze względu na charakter badania z 91 respondentów wytypowano 23 , na których decyzje miał realny wpływ zakaz lotów. Sposób doboru: pierwszym stopniem weryfikującym była zaplanowana podróż samolotem na rok 2020 - 70 osób chciało taką odbyć. Autorka zapytała tych respondentów o wprowadzanie ewentualnych zmian w wycieczkach. W przypadku $27 \%$ odpowiadających wszystkie zaplanowane wyjazdy odbyły się bez zmian. 17 osób $(24,3 \%)$ zrezygnowało w ogóle z wyjazdu, wskazując, że wprowadzenie obostrzeń oznacza poważne zagrożenie. Zmiany w swoich podróżach wprowadziły łącznie 34 osoby, z czego 23 z przyczyn wynikających bezpośrednio z zakazu lotów.

Kwestionariusz dla ostatecznie wytypowanych respondentów (wprowadzających zmiany z powodu zakazu lotów) zawierał metryczkę oraz łącznie 11 pytań, z czego 1 warunkujące udzielanie dalszych odpowiedzi. Dotyczyło ono ilości modyfikowanych wyjazdów w związku z zakazem lotów. Pozostałe pytania odnosiły się do: liczby lotów wymagających zmian, sposobu pozyskiwania informacji o zakazie oraz jego ocenie. Jedno otwarte pozwalało na podanie propozycji zmian lub usprawnień działania zakazu lotów. Zamieszczono również pytania o stosunek do COVID-19.

Wybór Internetu jako medium pozyskiwania odpowiedzi respondentów wynika z ograniczeń związanych z pandemią oraz z wniosku, że odpowiedzi pozyskane $\mathrm{w}$ formularzu internetowym $\mathrm{w}$ porównaniu do papierowego dają bardzo zbliżone wyniki (Coles i in., 2007, za: Malesza, Kaczmarek, 2020).

Hipotezą badawczą postawioną przez autorkę jest stwierdzenie, że polscy podróżnicy nie zrezygnowali całkowicie $z$ wyjazdów zagranicznych w celach turystycznych mimo wprowadzonego zakazu lotów, ponieważ źle oceniają działania polskiego rządu w tym zakresie.

\section{Wyniki badań}

Jak wspomniano, w ankiecie wzięło udział 91 respondentów. Jednak ze względu na badane zagadnienie wyłoniono 23 osoby w celu zawężenia kręgu do osób, które rzeczywiście miały doświadczenie z obostrzeniem. Badani łącznie zmodyfikowali ponad 41 wyjazdów. W wybranej grupie było 3 razy więcej kobiet niż mężczyzn, głównie w dwóch przedziałach wiekowych: 19-24 (43\%) i 31-45 lat (30\%). $82 \%$ to osoby pracujące, z czego $30 \%$ to studenci. Pozostali uczęszczają na uczelnię, jednak nie pracują. Prawie $70 \%$ stanowią respondenci z wyższym wykształceniem. Co trzeci badany mieszka w mieście powyżej 500 tys. mieszkańców. Natomiast 35\% w miejscowościach o liczbie ludności większej niż 100 tys. Jako że zakaz nierozłącznie wiąże się z COVID-19, zapytano respondentów, czy wierzą w pandemię $\mathrm{i}$ jak oceniają zagrożenie $z$ nią związane. 15 osób na 23 wierzy, 
że pandemia istnieje. 3 osoby chorowały, z czego 1 bezpośrednio po wyjeździe. 10 osób przypuszcza, że mogło przechodzić SARS-CoV-2. Średnia ocena zagrożenia związanego $z$ chorobą w tej grupie to 3,39, gdzie 1 oznacza zwykłe przeziębienie, a 5 - poważną, wręcz śmiertelną chorobę.

Dalej pytania dotyczyły źródeł informacji o pandemii i podróżach podczas niej: zakazu lotów, sytuacji pandemicznej w krajach docelowych oraz możliwości modyfikacji wyjazdów (ryc. 1).

Sam/Sama wpadłam na pomysł

Powiadomienia od przewoźników/pośredników

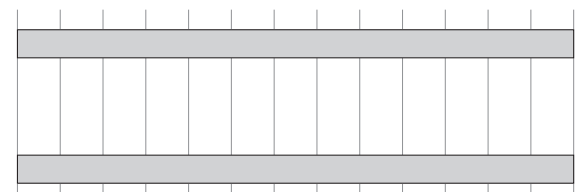

Biuro podróży

Telewizja

Strony związane z organizacją wyjazdów na własną rękę
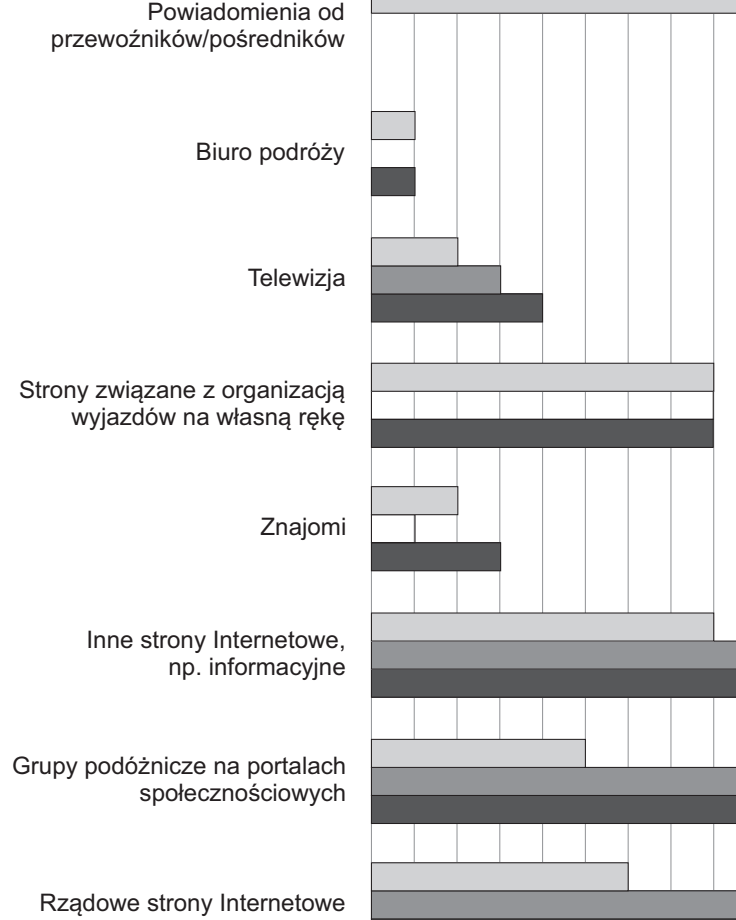

Rządowe strony Internetowe

0

5

10

$\square$ Możliwe modyfikacje

Miejsce docelowe

Zakaz lotów

Ryc. 1. Wykorzystywane źródła informacji w zależności od rodzaju poszukiwanych treści Źródło: opracowanie własne.

W dwóch pierwszych kwestiach najczęściej wskazywanym źródłem danych były rządowe strony internetowe. Następnie wymiennie grupy podróżnicze na portalach społecznościowych i inne strony internetowe, np. informacyjne. W obu kwestiach na czwartej pozycji były strony internetowe związane $z$ organizacją 
wyjazdów na własną rękę. Odmiennie układ wyglądał dla poszukiwania możliwych modyfikacji. Tutaj najczęstszym źródłem były powiadomienia od przewoźników bądź pośredników. Później znaczenie miała kreatywność respondentów, którzy deklarowali, że sami wpadli na konkretne pomysły. Trzecią pozycję zajęły ex aequo strony internetowe związane $z$ organizacją wyjazdów na własną rękę oraz inne strony internetowe, np. informacyjne. Podsumowując, ogólnie dla wszystkich aspektów najczęściej wybieranym sposobem dotarcia do informacji były internetowe strony rządowe, a medium przekazu - internet.

W następnych pytaniach respondenci byli proszeni o ocenienie (w skali 1-5, gdzie 1 oznacza kompletnie nietrafiony pomysł/całkiem za późno, a 5 - bardzo dobre rozwiązanie/z wyprzedzeniem pozwalającym na przygotowanie się) idei zakazu lotów pod kątem różnych kryteriów oraz zakazu jako całości. Poszczególne średnie ocen przedstawiono na rycinie 2 .

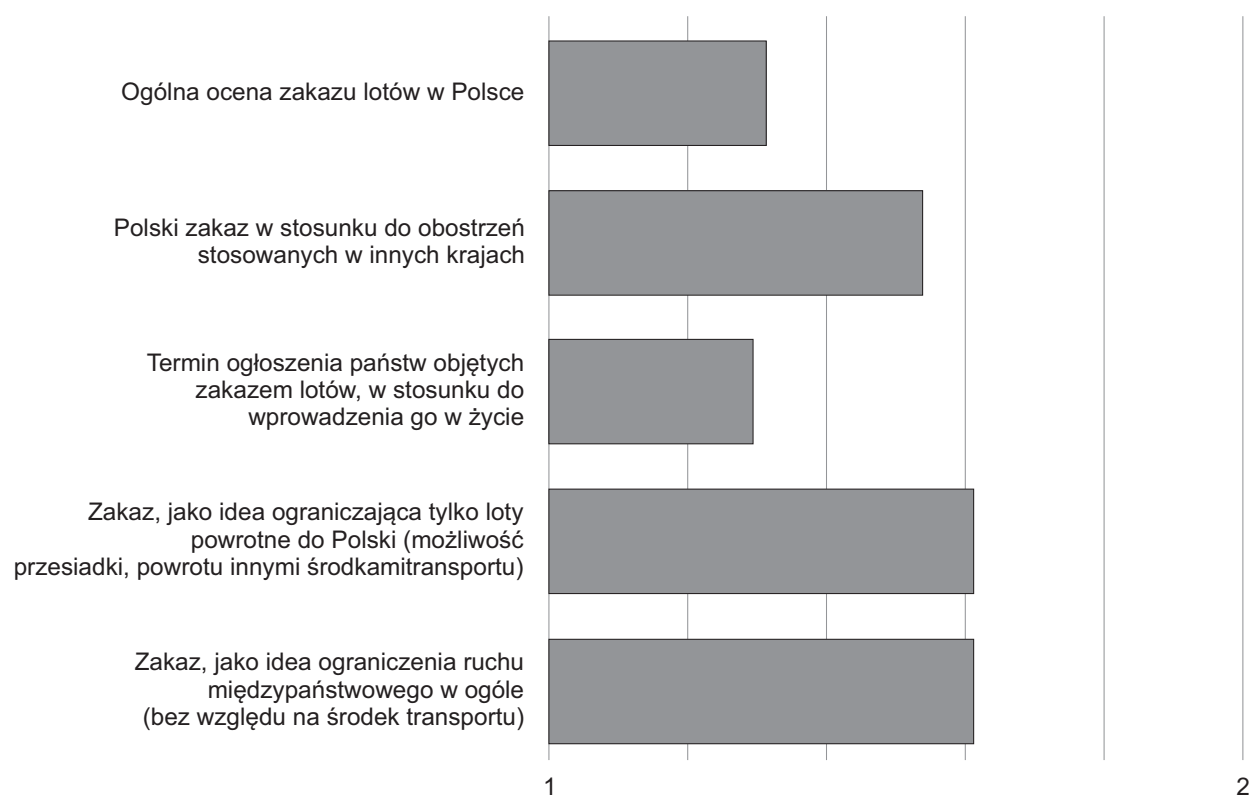

Ryc. 2. Średnia ocen zakazu lotów

Źródło: opracowanie własne.

Najniższa jednostkowa średnia ocen dla zakazu pod kątem wskazanych wytycznych to 1 występująca 11 razy. Tych osób nie da się jednoznacznie scharakteryzować, ponieważ cechują się dużą różnorodnością $\mathrm{w}$ stosunku do zadanych przez autorkę pytań oraz metryki - znajdują się w niej przedstawiciele wszystkich grup. Natomiast najwyższa jednostkowa średnia ocen to 3,8 . Jest to zdecydowanie wyróżniający się wynik, ponieważ poza jedną średnią 3 pozostałe są równe 2 lub najczęściej poniżej tej wartości.

Autorka zamieściła też dobrowolne pytanie otwarte, w ramach którego respondenci mogli wypowiedzieć się o istotności zakazu, możliwych zmianach, 
które chcieliby zaproponować. Badani wskazywali na opcję testów antygenowych wykonywanych na lotniskach. Wspominali, że zakazy były wprowadzane zbyt chaotycznie, powodowały panikę i straty finansowe turystów, by ostatecznie i tak pozostawała możliwość odbycia konkretnej podróży. Pisali, że podróżowanie powinno być wyborem, tym bardziej że może to być forma odpoczynku psychicznego, co w sytuacjach stresogennych jest wskazane. Stwierdzili, że zakaz jest nieużyteczny, ewentualnie miałby sens, gdyby dotyczył przekraczania granicy, ale każdym środkiem transportu, nie tylko lotów powrotnych, i to nie wszystkich, np. czarterów.

\section{Zakończenie}

W Polsce po raz pierwszy ruch lotniczy został ograniczony 15 marca 2020 r. Rozpoczęła się akcja \#LOTdoDomu, trwająca do kwietnia. Następne obostrzenia zaczęły wchodzić w życie od września 2020 r. Zakaz lotów na przestrzeni miesięcy był modyfikowany i przedłużany. Celem pracy było wskazanie postaw polskich turystów wobec wprowadzanych zakazów w Polsce w 2020 r. Hipotezą natomiast było stwierdzenie, że polscy turyści nie zrezygnowali całkowicie z turystycznych wyjazdów zagranicznych mimo zakazu lotów, ponieważ źle oceniają działania polskiego rządu w tym zakresie. Ze względu na małą liczbę respondentów autorka ostatecznie nie może stwierdzić, że badania odnoszą się do całej populacji polskich turystów. Praca może jedynie wskazać kierunek przyszłych analiz tej części społeczeństwa i być uznana za badanie pilotażowe.

Respondenci wykazali jednoznaczną i dominującą negatywną postawę wobec zakazu lotów. Zdecydowana ich większość oceniła go bardzo źle we wszystkich aspektach oraz jako całość. Warto nadmienić, że ponad dwa razy więcej osób $\mathrm{w}$ tej grupie wierzyło $\mathrm{w}$ istnienie pandemii niż nie, a średni poziom zagrożenia związany bezpośrednio z chorobą osiągnął wartość 3,36, co jest dość zbliżone do średniej uzyskanej przez wszystkich badanych. Oznacza to, że respondenci zdają sobie sprawę $z$ powagi sytuacji na podobnym poziomie co reszta osób biorąca udział w badaniu.

Liczba odbywanych podróży i ich modyfikacji charakteryzowała się zakresem od 1 do 4 i więcej, czyli pełnym spektrum przedstawionym w kwestionariuszu. Głównym źródłem informacji dla tej grupy był Internet, a najczęściej rządowe strony internetowe. Warto wspomnieć, że, jak wynika $z$ analizy autorki na podstawie komunikatów MSZ, dane często były tam publikowane z opóźnieniem lub jak w jednym przypadku - wcale.

Badanie, ze względu na niewielką liczbę respondentów, można traktować jedynie jako pilotażowe. Warto jednak zwrócić uwagę, że mimo tak małej grupy istnieje bardzo duża zbieżność oceny zakazu lotów przez praktycznie wszystkich badanych, bez względu na wiek, płeć czy status zawodowy. Rozwinięciem badania mogłoby być przede wszystkim przeprowadzenie go na większej próbie badawczej, ale także zróżnicowanie odpowiadających pod kątem zajmowanego stanowiska pracy. 


\section{Literatura}

Brydak L.B. (2012). Grypa - problem stary jak świat. Hygeia Public Health, 47(1): 1-7.

Dz.U. 2020 poz. 435.

Dz.U. 2020.1845.

Krzysztofik R., Katnor-Pietraga I., Spórna T. (2020) Spatial and functional dimensions of the COVID-19 epidemic in Poland. Eurasian Geography and Economics.

Lisiecki A. (2016). Zapobieganie zagrożeniom epidemiologicznym na przestrzeni wieków. Zeszyty Naukowe Państwowej Wyższej Szkoły Zawodowej im. Witelona w Legnicy, 1(18): 45-51.

Malesza M., Kaczmarek M.C. (2020). Predictors of anxiety during the COVID-19 pandemic in Poland. Personality and Individual Differences, 170: 110419

Niezgoda A. (2012). Popyt turystyczny: uwarunkowania i perspektywy rozwoju. Ekonomiczne Problemy Usług, 82: 11-25.

PPL LOT \#LOTdoDomu - zrealizowane połączenia (www.lot.com; dostęp: 17.12.2020).

PPL LOT (2020) \#LOTdoDomu - podsumowanie projektu (www.lot.com; dostęp: 17.12.2020).

Roman M., Niedziółka A., Krasnodębski A. (2020). Respondents' Involvement in Tourist Activities at the Time of the COVID-19 Pandemic. Sustainability, 12, 9610.

Rosa G. (2012). Czynniki kształtujące zachowania nabywców usług turystycznych na przykładzie badań rynku europejskiego. Ekonomiczne Problemy Usług, 84: 123-135.

The New York Times (2020). A Timeline of the Coronavirus Pandemic (www.nytimes. com; dostęp: 16.12.2020).

UNWTO (2020). Tourism back to 1990 levels as arrivals fall by more than $70 \%$ (www. unwto.org; dostęp: 18.12.2020).

WHO (2020). Archived: WHO Timeline - COVID-19 (www.who.int; dostęp: 16.12.2020).

WHO (2020). WHO Coronavirus Disease (COVID-19) Dashboard (www.who.int; dostęp: 16.12.2020).

WHO (2020). Coronavirus disease 2019 (COVID-19) Situation Report - 94.

WHO (2009). No rationale for travel restrictions.

WHO (2003). Summary of SARS and air travel.

Wnęk J. (2014). Pandemia grypy hiszpanki (1918-1919) w świetle polskiej prasy. Archiwum Historii i Filozofii Medycyny, 77: 16-23.

Wróblewski M., Meler A., Afeltowicz Ł. (2020). Ryzyko, zaufanie, choroby zakaźne. Polki i Polacy o pandemii.

\section{Poland's flight ban during Covid-19 pandemic and travellers' decisions}

This paperwork focuses on the introduced ban on landing on Polish territory of civil aircraft performing international flights during the COVID-19 pandemic. The aim of the article is to present the travellers' attitudes towards the introduced restrictions. This paper presents an attempt to answer following questions: Did Polish tourists have to change their travel plans or cancel them? Do Polish tourists believe in the existence of the COVID-19 pandemic and how do they assess the threat from it? What is their attitude towards the ban on flights to Poland introduced by the Polish government? The study is based on the analysis of official documents, media messages and as well as the survey conducted on social network 
Magdalena Wawoczny

Uniwersytet Ekonomiczny w Krakowie

wmagda13@gmail.com

\section{Wpływ pandemii COVID-19 na zmiany W wielkości ruchu pasażerskiego transportu lotniczego w Polsce i na świecie}

\section{Streszczenie}

Wybuch pandemii COVID-19 spowodował ograniczenie przemieszczania się ludności na świecie, wskutek czego popyt na usługi transportowe gwałtownie spadł. Lotnictwo cechujące się dynamicznym rozwojem dziś ponosi duże straty, czego wyrazem jest kryzys tej branży. Celem rozdziału jest rozpoznanie wpływu pandemii na zmiany wielkości popytu na usługi lotnicze w Polsce i na świecie. Analiza literatury przedmiotu oraz danych wtórnych pozwoliła na zidentyfikowanie zmian wielkości ruchu pasażerskiego spowodowanych pandemią, ze szczególnym uwzględnieniem rynku chińskiego jako benchmarkingu dla branży lotniczej.

\section{Wprowadzenie}

W obecnych czasach transport lotniczy stał się powszechnie wykorzystywanym środkiem transportu. Postęp techniczno-technologiczny oraz wzrost poziomu zamożności społeczeństw to jedne z wielu czynników, które sprawiły, że latać można wszędzie oraz często przy wykorzystaniu niewielkich nakładów finansowych. Według danych polskiego Urzędu Lotnictwa Cywilnego (2019) w 2019 r. polskie lotniska obsłużyły $49 \mathrm{mln}$ pasażerów, czyli o 7\% więcej niż w roku ubiegłym. Pojawienie się w 2020 r. pandemii COVID-19 sprawiło, że sytuacja branży lotniczej w Polsce i na świecie może niespodziewanie powrócić do stanu sprzed kilku dekad. Celem pracy jest rozpoznanie wpływu pandemii COVID-19 na zmiany wielkości popytu na usługi lotnicze. Szczególne rozważania w tej kwestii odnoszą się do rynku chińskiego jako wzorca przeciwdziałania zaistniałej sytuacji. 
W opracowaniu dokonano przeglądu literatury przedmiotu, a także wykorzystano dane empiryczne pochodzące z publikowanych źródeł wtórnych. Dodatkowo przedstawione zostały prognozy dotyczące sytuacji branży lotniczej w najbliższej przyszłości.

\section{Transport powietrzny w strukturze środków transportu i determinanty jego rozwoju}

Transport jest obszarem gospodarki, który umożliwia swobodne przemieszczanie się osób oraz towarów. Definiuje się go jako celowe przemieszczanie się ładunków i osób, wydzielone $z$ innych czynności ekonomicznie, technicznie oraz organizacyjnie. Oznacza to, że transport związany jest $z$ wykorzystaniem infrastruktury, środków transportu, a także obecnością podmiotów gospodarczych, świadczących usługi transportowe (Koźlak, 2008).

Odgrywa on istotną rolę, gdyż umożliwia funkcjonowanie innych sektorów gospodarki i przyczynia się do rozwoju gospodarczego. Pełni funkcję wymiany dóbr i usług, lokalizacji osadnictwa i produkcji, czynnika wzrostu PKB oraz instrumentu zaspokajającego potrzeby transportowe ludności (Grzywacz, Burnewicz, 1989).

Powszechnie stosowaną klasyfikacją transportu jest podział ze względu na środowisko, w którym porusza się dany środek transportu. Wyróżnia się zatem transport lądowy, wodny oraz powietrzny. W następstwie należy przytoczyć podział ze względu na środek transportu, w którym wymienia się transport samochodowy, kolejowy, morski oraz lotniczy (Page, 2005).

Transport lotniczy, z uwagi na przewóz pasażerów, rozwija się najszybciej z pozostałych rodzajów transportu. Cechuje go możliwość szybkiego przemieszczania się na długich dystansach, duży zasięg przestrzenny dzięki lokalizacji terminali lotniczych, komfort oraz najwyższy wskaźnik bezpieczeństwa. Do negatywnych cech należy zaliczyć dojazd do terminali lotniskowych i wysoki koszt przemieszczania się (Urbanyi-Popiołek, 2013).

Przedmiotem przejazdów lotniczych są ładunki pocztowe i towarowe, a przede wszystkim pasażerowie, na których przypada $70 \%$ pracy przewozowej lotnictwa. Przejazdy następują na relacjach krajowych lub międzynarodowych, o zasięgu międzykontynentalnym, średnim lub krótkim. Jeśli chodzi o przejazdy międzykontynentalne, lotnictwo jest monopolistą na rynku ze względu na czas przeprawy (Urbanyi-Popiołek, 2013).

Podaż $\mathrm{w}$ transporcie lotniczym reprezentowana jest przez porty lotnicze oraz przewoźników tradycyjnych i niskokosztowych. Przewoźnicy tradycyjni to przedsiębiorstwa powstałe $z$ inicjatywy konkretnych państw, oferujące regularne połączenia na wybranych trasach. W cenę biletu często wliczone są udogodnienia, takie jak bagaż o określonej wadze czy posiłki. Przewoźnicy niskokosztowi z kolei oferują przejazdy po niższych cenach, jednak udogodnienia są dodatkowo płatne. Przedstawiciele strony popytowej na usługi lotnicze to pasażerowie grupowi lub 
indywidualni, firmy oraz pośrednicy. Popyt charakteryzuje się wahaniami i sezonowością, a także brakiem elastyczności względem ceny (Rucińska i in., 2010).

Postęp technologiczny oraz zmiany w strukturach gospodarczych krajów na przestrzeni lat wpłynęły na rozwój w wielu obszarach gospodarki, także transportu lotniczego. Do determinant jego rozwoju zalicza się m.in. czynniki techniczne. Dzięki rozwojowi Internetu i urządzeń technicznych poprawił się komfort planowania i odbywania przejazdu. Warto wspomnieć o czynnikach politycznych, przez które rozumie się inwestycje państw w rozwój infrastruktury lotniczej oraz prowadzenie przyjaznej polityki zagranicznej, dzięki której możliwe jest tworzenie siatek połączeń międzynarodowych. Na rozwój lotnictwa mają wpływ także czynniki społeczne, powodujące zmiany w odczuwanych potrzebach ludzi, będące skutkiem wzrostu poziomu edukacji czy normalizacji czasu pracy. Ponadto czynniki ekonomiczne, czyli korzystna koniunktura gospodarczo-społeczna lub wzrost dochodów ludności i ich odpowiedni podział, również stymulują rozwój transportu lotniczego (Kaczmarska, 2014). Niestety istnieją też czynniki, które oddziałują negatywnie na rozwój lotnictwa lub całkowicie go hamują. Konflikty polityczne, ataki terrorystyczne czy kryzysy gospodarcze to tylko niektóre destymulanty, niosące pejoratywne skutki dla rozwoju branży lotniczej. W ostatnim czasie czynnikiem determinującym sytuację transportu powietrznego na świecie jest pandemia, będąca następstwem masowego przemieszczania się ludności.

\section{Rola transportu lotniczego $\mathrm{w}$ rozwoju turystyki}

Powszechnie wiadomo, że związek transportu z turystyką jest nierozerwalny. Jako jeden $z$ bazowych elementów infrastruktury turystycznej jest spoiwem pomiędzy miejscem stałego przebywania a destynacją turystyczną. Turystyka nie tylko zależy od transportu, ale także stwarza warunki jego rozwoju i oddziałuje na niego. Oprócz zapewnienia turystom połączenia komunikacyjnego do punktu docelowego baza transportowa gwarantuje swobodne poruszanie się w miejscu recepcji turystycznej oraz dostęp do jej walorów turystycznych (Gross, Klemmer 2014).

O ile każdy rodzaj transportu odgrywa ważną rolę na rynku turystycznym, o tyle duży wpływ lotnictwa na rozwój ruchu turystycznego w ostatnich latach jest niezaprzeczalny. Transport lotniczy winno określać się mianem fundamentu globalizacji, bowiem dyktuje on procesy globalizacyjne, tym samym im podlegając. Należy zatem stwierdzić, że przemysł turystyczny nie może istnieć bez usług lotniczych. Według danych IATA (2019) w 2019 r. współczynnik obłożenia pasażerów wzrósł o ponad 3,4\%, czyniąc jednocześnie ten wynik nowym rekordem. Ponadto turyści korzystający z usług lotniczych przeznaczyli na nie ponad 900 mld dolarów. Można zatem zaryzykować stwierdzenie, że transport lotniczy jest jednym z najchętniej i najczęściej wybieranych środków transportu.

Korzyści, jakie stwarza dla turystyki transport lotniczy, to przede wszystkim spadek kosztów transportu pasażerów. Tani przewoźnicy, oferujący przeloty w niskich cenach, uczynili podróżowanie bardziej dostępnym, kwalifikując turystykę do dóbr podstawowych. Dodatkowo efektywność transportu lotniczego ma 
bezpośredni wpływ na sytuację społeczno-gospodarczą w wielu krajach. Działanie aktywnych portów lotniczych w regionach zwiększa jego konkurencyjność oraz wspiera gospodarkę. Oprócz przypływu turystów należy zaznaczyć, że umożliwia on przepływ wszelkiego rodzaju towarów, powodując rozwój nowoczesnych gałęzi przemysłu (Nedeva, Genchev, 2018).

Stale rosnący popyt na usługi lotnicze i prognozy dotyczące jego systematycznego wzrostu zobligowały linie oraz porty lotnicze do poszerzania siatki i częstotliwości połączeń, zgodnie $z$ trendami i potrzebami rynku.

\section{Rozwój turystyki w Polsce i na świecie do roku 2019 - wybrane aspekty}

W ostatnich dekadach można było zaobserwować rozwój międzynarodowego ruchu turystycznego. Od 1995 r. wzrastał on co roku w tempie 4\% w skali światowej. Stabilny w czasie rozwój turystyki był możliwy dzięki zwiększeniu się funduszu swobodnej decyzji ludności na świecie, który zaczęto przeznaczać na konsumpcję turystyczną. Dynamika jej rozwoju sprawiła, że wiele krajów, inwestując w turystykę, uczyniło z niej główny czynnik rozwoju społeczno-ekonomicznego (Polski Instytut Ekonomiczny, 2020). W 2015 r. liczba podróży międzynarodowych wynosiła $1186 \mathrm{mln}$, a łączne wydatki na turystykę sięgały nawet 1260 mld dolarów. Zaledwie cztery lata później, w 2019 r., liczba podróży zwiększyła się do 1,4 mld, czyli o 4\% w porównaniu do 2018 r., natomiast suma wydatków turystycznych wzrosła do 1,7 tryliona (UNWTO, 2016-2020).

Również w Polsce odnotowano tendencje wzrostowe, dotyczące oddziaływania turystyki na gospodarkę krajową. Łączne wpływy z zagranicznej turystyki do Polski wynosiły w 2019 r. 29 mld zł, czyli wzrosły o 3,3\% w porównaniu do roku poprzedniego. Wydatki turystyczne Polaków w kraju w 2019 r. były większe o ponad $11 \%$ od tych w 2018 r. i wynosiły 11 mld zł. Polacy chętniej niż w poprzednich latach podejmowali podróże krajowe i zagraniczne. W 2019 r. zanotowano 20,6 mln podróży krajowych (wzrost o 5,1\% do roku ubiegłego) oraz 5,7 mln podróży zagranicznych, czyli o 5,7\% więcej niż w roku 2018 (Ministerstwo Sportu i Turystyki, 2019).

Jeśli chodzi o turystykę międzynarodową, państwem, do którego od lat najchętniej przyjeżdżają turyści, jest Francja. Drugie miejsce, do 2017 r., zajmowały Stany Zjednoczone, jednak rok później USA spadły o poziom niżej w rankingu, ustępując miejsca Hiszpanii. W latach 2016-2019 wśród krajów mających największe wpływy z turystyki znalazły się Stany Zjednoczone, Chiny, Hiszpania oraz Tajlandia. Warto również zaznaczyć, że krajem, którego mieszkańcy wydają najwięcej na turystykę, są Chiny, a zaraz po nich Hiszpania, Tajlandia oraz Francja (UNWTO, 2016-2020).

Jeśli chodzi o sytuację światowego rynku lotniczego w ostatnich dekadach, latanie stało się bardziej dostępne niż kiedykolwiek. Biorąc pod uwagę liczbę obsłużonych podróżujących, liderami na rynku światowym są kolejno Southwest 
Airlines, Delta Airlines, American Airlines oraz Ryanair. Z kolei w Polsce najchętniej wybieranymi liniami okazały się Ryanair oraz Lot. W 2019 r. polskie lotniska pobiły rekord, obsługując prawie $49 \mathrm{mln}$ pasażerów, czyli o $7 \%$ więcej niż w roku poprzednim (IATA, 2019).

Pomimo występowania w przeszłości zdarzeń kryzysowych i chwilowych spadków wielkości ruchu pasażerskiego branża lotnicza odnotowywała jego wzrost do 2020 r. na poziomie 4,5 mln pasażerów (ryc. 1). Wirus Sars-CoV-2, powodujący pandemię COVID-19, zapoczątkował szereg poważnych zmian najpierw w samych Chinach. Chiny bowiem od lat zajmowały czołowe miejsce wśród krajów generujących największą liczbę turystów. Pojawienie się zatem nowego wirusa, który zmusił chiński rząd do izolacji obywateli, spowodował spadek popytu na usługi lotnicze, czego skutki stopniowo zaczynały odczuwać pozostałe kraje, do których wcześniej masowo latali Chińczycy. Początek roku 2020 to czas rozprzestrzeniania się wirusa na obszar całego świata, co niosło szereg negatywnych dla branży lotniczej skutków, które wymagać będą opracowania nowych rozwiązań.

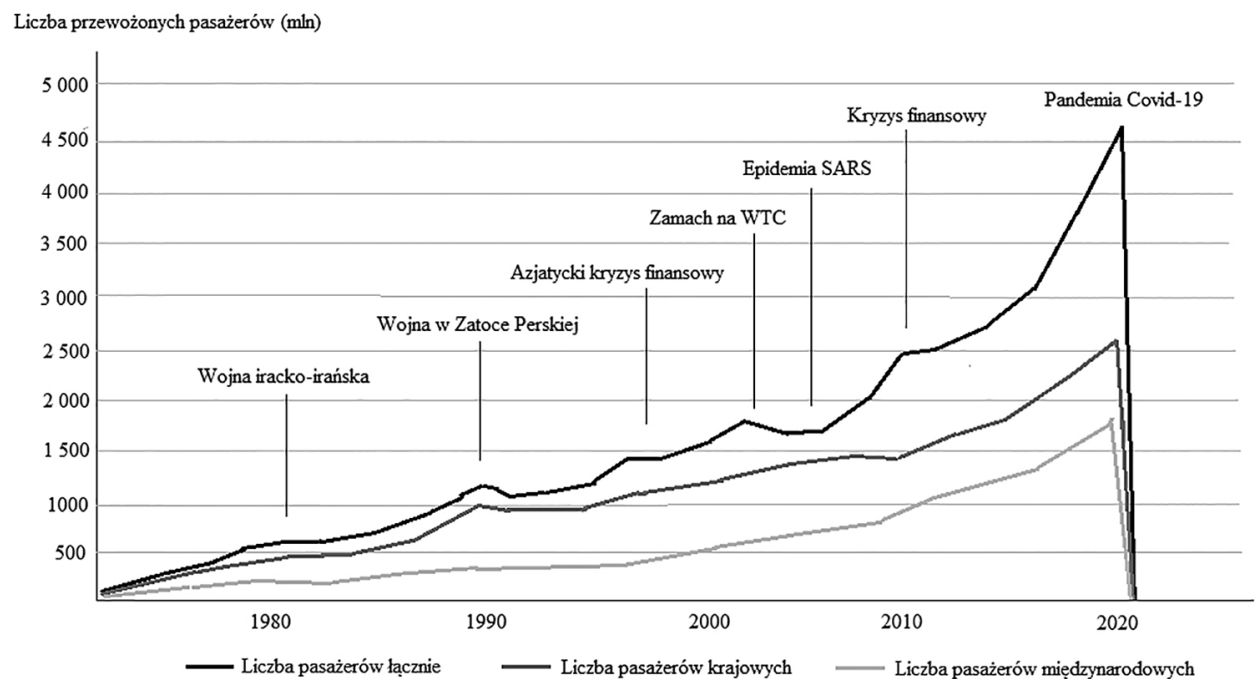

Ryc. 1. Ewolucja światowego ruchu pasażerskiego do roku 2020

Źródło: opracowanie własne na podstawie danych pochodzących z panelu „Quo Vadis Turystyko?” w ramach 12 Międzynarodowej Konferencji Naukowej Kolegium Nauk o Zarządzaniu i Jakości Uniwersytetu Ekonomicznego w Krakowie.

\section{Ruch pasażerski w czasie pandemii COVID-19}

W ostatnich latach na podstawie danych statystycznych przedstawiających coroczny wzrost poziomu ruchu pasażerskiego oszacowano, że w 2020 r. obsłużonych zostanie ponad 9 mld pasażerów na świecie. Pojawienie się nowego wirusa pod koniec 2019 r. spowodowało obniżenie się dotychczasowego poziomu ruchu o ponad 5,5 mld. 
Nigdy wcześniej branża lotnicza nie zanotowała tak nagłego spadku poziomu ruchu. Pomimo chwilowych regresji, wywołanych konkretną bariera, ruch ten szybko się ożywiał. Pandemia COVID-19, która początkowo zapowiadała kryzys obejmujący swoim zasięgiem jedynie Chiny i kraje ościenne, spowodowała powrót pasażerskiego ruchu lotniczego do poziomu sprzed kilkudziesięciu lat. Zjawisko to przedstawiono na rycinie 2, na której spadek światowego ruchu pasażerskiego zobrazowany został na podstawie wskaźnika RPK, pokazującego przychody przewoźnika lotniczego, przeliczane na jeden pasażero-kilometr.

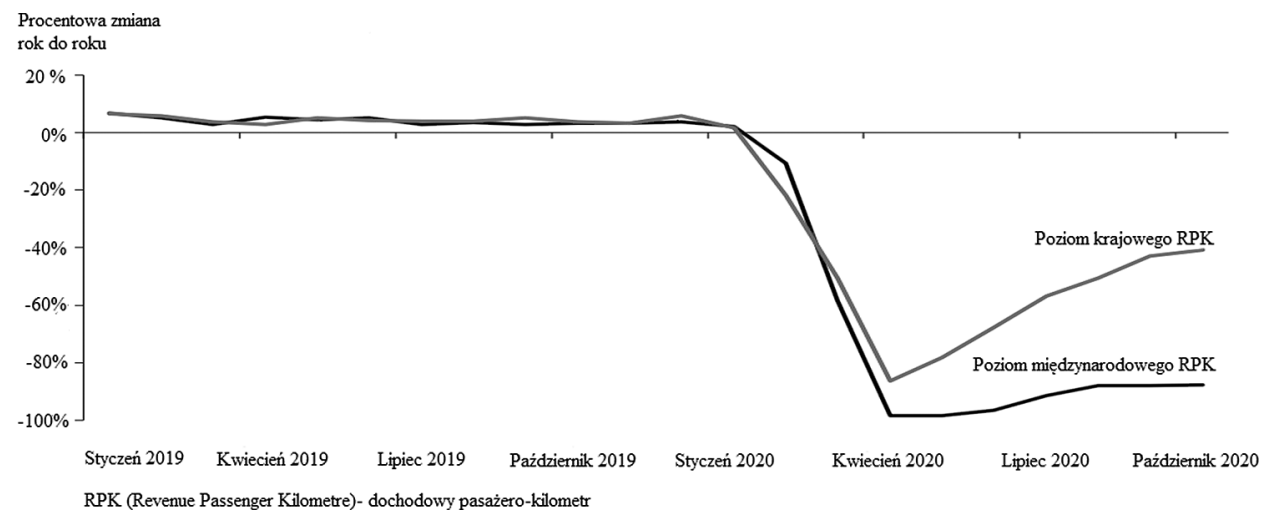

Ryc. 2. Spadek lotniczego ruchu pasażerskiego na świecie na przykładzie RPK Źródło: opracowanie własne na podstawie IATA Statistics.

Sytuację na rynku polskim odzwierciedla rycina 3, na której porównano ruch pasażerski na lotnisku w Balicach w latach 2019-2020 od stycznia do października. Pomimo dobrze zapowiadającego się początku roku, wybuch pandemii w Europie ograniczył ten ruch do zera. Stopniowe luzowanie obostrzeń pozwoliło w następnych miesiącach na przywrócenie jedynie $37 \%$ ruchu z poprzedniego roku. Największy udział w odbudowie przypadł tanim przewoźnikom, którzy przywrócili $46 \%$ operacji od lipca do października, a przewoźnicy tradycyjni $41 \%$.

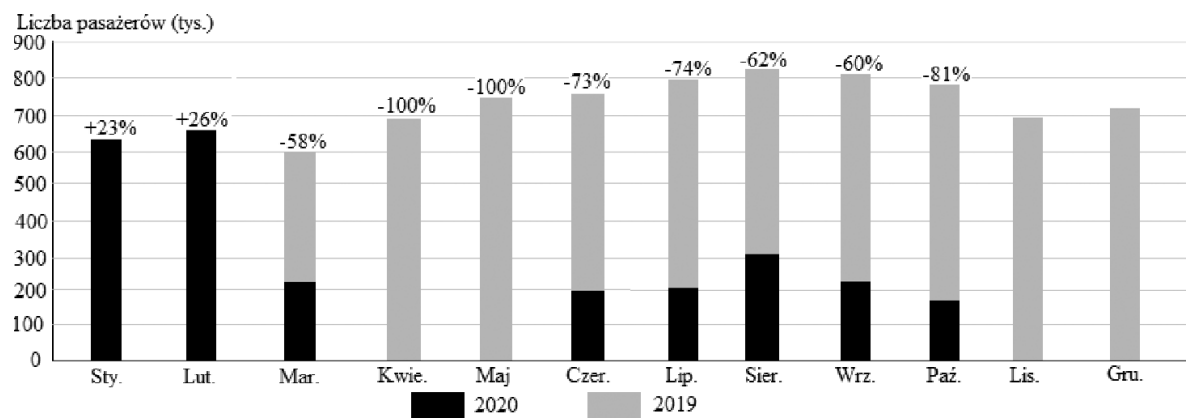

Ryc. 3. Poziom ruchu pasażerskiego krakowskiego lotniska w 2020 r. na tle poziomu z 2019 r. (styczeń-wrzesień)

Źródło: opracowanie własne na podstawie danych pochodzących z panelu „Quo Vadis Turystyko?” w ramach 12 Międzynarodowej Konferencji Naukowej Kolegium Nauk o Zarządzaniu i Jakości Uniwersytetu Ekonomicznego w Krakowie. 
Chiny były pierwszym krajem zmagającym się z pandemią, również pierwszym, który zaczął podejmować działania w celu ożywienia rynku transportu lotniczego. W przeciwnej sytuacji znalazła się pozostała część świata, która odnotowywała w tym czasie gwałtowne wzrosty zakażeń. Sukces stopniowego wyjścia Chin z kryzysu widać na tle porównania danych, przedstawiających stosunek dziennej liczby zakażeń do liczby dziennych lotów krajowych i międzynarodowych w Chinach, Europie i USA, ukazanych na rycinach 4 i 5.

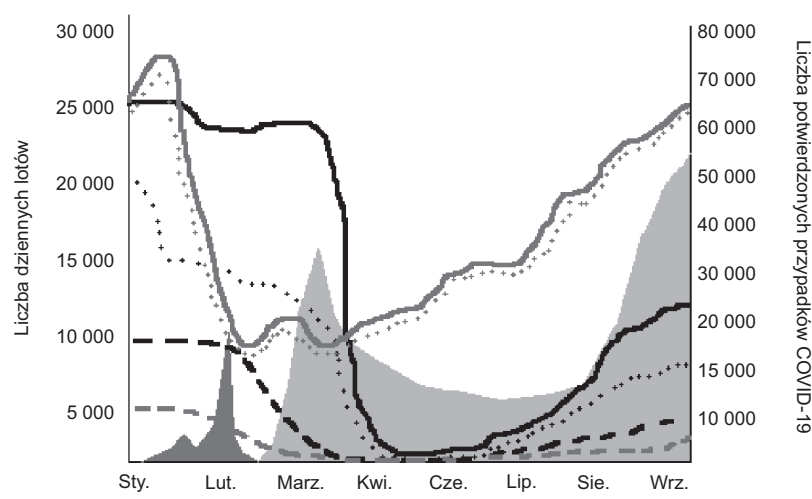

$\square$ Liczba dziennych zakażeń w Europie $\quad \square$ Liczba dziennych zakażeń w Chinach

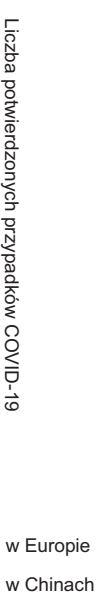

Ryc. 4. Dzienne loty i potwierdzone przypadki w pierwszej połowie $2020 \mathrm{r}$. w Chinach

i Europie

Źródło: opracowanie własne na podstawie danych ADS- B, Flightradar24 i Europejskiego Centrum ds. Zapobiegania i Kontroli Chorób.

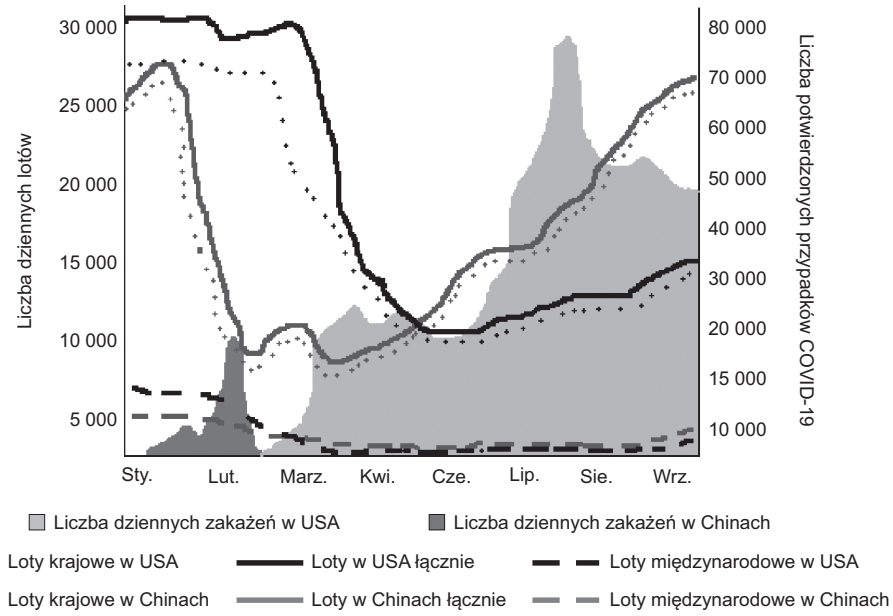

Ryc. 5. Dzienne loty i potwierdzone przypadki w pierwszej połowie $2020 \mathrm{r}$. w Chinach i w USA

Źródło: opracowanie własne na podstawie danych ADS-B, Flightradar24 i Europejskiego Centrum ds. Zapobiegania i Kontroli Chorób. 
W momencie wprowadzenia w krajach europejskich nakazu izolacji popyt na usługi lotnicze spadł, a ruch pasażerski został wstrzymany. Odwrotnie rzecz miała się na rynku chińskim, gdzie w tym czasie odnotowywano wzrost popytu na krajowe usługi lotnicze oraz brak nowych przypadków zakażeń. W Europie zmiana nastąpiła dopiero na początku czerwca, kiedy popyt zaczął rosnąć przy jednoczesnym spadku liczby nowych zakażeń. Co ciekawe, tendencja ta utrzymywała się w sezonie wakacyjnym pomimo ponownego wzrostu zachorowań. Podobnie jak w przypadku Europy, USA również odnotowały znaczny spadek liczby dziennych lotów krajowych, który utrzymywał się do czasu względnego spadku poziomu zachorowań. Co ciekawe, odmiennie niż w Europie, wbrew ponownemu wzrostowi dziennych zakażeń w USA liczba dziennych lotów utrzymuje się na względnie stałym poziomie, momentami nawet wzrastając.

Według analiz dokonanych przez serwis Flightradar24 (2020), pomyślność chińskiej branży lotniczej w stopniowym przywracaniu ruchu pasażerskiego zależała od wprowadzenia trzech faz ożywienia (ryc. 6). W fazie I, po gwałtownym spadku zachorowań, chińskie linie lotnicze przywróciły loty krajowe, na które popyt wzrósł natychmiast. Jednocześnie ruch międzynarodowy w dalszym ciągu pozostawał stłumiony ze względu na panujące obostrzenia. W fazie II, przypadającej na kwiecień 2020 r., zniesione zostały restrykcje dotyczące nakazu kwarantanny w Chinach. Popyt na loty krajowe w dalszym ciągu wzrastał miesięcznie średnio o $10 \%$, co w maju pozwoliło osiągnąć poziom liczby lotów krajowych sprzed

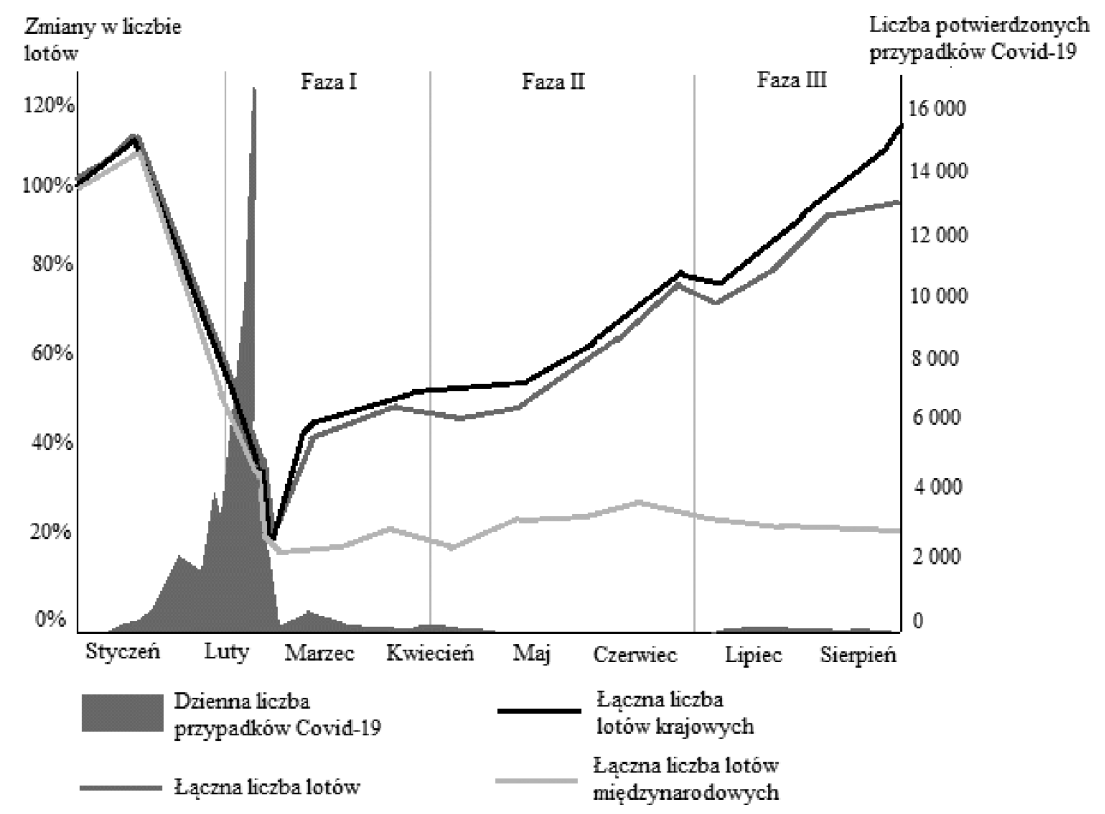

Ryc. 6. Zmiany w krajowych i międzynarodowych dziennych lotach w Chinach w 2020 r. (styczeń-sierpień)

Źródło: opracowanie własne na podstawie danych ADS-B, Flightradar24 i Europejskiego Centrum ds. Zapobiegania i kontroli Chorób. 
pandemii. W tym czasie zaobserwowano też powolny wzrost liczby lotów międzynarodowych, które z kolei szybko zostały zniesione wskutek pojawienia się znikomej liczby nowych zakażeń. Jednak natychmiastowa reakcja Chin i szybkie wprowadzenie ponownych ograniczeń pozwoliły na stłumienie nowych ognisk wirusa. Dzięki owym ograniczeniom w III fazie nastąpiło ponowne przywrócenie lotów krajowych i ciągły wzrost poziomu ruchu pasażerskiego. Według analiz do uzyskania takiego wyniku przyczyniły się masowe obniżki cen biletów i wzrost udziału tanich przewoźników (Flightradar24, 2020).

Analizując sytuację Europy, USA oraz Chin, można zauważyć, że żadne z nich nie odnotowało znaczącego wzrostu popytu i ruchu pasażerskiego w odniesieniu do lotów międzynarodowych. Dzieje się tak ze względu na zależność dostosowania siatki lotów międzykontynentalnych do sytuacji epidemicznej każdego państwa. Strategia Chin, dotycząca lotów na trasach międzynarodowych, miała charakter restrykcyjny. Od 12 marca 2020 r. każdej chińskiej linii lotniczej zezwolono na zrealizowanie jednego lotu tygodniowo do każdego państwa znajdującego się w jej siatce połączeń. Z kolei każda zagraniczna linia lotnicza uzyskała pozwolenie na obsłużenie jednej trasy do Chin tygodniowo, z obłożeniem pasażerów nie większym niż $75 \%$. Warunki te obowiązywały do momentu zamknięcia granicy chińskiej w dniu 27 marca (Flightradar24, 2020). Można przypuszczać, że szybkie podjęcie działań naprawczych przez Chiny było możliwe dzięki współpracy rządu i linii lotniczych oraz ich natychmiastowej reakcji na ponowne wzrosty zachorowań. Dodatkowo aspektem, który mógł ułatwić wdrażanie w życie działań naprawczych, jest mentalność i specyfika społeczeństwa chińskiego, a także jego stosunek do przestrzegania zaleceń wydawanych przez władze.

\section{Zakończenie}

Stopniowy powrót do realizacji liczby lotów krajowych sprzed pandemii ułatwiło powstanie wymuszonego trendu na turystykę krajową. Nawroty ognisk wirusa w sezonie zimowym i wzrosty zakażeń powodują wahania i uniemożliwiają opracowanie długoterminowych prognoz. Obecnie lotnictwo nie znajduje się $\mathrm{w}$ sytuacji, w której pandemia została opanowana, a testowanie pasażerów przed każdorazową podróżą jest rozwiązaniem chwilowym, kosztownym i ograniczającym popyt.

Transport lotniczy, który obsługuje $60 \%$ wszystkich podróżujących na świecie, może spodziewać się ponownego wzrostu popytu, jeśli wprowadzone zostaną odpowiednie procedury gwarantujące bezpieczeństwo. Na pytanie, kiedy branża wróci do sytuacji sprzed pandemii, istnieje, jak się wydaje, tylko jedna odpowiedź, a mianowicie wdrożenie szczepionki. Można zaryzykować stwierdzenie, że w przyszłości jedynie zaszczepieni pasażerowie będą mogli korzystać z usług lotniczych nie tylko na trasach międzynarodowych, ale i krajowych, a szczepionka stanie się przepustką do podróżowania. Za przykład poparcia tej tezy może posłużyć spot reklamowy linii Ryanair, który zachęca do kupna tanich biletów hasłem „zaszczep się i leć”. 
Branża transportu lotniczego niejednokrotnie pokazała, jak duże znaczenie ma dla światowej gospodarki. Lotnictwo zdolne do pokonania takich barier, jak recesje czy konflikty militarne, będzie w stanie poradzić sobie z kryzysem, jakim jest pandemia COVID-19. Oprócz szczepień wzrostowi popytu sprzyjają prognozy dotyczące cen biletów. Największy udział w rynku europejskim mają obecnie tanie linie, oferujące niskie taryfy. Duża ilość tanich biletów oraz szeroka siatka połączeń siłą rzeczy wymusi walkę konkurencyjną między tanimi a tradycyjnymi liniami lotniczymi, co może skutkować spadkiem cen przelotów linii tradycyjnych.

W wariancie optymistycznym do wygaszenia pandemii może dojść w sezonie letnim 2021 r. W dłuższej perspektywie pandemia COVID-19 tylko przyspieszyła procesy, których realizacja normalnie trwałaby latami. Zmuszają one zatem przedstawicieli nie tylko branży lotniczej do analizy negatywnego wpływu procesów globalnych i masowego przemieszczania się, a także do wprowadzenia rozwiązań zgodnych z ideą zrównoważonego rozwoju.

\section{Literatura}

Flightradar24 (2020). Can we learn from China's traffic recovery? (www.flightradar24. com; dostęp: 20.12.2020).

Gross S., Klemmer L. (2013). Introduction to tourism transport. Hochschule Harz - University of Applied Sciences, Berlin.

Grzywacz W., Burnewicz J. (1989). Ekonomika transportu. WKiŁ, Warszawa.

IATA (2019). In numbers: World Air Transport Statistics (www.airlines.iata.org; dostęp: 9.01.2020).

Kaczmarska A. (2014). Wybrane czynniki rozwoju turystyki. Studia Ekonomiczne, 176(14): 201-215.

Koźlak A. (2008). Ekonomika transportu. Teoria i praktyka gospodarcza. WUG, Gdańsk.

Ministerstwo Sportu i Turystyki (2019). Podstawowe dane statystyczne z turystyki za I półrocze 2019 (www.msit.gov.pl; dostęp: 9.01.2020).

Nedeva K., Genchev E. (2018). Air Transport - a source of competitive advantages of the region. Marketing and Branding Research, 5: 206-216.

Page S. (2005). Transport and tourism. Global Perspectives. Pearson Prentice Hall, Edinburgh.

Polski Instytut Ekonomiczny (2020). Branża turystyczna w Polsce. Obraz sprzed pandemii. Warszawa.

Rucińska D., Ruciński A., Tłoczyński D. (2010). Transport lotniczy - ekonomika i organizacja. WUG, Gdańsk.

UNWTO (2016-2019). Tourism Highlights 2016-2019 Editions (www.unwto.org; dostęp: 9.01.2020).

Urbanyi-Popiołek I. (red.) (2013). Ekonomiczne i organizacyjne aspekty transportu. Wydawnictwo Uczelniane WSG, Bydgoszcz.

Urząd Lotnictwa Cywilnego (2020). Przewozy pasażerskie w transporcie lotniczym w 2019 r. (www.ulc.gov.pl; dostęp: 25.12.2020). 


\section{The impact of COVID-19 pandemic on changes in the volume of passenger air traffic in Poland and in the world}

The outbreak of COVID-19 pandemic caused the restriction on the movement of people around the world, as a result of which the demand for transport services instantly fell down. Aviation, which is characterized by dynamic development, today suffers from large losses, which is reflected in the crisis of this industry. The aim of the article is to identify the impact of the pandemic on changes in the demand for air services in Poland and around the world. The analysis of the literature and secondary data allowed to identify changes in the volume of the passenger traffic caused by the pandemic, with particular emphasis on the chinese market as a benchmarking for the aviation industry.

Translated by Magdalena Wawoczny 

Franciszek Bolechowski

Uniwersytet Ekonomiczny w Krakowie

franciszek.bolechowski93@gmail.com

(D) https://orcid.org/0000-0002-5546-3817

\section{Socjodemograficzne determinanty aktywności turystycznej beneficjentów programu socjalnego Rodzina 500+ w Polsce}

\section{Streszczenie}

Głównym celem rozdziału jest wskazanie socjodemograficznych determinant aktywności turystycznej beneficjentów programu socjalnego Rodzina 500+ w Polsce. W oparciu o wyniki badań przeprowadzonych od stycznia do maja 2020 r. za pomocą sondażu diagnostycznego wśród 64 Polaków korzystających z tego rodzaju wsparcia socjalnego pozytywnie zweryfikowano tezę główną mówiącą o tym, że po zaspokojeniu potrzeb podstawowych na pewnym poziomie rodziny mogą sobie pozwolić na konsumpcję według upodobania, a w jej ramach na aktywność turystyczną lub częstsze jej podejmowanie. Ponadto, stosując test zależności chi-kwadrat Pearsona, potwierdzono następujące hipotezy cząstkowe: 1. Wraz ze wzrostem miesięcznego dochodu na członka rodziny wzrasta częstotliwość wyjazdów turystycznych. 2. Im liczniejsze gospodarstwo domowe, tym rzadziej jego członkowie podróżują za granicę. 3. Im wyższe wykształcenie rodzica, tym częściej rodzina wyjeżdża w celach poznawczych. Część empiryczną poprzedził przegląd piśmiennictwa na temat wpływu pomocy socjalnej na gospodarkę i rynek.

\section{Wprowadzenie}

Obecna sytuacja demograficzno-ekonomiczna w Polsce związana jest z dwoma zagrożeniami, tj.: pułapką niskiej dzietności oraz pułapką średniego dochodu (Jodko, 2017, s. 80-90). Pierwsza z nich wynika z ukształtowania nowych wzorców, które odnoszą się do modelu rodziny opartego na jednodzietności lub bezdzietności. Taki stan rzeczy spowodowany jest przemianami świadomości społecznej, 
stylu życia i wyznawanych wartości (Sołdra-Gwiżdż, 2017, s. 39). Z kolei pułapka średniego dochodu związana jest $z$ występowaniem sytuacji, w której historyczne tempo wzrostu gospodarczego zwalnia na tyle trwale, że znacząco spowalnia lub nawet uniemożliwia zbliżenie poziomu wielu państw do poziomu krajów o wysokim dochodzie narodowym (Fic i in., 2016, s. 129). Zagrożenia te, w połączeniu ze wzrostem długości życia (wynikającym z poprawy warunków bytowych i zdrowia) oraz zwiększającym się ruchem przestrzennym (migracją za granicę ludzi młodych w wieku 25-35 lat), spowodowały wzrost liczby osób starszych w społeczeństwie (Organiściak-Krzykowska, 2018, s. 131-132). Aby zapobiec pogłębianiu się tego zjawiska i poprawić strukturę demograficzno-ekonomiczną, poszczególne państwa wprowadzają rozmaite rozwiązania. Rząd polski zaproponował w tym względzie 1 kwietnia 2016 r. program socjalny typu Rodzina 500+. Jego efektem jest wzrost konsumpcji Polaków (Liszatyński, 2017, s. 211), a przez to rozwój podaży wielu produktów (takich jak: artykuły żywnościowe, sprzęt RTV, AGD i IT, materiały budowlane, artykuły wyposażenia wnętrz itd.). Po zaspokojeniu potrzeb podstawowych na pewnym poziomie rodziny mogą bowiem pozwolić sobie na konsumpcję według upodobania. W jej ramach na szczególną uwagę zasługuje aktywność turystyczna i częstotliwość jej podejmowania.

Celem pracy jest identyfikacja socjogeograficznych uwarunkowań kształtujących uczestnictwo w ruchu turystycznym beneficjentów programu socjalnego Rodzina $500+$. Wykorzystując wyniki badań przeprowadzonych od stycznia do maja 2020 r. za pomocą sondażu diagnostycznego wśród 64 Polaków pobierających tego rodzaju świadczenia, postanowiono potwierdzić (lub odrzucić) następujące hipotezy cząstkowe: 1 . Wraz ze wzrostem miesięcznego dochodu na członka rodziny wzrasta częstotliwość wyjazdów turystycznych. 2. Im liczniejsze gospodarstwo domowe, tym rzadziej jego członkowie podróżują za granicę. 3. Im wyższe wykształcenie rodzica, tym częściej rodzina wyjeżdża w celach poznawczych. Do weryfikacji hipotez użyto testu chi-kwadrat Pearsona.

Analizę empiryczną poprzedziła kwerenda literatury dotyczącej skutków wprowadzenia świadczeń Rodzina 500+ w Polsce.

\section{Przegląd literatury}

W literaturze przedmiotu istnieje znaczna liczba publikacji poświęconych programowi socjalnemu Rodzina 500+ i jego odniesieniom do wielu aspektów życia. Odnaleźć można artykuły zawierające ocenę mikroekonomicznych efektów dofinansowania publicznego w zakresie utrzymana dzieci $z$ tego programu (Liszatyński, 2017, s. 211). Pewna część publikacji traktuje o tym, że program 500+ realizowany w formie gotówkowej zapewnia większą użyteczność konsumpcji niż wypłacanie jego równowartości w bonach lub też zwolnienia z podatku VAT produktów spożywczych czy artykułów dziecięcych. Taka pomoc socjalna ma ponadto charakter bardziej prorynkowy niż przeznaczenie środków potrzebnych na jego realizację, np. na bezpłatne przedszkola i żłobki (Brzęczek, 2019). Innym przykładem publikacji dotyczących programu socjalnego Rodzina $500+$ są te, w których 
poruszono problematykę jego wpływu na poziom dochodów rozporządzalnych (Wojciuk, 2018) czy też stymulowanie wzrostu demograficznego (Puślecki, 2016). Interesujące są ponadto opracowania mówiące o wpływie programu 500+ na podaż pracy kobiet w Polsce (Magda i in., 2018) oraz o negatywnych skutkach takiej pomocy socjalnej (Dziwosz, 2017). Brak jednak w literaturze analizy socjodemograficznych determinant aktywności turystycznej beneficjentów programu Rodzina 500+. Niniejszy rozdział wypełnia tę lukę badawczą.

\section{Metodyka badań}

W celu określenia, które cechy socjodemograficzne beneficjentów programu Rodzina 500+ wpływają na uczestnictwo w ruchu turystycznym, wykorzystano wyniki badań przeprowadzonych od stycznia do maja 2020 r. za pomocą sondażu diagnostycznego wśród 64 Polaków pobierających tego rodzaju świadczenia socjalne. Respondentów zapytano m.in., ile razy w ciągu roku podróżują, czy są to wyjazdy krajowe czy zagraniczne oraz $\mathrm{w}$ jakim celu je odbywają. W opracowaniu do analizy wykorzystano 6 cech socjodemograficznych osób badanych $\left(X_{u}\right)$, tj. wiek, płeć, wykształcenie, wielkość miejsca zamieszkania, liczbę osób w gospodarstwie domowym oraz miesięczny dochód brutto na członka rodziny. $\mathrm{Na}$ podstawie uzyskanych wyników postanowiono zweryfikować następujące hipotezy badawcze:

- $\mathrm{H}_{\mathrm{A}}$ : Wraz ze wzrostem miesięcznego dochodu na członka rodziny wzrasta częstotliwość wyjazdów turystycznych.

- $\mathrm{H}_{\mathrm{B}}$ : Im liczniejsze gospodarstwo domowe, tym rzadziej jego członkowie podróżują za granicę.

- $\mathrm{H}_{\mathrm{C}}$ : Im wyższe wykształcenie rodzica, tym częściej rodzina wyjeżdża w celach poznawczych.

Postawiono 18-krotnie (dla każdej pary zmiennych $Y_{1}$ i $X_{u}, Y_{2}$ i $X_{u}$ oraz $Y_{3}$ i $X_{u}$ ) następujące hipotezy statystyczne: $\mathrm{H}_{0}$ - częstotliwość wyjazdów turystycznych $\left(Y_{1}\right)$, uczestnictwo w podróżach zagranicznych $\left(Y_{2}\right)$ oraz wyjazd w celu poznawczym $\left(Y_{3}\right)$ nie zależą od danej cechy socjodemograficznej beneficjenta programu socjalnego Rodzina $500+\left(X_{u}\right)$ oraz $\mathrm{H}_{1}$ jako hipotezę alternatywną. Do ich weryfikacji użyto testu chi-kwadrat Pearsona. Przyjmując, zgodnie z regułami powszechnie stosowanymi $\mathrm{w}$ ekonomii, istotność na poziomie $\alpha=0,05$, przy prawdopodobieństwie testowym $p$ mniejszym od 0,05 , należało odrzucić hipotezę $\mathrm{H}_{0}$ i przyjąć hipotezę $\mathrm{H}_{1}$ W przeciwnym razie nie było podstaw do odrzucenia hipotezy $\mathrm{H}_{0}$. Uzyskane wyniki prezentuje tabela 1 . Po przeanalizowaniu zawartych w niej danych można wywnioskować, że częstotliwość wyjazdów turystycznych $\left(Y_{1}\right)$ istotnie determinują 2 z 6 cech socjodemograficznych $\left(X_{u}\right)$ - nie jest ona zależna od płci, wieku, wielkości miejsca zamieszkania oraz liczby osób w gospodarstwie domowym.

Uczestnictwo w podróżach zagranicznych $\left(Y_{2}\right)$ istotnie zależy z kolei od 4 z 6 cech (nieistotne okazały się: wiek i wielkość miejsca zamieszkania). Natomiast na cel poznawczy podróżowania istotnie wpływa tylko jedna cecha - wykształcenie 
Tabela 1. Wysokość prawdopodobieństwa testowego $p$ dla zależności pomiędzy częstotliwością wyjazdów turystycznych, uczestnictwem w podróżach zagranicznych oraz celem poznawczym wyjazdów a cechami socjodemograficznymi beneficjentów programu socjalnego Rodzina $500+\left(X_{u}\right)^{*}$

\begin{tabular}{|c|c|c|c|}
\hline $\begin{array}{c}\text { Cechy } \\
\text { socjodemograficzne } \\
\left(X_{u}\right)\end{array}$ & $\begin{array}{c}\text { Częstotliwość } \\
\text { wyjazdów } \\
\text { turystycznych }\left(Y_{1}\right)\end{array}$ & $\begin{array}{c}\text { Uczestnictwo } \\
\text { w podróżach } \\
\text { zagranicznych }\left(Y_{2}\right)\end{array}$ & $\begin{array}{c}\text { Cel poznawczy } \\
\text { podróżowania }\left(Y_{3}\right)\end{array}$ \\
\hline Płeć $\left(X_{1}\right)$ & $p=0,90172$ & $p=0,03802$ & $p=0,76057$ \\
\hline Wiek $\left(X_{2}\right)$ & $p=0,92198$ & $p=0,07488$ & $p=0,51100$ \\
\hline Wykształcenie $\left(X_{3}\right)$ & $p=0,00381$ & $p=0,00112$ & $p=0,03514$ \\
\hline $\begin{array}{l}\text { Wielkość miejsca } \\
\text { zamieszkania }\left(X_{4}\right)\end{array}$ & $p=0,78073$ & $p=0,52967$ & $p=0,65606$ \\
\hline $\begin{array}{l}\text { Liczba osób } \\
\text { w gospodarstwie } \\
\text { domowym }\left(X_{5}\right)\end{array}$ & $p=0,10025$ & $p=0,04575$ & $p=0,32132$ \\
\hline $\begin{array}{l}\text { Miesięczny dochód } \\
\text { brutto na } 1 \text { członka } \\
\text { rodziny }\left(X_{6}\right)\end{array}$ & $p=0,00471$ & $p=0,00212$ & $p=0,15108$ \\
\hline
\end{tabular}

*Pogrubioną czcionką oznaczono zależności istotne statystycznie.

Źródło: obliczenia własne na podstawie przeprowadzonych badań.

(nieistotne są: wiek, płeć, wielkość miejsca zamieszkania, liczba osób w gospodarstwie domowym oraz miesięczny dochód brutto na 1 członka rodziny).

\section{Wyniki badań}

Analizując częstotliwości wyjazdów turystycznych w zależności od wysokości miesięcznego dochodu brutto na 1 członka rodziny (zob. ryc. 1), należy stwierdzić, że w przypadku osób deklarujących dochody na poziomie do 1000 zł częstotliwość wyjazdów turystycznych rozłożyła się równomiernie - po 1/4 respondentów stanowiły osoby wyjeżdżające $\mathrm{w}$ celach turystycznych raz na kilka lat, co dwa lata, raz na rok i dwa razy w roku.

Wśród badanych deklarujących zarobki w przedziale 1001-2000 zł największą grupę stanowiły osoby wyjeżdżające dwa razy w roku (blisko $2 / 5$ respondentów tej grupy). Prawie $30 \%$ ankietowanych $z$ tego segmentu wyjeżdżało raz na rok. Podróżujący raz na kilka lat oraz trzy razy w roku stanowili podobne części tej zbiorowości (odpowiednio 11\% i 17\%). Osoby podróżujące częściej niż trzy razy $\mathrm{w}$ roku tworzyły natomiast niespełna $6 \%$ tego segmentu.

Spośród osób deklarujących wielkość dochodów na poziomie 2001-3000 zł największy udział miały te, wyjeżdżające w celach turystycznych dwa razy w roku (ponad 2/5 badanych). Drugą grupą pod względem liczebności były osoby podróżujące raz na rok (30\%). Osoby uczestniczące w wyjazdach trzy razy w roku i częściej niż trzy razy w roku stanowiły taki sam odsetek w tej grupie (po 13\%).

Analizując przedział w zakresie 3001-4000 zł deklarowanego miesięcznego dochodu przypadającego na 1 członka rodziny, należy stwierdzić, że dokładnie 


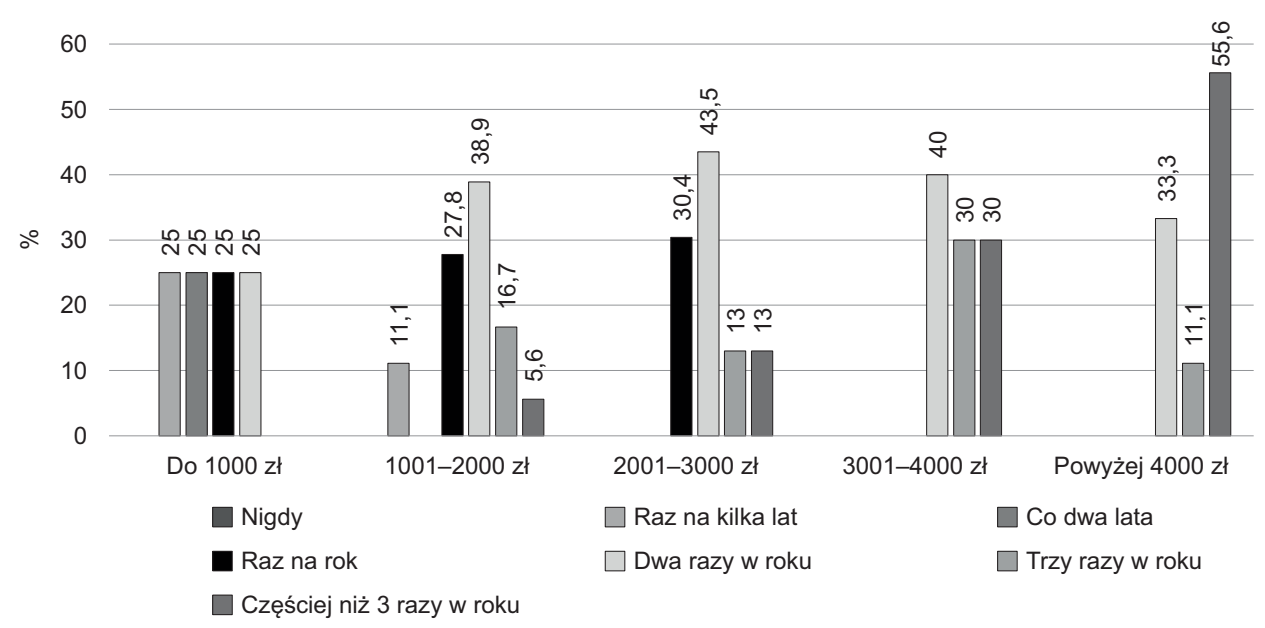

Ryc. 1. Częstotliwość wyjazdów turystycznych w zależności od wysokości miesięcznego dochodu brutto na 1 członka rodziny

Źródło: opracowanie własne na podstawie przeprowadzonych badań.

2/5 osób z tej grupy wyjeżdżało w celach turystycznych dwa razy w roku. Wysoki udział miały też osoby podróżujące trzy razy w roku i częściej niż trzy razy w roku (po 30\%).

Wśród ankietowanych dysponujących kwotą miesięcznego dochodu na 1 członka rodziny powyżej 4000 zł ponad połowę stanowiły osoby wyjeżdżające w celach turystycznych częściej niż trzy razy w roku. Ponad 30\% osób wyjeżdżało dwa razy w roku, a ponad $10 \%$ - trzy razy w roku.

Uwzględniając fakt, że wraz ze wzrostem miesięcznego dochodu na 1 członka rodziny maleje odsetek osób wyjeżdżających raz na kilka lat i co dwa lata (z 25\% na $0 \%$ ), a wzrasta początkowo udział odpowiedzi „raz na rok” (z 25\% na 30\%) i „dwa razy w roku” (z 25\% na 44\%), następnie wskazań na „trzy razy w roku” (z 13\% na 30\%) i dalej - deklaracji „wyjeżdżam częściej niż trzy razy w roku” (z 5\% na 55\%), można uznać, że pierwsza hipoteza cząstkowa $\left(\mathrm{H}_{\mathrm{A}}\right)$ została potwierdzona: wraz ze wzrostem miesięcznego dochodu na członka rodziny wzrasta częstotliwość wyjazdów turystycznych.

Analizując z kolei zależności pomiędzy liczbą osób w gospodarstwie domowym a częstotliwością wyjazdów zagranicznych (zob. ryc. 2), należy stwierdzić, że turystykę zagraniczną uprawiało ponad 3/4 respondentów, u których liczba osób w gospodarstwie domowym wynosi 3 , ponad $63 \%$ badanych, w których rodzinie znajdowało się 4 członków, oraz ponad $46 \%$ ankietowanych z gospodarstw domowych, w skład których wchodziło 5 członków. Najmniejszy odsetek badanych biorących udział w podróżach zagranicznych (ok. 14\%) pochodził z sześcioosobowych gospodarstw domowych. Tym samym założona na wstępie hipoteza $\mathrm{H}_{\mathrm{B}}$ mówiąca, że im liczniejsze gospodarstwo domowe, tym rzadziej jego członkowie podróżują za granicę, została empirycznie potwierdzona.

Rozpatrując trzecią hipotezę $\left(\mathrm{H}_{c}\right)$, trzeba zauważyć, że wykształcenie rodziców ma znaczący wpływ na podejmowanie wyjazdów turystycznych w celach 


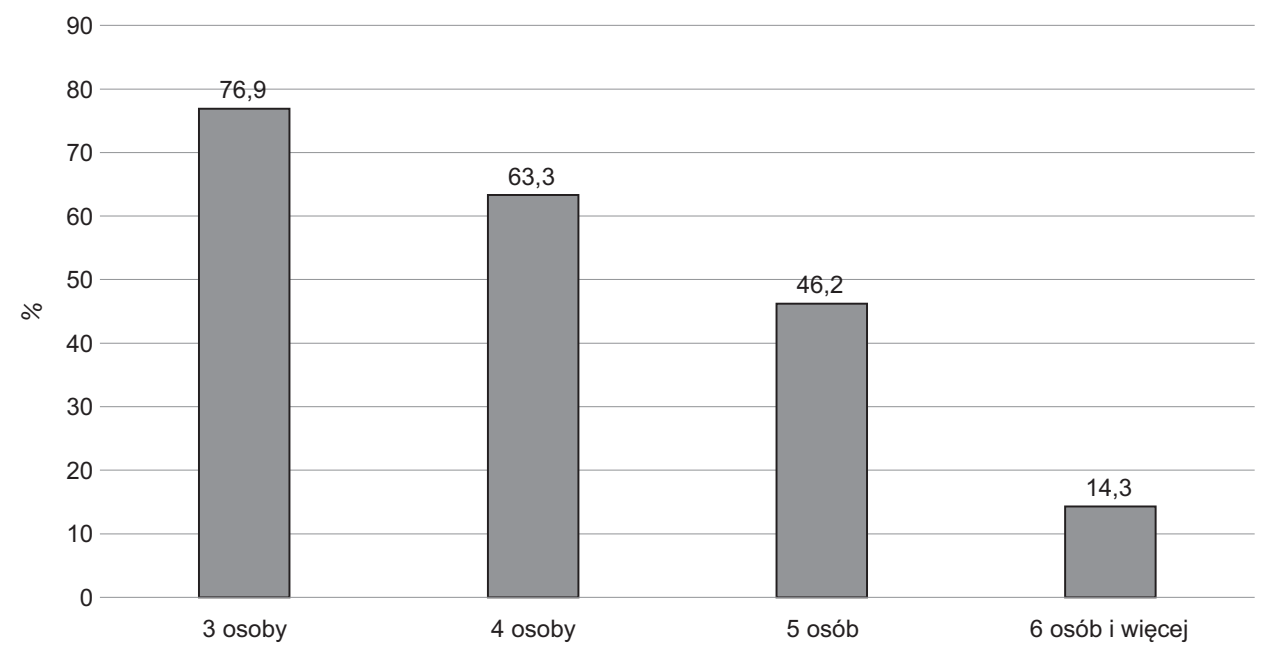

Ryc. 2. Deklarowane turystyczne wyjazdy zagraniczne w zależności od liczebności gospodarstw domowych

Źródło: opracowanie własne na podstawie przeprowadzonych badań.

poznawczych (zob. ryc. 3). Z przeprowadzonych badań wynika, że w podróżach o tych motywach brało udział prawie $58 \%$ respondentów deklarujących wykształcenie wyższe, blisko $27 \%$ osób po szkole średniej oraz tylko $1 / 5$ ankietowanych $\mathrm{z}$ wykształceniem zawodowym.

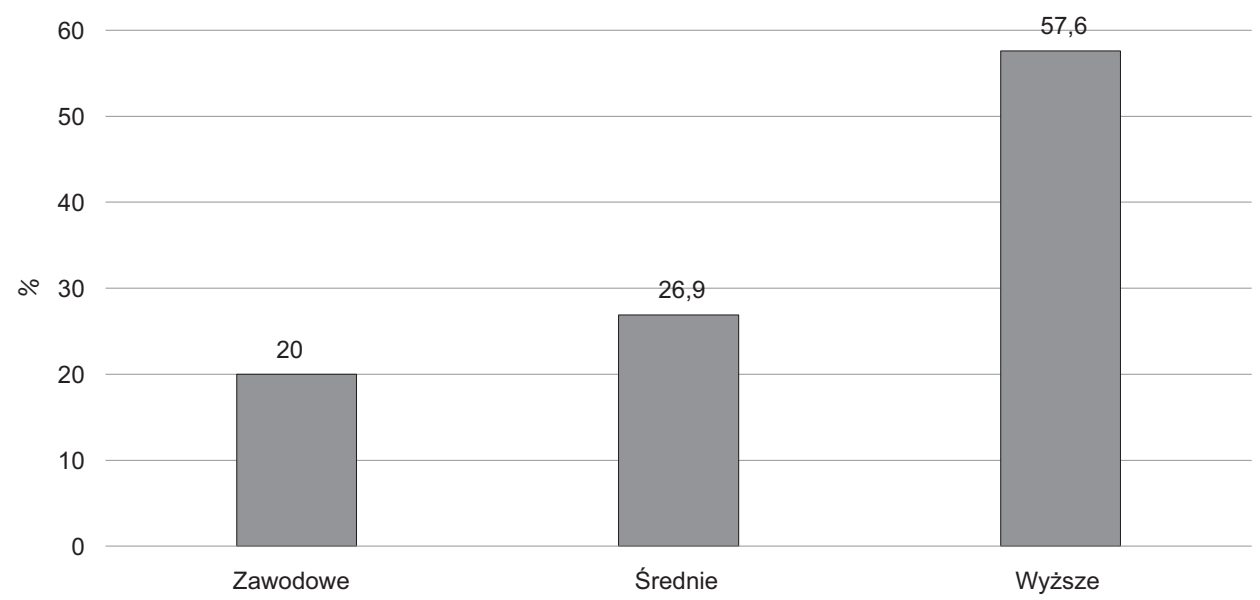

Ryc. 3. Wykształcenie rodziców a motyw poznawczy wyjazdów turystycznych Źródło: opracowanie własne na podstawie przeprowadzonych badań.

Zatem hipotezę $\mathrm{H}_{c,}$ która brzmiała: im wyższe wykształcenie rodzica, tym częściej rodzina wyjeżdża w celach poznawczych, należy uznać za prawdziwą. 


\section{Zakończenie}

Z analizy danych pozyskanych z sondażu diagnostycznego wynika, że postawiona na wstępie niniejszego rozdziału teza główna jest właściwa - po zaspokojeniu potrzeb podstawowych na pewnym poziomie rodziny mogą sobie pozwolić na konsumpcję według upodobania, a w jej ramach na aktywność turystyczną lub częstsze jej podejmowanie. Potwierdzeniem słuszności tego stwierdzenia jest zwłaszcza pozytywna weryfikacja pierwszej z hipotez cząstkowych: wraz ze wzrostem miesięcznego dochodu na członka rodziny wzrasta częstotliwości wyjazdów turystycznych. Jeśli jednak przyjąć, że wyjazd zagraniczny jest z reguły droższy niż wyjazd krajowy, to również druga z hipotez cząstkowych: im liczniejsze gospodarstwo domowe, tym rzadziej jego członkowie podróżują za granicę, potwierdza tezę główną opracowania. Jeśli z kolei założyć, że wyższe wykształcenie pociąga za sobą wyższe dochody, to również ostatnia z hipotez cząstkowych: im wyższe wykształcenie rodzica, tym częściej rodzina podróżuje w celach poznawczych, pozytywnie weryfikuje tezę główną pracy.

$\mathrm{Z}$ analizy wynika ponadto, że aktywność turystyczną beneficjentów programu socjalnego Rodzina 500+ w Polsce determinują takie ich cechy socjodemograficzne, jak: płeć, wykształcenie, liczba osób w gospodarstwie domowym i dochód na członka rodziny. Spośród tych cech najważniejsze okazało się wykształcenie było ono istotnie skorelowane $\mathrm{z}$ wszystkimi badanymi zmiennymi. Trzeba $\mathrm{w}$ tym miejscu zaznaczyć, że omówione badania miały charakter pilotażowy i objęto nimi tylko nielicznych świadczeniobiorców programu Rodzina 500+. Należy jednak je kontynuować, gdyż znajomość zidentyfikowanych zależności może mieć duży wpływ na kształtowanie planów rozwoju społeczno-ekonomicznego w Polsce, a prawidłowe ich rozpoznanie i monitorowanie pozwoli na właściwe dopasowanie oferty turystycznej do potrzeb rodzin z dziećmi.

\section{Literatura}

Brzęczek T. (2019). Ocena programu socjalnego „Rodzina 500+” w świetle teorii konsumenta. Zeszyty Naukowe Politechniki Poznańskiej, Organizacja i Zarządzanie, 80: $7-17$.

Dziwosz E. (2017). Minusy Programu 500 Plus. Zeszyty Naukowe Politechniki Śląskiej, Organizacja i Zarządzanie, 104: 209-216.

Fic M., Fic D., Ropuszyńska-Surman E. (2016). Pułapka średniego dochodu zagrożeniem dla rozwoju gospodarki polskiej. Problemy Współczesnej Ekonomii, Studia i Prace WNEIZ US, 44(3): 127-139.

Jodko M. (2017). Demografia a przyszłość finansów publicznych w Polsce. Studia Ekonomiczne, Zeszyty Naukowe Uniwersytetu Ekonomicznego w Katowicach, 310: 80-90.

Liszatyński D. (2017). Analiza skutków społeczno-ekonomicznych wprowadzenia programu „Rodzina 500+”. Humanum, 27(4): 209-219.

Magda I., Kielczewska A., Brandt N. (2018). The „Family 500+” child allowance and female labour supply in Poland. IBS Working Paper, 1: 2-18. 
Organiściak-Krzykowska A. (2018). Konsekwencje społeczno-ekonomiczne sytuacji demograficznej w Polsce. W: J. Hrynkiewicz, J. Witkowski, A. Potrykowska (red.), Sytuacja demograficzna Polski jako wyzwania dla polityki społecznej i gospodarczej. Rządowa Rada Ludnościowa, Warszawa, s. 130-144.

Puślecki D. (2016). Polityka wsparcia rodziny czy stymulowanie wzrostu demograficznego w Programie Rodzina 500 plus. Przegląd Politologiczny, 6: 79-91.

Sołdra-Gwiżdż T. (2017). Czy „pułapka niskiej dzietności” w województwie opolskim? Perspektywa socjologiczna. Studia Ekonomiczne, Zeszyty Naukowe Uniwersytetu Ekonomicznego w Katowicach, 309: 39-48.

Wojciuk M. (2018). Wpływ programu „Rodzina 500+” na poziom dochodów rozporządzalnych. Prace Naukowe Uniwersytetu Ekonomicznego we Wrocławiu, 529: 412-422.

\section{Sociodemographic determinants of tourist activity of the family $500+$ social program beneficiaries in Poland}

The main aim of the article is to indicate the socio-demographic determinants of tourism activity of the beneficiaries of the Family $500+$ social program in Poland. Based on the results of the research carried out from January to May 2020, using a diagnostic survey among 64 Poles using this type of social support, the main thesis was positively verified that after satisfying basic needs at a certain level, families can afford to consume as they like and within it, tourist activity or taking it up more frequently. Moreover, using the Pearson chi-square dependency test, the following partial hypotheses were confirmed: 1. The frequency of tourist trips increases with the increase in monthly income per family member. 2 . The larger the household, the less frequently its members travel abroad. 3. The higher the parent's education, the more often the family goes away for educational purposes.

The empirical part was preceded by a literature review on the impact of social aid on the economy and the market. 


\section{Magdalena Kosiada-Sylburska}

Uniwersytet Łódzki

magda.kosiada@gmail.com

(D) https://orcid.org/0000-0002-2598-0434

\section{Dlaczego konsumenci angażują się w przygotowanie usług $\mathrm{w}$ muzeach? Wstęp do badań}

\section{Streszczenie}

Rynek doznań i kształtowanie pozytywnego doświadczenia konsumenta stają się coraz częściej przedmiotem zainteresowania muzeów. Referat prezentuje wyniki badania jakościowego $\mathrm{w}$ formie pogłębionego wywiadu strukturyzowanego z osobami biorącymi udział $\mathrm{W}$ warsztacie dotyczącym projektowania przestrzeni muzealnej. Wskazano na kluczowe, w ocenie respondentów, uwarunkowania niezbędne do budowania zaangażowania konsumentów. Analizie poddano również motywację konsumentów do podejmowania aktywności w tej dziedzinie. Badanie miało charakter wstępny i pozwoliło na wyciągnięcie wniosków oraz zarysowanie perspektyw badawczych do dalszych etapów badań w zakresie angażowania konsumentów w działalność instytucji kultury.

\section{Wprowadzenie}

Idea konsumpcji hedonicznej narodziła się na początku lat 80. XX w. Od tego czasu koncepcja tworzenia doświadczeń klienta i strategicznego zarządzania nimi była rozwijana i zyskiwała coraz większe zainteresowanie zarówno praktyków, jak i naukowców (Steffen, Doppler, 2020). Jest ona przedmiotem badań w różnych dziedzinach, w tym w turystyce i kulturze (por. Gopalana, Narayanb, 2010; Godovykh, Tasci, 2020; Sarantou i in., 2021).

Instytucje kultury, nie zatracając swoich pierwotnych funkcji związanych m.in. z ochroną i udostępnieniem zbiorów, coraz więcej uwagi poświęcają swoim odbiorcom. Budowanie pozytywnego doświadczenia konsumentów oraz 
angażowanie ich w działalność instytucji kultury jest wciąż nowym konceptem, szczególnie od strony praktycznej w Polsce; jednak pojawia się coraz więcej badań w tym zakresie. Opierając się na doświadczeniu odbiorców jednego z polskich muzeów, którzy wzięli udział w warsztacie poświęconym projektowaniu i zmianom przestrzeni muzealnej, postanowiono zbadać, co motywowało te osoby do poświęcenia własnego czasu, aby podzielić się wiedzą, doświadczeniem i pomysłami z instytucją kultury. W tym celu przeprowadzono badanie jakościowe $\mathrm{w}$ formie indywidualnych pogłębionych wywiadów strukturyzowanych. Ma ono charakter wstępny i służy nakreśleniu dalszych perspektyw badawczych w zakresie angażowania konsumentów w projektowanie produktów i usług na rynku kultury.

W rozdziale zaprezentowano przegląd literatury naukowej, przedstawiono metodę oraz wyniki badania, na zakończenie podsumowano prace badawcze i podjęto próbę zarysowania perspektywy kolejnych badań.

\section{Przegląd literatury}

Nauka dostarcza szeregu badań i wniosków związanych $z$ angażowaniem konsumentów w przygotowanie produktów i usług oraz tworzeniem doświadczeń klientów. Szerokie badania były prowadzone zwłaszcza w zakresie działalności biznesowej. Jednak od pewnego czasu widoczne jest zainteresowanie obszarem usług publicznych, w tym na rynku kultury. W tej części pracy przedstawiono wybrane zagadnienia związane $z$ doświadczeniem klienta, zaangażowaniem konsumentów, crowdsourcingiem oraz otwieraniem się instytucji kultury na nowe formy tworzenia oferty i współpracy z publicznością.

W literaturze wskazano, że we współczesnej gospodarce projektowanie usług związanych $z$ doświadczeniem klienta powinno być priorytetem badawczym. Opracowywane są narzędzia do analizy i projektowania doświadczenia klienta (por. Lim, Kim, 2018). Warto zastanowić się nad ich wykorzystaniem w sektorze kultury.

Muzea są instytucjami, które gromadza, zabezpieczają i prezentują artefakty i wspomnienia w celach niezarobkowych, odnoszących się do nauki i zabawy. Jednakże znaczące zmiany w środowisku, w którym działają, doprowadziły do powstania nowych rodzajów aktywności mających na celu przyciągnięcie różnych grup odbiorców, co przyczynia się do ich przyszłej równowagi ekonomicznej i społecznej (Barron, Leask, 2017). W literaturze podkreśla się, że obecnie kluczem do sukcesu placówki muzealnej jest świadome kształtowanie oferty, przy wsparciu badań marketingowych oraz analizowaniu zmieniających się potrzeb współczesnego konsumenta. Wbrew obawom nie musi się to odbywać kosztem realizacji statutowej misji chronienia dziedzictwa kulturowego (Macalik, 2014). Dziś muzea nie tylko docierają do szerszej publiczności i budują popyt wśród nowych grup, ale proaktywnie projektują aranżacje, usługi i oferty, które będą generować satysfakcję i pozytywne efekty dla zwiedzających (Kotler, Kotler, 2000). 
W instytucjach kultury na świecie w proces decyzyjny włącza się odbiorców; znane są przykłady zastosowania konsensusu w procesie decyzyjnym oraz wykorzystania podejścia crowdsourcingowego (por. Ciurea, Owsiński, 2019). Crowdsourcing jest definiowany jako celowe wykorzystywanie tłumów do rozwiązywania problemów, tworzenia nowych produktów i poprawy doświadczeń konsumentów (Bal i in., 2017). Podstawową koncepcją kryjącą się za tym pojęciem jest wykorzystanie umiejętności, pomysłów i wysiłku grupy ludzi do tworzenia treści wysokiej jakości (Ciurea, Owsiński, 2019). Proces ten musi być jednak dobrze przygotowany i przeprowadzony; dla jego sukcesu ważne wydaje się poznanie i zrozumienie postaw oraz potrzeb konsumentów.

Trzeba podkreślić, że zaangażowani konsumenci odgrywają istotną rolę w rozwoju społeczności i firmy. W literaturze przedmiotu formułuje się zatem zalecenia dotyczące tworzenia sprzyjających warunków, aby przekonać większą liczbę konsumentów do „poważnego” zaangażowania (de Almeida i in., 2018). Zaangażowani konsumenci wykazują zwiększoną lojalność, satysfakcję, upodmiotowienie, więź emocjonalną, zaufanie i przywiązanie do marki (Brodie i in., 2013). Warto zatem, planując ofertę i tworząc doświadczenia klienta, otwierać się na nowe formy uczestnictwa odbiorców w działalności instytucji kultury. Angażowanie konsumentów może przybierać różne formy, chociażby dzielenie się wiedzą, informowanie, współtworzenie, uczenie się, wspieranie i zacieśnianie więzi społecznych. Widoczna jest coraz aktywniejsza rola konsumentów we współtworzeniu treści marketingowych (Hanna i in., 2011). Tę szansę powinny wykorzystać instytucje kultury.

Badacze wskazują na zaufanie i lojalność jako czynniki wpływające na pozytywne nastawienie konsumenta i jego większą skłonność do bycia bardziej aktywnym (Kujur, Singh, 2017; Coelho i in., 2018). Zaangażowanie konsumentów w kontekście wpływu na kontynuację korzystania z usług o charakterze hedonistycznym, do których zaliczamy również kontakt z kulturą, jest czynnikiem przeważającym nawet nad samą satysfakcją klienta związaną z wyświadczoną usługą (Hepola i in., 2020). Raïes i in. (2015) zwracają jednak uwagę, że samo zaangażowanie nie jest ani wystarczające, ani konieczne dla zachowania lojalności wobec marki.

Co zatem motywuje konsumentów do bycia zaangażowanymi? Pozytywny wpływ ma bez wątpienia identyfikacja konsumenta $z$ danym przedsięwzięciem społecznym (Hall-Phillips i in., 2016). Dla konsumentów, szczególnie tych motywowanych zewnętrznie, zaangażowanie zaspokaja ich potrzebę w zakresie bycia częścią społeczności (Kim, Drumwright, 2016). Powiązanie marki ze samym sobą oraz postrzeganie korzyści psychologicznych, takich jak autonomia, kompetencja i przywiązanie, jest silnie motywujące w zakresie chęci współtworzenia danej oferty (Hsieh, Chang, 2016). Motywacja konsumentów do zaangażowania płynie również z chęci rozwoju wiedzy, samorealizacji lub poszukiwania uznania zewnętrznego przez danego konsumenta (de Almeida i in., 2018). Ważną rolę w chęci konsumenta włączenia się w działalność danej marki odgrywają jego wcześniejsze doświadczenia, zaufanie i identyfikacja ze społecznością. Istotne 
jest też zapewnienie informacji na temat samego zaangażowania danego konsumenta (Martínez-López i in., 2017).

Jak wykazano w ramach zaprezentowanego powyżej przeglądu literatury, pozytywne skutki angażowania konsumentów zarówno w działalności biznesowej, jak i nienastawionej na zysk są łatwe do zauważenia. Dlatego oferta instytucji kultury kształtowana przy zaangażowaniu konsumentów nie powinna pozostawać poza obszarem zainteresowania badaczy i praktyków.

\section{Metodyka badań}

Celem badania było uchwycenie perspektywy konsumentów w zakresie ich zaangażowania $\mathrm{w}$ działalność instytucji kultury. Postawiono następujące pytania badawcze:

- W jaki sposób konsumenci angażują się w działalność instytucji kultury?

- Co sprawia, że konsumenci angażują się w działalność instytucji kultury?

- Jakie należy stworzyć warunki, aby konsumenci angażowali się w działalność instytucji?

Badanie przeprowadzono wśród osób, biorących udział w warsztacie dotyczącym projektowania zmian $\mathrm{w}$ przestrzeni muzealnej, który odbył się $\mathrm{w}$ jednym z muzeów w Polsce na początku 2020 r. Warsztat, prowadzony przez inny zespół badawczy, został potraktowany jako zbudowanie wspólnego doświadczenia respondentów do wykonania prezentowanego w pracy badania. W warsztacie łącznie uczestniczyło 10 osób; do wymienionego badania zaproszono z tej grupy 3 respondentów.

Badanie odbyło się w kwietniu 2020 r. w formie indywidualnych pogłębionych wywiadów strukturyzowanych. Ze względu na COVID-19 wywiady przeprowadzono za pomocą komunikatorów internetowych pozwalających na połączenie audio i wideo. Każdy z wywiadów trwał około 60 minut i na potrzeby przygotowania transkrypcji był rejestrowany. Narzędzie badawcze stanowił kwestionariusz wywiadu, składający się z 12 pytań.

Badanie miało charakter wstępny. Ze względu na to celem było również określenie i doprecyzowanie dalszych perspektyw badawczych.

\section{Wyniki badań}

Jednym z badanych wątków była motywacja osób korzystających z oferty instytucji kultury do zaangażowania się w jej działalność. Respondenci jako kluczowy motywator, który wpłynął na ich chęć wzięcia udziału w warsztacie, wskazali ciekawość. Ten wątek pojawił się w każdym z wywiadów. Rozwijając tę myśl, respondenci doprecyzowali, że byli ciekawi m.in., jak będzie wyglądał warsztat; jakie są możliwości, aby coś udoskonalić w przestrzeni muzeum; dlaczego klasyczna instytucja, jaką jest muzeum, pyta swoich odbiorców, co chcieliby, aby $\mathrm{w}$ tym muzeum było albo jakby ono miało funkcjonować. $\mathrm{W}$ wywiadach wskazano 
również, że ważna dla respondentów była możliwość przedstawienia swoich pomysłów. Bez wątpienia osoby, które same mają w sobie dużą chęć aktywności, wykazują się kreatywnością i chciałyby podzielić się swoimi koncepcjami na ulepszenie funkcjonowania oferty, z której korzystają. Motywujące dla respondentów było także poczucie wpływu na zmiany, które zachodzą lub powinny zachodzić w muzeum. Oczekiwali, że ich propozycje znajdą odzwierciedlenie w działalności instytucji, i chcieli sprawić, aby oferta była bardziej atrakcyjna dla innych odbiorców. Co jednak ciekawe, nie uznawali, że muzeum powinno przyjmować pomysły swoich odbiorców w sposób bezkrytyczny i bezwarunkowy. Podkreślano konieczność ustalenia kryteriów i utrzymywania odpowiedniego poziomu artystycznego i funkcjonalnego: „Instytucja nie może przerzucić decyzyjności na taką grupę [konsumentów] i obarczyć ich odpowiedzialnością, mogą być oni głosem doradczym" (cytat z wywiadu). Więź z konkretną instytucją kultury okazała się jednym z ważnych czynników zachęcających respondentów do poświęcenia ich czasu i podzielenia się pomysłami na udoskonalenie oferty. Jedna $z$ badanych osób powiedziała: „Lubię to muzeum i jego przestrzenie. Pomyślałam, że byłoby fajnie mieć wpływ na to, co się dzieje w tych przestrzeniach”.

Podsumowując, jako kluczowe motywatory do zaangażowania konsumentów w działalność instytucji kultury można wskazać: ciekawość, możliwość przedstawienia swoich pomysłów, sprawczość, więź z instytucją. Co ciekawe, wszystkie wymienione czynniki motywujące mają charakter wewnętrzny i pochodzą od odbiorcy. W wywiadach wskazano, że ważne jest, aby instytucja była dobrze przygotowana do włączania odbiorców w swoją działalność, jednak nie powinna stosować zachęt typu odpłatność za udział w tego rodzaju pracach.

Tabela 1. Wybrane wypowiedzi respondentów

- „Dzisiaj bardziej bywam w instytucji kultury, odbieram ją w sposób bardziej jednostronny".

- „Mogłabym się zaangażować w działalność instytucji, która jest dla mnie ważna”.

- „Zaangażowałabym się, gdybym wiedziała, że może to coś zmienić w danej instytucji. Jeśli miałabym poczucie, że to nic nie da, to nie”.

- „Ważna jest pozytywna relacja emocjonalna z instytucją, abym chciała się zaangażować”.

- „Tworzenie rad w instytucjach kultury, ale takich z prawdziwego zdarzenia, a nie tylko "fasadowych», gdzie są tylko «bardzo ważne osoby», mogłoby być skuteczne dla włączenia odbiorców".

- „Wszystkie moje uwagi zostały zapisane, sfotografowane, odnotowane. Miałem odczucie, że ktoś mnie słucha i jest to dla niego ważne, co mam do przekazania".

Źródło: opracowanie własne.

Analiza odpowiedzi na pytania w zakresie roli, jaką respondenci obecnie odgrywają w działalności instytucji kultury w relacji do tego, jak swoją rolę w instytucji kultury chcieliby widzieć, pozwoliła na sformułowanie hipotezy, że rola konsumenta oferty kulturalnej będzie ulegała analogicznym przemianom, jak ma to miejsce w przypadku roli konsumenta na rynku komercyjnym. Można zatem sformułować wstępne wnioski, że mamy do czynienia z transformacją roli konsumenta 
w funkcjonowaniu instytucji kultury z postawy biernej do aktywnej. Dotychczasowa bierna postawa sprowadzała się do przyjmowania roli widza, odbiorcy, który kupuje bilet i otrzymuje przygotowany bez jego wpływu jednostronny komunikat. Brak było i wciąż jest zaangażowania zarówno inicjowanego przez odbiorcę, jak $\mathrm{i}$ instytucję kultury. Nowa, aktywna postawa przejawia się $\mathrm{w}$ chęci bycia uczestnikiem - współtwórcą danej oferty kulturalnej. Konsument oferty chce mieć na nią wpływ, chce, by była interaktywna i odpowiadała na jego potrzeby.

Wywiady dostarczyły również szeregu wniosków do sformułowania wstępnych wytycznych dla instytucji służących do stworzenia lepszych warunków do angażowania konsumentów $\mathrm{w}$ działalność instytucji kultury. W tabeli 2 przedstawiono najważniejsze spostrzeżenia respondentów w podziale na cztery grupy tematyczne.

Tabela 2. Uwarunkowania chęci konsumentów do angażowania w działalność instytucji kultury

\begin{tabular}{|c|c|}
\hline Relacje $\mathrm{z}$ instytucją & Wiarygodność instytucji \\
\hline $\begin{array}{l}\text { - dialog z odbiorcami, budowanie relacji } \\
\text { - budowanie grup wsparcia } \\
\text { - szczerość i zaufanie są ważnymi } \\
\text { czynnikami wpływającymi na } \\
\text { zaangażowanie konsumentów } \\
\text { - świadectwa tego, że udział } \\
\text { konsumentów ma realny wpływ na } \\
\text { funkcjonowanie tej instytucji } \\
\text { - docenienie osób zaangażowanych, } \\
\text { informowanie o tym, że pewne zmiany } \\
\text { są dzięki nim }\end{array}$ & $\begin{array}{l}\text { - realna chęć zaangażowania odbiorców } \\
\text { i wdrożenia zmian } \\
\text { - konsekwencja w działaniu instytucji } \\
\text { - konsultowanie przez instytucję różnych } \\
\text { zmian z odbiorcami } \\
\text { - widoczny efekt wprowadzanych zmian } \\
\text { - instytucje powinny dbać o to, żeby } \\
\text { szybko wprowadzać zmiany }\end{array}$ \\
\hline Dostęp do informacji & Forma badań i angażowania konsumentów \\
\hline $\begin{array}{l}\text { - informacja o badaniu powinna być } \\
\text { skierowana do szerokiego grona, aby } \\
\text { jak najwięcej osób mogło się o tym } \\
\text { dowiedzieć } \\
\text { - w przestrzeni muzealnej (realnej } \\
\text { i cyfrowej) powinny znaleźć się } \\
\text { informacje, że jakieś rozwiązanie } \\
\text { powstało dzięki zaangażowaniu } \\
\text { konsumentów } \\
\text { - poprawa dostępu do informacji } \\
\text { o szeroko rozumianej działalności } \\
\text { instytucji kultury (obecnie zdobycie } \\
\text { informacji wymaga sporo trudu) } \\
\text { - informowanie osób, które są na miejscu } \\
\text { w danej instytucji o możliwościach } \\
\text { zaangażowania (te osoby wykazały już } \\
\text { pewną aktywność i zainteresowanie) } \\
\text { - szybka reakcja na zapytania oraz } \\
\text { dzielenie się informacjami z odbiorcami }\end{array}$ & $\begin{array}{l}\text { - atrakcyjna forma przeprowadzenia badań } \\
\text { - dobrze przygotowane i przeprowadzone } \\
\text { badania } \\
\text { - instytucje nie powinny płacić za udział } \\
\text { w badaniach } \\
\text { - wszyscy pracownicy instytucji powinni } \\
\text { być poinformowani o badaniach, tak aby } \\
\text { ich uczestnicy nie czuli się „intruzami” } \\
\text { - przekazanie informacji, jak wiedza } \\
\text { płynąca z warsztatu zostanie } \\
\text { wykorzystana, jak i kiedy uwagi } \\
\text { uczestników zostaną wdrożone }\end{array}$ \\
\hline
\end{tabular}

Źródło: opracowanie własne. 
Na tej podstawie można określić warunki, które powinna zapewnić instytucja, aby konsumenci angażowali się w jej działalność. Istotne wydaje się, aby osoby biorące udział w badaniu poczuły się potrzebne, ważne i docenione. Osoby angażujące się nie powinny być oszukiwane ani czuć się oszukiwane. Konieczne jest zatem zapewnienie dostępu do informacji oraz jasne definiowanie zadań, celów i obszarów, na które mają wpływ, oraz wyjaśnienie, jak i kiedy ich wkład zostanie wykorzystany. Zaangażowanie konsumentów powinno odzwierciedlić się w działaniu instytucji kultury. Respondenci oczekują, że będą mogli zobaczyć konkretne zmiany wprowadzone dzięki ich wkładowi, chcą czuć się współtwórcami, a ich zaangażowanie powinno być docenione. Przy czym z badania wynika dość jasno, że ważniejsze jest tu docenienie o charakterze niematerialnym. Ponadto udział w dobrze przeprowadzonym warsztacie zachęca uczestników do kolejnych aktywności. A zatem im lepiej instytucje przygotują się na pierwsze angażujące relacje z konsumentami, tym większe mają szanse na budowanie trwałego zaangażowania swoich odbiorców.

\section{Zakończenie}

W badaniu wykazano, że z perspektywy konsumentów uwarunkowania dotyczące chęci ich zaangażowania w działalność instytucji kultury można sklasyfikować w czterech obszarach: relacje $z$ instytucją, wiarygodność instytucji, dostęp do informacji, forma badań i angażowania konsumentów. Badani respondenci byli motywowani do zaangażowania przede wszystkim wewnętrznie.

Kluczowym ograniczeniem prowadzonego badania jest jego wstępny charakter. Nie należy zatem uogólniać wniosków płynących z przedstawionych wywiadów; próba badawcza była mała i dość jednorodna. Trzeba mieć to na uwadze, analizując wyniki. Celem badania było jednak przeprowadzenie wstępnych analiz i sformułowanie wniosków do dalszych badań.

W kolejnych badaniach zarówno jakościowych, jak i ilościowych powinna być analizowana perspektywa konsumentów w zakresie ich zaangażowania się w działalność instytucji kultury zwłaszcza w zakresie dzielenia się wiedzą, informowania, współtworzenia, uczenia się i budowania społeczności.

W ramach prezentowanego badania wstępnego cel badawczy został zrealizowany. Zidentyfikowano sposoby zaangażowania konsumentów w działalność instytucji kultury; określono wstępnie ich motywację do takiego zaangażowania oraz warunki, które powinny być spełnione, aby konsumenci chętnie angażowali się $\mathrm{W}$ działalność instytucji kultury. Ponadto nakreślono perspektywy dalszych badań.

\section{Literatura}

Bal A.S., Weidner K., Hanna R., Mills A.J. (2017). Crowdsourcing and brand control. Business Horizons, 60(2): 219-228. 
Barron P., Leask A. (2017). Visitor engagement at museums: Generation Y and 'Lates' events at the National Museum of Scotland. Museum Management and Curatorship, 32(5): 473-490.

Brodie R.J., Ilic A., Juric B., Hollebeek L. (2013). Consumer engagement in a virtual brand community: An exploratory analysis. Journal of Business Research, 66(1): 105-114.

Ciurea C., Owsiński J.W. (2019). Consensus versus Crowdsourcing in Collaborative Decision-Making Applied in Cultural Institutions. Procedia Computer Science, 162: 547-554.

Coelho P.S., Rita P., Santos Z.R. (2018). On the relationship between consumer-brand identification, brand community, and brand loyalty. Journal of Retailing and Consumer Services, 43: 101-110.

de Almeida S.O., Scaraboto D., dos Santos Fleck J.P., Dalmoro M. (2018). Seriously Engaged Consumers: Navigating Between Work and Play in Online Brand Communities. Journal of Interactive Marketing, 44: 29-42.

Godovykh M., Tasci A.D.A. (2020). Customer experience in tourism: A review of definitions, components, and measurements. Tourism Management Perspectives, 35: 100694.

Gopalana R., Narayanb B. (2010). Improving customer experience in tourism: A framework for stakeholder collaboration. Socio-Economic Planning Sciences, 44(2): 100112.

Hall-Phillips A., Park J., Chung T.-L., Anaza N.A., Rathod S.R. (2016). I (heart) social ventures: Identification and social media engagement. Journal of Business Research, 69(2): 484-491.

Hanna R., Rohm A., Crittenden V.L. (2011). We're all connected: The power of the social media ecosystem. Business Horizons, 54(3): 265-273.

Hepola J., Leppäniemi M., Karjaluoto H. (2020). Is it all about consumer engagement? Explaining continuance intention for utilitarian and hedonic service consumption. Journal of Retailing and Consumer Services, 57: 102232.

Hsieh S.H., Chang A. (2016). The Psychological Mechanism of Brand Co-creation Engagement. Journal of Interactive Marketing, 33: 13-26.

Kim E., Drumwright M. (2016). Engaging consumers and building relationships in social media: How social relatedness influences intrinsic vs. extrinsic consumer motivation. Computers in Human Behavior, 63: 970-979.

Kotler N., Kotler P. (2000). Can museums be all things to all people? Missions, goals, and marketing's role. Museum Management and Curatorship, 18(3): 271-287.

Kujur F., Singh S. (2017). Engaging customers through online participation in social networking sites. Asia Pacific Management Review, 22(1): 16-24.

Lim Ch., Kim K.-J. (2018). Experience Design Board: A tool for visualizing and designing experience-centric service delivery processes. Journal of Retailing and Consumer Services, 45: 142-151.

Macalik J. (2014). Współczesny odbiorca masowy jako wyzwanie dla usług muzealnych. Prace Naukowe Uniwersytetu Ekonomicznego we Wrocławiu, 354: 51-60.

Martínez-López F.J., Anaya-Sánchez R., Molinillo S., Aguilar-Illescas R., Esteban-Millat I. (2017). Consumer engagement in an online brand community. Electronic Commerce Research and Applications, 23: 24-37.

Raïes K., Mühlbacher H., Gavard-Perret M.-L. (2015). Consumption community commitment: Newbies' and longstanding members' brand engagement and loyalty. Journal of Business Research, 68(12): 2634-2644.

Sarantou M., Kugapi O., Huhmarniemi M. (2021). Context mapping for creative tourism. Annals of Tourism Research, 86: 103064. 
Steffen A., Doppler S. (2020). Introduction to the experience economy. W: A. Steffen, S. Doppler (red.), Case Studies on Food Experiences in Marketing, Retail, and Events. Woodhead Publishing, s.1-12.

\section{Why do consumers engage in service design at museums? Introduction to research}

The experience economy and shaping a positive consumer experience are increasingly becoming an object of interest for museums. The paper presents the results of the qualitative research in the form of an in-depth structured interview with the participants of the workshop on museum space design. The key conditions for building consumer engagement were pointed out by the respondents. The analysis was also conducted on the motivation of consumers to become active in this area. The study was preliminary and allowed to draw conclusions and outline research perspectives for further study stages in the field of consumer engagement in cultural institutions.

Translated by Magdalena Kosiada-Sylburska 

Agata Smyka

Uniwersytet Ekonomiczny we Wrocławiu

180212@student.ue.wroc.pl

\section{Determinanty rozwoju turystyki w gminie miejsko-wiejskiej Wleń}

\section{Streszczenie}

Celem rozdziału jest identyfikacja i ocena kluczowych determinant rozwoju turystyki w gminie Wleń. Autorka wykorzystała głównie wyniki badań ankietowych, analizę danych statystycznych oraz metodę opisową. Analizy wykazały, że ocena wpływu wybranych czynników na rozwój turystyki jest zdaniem turystów zróżnicowana. Podobnie jak ocena walorów i elementów infrastruktury turystycznej oraz aktywności władz gminy Wleń.

\section{Wprowadzenie}

W literaturze przedmiotu występują różne klasyfikacje i hierarchie determinant oddziałujących na tempo i kierunek rozwoju turystyki (m.in. Gaworecki, 2003; Kożuchowski, 2005; Kurek, 2007). Analizy prowadzone na poziomie regionalnym wskazują dwie podstawowe grupy czynników (Kozak, 2008). Pierwsza z nich określa tzw. atrakcyjność turystyczną obszaru, na którą wpływa przede wszystkim infrastruktura turystyczna wraz z elementami warunkującymi dostępność atrakcji turystycznych oraz stan i charakter walorów regionalnych służących rozwojowi turystyki. Druga grupa związana jest natomiast ze sferą regulacji. Istotne miejsce w kształtowaniu gospodarki turystycznej zajmują w niej instytucje i tworzona przez nie polityka rozwoju danego obszaru.

Podjęta problematyka dotyczy aktualnych i ważnych zagadnień z punktu widzenia rozwoju terenów turystycznych, stąd stanowi przedmiot zainteresowania autora.

Celem pracy jest identyfikacja i ocena kluczowych determinant rozwoju turystyki w gminie wiejsko-miejskiej Wleń. Uzupełnieniem opracowania jest krótka 
prezentacja gminy. W rozdziale wykorzystano głównie wyniki badań ankietowych turystów, analizę danych statystycznych oraz metodę opisową.

Opracowanie zawiera wprowadzenie, opis wybranych determinant w oparciu o literaturę, prezentację metodyki badań i wyników badań ankietowych, krótką prezentację gminy Wleń wraz z oceną jej walorów i infrastruktury turystycznej oraz zakończenie.

\section{Wybrane determinanty rozwoju turystyki - ujęcie teoretyczne}

Jednym z najważniejszych, jeśli nie najważniejszym czynnikiem rozwoju turystyki, zwłaszcza obszarów wiejskich, są walory turystyczne ${ }^{1}$. Dzielone są one na walory przyrodnicze i antropogeniczne.

Elementy środowiska naturalnego wpływają na różnicowanie atrakcyjności turystycznej regionów, warunkują zagospodarowanie turystyczne i są podstawowym dobrem turystycznym, które im bardziej unikalne, tym bardziej przyciąga uwagę turystów. Tworzą one podstawę do kreowania odpowiednich produktów w regionie, pozwalają bowiem na właściwą alokację zasobów pozostających w dyspozycji podmiotów turystycznych. W literaturze przedmiotu są różnie definiowane ${ }^{2}$. Autorzy często wskazują na elementy środowiska przyrodniczego przyciągające zainteresowanie turysty, wymieniając mniej lub bardziej szczegółowo jego składowe. Przykładowo Kożuchowski zalicza do nich podłoże skalne, glebę, rzeźbę terenu, florę i faunę, wody powierzchniowe i podziemne, pogodę i klimat lokalny. Naturalne walory są powszechne, lecz różnią się intensywnością występowania w przestrzeni.

Walory antropogeniczne uzupełniają walory przyrodnicze, tworząc efekt synergii. Określane są jako ogół elementów, które wiążą się z działalnością człowieka. Nazywane są również walorami kulturowymi (Kurek, 2007). Zalicza się do nich niematerialne składniki kultury (tradycje historyczne), historyczne elementy materialne oraz elementy kultury współczesnej (Gołembski, 2007).

Udostępnianie walorów turystycznych umożliwia zagospodarowanie turystyczne. Obejmuje ono bazę: noclegową, żywieniową, komunikacyjną i towarzyszącą (tab. 1).

Zaprezentowany $\mathrm{w}$ tabeli 1 podział infrastruktury turystycznej jest $\mathrm{w}$ literaturze przedmiotu niejednoznaczny i może powodować nieścisłości w analizach porównawczych i ocenie poziomu zagospodarowania obszarów.

\footnotetext{
1 Walory turystyczne to wszystkie wartości występujące na obszarze, które stworzyła natura (przyroda), ukształtowała historia i tworzy współczesność, będące przedmiotem zainteresowania turystów (Mazur, 2003).

2 Zobacz m.in.: Gaworecki (2003), Kurek (2007), Wojcieszak (2016).
} 
Tabela 1. Podział i charakterystyka infrastruktury turystycznej

\begin{tabular}{|c|c|c|}
\hline $\begin{array}{c}\text { Infrastruktura } \\
\text { turystyczna }\end{array}$ & Definicja & Charakterystyka \\
\hline $\begin{array}{l}\text { Infrastruktura } \\
\text { podstawowa }\end{array}$ & $\begin{array}{l}\text { Niezbędna } \\
\text { do realizacji } \\
\text { funkcji } \\
\text { turystycznej }\end{array}$ & $\begin{array}{l}\text { Baza noclegowa to m.in.: hotele, motele, kempingi, } \\
\text { pola biwakowe, domy wycieczkowe, schroniska, domy } \\
\text { turysty, pensjonaty } \\
\text { Baza gastronomiczna dzielona jest na: } \\
\text { - zakłady gastronomiczne typu żywieniowego, tj. re- } \\
\text { stauracje, bary uniwersalne, mleczne, szybkiej obsłu- } \\
\text { gi, bistra, jadłodajnie itp. } \\
\text { - zakłady gastronomiczne uzupełniające, tj. kawiar- } \\
\text { nie, bary kawowe, herbaciarnie, winiarnie, cukiernie, } \\
\text { puby } \\
\text { - punkty gastronomiczne, tj. bufety, smażalnie, lo- } \\
\text { dziarnie, pijalnie itp. } \\
\text { Baza komunikacyjna - zalicza się tu m.in.: szlaki lotni- } \\
\text { cze, sieć dróg, linie kolejowe, porty lotnicze, morskie, } \\
\text { stacje kolejowe }\end{array}$ \\
\hline $\begin{array}{l}\text { Infrastruktura } \\
\text { towarzysząca }\end{array}$ & $\begin{array}{l}\text { Uzupełnienie } \\
\text { bazy } \\
\text { podstawowej }\end{array}$ & $\begin{array}{l}\text { Dzielona jest na: } \\
\text { - urządzenia turystyczne - m.in.: kąpieliska, kolejki } \\
\text { linowe, sale sportowe, korty tenisowe, szlaki żeglow- } \\
\text { ne, wyciągi narciarskie, szlaki turystyczne: konne, } \\
\text { piesze, ścieżki zdrowia } \\
\text { - urządzenia paraturystyczne - techniczne uzbrojenie } \\
\text { terenu (sieć elektryczna, wodna, gazowa, kanaliza- } \\
\text { cyjna), sieć handlu detalicznego, usługi (fryzjerskie, } \\
\text { fotograficzne), urządzenia pocztowe, ochrony zdro- } \\
\text { wia, instytucje kulturalne i bezpieczeństwa publicz- } \\
\text { nego }\end{array}$ \\
\hline
\end{tabular}

Źródło: opracowanie własne na podstawie Lijewski i in. (2002).

Do podstawowych podmiotów otoczenia instytucjonalnego, których zadaniem jest wspieranie turystyki, zaliczane są przede wszystkim organy państwa oraz różnego rodzaju instytucje i organizacje pozarządowe, w tym związki i zrzeszenia branżowe oraz stowarzyszenia.

Od działań podejmowanych na różnych szczeblach władzy państwowej uzależnione jest tempo i zakres rozwoju zarówno popytu, jak i podaży turystycznej. Wyrazem aktywności tych instytucji jest określenie celów ekonomicznych, politycznych, kulturalnych i społecznych rozwoju turystyki. Jednym z głównych działań administracji centralnej jest opracowywanie dokumentów wyznaczających priorytety i podstawowe kierunki rozwoju turystyki w kraju. Z kolei samorządy lokalne kształtują warunki dla rozwoju gospodarki turystycznej na własnym obszarze oraz tworzą płaszczyzny współdziałania podmiotów w regionie.

Do najważniejszych instytucji i organizacji wpływających na rozwój turystyki w Polsce należy zaliczyć m.in.: Dział Turystyki w Ministerstwie Rozwoju, Pracy i Technologii, Polską Organizację Turystyki (POT) i jej wojewódzkie oddziały, Polską Izbę Turystyki (PIT), samorządy wojewódzkie, powiatowe i gminne, 
Związek Gmin Wiejskich RP, lokalne i regionalne stowarzyszenia agroturystyczne i turystyki wiejskiej oraz Polską Federację Turystyki Wiejskiej „Gospodarstwa Gościnne".

\section{Metodyka badań}

Badania empiryczne przeprowadzono w 2021 r. na terenie gminy Wleń. Ich celem była identyfikacja wybranych czynników rozwoju turystyki oraz ocena ich realizacji na omawianym obszarze. Badaniami objęto dziewięć z dwunastu sołectw gminy, w tym miasto Wleń. Zastosowano kwestionariusz ankiety. Wykorzystano badania bezpośrednie, które przeprowadzili ankieterzy. Forma ta pozwoliła na większą kontrolę zbieranych danych. W kwestionariuszu wykorzystano pytania zamknięte. Próba badawcza miała charakter losowy. Łącznie w badaniach uczestniczyło 70 turystów, z czego do analizy przyjęto 53 kwestionariusze (tab. 2).

Tabela 2. Charakterystyka badanych turystów

\begin{tabular}{lc}
\hline Płeć & \% badanych \\
\hline kobieta & 53 \\
mężczyzna & 52 \\
\hline Wykształcenie & \\
\hline zawodowe & 10 \\
średnie & 54 \\
$\quad$ wyższe & 36 \\
\hline Miejsce zamieszkania & \\
\hline miasto & 65 \\
wieś & 35 \\
\hline
\end{tabular}

Źródło: opracowanie własne.

Wśród uczestników badań 53\% stanowiły kobiety, a 52\% mężczyźni. Najczęściej były to osoby z wykształceniem średnim (54\%) i wyższym (36\%) oraz mieszkańcy miast (65\%). Materiał empiryczny opracowano metodami statystycznymi, a wyniki przedstawiono w oparciu o procentowy rozkład liczebności.

\section{Prezentacja wyników badania}

W odniesieniu do rozwoju turystyki na obszarach wiejskich duże znaczenie turyści przypisują walorom przyrodniczym i antropogenicznym oraz szlakom turystycznym (tab. 3). Te pierwsze zdaniem prawie 95\% respondentów to czynnik o bardzo dużym lub dużym znaczeniu. Atrakcje turystyczne stworzone przez człowieka bardzo duży lub duży wpływ mają dla prawie $75 \%$ badanych, a szlaki turystyczne to dla prawie $93 \%$ respondentów czynnik o bardzo dużym lub dużym znaczeniu dla rozwoju turystyki. Zagospodarowanie turystyczne terenu, głównie w postaci obiektów sportowo-rekreacyjnych, bazy gastronomicznej i noclegowej, 
to czynniki o dużym lub bardzo dużym wpływie na rozwój turystyki w regionie analogicznie dla prawie $85 \%, 87 \%$ i $63 \%$ badanych.

Tabela 3. Ocena wpływu wybranych czynników na rozwój turystyki na obszarach wiejskich (w\%)

\begin{tabular}{|c|c|c|c|c|c|}
\hline \multirow[b]{2}{*}{ Rodzaj czynnika } & \multicolumn{5}{|c|}{ Wpływ czynnika na rozwój turystyki } \\
\hline & $\begin{array}{l}\text { bardzo } \\
\text { duży }\end{array}$ & duży & średni & niski & $\begin{array}{l}\text { bardzo } \\
\text { niski }\end{array}$ \\
\hline $\begin{array}{l}\text { Przyroda (np. lasy, parki krajobrazowe, woda, } \\
\text { góry) }\end{array}$ & 84,90 & 9,44 & 5,66 & - & - \\
\hline $\begin{array}{l}\text { Atrakcje turystyczne, np. zabytki, kościoły, } \\
\text { muzea }\end{array}$ & 56,60 & 18,87 & 18,88 & 5,65 & - \\
\hline Imprezy kulturalne, sportowo-rekreacyjne & 37,73 & 18,87 & 28,30 & 15,10 & - \\
\hline Baza noclegowa i jej zróżnicowanie & 33,96 & 28,30 & 37,74 & - & - \\
\hline Baza gastronomiczna i jej zróżnicowanie & 41,51 & 45,28 & 13,21 & - & - \\
\hline $\begin{array}{l}\text { Obiekty sportowo-rekreacyjne (np. baseny, } \\
\text { boiska, lodowiska) }\end{array}$ & 54,70 & 30,20 & 15,10 & - & - \\
\hline Dojazd do obszaru, drogi & 18,87 & 15,10 & 41,51 & 24,52 & - \\
\hline Szlaki turystyczne, np. piesze, konne, rowerowe & 60,40 & 32,10 & 7,50 & - & - \\
\hline Władze gminy & 22,64 & 33,96 & 13,21 & 24,53 & 5,66 \\
\hline $\begin{array}{l}\text { Stowarzyszenia lokalne, lokalne grupy } \\
\text { działania }\end{array}$ & 9,43 & 18,87 & 13,21 & 52,83 & 5,66 \\
\hline $\begin{array}{l}\text { Instytucje turystyczne, np. Polska Izba } \\
\text { Turystyki }\end{array}$ & 15,10 & 16,97 & 24,52 & 32,10 & 11,31 \\
\hline
\end{tabular}

Źródło: opracowanie własne.

Badania wykazały również, że zdaniem turystów najniższy wpływ na rozwój turystyki w regionie mają stowarzyszenia lokalne (prawie $60 \%$ oceniło go jako niski i bardzo niski), następnie instytucje turystyczne (43\% wskazań jako niski i bardzo niski) oraz władze gminy (niecałe $31 \%$ wskazań jako niski).

Uzupełnieniem oceny wpływu wybranych czynników na rozwój turystyki na obszarach wiejskich jest niewątpliwie deklaracja znaczenia dla turysty elementów wiejskiej przestrzeni recepcji turystycznej. Wskazuje ona na motywy ich wyborów wypoczynkowych.

Podczas analizy znaczenia dla turysty wybranych charakterystyk wiejskiego obszaru turystycznego istotnych dla przyjazdu do regionu na uwagę zasługują odpowiedzi wskazujące na elementy walorów przyrodniczych (piękno przyrody, cisza i spokój), walorów antropogenicznych (aktywny wypoczynek i aspekt poznawczy) oraz przypisanie wysokiego znaczenia wyżywieniu (tab. 4).

Porównując ocenę wpływu wybranych czynników na rozwój turystyki dokonaną przez turystów z motywami ich wyboru wiejskiej przestrzeni turystycznej, należy zauważyć korelację między wskazanymi determinantami. W obu przypadkach największe znaczenie mają walory przyrodnicze i antropogeniczne oraz zagospodarowanie turystyczne (w tym głównie baza gastronomiczna oraz infrastruktura służąca aktywnemu wypoczynkowi). 
Tabela 4. Znaczenie dla turysty charakterystyk wiejskiego obszaru turystycznego

\begin{tabular}{lccccc}
\hline \multirow{2}{*}{ Możliwości i elementy } & \multicolumn{5}{c}{ Znaczenie } \\
\cline { 2 - 6 } & $\begin{array}{c}\text { bardzo } \\
\text { duże }\end{array}$ & duże & średnie & niskie & $\begin{array}{c}\text { bardzo } \\
\text { niskie }\end{array}$ \\
\hline Cisza i spokój & 15,10 & 32,10 & 24,53 & 11,30 & 16,97 \\
Piękno przyrody & 50,95 & 26,41 & 22,64 & - & - \\
Wyżywienie & 43,40 & 33,96 & 16,97 & 5,67 & - \\
Możliwość aktywnego wypoczynku & 32,10 & 24,53 & 9,42 & 26,41 & 7,54 \\
Wydarzenia kulturalne, sportowe, & 16,97 & 26,41 & 15,10 & 32,10 & 9,42 \\
turystyczne & & & & & \\
$\begin{array}{l}\text { Możliwość interesującego spędzenia czasu } \\
\text { wolnego }\end{array}$ & 58,50 & 26,41 & 13,30 & 1,88 & - \\
$\begin{array}{l}\text { Możliwość poznania m.in. kultury, } \\
\text { zwyczajów }\end{array}$ & 50,94 & 28,30 & 20,76 & - & - \\
\hline
\end{tabular}

Źródło: opracowanie własne.

\section{Walory i infrastruktura turystyczna oraz instytucje wspierające rozwój turystyki w gminie Wleń}

Wleń jest gminą miejsko-wiejską, położoną w południowo-zachodniej części województwa dolnośląskiego w powiecie lwóweckim, na pograniczu Pogórza Izerskiego i Kaczawskiego. W skład gminy wchodzi 1 miasto (Wleń) i 12 sołectw. Gmina zajmuje powierzchnię $86 \mathrm{~km}^{2}$, z czego $94,26 \%$ to grunty rolne i leśne. Gmina charakteryzuje się zróżnicowanym ukształtowaniem powierzchni i w $70 \%$ leży w granicach Parku Krajobrazowego Doliny Bobru, a na jej obszarze znajdują się dwa rezerwaty przyrody (Na Ostrzycy Proboszczowickiej i Góra Zamkowa położony nad miastem Wleń). Oba wchodzą w skład obszarów Natura 2000, pod nazwą Ostrzyca Proboszczowicka oraz Ostoja nad Bobrem (Wleń, 2009; UMiG Wleń 2021).

Wśród atrakcji gminy na szczególną uwagę zasługuje (Wleń, 2009; Wiklik, 2011; UMiG Wleń, 2021):

- Wleński Gródek - to ruiny średniowiecznej warowni, zespół pałacowo-parkowy, kościół pw. św. Jadwigi oraz rezerwat przyrody „Góra Zamkowa”.

- Jezioro Pilchowickie - największy akwen w Sudetach Zachodnich (powierzchnia 240 ha, głębokość przy zaporze ok. 46 m, a długość jeziora 6 km).

- Kolej Doliny Bobru - najpiękniejszy, najbardziej malowniczy odcinek kolei w Polsce. Obecnie nieczynna.

- Pomnik Gołębiarki - zlokalizowany na rynku miasta, a wzniesiony z okazji 700-lecia jego założenia w 1914 r. Główną część pomnika stanowi figura dziewczyny z gołębiem na prawym ramieniu.

Ścieżka św. Jadwigi Śląskiej - trasa około 2 km, którą można pokonać pieszo.

W gminie odbywa się szereg imprez (wg danych GUS w 2018 r. było ich 42, a w 2019 - 29) (GUS, 2021). Niestety jedynie Dni Wlenia mają zasięg krajowy, a nawet międzynarodowy. Większość imprez nie jest też dostępna dla turysty. 
Na terenie gminy Wleń funkcjonują według danych GUS 3 obiekty noclegowe (tab. 5). Dysponują one łącznie 100 miejscami noclegowymi. Nie odzwierciedla to ilości bazy noclegowej w gminie, gdyż działa na jej terenie szereg gospodarstw agroturystycznych i innych obiektów noclegowych. Na stronie gminy podanych jest ich 9, jednak jest ich przynajmniej 16.

Tabela 5. Turystyczne obiekty noclegowe ogółem w gminie Wleń (stan w dniu 31 lipca)

\begin{tabular}{lrrrrrr}
\hline Wyszczególnienie & 2015 & 2016 & 2017 & 2018 & 2019 & 2020 \\
\hline Obiekty & 4 & 4 & 3 & 3 & 3 & 3 \\
Miejsca noclegowe, w tym: & 121 & 122 & 100 & 100 & 100 & 100 \\
Szkolne schroniska młodzieżowe & 41 & 42 & 41 & 41 & 41 & 41 \\
Pokoje gościnne/kwatery prywatne & 0 & 0 & 10 & 10 & 10 & 10 \\
Pozostałe turystyczne obiekty noclegowe & 49 & 49 & 49 & 49 & 49 & 49 \\
\hline
\end{tabular}

Źródło: opracowanie własne na podstawie GUS (2021).

Do gastronomii na stronie gminy zaliczona została jedynie Gołębiarka Cafe kawiarnia, która mieści się na wleńskim rynku. Na terenie gminy działa jeszcze bar przy zaporze w Pilchowicach.

Przez terytorium gminy przebiega pięć szlaków turystycznych: szlak Via Cervimontana - prowadzi na koniec świata, niebieski Europejski Szlak Długodystansowy [E-3], czarny szlak prowadzący z Marczowa do Płoszczycy, zielony Szlak Zamków Piastowskich, żółty szlak (Szlak Wygasłych Wulkanów) biegnący z Nowego Lądu do Świerzawy oraz Euroregionalny Turystyczny Szlak Rowerowy „Dolina Bobru” [ER-6].

Do elementów infrastruktury paraturystycznej gminy należy: Ośrodek Kultury, Sportu i Turystyki, Miejsko-Gminny Ośrodek Pomocy Społecznej, Urząd Pocztowy, Ośrodek Zdrowia, apteka, 4 sklepy spożywcze/przemysłowe, w tym jeden supermarket. W gminie jest również jedno targowisko o powierzchni sprzedażowej $90 \mathrm{~m}^{2}, 5$ boisk, 8 siłowni zewnętrznych i innych obiektów oraz 3 biblioteki.

W gminie w rozwój turystyki zaangażowane są przede wszystkim władze gminy oraz Partnerstwo Izerskie Stowarzyszenie LGD. Z innych organizacji można wymienić Stowarzyszenie „Modrzewie”, które zajmuje się głównie rozwojem wsi agroturystycznej Modrzewie.

Władze gminy Wleń w szerokim zakresie w porównaniu z możliwościami starają się aktywnie rozwijać turystykę w gminie. W 2007 r. przeprowadzono modernizację dwóch tras turystycznych (Radomice-Klecza i Pilchowice-Zapora-Strzyżowiec). W latach 2000-2011 wyremontowano i zagospodarowano Zamek Lenno (wpisany do rejestru zabytków). Władze gminy sukcesywnie wzbogacają ofertę turystyczną, głównie w zakresie imprez turystycznych. Prowadzone są również w sposób ciągły działania promujące gminę.

Władze lokalne wykorzystują zróżnicowane działania mające na celu aktywizację turystyki w gminie, w tym m.in. intensywnie pozyskują środki finansowe na realizację zaplanowanych działań oraz wykorzystują instrumenty organizacyjne, współpracując z innymi podmiotami z regionu, w tym z Euroregionem Nysa oraz Partnerstwem Izerskie Stowarzyszenie LGD. To ostatnie aktywnie przyczynia 
się do rozwoju turystyki na podlegającym mu obszarze, w tym na terenie gminy Wleń. Działania LGD koncentrują się na wzbogacaniu i poprawie infrastruktury turystycznej i paraturystycznej regionu (np. wytyczenie i oznakowanie ok. 100 km szlaków konnych), oferty turystycznej, odnowie zabytków architektury (rewitalizacja obiektów i miejsc należących do dziedzictwa przyrodniczego w latach 2016-2018), podnoszeniu wiedzy i umiejętności mieszkańców Pogórza oraz promocji obszaru i jego walorów turystycznych i podmiotów prowadzących działalność w sferze turystyki (np. wydanie katalogu ofert weekendowych wypoczynku na Pogórzu Izerskim).

Badania pozwoliły na ocenę omówionych wyżej czynników rozwoju turystyki w prezentowanej gminie. Ocenie poddano szereg elementów obszaru, w tym głównie walory i infrastrukturę turystyczną, oraz elementy będące wynikiem działań władz gminnych i innych organizacji (tj. dbałość o zabytki oraz czystość i porządek).

Analizując wypowiedzi respondentów, należy zauważyć, że w gminie najlepiej oceniona została „przyroda” (prawie 93\% ocen dobrych lub bardzo dobrych), następnie wyżywienie w obiektach noclegowych (prawie $88 \%$ wskazań na ocenę dobrą lub bardzo dobra) oraz możliwości uprawiania turystyki aktywnej (prawie $70 \%$ ocen dobrych lub bardzo dobrych).

Tabela 6. Ocena istniejących w gminie Wleń warunków do świadczenia usług turystycznych (w \%)

\begin{tabular}{|c|c|c|c|c|c|}
\hline \multirow[b]{2}{*}{ Elementy oceny } & \multicolumn{5}{|c|}{ Ocena } \\
\hline & $\begin{array}{c}\text { bardzo } \\
\text { dobra }\end{array}$ & dobra & średnia & niska & $\begin{array}{c}\text { bardzo } \\
\text { niska }\end{array}$ \\
\hline Zakwaterowanie & - & 41,5 & 35,83 & 22,67 & - \\
\hline Wyżywienie ogólnodostępne & - & - & - & 52,84 & 47,16 \\
\hline Wyżywienie w obiektach noclegowych & 49,10 & 39,60 & 11,30 & - & - \\
\hline $\begin{array}{l}\text { Możliwości uprawiania turystyki aktywnej, } \\
\text { np. szlaki piesze, rowerowe, konne, wodne }\end{array}$ & 35,83 & 33,96 & 22,67 & 7,54 & - \\
\hline Infrastruktura do wypoczynku nad wodą & - & 5,67 & 20,74 & 30,19 & 43,40 \\
\hline $\begin{array}{l}\text { Obiekty sportowo-rekreacyjne (np. baseny, } \\
\text { boiska) }\end{array}$ & - & - & 28,30 & 37,74 & 33,96 \\
\hline Przyroda, ukształtowanie terenu, lasy itp. & 67,93 & 24,53 & 7,54 & - & - \\
\hline Atrakcje do zwiedzania, np. zamki & 20,74 & 18,87 & 28,32 & 24,53 & 7,54 \\
\hline Imprezy kulturalne, sportowo-rekreacyjne & & 7,54 & 33,97 & 37,75 & 20,74 \\
\hline $\begin{array}{l}\text { Infrastruktura drogowa (drogi, dostępność } \\
\text { atrakcji, parkingi) }\end{array}$ & - & 26,41 & 33,96 & 20,74 & 18,87 \\
\hline Dbałość o zabytki (oznakowanie, renowacja) & - & 32,07 & 52,84 & 15,09 & - \\
\hline Czystość i porządek & - & 41,52 & 41,52 & 7,54 & 9,42 \\
\hline
\end{tabular}

Źródło: opracowanie własne.

Działania władz gminnych i innych podmiotów zostały ocenione generalnie na poziomie średnim i dobrym. 
Najniżej turyści ocenili zagospodarowanie turystyczne w zakresie bazy gastronomicznej ogólnodostępnej (100\% ocen niskich lub bardzo niskich), infrastruktury umożliwiającej wypoczynek nad wodą (prawie $74 \%$ ocen niskich), zagospodarowania w obiekty sportowo-rekreacyjne (prawie $72 \%$ ocen niskich) oraz infrastruktury drogowej (prawie $40 \%$ ocen niskich). Nisko oceniono również imprezy kulturalne i sportowo-rekreacyjne.

W gminie, zdaniem turystów, należy przede wszystkim poprawić i/lub rozwinąć określone elementy zagospodarowania turystycznego (prawie 55\% wskazań). Jeżeli wszystkie udzielone odpowiedzi w tej grupie uznane zostaną za $100 \%$, to nakładów wymaga głównie rozwój: bazy kulturalnej, sportowej i rekreacyjnej (ponad 65\%), bazy gastronomicznej (prawie 59\%) oraz dostępności komunikacyjnej, w tym głównie poprawa stanu dróg i tworzenie parkingów przy atrakcjach (niecałe 42\%).

Można zauważyć, że powinna również wzrosnąć liczba obiektów sportowo-rekreacyjnych (prawie 36\% badanych) oraz zostać rozbudowana infrastruktura zwiększająca dostępność wypoczynku nad wodą (prawie co trzeci badany wskazuje na jej rozwój). W odniesieniu do tej ostatniej należy zauważyć, że gmina ma zasoby wodne, które można w większym stopniu udostępnić turystom. Obecnie są one wykorzystywane w niewielkim zakresie - zbiornik wodny w Pilchowicach jest niezbyt zagospodarowany, podobnie jak rzeka Bóbr płynąca przez teren gminy.

\section{Zakończenie}

Zestawienie oceny wpływu wybranych czynników na rozwój turystyki na obszarach wiejskich, ich znaczenia dla turysty z oceną istniejących $\mathrm{w}$ gminie Wleń warunków do świadczenia usług turystycznych pozwala na sformułowanie m.in. następujących wniosków:

1. Podstawowe czynniki rozwoju turystyki na obszarach wiejskich to zdaniem turystów przede wszystkim: walory turystyczne (przyrodnicze i antropogeniczne) oraz wybrane elementy zagospodarowania turystycznego, w tym głównie: szlaki turystyczne, obiekty sportowo-rekreacyjne, baza gastronomiczna i w mniejszym stopniu noclegowa.

2. Istotne znaczenie dla przyjazdu turysty do regionu mają: elementy walorów przyrodniczych (piękno przyrody, cisza i spokój) i antropogenicznych (aspekt poznawczy) oraz baza gastronomiczna.

3. W gminie Wleń najlepiej oceniona została „przyroda”, następnie wyżywienie w obiektach noclegowych oraz możliwości uprawiania turystyki aktywnej. Najniżej turyści ocenili zagospodarowanie turystyczne w zakresie bazy gastronomicznej ogólnodostępnej, infrastruktury umożliwiającej wypoczynek nad wodą, infrastruktury drogowej oraz obiektów sportowo-rekreacyjnych.

4. Walory turystyczne (zwłaszcza przyrodnicze) mają duże znaczenie dla rozwoju turystyki, przyjazdu do obszaru oraz zostały wysoko ocenione w gminie. Podobnie wygląda ocena elementów zagospodarowania turystycznego, jakim 
są szlaki turystyczne. Z kolei duże znaczenie ma infrastruktura gastronomiczna oraz obiekty sportowo-rekreacyjne, które otrzymały niskie noty w gminie.

5. Zdaniem respondentów stosunkowo niewielki wpływ na rozwój turystyki w regionie mają działania stowarzyszeń lokalnych, instytucji turystycznych oraz władze gminy. Działania wspomnianych instytucji zostały na terenie gminy Wleń ocenione przez turystów na poziomie średnim i dobrym.

6. Podejmowane przez lokalne władze oraz inne organizacje funkcjonujące na terenie gminy działania w zakresie turystyki dotyczą różnych aspektów wpływających na rozwój turystyki, w tym m.in.: zagospodarowania i ochrony walorów przyrodniczych i antropogenicznych, aktywizacji podmiotów gospodarki turystycznej, promocji własnego regionu oraz wzbogacania jego oferty turystycznej. Stosunkowo niska ocena tego czynnika rozwoju turystyki w gminie może wynikać przykładowo z nieznajomości działań prowadzonych przez te instytucje.

Dogłębna analiza porównawcza oczekiwań turystów w zakresie realizacji czynników rozwoju na obszarach wiejskich z pewnością pozwoliłaby na lepsze ich wykorzystanie i dopasowanie do potrzeb odwiedzających, a tym samym wzrost atrakcyjności turystycznej wskazanych regionów.

\section{Literatura}

Gaworecki W. (2003). Turystyka. PWE, Warszawa.

Gołembsk, G. (2006). Kompendium wiedzy o turystyce. PWN, Warszawa.

GUS (2021). Główny Urząd Statystyczny (www.bdl.stat.gov.pl; dostęp: 5.01.2021).

Kozak M.W. (2008). Koncepcje rozwoju turystyki. Studia Regionalne i Lokalne, 1(31): 18 (www.studreg.uw.edu.pl).

Kożuchowski K. (2005). Walory przyrodnicze w turystyce i rekreacji. Wyd. Kurpisz, Poznań.

Kurek W. (2007). Turystyka. PWN, Warszawa.

LGD (2021). Partnerstwo Izerskie. Stowarzyszenie LGD (www.lgdpartnerstwoizerskie.pl; dostęp: 6.01.2021).

Lijewski T., Mikułowski B., Wyrzykowski J. (2002). Geografia turystyki Polski. PWE, Warszawa.

UMiG Wleń (2021). Urząd Miasta i Gminy Wleń (www.wlen.pl; dostęp: 5.01.2021).

Urząd Miasta i Gminy Wleń (2009). Wleń. Już nie zginiesz w naszej gminie. Przewodnik po gminie Wleń. IMAGO.

Wiklik C. Izerskie klimaty. AD REM, Jelenia Góra.

Wojcieszak M. (2016). Zróżnicowanie walorów przyrodniczych na wybranych obszarach metropolitalnych Polski. Cz. 1. Uniwersytet Przyrodniczy w Poznaniu, Poznań.

Zamek Wleń (2021). Zamek Wleń (Lenno) (zameklenno.pl; dostęp: 5.01.2021). 


\section{Determinants of tourism development in the urban-rural community of Wleń}

The aim of the article is to identify and evaluate the essential determinants of tourism development in Wlen. The article uses mainly survey results, statistical data analysis, a descriptive method and document analysis. The conducted analyses showed that according to tourists the valuation of selected factors on tourism development is varied. Similarly, the evaluation of the values and elements of tourist infrastructure and the activity of the authorities of Wleń community.

Translated by Agata Smyka 

Alicja Chrabańska-Czerwińska

Uniwersytet Ekonomiczny w Krakowie

alicja.chrabanska@gmail.com

\section{Wpływ „odmrożenia” gospodarki po blokadzie z powodu COVID-19 na natężenie ruchu turystycznego w Tatrzańskim Parku Narodowym}

\section{Streszczenie}

W wyniku ogłoszenia światowej pandemii COVID-19 w marcu 2020 r. w Polsce ustanowiono tzw. lockdown. Poza uniemożliwieniem bądź ograniczeniem działalności wielu gałęzi gospodarki, zamknięto również czasowo ruch turystyczny oraz rekreacyjny w parkach i lasach. Wiązało się to $z$ brakiem możliwości legalnego wejścia na teren Tatrzańskiego Parku Narodowego. Celem niniejszego rozdziału jest zbadanie, jak czasowe wyłączenie możliwości uprawiania turystyki w Tatrach wpłynęło na natężenie ruchu turystycznego w okresie „odmrażania gospodarki” i późniejszym w oparciu o analizy liczby sprzedanych biletów, ale również zapisków kroniki interwencji TOPR w okresie od maja do września 2019 r. oraz w analogicznym okresie 2020 r.

\section{Wprowadzenie}

W 2020 r. kluczowym zagadnieniem poruszającym całe społeczeństwa był rozwój pandemii COVID-19. W Polsce od 20 marca 2020 r. wprowadzony został stan epidemii, z którym wiązały się liczne obostrzenia, a w konsekwencji ich narastania zamknięcie gospodarki (GOV, 2020). Jeden z istotnych zakazów dotyczył zamknięcia parków i lasów. Skutkiem tego 13 marca 2020 r. zamknięty został także Tatrzański Park Narodowy. 4 maja 2020 r. TPN ogłosił ponowne otwarcie parku (TPN, 2021). Ponieważ lockdown był wyjątkową sytuacją w dziejach III RP,

Cytowanie: Chrabańska-Czerwińska A. (2021). Wpływ „odmrożenia” gospodarki po blokadzie z powodu COVID-19 na natężenie ruchu turystycznego w Tatrzańskim Parku Narodowym. W: K. Borodako (red.), Turystyka w okresie pandemii. Bogucki Wydawnictwo Naukowe, Poznań-Kraków, s. 241-249. https://doi. org/10.12657/9788379863501-23 
niełatwo było opracować prognozy, jak wpłynie on na poszczególne gałęzie gospodarki. Również niewiadomą było, jak zareaguje turystyka górska ani czy turyści po okresie zamknięcia szlaków tłumnie wznowią ruch turystyczny, kompensując jego brak w okresie od połowy marca do początku maja czy też ciągle obecny stan światowej pandemii, ryzyko zakażeń i strach spowodują zmniejszenie ruchu turystycznego $\mathrm{W}$ stosunku do analogicznego okresu w roku ubiegłym. W niniejszym rozdziale podjęto tematykę wpływu „odmrożenia” gospodarki polskiej po okresie zamknięcia na liczbę turystów w TPN. Podstawowym miernikiem natężenia ruchu turystycznego była liczba sprzedanych biletów wstępu. Analizie poddano także interwencje TOPR w analogicznych okresach 2019 i 2020 r. W związku z ograniczonymi możliwościami podróżowania oraz długim okresem, w którym większość aktywności została ograniczona, uznano za prawdopodobne, że turystykę górską wybrała większa liczba osób o niższych kwalifikacjach.

\section{Turystyka górska - formy}

Punktem wyjścia do rozważań na temat turystyki górskiej musi być stwierdzenie, że wiąże się ona $z$ intencjonalną aktywnością fizyczną, zarówno pod kątem sportowym, jak i hobbystycznym (Merski, Warecka, 2009).

W skład szeroko pojmowanej turystyki aktywnej wchodzi turystyka kwalifikowana, która zgodnie z nazwą wymaga szczególnych kwalifikacji - od kwestii dotyczących formy fizycznej turysty po specjalne uprawnienia, licencje czy też specjalistyczny sprzęt (Kurek i in., 2007). Mokras-Grabowska (2015) wskazuje, że turystyka kwalifikowana $\mathrm{w}$ tym rozumieniu dotyczy nielicznej grupy turystów, którzy do turystyki mają podejście bardzo ambicjonalne i dążą do wysokich i wybitnie wysokich kwalifikacji w tej dziedzinie. Podkreśla nieodzowne cechy turystyki kwalifikowanej, takie jak specyficzne czynniki motywujące turystę (wyczyn turystyczny, zdobywanie szczytów, odznak), kompetencje twarde, np. umiejętności wspinaczkowe, przygotowanie psychofizyczne oraz proaktywna postawa w organizacji.

Można zauważyć, że pojęcie turystyki kwalifikowanej zazębia się z istnieniem obszaru, który nazwać można turystyką sportową. Najprościej ujmując, jest to turystyka kwalifikowana, szczególnie nastawiona na ruch, ekspozycję na ryzyko, osiąganie celów sportowych, której elementem jest kontemplacja przyrody (Ghețe, 2016). Turystykę sportową od uprawiania sportu sensu stricte odróżnia brak rywalizacji między sportowcami, jak również konieczność przemieszczenia poza miejsce stałego zamieszkania (Tomik, 2013).

W kontekście turystyki, szczególnie turystyki sportowej, możemy mówić także o turystyce ekstremalnej. Niewątpliwie wiąże się ona z wyczynami sportowymi, jednak kładzie nacisk na zaistnienie elementu ryzyka. Dotyczyć może uprawiania sportów niszowych, w przypadku Tatr może to być wspinaczka na drogach nieubezpieczonych czy też wspinaczka zimowa po lodospadach. Grono turystów, którzy podejmują taki rodzaj aktywności, jest bardzo zawężone (Malchrowicz-Mośko, Sekida, 2016). Warto jeszcze przywołać pojęcie eko-turystyki jako formy 
nastawionej na przyrodę, naturę, jej ochronę, która zdecydowanie może odnosić się do ruchu turystycznego w Tatrach. W ujęciu szerszym również zaangażowanie w ochronę dorobku kulturowego, odpowiedzialny marketing i zaangażowanie lokalnych społeczności w działania (Sambotin i in., 2011).

\section{Tatrzański Park Narodowy - atrakcje i natężenie ruchu turystycznego w poszczególnych punktach}

Tatrzański Park Narodowy w obecnej formie istnieje od 1 stycznia 1955 r. Od tego czasu powierzchnia łączna parku ulegała zmianom, by ostatecznie w $2018 \mathrm{r}$. osiągnąć 21 197,11 ha. TPN oferuje liczne atrakcje dla zwiedzających w postaci $275 \mathrm{~km}$ ścieżek pieszych i tras narciarskich, 6 ścieżek rowerowych i tyluż jaskiń. Zauważyć można, że z roku na rok rośnie liczba turystów w Tatrach, konkretne jednak wartości liczbowe podano w dalszej części pracy (Szlubowska, 2020). Wejście na teren parku wymaga wniesienia opłaty, określonej w zarządzeniu dyrektora TPN. Istotną informacją w kontekście sprzedaży biletów jest fakt, że $15 \%$ wpływów z opłat przekazywane jest na rzecz działalności ratowniczej TOPR (TPN, 2021). Administracją parku zarządza dyrektor, którym od 1 kwietnia 2014 r. jest Szymon Ziobrowski (BIP, 2016). Bogata oferta Tatrzańskiego Parku Narodowego pozwala na uprawianie turystyki w wielu aspektach. Drogi wspinaczkowe oraz dostępność obszarów górskich dla skiiturowców pozwalają na rozwój turystyki z jednej strony ekstremalnej, a z drugiej sportowej (w zależności od założonych celów). Wyjścia w partie górskie, powyżej schronisk, wymagają dobrej sprawności fizycznej, wpisując się w ideę turystyki kwalifikowanej. Duża dostępność dolin i ścieżek o niskim stopniu trudności pozwala na uprawianie w TPN szeroko pojętej turystyki aktywnej. Działalność noclegowa schronisk może z powodzeniem zostać zakwalifikowana do ekoturystyki.

Do głównych atrakcji Tatrzańskiego Parku Narodowego zdecydowanie należą szlaki piesze. Według statystyk przytaczanych przez Skowrońskiego (2010) około jednej czwartej wszystkich turystów udaje się w kierunku Morskiego Oka. Na drugim miejscu znalazły się szlaki prowadzące z Kuźnic w wyższe partie Tatr (np. Hala Gąsienicowa), następnie była to Dolina Kościeliska oraz kolej linowa na Kasprowy Wierch.

Hibner (2012) w swoich badaniach dotyczących zróżnicowania ruchu turystycznego w Tatrach jako obiekty badań wybrał takie atrakcje, jak Orla Perć, Kasprowy Wierch i Dolina Strążyska. Orla Perć, uznawana za najtrudniejszy szlak w Polsce, ma 3,9 km. Kasprowy Wierch, znajdujący się w Tatrach Zachodnich, swoją ogromną popularność zawdzięcza wybudowanej w 1936 r. kolejce. Dolina Strążyska jest atrakcją Tatr Reglowych, jest stosunkowo łatwo dostępna z centrum Zakopanego, a jej powodzenie wynika z tego, że prowadzi przez nią szlak na Giewont. 


\section{Ratownictwo górskie - Tatrzańskie Ochotnicze Pogotowie Ratunkowe jako organizacja udzielająca pomocy turystom w Tatrach}

Już samo pojęcie turystyki aktywnej górskiej wiąże się z pewnymi elementami zwiększonego ryzyka wypadków bądź drobniejszych urazów. Trudne ukształtowanie terenu, zmienne warunki, jak również brak dostępności tych miejsc dla standardowych służb ratunkowych sprawiają, że turyści, którzy ulegają wypadkom, których dotykają kontuzje lub którzy tracą rozeznanie w terenie, potrzebują pomocy wyspecjalizowanych ratowników. Ze względu na kraj/region położenia danego pasma górskiego, natężenie ruchu turystycznego i charakterystykę pasm górskich kwestie dotyczące ratownictwa górskiego kształtują się w różny sposób. W polskich Tatrach pomoc niosą ratownicy TOPR. Odpowiedzialna i niezwykle ważna jest rola, jaką górskie służby ratunkowe pełnią w rozwoju turystyki. Można założyć, że dzięki nim turyści czują się bezpieczni, skutkiem czego chętniej wyruszają w różne partie Tatr.

Pomoc poszkodowanym w Tatrach po stronie polskiej niosą ratownicy górscy, członkowie Straży Ratunkowej, która stanowi jedną z dwóch jednostek organizacyjnych Tatrzańskiego Ochotniczego Pogotowia Ratunkowego. Drugą jednostką organizacyjną TOPR jest Zarząd i Walne Zgromadzenie Członków. Poza ratowaniem zdrowia i życia turystów na terenach tatrzańskich w zakres celów realizowanych przez TOPR wchodzi działalność edukacyjna, ochrona środowiska, wzmożenie bezpieczeństwa na szlakach turystycznych w Tatrach, ale też szeroko pojęte propagowanie aktywności fizycznej (Statut Tatrzańskiego Ochotniczego Pogotowia Ratunkowego z dnia 28 października 2017 r.). Pod kątem formy prawnej TOPR jest stowarzyszeniem, wpisanym do rejestru organizacji non profit (TOPR, 2021).

W kontekście akcji ratunkowych i innych interwencji TOPR w terenie warto przyjrzeć się Straży Ratunkowej jako suborganizacji wewnątrz struktury TOPR. Już w postanowieniach ogólnych Regulaminu Straży Ratunkowej Tatrzańskiego Ochotniczego Pogotowia Ratunkowego z dnia 21 lutego 2019 r. wskazane są cele organizacji: organizowanie, kierowanie, koordynacja i prowadzenie akcji ratowniczych, ponadto opracowywanie komunikatów lawinowych oraz prowadzenie szkoleń dla ratowników górskich. Aby zapewnić wysoką jakość świadczonych usług, wstąpienie w szeregi Straży Ratunkowej jest obwarowane licznymi wymaganiami. Ważne jest, że jednym z regulaminowych obowiązków ratownika jest ciągłe utrzymywanie wysokiej sprawności fizycznej oraz rozwój kwalifikacji w dziedzinie ratownictwa i działalności górskiej. W regulaminie zapisane są szczegółowo wymagane szkolenia, ale również kwestie dotyczące podnoszenia kwalifikacji w postaci systemu szkolenia ratowników górskich.

Najważniejsze jednak w kontekście niniejszej pracy jest przedstawienie, zgodnie z Regulaminem Straży..., rodzaju działań ratunkowych w Tatrach:

- interwencja - forma krótkotrwała, zakładająca pomoc przedmedyczną bez konieczności transportowania poszkodowanego, 
- akcja ratunkowa - każde działanie, które w konsekwencji wymaga transportu poszkodowanego i przekazania jednostkom PRM,

- fałszywe (zbędne) alarmy - zgłoszenie, które skutkowało podjęciem działania ratunkowego na zorganizowanym obszarze narciarskim, a które okazało się zbędne lub fałszywe.

\section{Analiza porównawcza danych ilościowych dotyczących interwencji TOPR oraz sprzedaży biletów do TPN w okresie od maja do września 2019 i 2020 r.}

Analiza natężenia i struktury ruchu turystycznego jest niezwykle istotna z punktu widzenia decyzji związanych z ochroną przyrody, infrastrukturą turystyczną oraz szeroko pojętego zarządzania turystyką. Badania takie powinny prowadzić do określenia dopuszczalnego obciążenia szlaków i ewentualnego ograniczenia ilości możliwych wejść na teren parku narodowego. W Tatrzańskim Parku Narodowym kluczową formą pomiaru natężenia ruchu turystycznego jest monitorowanie liczby sprzedanych biletów. Periodycznie jednak, w zależności od potrzeb informacyjnych, dodatkowo prowadzone są obserwacje bezpośrednie, polegające na zliczaniu turystów na szlakach w określonych punktach (Buchwał, Fidelus, 2010). Statystyki sprzedanych biletów w poszczególnych punktach prowadzi TPN, udostępniając je na swoim portalu internetowym. Celem rozdziału jest określenie, jak „odmrożenie” gospodarki po okresie zamknięcia wpłynęło na liczbę turystów na szlakach Tatrzańskiego Parku Narodowego. Dokonana została analiza ilościowa sprzedanych biletów, a na jej tle liczby działań ratowniczych TOPR od maja do września 2019 i 2020 r. Warto nadmienić, że podsumowanie dotyczy tylko realnie sprzedanych biletów, nie uwzględnia doszacowania, które publikowane jest przez administrację TPN po zakończeniu roku. W związku z oczywistym brakiem danych za 2020 r., współczynnik doszacowujący został pominięty. Wyniki analizy ilościowej wezwań ratowników zostały porównane z liczbą sprzedanych biletów celem potwierdzenia słuszności korelacji pomiędzy liczbą turystów a liczbą zdarzeń podlegających działaniom TOPR w podziale na interwencje, akcje ratunkowe i fałszywe/zbędne alarmy.

\section{Analiza ilościowa interwencji TOPR w latach 2019 i 2020 oraz wolumeny sprzedanych biletów wstępu do TPN}

Kronika TOPR (www.topr.pl) jest publikowana na stronie internetowej tej organizacji co tydzień i obejmuje wydarzenia z całego tygodnia. Opis każdego działania ratunkowego zawiera detale pozwalające zakwalifikować je do odpowiedniej grupy według klasyfikacji zawartej w Regulaminie Straży Ratunkowej. Dane ilościowe dotyczące sprzedaży biletów podane są za statystykami TPN pobranymi ze strony parku (TPN, 2020). 
Tabela 1. Liczba sprzedanych biletów w TPN w okresie maj-sierpień 2019 oraz 2020 r.

\begin{tabular}{lcc}
\hline \multicolumn{1}{c}{ Miesiąc } & 2019 & 2020 \\
\hline Maj & 270439 & 113842 \\
Czerwiec & 407979 & 285598 \\
Lipiec & 732199 & 703361 \\
Sierpień & 882046 & 791484 \\
\hline
\end{tabular}

Źródło: opracowanie własne na podstawie danych TPN (2020).

Pomimo zamknięcia granic TPN do 4 maja 2020 r. kronika TOPR donosiła o łamaniu zakazu i wynikających z tego interwencjach (łącznie opisane są 2 interwencje w marcu i $1 \mathrm{w}$ kwietniu). Właściwy jednak okres do dalszych rozważań nastąpił od 4 maja. W pierwszym tygodniu funkcjonowania parku TOPR podjął 3 interwencje (w rozumieniu regulaminu). W kolejnym tygodniu wzywany był do poszkodowanych aż sześciokrotnie, wszystkie zdarzenia zaliczamy do interwencji. W następnych tygodniach ratownicy podjęli 10 akcji ratunkowych, odnotowano 2 ofiary śmiertelne, 4 interwencje (w tym 2 wezwania skutkujące podaniem jedynie wytycznych turystom). Według statystyk sprzedaży biletów liczba turystów wyniosła 113 842, przy 20 interwencjach TOPR. W analogicznym okresie 2019 r. TOPR podjął działania 42 razy (29 akcji, 13 interwencji, 1 ofiara śmiertelna), dwukrotnie wezwanie można uznać za zbędne. Łączna liczba biletów była z kolei ponad 2 razy wyższa niż w roku kolejnym i wynosiła 270439 . Istotne jest zauważenie faktu, że w obu przypadkach odsetek wypadków i stosunku do ilości turystów był podobny i wynosił kolejno $0,017 \%$ oraz $0,016 \%$.

W czerwcu turystyka mogła ruszyć pełną parą, co przełożyło się na liczbę wezwań TOPR oraz łączną sprzedaż biletów. W 2020 r. ratownicy podjęli akcje ratunkowe 27 razy, łącznie wszystkich przypadków było 39. Uwzględnić należy także 5 bezpodstawnych lub niewymagających interwencji wezwań. Sprzedaż biletów wyniosła 285 598. W analogicznym okresie 2019 r. Straż Ratunkowa działała w terenie 40 razy, 3 razy wezwania były bezzasadne. Liczba sprzedanych biletów była bardzo duża i wynosiła 407979 . Przeliczenie procentowe wskazuje 0,016\% wypadków na liczbę turystów w 2020 r. oraz 0,011\% dla 2019 r. Widać zatem, że im większa liczba turystów, tym współczynnik ten ma większą tendencję do wypłaszczania się do 0,011\%, im mniejsze liczby, tym bardziej oscyluje wokół 0,016\%.

Lipiec 2020 r. był okresem rozkwitu turystyki górskiej. TPN odwiedziło 703361 osób, co stanowi ponad dwukrotność liczby sprzedanych biletów w czerwcu. Również ponaddwukrotnie wzrosła liczba zgłoszeń do centrali TOPR. Ratownicy podjęli akcję 52 razy (w tym 1 wypadek śmiertelny) oraz interweniowali 21 razy. W 5 przypadkach działanie ze strony TOPR po podjęciu informacji było niewymagane. W 2019 r. liczba turystów była porównywalna (732 199 osób). Również porównywalna była liczba zgłoszeń zdarzeń na szlakach. TOPR koordynował akcję 51 razy (2 ofiary śmiertelne), podjął też 34 interwencje, przy czym ani razu zgłoszenie nie mogło zostać uznane za niekonieczne. W obu przypadkach odsetek interwencji w stosunku do liczby turystów wynosił 0,011\%. 
Tabela 2. Liczba wezwań TOPR w okresie maj-sierpień 2019 oraz 2020 r.

\begin{tabular}{llcc}
\hline \multicolumn{1}{c}{ Miesiąc } & Rodzaj wezwania & 2019 & 2020 \\
\hline Maj & Interwencje & 13 & 10 \\
& Akcje & 29 & 10 \\
& Fałszywe alarmy & 0 & 0 \\
\hline Czerwiec & Interwencje & 11 & 12 \\
& Akcje & 40 & 27 \\
& Fałszywe alarmy & 3 & 5 \\
\hline Lipiec & Interwencje & 34 & 21 \\
& Akcje & 51 & 52 \\
& Fałszywe alarmy & 0 & 5 \\
\hline Sierpień & Interwencje & $14^{*}$ & 45 \\
& Akcje & $31^{*}$ & 61 \\
& Fałszywe alarmy & 0 & 0 \\
\hline
\end{tabular}

Źródło: opracowanie własne na podstawie danych TPN (2020).

*dane za połowę miesiąca

W sierpniu 2020 r. liczba sprzedanych biletów wzrosła jeszcze w stosunku do lipca i wyniosła 791 484. Rekordowo duża była liczba interwencji TOPR i wyniosła 106 (61 akcji i 45 interwencji). W tym samym miesiącu roku poprzedniego liczba sprzedanych biletów była rekordowa i uplasowała się na poziomie 882 046. Analiza ilościowa działań TOPR w sierpniu 2019 r. jest znacznie utrudniona, ponieważ brakuje w niej danych za około 2 tygodnie sierpnia. Dla potrzeb wyliczeń załóżmy jednak, że liczbę sprzedanych biletów należy podzielić przez 2 (441 023). Zatem w ciągu dwóch tygodni (pierwszy i ostatni tydzień sierpnia) TOPR interweniował łącznie 41 razy (31 akcji i 14 interwencji). Wyliczenia procentowe znów wskazują na pewną stałą tendencję i dla 2020 r. wynoszą 0,013\%, $z$ kolei dla połowy miesiąca $0,010 \%$, przy czym należy zaznaczyć, że analiza sierpnia 2019 r. jest robocza i trudno określić jej wiarygodność bez pełnych danych. Założyć można jednak, że po raz kolejny przy pełnych danych procent ten oscylowałby wokół 0,011\%.

\section{Wnioski z analiz}

Zestawienie liczby sprzedanych biletów wstępu do TPN wskazuje, że „odmrożenie" gospodarki po zamknięciu nie wywołało zwiększenia ruchu turystycznego w okresie bezpośrednio następującym po złagodzeniu obostrzeń. Zwłaszcza maj był miesiącem wyjątkowo słabym turystycznie w TPN. Należy zaznaczyć, że ruch turystyczny został wznowiony dopiero po majówce, która zwykle charakteryzuje się wysoką aktywnością turystów. Kolejnym powodem zmniejszonej liczby zakupionych biletów może być słaby przepływ informacji i niewiedza dotycząca otwarcia granic parku, ale można też założyć, że ludzi powstrzymywał strach przed pandemią oraz same zachorowania czy kwarantanny. Czerwiec podobnie 
pokazał, że stan pandemii ciągle trwa, co przekłada się na dużo słabszy ruch turystyczny w TPN niż w roku ubiegłym. Dopiero w lipcu i sierpniu 2020 r. liczba sprzedanych biletów do parku zaczęła zbliżać się do wartości z zeszłego roku, wciąż jednak im nie dorównując. Równoległa analiza ilościowa działań TOPR w poszczególnych miesiącach pokazała, że odsetek zdarzeń wymagających zaangażowania ratowników był względnie stały i skorelowany z liczbą turystów ogółem. Wraz ze wzrostem natężenia ruchu turystycznego wzrastała liczba interwencji TOPR. Należy jednak pamiętać, że wskaźnik wykazuje dużą wrażliwość na czynniki zewnętrzne, np. warunki na szlakach, które mogą prowadzić do wzmożonej liczby wypadków.

\section{Zakończenie}

Aktualnie najbardziej wiarygodnym i miarodajnym wskaźnikiem natężenia ruchu turystycznego jest sprzedaż biletów w punktach wejścia do TPN, skorygowana o współczynnik wejść poza godzinami pracy kas, odwiedzin parku przez okolicznych mieszkańców, dla których wstęp jest darmowy, oraz inne elementy ustalone w statystykach TPN. Liczba działań ratunkowych TOPR rośnie wraz ze wzrostem ruchu turystycznego w TPN, jednak bez analizy jakościowej (warunki pogodowe, podział na profesjonalistów - taterników, grotołazów oraz turystów bez profesjonalnego przygotowania, zagregowanie zdarzeń np. pod względem uszczerbku na zdrowiu, inne szczególne okoliczności) nie stanowi dobrego wskaźnika trendów. Ostatecznie, opierając się na analizie liczby sprzedanych biletów, można stwierdzić, że ruch turystyczny w TPN nie wrócił do swoich rozmiarów sprzed blokady, wykazując pierwszy od kilku lat spadek łącznej liczby turystów odwiedzających park. W toku dalszych rozważań warto byłoby zbadać kluczowe przyczyny spowolnienia turystyki w Tatrach, którymi mogą być strach przed pandemią, przebycie choroby czy też nałożenie kwarantanny.

\section{Literatura}

Buchwał A., Fidelus J. (2010). Monitoring ruchu turystycznego przy użyciu czujników ruchu na przykładzie Tatrzańskiego i Babiogórskiego Parku Narodowego. Zakopane. Nauka a Zarządzanie Obszarem Tatr i ich Otoczeniem, 3: 45-54.

Ghețe A.M. (2016). Classification of Various Forms of Tourism. Annals of Faculty of Economics, University of Oradea, 25, 2: 313-319.

Giergiczny M., Zwijacz-Kozica T. (2018). Optymalny społecznie model ochrony lasów Tatrzańskiego Parku Narodowego dotkniętych zjawiskami klęskowymi. Studia i Materiały CEPL w Rogowie, 54, 4: 69-74.

Hibner J. (2012). Zróżnicowanie ruchu turystycznego w Tatrzańskim Parku Narodowym na wybranych przykładach. Problemy Ekologii Krajobrazu, 34: 41-47.

Kurek W., Mika M., Pitrus E. (2007). Formy turystyki kwalifikowanej. W: W. Kurek (red.), Turystyka. Wydawnictwo Naukowe PWN, Warszawa. 
Malchrowicz-Mośko E., Sekida M. (2016). Turystyka ekstremalna vs. sporty ekstremalne. Journal of Education, Health and Sport, 6: 12.

Merski J., Warecka J. (2009). Turystyka kwalifikowana. Turystyka aktywna. DrukTur, Warszawa.

Mokras-Grabowska J. (2015). Turystyka kwalifikowana - od idei do praktyki. Przykład turystów odwiedzających Tatrzański Park Narodowy. Wczoraj, dziś i jutro turystyki aktywnej i specjalistycznej. Wydawnictwo PTTK „Kraj”, s. 347-358.

Regulamin Straży Ratunkowej Tatrzańskiego Ochotniczego Pogotowia Ratunkowego $z$ dnia 21 lutego $2019 \mathrm{r}$.

Sambotin D., Sambotin A., Patrascoiu M., Coroian A., Merce I.I. (2011). Ecotourism a model of sustainable development of tourism means. Lucrări Ştiințifice, seria 1 , 13(4).

Skawiński P. (2010). Zarządzanie ruchem turystycznym w Tatrzańskim Parku Narodowym. Folia Turistica, Turystyka i Ekologia, 22: 25-34.

Statut Tatrzańskiego Ochotniczego Pogotowia Ratunkowego z dnia 28 października 2017 r.

Szlubowska A. (red.) (2020). Turystyka w województwie małopolskim w latach 2018 i 2019. Urząd Statystyczny w Krakowie, Kraków.

Tomik R. (2013). Znaczenie turystyki aktywnej i jej rozumienie w kontekście dotychczasowych koncepcji podziałów turystyki. W: R. Tomik (red.), Turystyka aktywna w województwie śląskim - wybrane zagadnienia. T. 1. AWF, Katowice, s. 11-24.

BIP (2016). Tatrzański Park Narodowy. Status prawny (https://bip.malopolska.pl/tpnzakopane,m,107096,status-prawny.html; dostęp: 8.01.2021).

GOV (2020). Wprowadzamy stan epidemii w Polsce (www.gov.pl; dostęp: 8.01.2021).

TOPR (2021) (http://www.topr.pl/; dostęp: 8.01.2021).

TPN (2020). Tatrzański Park Narodowy otwarty dla turystów/TPN zamknięty dla turystów - zagrożenie epidemiczne / Opłaty/Sprzedaż biletów wstępu w roku 2020/Sprzedaż biletów wstępu w roku 2019 (www.tpn.pl; dostęp: 8.01.2021).

\section{The influence of the "defrosting" of the economy after lockdown due to COVID-19 on the volume of tourist traffic in the Tatra National Park}

As a result of the announcement of the global COVID-19 pandemic, a lockdown was established in Poland in March 2020. Apart from preventing or limiting the activity of many branches of the economy, tourist and recreational traffic in parks and forests was also temporarily closed. This was due to the inability to legally enter the Tatra National Park. The aim of this article is to investigate how the temporary exclusion of tourism in the Tatras influenced the intensity of tourist traffic during the "economic defrosting" period and later, based on the analysis of the number of tickets sold, but also the records of the TOPR intervention chronicle in the period from May to September 2019 and in the same period of 2020. 



\section{Dziedzictwo kulinarne województwa małopolskiego w opinii podróżujących}

\section{Streszczenie}

Celem niniejszego rozdziału jest dokonanie ogólnej charakterystyki dziedzictwa kulinarnego województwa małopolskiego oraz poznanie stanu wiedzy i opinii podróżujących po tym regionie turystów na jego temat. W pierwszej części pracy krótko przedstawiono bogactwo kulinarne Małopolski. W drugiej natomiast omówiono wyniki badań własnych, przeprowadzonych z wykorzystaniem anonimowego kwestionariusza ankiety. W podsumowaniu znalazły się uwagi i wnioski wynikające $z$ analiz, w tym odnoszące się do weryfikacji czterech postawionych hipotez badawczych.

\section{Wprowadzenie}

Gotowanie, zdrowe odżywianie i produkty ekologiczne od kilku lat budzą coraz większe zainteresowanie społeczeństwa (Raheem i in., 2019). Również turyści, podróżując po różnych miejscach naszego globu, coraz częściej degustują specjały swoiste dla danego kraju, regionu czy miejscowości. Systematycznie wzrasta więc liczba osób, których podstawowym lub znaczącym motywem podróży jest poznanie lokalnej kuchni. Każdy lubi bowiem smacznie zjeść, skosztować nowe lub wcześniej nieznane potrawy, napoje, produkty, a tym samym poczuć wywołane dzięki nim ekscytujące doznania kulinarne (Orłowski, Woźniczko, 2016).

Województwo małopolskie jest jednym z najbardziej turystycznych regionów Polski, a ważnym fundamentem budowania atrakcyjnej i zróżnicowanej jego oferty są kultywowane do tej pory zwyczaje kulinarne. Z badań prowadzonych w województwie wynika, że w 2019 r. Małopolskę odwiedziło 17,86 mln osób, w tym 3,78 mln gości z zagranicy (Małopolska Organizacja Turystyczna, 2020). 
Rok 2020, z uwagi na pandemię koronawirusa, spowodował ogromne zmiany w ruchu turystycznym. Jednak pomimo znacznego spadku liczby turystów międzynarodowych, zauważalne było ożywienie turystyki krajowej i zainteresowanie lokalnymi atrakcjami turystycznymi.

Celem opracowania jest ukazanie bogactwa kulinarnego województwa małopolskiego oraz omówienie wyników badań własnych, dotyczących opinii turystów podróżujących po regionie na temat jego atrakcyjności.

\section{Dziedzictwo kulinarne województwa małopolskiego}

Gąsiorowski (2006) określa dziedzictwo kulinarne jako produkty żywnościowe i potrawy, które charakteryzują się szczególnymi cechami jakościowymi, tradycyjnymi sposobami przyrządzania i wytwarzania, sięgającymi przeważnie do odległej historii. Produkty i potrawy te wytwarzane są zazwyczaj w małej skali, przy wykorzystaniu specyficznych umiejętności i technologii. Dodatkowo związane są one $z$ określonym obszarem geograficznym. Na dziedzictwo kulinarne duży wpływ mają bowiem warunki naturalne danego terenu, czyli to, gdzie produkowana jest żywność, ale także, w jaki sposób się ją wytwarza (Zhang i in., 2019).

Dziedzictwo kulinarne Polski jest bardzo bogate i zróżnicowane. Zwyczaje kulinarne naszego kraju cechuje też przywiązanie i szacunek do lokalnych tradycji oraz polska gościnność. Kuchnie w poszczególnych regionach różnią się między sobą głównie rodzajem najczęściej używanych produktów i sposobem ich przyrządzania (Jędrysiak, 2008).

Województwo małopolskie słynie ze swojego bogactwa kulinarnego. Kultywowane są tutaj zwyczaje kulinarne, a przepisy przekazywane są z pokolenia na pokolenie. Tak samo jest w przypadku technologii wytwarzania lokalnych produktów - do tej pory uprawiane są w Małopolsce ${ }^{1}$ stare odmiany roślin oraz hodowane są stare rasy zwierząt.

Małopolska kuchnia zawdzięcza swoją różnorodność wpływom różnych nacji żyjących dawniej na tych terenach. Mieszkająca tu ludność ukraińska, żydowska, austriacka i węgierska odcisnęła swoje piętno na małopolskich zwyczajach kulinarnych. Znaczący wpływ miało także osadnictwo wołoskie, któremu zawdzięczamy sery owcze, oscypek czy bryndzę (Woźniczko i in., 2015).

$\mathrm{Na}$ terenie województwa małopolskiego można wyróżnić dwie charakterystyczne kuchnie regionalne: galicyjską oraz podhalańską, zwaną góralską. Pierwsza z nich odnosi się głównie do Krakowa, natomiast kuchnia podhalańska związana jest z obszarami wiejskimi województwa (Barowicz 2017).

W województwie małopolskim przeważają potrawy z mąki, kasz, ziemniaków, kapusty oraz zupy na mleku i jarzynach.

\footnotetext{
W niniejszym rozdziale termin Małopolska używany jest zamiennie $z$ terminem województwo małopolskie. Choć historycznie jest to region bardziej rozległy z bardziej zróżnicowanymi tradycjami kulinarnymi, to rozpatrywany jest stan obecny - produkty regionalne rejestrowane są w ujęciu administracyjnym. W literaturze przedmiotu nazewnictwo to również traktowane jest jako synonimy.
} 
Małopolska słynie ze wspaniałych wypieków. Kulinarnym symbolem Krakowa jest obwarzanek. Często niesłusznie jest on mylony z bajglem czy preclem, a każde z nich jest określeniem innego małopolskiego specjału. Obwarzanek to wyrób w kształcie pierścienia, spiralnie zwinięty. Inne popularne wypieki w Małopolsce to: chleb prądnicki, chleb jurajski czy kołacz jurajski. Jednymi z najsłynniejszych produktów regionalnych Podhala są natomiast sery owcze. Prym wśród nich wiedzie oscypek, zwany królem polskich serów. Przygotowywany jest on przez górali według niezmienionej od kilkuset lat receptury (Woźniczko i in., 2015; Pawlak i in., 2016).

Ważnym potwierdzeniem tego, że małopolskie dziedzictwo kulinarne wyróżnia się na tle całego kraju, jest fakt, że to właśnie z Małopolski pochodzi najwięcej polskich produktów regionalnych, zarejestrowanych w Komisji Europejskiej - na 44 aż 15. Oznaczenie Chroniona Nazwa Pochodzenia lub Chronione Oznaczenie Geograficzne posiadają następujące specjały: oscypek, redykołka, bryndza podhalańska, fasola „Piękny Jaś”, chleb prądnicki, obwarzanek krakowski, suska sechlońska, jabłka łąckie, karp zatorski, jagnięcina podhalańska, kiełbasa lisiecka, kiełbasa piaszczańska, kiełbasa krakowska sucha staropolska, czosnek galicyjski oraz miód spadziowy z Beskidu Wyspowego (Ministerstwo Rolnictwa i Rozwoju Wsi, 2020).

Małopolska przoduje też wśród regionów pod względem liczby produktów tradycyjnych. Aktualnie na liście prowadzonej przez Ministerstwo Rolnictwa i Rozwoju Wsi znajdują się aż 224 małopolskie produkty (tab. 1). Największą grupę stanowią produkty mięsne. Oczywiście wszystkie produkty regionalne, czyli te docenione przez Komisję Europejską, są także na liście produktów tradycyjnych. Większą liczbą produktów może poszczycić się tylko województwo podkarpackie (247), natomiast podobny wynik do Małopolski osiągnęło województwo lubelskie (227). Tereny tych województw to po części ziemie historycznej Małopolski, co tylko podkreśla popularność i znaczenie tej kuchni.

Grębowiec (2014), próbując określić rolę produktów regionalnych w budowaniu konkurencyjnej oferty regionu małopolskiego w UE na przykładzie obwarzanka, zbadał postrzegalność małopolskich specjałów przez konsumentów. Według jego wyników, spośród tradycyjnych i regionalnych małopolskich produktów najbardziej znany jest oscypek - wskazało go prawie 99\% ankietowanych. Na wysokich pozycjach uplasowały się także: obwarzanek krakowski (85\%) oraz bryndza podhalańska $(64,7 \%)$. Popularnym produktem $(42,4 \%)$ okazała się również kiełbasa lisiecka. Chleb prądnicki, karp zatorski, jagnięcina podhalańska oraz jabłka łąckie odznaczają się natomiast średnim stopniem rozpoznawalności. Najmniej znanym produktem jest redykołka $(5,3 \%)$ oraz suska sechlońska $(1,8 \%)$. Autorka niniejszego tekstu postanowiła zweryfikować te wyniki, a ponadto ustalić rozpoznawalność kulinarnych specjałów Małopolski oraz poznać opinie turystów podróżujących po regionie na temat ich atrakcyjności. 
Tabela 1. Lista przykładowych produktów tradycyjnych z województwa małopolskiego

\begin{tabular}{|c|c|c|}
\hline $\begin{array}{c}\text { Grupy } \\
\text { produktów }\end{array}$ & Liczba & Przykładowe produkty \\
\hline $\begin{array}{l}\text { Produkty } \\
\text { mleczne }\end{array}$ & 12 & $\begin{array}{l}\text { lody nowotarskie, ser gazdowski - gołka (pucok, kara), bundz/ } \\
\text { bunc, redykołka, bryndza podhalańska, żentyca, sądeckie lody, mle- } \\
\text { ko od krów rasy polskiej czerwonej }\end{array}$ \\
\hline $\begin{array}{l}\text { Produkty } \\
\text { mięsne }\end{array}$ & 70 & $\begin{array}{l}\text { jagnięcina podhalańska, tuszka gęsi zatorskiej, kiełbasa lisiecka, } \\
\text { szynka podstolego z nogą, kiełbasa wiejska z Podstolic, jagnięcina } \\
\text { jurajska z owcy olkuskiej, tuszka zielononóżki kuropatwianej, kieł- } \\
\text { basa piaszczańska, wołowina z krowy rasy polskiej czerwono-białej, } \\
\text { kiełbasa proszowicka ze słoja, boczek duszony w piwie, kiełbasa } \\
\text { wiejska z Proszówek, szynka iwkowska, polędwica wiejska sądecka } \\
\text { tradycyjna, kabanos wiejski z Andrychowa, kiełbasa wiejska z gala- } \\
\text { retką z Nowej Wsi Szlacheckiej, kiełbasa swojska sądecka, słonina } \\
\text { rosolona podegrodzka, schab tradycyjny raciechowicki, kiełbasa kra- } \\
\text { kowska sucha, kaszanka proszowicka, pasztet proszowicki, kiełba- } \\
\text { sa małopolska, kiełbasa wiejska z Czernichowa, sołdra (sołdrzyna) } \\
\text { spiska, kiełbasa swoja z Rajbrotu, kiełbasianka z Rajbrotu, szołdra } \\
\text { z Rajbrotu, szynka lipnicka }\end{array}$ \\
\hline
\end{tabular}

Produkty $\quad 8$ karp zatorski, karp zatorski wędzony, karp osiecki, pstrąg ojcowski rybołówstwa 8 potokowy, pstrąg ojcowski tęczowy, fileciki karpiowe w pomidorach

charsznicka kapusta kwaszona, nasiona fasoli „Piękny Jaś” z doliny Warzywa $\quad 15$ Dunajca, łukowicka śliwka suszona, suska sechlońska, jabłko z Rai owoce $\quad 15$ ciechowic, jabłka łąckie, polska fasola $z$ orzełkiem, dżem z płatków róż

\begin{tabular}{ll}
\hline & $\begin{array}{l}\text { bajgiel z Kazimierza, chleb żarnowy z Łomnej, ciasteczka wyśmie- } \\
\text { nite, baba z chleba żytniego, chleb jurajski, obwarzanek krakowski, } \\
\text { Wyroby }\end{array}$ \\
piekarnicze & jodłownicki kołacz z serem, chleb prądnicki, precelek krakowski, \\
i cukierni- & kukiełka lisiecka, kołacz jurajski, kukiełka podegrodzka, sernik ju- \\
cze & $\begin{array}{l}\text { rajski, orawskie zawijańce weselne, chleb orawski na liściu kapusty, } \\
\text { koziołki, paluszki krakowskie, sernik królewski, chleb świąteczny, } \\
\text { cwibak z fasoli z bakaliami }\end{array}$ \\
\hline
\end{tabular}

\begin{tabular}{|c|c|c|}
\hline $\begin{array}{l}\text { Oleje } \\
\text { i tłuszcze }\end{array}$ & 1 & masło rzuchowskie \\
\hline Miody & 8 & $\begin{array}{l}\text { sądecki miód spadziowy, małopolski miód spadziowy, miód wielo- } \\
\text { kwiatowy leśny z Podksięża, miód nawłociowy z gminy Skrzyszów }\end{array}$ \\
\hline $\begin{array}{l}\text { Gotowe } \\
\text { dania } \\
\text { i potrawy }\end{array}$ & 43 & $\begin{array}{l}\text { żurek po krakowsku, barszcz czerwony krakowski, ziemniaki po } \\
\text { cabańsku, pierogi łomniczańskie, moskol, zupa zoproska, siuśpaj, } \\
\text { kluski hałuski, tarcioki - kluski scykane - bukty, kaszana - kiszka } \\
\text { z kapustą zasmażana, rosół polski, kasza pęcak z kapustą, pasztet } \\
\text { z fasoli z marchewką lub grzybami, zupa karpielanka, pierogi z fa- } \\
\text { solą „Piękny Jaś”, klęczańska zupa wigilijna - jasiek ze śliwką, pie- } \\
\text { rogi kościeleckie, święconka (święcelina) spiska na ciepło, gulasz } \\
\text { czorsztyński, mętkowska marchwionka }\end{array}$ \\
\hline Napoje & 18 & $\begin{array}{l}\text { śliwowica łącka, jarzębiak izdebnicki, jarzębinka, balsam kapucyń- } \\
\text { ski, czar pustyni, imbirówka iwkowska, fasolówka, miodówka ry- } \\
\text { terska, ratafia z kwiatami czarnego bzu i głogu }\end{array}$ \\
\hline $\begin{array}{l}\text { Inne pro- } \\
\text { dukty }\end{array}$ & 5 & $\begin{array}{l}\text { sól wielicka, jajko zielononóżki kuropatwianej, wiśnicki makaron } \\
\text { domowy tradycyjny, kiszone rydze z gminy Uście Gorlickie }\end{array}$ \\
\hline
\end{tabular}

Źródło: opracowanie własne na postawie www.gov.pl/web/rolnictwo/produkty-regionalne-i-tradycyjne1; dostęp: 28.12.2020. 


\section{Metodyka badań}

Celem badania było określenie stanu wiedzy respondentów na temat dziedzictwa kulinarnego województwa małopolskiego. Autorce zależało także na ustaleniu, czy zdaniem podróżujących oferta kulinarna Małopolski może być atrakcją turystyczną regionu, oraz na poznaniu opinii ankietowanych odnośnie do atrakcyjności oferowanych w regionie kulinarnych produktów turystycznych.

W oparciu o uzyskane wyniki postanowiono zweryfikować cztery hipotezy: HA - oscypek i obwarzanek to najczęściej kojarzone z Małopolską produkty regionalne, HB - w opinii podróżujących po regionie turystów małopolska kuchnia jest najbardziej znana w naszym kraju, HC - z wyjazdów turystycznych częściej przywożone są oscypki niż obwarzanki krakowskie oraz HD - święta i festiwale kulinarne są atrakcyjniejszymi produktami kulinarnymi Małopolski niż organizowane w regionie targi, giełdy i kiermasze żywności lokalnej.

Zastosowano metodę sondażu diagnostycznego, wykorzystując kwestionariusz ankiety, składający się z 10 pytań zamkniętych oraz metryczki. Badanie zostało przeprowadzone drogą internetową w okresie styczeń-luty 2019 r. wśród 112 Polaków. Dzięki użyciu pytania filtrującego w ankiecie wzięły udział tylko osoby, które podróżują po Polsce w celach turystycznych.

\section{Wyniki badań własnych}

Kwestionariusz wypełniło więcej (67\%) kobiet niż mężczyzn (tab. 2). Ponad połowa respondentów (53\%) znajdowała się w przedziale wiekowym 26-35 lat. Znaczącą grupę (38\%) stanowiły także osoby z przedziału 36-50 lat. Badani to osoby z minimum średnim wykształceniem, z czego aż $89 \%$ było po studiach. Połowa ankietowanych oceniła sytuację materialną swojego gospodarstwa domowego jako dobrą, a co piąty jako bardzo dobrą. Dominowali (65\%) mieszkańcy dużych miast (powyżej 200 tys. mieszkańców), ale odpowiedzi udzielili też mieszkańcy wsi i małych miejscowości (poniżej 50 tys. mieszkańców) - w sumie ponad 25\%. Znaczącą grupę respondentów (prawie 80\%) stanowili mieszkańcy województwa małopolskiego podróżujący po regionie w celach turystycznych. Niemniej jednak w sondażu wzięli udział również mieszkańcy reprezentujący województwa: dolnośląskie, lubelskie, mazowieckie, podkarpackie, śląskie, świętokrzyskie oraz wielkopolskie.

Prawie $90 \%$ ankietowanych podczas podróży turystycznych po Małopolsce miało okazję spróbować regionalnych, tradycyjnych produktów bądź potraw. W prawie wszystkich przypadkach respondenci poproszeni o samodzielnie wymienienie potraw/produktów, które degustowali, samoistnie wymienili oscypek lub sery podhalańskie. Często wskazywany był także obwarzanek krakowski. W odpowiedziach pojawiały się ponadto: kiełbasa lisiecka, kwaśnica i maczanka krakowska.

Podobnie wyniki rozłożyły się, gdy zapytano o znajomość wskazanych produktów i potraw regionalnych pochodzących z południa Polski (ryc. 1). Prawie wszyscy kojarzyli oscypka (97\%) i obwarzanka krakowskiego (95\%). Kolejny 
Tabela 2. Charakterystyka respondentów

\begin{tabular}{|c|c|c|c|c|c|}
\hline \multirow[b]{2}{*}{$\begin{array}{l}\text { Charakterystyka } \\
\text { respondentów }\end{array}$} & \multirow[b]{2}{*}{$\begin{array}{l}\text { Liczba re- } \\
\text { spondentów } \\
(\mathrm{N}=112)\end{array}$} & \multicolumn{4}{|c|}{$\begin{array}{c}\text { Rozpoznawalność małopolskiej kuchni w Polsce } \\
\text { na tle innych regionalnych kuchni w opinii } \\
\text { respondentów ( } \mathrm{w} \%)\end{array}$} \\
\hline & & $\begin{array}{c}\text { Jedna } \\
\text { z naj- } \\
\text { bardziej } \\
\text { znanych } \\
(\mathrm{N}=37)\end{array}$ & $\begin{array}{l}\text { Średnio } \\
\text { znana } \\
(\mathrm{N}=47)\end{array}$ & $\begin{array}{c}\text { Mało } \\
\text { znana } \\
(\mathrm{N}=26)\end{array}$ & $\begin{array}{c}\text { Nieznana } \\
(\mathrm{N}=2)\end{array}$ \\
\hline \multicolumn{6}{|c|}{ Płeć } \\
\hline Kobiety & $75(67,0 \%)$ & $30,7 \%$ & $48,0 \%$ & $20,0 \%$ & $1,3 \%$ \\
\hline Mężczyźni & $37(33,0 \%)$ & $37,8 \%$ & $29,7 \%$ & $29,7 \%$ & $2,7 \%$ \\
\hline \multicolumn{6}{|c|}{ Wiek } \\
\hline 18-25 lat & $4(3,6 \%)$ & $25,0 \%$ & $50,0 \%$ & $25,0 \%$ & - \\
\hline 26-35 lat & $59(52,7 \%)$ & $44,1 \%$ & $39,0 \%$ & $16,9 \%$ & - \\
\hline 36-50 lat & $43(38,4 \%)$ & $20,9 \%$ & $48,8 \%$ & $25,6 \%$ & $4,7 \%$ \\
\hline 51 lat i więcej & $6(5,4 \%)$ & $16,7 \%$ & $16,7 \%$ & $66,7 \%$ & - \\
\hline \multicolumn{6}{|c|}{ Wykształcenie } \\
\hline Średnie & $12(10,7 \%)$ & $50,0 \%$ & $41,7 \%$ & $8,3 \%$ & - \\
\hline Wyższe & $100(89,3 \%)$ & $31,0 \%$ & $42,0 \%$ & $25,0 \%$ & $2,0 \%$ \\
\hline \multicolumn{6}{|c|}{ Miejsce zamieszkania } \\
\hline Wieś & $16(14,3 \%)$ & $37,5 \%$ & $43,8 \%$ & $18,8 \%$ & - \\
\hline $\begin{array}{l}\text { Miasto poniżej } 50 \text { tys. } \\
\text { mieszkańców }\end{array}$ & $14(12,5 \%)$ & $50,0 \%$ & $28,6 \%$ & $21,4 \%$ & - \\
\hline $\begin{array}{l}\text { Miasto 50-200 tys. } \\
\text { mieszkańców }\end{array}$ & $9(8,0 \%)$ & $33,3 \%$ & $33,3 \%$ & $22,2 \%$ & $11,1 \%$ \\
\hline $\begin{array}{l}\text { Miasto powyżej } \\
200 \text { tys. mieszkańców }\end{array}$ & $73(65,2 \%)$ & $28,8 \%$ & $45,2 \%$ & $24,7 \%$ & $1,4 \%$ \\
\hline \multicolumn{6}{|c|}{ Województwo } \\
\hline Małopolskie & $89(79,5 \%)$ & $36,0 \%$ & $42,7 \%$ & $21,3 \%$ & - \\
\hline Lubelskie & $4(3,6 \%)$ & $50,0 \%$ & - & $50,0 \%$ & - \\
\hline Mazowieckie & $4(3,6 \%)$ & - & $50,0 \%$ & $50,0 \%$ & - \\
\hline Śląskie & $4(3,6 \%)$ & - & $50,0 \%$ & $50,0 \%$ & - \\
\hline Świętokrzyskie & $4(3,6 \%)$ & $25,0 \%$ & $75,0 \%$ & - & - \\
\hline Podkarpackie & $3(2,7 \%)$ & $33,3 \%$ & - & - & $66,7 \%$ \\
\hline Dolnośląskie & $3(2,7 \%)$ & $33,3 \%$ & $33,3 \%$ & $33,3 \%$ & - \\
\hline Wielkopolskie & $1(0,9 \%)$ & - & $100,0 \%$ & - & - \\
\hline
\end{tabular}

Źródło: opracowanie własne.

najwyższy wynik uzyskała śliwowica łącka, którą wskazało 3/4 badanych. Zaskakująco niski wynik miała redykołka - zaledwie $22 \%$. Z pewnością jest to efekt niewiedzy, braku świadomości, że niektóre sery, które większość osób bierze za oscypka, tak naprawdę noszą miano redykołki. Wyniki świadczą o tym, że wiele małopolskich produktów jest rozpoznawalnych. Dotyczy to także potraw regionalnych - co drugi badany przyznał, że nie jest mu obca maczanka krakowska. 


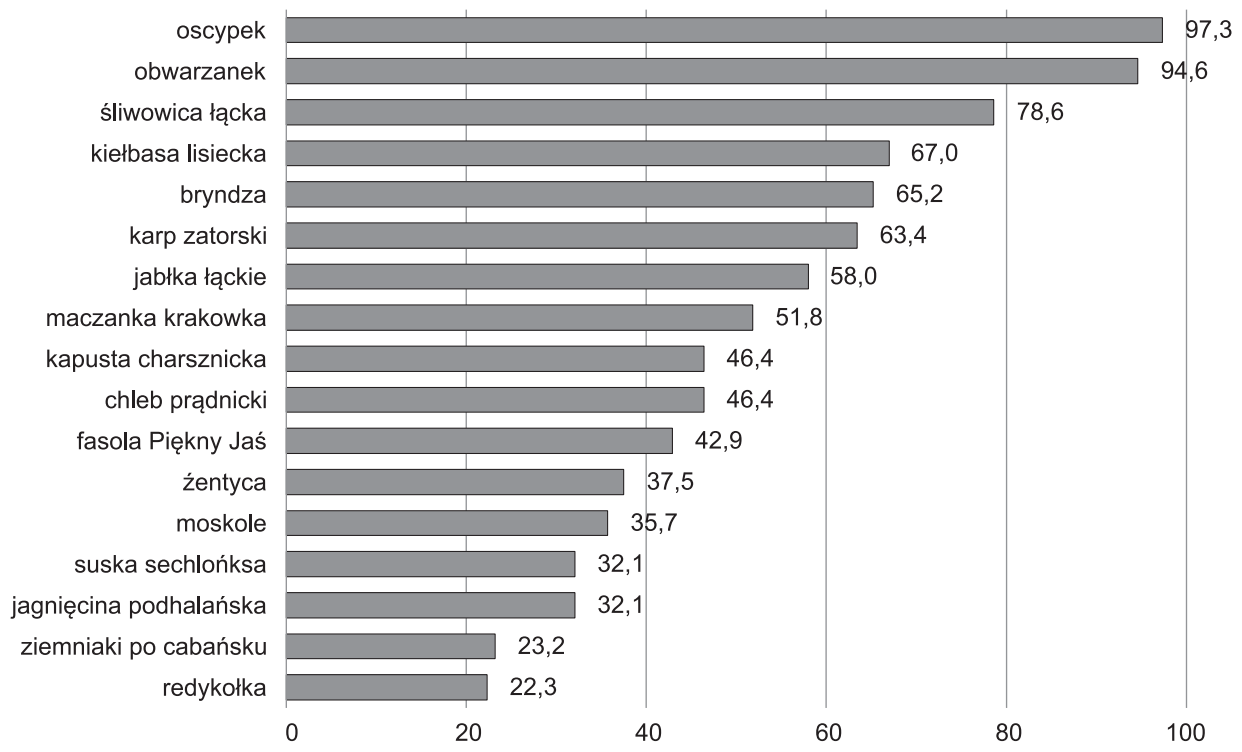

Ryc. 1. Znajomość małopolskich produktów i potraw regionalnych (w \%)

Źródło: opracowanie własne.

Większość respondentów (ponad 89\%) uważała, że sztuka kulinarna jest ważnym elementem tradycji kulturowej Małopolski. Opinia ta ma duże znaczenie, ponieważ ankietowani przyznali się do próbowania lokalnych specjałów i bezbłędnie, samodzielnie potrafili wskazać ich nazwy.

Jednak w przypadku oceny małopolskiej kuchni na tle innych regionów wyniki nie są już tak optymistyczne. Najwięcej osób (aż 42\%) było zdania, że kuchnia ta jest średnio znana w Polsce (ryc. 2). Wprawdzie co trzeci badany wskazał, że jest ona najbardziej znana, ale niewiele mniej (23\%) respondentów uważało, że jest to kuchnia mało znana w Polsce. Szczegółowa analiza odpowiedzi udzielonych przez respondentów na to pytanie została przedstawiona w tabeli 2.

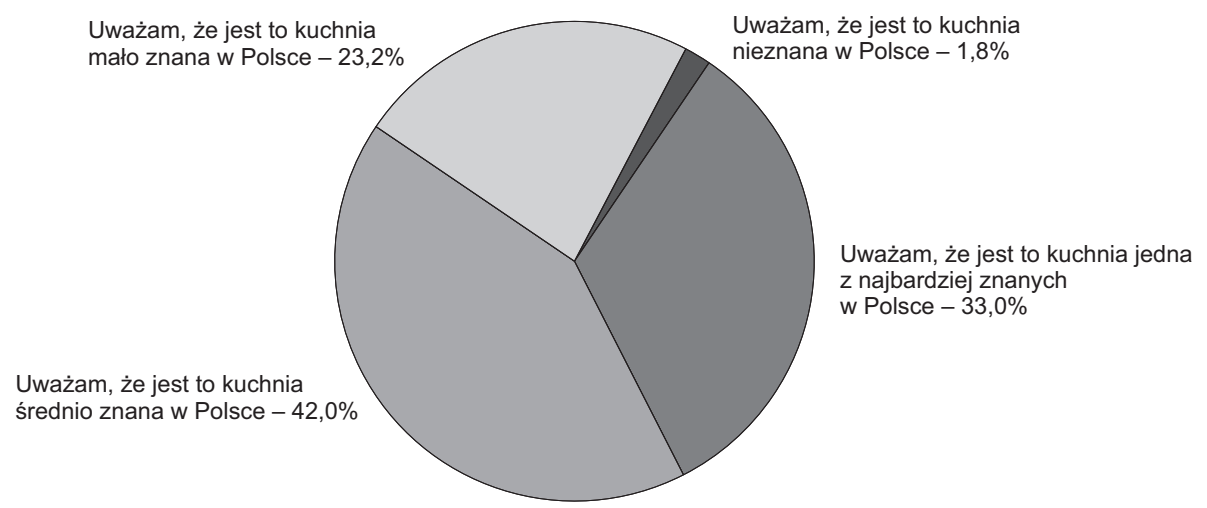

Ryc. 2. Małopolska kuchnia na tle innych regionalnych kuchni w opinii badanych Źródło: opracowanie własne. 
Zdecydowana większość ankietowanych (prawie 94\%) przywozi z podróży po Małopolsce produkty, potrawy regionalne wytworzone przez lokalnych producentów. Może to być związane z chęcią zabrania do domu smaków, które wywołały pozytywne emocje, i tym samym, które umożliwiają sentymentalny powrót do miejsc ich zakupu. Innym motywem może być chęć obdarowania najbliższych tego typu prezentami.

$\mathrm{Na}$ prośbę o wskazanie, które produkty najchętniej są przez respondentów przywożone $z$ wyjazdów turystycznych, najwięcej wskazań zebrały ponownie oscypki - 94,3\%. Relatywnie dużo osób (rzędu 50-60\%) zaznaczyło też: sery i nabiał, miód oraz obwarzanki. Pomimo tego, że ten ostatni jest jednym z najbardziej rozpoznawalnych produktów pochodzących z Małopolski, to tylko co drugi turysta przywozi go ze swoich podróży. Około $40 \%$ ankietowanych przyznało się do zakupów regionalnych napojów alkoholowych, takich jak piwa, wódki czy nalewki regionalne. Najmniej wskazań uzyskały wina regionalne (19\%) oraz ryby (20\%).

Respondenci zostali również poproszeni o opinię na temat małopolskich specjałów jako atrakcji turystycznej. Zdecydowana większość osób (92,9\%) uznała, że regionalna oferta kulinarna Małopolski może być atrakcją turystyczną regionu. Jest to bardzo budujący rezultat - respondentom, turystom nie jest obca kuchnia południa Polski, ich opinia opiera się na własnych doświadczeniach, stąd jest tym bardziej wartościowa.

Badani oceniali ponadto atrakcyjność oferowanych w Małopolsce kulinarnych produktów turystycznych. Najwięcej osób $(90,2 \%)$ stwierdziło, że najatrakcyjniejsze są święta i festiwale kulinarne (ryc. 3). Za atrakcyjne produkty turystyczne

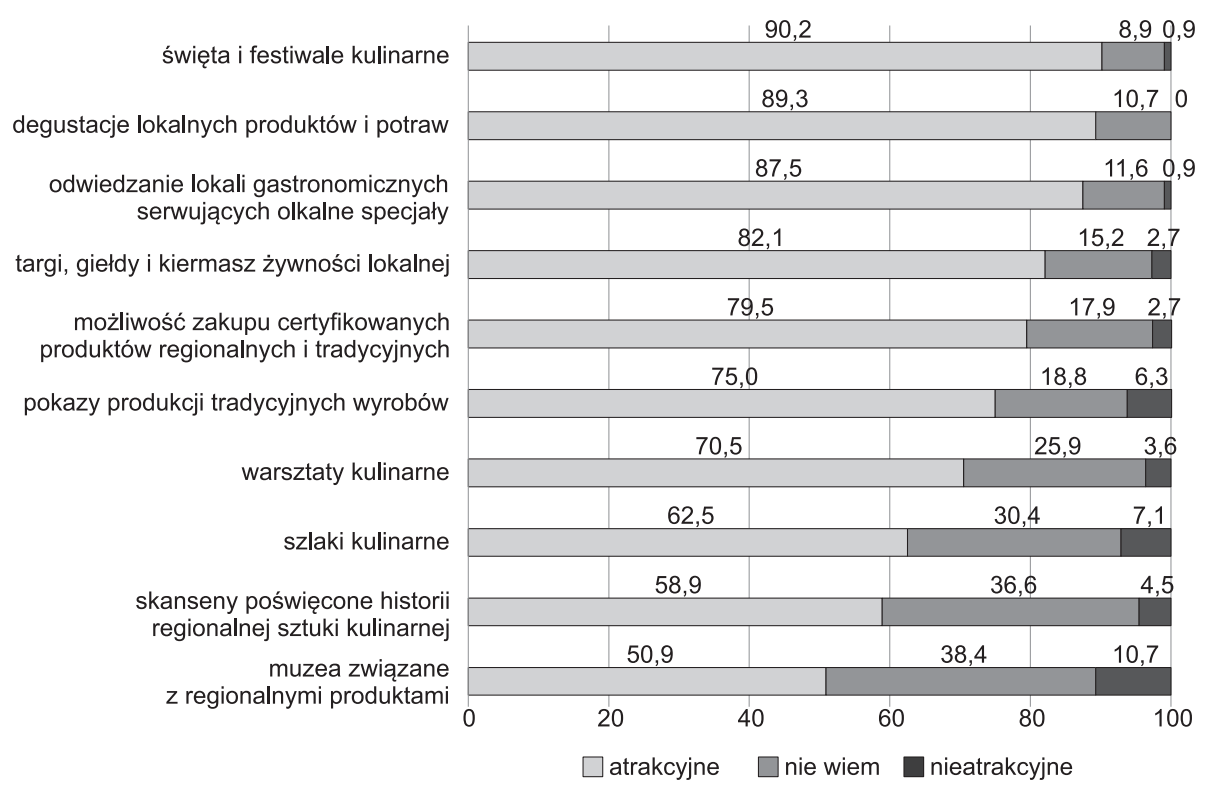

Ryc. 3. Atrakcyjność kulinarnych produktów turystycznych oferowanych w Małopolsce w opinii badanych

Źródło: opracowanie własne. 
respondenci uznali także te, które w sposób bezpośredni i indywidualny pozwalają zasmakować w lokalnych specjałach, tj. degustacje lokalnych produktów i potraw (89\%) czy odwiedzanie lokali gastronomicznych serwujących miejscowe specjały ( $88 \%$ wskazań). Dopiero na czwartej pozycji uplasowały się targi, giełdy i kiermasze żywności lokalnej (82\%).

Spora grupa badanych (ponad 30\%) nie ma zdania na temat atrakcyjności zwiedzania muzeów, skansenów czy szlaków kulinarnych. Taki wynik może wskazywać, że te kulinarne produkty turystyczne są ankietowanym nieznane i nie mieli oni możliwości ustosunkowania się co do ich atrakcyjności. Muzea kulinarne zostały również uznane za najmniej atrakcyjne (11\% wskazań).

\section{Zakończenie}

Dobre, lokalne jedzenie to dla współczesnego turysty nie tylko dodatek do wakacji. Degustowanie lokalnej kuchni oraz smakowanie tradycyjnych potraw znacząco wpływa na satysfakcję z odbywanego wyjazdu (Cohen, Avieli, 2004). Ten kontakt z lokalną kuchnią stwarza możliwość doznawania autentyczności miejsca, stając się unikatowym atraktorem - czynnikiem, nieuświadomionym w pierwszej chwili, jednak w momencie gdy jest doświadczany, ma on kluczowy wpływa na postrzeganie destynacji (Apetyt na region, 2013). Stąd tak ważny jest potencjał kulinarny danego miejsca, wachlarz lokalnych produktów i potraw oraz ich wykorzystanie do tworzenia atrakcyjnej, kulinarnej oferty turystycznej.

Biorąc pod uwagę wzrost świadomości kulinarnej turystów oraz nastawienie na doświadczanie lokalnych smaków, należy stwierdzić, że Małopolska ma wiele do zaoferowania podróżnym. Potwierdzają to wyniki badań własnych. Ponad 90\% respondentów uznało, że oferta kulinarna Małopolski może być atrakcją turystyczną regionu. Najczęściej kojarzonymi z Małopolską produktami regionalnymi okazały się oscypek i obwarzanek, co pozytywnie zweryfikowało pierwszą $z$ założonych hipotez badawczych (HA). Są one również chętnie nabywane podczas podróży turystycznych jako pamiątki lub prezenty dla najbliższych. Zgodnie z przypuszczeniem (hipoteza HC) z wyjazdów częściej przywożone są oscypki niż obwarzanki krakowskie. Zakładano również, że w opinii podróżujących po regionie turystów małopolska kuchnia jest najbardziej znana w naszym kraju. Tymczasem wśród ankietowanych przeważa opinia, że małopolska kuchnia jest tylko umiarkowanie znana na tle innych regionów. Zatem hipotezę HB trzeba było odrzucić. Z kolei hipoteza HD - święta i festiwale kulinarne są atrakcyjniejszymi produktami kulinarnymi Małopolski niż organizowane $\mathrm{w}$ regionie targi, giełdy i kiermasze żywności lokalnej, została potwierdzona empirycznie. 


\section{Literatura}

Barowicz T. (2007). Polskie kuchnie regionalne. Klub dla Ciebie, Warszawa.

Cohen E., Avieli N. (2004). Food in tourism: Attraction and Impediment. Annals of Tourism Research, 31(4): 755-778.

Gąsiorowski M. (2006). Produkty regionalne i tradycyjne - wpis na listę, promocja i ochrona produktów, sprzedaż bezpośrednia z gospodarstw agroturystycznych. W: B. Ditrich, D. Słubik (red.), Produkt regionalny i tradycyjny a agroturystyka. Pomorski Ośrodek Doradztwa Rolniczego, Gdańsk, s. 7-20.

Grębowiec M. (2014). Rola produktów tradycyjnych i regionalnych w budowaniu konkurencyjnej oferty regionu małopolskiego w Unii Europejskiej na przykładzie „Obwarzanka Krakowskiego". Zeszyty Naukowe SGGW w Warszawie, Problemy Rolnictwa Światowego, 14(29), 2: 70-79.

Jędrysiak T. (2008). Turystyka kulturowa. PWE, Warszawa.

Małopolska Organizacja Turystyczna (2020). Ruch turystyczny w Małopolsce w 2019 roku. MOT, Kraków.

Ministerstwo Rolnictwa i Rozwoju Wsi (www.gov.pl/web/rolnictwo/produkty-regionalne-i-tradycyjne1; dostęp: 28.12.2020).

Orłowski D., Woźniczko M. (2016). Turystyka kulinarna w Polsce - wstępne badania nad fenomenem zjawiska. Turystyka Kulturowa, 5: 60-100.

Pawlak A., Czarniecka-Skubina E., Leszczyńska D. (2016). Polska kuchnia regionalna w turystyce na przykładzie Podhala. W: H. Makała (red.), Trendy żywieniowe w turystyce. Tradycje i dziedzictwo kulinarne. Wyższa Szkoła Turystyki i Języków Obcych, Warszawa, s. 77-103.

Raheem D., Shishaev M., Dikovitsky V. (2019). Food System Digitalization as a Means to Promote Food and Nutrition Security in the Barents Region. Agriculture, 9(8): 1-19.

Woźniczko M., Jędrysiak T., Orłowski D. (2015). Turystyka kulinarna. PWE, Warszawa.

Zhang T., Chen J., Hu B. (2019). Authenticity, Quality, and Loyalty: Local Food and Sustainable Tourism Experience. Sustainability, 11(12): 1-18.

\section{The culinary heritage of the Małopolska region in the opinion of travellers}

The aim of this article is to provide a general description of the culinary heritage of the Małopolska region, and to know the state of knowledge and opinions of travellers about it. In the first part of paper the culinary heritage of the Małopolska region was briefly presented. In the second part the results of own research, conducted with the use of anonymous questionnaire were discussed. The summary includes comments and conclusions resulting from the analysis, including those relating to the verification of four research hypotheses. 


\author{
Łukasz Szat, Weronika Terlecka \\ Uniwersytet im. Adama Mickiewicza w Poznaniu \\ lukasz.szal@amu.edu.pl \\ (D) https://orcid.org/0000-0003-0258-8875 \\ weronika.terlecka@amu.edu.pl \\ (1) https://orcid.org/0000-0002-2701-0554
}

\title{
Zmiany zachowań wolnoczasowych dotyczących rekreacji fizycznej osób młodych w obliczu pandemii COVID-19 ${ }^{1}$
}

\section{Streszczenie}

Publikacja dotyka problemu rekreacji fizycznej ludzi młodych w okresie pandemii COVID-19 i zmian, jakie w tym obszarze zaszły w jej trakcie. Opracowanie stanowi wycinek badań przeprowadzonych w grudniu 2020 r. w ramach projektu pt. „Zmiany w budżecie czasu wolnego i zachowaniach wolnoczasowych mieszkańców dużych miast w wyniku pandemii COVID-19". W rozdziale, w oparciu o wypełniony przez respondentów kwestionariusz budżetu czasu wolnego, opracowano wyniki odnoszące się do tygodniowej ilości godzin poświęcanych aktywności fizycznej. Na podstawie wybranych pytań z wywiadów przeprowadzanych z tymi samymi respondentami przedstawiono ich odpowiedzi dotyczące zmian $\mathrm{w}$ podejmowaniu rekreacji ruchowej $\mathrm{w}$ trakcie pandemii.

\section{Wprowadzenie}

Kwilecki (2011, s. 5) we wstępie do monografii pt. „Rozważania o czasie wolnym. Wybrane zagadnienia” konstatuje, że jest on „,...) symptomem przemian, (...) wyrazem szukania nowych dróg do poprawy zdrowotności społeczeństwa". Stwierdzenie to nabiera szczególnej wagi w dobie pandemii COVID-19. Zmiany w charakterze i warunkach pracy, restrykcje wprowadzane przez rządy

\footnotetext{
1 Badania zostały sfinansowane z konkursu pn. „Badania nad COVID-19” ze środków Uniwersytetu
} im. Adama Mickiewicza w Poznaniu na lata 2020-2021, kierownik grantu: Alina Zajadacz.

Cytowanie: Szał Ł., Terlecka W. (2021). Zmiany zachowań wolnoczasowych dotyczących rekreacji fizycznej osób młodych w obliczu pandemii COVID-19. W: K. Borodako (red.), Turystyka w okresie pandemii. Bogucki Wydawnictwo Naukowe, Poznań-Kraków, s. 261-270. https://doi.org/10.12657/9788379863501-25 
poszczególnych państw czy indywidualne obawy ludzi przed możliwością zarażenia się, wpływają na zakres i sposoby spędzania czasu wolnego, a co za tym idzie - mogą implikować zmiany w podejmowanej aktywności fizycznej.

Celem pracy jest przedstawienie wyników badań dotyczących owych zmian w konkretnym zakresie: rekreacji ruchowej młodych mieszkańców dużych miast. Rozważania stanowią wycinek szerszych badań przeprowadzonych $\mathrm{w}$ dniach 4-18 grudnia 2020 r. w ramach projektu pt. „Zmiany w budżecie czasu wolnego i zachowaniach wolnoczasowych mieszkańców dużych miast w wyniku pandemii COVID-19" pod kierunkiem prof. Aliny Zajadacz (Wydział Nauk Geograficznych i Geologicznych, UAM). Składające się z dwóch elementów badanie (budżet czasu wolnego $\mathrm{w}$ postaci samoraportowania respondentów oraz wywiady pogłębione) przeprowadzone na grupie 71 mieszkańców Warszawy, Wrocławia, Krakowa, Poznania, Lublina, Szczecina, Łodzi, Gdańska i Bydgoszczy dostarczyły różnorodnych danych $\mathrm{w}$ zakresie ewentualnych zmian w posiadanej ilości czasu wolnego i jego przeznaczenia.

W publikacji, w oparciu o literaturę przedmiotu, najpierw scharakteryzowano kluczowe dla przedstawianego zagadnienia pojęcia, takie jak: czas wolny, aktywność fizyczna, rekreacja ruchowa, styl życia i budżet czasu wolnego. Następnie pojawiło się odniesienie do badań o zbliżonej problematyce do tej poruszanej w opracowaniu. W końcu przedstawiono metodykę badań, w których brali udział autorzy niniejszej publikacji, oraz ich cząstkowe wyniki odnoszące się do zmian $\mathrm{w}$ zachowaniach związanych $\mathrm{z}$ rekreacją fizyczną wywołanych pandemią COVID-19 wśród respondentów w wieku 18-35 lat.

\section{Przegląd literatury}

Zagadnienie czasu wolnego jest przedmiotem zainteresowania wielu dyscyplin z kręgu nauk humanistycznych, społecznych i ścisłych. Badaniami tej interdyscyplinarnej kategorii zajmują się tradycyjnie m.in. socjolodzy i pedagodzy czasu wolnego oraz ekonomiści, ale także psycholodzy i antropolodzy (Winiarski, 2011). Pozostaje ona również w kręgu zainteresowań badawczych i dydaktycznych kierunków związanych z turystyką i rekreacją na różnego typu uczelniach wyższych. Ze względu na różnorodne perspektywy, w ramach których ujmowane są problemy czasu wolnego, Kosiewicz sugeruje, że nie istnieje jego uniwersalna definicja, a ,(...) każda próba jej ustalenia odnosi się jedynie do kontekstu danego opracowania i przyjętej w nim koncepcji badawczej” (Stanek, 2011, s. 174).

W przywoływanym przez Piętę (2014) potocznym odbiorze „czasu wolnego" jest to czas pozbawiony obowiązków, który można przeznaczyć na dowolne zajęcia. Propozycje badaczy - przedstawicieli różnych dyscyplin - są zbieżne z tym spontanicznym odbiorem pojęcia. Pedagog i socjolog Dumazedier kładzie nacisk na jego funkcje. W ujęciu francuskiego autora, obejmuje on zajęcia, którym można się oddawać z własnej woli „(...) dla odpoczynku, rozrywki, rozwoju swych wiadomości lub swego kształcenia (bezinteresownego), swego dobrowolnego udziału w życiu społecznym" (Banach, Orlińska, 2013, s. 82). Jak podkreśla 
Mroczkowska (2011, s. 7), „(...) trudno tu o jakąkolwiek regułę, o pewien zbiór właściwych tylko dla czasu wolnego i jednoznacznie przypisanych mu atrybutów”. Badacze socjologii czasu wolnego podkreślają bowiem relatywizm pojęcia, wynikający z indywidualizacji jego doświadczania - to, co pod nim rozumiemy, może się różnić $\mathrm{w}$ zależności od naszych osobistych przeżyć oraz interpretacji (Mroczkowska, 2011).

Jak podaje Mogiła-Lisowska (2017), pojęcie aktywności fizycznej dotyczy każdej działalności człowieka - począwszy od tej warunkującej życie, niezbędnej biologicznie, poprzez działalność związaną z funkcjami pełnionymi społecznie, do rekreacyjnej. Z kolei pojęcie „rekreacji fizycznej” (autorka postuluje termin „rekreacyjna aktywność ruchowa”) jest jednym z elementów składowych aktywności fizycznej (Mogiła-Lisowska, 2017). W definicji rekreacji ruchowej zaproponowanej przez Bielca i in. (2011) obejmuje ona wszelkie formy fizycznej aktywności, które są akceptowane społecznie i mają miejsce w czasie wolnym. Czynności te muszą być podejmowane dobrowolnie, bezinteresownie, z myślą o własnej przyjemności oraz służyć odnowie, umacnianiu sił i samorealizacji o cechach zabawy.

Aktywność ruchowa i rekreacja fizyczna są rozumiane jako zachowania prozdrowotne, związane ze zdrowym stylem życia (Mogiła-Lisowska, 2017). Wyjaśniając zasygnalizowany termin słowami Cynarskiego: „Styl życia jest pojęciem odnoszącym się do całościowego ujęcia codziennej ludzkiej aktywności lub pasywności, wyborów i działań. (...) obejmuje sfery świadomości, codziennych działań i odniesień przedmiotowych" (Cynarski, 2017, s. 121). Autor rozumie więc pojęcie bardzo szeroko, wymieniając także jego następujące składowe: poziom i charakter konsumpcji, wygląd zewnętrzny, sposoby urządzenia mieszkania i spędzania wolnego czasu, wzory życia rodzinnego, charakter kontaktów społecznych, aktywność z obszaru kultury zdrowia, kultury fizycznej i ekologicznej, poziom i charakter uczestnictwa w kulturze oraz deklarowane wartości (Cynarski, 2017).

Z badaniami nad czasem wolnym wiąże się także pojęcie jego budżetu, do którego odwoływał się np. pedagog Pięta (2014), definiując czas wolny. Ów „budżet czasu wolnego”, wprowadzony przez węgierskiego badacza Szalaiego i rozumiany jako określenie typowego dla danego środowiska rozkładu czasu przeznaczanego na różne czynności (Cynarski, 2017), odgrywa szczególnie ważną rolę w ilościowych badaniach czasu wolnego.

\section{Badania o zbliżonej tematyce}

Zagadnienie zmian w zakresie czynności wolnoczasowych związanych z pandemią COVID-19 jest tematem nowym. Pomimo to doczekało się opracowań, które mogą stanowić pewne tło i punkt odniesienia do przedstawianych rozważań. Badanie ankietowe przeprowadzone online w osiemnastu krajach $\mathrm{w}$ pierwszej fali pandemii (marzec-maj 2020 r.) na próbie 13696 respondentów (ich średnia wieku w zależności od kraju: 24-41 lat) doprowadziły do wniosku, że osoby, które przed nadejściem pandemii regularnie ćwiczyły, w jej trakcie utrzymały lub 
zwiększyły swoją dotychczasową aktywność. Z kolei część osób, która przed pandemią nie ćwiczyła, zaczęła podejmować aktywność w tym zakresie (Brand i in., 2020).

Podobne wyniki przyniosło badanie ankietowe przeprowadzone w Polsce na próbie 65 osób w wieku od 17 do 52 lat, związane $z$ wpływem izolacji społecznej na poziom aktywności fizycznej oraz samopoczucie i stan psychiczny ludzi podczas pandemii COVID-19 (Parfin i in., 2020). Z punktu widzenia przytaczanych rozważań ważnym aspektem zrealizowanego na przełomie kwietnia i maja badania było wskazanie najczęściej podejmowanych przez respondentów aktywności fizycznych zarówno przed pandemią, jak i w jej trakcie, oraz ich częstotliwości. W świetle przedstawionych wyników do najczęściej wymienianych aktywności z pierwszego okresu pandemii należały: spacery (ok. $22 \%$ respondentów), bieganie (ok. $19 \%)$, trening siłowy (18\%), jazda na rowerze (12\%) oraz fitness $(11 \%)$.

\section{Metodyka badań}

Badanie ma przede wszystkim wymiar jakościowy. Rozważania w rozdziale koncentrują się na odpowiedziach respondentów w wieku 18-35 lat na pytania dotyczące zmian w sposobach spędzania przez nich czasu wolnego oraz o ewentualne zmiany w stylu życia spowodowane przez pandemię COVID-19. Odwołują się także do wypełnianych przez badanych kwestionariuszy budżetu czasu wolnego w zakresie czynności związanych ze sportem i aktywnością fizyczną. Zasygnalizowana już w tytule kategoria „ludzi młodych” odnosi się do stosowanego przez nauki społeczne terminu „wczesnej dorosłości” w przedziale wiekowym proponowanym przez Brzezińską, Applet i Ziółkowską (Lubrańska, 2018).

Poszczególne budżety czasu wolnego są efektem samoraportowania badanych w oparciu o otrzymany kwestionariusz z przygotowaną listą czynności. Na jego podstawie respondentów podzielono na tych, którzy podejmują rekreacyjną aktywność fizyczną, oraz na tych, którzy nie zadeklarowali takiej aktywności. W kolejnym kroku przydzielono ankietowanych do następujących kategorii ze względu na częstotliwość podejmowanych czynności: codziennie, kilka razy w tygodniu, raz w tygodniu.

Uzupełnieniem budżetów czasu wolnego były wypowiedzi ankietowanych w kolejnych pytaniach kwestionariuszowych dotyczących rodzajów podejmowanych aktywności wolnoczasowych przed epidemią i w trakcie jej trwania z uwzględnieniem podziału jej etapów na czas od marca do maja, czerwca do sierpnia oraz od września do momentu przeprowadzenia badań. Na tej podstawie ankietowanych podzielono na osoby, które: zdecydowały się podjąć rekreacyjną aktywność fizyczną podczas pandemii, częściowo lub całkowicie, zrezygnowały z niej z przyczyn związanych z pandemią lub kontynuowały aktywność pomimo jej trwania. Ponadto na podstawie kwestionariusza wyłoniono najczęściej podejmowane przez respondentów dyscypliny sportu lub rodzaje aktywności. 


\section{Charakterystyka badanej grupy}

Spośród 71 respondentów na potrzeby pracy wybrano odpowiedzi 32 ankietowanych, którzy spełniali założone kryterium wieku. Kobiety stanowiły $38 \%$, a mężczyźni $62 \%$ badanych. Spośród ankietowanych $75 \%$ to ludzie z wykształceniem wyższym, $19 \%$ ze średnim, $6 \%$ z podstawowym. Struktura ich zatrudnienia przedstawia się następująco: $22 \%$ to pracownicy biurowi, $16 \%$ - uczniowie lub studenci, $16 \%$ - osoby związane z działalnością naukową, $9 \%$ - reprezentanci zawodów specjalistycznych (inżynierowie, serwisanci, programiści), następne $9 \%$ - nauczyciele, kolejne 9\% - urzędnicy, $6 \%$ - przedstawiciele branży medycznej (farmaceuci, lekarze), również $6 \%$ - osoby pracujące bezpośrednio z klientem i następne $6 \%$ - osoby prowadzące własną działalność. W badanej grupie $25 \%$ to mieszkańcy Krakowa, 22\% - Poznania, 16\% - Wrocławia, 13\% - Warszawy, 9\% - Łodzi, również 9\% - Szczecina, 3\% - Gdańska oraz kolejne 3\% - Lublina. Jeżeli wziąć pod uwagę charakter zabudowy miejsca ich zamieszkania, $66 \%$ respondentów to mieszkańcy bloków, $9 \%$ - mieszkańcy domów jednorodzinnych z ogródkiem, 22\% - mieszkańcy historycznych części miast, a 3\% - studenci mieszkający w bursach. Tylko 16\% spośród ankietowanych było zakażonych COVID-19, a $22 \%$ poddanych kwarantannie.

\section{Wyniki badań}

Badania wykazały, że spośród wszystkich 32 respondentów jedynie 3 osoby zrezygnowały całkowicie $z$ rekreacyjnej aktywności ruchowej przez pandemię wywołaną przez COVID-19. Z kolei 2 osoby na skutek wprowadzonego stanu epidemicznego i związanej z nim izolacji rozpoczęły ćwiczenia w warunkach domowych. Aktywność fizyczną podejmowaną przed pandemią częściowo porzuciło w jej trakcie 18 osób. Natomiast na pozostałe 9 osób ograniczenia związane $z$ epidemią nie wywarły w tym zakresie żadnego wpływu. Ankietowani wskazywali również, że częstotliwość lub brak rekreacji ruchowej wynikał z obowiązujących obostrzeń, do których się stosowali. Zdaniem badanych okresem, w którym „ruszenie się" z domu stanowiło trudność, był tzw. pierwszy lockdown trwający od marca do maja 2020 r. Poluzowanie obostrzeń w wakacje w sposób znaczący wpłynęło na powrót respondentów do rekreacji fizycznej: uprawiania sportu lub spacerowania. Badania potwierdziły także, że aktywności ponownie podjęte w okresie letnim były w miarę warunków pogodowych oraz możliwości wynikających z kolejnych obostrzeń kontynuowane w późniejszym czasie. Wpływ stanu epidemicznego na rekreacyjną aktywność fizyczną badanych zaprezentowano na rycinie 1.

Częstotliwość aktywności przedstawia się w sposób zróżnicowany. Wśród ankietowanych nie brakowało osób, które rekreację ruchową podejmowały codziennie (13\%), a także kilka razy w tygodniu (41\%) lub chociaż raz w tygodniu (9\%). Z kolei $9 \%$ badanych w ogóle nie uprawiało takich aktywności od momentu wprowadzenia stanu epidemicznego, a $28 \%$ nie podjęło ich $w$ wybranym 


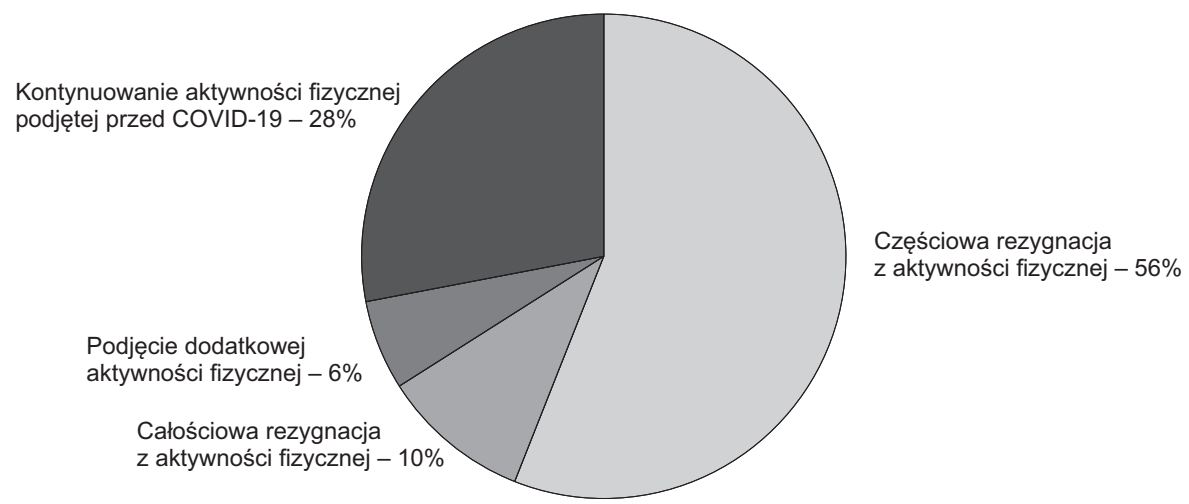

Ryc. 1. Wpływ stanu epidemicznego na rekreacyjną aktywność fizyczną badanych Źródło: opracowanie własne.

tygodniu raportowania, choć $\mathrm{w}$ kolejnych odpowiedziach potwierdziło ją w okresie pandemii. Respondenci (19 osób), którzy zadeklarowali podejmowanie aktywności w zakresie rekreacji fizycznej (jazda na rowerze, bieganie, fitness itp.), W arkuszu samoraportowania poświęcali tej aktywności średnio 3 godz. i 45 min tygodniowo. Na rycinie 2 zestawiono częstotliwość podejmowania aktywności fizycznej przez badanych.

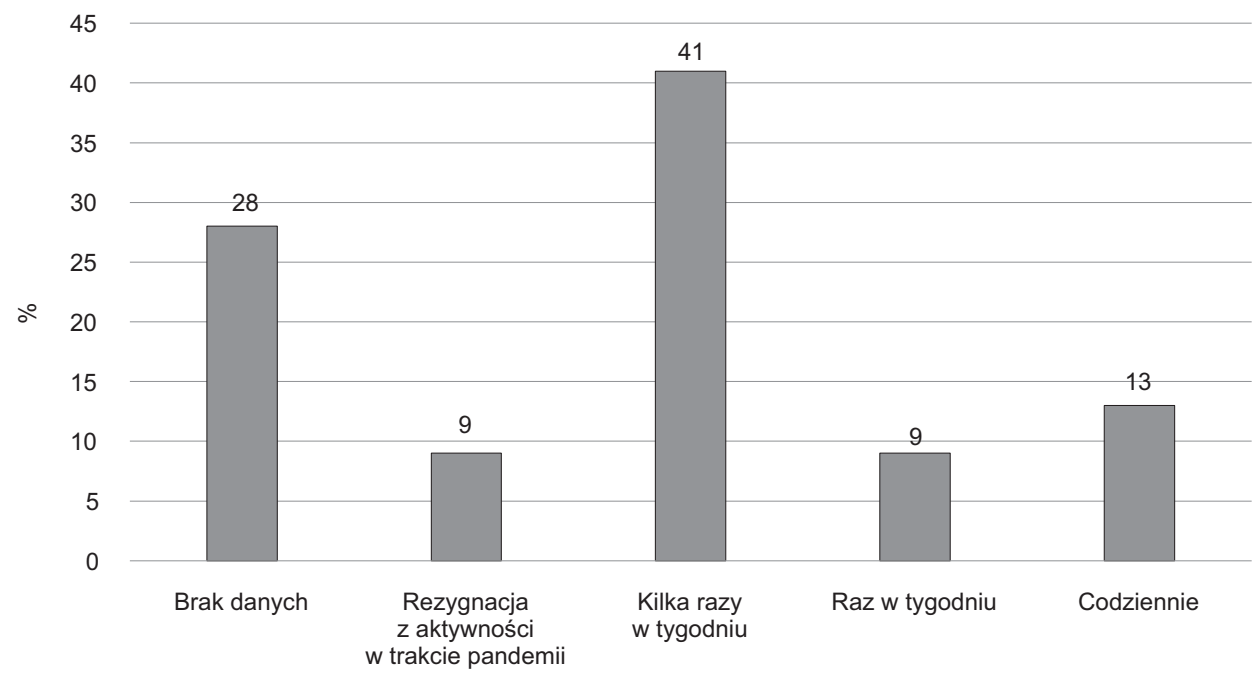

Ryc. 2. Częstotliwość podejmowania rekreacyjnej aktywności fizycznej w trakcie COVID-19 Źródło: opracowanie własne.

* Brak danych oznacza niewpisanie żadnych godzin poświęconych aktywności fizycznej w wybranym tygodniu samoraportowania przez ankietowanych.

Spośród rodzajów aktywności wybieranych przez badanych dominowały spacery $(78 \%)$. Respondenci wskazywali, że możliwość spacerowania nie ustała podczas pandemii (z wyjątkiem czasu zamknięcia lasów i parków), co więcej - często 
pozostawała ona jedyną opcją aktywności ruchowej, gdy zamknięto obiekty sportowe (ryc. 3). Poza spacerami podejmowanymi aktywnościami były: jazda na rowerze (34\%), bieganie (19\%), ćwiczenia na siłowni (19\%), pływanie (13\%), fitness $(6 \%)$, jazda na rolkach $(6 \%)$ oraz inne (9\%: kajaki, karate, szermierka).

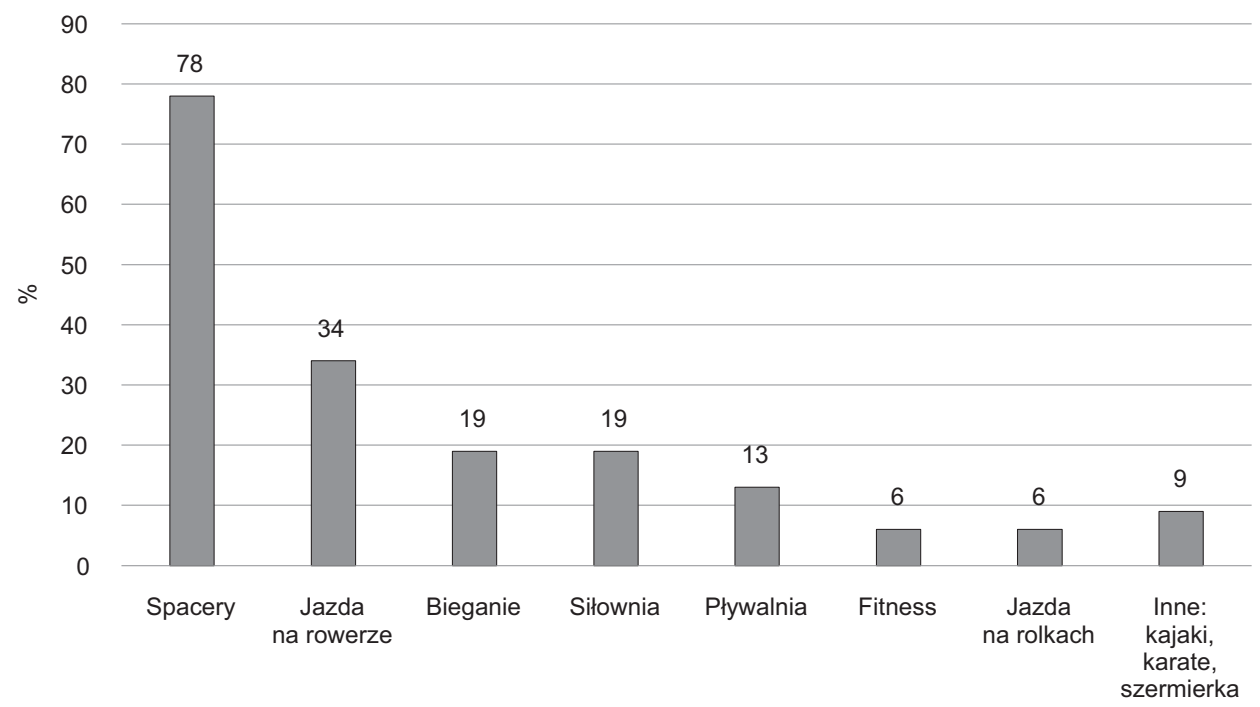

Ryc. 3. Rodzaje rekreacyjnych aktywności fizycznych podejmowanych przez ankietowanych podczas pandemii COVID-19

Źródło: opracowanie własne.

Jak podkreślali ankietowani, wspomniane czasowe zamykanie obiektów sportowych znacząco wpływało na ich decyzje w zakresie podejmowania rekreacyjnej aktywności fizycznej. Troje odpowiadających zwróciło uwagę na rezygnację z jakiejkolwiek aktywności ze względu na obostrzenia oraz brak poczucia bezpieczeństwa, co przemawiało za pozostaniem w domu. Ankietowani wraz z wprowadzaniem kolejnych obostrzeń najczęściej rezygnowali z ćwiczeń na siłowni (13\%), korzystania z pływalni (13\%) oraz jazdy na rowerze (13\%). Ponadto dwoje z nich musiało całkowicie zrezygnować z treningów w dyscyplinach sportowych, takich jak karate oraz szermierka. Jeden z respondentów podkreślił też fakt, że został pozbawiony możliwości uprawiania w jego opinii podstawowej aktywności fizycznej związanej z dojazdem rowerem do miejsca zatrudnienia, gdy przeszedł na pracę zdalną. Inny z uczestników badań wskazał na podjętą w trakcie pandemii decyzję o przygarnięciu psa pod swój dach, aby m.in. mieć możliwość częstszego wychodzenia z domu podczas „home office”.

Kolejnym aspektem badań była ocena zmiany stylu życia w zakresie rekreacyjnej aktywności fizycznej w związku z COVID-19. Aż 66\% respondentów uważa, że zmiany, które zaszły w ich życiu w powyższym zakresie, były negatywne, dla $12 \%$ były one neutralne, natomiast dla $22 \%$ pozytywne (ryc. 4 ). Wśród negatywnych opinii respondenci zwracali uwagę na: potrzebę swobodnego korzystania z obiektów sportowych (takich jak siłownia czy pływalnia - 24\%), brak 
poczucia komfortu podczas chodzenia w maseczce - 29\%, wprowadzanie kolejnych obostrzeń - $29 \%$, kolejne $29 \%$ niezadowolonych osób deklarowało potrzebę częstszego wychodzenia $z$ domu, a $14 \%$ ankietowanych stwierdziło, że rezygnacja $z$ ruchu demotywuje również do podejmowania innych aktywności. Ponadto w pojedynczych wypowiedziach zwracano uwagę na fakt, że aktywny sposób spędzania czasu jest zdrowszy i pożyteczniejszy, spacery bez możliwości spotkań ze znajomymi wpływają negatywnie na samopoczucie, wiele planów uległo anulowaniu. Jedna $z$ wypowiedzi wskazywała na znaczne ograniczenie wolności i brak możliwości podejmowania działań, na które ma się aktualnie ochotę. Kolejna zaś, że „niewychodzenie w weekend $\mathrm{z}$ domu to marnowanie życia, stagnacja, obniżony nastrój czy obrastanie w tłuszcz".

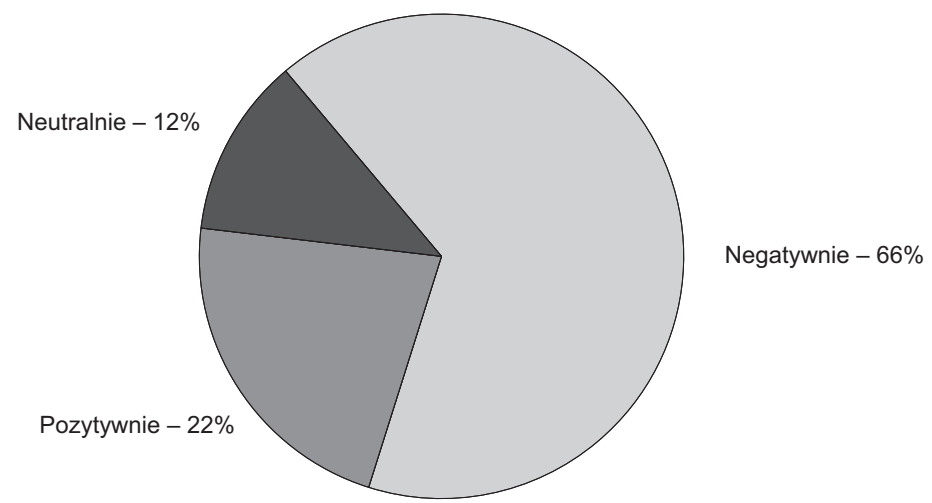

Ryc. 4. Ocena zmiany stylu życia w związku z pandemią COVID-19 Źródło: opracowanie własne.

Osoby, które neutralnie oceniały wpływ pandemii na ich styl życia, zaznaczały, że: „obiekty fitness są co prawda zamknięte, ale dzięki posiadaniu psa mamy obowiązek wychodzenia na spacer", oraz że związana ze stanem epidemii sytuacja nie wpłynęła na częstotliwość wyjazdów rowerowych, a jedynie na fakt, że nie zawsze była możliwość skorzystania z obiektów gastronomicznych w ich trakcie. Kolejny z respondentów stwierdził, że podejmował aktywność niezależnie od obostrzeń, a inny, że nie zakłóciła ona jego planów rowerowych.

U każdej osoby z grupy pozytywnie oceniającej wybrane aspekty sytuacji pandemicznej dominuje przeświadczenie, że wpłynęła ona na zwiększoną częstotliwość spacerowania. Jedna $z$ badanych, która zaczęła $\mathrm{w}$ jej trakcie regularne ćwiczenia fizyczne, podczas gdy wcześniej nie dysponowała czasem na tego typu aktywność, zauważyła, że poprawiły się jej kontakty z partnerem, bo zaczęli więcej rozmawiać, spędzać razem więcej czasu na świeżym powietrzu. Ci z ankietowanych, którzy pozytywnie ocenili zaistniałą sytuację, zauważyli, że paradoksalnie wraz z koniecznością pozostawania w domu wykorzystywali każdą okazję do wyjścia na zewnątrz, dzięki czemu poznali atuty spędzania czasu wśród zieleni. 


\section{Zakończenie}

Autorzy opracowania przyjęli za cel ukazanie zmian w zachowaniach związanych z rekreacją fizyczną wśród respondentów w wieku 18-35 lat, wywołanych pandemią COVID-19. Należy stwierdzić, że odpowiedzi respondentów odzwierciedlają zróżnicowanie społeczeństwa w naszym kraju. Chociaż większość osób negatywnie oceniła wpływ pandemii na ich życie, to nie brakuje i takich, które dostrzegają pozytywne aspekty zmian wywołanych wprowadzeniem stanu epidemicznego. Tylko troje $z$ ankietowanych zdecydowanie porzuciło aktywność fizyczną w trosce o swoje bezpieczeństwo lub stosując się do obostrzeń ogłaszanych przez rząd. Pozostali, nawet jeśli częściowo zmuszeni byli do rezygnacji z dotychczasowych działań związanych z rekreacyjną aktywnością ruchową, dostosowywali się do sytuacji, podejmując aktywność zgodnie z obowiązującymi restrykcjami. W związku z powyższym badania należałoby powtórzyć $\mathrm{w}$ momencie, kiedy rzeczywistość powróci do stanu sprzed epidemii lub gdy złagodzone zostaną obowiązujące obostrzenia, tak aby zweryfikować trwałość przedstawionych zmian.

\section{Literatura}

Banach M., Orlińska M. (2013). Formy aktywności wolnoczasowej ludzi starszych. W: M. Banach, T.W. Gierat (red.), Formy spędzania czasu wolnego. Wydawnictwo Scriptum, Kraków, s. 75-105.

Bielec G., Półtorak W., Warchoł K. (2011). Zarys teorii i metodyki rekreacji ruchowej. Wydawnictwo Proksenia, Kraków.

Brand R., Timme S., Nosrat S. (2020). When Pandemic Hits: Exercise Frequency and Subjective Well-Being During COVID-19 Pandemic. Frontiers in Psychology (https://doi. org/10.3389/fpsyg.2020. 570567; dostęp: 11.01.2020).

Cynarski W.J. (2017). O socjologii czasu wolnego. W: W.J. Cynarski. Czas wolny, turystyka i rekreacja w perspektywie socjologicznej. Wydawnictwo Universitas, Kraków, s. $103-122$.

Kwilecki K. (2011). Rozważania o czasie wolnym. Wybrane zagadnienia. Górnośląska Wyższa Szkoła Handlowa im. Wojciecha Korfantego, Katowice.

Lubrańska A. (2018). Dorosłość i jej różne przejawy. W: A. Lubrańska, Psychospołeczne aspekty życia i pracy w kontekście różnic międzypokoleniowych i polityki organizacyjnej. Wydawnictwo Uniwersytetu Łódzkiego, Łódź, s. 11-28.

Mogiła-Lisowska J. (2017). Rekreacyjna aktywność ruchowa dorosłych Polaków - uwarunkowania i styl uczestnictwa. Wydawnictwo AWF, Warszawa.

Mroczkowska D. (2011). Wprowadzenie. W: D. Mroczkowska (red.), Czas wolny. Refleksje, dylematy, perspektywy. Wydawnictwo Difin, Warszawa, s. 7-18.

Parfin A., Wdowiak K., Furtak-Niczyporuk M., Herda J. (2019). Wpływ izolacji społecznej na poziom aktywności fizycznej oraz samopoczucie i stan psychiczny ludzi podczas pandemii koronawirusa COVID-19. Zdrowie Publiczne, 129(4): 127-131 (http://doi. org/10.2478/pjph-2019-0029).

Pięta J. (2014). Pedagogika czasu wolnego. Wydawnictwo FReL, Nowy Dwór Mazowiecki. 
Stanek L. (2011). Aktywność rekreacyjno-sportowa młodzieży akademickiej w czasie wolnym. W: D. Mroczkowska (red.), Czas wolny. Refleksje, dylematy, perspektywy. Wydawnictwo Difin, Warszawa, s. 171-177.

Uczestnictwo Polaków w sporcie i rekreacji ruchowej w 2012 roku (2013). Główny Urząd Statystyczny (http://stat.gov.pl/download/gfx/portalinformacyjny/pl/defaultaktualnosci/5475/5/3/5/pw_aktywnosc_ekonomiczna_ludnosci_2010-2012.pdf; dostęp: 13.01.2021).

Winiarski R. (2011). Wprowadzenie do zagadnień rekreacji i czasu wolnego. W: R. Winiarski (red.), Rekreacja i czas wolny. Studia humanistyczne. Wydawnictwa Akademickie Oficyna Wydawnicza Łośgraf - Wiesław Łoś, Warszawa, s. 13-28).

\section{Changes in the leisure behavior of physical recreation of young people during the COVID-19 pandemic}

The publication touches upon the problem of physical recreation of young people during the COVID-19 pandemic and the changes that took place in this area during its duration. The study is a part of the research carried out in December 2020 by a team led by prof. Alina Zajadacz (WNGiG, AMU) as part of the project entitled Changes in the leisure budget and leisure behavior of residents of large cities as a result of the COVID-19 pandemic. In the article, the results related to the weekly number of hours devoted to physical activity were prepared on the basis of the free time budget questionnaire completed by the respondents. On the basis of selected questions from interviews conducted with the same respondents, their responses to changes in taking up physical recreation during the COVID-19 pandemic. 


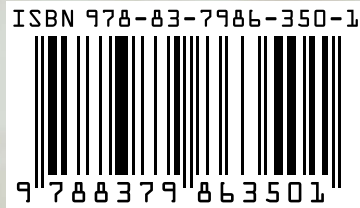

